\title{
Universiteit
}

Leiden

The Netherlands

\section{Unheimlich moederland : (Anti-)pastorale letteren in} Zuid-Afrika

Postel, Gitte

\section{Citation}

Postel, G. (2006). Unheimlich moederland : (Anti-)pastorale letteren in Zuid-Afrika. Leiden University Press. Retrieved from https://hdl.handle.net/1887/27388

Version: $\quad$ Not Applicable (or Unknown)

License: $\quad$ Leiden University Non-exclusive license

Downloaded from: $\quad$ https://hdl.handle.net/1887/27388

Note: To cite this publication please use the final published version (if applicable). 
Gitte Postel

Unheimlich

moederland

(ANTI -) PASTORALE

LETTEREN IN ZUID-AFRIKA

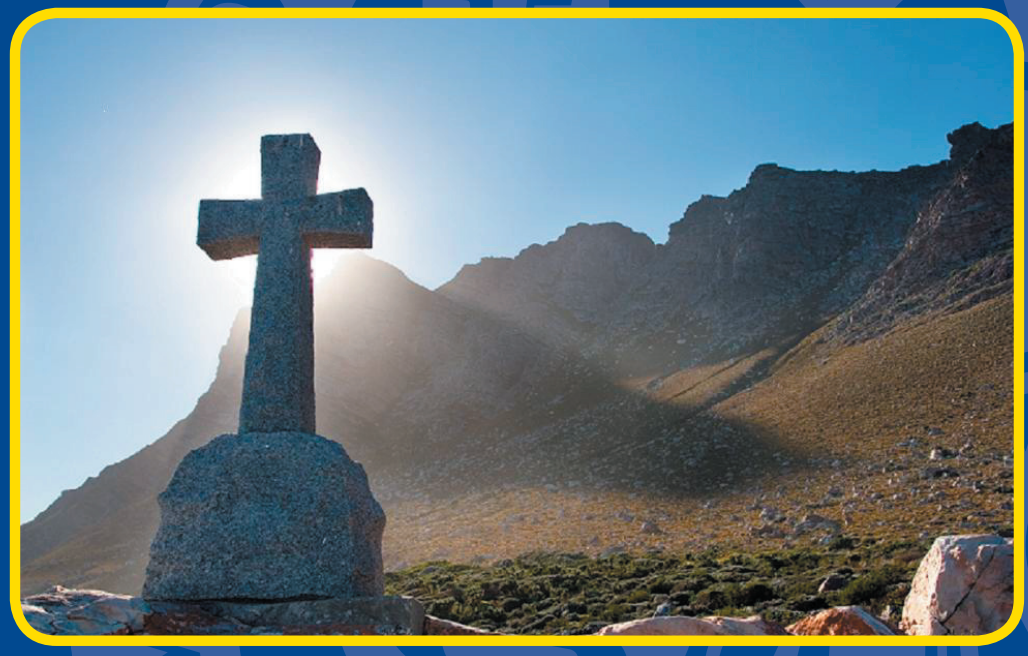

LEIDEN UNIVERSITY PRESS 


\section{Unheimlich moederland}

(Anti-)pastorale letteren in Zuid-Afrika 
Leiden University Press is een imprint van Amsterdam University Press

Deze publicatie is tot stand gekomen met steun van

het Centrum van Niet-Westerse Studies en

de Faculteit Letteren van de Universiteit Leiden

Afbeelding omslag: Grave next to the sea. Gordons bay, South Africa. Sean Nell, Shutterstock, inc.

Ontwerp omslag: Randy Lemaire, Utrecht

isbn 9789087280031

nur 630

(C) Leiden University Press, 2006

Alle rechten voorbehouden. Niets uit deze uitgave mag worden verveelvoudigd, opgeslagen in een geautomatiseerd gegevensbestand, of openbaar gemaakt, in enige vorm of op enige wijze, hetzij elektronisch, mechanisch, door fotokopieën, opnamen of enige andere manier, zonder voorafgaande schriftelijke toestemming van de uitgever.

Voorzover het maken van kopieën uit deze uitgave is toegestaan op grond van artikel 16B Auteurswet $1912 \mathrm{j}^{\circ}$ het Besluit van 20 juni 1974, Stb. 351, zoals gewijzigd bij het Besluit van 23 augustus 1985, Stb. 471 en artikel 17 Auteurswet 1912, dient men de daarvoor wettelijk verschuldigde vergoedingen te voldoen aan de Stichting Reprorecht (Postbus 3051, 2130 KB Hoofddorp). Voor het overnemen van gedeelte(n) uit deze uitgave in bloemlezingen, readers en andere compilatiewerken (artikel 16 Auteurswet 1912) dient men zich tot de uitgever te wenden. 


\section{Unheimlich moederland}

(Anti-)pastorale letteren in Zuid-Afrika

\section{PROEFSCHRIFT}

ter verkrijging van

de graad van Doctor aan de Universiteit Leiden, op gezag van de Rector Magnificus Dr.D.D.Breimer, hoogleraar in de faculteit der Wiskunde en Natuurwetenschappen en die der Geneeskunde, volgens besluit van het College voor Promoties te verdedigen op woensdag 7 juni 2006 klokke 16:15 uur

door

Christine Geertrui Postel

geboren te Lochem, in 1963 


\section{Promotiecommissie}

Promotor:

Referent:

Overige leden:
Prof. dr. W.J.J. Schipper de Leeuw

Prof. dr. J.M. Coetzee (prof. em. University of Cape Town; University of Adelaide)

Prof. dr. E.J. van Alphen

Dr. E. Francken

Dr. D. Merolla

Prof. dr. R.J. Ross 
Voor Joost 


\section{Inhoudsopgave}

Voorwoord

1 Inleiding

1.1 VRAGEN ROND LAND EN DOOD 1

1.2 ONDERZOEKSTERREINEN

1.3 THEORETISCHE UITGANGSPUNTEN 12

2 "Alleen in die wye eensaamheid" De besloten domeinen van plaas en plaasroman $\quad 21$

2.1 INLEIDING 21

2.2 DE BOERDERIJROMAN: SCHEPPING VAN EEN TIJDLOOS TERRITORIUM 24

2.3 BEZIT, ARBEID, CULTUUR: NATIONALISTISCHE MYTHEN IN DE PLAASROMAN 27

2.4 VAN VEEBOEREN EN LANDHEREN: ONTWIKKELING VAN DE PLAAS

2.5 DE VELE GEZICHTEN VAN HET PATERNALISME 42

2.6 PATERNALISME IN PLAASROMANS 50

2.7 CONCLUSIE $\quad 57$

3 "Old frontier fears" Een falende idylle tussen slavernij en barbarij

3.1 INLEIDING

62

3.2 FROM CAPE TO CAIRO EN ANDERE MISSIES 63

3.2.1 Het gekerstende platteland als all purpose metaphor 66

3.3 HET PLATTELAND VAN THOMAS PRINGLE: "A LIMINAL ZONE BETWEEN THE SELF AND SAVAGERY". 73

3.4 ADAMASTOR EN DE GENADELOZE KAROO 78

3.4.1 De razernij van Adamastor $\quad 80$

3.4.2 Adamastor in Schreiners African farm 83

3.5 NA 1910: "DOUBLY DISPLACED, DOUBLY INVOLVED, DOUBLY DETACHED" 86

3.5.1 Campbell, Plomer, Van der Post, Bosman 86

3.5.1 Pauline Smith en de kroon van Ludovitje 89

3.6 "DIE VERSKRIKLIKE EENHEID": NATUUR, FAMILIE EN DOOD 98

4 De dood als pluriforme metafoor: orde, chaos, das unheimliche

4.1 DOOD EN RUIMTE IN “UNTO DUST" 104

4.2 DE CONSOLIDERENDE DOOD 106

4.2.1 Continuïteit als bezwering van de chaos 107

4.2.2 Ordening door ruimtelijke metaforen 110

4.3 DE REIS DOOR HET DUISTER 113

4.3.1 Kolonisatie als rite de passage 113 
4.3.2 Doden als voertuig van de herinnering

4.4 DE VERSCHIJNING VAN MORBIDE SYMPTOMEN: DAS

UNHEIMLICHE

4.4.1 Freud: herrijzenis van oude angsten

4.4.2 Shipoko, het spook van Witwatersrand

4.4.3 "A secret geography of the unspoken"

4.4.4 Ruimte voor pluraliteit: het unheimliche als cultuurkritiek

5 Eva, amandla en abathakathi. Scheppingsmythen en transformatierituelen in The conservationist

5.1 INLEIDING

5.2 GORDIMERS HOOGVELD 145

5.3 MEHRINGS RUIMTE 147

5.3.1 Stad \& land; erf \& vlei 149

5.3.2 Hof van Eden \& Land van God 152

5.3.3 De broedermoord 159

5.3.4 Conclusie: de vlei als paradox 161

5.4 CALLAWAY'S RUIMTE 162

5.4.1 Religieuze domeinen in de tijd van Callaway 165

5.4.2 De derde scheppingsmythe 168

5.6 RITUELE TERRITORIA 179

5.6.1 Vuur en vlei: zuivering en transformatie 180

5.6.2 De liminale dode 184

5.6.3 Mehrings ziekte 190

5.7 CONCLUSIE 192

6 "Satang dwaal vennag" Ambiguïteit en liminaliteit in Kroniek $\begin{array}{ll}\text { van Perdepoort } & 197\end{array}$

6.1 INLEIDING 197

6.2 PERDEPOORT: GESCHONDEN PARADIJS 203

6.2.1 Vacuüm 206

6.3 DE UNHEIMLICHE AMBIGUÏTEIT VAN HET HIER EN NU 215

6.3.1 Afrikaners, kleurlingen en Khoisan 217

6.3.2 //Gãuwa: schelm, god en duivel. 224

6.3.3 De maan: vruchtbaarheid, geweld en wedergeboorte 229

6.3.4 Adriana: meisje, vrouw en kikker 233

6.3.5 /Kaggen: ordeverstorend en levengevend 236

6.3.6 Rite de passage: separatie, liminaliteit, ...? $\quad 240$

7 Conclusie 246

Bibliografie $\quad 265$

Index 281

Summary 285

Curriculum Vitae 289 


\section{Voorwoord}

Op een rommelmarkt in Nijmegen kocht ik twintig jaar geleden een boek om de titel en de merkwaardige omslagillustratie. De schrijver kende ik niet. Maar Waiting for the barbarians trof me als een mokerslag; ik zou daarna al Coetzee's boeken lezen en veel meer uit Zuid-Afrika. Ik raakte gefascineerd door de turbulente en onthutsende geschiedenis van het land en de fundamenteel menselijke thematiek die in haar literatuur aan de oppervlakte lag: de zoektocht naar een thuis en falende communicatie tussen culturen. Maar ook door het angstig verlangen dat het landschap leek op te roepen, en dat als een onuitgesproken, melancholische, maar ook dreigende sluier over alle romans lag die ik las. Een landschap als het stille, magische oog van een onzichtbare storm. "I sat watching the moon rise," schreef Coetzee in dat eerste boek, "opening my senses to the night, waiting for a sign that what lay around me was not only sand, the dust of bones, flakes of rust, shards, ash. The sign did not come. There was no tremor of ghostly fear. (..) Ridiculous I thought, a greybeard sitting in the dark waiting for the spirits from the byways of history to speak to him before he goes home (..). Space is space, life is life, everywhere the same. But (..) I pamper my melancholy and try to find in the vacuousness of the desert a special historical poignancy. Vain, idle, misguided!"

Als deze magistraat misleid was, dan was ik het ook, want diezelfde geesten hebben mij nooit meer los gelaten. En toen ik me later bij Kairos in Utrecht verdiepte in de Zuid-Afrikaanse landproblematiek en ontdekte dat er heel helder omlijnde zwarte tegenhangers waren voor deze onbenoembare "spirits from the byways of history", en dat die te maken hadden met zoiets tastbaars als landrechten, wist ik dat er ooit een boek over moest komen. Ik wist alleen niet hoe ik het allemaal bij elkaar moest brengen.

Gelukkig was ik niet alleen. Eric van den Bergh, Robert Dorsman, en Hans Hartman hebben me al vroeg met veel deskundige mensen en ter zake doend materiaal laten kennismaken. De bijzonder inspirerende gesprekken die ik voerde met Sherman de Jesus en Prakash Shah hielpen me vervolgens richting te bepalen en ideeën trouw te blijven. Werner Menski gaf me op het juiste moment een subtiele schop in de goede richting. In een andere fase hielpen Ena Janssen en Els Postel-Coster me orde te scheppen in de inmiddels ontstane chaos. Door de tijd heen heb ik het regelmatige contact met en commentaar van mede-promovendi altijd als heel verhelderend en verlichtend ervaren. Toen ik eindelijk echt begon te schrijven stelden de vakgroep Literatuurwetenschap en later het CNWS van de Universiteit

${ }^{1}$ J.M. Coetzee Waiting for the Barbarians, 16 
Leiden tot mijn opluchting de broodnodige faciliteiten beschikbaar. De verwarmende aanwezigheid van Andrea Lion en Hedda Post en de prikkelende e-maildiscussies met Inti Suarez, evenals het motto waarmee de laatste al die e-mails afsloot ("It is astonishing what foolish things one can temporary believe if one thinks too long alone" (J.M. Keynes)) vormden onmisbare bijdragen op eenzame schrijfdagen in Leiden. Douwe Fokkema ben ik dankbaar omdat hij me de kans gaf mijn werk op een internationaal congres te presenteren, en de Stichting Catharina van Tussenbroeck voor de reisbeurs die het me mogelijk maakte erheen te gaan. Eric van den Bergh, Robert Ross, Yasco Horsman en Jan Janssen hebben me een grote dienst bewezen door hoofdstukken te lezen en van waardevol commentaar te voorzien.

Ik dank verder mijn familie en goede vrienden voor hun geduld, aanmoedigingen en bestaan. Ik dank mijn schoonouders Ed en Fritzi in het bijzonder voor hun praktische en morele steun. Mijn jonge zonen Tibert en Aron hebben me met beide benen op de grond gehouden en leerden me prioriteiten te stellen. Aan mijn man Joost, ten slotte, draag ik dit boek op, uit dank voor de ruimte die hij me gaf om het te schrijven, en voor zijn nietaflatende interesse, kritiek en vertrouwen. 
Entire bodies of writing emerged out of the imperial front, that line of contact between colonizer and colonized which is characterized as much by reciprocal envy and adulation as by reciprocal fear and resentment.

Rivkin \& Ryan 1998, 852.

\section{Inleiding}

\subsection{VRAGEN ROND LAND EN DOOD}

Umntu ngumntu ngabantu, zegt het Xhosa spreekwoord: een mens is een mens dankzij andere mensen. Maar voor de van oorsprong Europese kolonisten in Zuid-Afrika leek de relatie met het uitgestrekte, droge land lange tijd bijna belangrijker om het mens-zijn in Afrika te definiëren dan de relatie met andere mensen. Dat is tenminste het beeld dat naar voren komt in de pastorale literatuur in Zuid-Afrika. Net als Groot-Brittannië kende Zuid-Afrika in het begin van de twintigste eeuw, onder invloed van industrialisatie, verstedelijking en maatschappelijke reorganisatie, een opleving in de pastorale literatuur, deels uit gevoelens van nostalgie en de behoefte om te ontsnappen uit de chaotische wereld van alledag, maar ook als een vorm van reflectie. Want hoewel pastorale literatuur de natuur en/of de (oude) rurale orde tot onderwerp heeft, is er altijd, hoe impliciet ook, een cultureel en hedendaags of stedelijk perspectief; er is een beweging van retreat and return "either within the text, or in the sense that the pastoral retreat 'returned' some insights relevant to the (urban) audience"2. Op die manier is er een mogelijkheid om kritiek uit te oefenen op het establishment, meestal zonder de fundamenten van dat establishment te ondermijnen. Binnen het Britse imperium is pastorale literatuur bijvoorbeeld vaak gebruikt om de relaties tussen het getormenteerde, ontwikkelde centrum en de benijdenswaardig onschuldige, maar onderontwikkelde onderdanen te helpen definiëren ${ }^{3}$.

Dit boek gaat over de geordende wereld van de (post)koloniale boerderij, een wereld waarbinnen natuur en cultuur, Afrika en Europa, centrum en periferie om ruimte strijden en van plaats en gedaante wisselen. J.M. Coetzee onderscheidde in White Writing (1988) twee ideale landschappen in de blanke Zuid-Afrikaanse literatuur. De eerste is de verbeelding van

\footnotetext{
${ }^{2}$ Gifford 1999, 1-2

${ }^{3}$ Zie Gifford 1999, 52
} 
Zuid-Afrika als een "vast, empty, silent space, older than man, older than the dinosaurs whose bones lie bedded in its rocks, and destined to be vast, empty and unchanged long after man has passed from its face." ${ }^{\prime 4}$ Dit ideale landschap is als een onbedorven paradijs zonder mensen en de grootste uitdaging is het vinden van een taal die iets van betekenis aan de leegte kan geven. Maar een dergelijk landschap was niet voor iedereen ideaal. Voor een ontdekkingsreiziger of veroveraar die de aanwezigheid van een autochtone bevolking wilde ontkennen, of voor een dichter die zocht naar een taal om het land te beschrijven was het wellicht handig, intrigerend en inspirerend, maar voor een missionaris of bestuurder of voor een schrijver die het zware maar zinvolle leven van de kolonisten wilde beschrijven, was het als concept niet hanteerbaar - en dus ook niet mooi. In een passage die later vaak door missionarissen werd aangehaald, schreef John Barrow, de Britse staatsman die eind achttiende eeuw de opdracht kreeg een regering te vestigen in de nieuw verworven Kaapkolonie: "[a]s none of the [lands] are enclosed there is a general appearance of nakedness in the country (...) which (...) if divided by fences, would become sufficiently beautifull's. Het tweede ideaaltype was dan ook een door noeste arbeid en erfafscheidingen getemde wildernis: "a netwerk of boundaries crisscrossing the surface of the land, marking off thousands of farms, each a separate kingdom ruled over by a benign patriarch with, beneath him, a pyramid of contented and industrious children, grandchildren, and serfs." ${ }^{6}$ De wildernis was in deze beeldvorming niet paradijselijk, maar barbaars of irrelevant, en het ideaal was niet het opgaan in de onbezoedelde wildernis, maar het tot stand brengen van een door mensen gecultiveerde natuur.

De verschillen tussen beide landschappen zijn overigens minder groot dan ze lijken. De koloniale dichter die middels de taal een band met een ongerept landschap wil bewerkstelligen, is opgezadeld met een paradox: de onbedorven staat van de wildernis is verdwenen met het benoemen ervan? Net als ontginning is benaming een vorm van in cultuur brengen van natuur en een manier om een ruimtelijke basis te verschaffen aan een culturele identiteit $^{8}$ Ook oorsprongssmythen vervullen dezelfde functie. Daarin "wordt de reis van de oerwezens herhaald, waarbij niet alleen de oriëntatie op het landschap wordt bewerkstelligd, of aan de nieuwe generatie wordt overgedragen, maar ook het bezit van het land (zowel fysiek als cognitief) wordt bevestigd."

Pogingen van (post-)koloniale schrijvers en dichters om de wildernis te beschrijven zijn dus in wezen pogingen om een "oorsprongs"mythe, en

\footnotetext{
${ }^{4}$ J.M. Coetzee 1988, 7

${ }^{5}$ Barrow (1801-4) geciteerd in Comaroff 1989, noot 17

${ }^{6}$ Coetzee 1988, 7

${ }^{7}$ Zie ook JM. Coetzee 1988

${ }^{8}$ Kommers 1994, 61-62

${ }^{9}$ Kommers 1994, 66
} 
daarmee een (nieuwe) orde of identiteit te scheppen. Zoals ook later zal blijken is de tegenstelling tussen beide ideale landschappen wellicht vooral gelegen in het doel van de schrijver of dichter; bescherming danwel (re)creatie van een bepaalde menselijke orde. De gecontroleerde, omheinde natuur is een orde die beschermd moet worden tegen de oncontroleerbare krachten van stad en/of wildernis, terwijl de paradijselijke wildernis een mogelijkheid biedt voor constructie, of de- en reconstructie, van een samenleving.

Binnen de pastorale romanliteratuur groeide de plaasroman of farm novel in Zuid-Afrika uit tot een serieus en beladen subgenre. Sinds de jaren twintig en dertig van de twintigste eeuw, dat wil zeggen de decennia waarin het Afrikaner nationalisme tot bloei kwam, maakten plaasstories en plaasromans een belangrijk onderdeel uit van de Afrikaanstalige literatuur. Oorspronkelijk streed in deze verhalen een blanke boer met zijn familie en zwarte knechten tegen onrecht, barbarij, armoede en sprinkhaanplagen, maar ook voor het behoud van zijn eigen identiteit en integriteit in een wereld die in rap tempo veranderde. Engelstalige schrijvers waren in mindere mate gefocust op de boerderij. Toch gebruikten ook zij, vanuit de Britse pastorale traditie, verhalen over (Afrikaner) boeren om een culturele identiteit of het zoeken naar zo'n identiteit te verbeelden. Identiteit wordt hier niet gezien als iets statisch, maar als veranderlijke positioneringen, niet alleen "geformuleerd in vertellingen over verleden en cultuur", maar ook over ruimte, en "per definitie toekomstgericht"10 Of een bevredigende identiteit (en dus toekomstbeeld) gevonden werd - of de Afrikaner protagonist(e) zijn of haar ziel verkocht of niet, of de Engelse held(in) Zuid-Afrikaan werd of vreemdeling bleef - hing in deze teksten vaak niet zozeer af van zijn of haar relatie met andere Zuid-Afrikanen, maar vooral van de mate waarin een onbemiddelde relatie tot stand gebracht kon worden met de onverbiddelijke Afrikaanse aarde. Sterven was daarbij een belangrijk hulpmiddel. Leven "van het gewas des velds" en "tot de aardbodem wederkeren" $" 11$ werd de queeste van de kolonist ${ }^{12}$.

Maar de kenmerkende paradox van de pastorale literatuur en dus ook van de boerderijroman is dat haar onderwerp niet haar eigenlijke onderwerp is, en "that a retreat to a place apparently without the anxieties of the town, or the court, or the present, actually delivers insights into the culture from which it originates. (..) Thus the pastoral construct always reveals the preoccupations and tensions of its time." ${ }^{13}$ Contemporaine spanningen had-

\footnotetext{
${ }^{10}$ Speerstra, 12. Zie ook Ernst van Alphen en Maaike Meyer (1991) De canon onder vuur. Nederlandse literatuur tegendraads gelezen; Stuart Hall en Paul du Gay (red.) (1992). Questions of cultural identity; en James Clifford $(1986,1988)$.

${ }^{11}$ Genesis $3: 17-19$

${ }^{12}$ Zie ook J. Coetzee 1988, bijv. 79 en 109.

${ }^{13}$ Gifford 1999, 82
} 
den in Zuid-Afrika niet alleen betrekking op de steden. Wellicht anders dan bijvoorbeeld in Engeland, zorgde industrialisatie hier niet zozeer voor een leegloop van het platteland, maar voor een herinrichting ervan; landbouw werd een van de belangrijkste industrieën van Zuid-Afrika, en ondanks de trek naar de steden bleef de plattelandsbevolking, ook om andere redenen, groeien. Bovendien verwees de problematiek van de stad in essentie altijd terug naar de problematiek van het platteland: landrechten vormen, zeker in een Afrikaanse setting, een belangrijke voorwaarde voor sociale identiteit, en het ontkennen van die rechten vormde de basis van de gedwongen proletarisatie, verstedelijking en ontheemding van de zwarte bevolking. Met andere woorden: Zuid-Afrkaanse (anti-)pastorale literatuur is niet alleen een bewuste weerspiegeling van de problematiek van het stedelijke of koloniale centrum, maar laat ook (vaak onbedoeld) zien dat een deel van die problematiek voortkomt uit het gebrek aan belangstelling voor of informatie over haar rurale periferie. Dit is een van de vele complicerende factoren bij de constructie van een heilzame idylle naar Europees voorbeeld in een Afrikaanse kolonie ${ }^{14}$. In dit onderzoek zal ik me daarom niet zozeer bezighouden met de relatie tussen pastorale literatuur en een stadse of eigentijdse werkelijkheid, maar op de relatie tussen de verwrongen geschiedenis en werkelijkheid van het platteland en de representatie daarvan in de literatuur - of, om op het onbegrijpelijke af precies te zijn, tussen de verwrongen geschiedenis en werkelijkheid van het platteland en de representatie van de stedelijke of contemporaine gevolgen daarvan in een pastorale literatuur.

Bij dit alles richt ik me vooral op de verbanden tussen ruimte, identiteit en dood; zowel op Zuid-Afrikaanse boerderijen als in Zuid-Afrikaanse boerderijromans. Ruimte, dat wil zeggen: de begrenzing en vormgeving van ruimte, is als ordenend principe zowel toepasbaar op de materiële als de niet-materiële werkelijkheid. "Individual or group, we are traversed by lines, meridians, geodesics, tropics and zones, marching to different beats and differing in nature," schreven Deleuze en Guattari, en David Harvey stelt dat "any struggle to reconstitute power relations is a struggle to reorganize their spatial basis" ${ }^{15}$. In het twintigste eeuwse Zuid-Afrika is die ruimtelijke basis van machtsrelaties de verdeling van land op zowel grote als kleine schaal. Landrechten vormen niet alleen een basis voor een sociale identiteit, maar ook van macht over anderen, en het is dankzij die macht dat "land rights can be conceived by landowners as merely as 'a relation between people and things' rather than a 'relation between people"' ${ }_{16}$. In

\footnotetext{
${ }^{14}$ Zie ook J. Coetzee 1988, 3-6

${ }^{15}$ Gilles Deleuze and Félix Guattari. A thousand plateaus: capitalism and schizophrenia. London, Athlone press, 1988: 202

${ }^{16}$ Wenzel $(2000,96)$ citeert Tony Buckle, "Land relations and social dynamics: reflections on contemporary land issues in South Africa, with partical reference to the Eastern Cape“. Anthony Lemon
} 
landwetten, en in landschapsbeschrijvingen, mythen en literaire teksten wordt deze relatie tussen mensen en dingen (en dus impliciet tussen mensen onderling) vormgegeven. Maar ook rituelen aan de hand waarvan mensen zich in de ruimte oriënteren of die ruimte en tijd met elkaar verbinden, vervullen die functie. In dit opzicht zijn vooral rites de passage interessant, als rituelen die fundamentele veranderingen begeleiden: geboren worden, volwassen worden, doodgaan. Met name de dood verwijst als ultieme grens en transformaties naar alle bestaande grenzen en transformaties, zodat ook ruimte en identiteit door representatie van de dood vormkrijgen.

In een stabiele situatie zullen deze representaties elkaar beïnvloeden, weerspiegelen en legitimeren. Maar er treden altijd verschuivingen op, en in tijden van verandering zullen ze elkaar wellicht vooral tegenspreken en ondermijnen. Dat laatste was in Zuid-Afrika het geval toen in de jaren zeventig soms openlijk en dan weer met zwaar geweld onderdrukt verzet het wankel evenwicht van blanke overheersing begon te ondergraven. ZuidAfrika naderde haar dekolonisatie, met als gevolg dat de inrichting van de ruimte (waaronder verdeling van land) haar vanzelfsprekendheid verloor. Het weer in bezit nemen van de ruimte door actieve herinnering is een belangrijk onderdeel van het postkoloniale "project of reclamation" ${ }^{17}$. In postkoloniale literaire theorieën is veel aandacht besteed aan dit soort "problems of transmuting time into space, with the present struggling out of the past" ${ }^{18}$ en de complexe communicatie tussen (ex-)kolonist en (ex-)gekoloniseerde die daar onontkoombaar deel van is. Maar postkolonialisme is een ambivalent begrip, zeker in Zuid-Afrika, en zeker voor Afrikaners. Officieel was het land in de jaren zeventig al lang geen kolonie meer, maar er was maar zeer beperkt sprake van dekolonisatie nadat de officiële banden met Engeland waren doorgesneden. Het twintigste eeuwse Zuid-Afrika was de enige settler colony met een blanke minderheid en bijna de enige oud-kolonie in Afrika met een blank regime. De Afrikaanstalige plaasroman uit de jaren twintig en dertig is ongetwijfeld onderdeel geweest van een proces van dekolonisatie (het (opnieuw) in bezit nemen van ruimte door actieve herinnering), maar tegelijk van kolonisatie. Toen voor veel Afrikaners de echte "bevrijding" gerealiseerd werd op het moment dat in 1948 de Nationalistiese Party aan de macht kwam ${ }^{19}$, moest de zwarte ZuidAfrikaanse meerderheid nog een jaar of vijftig op haar bevrijding wachten. Louise Viljoen merkte terecht op dat "[die] heterogeniteit van die SuidAfrikaanse situasie en letterkunde uiteindelik die volgende uitspraak in verband met die post-kolonialisme [ondersrkyf]: 'Postcolonialism (..) is not a homogeneous category either across all postcolonial societies, or even

(ed) The geography of change in South Africa. Chichester, Wiley, 1995: 80

${ }^{17}$ Gunner 2000, 123

${ }^{18}$ Ashcroft, et al. 1989, 36

${ }^{19}$ Zie Giliomee 2003b, 487 
within a single one. Rather it refers to a typical configuration which is always in the process of change, never consistent with itself." ${ }^{20}$ Het préfix "post" in postkoloniaal wijst dan ook niet zozeer op een periode na een politieke omwenteling, maar op een zekere mate van verwerking van de koloniale situati $\mathrm{e}^{21}$; koloniaal en postkoloniaal kunnen naast elkaar bestaan: binnen een continent, een land, een ideologie. Of, zoals Ania Loomba het stelt: "it is more helpful to think of postcolonialism as (..) the contestation of colonial domination and the legacies of colonialism" ${ }^{22}$. Postkolonialisme gaat dus over verandering en over de tegenstrijdige krachten die daarin een rol spelen. Te grote veralgemeniseringen missen hun doel, belangrijker is het te werken met, in de woorden van Viljoen, "kleinere narratiewe wat die historiese omstandighede van die verskillende postkoloniale literature meer noukeurig omskryf ${ }^{\prime 23}$.

Als het in de jaren zeventig van de 20ste eeuw langzaam begint door te dringen dat politieke verandering niet is tegen te houden, wordt het voor de blanke minderheid noodzakelijk om zich van haar identiteit te bevrijden, of die op zijn minst te veranderen, wilde men in het veranderend Zuid-Afrika een plek behouden. Anderzijds kwam juist daardoor de plek die men had, het "thuis" op de helling te staan. In die jaren zeventig keren schrijvers terug naar de boerderijroman, om hun thuis-constructie en de mogelijkheden om die aan een nieuwe situatie aan te passen, nader te onderzoeken. De begrensde, overzichtelijke wereld van de boerderij werd nu gebruikt om een op het eerste gezicht anti-pastorale boodschap uit te dragen: de boerderij was niet alleen een verbeelding van een thuis (heim), maar ook van het unheimliche $e^{24}$. Juist hier was de meest concrete, ruimtelijke oorsprong te vinden van het conflict dat nu zo onontkoombaar en onbeheersbaar leek op te doemen. Maar tegelijkertijd was de werkelijkheid die in deze romans gepresenteerd werd een problematische, gespleten, ongrijpbare werkelijkheid. Ze was vol halfbedekte tegenstrijdigheden; enerzijds zeer statisch en anderzijds vol toekomstige maar nog ondefinieerbare verandering. Voor zover de verschillende betekenisvelden nog in elkaar grepen, leidden ze niet meer tot stabiliteit en zekerheid, maar tot verstarring en (zelf)destructie - een spin verstrikt in haar eigen web. De geschiedenis leek een doemscenario geweest te zijn voor een apocalyptische toekomst.

Ik zal laten zien dat schrijvers, bij hun terugkeer naar deze unheimliche oorsprong, vervolgens de metafoor van de dood gebruikten om een

\footnotetext{
${ }^{20}$ L. Viljoen 1996, 162. Ze citeert uit Vijay Mishra \& Bob Hodge "What is post-colonialism". In: Williams \& Chrisman. Colonial discourse and post-colonial theorie. A reader. London/New York, 1993: 289

${ }^{21}$ Korsten 2002, 293

${ }^{22}$ Loomba, A. Colonialism/Postcolonialism. London, Routledge, 1998: 12

${ }^{23}$ Viljoen 1996, 162

${ }^{24}$ Het begrip is in wetenschappelijke kringen geïntroduceerd door Sigmund Freud, die het definieert als "that class of frightening that leads back to what is known of old and long familiar".(S. Freud, "Das Unheimliche". 1976, 620).
} 
ontsnappingsmogelijkheid te bieden uit het web van mythen dat de werkelijkheid leek te bezweren. De dood verloor nu haar functie als anker in de orde der dingen en vertegenwoordigde het ongewisse, het onbekende bewustzijn. Terwijl de Ander bij leven nog steeds een onderdrukte aanwezigheid was, kroop in The conservationist van Nadine Gordimer een dode Zulu langzaam maar zeker het hoofd van Mehring binnen en doorkruiste zijn cirkelredenaties. Ook in Kroniek van Perdepoort van Anna Louw brengen onbegraven doden de bestaande orde aan het wankelen door alternatieve perspectieven op de werkelijkheid te openen. In de jaren tachtig en negentig borduren met name J.M. Coetzee en Etienne van Heerden voort op deze dodenrollen, waarbij er door de veranderende maatschappelijke en politieke omstandigheden voortdurend betekenisverschuivingen optreden. De dood lijkt ruimte te creëren voor dat wat niet wordt gezegd of bewust waargenomen: een andere visie; het verhaal, wellicht, van de Ander.

\subsection{ONDERZOEKSTERREINEN}

Dit boek gaat dus over literaire teksten, maar ook over veranderende werkelijkheden en percepties die de betekenis van die teksten beïnvloeden. Dat levert nieuwe dilemma's op. De vraag, bijvoorbeeld, van wie bovenstaande alternatieve set van cultuuruitingen, representaties en vertellingen zou kunnen zijn, zal in z'n algemeenheid moeilijk te beantwoorden zijn. Denken in termen van etniciteit is problematisch in dit verband, want, zo toonden structuralistische en feministische denkers aan, het biedt geen plaats aan historische aspecten, aan genderverschillen en aan verandering in het algemeen $^{25}$ - en verandering is precies waar het hier om gaat. Bovendien zijn ook de ontmoetingen die ten grondslag lagen aan het "gezwabber" van het koloniale discours ${ }^{26}$, niet statisch of eenduidig. Volgens Clifton Crais, die zich in The politics of evil richt op de "messiness of history and the confusions of cross-cultural encounters" ${ }^{27}$,

[c]ross-cultural encounters are neither simply situations in which two cultures collide, and in their collision are transformed, nor are they situations of perfect translations in which historical actors share a universal practical rationality. There is speech and communication and translation across culture, but there is also, and very often si-

\footnotetext{
${ }^{25}$ Rivkin \& Ryan 1998, 853

26 "If Said shows that misrelation is the secret of orientalism, Bhabha demonstrates that oscillation is at the heart of the colonist." (Young, 1994, 14) Zie voor incoherentie in de Afrikaner "missie" ook Du Toit 1983.

${ }^{27}$ Crais 2002, 7
} 
multaneously, misapprehension and misunderstanding. ${ }^{28}$

Ondanks al deze complicerende factoren kan veilig verondersteld worden dat er in voorgaande jaren en eeuwen een reeks non-fictieve interculturele ontmoetingen hebben plaatsgevonden, die licht kunnen werpen op wat in literaire teksten uit de jaren zeventig en tachtig slechts spookachtig aanwezig leek.

Postmoderne benaderingen dragen door hun preoccupatie met het begrip discours het risico in zich basale dingen over het hoofd te zien ${ }^{29}$. De meest basale ingrediënten van de geschiedenis van het Zuid-Afrikaanse platteland waren aarde en water. Wel of geen toegang tot land en water vormden de belangrijkste redenen voor honger, oorlog, onteigening en structureel geweld. Land vormde (daarom) ook de basis voor de meest pregnante mythen en discoursen van Zuid-Afrika, maar kan daar andersom nooit geheel door worden gedefinieerd. Land was de gemeenschappelijke grond van verschillende discoursen, de arena van onontkoombare confrontaties, maar ook de ontmoetingsplek voor samenwerking en communicatie. Hoewel de harde, politieke geschiedenis er een was van ontworteling, onteigening, vervreemding, verpaupering en destructie, zijn ook schijnbaar monologische processen als overheersing of kolonisatie te zien als ontmoetingen tussen verschillende partijen ${ }^{30}$. Er is weinig aandacht geweest voor de reacties van de gekoloniseerden op deze ontmoetingen, maar dat wil bepaald niet zeggen dat ze er niet waren.

Toen vanuit de Kaap in de $18^{\mathrm{e}}$ en $19^{\mathrm{e}}$ eeuw de grenzen van de kolonie steeds verder oprukten naar het Noorden en Oosten, was steeds minder land van de zuidelijke punt van Afrika officieel in zwarte handen. Wel bleven er lange tijd frontier areas bestaan tussen blank en zwart grondgebied - ook binnen de koloniale grenzen. Vooral de blanke boerderijen werden de fluctuerende grensgebieden van het volgens de wet "blanke" Zuid-Afrika. Hier werden strijd en dialoog voortgezet. Tot in de jaren tachtig werden steeds verderstrekkende wetten aangenomen die tot doel hadden zwarte pachters en landarbeiders elk recht op de grond of zelfs op bewoning te ontnemen. Iedere wet had weer een nieuwe stroom uitzettingen tot gevolg, maar ook veel hardnekkig verzet en ontduiking. Over die kant van de geschiedenis, over de conceptuele voedingsbodem en de invloed van dit verzet, is nog veel onbekend. Recente geschiedkundige bronnen tonen aan dat in de jaren van kolonisatie en apartheid een belangrijk deel van de historische werkelijkheid nauwelijks opgetekend is en nu slechts nog

\footnotetext{
${ }^{28}$ Crais 2002, 6

${ }^{29}$ Zie bijvoorbeeld Chandra Talpade Mohanty "Under Western eyes: Feminist Scholarship and Colonial Discourses" Boundary 2 (1984); Benita Parry "Poblems in current theories of Colonial Discourse" Oxford Literary Review 9 (1987); en Clifton Crais, 2002.

${ }^{30}$ Crais 2002, 7
} 
gedeeltelijk kan worden achterhaald ${ }^{31}$. "We are left with an historical puzzle missing many of its most important pieces, pieces whose shape we can describe only indirectly and by inference and at times by conjecture, as so many "probable truths' ${ }^{32}$ of an elusive past" ${ }^{33}$.

Misschien is in sommige periodes literatuur, eerder of gemakkelijker dan geschiedschrijving, in staat geweest om verborgen werkelijkheden op wat voor manier dan ook vorm te geven. Als grensgebieden vormden de boerderijen niet alleen het decor voor juridische en economische schermutselingen en verschuivingen, maar ook voor semiotische processen. "In frontier areas", stelt Lotman, "semiotic processes are intensified because there are constant invasions from the outside. The boundary (..) is ambivalent and one of its sides is always turned to the outside." ${ }^{{ }^{34}}$ In deze semiotische processen speelt de dood, als metafoor voor zowel een grens als een grensoverschrijding, een belangrijke rol. Lakoff en Johnson waarschuwen ervoor dat "no metaphor can ever be comprehended or even adequately represented independent of its experiential basis" ${ }_{35}$. Dat is een van de redenen waarom ik in deze studie ook veel aandacht besteed aan niet-literaire teksten. Met behulp van aanvullende informatie uit historisch en antropologisch materiaal, zal ik proberen na te gaan in hoeverre in boerderijromans, de destijds "onzichtbare" alternatieve percepties van ruimte en geschiedenis, de semiotische invasies van buitenaf, zichtbaar gemaakt zijn, of te maken zijn. Met andere woorden: in hoeverre is het als schrijver, of als lezer, mogelijk om in de boerderijroman over de horizon van het pastorale of plaasdiscours heen te kijken en het land te zien als onderdeel van een andere werkelijkheid?

Om die vraag te kunnen beantwoorden zal ik eerst aandacht besteden aan het tot stand komen van een maatschappelijke orde en de bijbehorende (anti-)pastorale discoursen. De opkomst van de plaasroman in de jaren twintig en dertig van de $20^{\text {ste }}$ eeuw; het Afrikaner nationalisme waar de plaasroman veelal mee in verband is gebracht; en de grote maatschappelijke veranderingen die daaraan te grondslag lagen komen aan bod in Hoofdstuk 2. Ik heb ervoor gekozen me hier vooral op plaasromans te concentreren en niet op de plaasstories die (al eerder) in tijdschriften verschenen. Dit is deels omdat deze romans onderdeel zijn van een literaire canon en daardoor van grote invloed zijn geweest op werk dat in latere hoofdstukken aan de orde zal komen, en deels een gevolg van het feit dat ik me bij mijn keuze heb laten leiden door de mate waarin de dood als onderdeel van een pastoraal discours wordt opgevoerd. Desondanks ben ik me

\footnotetext{
${ }^{31}$ Zie bijvoorbeeld het werk van John en Jean Comaroff, Clifton Crais, Henry Bernstein, Charles van Onselen, Colin Bundy en William Beinart.

${ }^{32}$ Carlo Ginzburg, History Rhetoric and Proof Hanover \& London, 1999

${ }^{33}$ Crais 2002, 13

${ }^{34}$ Yuri Lotman, Universe of the mind. A semiotic theorie of culture, 1990:141/2

${ }^{35}$ Lakoff \& Johnson 1980, 19
} 
bewust van de schaduwzijde van die keuze: de tijdschriften bereikten een breder lezerspubliek dan de relatief schaars gedrukte boeken, en hebben daarom wellicht directer invloed uitgeoefend op het ontstaan van een Afrikaner identiteit. In hoofdstuk 3 plaats ik Engelstalige pastorale literatuur uit de jaren twintig en dertig tegen de geschiedenis van Brits (post)kolonialisme in Zuid-Afrika. Voor deze beide hoofdstukken geldt dat er speciale aandacht is voor landverdeling en interraciale verhoudingen op blanke boerderijen, zowel in literaire teksten als recente historische interpretaties. De discrepanties die in deze hoofdstukken worden aangetroffen tussen ideaal en werkelijkheid, tussen herinnering en geschiedenis, ambivalenties die sindsdien in boerderijdiscoursen, maar daarom ook in nationalistische, (post)koloniale en apartheidsdiscoursen verscholen hebben gezeten, zijn onmisbaar voor de interpretatie van de teksten die in hoofdstuk 5 en 6 aan de orde komen. Ook onmisbaar zijn daarbij mijns inziens discoursen rond de dood en het unheimliche, in Europese en Afrikaanse, maar vooral in een interculturele context. Ik pretendeer hierbij niet een volledig beeld te geven van de pastorale literatuur uit Zuid-Afrika in de twintigste eeuw. Om de samenhang tussen dood, identiteit en ruimte te kunnen onderzoeken, met andere woorden "to select a framework in which the relationship with which we are concerned may be clearly seen" ${ }^{36}$, heb ik me op die teksten gericht waarin zowel dood als ruimte een rol van betekenis spelen. In hoofdstuk 4 worden vervolgens verschillende literaire en sociaal-culturele opvattingen over de dood uiteengezet. Daarna maak ik een sprong naar de jaren zeventig, en kijk ik naar twee romans waarin de dood bijzonder centraal staat. Deze romans van Gordimer en Louw, die vrijwel tegelijkertijd verschenen, maak ik tot onderwerp van casestudies die het zwaartepunt, en eigenlijk ook het uitgangspunt vormen van dit boek.

Om niet al teveel in mijn eigen staart te bijten, wil ik hier even een ander aspect aanstippen, dat in feite buiten het bestek van dit boek valt. Ooit waren, zoals Michael Chapman het in zijn (postkoloniale) literatuurgeschiedenis stelde, "[t]he Xhosa bard and the settler journalist, though divided by language, literacy, race and probably sentiment, (..) both part of the same story" ${ }^{37}$. Wat is er in de literatuur van die Ander, die tenslotte de grens bepaalde van het territorium dat de bestaansgrond vormde voor de blanke minderheid, terug te vinden van het grensconflict? Of is de grens zo diffuus geworden, dankzij een geschiedenis van landwetten en volksverhuizingen dat er van een duidelijke andere stem in de geschreven literaire traditie nauwelijks meer sprake is?

Sol Plaatje gaf in 1916 een heel duidelijk antwoord op de Landwetten van 1913 met zijn boek Native life in South Africa, waarmee hij de Engelse

\footnotetext{
${ }^{36}$ Gerwel (16) citeert Ralph Ellison "Twentieth century fiction and the Black mask of humanity."

${ }^{37}$ Chapman 1996, XVII.
} 
Kroon hoopte te overtuigen van de onrechtvaardigheid van de nieuwe wet. Dat hij als politiek geëngageerde Afrikaan een boek over de plattelandsproblematiek schreef was echter een uitzondering. De meeste mensen uit zijn omgeving kenden aan de stedelijke problematiek een grotere prioriteit toe dan aan de drama's die zich op de boerderijen afspeelden. Romans van zwarte schrijvers speelden zich nauwelijks af op het platteland. Literatuur was lange tijd (ook) een politiek wapen en de politieke arena bevond zich in de steden ${ }^{38}$. Als het platteland al plaats van handeling was, dan betrof dat gemeenschappen waarin blanken nauwelijks een rol spelen. Blanke boeren zijn in de zwarte literatuur bijna net zo onzichtbaar als zwarte boeren in de blanke.

Dat er zo weinig zwarte antwoorden lijken te zijn, komt echter ook door de focus op het geschreven woord. Hoewel orale literatuur in deze studie wel aan bod zal komen, maak ook ik, door de aard van het onderzoek, uiteindelijk alleen gebruik van gedrukte bronnen ${ }^{39}$. Toch had het geschreven woord in Zuid-Afrika lang niet de centrale positie die het in West-Europa in dezelfde periode heeft gehad $^{40}$. Orale literatuur speelde van oudsher een belangrijke rol in (Zuid-)Afrika, vooral als het gaat om identificatie met het land. Die traditie is ondanks alle veranderingen en ontheemding blijven voortbestaan ${ }^{41}$. Deels omdat in het algemeen "oral cultures prove exceedingly stubborn and tenacious in their resistance to literacy," ${ }^{\prime 42}$ maar ook omdat de apartheidspolitiek de voorwaarden schiep voor haar voortbestaan en bloei. Geschreven literatuur van zwarte Zuid-Afrikanen werd bijvoorbeeld lange tijd alleen door de dominante cultuur gewaardeerd - en dus gepubliceerd - als het de apartheidsideologie ondersteunde en gebruikt werd om een cultuur te definiëren die zowel anders als machteloos was, een cultuur "with no national voice and no access to national memory" was, kortom, niet de bedoeling dat er op de ideologische boodschap van de pastorale roman een literair antwoord kwam. Soms kwam dat antwoord toch. H.I.E. Dhlomo en B.W. Vilakazi schreven in de jaren dertig en veertig van de vorige eeuw poëzie "concerned with loss - of land, nation, history - and each (..) was intent on a process of reclamation through culture. ${ }^{\prime 4}$ Hun respons was minimaal, omdat ze door het medium (en de taal)

\footnotetext{
${ }^{38}$ Chapman 1996, XVI

${ }^{39}$ Waaronder transcripties en vertalingen van orale literatuur.

${ }^{40}$ Voor een compleet beeld zullen uiteindelijk ook de andere media, die in Zuid-Afrika vaak veel invloedrijker zijn, onderzocht moeten worden. "Print, film, broadcasting and oral performance augment and diminish each other in a host of ways," schrijft Isabel Hofmeyr (Hofmeyr 1991, 652).

41 "Traditie" wordt hier niet gebruikt in de passieve, statische zin van het woord. Want hoewel het blanke minderheidsregime het begrip "traditie" misbruikt heeft om de eigen macht veilig te stellen en veel hedendaagse jongeren daardoor een hekel hebben gekregen aan alles wat het beeld van de Afrikaan als traditioneel, ruraal en exotisch bevestigt, is traditie tegelijkertijd door Afrikanen zelf gebruikt "as a necessary means of resisting white politics of divide and rule." (Gunner 1996, 41)

${ }^{42}$ Hofmeyr 1991, 634

${ }^{43}$ Gunner 1996, 121

${ }^{44}$ Gunner 1996, 121
} 
die ze gekozen hadden, afgesneden waren van een groot deel van hun zwarte publiek. Orale literatuur daarentegen bood als onafhankelijk medium veel meer mogelijkheden om een eigen boodschap uit te dragen, wat in hoge mate bijdroeg aan haar populariteit. Ook andere effecten van Apartheid droegen bij aan het voortbestaan van de orale literatuur: "in South Africa the demeaning landscape of Apartheid in which rural people were violently detached from their roots and torn from families and communities, has created, ironically, the psychological and social conditions for a thriving continuation and renewal of oral expression." ${ }^{45}$

Pas recentelijk erkent men in literaire studies schoorvoetend dat de grenzen tussen orale en geschreven literatuur poreus zijn: er ligt op dit gebied nog veel onderzoek braak. In het beperkte kader van deze studie zal ik van oorsprong orale literatuur slechts gebruiken voor zover ze van belang is als intertekstuele bron, of als betekenisgenererende context voor de romans of verhalen die ik bespreek. Uiteindelijk gaat het me om de boerderijromans en -verhalen zelf, en om de manier waarop in die teksten door intertekstualiteit, ambivalenties of "lege plekken", een andere perceptie van de werkelijkheid ruimte en/of vorm krijgt.

\subsection{THEORETISCHE UITGANGSPUNTEN}

Ik baseer dit boek op verscheidene theoretische uitgangspunten. De oorspronkelijk van Michel Foucault afkomstige theorie over objectivering van het subject door "discourses of power" 46 is een onvermijdelijke, ook al wil ik niet geloven in de absolute almacht van het discours. Ook in sommige theorieën over intertekstualiteit wordt gebruik gemaakt van Foucaults bevindingen, waaronder die van Julia Kristeva, die het begrip intertekstualiteit definieert als "a transposition of one (or several) sign system(s) into another" "47. Voor dit onderzoek is deze definitie zeer bruikbaar. De invloed van "zwarte" "tekensystemen" is in de "blanke" Zuid-Afrikaanse literatuur overal merkbaar. Soms in de vorm van verhalen: in The story of an African farm (1880) van Olive Schreiner vertelt een niet nader benoemde vreemdeling een versie van een oude San mythe. Zelfs al zou de schrijfster zich, zoals Chapman beweert, niet bewust zijn van de oorsprong van het verhaal ${ }^{48}$, dan nog is er een tegenstem hoorbaar, hoe vertekend ook. J.M. Coetzee weet een eeuw later in elk geval wel wie zijn inspiratiebronnen zijn: hij maakt het proces van existentiële toe-eigening en objectivering regelmatig tot onderwerp van zijn romans. In Waiting for the barbarians

\footnotetext{
${ }^{45}$ Gunner 1996, 41

${ }^{46}$ Bullock \& Trombley, 230. Zie bijvoorbeeld Michel Foucault, The order of things, 1966; Discipline and punish, 1975

${ }^{47}$ Julia Kristeva, Revolution in poetic language. New York, Columbia University Press, 1984: 59

${ }^{48}$ Chapman 1996, 29
} 
verwijst hij zowel naar het verhaal van hoe Bleek en Lloyd aan hun San verzen kwamen als naar de thematiek uit de verzen zelf. Ook in andere boeken die hier besproken zullen worden, komen dergelijke verwijzingen voor. Soms gebeurt dit in de vorm van expliciete verwijzingen naar bepaalde masterteksten, een andere keer gaat het om de ogenschijnlijk onbetekenende aanwezigheid van de volle maan of een rivier. Deze kunnen de aanwezigheid of de invloed van een ander wereldbeeld verraden, waardoor er zelden sprake is van een blank Zuid-Afrikaanse tekst, maar van wat Kristeva noemt "a field of transpositions of various signifying systems (an inter-textuality)" ${ }^{\prime 49}$. Immers:

every artefact carries with it an index - though an imperfect one - to the culture which produces it. (...) Such artefacts can change, subvert, or destroy the cultures they are carried into - not just the arrow heads, the pots as well. Even trinkets can 'buy' Manhattan, introducing with them an alien concept of land ownership ${ }^{50}$.

Het lezen van de tekst als dooreengevlochten of concurrerende discoursen is van invloed op de invulling van de "intertekstuele ruimte", dat wil zeggen: "the realm in which all signifying practices (..) exist in the consciousness of writers and readers" " , al is moeilijk vast te stellen wat eerst kwam: de tekst, of het betekenen. "Like outer space," stelt Andrews, "intertextual space in a given culture would seem to be constantly expanding. But how can we tell when and how such expansion of discursive space takes place?" ${ }^{2}$ Een belangrijk aspect van deze vraag is wat de invloed is van (de positie van) het schrijvende, vertellende of focaliserende subject op het proces van betekenisgeving. Of zoals Barbara Johnson schreef over Mallarmé die in zijn tijd probeerde de tot zwijgen gebrachte vrouwen een stem te geven: "Mallarmé may be able to speak from the place of the silenced woman, but as long as he is occupying it, the silence that is broken in theory is maintained in reality." ${ }^{\prime 33}$

Dit lijkt ook van toepassing op blanke schrijvers in Zuid-Afrika in de jaren zeventig. Er vond in die tijd nog steeds een dialoog plaats in de boerderijroman, maar die dialoog werd steeds meer een interne dialoog. De Ander die voorheen zo duidelijk te herkennen was, met een eigen cultuur en geschiedenis, en vooral een eigen ruimte, wordt binnen het territorium van de boerderij en de boerderijroman steeds ondefinieerbaarder, terwijl zijn aanwezigheid desalniettemin onmiskenbaar is. Tegelijkertijd wordt het Ik -

\footnotetext{
${ }^{49}$ Julia Kristeva, Revolution in poetic language. New York, Columbia UP, 1984: 59

${ }^{50}$ Ward 1989, 4/5 )

${ }^{51}$ Andrews 1991, 300

${ }^{52}$ Andrews 1991, 301

${ }^{53}$ Johnson, Barbara "Les fleurs du Mal Armé: Some reflections on intertextuality" In: $A$ world of difference Baltimore, John Hopkins UP, 1987, 133
} 
het schrijvende, vertellende of focaliserende subject - een gespleten, in M.M. Bakhtins terminologie "double-voiced" subject. ${ }^{54}$

Dit is geen onbekend verschijnsel binnen de (post)koloniale literatuur ${ }^{55}$. Immers, het gebruik van sociale identiteiten die gebaseerd zijn op verschillen in ras, is een politiek geïnspireerde constructie van de werkelijkheid. "Race," stelt Aldon Nielsen ten aanzien van de Verenigde Staten,

serves simultaneously as the means by which hegemonic discourse organizes its policing functions, erecting boundaries that define and oppress an other, and as the ever shifting strategic locus from which others assault and reterritorialize American identity. (..) Clearly, "races" are textbook examples of discursive formations. ${ }^{56}$

Het onderscheiden van Ik en Ander is een "nomadic affair of constant 'othering', in which white [American] writers describe the black as radically other, and black [American] writers describe themselves as radically other than what the 'others' have defined as their ontological reality." ${ }^{57}$ Waar echter de blanke Amerikaan zich dankzij zijn of haar onbedreigde positie niet bezig hoeft te houden met hoe een zwarte Amerikaan hem of haar definieert, was dit voor de blanke Zuid-Afrikaan een heikele en steeds dringender kwestie. Natuurlijk hoorden blanke Zuid-Afrikanen tot de machthebbers die het dominante discours konden bepalen, maar ze behoorden ook tot de (numerieke) minderheid die zich bedreigd voelde in haar eigen identiteit. Deze minderheidsstrijd was een schaduwgevecht: zijn of haar "ontologische realiteit" werd, anders dan voor de zwarte Amerikaan, immers niet openlijk door de ander gedefinieerd, omdat die daar de macht en de middelen niet toe had. Maar dat wil niet zeggen dat ze er niet waren, of zelfs dat ze niet tot het algemeen gedachtegoed hoorden. Nu de machtsbalans verschoven is, gelden er nieuwe waarheden en percepties. Veranderde waarheden, of waarheden die eerder niet benoemd werden. Toch waren veel van die concepten, ondanks hun ondergronds bestaan, ook voorheen "of great importance in the colonial encounter"s8.

Wat betreft de (geschreven) literatuur geldt voor Zuid-Afrika evengoed als voor de Verenigde Staten dat "[a] black line [is] drawn by pens in white hands around the constituted field of the literary in an attempt to bring into being an inside and an outside, to create an aesthetic space determined by race" 59 . Een dergelijke tweedeling verhult echter de gelaagdheid en interne tegenstellingen van het dominante discours. In de woorden van Lisa Lowe:

\footnotetext{
${ }^{54}$ Zie bijvoorbeeld The dialogic Imagination (1981) en Problems of Dostoevski's poetics (1984).

${ }^{55}$ Zie bijvoorbeeld Gates (1988) Bhabha (1994) en Nielsen (1994).

${ }^{56}$ Nielsen, 3

${ }^{57}$ Nielsen, 11

${ }^{58}$ Crais 2002,7

${ }^{59}$ Nielsen, 8
} 
iThe view that a dominant discourse produces and manages others, universally appropriating and containing all dissenting positions within it, underestimates the tensions and contradictions within a discourse, the continual play of resistance, dissent and accommodation by different positions. By beginning to account for resistance, yet continuing to recognize the functioning category of "otherness" in discourse, I believe we must consider instead the heterogeneity of acts of representation (..) Discourses are what I call "heterotopical": discourses are heterogeneously and irregularly composed of statements and restatements, contestations and accommodations, generated by a plurality of writing positions at any given moment. ${ }^{60}$

In navolging van Homi Bhabha zie ik dialoog dan ook niet persé als een "gesprek" tussen gelijkwaardige en gelijkgestemde gesprekspartners, maar ook als een "clash between languages and utterances which can foreground not only social division but a radically divided space of discursive formations within an individual subject" ${ }^{\prime 61}$. Bhabha noemt deze gespletenheid hybridity: "a difference 'within', a subject that inhabits the rim of an 'inbetween' reality" ${ }^{\prime 2}$. Nielsen propageert op grond van dergelijke inzichten een "interraciale" intertekstuele lezing van literaire teksten die niet blijft hangen in monologische definities van raciale of culturele identiteit ${ }^{63}$.

Literaire ruimte is per definitie gebonden aan tijd en aan perceptie. Deze ruimte wordt gevuld met herinneringen, vrees en hoop, waardoor het als realiteit afhankelijk is van degene die de ruimte waarneemt en ervaart. ${ }^{64} \mathrm{Het}$ is een abstractie, afgeleid, aldus Gúllon, uit de

realities in which we function. If it can be imagined, it is because it can be thought of, and consequently, 'understood', at least up to a certain point. However, if in an effort to 'understand' the abstraction, we merely translate 'space' for 'universe', 'world' or 'scenario', we are really only escaping through the back door and degrading the question, reducing the intangible to the tangible; the connection between these terms is, nevertheless, certain: all of them refer to creation and, in our context, literary creation. All allude to a zone in

\footnotetext{
${ }^{60}$ Lowe, $142-143$

${ }^{61}$ Allan 2000, 165

${ }^{62}$ Bhabha 1994, 13

${ }^{63}$ Nielsen baseert zich hier vooral op Kristeva: "If one grants that every signifying practice is a field of trans-positions of various signifying systems (an inter-textuality), one then understands that its 'place' of enunciation and its denoted 'object" are never single, complete and identical to themselves, but always plural, shattered, capable of being tabulated. (Julia Kristeva, Revolution in poetic language. New York, Columbia UP, 1984: 59-60)

${ }^{64}$ Gúllon 1975, 12
} 
which one is situated, in which one lives, but while the substitute terms seem to postulate life, movement, and situated objects, the original is somewhat indifferent, and remains aloof, in an almost insolently proud solitude. ${ }^{65}$

Mieke Bal (1997) kent een tekst drie lagen toe, en iedere laag heeft zijn eigen "ruimte". In de onderliggende structuur van de tekst, de fabula", wordt de ruimte aangeduid met place of locatie. In het verhaal, de manier waarop de elementen uit de fabula (tijd, plaats, gebeurtenissen en actoren) worden gepresenteerd, wordt de locatie gekoppeld aan de waarneming en ervaring van een focalisator en wordt zodoende space of ruimte. In de narratieve tekst, de manier waarop een verhaal door een bepaalde verteller wordt verteld, krijgt die ruimte de beschrijving, de bewoordingen van de betreffende verteller.

Een fabula hoeft niet perse literair te zijn. Mythen, rituele handelingen, alledaagse gewoonten en partijprogramma's hebben ook een fabula ${ }^{67}$. Gordimer maakt in The conservationist gebruik van de fabula van verschillende mythen en rituelen om Mehrings werkelijkheid gestalte te geven. Zoals gezegd zijn mythen in de meest algemene zin verhalen die verklaren waarom dingen zijn zoals ze zijn ${ }^{68}$. Ze hebben invloed op het definiëren en begrenzen van groepen, het vaststellen van $\mathrm{Wij}$ en $\mathrm{Zij}$, niet alleen door de informatie die ze overdragen, maar ook door de overdracht zelf: "a discursive act through which actors evoke the sentiments out of which society is actively constructed" ${ }^{\prime 9}$. Het herhaaldelijk vertellen en horen (lezen) van mythen creëert een gemeenschappelijke basis (een gedeelde oorsprong of geschiedenis, gemeenschappelijke helden en vijanden) en dus een gevoel van saamhorigheid en identiteit voor de toehoorders. Op het niveau van verhaal en tekst worden de basiselementen van de fabula gekoppeld aan het heden, de herinnering of de toekomstvisie van verteller en publiek en krijgt het zijn ideologische lading. Zoals Barthes zei: "myth has the task of giving historical intention a natural justification, and making contingency appear eternal" "7. Dit gebeurt volgens Lévi-Strauss niet in het verhaal zelf, maar in de onderliggende structuur, dat wat Bal fabula noemt. In die onderliggende structuur worden de basiselementen zo tegenover elkaar geplaatst dat tegenstrijdigheden worden opgelost. ${ }^{71}$

Een van die basiselementen is de ruimte waarin het verhaal zich afspeelt: dat wat Bal locatie noemt en Gúllon the original. Bals space zal vergelijk-

\footnotetext{
${ }^{65}$ Gúllon 1975, 13/4

${ }^{66}$ Een fabula is "a series of logically and chronologically related events that are caused or experienced by actors." Bal 1997, 5

${ }^{67}$ Bal 1997, 178

${ }^{68}$ Zie hoofdstuk 1

${ }^{69}$ Lincoln 1989, 25

${ }^{70}$ Roland Barthes, Mythologies, 1972: 142.

${ }^{71}$ Bullock et al, 2000, 555
} 
baar zijn met Gúllons "realities in which we function"72. Maar waar Gúllons originele abstractie ongrijpbaar is, is Bals locatie weliswaar een afgeleid begrip, maar wel de meest concrete van haar ruimtelijke concepten. "The concept of place is related to the physical, mathematically measurable shape of spatial dimensions, "' ${ }^{\prime 3}$ stelt Bal, terwijl space de ruimte is die verbonden is aan een bepaalde perceptie - namelijk die van de focalisator. Toch verraadt haar definitie van het in principe neutrale begrip locatie ook al een perceptie, namelijk een positivistisch wereldbeeld dat onderscheid maakt tussen "waar" en "niet-waar" en waarin dus slechts één echte (feitelijke, meetbare, zichtbare) ruimte bestaat. Maar de empirische principes van onze geografie zijn niet universeel geldig. Er bestaat niet zoiets als een perceptieloze ruimte; ruimte is per definitie onderdeel van een wereldbeeld en dus van een verhaal. Wat daarbuiten valt is, vanuit dat wereldbeeld, irrelevant en wordt daardoor niet waargenomen of erkend". Of de "physical, mathematically measurable" kenmerken van Bals "concrete" ruimte "waar" zijn, hangt ervan af of ze worden waargenomen en is dus afhankelijk van de waarnemer: de focalisator en, uiteindelijk, de lezer. "The map", stelt Vivan, "is part and parcel of the game of representation and as such it may skip the reader's attention, in a way not dissimilar from that of narrative discourse. Both map and narrative adopt fictional techniques and a strategy of veiling/unveiling leading from cartography to cryptography." 75 Bij de bestudering van ruimte in een tekst die zich in een intercultureel strijdperk bevindt, zoals de roman van Gordimer, staan er onvermijdelijk meerdere waarheden tegenover elkaar, in verschillende mate van gesluierdheid. In feite, zo zal blijken, worden er meerdere "kaarten" over elkaar gelegd.

De vraag is dus misschien niet zozeer of en hoe er ruimte voor de ander gecreëerd kan worden vanuit het dominante discours, maar of en hoe we kunnen (h)erkennen dat de grenzen van dat discours arbitrair zijn. Johnson's hierboven genoemde veronderstelling dat het spreken van de een het zwijgen van de ander impliceert wordt hiermee weersproken. Juist het steeds opnieuw bevestigen van elkaar uitsluitende categorieën wil Nielsen vorkomen. Zijn ideale manier van lezen is

a reading willing to take writing wherever it can go, rather than a reading that always and only finds itself already written into the text as a single and self-possessing subjectivity. (..) Such a reading requires that we find meaning in texts in their relation with other texts. (..) It is a matter of recognizing the permeability of the walls racism has

\footnotetext{
${ }^{72}$ Gullon $1975,13 / 4$

${ }^{73}$ Bal 1997, 133

${ }^{74}$ Zie Hoofdstuk 4; Kommers 1994, 66; Vivan 2000, 51

${ }^{75}$ Vivan 2000,50
} 
erected in language (..). In its most basic sense, intertextuality describes, not just the direct textual sources exercising an influence upon a subsequent text, but the transposition of sign systems. ${ }^{76}$

Om hybriditeit in de tekst te kunnen onderkennen is bestudering van focalisatie onontbeerlijk. Net als historicus Crais zei te willen weten wie de mannen met en zonder geweren waren, wat ze dachten en wat ze zagen ${ }^{77}$, is in dit onderzoek de narratologische vraag van belang wie wat zegt en ziet: wie definieert of kleurt de ruimte. Maar misschien nog belangrijker in dit verband, om te voorkomen dat er dankzij de representatie van "signifying blindness" ${ }^{\text {" }} 8$ een lezing geproduceerd wordt die "only finds itself already written into the text as a single and self-possessing subjectivity" ${ }^{\prime \prime 9}$ is de vraag: wie spreekt en kijkt niet en wat blijft daardoor onzichtbaar? En hoe is het mogelijk dat er ondanks die eenzijdige stilte, ondanks de blindheid, toch een interne "difference" zichtbaar wordt?

In dit proces blijken dode personages een belangrijke rol te spelen. Op grond van uitgangspunten uit de culturele studies, waarin literaire teksten, net als andere culturele teksten, worden beschouwd als een van de vele vormen van culturele representatie die elkaar voortdurend beïnvloeden, kan de literaire functie van de dood worden vergeleken met de sociaal-culturele functie. Sterker nog: omdat niemand de dood kan waarnemen, krijgt de dood zowel in een sociaal-culturele als in een literaire context vooral betekenis als metafoor, wat wil zeggen: als verwijzing naar iets anders ${ }^{80}$ binnen een geheel aan vertellingen: persoonlijke verhalen, geschiedschrijving, collectieve mythen, rituelen.

Vooral in de laatste twee categorieën is er een duidelijk verband te zien tussen ruimte en dood. Zowel mythen als (begrafenis)rituelen zijn instrumenten die gebruikt worden voor het trekken of bewaken van sociale, maar ook geografische grenzen.

Ritual can be seen as a literal presentation of the set of metaphors through which death is encountered in a particular society. Within the framing of ritual time and space, everyday objects and familiar spatial and temporal arrangements are re-ordered, thereby evoking participants' most fundamental physical and emotional experience and bringing it to line with the most abstract cosmological theorising" ${ }^{\prime 1}$.

\footnotetext{
${ }^{76}$ Nielsen, $22-23$

${ }^{77}$ Crais 2002, 11

${ }^{78}$ Nielsen, 11

${ }^{79}$ Nielsen, 23

${ }^{80}$ De essentie van een metafoor is "understanding and experiencing one kind of thing in terms of another". (Lakoff \& Johnson 1980, 5)

${ }^{81}$ Hockey 1990, 89
} 
Mythen zijn in de meest algemene zin verhalen die verklaren waarom alles is zoals het is. De antropoloog Lévi-Strauss heeft een belangrijke impuls aan het mytheonderzoek gegeven door te stellen dat de werkelijke betekenis van de mythe niet in het verhaal zelf, maar in de onderliggende structuur ligt: de manier waarop elementen tegenover elkaar geplaatst worden, met als doel tegenstrijdigheden op te $\operatorname{lossen}^{82}$. $\mathrm{Na}$ en naast Lévi-Strauss' structuralistische benadering is er nadruk komen te liggen op de politieke en maatschappelijke implicaties van het gebruik van mythen. Roland Barthes noemde mythe bij uitstek ideologisch en benadrukte dat "myth has the task of giving historical intention a natural justification, and making contingency appear eternal" ${ }^{\prime 3}$. Dat wil niet zeggen dat mythen perse de status quo handhaven, ze kunnen ook gebruikt worden als middel om sociale of politieke verandering te bewerkstelligen: "change comes (..) when [groups or individuals] employ thought and discourse, including even such modes as myth and ritual, as effective instruments of struggle" ${ }^{{ }^{4} 4}$.

Met name rituelen hebben een transformerende werking; het ritueel kan gedefinieerd worden als "a coherent set of symbolic actions that has a real, transformative effect on individuals and social groups" ${ }^{85}$. Vaak vindt die transformatie plaats van de ene erkende categorie naar de andere erkende categorie binnen de grenzen van een groep: van "meisje" naar "vrouw", of van "levende" naar "dode". Maar er kan ook een herdefiniëring van (sub)categorieën plaatsvinden. Mythen en rituelen hebben in elk geval, en dat is ook waarom ze zo belangrijk zijn bij de bestudering van literaire ruimte, invloed op het definiëren en begrenzen van groepen; het vaststellen van Wij en $\mathrm{Zij}$. Het is zelfs zo dat een literaire tekst de vorm en functie kan hebben van een ritueel, met name bij schrijvers die zich tussen twee culturen bevinden en zich bewust zijn van de "conflicting or differing ritualized ways" waarin de werkelijkheid wordt ervaren ${ }^{86}$. Mythen en rituelen zijn niet alleen een "coding device in which important information is conveyed, on the basis of which actors can then construct society. It is also a discursive act through which actors evoke the sentiments out of which society is actively constructed." ${ }^{87}$. Die actieve constructie is in een samenleving die aan fundamentele verandering onderhevig is voor alle partijen van levensbelang. De januskop van de dood, als metafoor voor zowel stabiliteit en verandering, duikt hierbij steeds weer op.

\footnotetext{
${ }^{82}$ Bullock et al. 2000, 555

${ }^{83}$ Roland Barthes, Mythologies, 1972, 142.

${ }^{84}$ Lincoln 1989, 7

${ }^{85}$ Bruce Llincoln Emerging from the Chrysalis: studies in the Rituals of Women's initiation. Cambridge: Harvard UP 1981 (2-3)

${ }^{86}$ Elsbree, 4

${ }^{87}$ Lincoln 1989, 25
} 
Mijn doel is niet alleen te onderzoeken in hoeverre er een alternatief discours zichtbaar gemaakt wordt of gemaakt kan worden in twee boerderijromans uit de jaren zeventig, maar ook hoe dat gebeurt en hoe de dood daarin vorm krijgt. In welke betekenisvelden wordt de dood geplaatst, aan welke andere metaforen wordt hij/zij gerelateerd? Is de dood in staat een uitweg te bieden uit een schijnbaar gesloten discours? En zo ja, heeft dat dan te maken met de waarneming van de Ander (en/of van de werkelijkheid die die Ander waarneemt), of met de formulering van een andere eigen identiteit? Of gaan die twee dingen altijd gelijk op? Met behulp van discoursanalyse en close reading, gefocust op narratologische keuzes (wie ziet wat (wie creëert welke ruimte) en zegt wat; wie ziet en zegt wat niet) en intertekstuele verbanden, zal ik proberen te achterhalen hoe dood en ruimte in verschillende teksten uit verschillende tijden in elkaar grijpen en betekenis en/of identiteit genereren, en welke invloed de maatschappelijke omstandigheden en veranderingen op dit proces hebben. 
Ek het 'n huissie by die see. Dis nag.

Ek hoor aaneen, aaneen die golwe slaan teenaan die rots waarop my huissie staan met al die oseaan se woeste krag.

Ek hoor die winde huil - 'n kreun, 'n klag soos van verlore siele in hul nood al dwalend, klagend, wat in graf en dood geen rus kon vind nie, maar nog soek en smag.

My vuurtjie brand, my kersie gee sy lig.

Ek hoor dan maar hoe loei die storm daarbuite, ek hoor hoe ruk die winde aan my ruite;

hierbinne is dit veilig, warm en dig.(..)

H.A. Fagan, 1949

\section{"Alleen in die wye eensaamheid" De besloten domeinen van plaas en plaasroman}

\subsection{INLEIDING}

In 1990, terwijl heel Zuid-Afrika zich hoopvol en/of met angst en beven opmakkte voor de dingen die komen gingen, dingen die niemand kon overzien, was in het godsdienstmuseum in Kimberley een tentoonstelling te zien die volledig gericht was op het verleden. Prehistorische rotstekeningen van de San werden afgewisseld met tableaus van vuurmakende "Boesmans"; een weinig verrassende reeks, tot vlak voor de uitgang. Op iets dat eruit zag als een ouderwetse schoolplaat waren tekeningen te zien van planten en dieren, onder de titel: "Local plants and animals mentioned in the bible." De plaat intrigeerde me bijzonder. Wat was de bedoeling ervan? Was het een conclusie? Een relativering? Een herinnering? Was het de bedoeling het christendom een Zuid-Afrikaanse "oorsprong" te geven, of Zuid-Afrika een bijbelse, minstens zo oud en onweerlegbaar als de rode rotstekeningen?

Het gaat waarschijnlijk nog verder. Liz Gunner schreef over Zulu praise poetry:

J.M. Coetzee has spoken of the schema of seeing which operates in turning landscape and which modifies the vision of white painting and letters. What operates as a schema in the Zulu and Sotho poetry from which I have been quoting is what could be called a schema of naming; what is in fact in operation is an aesthetics [or metaphysics] 
of naming as the land and the elements are absorbed into the names of people and become signifiers of poetry that is both biography and autobiography. These names in turn become reabsorbed in the poetic (auto)biographies and statements of identity of successive generations. (..) Even fine details of flora and fauna as well as place in the sense of locality, of particular places, can be absorbed into the personal through praise poetry which names and identifies a person. In (..) this poetry the land frequently becomes the person, and becomes part of the body's text; the social and historical self is perceived through the land. ${ }^{88}$

Gunner schrijft hier over een bepaald genre in de Zulu en Sotho poëzie, waarin het gedicht fungeert als postuum portret van een belangrijk persoon. Ik zal in dit boek proberen aan te tonen dat een dergelijk soort identificatie met het land evenzeer plaats heeft gevonden in Afrikaanstalige en Engelse teksten, geschreven door blanke Zuid-Afrikanen. En dat de benoeming, toeeigening en inrichting van het land evenzeer voor boeren als voor dichters en schrijvers een bron van strijd en concurrentie, maar ook van herkenning was.

Hetzelfde geldt voor de geschiedenis. Met zijn revolutionaire, invloedrijke theorie over het geheugen als sociale constructie maakte Maurice Halbwachs onderscheid tussen collectieve herinnering en geschiedenis ${ }^{80}$. Geschiedenis pretendeert in al zijn objectieve wetenschappelijkheid een universeel geheugen te zijn, maar ook geschiedenis bestaat bij de gratie van mensen die zich herinneren. Soms zal de collectieve herinnering van een bepaalde groep samenvallen met wat op dat moment voor "geschiedenis" doorgaat. Maar door de twee naast elkaar te laten bestaan, maakte Halbwachs ruimte voor "tegenstromingen" die het dominante discours bestrijden. Sociale herinnering is in Halbwachs definitie altijd gekoppeld aan "social forgetting: every act of recall entails an act of oblivion," en "the alienation or exclusion of any individual from social memory will be tantamount to both social extinction and deprivation of identity"90. Bovendien heeft geen enkele collectieve herinnering het eeuwige leven: "de in tijd en plaats begrensde groep, [zal] dat geheugen alleen (..) bewaren zolang beelden uit het verleden nog in het heden doorwerken en daarin een rol spelen"'.

Met de opkomst van culturele studies is de focus op het collectieve geheugen verschoven van het sociale naar het culturele domein, een interdisciplinair onderzoeksveld van geschiedenis, psychoanalyse, literaire en postkoloniale studies. Hierin speelt ook de empirische werkelijkheid een rol: om

\footnotetext{
${ }^{88}$ Gunner 1996, 120

${ }^{89}$ Maurice Halbwachs. On Collective Memory. Chicago University Press 1992 (1925)

${ }^{90}$ Crewe 1999, 75

${ }^{91}$ Jonker 1993, 27.
} 
beelden uit het verleden te kunnen vasthouden, heeft het collectieve, culturele geheugen onveranderlijke elementen nodig: huizen, steden, landschappen. Plus een waarneming van die geografische werkelijkheid, gestuurd door verhalen, genealogieën en monumenten: tempels, paleizen, beelden, graven $^{92}$. Het Zuid-Afrikaanse landschap maakt zo onderdeel uit van het Zuid-Afrikaanse culturele geheugen, evenals de interpretatie van dat landschap (zoals bovengenoemde plaat in het museum van Kimberley), en de (literaire) teksten die het landschap, of de inrichting van het landschap beschrijven. Volgens Crewe is de rol van literaire teksten in de constructie van de culturele herinnering lang onderschat gebleven, ondanks het feit dat "the historic functioning of literature as cultural memory can hardly be disputed, especially if 'literature' is broadly interpreted as to include sanctioned cultural lore like myth, legend, oral tradition, charged historical episodes, folk tales, hagiography, and anecdote" ${ }^{93}$.

De boerderijroman gaat bij uitstek over landinrichting en een daaraan gekoppelde culturele identiteit. In boerderijromans zijn centrum en periferie als vanzelf ruimtelijk bepaald, en is er langs de grenzen van de boerderij een voortdurende wisselwerking tussen binnen en buiten: cultuur en natuur, beschaving en barbarij, wij en zij. De plaasroman kwam tot bloei tijdens de overgang van een prekapitalistische, agrarische samenleving naar een industriële samenleving, een transformatie die zich in een paar decennia voltrok en de bestaande orde verbrijzelde, wat bij grote delen van de bevolking tot grote onzekerheid, zo niet grote armoede leidde. Het is geen toeval dat juist in deze tijd romans werden geschreven die zich richtten op wat gepresenteerd wordt als een oude, "natuurlijke" orde in een helder afgebakend territorium: de plaas, met haar in een naam gevangen geschiedenis, haar zelf getrokken grenzen, eigen wetten en moraal. Het is evenmin toevallig dat in dezelfde periode de Zulu dichters Dhlomo en Vilakazi hetzelfde doen; in hun poëzie "history speaks through the rewriting of the land and its names. ${ }^{{ }^{44}}$ Susan Bassnett stelt in Comparative Literature dat in alle "struggling cultures" dat wil zeggen culturen die in een proces zitten, die zekerheden zijn kwijtgeraakt, aan invloeden onderhevig zijn, die dreigen te verdwijnen of ten prooi zijn (geweest) aan onderdrukking, schrijvers op zoek gaan naar houvast: tradities, verleden, oorsprong ${ }^{95}$. Het afbakenen van een territorium in ruimte en tijd lijkt dus met elkaar verband te houden. Alsof iets uit het verleden het recht op culturele en geografische ruimte moet bewijzen, en vice versa: de ruimte bevestigt het verleden, de oorsprong. Bassnett doelt vooral op culturele of politieke ruimte (naties), maar in het geval van Zuid-Afrika is die ruimte (ook) heel letterlijk op te vatten als de afbakening van een stuk land.

\footnotetext{
92 Jonker 1993

${ }^{93}$ Crewe 1999, 76

${ }^{94}$ Gunner 1996, 123

${ }^{95}$ Bassnett 1993, 14
} 
Dit hoofdstuk behandelt het ontstaan en de ontwikkeling van de plaas $^{96}$, en de bloei van de plaasroman als twee verschillende, maar elkaar beïnvloedende culturele herinneringen of representaties die hebben doorgewerkt tot op zijn minst het eind van de twintigste eeuw. Om tegendiscoursen, interculturele intertekstuele verbanden, en alternatieve percepties van ruimte in moderne plaasromans te kunnen traceren is niet alleen kennis van de geschiedenis van de plaasroman noodzakelijk, maar ook van andere discoursen, in het bijzonder van de geschiedenis van de plaas. Kolonisten betrokken het territorium van een ander en bakenden daarbinnen een eigen (existentieel) territorium af dat echter altijd, van binnen uit en van buiten af, bevochten zou blijven worden. Schrijvers gebruikten hun eigen interpretatie van die bakens vervolgens als basis voor de formulering van een culturele identiteit ${ }^{97}$. De kiem voor de onderhuidse explosiviteit uit de teksten uit de jaren zeventig is voor een groot deel gelegd door wat in de eerste boerderijromans gezegd én (opnieuw) verzwegen werd.

\subsection{DE BOERDERIJROMAN: SCHEPPING VAN EEN TIJDLOOS TERRITORIUM}

Cruciaal voor het ontstaan van de plaasroman is de periode geweest tussen de Boerenoorlog (1899- 1902) en de invoering van apartheid in 1948. Met name de jaren tussen 1920 en 1940 waren jaren van economische crisis, van groeiende tegenstellingen tussen zwart en wit en van grote, snelle maatschappelijke veranderingen. Uit deze tijd stamt het verbod op interraciaal seksueel verkeer, de afschaffing van het zwarte Kaapse kiesrecht en toenemende restricties voor zwarte boeren. Zowel Engels- als Afrikaanssprekende blanken leken het er over eens te zijn dat "het nieuwe ZuidAfrika" ${ }^{98}$ er was voor de blanken. De blanke literatuur werd daarentegen gekenmerkt door een opvallend zwijgen over raciale kwesties.

Binnen de blanke gelederen ontstond ook een tegenstelling, namelijk tussen een internationaal georiënteerd, kapitalistisch ingesteld deel van de bevolking (voor een groot deel, maar zeker niet uitsluitend, Engelstalig), en een verpauperende groep van vaak Afrikaanssprekenden: niet of nauwelijks geschoolde arbeiders en landloze of niet-commerciële boeren. Op het platteland was de situatie in deze periode zo nijpend, dat men spreekt van "de plattelandscrisis". Deze crisis en de veranderingen die er het gevolg van waren, troffen veel Zuid-Afrikanen in hun ziel. Romans weerspie-

\footnotetext{
${ }^{96}$ Volgens het Verklarende Handwoordeboek van die Afrikaanse Taal (1988) is plaas “"n Stuk grond waarop geboer word."

${ }^{97}$ Zie bijvoorbeeld Hofmeyr 1987, 95

98 "New South Africa" is een term die ook na de eerste democratische verkiezingen in de jaren negentig in zwang was, maar hier gebruikt werd om aan te duiden dat na de Boerenoorlog Boeren en Britten nu de handen ineen geslagen hadden in de Unie van Zuid-Afrika (1910)
} 
gelden dit. Tussen 1920 en 1940 "the Afrikaans novel concerned itself almost exclusively with the farm and platteland society, with the Afrikaners painful transition from farmer to townsman." "99 Maar ook de Engelstalige literatuur liet een opvallende belangstelling zien voor het Zuid-Afrikaanse platteland.

Wat de Zuid-Afrikaanse pastorale literatuur van de twintigste eeuw betreft wordt in vrijwel alle studies onderscheid gemaakt tussen de Engelstalige (van bijvoorbeeld Olive Schreiner, Herman Charles Bosman, Pauline Smith, Nadine Gordimer) en de Afrikaanstalige. Ampie Coetzee, die zich in 'n Hele os vir ' $n$ ou broodmes (2000) op uitsluitend Afrikaanstalige boerderijromans richt, benadrukt de verschillen: "[Dat] Nadine Gordimer se The Conservationist al gelees [is] as ' $n$ aanduiding van die einde van 'die SuidAfrikaanse pastoraal' (...) sou miskien kon verwys na Engelse letterkunde in Suid-Afrika, waar die soeke na betekenis nooit werklig gerig is op grond en die plaas nie." J.M. Coetzee is in White writing (1988) iets voorzichtiger, maar ook hij betoogt dat de Engelse schrijver de boerderij niet helemaal benadert zoals een Afrikaner dat doet. De eerste staat misschien meer in een Engelse (koloniale) traditie dan in een (lokale, nationale) Afrikaanse. "In their different ways [English farm novelists] conceive - indeed, cannot help conceiving - the farm in a wider context than the Afrikaans farm novelist. At the very least they provide a foil to the plaasroman, throwing its preconceptions into relief" ${ }^{100}$. Wat beide tradities volgens J.M. Coetzee wel gemeen hebben is hun dubbele taak: 1. de deugden van het platteland benadrukken tegenover de ondeugden van de grote stad en 2 . het hooghouden van de gecultiveerde tuin ("the garden in bloom") tegenover de tuin die afglijdt naar wildernis. De literatuur die hieruit voortkomt, heeft de volgende kenmerken:

It is essentially conservative (...); it looks back, usually in a spirit of nostalgia, to the calm and stability of the farm, a still point mediate between the wilderness of lawless nature and the wilderness of the new cities; it holds up the time of the forefathers as an exemplary age when the garden of myth became actualized in history. ${ }^{101}$

In alle pastorale literatuur, Afrikaans- of Engelstalig, is de idylle uiteindelijk maar heel broos. Het belangrijkste kenmerk van de boerderijroman, zegt J.M. Coetzee, is dat het zich bezig houdt met "the problem of the meaning of the farm." 102 De betekenis van de boerderij is een "probleem" omdat die betekenis blijft ontglippen en wringen. De boerderij staat ergens voor; voor een bepaalde manier van leven, samenleven, Godsbeleving,

\footnotetext{
${ }^{99}$ J.M. Coetzee 1988, 63

${ }^{100}$ J.M. Coetzee 1988, 63/64

${ }^{101}$ J.M. Coetzee 1988, 14

${ }^{102}$ Idem, 91
} 
zelfbeleving. Er spreekt uit deze teksten niet alleen het nostalgische verlangen naar het goede leven van "vroeger", maar ook naar het eenvoudige, onschuldige zelfbeeld dat daarbij hoorde, een zelfbeeld dat in feite geen stand meer kan houden. "'This earth kept its people what they are," citeert J.M. Coetzee uit Groei van Van den Heever; en voegt dan zelf toe: "in the cities, the Afrikaner will simply versleg." ${ }_{103}$ Maar in feite was het "nieuwe Zuid-Afrika", de kapitalistische, geïndustrialiseerde Unie van Zuid-Afrika met haar ingewikkelde netwerk van economische en rassenwetgeving, ook een spiegel waar men niet graag in keek. Het was een toekomstbeeld dat ook iets zei over het verleden. Om de idylle en het bijbehorende zelfbeeld te laten bestaan, moet er iets worden weggelaten. De plaas wordt buiten de werkelijkheid geplaatst: “'n Geslote eenheid word geskep, 'n vreedsame plek, 'n selfonderhoudende wêreld waar bedreiging van buite afgeweer kan word, veral dreigemente van spesifieke sociale veranderings en konfrontasies." 104

Engels- en Afrikaanstalige literatuur stuiten daarbij uiteindelijk op gelijksoortige dilemma's. Alle pastorale literatuur uit die tijd geeft blijk van onvermogen om de oorspronkelijke bewoners een plek te geven binnen de voorstelling van het paradijs ${ }^{105}$, terwijl ze, zeker op het platteland, met geen mogelijkheid weg te denken zijn. Er komen nauwelijks zwarte actanten voor in zowel Engels- als Afrikaanstalige pastorale romans, en als ze er zijn, vloeit hun marginale aanwezigheid direct voort uit de logica van de plaasideologie: "The literature of the white pastoral marks off for itself, and defends, a territory 'outside' history where disturbing realities of land and labour can be bracketed off, and questions of justice and power translated into questions of legal succession and personal relations between masters and servants." ${ }^{106}$ Een dergelijk proces van weglating laat z'n sporen na:

\section{Like the black corpse in Nadine Gordimer's novel The Conservatio- nist that keeps floating up out of the earth, however, doubts about the pastoral enterprise keep floating up, till in the end they subvert the genre. Was there no time before the time of the forefathers, and whose was the land then? Do white hands truly pick the fruit, reap the grain, milk the cows, shear the sheep in these bucolic retreats? Who truly creates wealth? ${ }^{107}$.}

Leemtes, inconsequenties en stiltes geven de tekst een verborgen kant die in de loop der tijd steeds luider zal gaan spreken - in nieuwe teksten, maar ook in nieuwe lezingen.

\footnotetext{
${ }^{103}$ Idem, 95

${ }^{104}$ A. Coetzee 2000, 11

${ }^{105}$ J.M. Coetzee 1988, 71/2

${ }^{106}$ Idem, 11

${ }^{107}$ Idem, 11
} 


\subsection{BEZIT, ARBEID, CULTUUR: NATIONALISTISCHE MYTHEN IN DE PLAASROMAN}

De Boerenoorlog was voor noordelijke Afrikaners in alle opzichten een traumatische gebeurtenis geweest ${ }^{108}$. Ze waren fysiek en mentaal verslagen, de Engelsen hadden hun huizen en akkers verwoest ${ }^{109}$ en hun vrouwen en kinderen in concentratiekampen ondergebracht waar er duizenden waren gestorven. Een runderpestepidemie had al voor de oorlog enorme schade aangericht onder het vee. Bovendien was de sociale cohesie door alle veranderingen aangetast. Familieverbanden die voorheen veel landloze Afrikaner boeren (bywoners) een respectabele plek in de gemeenschap gegarandeerd hadden, boetten aan betekenis in. Binnen het gezin "authority began to crumble along lines of age and sex as it so often does in a "protoindustrial' situation" "10. De samenstelling van de bevolking veranderde: Engelse boeren kochten boerderijen op, jonge mensen trokken weg, maar ook ouderen hadden vaak geen andere keus dan naar de stad te trekken, een Uitlander-stad ${ }^{111}$ waar een taal gesproken werd die ze niet of nauwelijks beheersten en waar ze moesten concurreren tegen zwarte arbeiders die beter geschoold waren dan $\mathrm{zij}^{112}$. Arme, ongeletterde boeren in het binnenland keerden zich steeds meer af van de kerk en de blanke gemeenschap die daarbij hoorde en vonden hun thuis in een interraciale rurale gemeenschap. ${ }^{113}$ In een poging de marginalisatie van deze groepen Afrikaners te stoppen en daarmee steun te verwerven voor eigen doeleinden, richtte de Afrikaner middenklasse zich op rehabilitatie van de armblankes ${ }^{114}$.

Afrikaans werd in dit proces een geuzentaal die, met name op initiatief van Kaapse Afrikaanssprekenden, Afrikaners uit het hele land voor het eerst met elkaar moest gaan verbinden. Al in de negentiende eeuw had een Afrikaanstalige elite in de Kaap zich sterk gemaakt voor emancipatie van het Afrikaans, dat voorheen als hotnotstaal of kombuistaal (keukentaal) weinig aanzien genoot in een streek waar Engels en Nederlands de officiële voertalen waren ${ }^{115}$. Na de oorlog werd deze taalstrijd gekoppeld aan de vooroorlogse nationalistische politiek van de Boerenrepublieken. Als gevolg van een zeer succesvolle campagne "to build the nation from words", ontpopte Die Taal zich tot een zowel op literair als sociaal gebied tot in de hoogste kringen geliefd medium. Die Genootskap van Regte

\footnotetext{
${ }^{108}$ Zie bijvoorbeeld Giliomee 2003b, 321/2

${ }^{109}$ In Oranje Vrijstaat was $90 \%$ van de boerderijen beschadigd. (Giliomee 2003b, 322):

${ }^{110}$ Hofmeyr 1987, 100

${ }^{111}$ Van Jaarsveld 1979, 25

${ }^{112}$ Giliomee 2003b, 323

${ }^{113}$ Zie bijv. Hofmeyr 1987, 101

${ }^{114}$ Hofmeyr 1987, 103

${ }^{115}$ Zie bijvoorbeeld Hofmeyr 1987: 96-99
} 
Afrikaners stelde spelling en grammatica van het Afrikaans vast door een woordenboek en grammatica te publiceren, en zorgde voor bijbelvertalingen. De taal werd daarbij gezuiverd van al teveel Engelse en Afrikaanse (African) invloeden en met veel Nederlands geïnjecteerd ${ }^{116}$. Een brede infrastructuur van uitgeverijen, culturele organisaties, vrouwenfederaties en taalbewegingen legden de basis voor een Afrikaanse literatuur en cultuur. De literatuur diende een dubbel doel. Enerzijds moest het het lezen (en daarmee het effect van het medium) zelf promoten. Men moet bedenken dat een van de belangrijkste oorzaken van de achterstand van Afrikaners hun ongeletterdheid was. De meeste blanke boeren vonden het niet nodig dat hun kinderen naar school gingen; rond de eeuwwisseling gingen er in de Kaapkolonie meer zwarte dan blanke kinderen naar school, in Transvaal was twee jaar school meestal het maximum ${ }^{117}$. Om lezen aantrekkelijker te maken, waren herkenbaarheid en een kleine afstand tussen schrijver en lezer belangrijk.

Anderzijds werden de teksten, die een zo breed mogelijk publiek moesten aanspreken en daarom een zo breed mogelijk spectrum aan "Afrikaanse onderwerpen" aansneden, als bouwstenen gebruikt om uit de diversiteit een meer gemeenschappelijke identiteit te construeren ${ }^{118}$. De Afrikaner werd afgezet tegen de Nederlander, de Engelsman, en de zwarte Afrikaan. Het gevolg van deze doelbewuste nationbuilding was een discours dat volgens Ampie Coetzee als volgt kan worden samengevat:

Dat kultuur die behoud van die volkseie is; die strewe tot mag by Afrikanermanne Suid-Afrika die sterkste land in Afrika kan maak; 'n trots op die verlede noodsakelik is; suiwerheid van bloed deel van jou wese as Afrikaner is; ' $n$ geloof dat die Afrikavolk hier geplaas is as deel van God se raadsplan - dié frase (...) was sekerlik boustene in die konstruksie van 'n vroeër Afrikaneridentiteit. ${ }^{119}$

Geschiedenis was een belangrijk wapen; fictie en non-fictie verschillen in deze tijd niet zoveel. Politici schreven romans, romanciers schreven geschiedenisboeken. S.J. du Toit, een van de oprichters van Die Genootskap, schreef Die geskiedenis van ons land, "which asserted that the good lord had caused it to rain so continuously that, to the mutual satisfaction of all, most ex-slaves were seen creeping meekly back into the service of their erstwhile owners" ${ }^{120}$. Afrikaanstalige fictie verscheen veelal in tijdschriften als Brandwag (va 1910) en Die Huisgenoot (v.a 1916). De verhalen speelden zich grotendeels af op het afgelegen platteland van Transvaal of Oran-

\footnotetext{
${ }^{116}$ Hofmeyr 1987, 105

${ }^{117}$ Giliomee 2003, 319

${ }^{118}$ Hofmeyr 1987, 109

${ }^{119}$ A. Coetzee 2000, 124

${ }^{120}$ Chapman 1996, 120
} 
jevrijstaat. Belangrijke thema's waren: de kleine boer en zijn liefde voor het land, de heroïsche geschiedenis van de trekboeren en de tragische maar dappere strijd tegen de Engelsen, de hechtheid van de Afrikaner familie.

In 1925 werd het Nederlands als tweede officiële taal vervangen door het Afrikaans. De Nasionale Party won in 1924 de verkiezingen en streefde 15 jaar lang naar een verbetering van de positie van de Afrikaner, vaak met behulp van discriminerende wetten die ten koste gingen van de zwarte bevolking. Maar pas toen het nationalisme zich, ook onder invloed van het Duits Nationaal Socialisme, consolideerde, werd de tegenstelling Afrikaner-Brit als expliciete retorische richtlijn vervangen door de tegenstelling zwart-wit ${ }^{121}$. Superioriteit van het blanke ras werd daarbij vanzelfsprekend geacht. Vanuit de NP, die 46 jaar regeerde, genoot Afrikaner cultuur bescherming en prestige. Vanuit literaire hoek kwam op haar beurt tot in de zeventiger jaren weinig serieuze kritiek op het gevolgde beleid ${ }^{122}$.

Tijdens de opkomst van het Afrikaner nationalisme ontwikkelde de plaasroman zich onder invloed van P.F. Malherbe, Johannes van Melle, Mikro en vooral C.M. van den Heever tot een serieuze en technisch verfijndere opvolger van de vele plaasstories die in tijdschriften waren verschenen. Elk plot en elk personage in de Zuid-Afrikaanse literatuur moet, zoals Mphahlele ooit schreef, "subserve a (..) message (..) in race relations" 123 , en het was vooral op de plaas, met "sy feodalistiese baas-kneg verhoudings", dat de door Hertzog voorgestelde verhouding tussen blanken en kleurlingen kon worden uitgebeeld. ${ }^{124}$ Ondanks deze onmiskenbaar ideologische lading heeft er altijd een schijn van "echtheid" om de plaasroman:en literaire canon gehangen. Henriette Roos schaart de plaasroman onder "klein realisme", waarin "slegs die konvensionele perspektiewe van Afrikaner nasionalisme verwoord is" ${ }^{25}$. In het voorwoord van een heruitgave van Laat Vrugte (1987 (1939)), noemt Elize Botha deze belangrijkste roman van C.M. van den Heever "'n herskepping van daardie vervloë fase toe boerdery die vernaamste Afrikaanse komponent van die samelewing was, ' $n$ bedryf onaangeraak deur meganisasie en moderne ekonomiese beginsels." ${ }^{126}$ Ook Helina du Plooy spreekt van "realistiese uitbeelding" van "werklikheidsomstandighede" in deze roman ${ }^{127}$. Over de (literaire) betekenis van deze romans is men het nog steeds niet eens. Botha roemt vooral het genu-

\footnotetext{
${ }^{121}$ Hertzog won in 1929 de verkiezingen door "die kiesers saam te snoer in vrees vir ' $n$ 'Swart Gevaar'. (Roos, 1998:35)

${ }^{122}$ Andre Brink, een van de vooraanstaande Sestigers, bekend om hun vernieuwing in de Afrikaanse literatuur, zegt achteraf over de maatschappijkritiek die zij destijds leverden: "'n Paar nuwe vorme. 'n Paar skuins woorde...'n Bietjie slaap by 'n meisie. 'n Bietjie satire. Heelparty simbole... ('n) toesmeer in mites terwyl miljoene... medemense daagliks deur mitelose werklikhede...geskend word..." André Brink. Tussen sestig en sewentig.

${ }^{123}$ Ezekiel Mphahlele The non-European character in South African English fiction. Unisa 1956, 99

${ }^{124}$ Gerwel 1988, 75/6

${ }^{125}$ Roos 1998, 38

${ }^{126}$ Botha 1987

${ }^{127}$ Du Plooy 1998, 655
} 
anceerd weergegeven menselijk drama in dit "kunswerk van durende betekenis" ${ }^{\prime 28}$. De ene alinea die Michael Chapman aan het hele genre wijdt in zijn omvangrijke literatuurgeschiedenis van Zuidelijk Afrika, is daarentegen bijna smalend van toon:

In minglings of romantic epiphany and German blood-and-soil mythologies, the fiction yearns for the restoration, amid rural poverty, of lineal memory in patriarchal, familial ownership. (...) Economics is elided into myth and the plaasroman takes its ideological role in the discourse of national destiny. ${ }^{129}$

Voor een deel is het waar dat de plaasroman past binnen het nationalistische streven de Afrikaners een identiteit te verschaffen die hen enerzijds onvervreemdbaar aan Afrika verbond ${ }^{130}$ en anderzijds onmiskenbaar anders maakte dan de andere Afrikanen. De Boer was het prototype van de "echte" Afrikaner: "a unique type that had been shaped by the country". ${ }^{131}$ Een heroïsche geschiedenis van gewone mensen; eerlijke arbeid; verbondenheid met en zorg voor familie, buren, arbeiders en land; liefde voor de natuur; gehoorzaamheid aan mannen en ouderen; het in ere houden van de voorouders; een speciale relatie met God; en georven landbezit waren allemaal ingrediënten van een unieke Afrikaner cultuur die in de plaasroman werd verbeeld.

Ook waar is dat verschillende van deze elementen niet of maar half historisch gefundeerd zijn: het zijn mythen. Volgens Barthes is voor de effectiviteit van een mythe niet de logica van belang, maar de indruk die het maakt: "[i]t does not matter if one is later allowed to see through the myth, its action is assumed to be stronger than the rational explanations which may later belie it." ${ }^{132}$ Een van de mythen die in de contekst van de Afrikaner identiteit effectief waren, was dat alle Afrikaner boeren landeigenaren waren. "Tot vandag toe leef die legende voort dat die Afrikaner uit die rykdomme van sy bodem deur vreemdelinge - Brits-Joodse kapitaliste- uitgekul is," schrijft de historicus Van Jaarsveld in $1979^{133}$. Een Kaapse schoolinspecteur schreef in 1892 dat "it was sad to see a class who were once land owners, endowed by nature with greater possibilities than the natives, allowing their heritage to slip from their hands, and sinking into the class of unskilled labourers" ${ }^{\text {134 }}$. Dit idee van een gemeenschappelijke heritage is al

\footnotetext{
${ }^{128}$ Idem

${ }^{129}$ M. Chapman 1996, 192. Er is overigens veel kritiek geweest op Chapmans beperkte en ongenuanceerde weergave van met name de Afrikaanstalige literatuur.

${ }^{130}$ Zie bijvoorbeeld Giliomee 2003b, 398.

${ }^{131}$ Giliomee, 2003b 399

${ }^{132}$ Barthes, Mythologies, 1984 Geraadpleegd op http://www.georgetown.edu/faculty/irvinem/theory/Barthes-Mythologies-MythToday.pdf : pag. 11

${ }^{133}$ Van Jaarsveld 1979, 33

${ }^{134}$ Geciteerd in Giliomee 2003b, 319
} 
ingezet in de $19^{\mathrm{e}}$ eeuw, toen "although large numbers of whites lived precariously on farms as overseers, tenants, or poor relatives, there was an increasing tendency for whites to define themselves as a community in which a common racial identity transcended the internal class differences ${ }^{135}$. Het in bezit houden van de familieplaas is dan ook een belangrijk thema binnen de plaasromanDie plaasroman," zegt Ampie Coetzee in 'n Hele os vir 'n ou broodmes (2000), “word redelik nougeset gesien as dié soort roman waarin die plaas sentraal staan: ten opsichte van sake soos erfpag, opeenvolging van geslagte, die natuur, arbeid, afskeid van die plaas; maar daardeur maak dit deel uit van 'n veel groter 'diskoers': die diskoers oor grond en grondbesit". ${ }^{136}$

In dat discours is bezit niet alleen een papieren eigendomsrecht, maar een natuurlijk recht op de grond, verworven door strijd, overerving, liefde en arbeid. De boeren zijn het verplicht aan hun voorouders, hun nakomelingen en aan zichzelf ("the farmer betrays himself when he quits the land" ${ }^{137}$ ) om "vooruit te boeren" en zo het land in de familie te kunnen houden. In de relatie tot het land wordt een bepaalde betekenis gezocht en gelegd, die zo essentieel is, dat er tot in de $21^{\text {ste }}$ eeuw aan gesleuteld zal worden. Behalve uit nostalgie werden de eerste plaasromans ook geschreven

uit ' $n$ besef van verlies: teenoor die natuur, teenoor die ekonomie, teenoor industrialisasie. Die soeke na die betekenis van die plaas kom vanuit 'n ontwrigting: die onteiening van die plaas. Die opeenvolging van plaasromans was 'n poging tot herbevestiging. Van identiteit, want identiteit sou die persepsie gebring het van die soliditeit van betekenis. Grond is gelyk aan identiteit, identiteit gelyk aan betekenis. ${ }^{138}$

Landbezit wordt gelijkgetrokken met verbondenheid met de natuur en de familie, met een bepaalde sociale organisatie en met God. J.M. Coetzee laat zien dat een van de belangrijkste plaasromanauteurs, C.M. van den Heever, in vrijwel al zijn boeken zijn protagonisten laat ruiken aan een hoger bewustzijn, waarin het individu zichzelf ervaart als onderdeel van een lineage.

The goal of [Van den Heevers] enterprise [is] to unite a social philosophy of agrarian conservatism (in reaction against both capitalism and socialism, one that finds its most sustained literary expression in the German Bauernroman of the years 1900-45) with an ingenious Romantic anti-individualism which advocates the submergence of

\footnotetext{
${ }^{135}$ Giliomee 2003b, 109

${ }^{136}$ A. Coetzee 2000; xiv

${ }^{137}$ J.M. Coetzee 1988, 95

${ }^{138}$ A. Coetzee 2000, 16
} 
the individual not in the race, but in the family line. ${ }^{139}$

Een van de voorwaarden voor dit opgaan in de familie is dat het land in eigendom is en zo van vader op zoon kan worden doorgegeven. Alleen dankzij zijn verbondenheid met de natuur die ook weer verbonden is met het voor- en nageslacht, kan een individu een spirituele ervaring krijgen die mogelijk bovengenoemd bewustzijn tot gevolg heeft. Op die manier wordt landbezit een onvervreemdbaar onderdeel van de Afrikaner identiteit.

Een ander onderdeel van de Afrikaner identiteit dat in volgende paragrafen tegen het licht gehouden zal worden, is arbeid. De bewuste nation building die in de eerste decennia van de twintigste eeuw plaatsvond, diende om verdwaalde bywoners en failliete boeren tot een zelfbewuste arbeidersklasse om te smeden. Ideologen uit de oude noordelijke republieken, kapitaalkrachtige Afrikaners uit de Kaapprovincie en het electoraat van verpauperde arbeiders en boeren moesten één front gaan vormen. Het grootste risico vormde de groeiende Afrikaner arbeidersklasse. Om te voorkomen dat arbeiders zich en masse tegen de bezittende klasse zou keren, gaf men hen een plek binnen het organische geheel van het Afrikanerdom, waarin weliswaar niet iedereen gelijk, maar toch beter (of beter af) was dan degenen die er niet bij hoorden."The process then of becoming a worker (...) was, for some, the process of being made into an Afrikaner." ${ }^{140}$ Dit identiteitsaspect wordt in de plaasromans met terugwerkende kracht op de boeren geprojecteerd; hun werklust is in de meeste romans ongeëvenaard. Zwarte arbeid is daarentegen zo niet onzichtbaar dan wel van een heel andere, inferieure orde, ontdaan van ieder initiatief, inzicht, en arbeidsvreugde.

Een belangrijke eigenschap van zowel culturele identiteit als de mythen die daaraan ten grondslag liggen, is flexibiliteit in geval van veranderende omstandigheden en behoeften. Maar in Zuid-Afrika leek in de loop van de twintigste eeuw deze flexibiliteit af te nemen. Sommige mythen hadden zodanig vorm gegeven aan de werkelijkheid, aan het politieke stelsel, aan de opdeling van de bevolking in rassen en etnische groeperingen, en vooral aan de nationale inrichting en verdeling van het land, dat Zuid-Afrika die mythen een rationele, empirische geldigheid verleend had, toen het nodig werd ze bij te stellen.

Aan de andere kant was en is de boerderij, het symbool van de Afrikaner identiteit, in werkelijkheid juist niet zo statisch geweest als men deed voorkomen. Ook dit kan een reden geweest zijn dat schrijvers in de jaren zeventig naar de boerderij terugkeerden om de werkelijkheid te demythologiseren. In de volgende paragraaf zal ik vrij gedetailleerd op de geschiede-

\footnotetext{
${ }^{139}$ J. Coetzee 1988,114

${ }^{140}$ Hofmeyr 1987, 116
} 
nis van het Zuid-Afrikaanse platteland ingaan, omdat het laat zien hoezeer boeren zich door de tijd heen in een frontier area bevonden hebben, i.e. een territorium met ambivalente grenzen en "constant invasions", zowel van buitenaf als van binnenuit ${ }^{141}$. Juist die grenzen die een Afrikaner identiteit moesten definiëren (de grenzen tussen binnen en buiten, Ik en Ander), die als tijdloos en vervreemdbaar baken moesten fungeren, waren in werkelijkheid voortdurend in beweging.

\subsection{VAN VEEBOEREN EN LANDHEREN: ONTWIKKELING VAN DE PLAAS}

Tegen de tijd dat de eerste Europeanen in Zuid-Afrika arriveerden, bestond de bevolking van het huidige Zuid-Afrika uit Bantusprekende landbouwers en veetelers en een aantal Khoisanvolken; niet-Khoisprekende semi-nomadische jager-verzamelaars wier jachtgronden min of meer door de hen omringende volken werden gerespecteerd, en Khoisprekende herders die in grote clans leefden, en hun grote kuddes (10.000 stuks vee was geen uitzondering) langs vaste, jaarlijkse routes leidden. De impact van de komst van Europese kolonisten was voor de verschillende bevolkingsgroepen heel verschillend. In de eerste eeuwen was "landbezit" vooral een kwestie van fysiek overwicht. De delegatie van de VOC die zich in 1652 aan de Kaap vestigde was officieel uit op vreedzame coëxistentie, maar de doelstellingen lieten daar weinig ruimte toe ${ }^{142}$. De Khoisan zagen weinig voordeel in de ruil van vee voor koperdraad. Na vijf jaar werden de eerste vrije burgers en de eerste Oost-Afrikaanse slaven aan land gebracht om de eigen productie te verhogen. Steeds grotere stukken land rondom het fort werden in bezit genomen. In een citaat van Jan van Riebeeck zegt de chief van de Goringhaiquas: "what would it signify if you remained here at the Fort, but you come quite into the interior, selecting the best for yourselves, and never once asking whether we like it, or whether it will put us to any inconvenience" ${ }^{\prime 43}$. Toen zij uit wraak vee stalen, leidde dat in 1660 tot de eerste officiele oorlog ${ }^{144}$. Veertig jaar en een flink aantal oorlogen later waren de Khoisan grotendeels hun vee en land kwijt en door sociale ontregeling verzwakt en zagen velen zich gedwongen als landarbeiders in dienst te treden bij de kolonisten.

Om te kunnen samenwerken met de voormalige vijand gaven de kolonisten hen een nieuwe identiteit. Terwijl de Khoisan die zich buiten de grenzen van de kolonie bevonden min of meer vogelvrij waren, hoorden zij die

\footnotetext{
${ }^{141}$ Yuri Lotman, Universe of the mind. A semiotic theorie of culture, 1990:141/2

${ }^{142}$ Keto 1978

${ }^{143}$ Extracts from the journal of Commander Van Riebeeck, 6 april 1660, in: D. Moodie, 1960, p205

${ }^{144}$ Diefstal van vee werd zowel door de Khoikhoi als de Compagnie beschouwd als een van de zwaarste misdrijven (Ross 1993, 169)
} 
erbinnen verbleven tot de "vrije burgers" en dienden als zodanig behandeld te worden. ${ }^{145}$ Eind $17^{\mathrm{e}}$, begin $18^{\mathrm{e}}$ eeuw integreerden veel Khoisan, meer of minder succesvol, in de koloniale gemeenschap, en mengden zich met zwarte slaven, Indiërs en blanke burgers ${ }^{146}$. Khoisan invloeden moeten binnen de "blanke" gemeenschap, zeker bij dezelfde trekboeren die zozeer deel uitgemaakt hebben van het mythische Afrikaner verleden, aanzienlijk zijn geweest.

Desalniettemin voelden sommige Khoisan die in de kolonie woonden zich meer Khoisan dan burger. De grenzen van de kolonie hadden in hun ogen niet veel betekenis. Achter de schermen liepen beide groepen (Khoisan guerilla's en Khoisan burgers) voortdurend in elkaar over. ${ }^{147}$ Zelfs in 1799, toen de guerilla's voorgoed overwonnen waren, wisten Khoisan de autoriteiten nog te verrassen door massaal van boerderijen weg te lopen en zich aan te sluiten bij de Xhosa, die zojuist aan hun honderdjarige oorlog tegen de kolonisten waren begonnen ${ }^{148}$. Voor hen die wel in de kolonie bleven, had dit tot gevolg dat ze weer als "hotnot" werden gezien, waardoor hun positie aanmerkelijk verslechterde. ${ }^{149}$

Maar dat was allemaal veel later. In de $17^{\mathrm{e}}$ en $18^{\mathrm{e}}$ eeuw ontwikkelde zich in de West-Kaap een economie met commerciële grootgrondbezitters en kooplieden aan de top, gebaseerd op de arbeid van slaven en Khoisan. Daaronder bevond zich een groeiende klasse handelaren en veeboeren, die op zoek gingen naar weidegrond en luxegoederen, beide te vinden bij de Khoisan in het binnenland. Land dat deze boeren door de Compagnie in eigendom werd aangeboden was aan hen niet besteed. Volgens Khoi gebruik trokken ze met het wisselen der seizoenen langs vaste routes. Hun grote kuddes koeien en schapen ${ }^{150}$ waren het resultaat van ruilhandel en illegale strooptochten.

Toen ze verder het binnenland introkken, belandden de boeren ook in de jachtterritoria van de jagende Khoisan volken ${ }^{151}$. Hun kuddes vertrapten de planten die de Khoisan verzamelden en verjoegen het wild van de drinkplaatsen. Op hun beurt doodden zij het vee van de boeren en ontketenden daarmee illegale strafexpedities. In de $18 \mathrm{e}$ eeuw voegden Khoisan uit de

\footnotetext{
${ }^{145}$ Zie bijvoorbeeld Giliomee 2003b, 88

${ }^{146}$ De kolonie beval gemengde huwelijken officieel aan wegens een gebrek aan Europese vrouwen. Hun kinderen vormden de basis voor een bevolkingsgroep die later onderverdeeld zou worden in Kaapse kleurlingen, Griqua, Basters en Afrikaners.

${ }^{147}$ Ross 1993, 173

${ }^{148}$ Ross 1993, 174

${ }^{149}$ Ross 1993, 176

${ }^{150}$ In 1692 waren er in totaal 48.522 schapen in de kolonie; individuele kuddes bestonden uit maximaal 5.300 schapen. (H.B. Thom 1936).

${ }^{151}$ Het door kolonisten gemaakte etnische onderscheid tussen Khoikhoi (Hottentotten) en San (Bosjesmannen) is nauwelijks te handhaven. Het verschil bestond uit de manier van leven en de mate van vijandigheid ten aanzien van de kolonisten. Maar de grenzen waren diffuus: "Khoi-speaking herders who lost their livestock could easily become Bushmen, and vice versa. This is precisely what happened in colonial times." (Barnard 1992, 159)
} 
kuststreek zich bij de Khoisan uit het binnenland en samen voerden ze een langdurige guerrillaoorlog tegen de kolonisten. De regering in de Kaap probeerde het geweld te beteugelen, maar na een forse nederlaag in 1770 gaf ze de boerenmilitia vrij spel en werden duizenden Khoisan werden afgeslacht ${ }^{152}$. Overlevenden trokken weg, mengden zich met de Nguni of werden door de kolonie opgeslokt. In 1778 meldde gouverneur Joachim van Plettenberg dat "there were no longer any Khoi who were not in service with a farmer." 153

In het Oosten en Noorden ondervonden de kolonisten grotere militaire weerstand. Halverwege de $18^{\mathrm{e}}$ eeuw stuitten de steeds verder oostwaarts trekkende boeren op het grondgebied van de Nguni. Het grondgebied was verdeeld in chiefdoms, politieke eenheden van duizend tot 35.000 mensen, "occupying a defined area under a recognized leader" ${ }^{154}$. De beschikbare landbouwgrond werd door de chiefs verdeeld onder zijn mannelijke volgelingen. Individueel "bezit" was onbekend, maar dat betekende niet dat al het land van de chief was: "the link between the land and the individual tribesman was stronger than the link between the land and the chief ${ }^{155}$. De toegang tot land was van fundamenteel belang, als economische hulpbron, maar ook

for recognition as members of the social group: the allocation of land to an individual was a badge of his membership of clan or tribe. Land was the communal property of the political community (...), [yet o]nce a piece of land had been allocated to a member of the community it was defined in terms of the claims of that particular family's rights of cultivation. (...) Once allocated, arable land was alienable only by dispossession: if a man lost his land he lost his membership in the community. ${ }^{156}$

Dit soort concepten zijn belangrijk om de conflicten en misverstanden te begrijpen die tot de dag van vandaag spelen omtrent landrechten in ZuidAfrika.

Aanvankelijk leefden Afrikaner boeren en Xhosa tamelijk vreedzaam naast elkaar. De grens tussen hen was ruimtelijk noch sociaal scherp te trekken. Ze dreven handel en roofden af en toe wat vee over en weer. Maar in de loop der tijd werden de schermutselingen, voornamelijk over graasrechten ${ }^{157}$, grimmiger. "Skirmishes foreshadowed the large scale conflicts

\footnotetext{
${ }^{152} \operatorname{Ross} 1999,22 / 3$

${ }^{153}$ Ross 1993,179

${ }^{154}$ Bundy 1979,20

${ }^{155}$ E. Letsoalo (1987) Land reform in South Africa. A black perspective. Geciteerd in Levin \& Weiner 1996; 104.

${ }^{156}$ Bundy 1979, 21

${ }^{157}$ De Reuck 1995, 34
} 
known as the Frontier Wars; barter preceded the greater economic involvement of the nineteenth century; cattle raids and boundary beacons prefigured the competition over resources and land." ${ }^{158}$ In 1781 nam een Boeren commando de taak op zich om de "kaffirs" uit het gebied te verdrijven; de eerste van een reeks van negen onteigeningsoorlogen die in de loop van een eeuw gevoerd zouden worden. Toen de Engelsen de macht in de Kaap hadden overgenomen, probeerde met name Gouverneur Somerset de gemoederen tot bedaren te brengen door het contact tussen beide bevolkingsgroepen terug te dringen, een niemandsland tussen blank en zwart in te stellen en de immigratie van Britse kolonisten in het gebied te bevorderen $^{159}$. Toen de Kaapse regering zich ook nog met de arbeidsrelaties ging bemoeien (ondermeer de afschaffing van de slavernij), hield een groot aantal Afrikaner boeren het voor gezien. In 1836 begon de Grote Trek.

In tien jaar tijd trokken zo'n veertienduizend kolonisten in trage colonnes naar het noorden. Daar kwamen ze terecht in een gebied waar zich door politieke reorganisatie, oorlogen en volksverhuizingen vijf machtige koninkrijken vormden: die van de Ndebele, Swazi, Zulu, Basotho en Bapedi. Deze roerige periode, die duurde van eind achttiende eeuw tot de dertiger jaren van de negentiende eeuw, staat bekend als difaqana ${ }^{160}$ of mfecane. ${ }^{161}$ Terwijl grote groepen vluchtelingen zuidwaarts trokken, voegden de voortrekkers zich bij de strijdende partijen ${ }^{162}$. In de tijd na en tijdens de grote trek, leken Afrikaner en Afrikaanse gemeenschappen sterk op elkaar: "small scale, closely-knit communities, based on subsistence agriculture, with wealth and prestige concentrated on cattle" ${ }^{163}$. Aanvallen bestonden vaak uit het over en weer roven van vee, "the dominant currency of political control over land and people." ${ }^{164}$ Toen Mzilikazi, de vorst van de Ndebele, zich onder grote druk terugtrok naar het huidige Zimbabwe, liet hij een machtsvacuüm achter dat door de voortrekkers en hun bondgenoten werd ingenomen. In wat later Oranje Vrijstaat zou worden vestigden ze zich als schapenboeren, terwijl ze meer naar het noorden (Transvaal), zoals ieder ander krijgshaftig Afrikaans volk, leefden van de arbeid, pacht en/of belasting van zwarte boeren, van jacht, oorlogsbuit, en allianties met naburige koninkrijken ${ }^{165}$.

\footnotetext{
${ }^{158}$ Bundy 1979, 30

${ }^{159}$ Saunders et. al. 156

${ }^{160}$ Murray 1992, 16

${ }^{161}$ Bernstein 1996, 3; Beinart \& Bundy 1987, 8

${ }^{162}$ Sol Plaatje schreef in 1920 over deze periode de historische roman Mhudi, waarin hij de botsingen van de Barolong met Matabele en Boeren beschrijft, en de vlucht naar Taba Nchoe. In 1930 werd het boek, met Bijbelse toevoegingen en vele weglatingen, uitgegeven. Pas in 1976 kwamen de verschillen met het origineel aan het licht. In $1978 \mathrm{kwam}$ alsnog een gerectificeerde versie op de markt. (Plaatje 1998, 216)

${ }^{163}$ Shula Marks, “African and Afrikaner History". In: Journal of African History XI.3

${ }^{164}$ Murray 1992, 16.

${ }^{165}$ Zie bijvoorbeeld Ross 1999
} 
Sommige trekkers waren doorgestoken naar het oosten, en versloegen daar Dingaan in een bloedige strijd. Door de gewelddadige opkomst van het Zulurijk was dit gebied enigszins dunbevolkt geraakt, maar nadat de boeren een bondgenoot op de Zulu troon hadden geholpen, keerden vluchtelingen in groten getale terug naar hun land. Tussen 1838 en 1843 groeide de Afrikaanse bevolking in de Voortrekker Republiek van Natalia van 10.000 tot $50.000^{166}$. Zij vestigden zich op grondgebied dat inmiddels door de voortrekkers was opgeëist, maar waarvan grote delen niet in gebruik waren. Politiek noch economisch waren de Afrikaner "boeren" sterk genoeg om de plakkers te controleren, of om hun eigen boerderijen levensvatbaar te maken; vaak voorzagen ze in hun bestaan door vee en graan te roven uit naburige Afrikaanse dorpen. In 1842 werd Natal geannexeerd door de Britten, die dit chaotisch soort kolonisatie een doorn in het oog was en bovendien hun handelsmonopolie in Port-Natal veilig wilden stellen. Een groot deel van de Boeren vestigde zich toen alsnog in het meer westelijk gelegen hoogland. De achtergelaten boerderijen werden door Engelse boeren ingenomen.

In de nieuwe republieken eisten de immigranten

bijna al het land binnen de grenzen op als eigendom. Behalve in de treaty areas (238.000 ha.) en government locations (493.000 ha.) moesten de inwoners van de Afrikaner republieken blank zijn en van Nederlandse afkomst. Zwarten konden zich slechts vestigen als bedienden. Er werden paswetten ingesteld: een schriftelijke arbeidsverklaring moest op het lijf gedragen worden ${ }^{167}$. Slechts vijf Afrikaanse families mochten op het land van een boer wonen. Ook in de Britse kolonie Natal werd in 1850500.000 (later uitgebreid tot $1 \mathrm{mln}$.) ha inferieure landbouwgrond aan de Afrikanen toegewezen - "fit only for the eagle and the baboon" aldus de Amerikaanse missionaris Grout en bedoeld om "so crowding the kaffirs as to compel them to leave their locations and seek work"168.

Het mocht niet baten. In feite, zo stelt Bundy,

the (..) coercive equipment was so lacking, the rule so tenuous, the value of land so low for so long, and the forms of African resistance so varied, that Africans occupied, tilled and grazed nominally white lands in enormous numbers; their ability to subsist was for a considerable period not dramatically altered. ${ }^{169}$

\footnotetext{
${ }^{166}$ Bundy 1979, 167

${ }^{167}$ De eerste versies van deze wetten stammen van halverwege de 18 e eeuw; de laatste zijn pas in de jaren tachtig van de twintigste eeuw afgeschaft.

${ }_{168}$ Bundy 1979, 169/170

${ }^{169}$ Bundy $1979,198 / 9$
} 
Sterker nog, Na de difaqana, halverwege de 19e eeuw, maakten zwarte boeren op grote schaal gebruik van gunstige pachtvoorwaarden bij landcompanies en blanke boeren in Natal, Transvaal en Oranje Vrijstaat om een eigen, onafhankelijk bestaan op te bouwen. Ze ontworstelden zich op die manier aan de oude machtsstructuren, die vaak weinig mogelijkheden voor persoonlijke vooruitgang boden ${ }^{170}$.

Net als voor de blanke boeren in Van den Heevers romans waren lineages binnen die Afrikaanse machtsstructuren belangrijke organisatieprincipes, die recht gaven op land. De belangrijkste politieke eenheid was een clan, die bestaat uit meerdere lineages met een gemeenschappelijke voorvader en een chief aan het hoofd ${ }^{171}$. Deze chiefs baseerden hun macht op de hoeveelheid vee en verwanten, waarbij vee vaak door strooptochten was vergaard en de bloedbanden niet zelden fictief waren. De clans waren dan ook flexibel in zowel omvang als samenstelling. Als de chief zijn taak niet naar tevredenheid volbracht, konden zijn volgelingen zich met vrouwen en vee aansluiten bij een andere chief. Een succesvol heerser had volgelingen die overal vandaan kwamen. ${ }^{172}$ Ook oorlogen en droogte zorgden voor migratiestromen. Tegenover migranten werd een zekere inschikkelijkheid aan de dag gelegd: "In indigenous South African black rural communities the land ethic demands that individual rights are circumscribed by social considerations, even if the prior right of first settlers is respected." ${ }^{173}$ Beschikking over landbouwgrond was ook voor nieuwkomers essentieel: "a right of access once conferred (...) grants civic status and the right to participate in community affairs". ${ }^{174}$

Op dezelfde wijze trokken in de tweede helft van de $19^{\mathrm{e}}$ eeuw hele families weg uit het overbevolkte Lesotho en de droge reservaten, om zich op het relatief dunbevolkte en vruchtbare land van de blanke boeren te vestigen, waar ze, zoals ze gewend waren, land toegewezen kregen voor eigen productie. Zoals Van Onselen het formuleerde: op het Hoogveld ontmoetten blanke boeren die land in bezit hadden, maar geen geld, trekossen of ploegen om graan te kunnen verbouwen, zwarte boeren die geen land hadden, maar wel zaad, vee en ploegen. Ze sloten sharecropoverenkomsten die, omdat ze elkaar even hard nodig hadden, vaak weinig hiërarchie vertoonden. ${ }^{175}$ In tegenstelling tot in de Afrikaanse gemeenschap, mochten de zwarte boeren de winst in veel gevallen zelf houden, terwijl door de vondst van diamanten en goud de afzetmarkt explosief groeide.

\footnotetext{
${ }^{170} \mathrm{R}$. Moorsom (1977) Underdevelopment and class formation: the origins of migrant labour in Namibia, 1850-1915, in T. Adler (ed) Perspectives on South Africa, geciteerd in Bundy 1979, 21

${ }^{171}$ Bundy 1979, 20

${ }^{172}$ Ross 1999,17

${ }^{173}$ Dolny \& Klug 1992; 333

${ }^{174}$ Dolny \& Klug 1992; 333

${ }^{175}$ Van Onselen 1997(a), 8
} 
Het gezin werd nu al snel de belangrijkste productie-eenheid, maar grotere familienetwerken werden in stand gehouden en bleven nuttig voor risicospreiding of als arbeidsreservoir of sociale zekerheid. Familie was een rekbaar begrip: het duidde meer een economische eenheid aan dan een netwerk gedefinieerd door bloedverwantschap ${ }^{176}$. Toen in de twintigste eeuw de kansen keerden en pachters massaal van de blanke boerderijen wegtrokken, werden (al dan niet fictieve) bloedbanden met clans en chiefs in ere hersteld om daarmee de kans op verblijf en landbouwgrond te vergroten in de thuislanden of de black spots ${ }^{177}$.

Maar vooralsnog hadden Afrikanen ruime keuze uit gebieden waar ze zich konden vestigen en onder welke (pacht)voorwaarden. Missieposten waren er bijvoorbeeld in Natal, net als in de Oost-Kaap, in overvloed en ze waren populair omdat ze goede landbouwgrond beschikbaar stelden en nieuwe landbouwtechnieken (zoals de ploeg) introduceerden. Maar ook absent landlords en land companies in Natal en Transvaal waren niet van plan de zwarte pachters, die met hun voedselproductie heel wat beter in de markt zaten dan hun blanke tegenhangers, te verdrijven ${ }^{178}$. Succesvolle zwarte gemeenschappen zagen in Natal en Transvaal regelmatig kans blanke boerderijen en kroondomeinen op te kopen. In 1904 boerden van de 900.000 Afrikanen in Transvaal er 130.000 op eigen grond, 438.000 huurden privégrond, 180.000 pachtten kroondomeinen, en slechts 50.000 hadden een fulltime dienstverband. Er was onder hen een klasse van welgestelde, onafhankelijke, gerespecteerde zwarte pachters en boeren ontstaan; families die gebruik gemaakt hadden van de individuele kansen die de markteconomie en farming-on-the-halves ${ }^{179}$ hen bood en scholing hadden genoten dankzij de (zwarte) kerken. Vaak waren ze beter geschoold dan hun "baas". Deze -meestal kapitaalarme- landeigenaar was volledig afhankelijk van het succes van zijn pachters, maar kon daar ook vaak goed van rond komen.

In de eeuw die volgt, wordt alles anders. In 1983 verdiende een Aziaat gemiddeld $37 \%$ van het loon van een blanke, een "kleurling" $26 \%$; een zwarte in de steden $22 \%$; en een zwarte op het platteland 6\% $\%^{180}$. In 1997 constateerde de nieuwe Zuid-Afrikaanse regering dat op het platteland driekwart van de kinderen onder het bestaansminimum leefde ${ }^{181}$. Ongeveer 60.000 blanke boerderijen hadden $86 \%$ van de landbouwgrond (ca. 85,8

\footnotetext{
${ }^{176}$ Van Onselen 1997(a), 9

${ }^{177}$ Keegan 1988, 104. Black spots zijn boerderijen in blank gebied, maar in eigendom van Afrikanen, die in de loop van de twinigste eeuw steeds meer zwarte boeren aantrokken. Echt landbouw bedrijven was tenslotte in deze overbevolkte stukken land slechts voorbehouden aan een happy few, de rest werkte elders, maar had zijn thuisbasis hier.

${ }^{178}$ Tegen 1880 woonden in Natal 169.000 Afrikanen in reservaten en op missieposten $(800.000+$ $70.000 \mathrm{ha}$ ); 162.000 als pachters op land van blanke boeren of land companies ( $2 \mathrm{mln}$. ha); en ca 43.000 boerden op kroondomeinen. (Bundy 1979, 170)

${ }^{179}$ Pachtsysteem waarbij pachter voor gebruik van de grond betaalt met een deel van oogst.

${ }^{180}$ Percentages zijn per hoofd van de bevolking. Ross 1999, 154

${ }^{181}$ White paper on South African Land Policy, Dept. of Land Affairs, April 1997
} 
mln. ha) in gebruik, waarvan 10,6 mln. geschikt was voor akkerbouw. Het totaal aan landbouwgrond voor de 14 miljoen mensen van de (voormalige) Bantustans was voor een groot deel eigendom van de staat en omvatte niet meer dan 14,3 mln ha. Geschikt voor akkerbouw, zo schatte men, was daarvan slechts $2,8 \mathrm{mln}$ ha. ${ }^{182}$. In 1993 telde Zuid-Afrika 1,5 miljoen landarbeiders. $40 \%$ van had slechts voor drie tot zes maanden per jaar werk. Lange tijd heeft men de oorzaken voor grootschalige verpaupering van zwarte boeren gezocht in (a) landonteigening, (b) ontwrichting van de traditionele economie en sociale structuur en (c) de kwetsbaarheid van een tribale samenleving en landbouwmethode, die qua techniek en efficiency niet kon concurreren met de omringende blanke boerenbedrijven. Colin Bundy (1979) en zijn navolgers hebben laten zien dat het eerder andersom was: de mate waarin zwarte boeren in staat waren te concurreren is een van de belangrijkste redenen geweest voor een beleid van landonteigening en sociale ontwrichting. De Unieregering zag het succes van zwarte pachters met lede ogen aan, vooral toen de Labour Commission concludeerde dat het succes van de zwarte boeren "would not only withhold labour from industry, but also bring them into competition with white agricultural producers". ${ }^{183}$ Nieuwe wetten moesten de zwarte boeren in economisch opzicht in toenemende mate afhankelijk maken van hun blanke werkgevers. "Numerous laws were enacted specifically to break their resistance to proletarianization. Land was identified as providing the material basis for this ongoing resistance and the white power bloc devised a strategy to alienate Africans totally from it." ${ }^{184}$ Deze wetten werkten echter alleen in het voordeel van blanke boeren die tegelijkertijd in staat waren te moderniseren. Door droogte, versnippering en kapitaalgebrek gingen velen van hen failliet.

Deze geschiedenis brengt verschillende peilers van de Afrikaner identiteit aan het wankelen. De periode waarin niet-kapitalistische blanke boeren grond in eigendom hadden, is relatief kort geweest. Pas in 1880 wordt in de Boerenrepublieken, die zich als eerste aan hun koloniale status onttrekken, eenzijdig bezitsrecht ingesteld ${ }^{185}$. Veel boeren waren in de eerste eeuwen van de kolonie trekboeren; eenmaal gevestigd waren veel boeren geen landeigenaar, maar bywoner of opzichter of knecht. Kleine landeigenaren werden als gevolg van de plattelandscrisis na 1900 alweer uitgekocht. Een meer sociaal gefundeerd recht op het land, verkregen door overerving, arbeid en ontginning, is als exclusief kenmerk van een Afrikaner identiteit evenmin houdbaar. Niet alleen tijdens het proces van kolonisatie werden "die gebruike van die indigeen" genegeerd, maar ook in de recentere ge-

\footnotetext{
${ }^{182}$ Levin \& Weiner 1991, 27

${ }^{183}$ Geciteerd in Bundy 1979, 210

${ }^{184}$ Dithlake 1997,222

${ }^{185}$ A. Coetzee 2000, 6/7
} 
schiedenis was de rol die zwarte boeren hebben gespeeld bij het ontginnen en economisch ontsluiten van het Zuid-Afrikaanse platteland, lange tijd onzichtbaar. Zelfs in de eenentwintigste eeuw zagen veel blanke ZuidAfrikaanse boeren de ontwikkeling van het Zuid-Afrikaanse platteland nog als een puur blanke verdienste: "the legacy of white pioneers" "186, beeldvorming die bevestigd lijkt te worden door de economische machteloosheid van zwarte boeren ten tijde van de laatste eeuwwisseling. De spreekwoordelijke werklust van Afrikaner boeren die hier onderdeel van is, wordt van meerdere kanten weersproken. J.M. Coetzee toonde al aan hoe dezelfde Boer die in de plaasromans gekenmerkt wordt door een niet te temmen werklust, door Engelse kolonisten eeuwenlang getypeerd is als lui ${ }^{187}$. De Britten noemden overigens iedereen lui die niet in de pas liep met het Britse politiek-economische streven - of dit nu Afrikanen waren die niet voor een ander wilden werken ${ }^{188}$, of Afrikaners die niet voor de markt wilden produceren. Maar de Engelsen waren niet de enigen. Op de vraag waarom zwarte pachters in het verleden vaak beter boerden dan blanke, antwoordde pachterszoon Ngakane: "the reason was simply that it was their attitude towards labour. The Afrikaners, even the poorest of them, regard hard labour as a 'kaffir's' work. And the bywoners even wanted to have servants." ${ }^{189}$ Terwijl in veel plaasromans de Boer wordt geportretteerd als degene die het laatst naar bed gaat en het vroegst op staat, en die regelmatig zijn zwarte knecht uit zijn bed moet trommelen als die vergeten is het schapenhek dicht te doen, herinnert Ngakane zich precies het tegenover gestelde: "[My landlord] was a farmer, but hardly did any farming." Het enige wat hij deed was de zakken maïs tellen die hem toekwamen. En "[t]he bywoners [=blanke pachters] in the surrounding areas they said: 'we don't know when those volke [ = zwarte pachters] go to bed. When we go to bed their fires are burning, when we get up in the morning their fires are burning. "'190

Ten slotte is er ook nooit sprake geweest van een unieke, raszuivere Afrikaner cultuur. Nog afgezien van de vele gemengde huwelijken en buitenechtelijke relaties die hebben plaatsgevonden, hebben juist de kleine boeren die model hebben gestaan voor de plaasroman, zich door de tijd heen sterk aangepast aan hun omgeving. Pas in de loop van de twintiger, dertiger jaren drong de raciale segregatiepolitiek, gekoppeld aan een kapitalistische stratificatie zodanig door in het platteland dat blank en zwart hun gemeenschappelijkheid grotendeels verloren.

\footnotetext{
${ }^{186}$ Steinberg 2002, 58

${ }^{187}$ J.M. Coetzee 1988; 12-35

${ }^{188}$ Bundy 1979, 53

${ }^{189}$ Keegan 1988, 86

${ }^{190}$ Keegan 1988, 84-87
} 


\subsection{DE VELE GEZICHTEN VAN HET PATERNALISME}

In de vorige paragraaf is gebleken hoe Afrikaners en Afrikanen elkaar op het platteland aantrokken en afstootten, hoe ze economisch van elkaar afhankelijk waren, hoe verschillende culturen en (land)discoursen botsten en vermengd raakten en hoe daar in de politiek op werd gereageerd. Het ging er vooral om te laten zien hoe en waar blank en zwart ruimte innamen binnen Zuid-Afrika en hoezeer de geschiedenis en cultuur van het blanke platteland ook door zwarte boeren is vormgegeven. In vroege plaasromans werd een werkelijkheid geschapen die veel blanker (en gecontroleerder en gewenster) was dan die van de voormalige of zelfs contemporaine Afrikaner boerderijen, een blankheid die, omdat door de politieke en maatschappelijke ontwikkelingen de droom intussen schijnbaar werkelijkheid geworden was, ook in latere plaasromans slechts met moeite bijgekleurd zou kunnen worden. In deze paragraaf wil ik inzoomen in tijd en ruimte: ten eerste op de periode die door de meeste vroege plaasromans wordt beschreven (de eerste decennia van de twintigste eeuw), en ten tweede op de binnenruimte van de plaas: de bestaande verhoudingen tussen blanke en zwarte boeren binnen de grenzen van de boerderij, en de representatie van die verhoudingen, ondermeer in de plaasromans.

In de eerste decennia van de twintigste eeuw werden in veel Afrikaner literaire teksten het verleden en het ouderwetse boerenbestaan sterk geïdealiseerd ${ }^{191}$. De plaasromans van de jaren dertig sloten hier in zekere zin op aan, maar met een andere lading: er was sprake van verlies, maar ook van hoop. Ook al raakte de held alles kwijt; dat wat hem gevormd had, zijn geschiedenis, zijn waarden, kon niemand hem afnemen - dat was de pastorale boodschap aan het stedelijk publiek. De boerderij, in de vorm van een merkwaardig, onbestaanbaar mengsel van oude waarden en toekomstidealen bleef daarbij het symbool van zijn identiteit. Dat leverde het probleem op dat "in hulle soeke na betekenis (..) die skrywers van die ou plaasroman nie die maatskappelike ontwrigting [kon] hanteer nie, hoofsakelik omdat sin vir hulle moes kom uit 'n kontinuïteit met die verlede, 'n kontinuïteit wat nie bestaan het nie"192.

De kleinschalige, patriarchale, rurale orde zoals die in de plaasromans tot uitdrukking kwam, was dus in veel opzichten niet dezelfde als de (voormalige) rurale orde van het Zuid-Afrikaanse platteland. Maar in minstens een opzicht komen ze wel overeen. Zoals gezegd stelt Coetzee dat "the literature of the white pastoral marks off for itself, and defends, a territory

\footnotetext{
${ }^{191}$ Zie ook Postel 2003, 311

${ }^{192}$ A. Coetzee 2000, 16
} 
'outside' history where disturbing realities of land and labour can be bracketed off, and questions of justice and power translated into questions of legal succession and personal relations between masters and servants" ${ }^{\prime 193}$. Dit gebeurde niet alleen in de literatuur. Ook in sociaal en economisch opzicht stond de boerderij enigszins "buiten de geschiedenis". Op veel blanke boerderijen werd gepoogd een wereld in stand te houden "beyond the reaches of the law and the coercive state" ${ }^{194}$, waar invloeden van buitenaf zoveel mogelijk geweerd werden, en waar tegenover buitenstaanders de indruk werd gewekt dat dat voor iedereen het beste was.

Het ontstaan en voortbestaan van dergelijke enclaves was mede mogelijk doordat arbeidsverhoudingen op blanke boerderijen paternalistisch waren of genoemd werden. De laatste jaren is er door historici veel aandacht besteed aan dit Zuid-Afrikaanse paternalisme ${ }^{195}$. Samenvattend kan men stellen dat paternalisme zo niet de belangrijkste organisatiestructuur, dan toch de heersende ideologie was die een bepaalde machtsrelatie kon laten voortbestaan, zowel bij Engelse als Afrikaner boeren Volgens Robert Ross is paternalisme gebaseerd op vier premissen, kortweg:

1. het hoofd van zowel de familie als de economische eenheid (de boerderij) is een man;

2. deze baas erkent dat zijn baasschap rechten en plichten inhoudt;

3. de baas beschouwt zijn pachters en arbeiders als een uitbreiding van zijn familie;

4. het systeem is gebaseerd op een door alle partijen geïnternaliseerde acceptatie van de verhoudingen ${ }^{196}$.

Wat betreft de situatie op $19^{\mathrm{e}}$ eeuwse Zuid-Afrikaanse boerderijen, stelt Ross dat de eerste twee kenmerken van toepassing zijn, maar dat kenmerk drie op z'n hoogst een oversimplificering van de situatie is en kenmerk vier niet meer dan wishful thinking van de heersende klasse ${ }^{197}$. Ook Giliomee stelt dat "the real purpose of paternalism is to justify slavery not to the slave but to the master" 198 . Het in bepaalde opzichten toelaten van knechten en slaven binnen de familiekring sterkte de laatste in zijn identiteit "as Christian colonizer of the land" 199 en behoedde hem (in zijn ogen) voor conflicten: "[s]lave-owners could not perceive of peace in or outside the house, were the paternalistic relationship disturbed" ${ }^{200}$.

\footnotetext{
193 J.M. Coetzee 1988, 11

${ }^{194}$ Tim Keegan, Rural Transformations in Industrializing South Africa: The southern Highveld to 1914 Johannesburg, Ravan Press, 1986, 157

${ }^{195}$ Zie bijvoorbeeld Ross 1995, Van Onselen 1997b, MJ Murray 1996, Bouch 1997, Giliomee 2003b

${ }^{196}$ Ross 1995

${ }^{197}$ Ross 1995, 46

${ }^{198}$ Giliomee 2003b, 49

${ }^{199}$ Giliomee 2003b, 49

${ }^{200}$ Giliomee 2003b, 91
} 
Nadat de slavernij in 1838 was afgeschaft, bleef het paternalistische model in veel gevallen gehandhaafd, maar niet overal op dezelfde manier. Slaven werden arbeiders die in principe de vrijheid hadden om hun biezen te pakken, wat hen een zekere (soms nauwelijks meer dan theoretische) onderhandelingspositie gaf $^{201}$. Pachters (sharecroppers) namen so wie so een andere positie in, maar ook zij maakten vaak deel uit van een in sommige opzichten paternalistische structuur. Voor wat betreft de verhouding tussen landheren en pachters in Transvaal en Oranje Vrijstaat heeft Van Onselen kunnen aantonen dat in eerste helft van de twintigste eeuw blanke patriarchen (nog steeds) gebruik maakten van een complex geheel van rituelen en sociale praktijken "predicated on quasi-kinship relationships that are powerfully informed by notions of patriarchy", om "notions of obedience, deference and subservience amongst black dependants" te bewerkstelligen $^{202}$.

Een vijfde kenmerk van paternalisme dat in veel studies naar voren wordt gebracht, en dat wellicht uit de bovenstaande vier kenmerken van Ross voortvloeit, is het besloten karakter ervan ${ }^{203}$. Met name in het prekapitalistische tijdperk (dat zich op sommige plekken tot ver in de twintigste eeuw uitstrekte), was de boerderij een "politically, physically and psychologically confined domain" dat geen inmenging van buitenaf verdroeg ${ }^{204}$. Voor sharecropper Kas Maine was daarom staken eind jaren twintig geen optie: "How can you have a strike in another man's home? You can't do a thing like that." ${ }^{205}$ Maar ook Engelse wolboeren in de Oost-Kaap, die altijd al een meer kapitalistische stratificatie hadden gekend, beschouwden zich als "the best judges of what their labourers should be satisfied with" ${ }^{206 \cdot}$ Zelfs in de arbeidswetgeving van de laat $20^{\text {ste }}$ eeuw werden arbeidsverhoudingen op boerderijen, evenals binnenshuis, nog gerespecteerd als een privé-aangelegenheid. "Paternalism as an ideology," stelt Keegan, "defined and shaped day-to-day interaction and conflict in the workplace, beyond the reaches of the law and the coercive state" ${ }^{207}$. Dit gold voor boeren die zich daadwerkelijk verantwoordelijk voelden voor het welzijn van "hun" mensen, maar het betekende ook dat een boer die zijn plichten als pater familias niet serieus nam, de quasi-familiestructuur kon gebruiken als legitimatie of verdoezeling van willekeur. Het paternalistische model - een zorgzame "vader" straft en beloont zijn "kinderen" naar het hen in zijn ogen toekomt - was veelal een façade waarachter een werkelijkheid school van ofwel ongepaste

\footnotetext{
${ }^{201}$ Giliomee 2003b, 116

${ }^{202}$ Van Onselen 1997b, 212

${ }^{203}$ Bouch, Van Onselen 1997b, Murray 1989, Keegan

${ }^{204}$ Van Onselen 1997b, 212

${ }^{205}$ Van Onselen 1997b, 208

${ }^{206}$ Bouch 1997, 104

${ }^{207}$ Tim Keegan, Rural Transformations in Industrializing South Africa: The southern Highveld to 1914 Johannesburg, Ravan Press, 1986, 157
} 
(in de ogen van de heersende ideologie) intimiteit, of geweld en openlijke cq verborgen conflicten.

Er was dus op de boerderijen lange tijd, net als in de plaasromans, sprake van beslotenheid, en, in sommige gevallen, zelfs van een zekere harmonie. Maar voor zover er harmonische verhoudingen bestonden, zijn die nooit gekoppeld geweest aan een onbetwiste hiërarchische arbeidsrelatie zoals die in de plaasromans weerspiegeld wordt. In de prekapitalistische setting werden paternalistische verhoudingen gekenmerkt door een zekere onafhankelijkheid en gelijkwaardigheid van de pachter, en aan de andere kant geschraagd door gebrek aan bewegingsruimte (bijvoorbeeld door de paswetten) en geweld. Beide aspecten -gelijkwaardigheid en dwang- zijn zo goed als afwezig in de plaasroman.

Met name in Transvaal en de Oranje Vrijstaat, waar pachters vaak een grote economische onafhankelijkheid genoten, werd de grote, interraciale "familie" op de blanke boerderijen gekenmerkt door een eigen, interculturele werkelijkheid. Tot halverwege de twintigste eeuw leefden veel boeren en pachters, ook in sociaal en cultureel opzicht, redelijk gelijkwaardig en gemengd. Soms ging de relatie zover dat er sprake was van vriendschap ${ }^{208}$. Blanke en zwarte kinderen speelden met en bij elkaar, leerden elkaars taal en gewoontes, luisterden naar de verhalen.

With no great economic distance between them, and with both parties far from their more densely populated cultural hinterlands, white landlords and black sharecroppers developed a modus vivendi embracing shared ideas about dress, health, justice, language, production, recreation and religious life. ${ }^{209}$

Er was echter een grote discrepantie tussen de dagelijkse werkelijkheid enerzijds en officieel beleid en presentatie anderzijds. Afrikaanse invloeden op het leven van Afrikaner boeren werden, vooral door de rijkere boeren, zo goed mogelijk verdoezeld ${ }^{210}$, met name toen de bestaande (arbeids)verhoudingen niet langer pasten binnen het moderne economische streven: "The passion of inter-war nationalist political rhetoric of economic advancement - black and white alike - was, in part, a public disavowal of private practices" ${ }^{211}$.

Een ander aspect van de "private praktijken" die niet in het publieke domein - en (dus) ook niet in de plaasromans - terecht kwamen, was zowel excessief geweld van de boeren als (angst voor) verzet en opstanden van de pachters. Dit was in het bijzonder aan de orde toen onder invloed van het

\footnotetext{
${ }^{208}$ Van Onselen 1997a, 7

${ }^{209}$ Van Onselen 1997a, 7

${ }^{210}$ Van Onselen 1990, 117-118

${ }^{211}$ Van Onselen 1997a, 7
} 
kapitalisme de sociale organisatie van de boerderij onder druk kwam te $\operatorname{staan}^{212}$. Paternalisme was in de Afrikaanse praktijk geen statische en conflictloze orde. Het patriarchaat (een belangrijke voorwaarde voor het succes van paternalisme) was een vorm van sociale organisatie die Afrikanen van oudsher niet onbekend was. "Obviously," stelt Ross, "there is a mass of evidence to show that ideologies and practices which can be described as patriarchal on a loose definition of that word were, and are, widely distributed within South Africa." ${ }^{213}$ De allianties die in de segregationistische twintigste eeuw tussen mannen gesmeed werden, versterkten nog eens de positie van de Afrikaanse man binnen zijn familie ${ }^{214}$. Pachtovereenkomsten waren meestal mondelinge afspraken tussen het ene familiehoofd en het andere, waarbij de blanke patriarch, met toestemming van de zwarte, de orde handhaafde. Dit dubbele leiderschap was tegelijkertijd de zwakke plek van het systeem ${ }^{215}$. Net zo min als vroeger de macht van de landverdelende chiefs absoluut was, werd de macht van de landheer door zwarte boeren als absoluut ervaren. Hield de boer zich niet aan afspraken, was hij gewelddadig of onaangenaam of eiste hij teveel van zijn pachters, dan leidde dat tot openlijk of lijdzaam verzet of het beëindigen van de overeenkomst. In de ogen van hun landheren waren zwarte werknemers dus regelmatig brutaal, ongezeglijk, lui of onbetrouwbaar; een van de redenen dat familiariteit, generositeit en een christelijke moraal gekoppeld werden aan geweld ${ }^{216}$. "Whipping of recalcitrant workers by their masters was widespread and often caused conflicts between landlords and tenant households," stelt Keegan $^{217}$.

Een andere bron van conflict was de discrepantie tussen ideologie en economische werkelijkheid. De manier waarop paternalistische relaties in stand werden gehouden was verkrampt ${ }^{218}$, "just because [the ideology of paternalism] was struggling to root itself successfully in a society already experiencing the first brutal transformations of a developing capitalist economy rather than in a relatively stable and hierarchical quasi-feudal order" ${ }^{219}$. Onder invloed van de markteconomie en de daarop toegespitste wetgeving, kapitaliseerden danwel proletariseerden zwarte pachters. Armere blanke boeren in afgelegen gebieden hielden vast aan het enige dat ze hadden: land en pachters. Rijkere boeren die in staat waren te moderniseren probeerden bij hun pachters arbeidsrelaties af te dwingen die voor de

\footnotetext{
${ }^{212}$ Van Onselen 1997b, 205

${ }^{213}$ Ross 1995,45

${ }^{214}$ Ross 1995,45

${ }^{215}$ Van Onselen 1997b, 198 e.v

${ }^{216}$ Van Onselen 1997b, 192-3

${ }^{217}$ Tim Keegan Rural Transformations in Industrializing South Africa: The southern Highveld to 1914 Johannesburg, Ravan Press, 1986, 156

${ }^{218}$ Stunted is het woord dat H. Bradford gebruikt in A taste of freedom. The I.C.U. in rural South Africa, 1924-1930. New Haven, Yale University Press, 263

${ }^{219}$ Van Onselen 1997b, 199
} 
laatsten bijzonder ongunstig waren. Rijke en arme blanke boeren hadden tegengestelde belangen, maar voor beide groepen was het uiterst belangrijk om arbeidskrachten te controleren en vast te houden, wat niet eenvoudig was. Land was niet schaars genoeg, de wetgeving niet effectief genoeg en de zelfafgeroepen superioriteit niet overtuigend genoeg "to counteract what the propertied classes perceived as the unchecked defiance of authority and the lack of proper respect for private property" ${ }^{220}$. Op sommige plekken veranderde er daarom tot halverwege de $20^{\text {ste }}$ eeuw weinig ${ }^{221}$.

Maar uiteindelijk ontstonden er overal scheuren in de sociale structuur, vaak tot woede of gekwetstheid van één of beide partijen. Van Onselen vertelt hoe een landeigenaar die jarenlang uitstekende relaties met zijn pachters onderhield, eind jaren veertig zijn pachter Maine van hem vervreemdt door hem, tegen de gewoonte in, het gebruik van zijn wagen te weigeren als hij zijn dochtertje naar de dokter wil brengen. Dit gebeurt onder invloed van Malans pogingen om interraciale verhoudingen vorm te geven in een gekapitaliseerde staat, waarbij paternalisme niet verdween, maar een andere, economisch gemotiveerde vorm kreeg $^{222}$. Maine hoort zijn landheer tegen de buurman verklaren dat hij niet kan toestaan dat een "kaffer" om puur sociale redenen de wagen gebruikt. Een paar dagen later, vertelt Maine,

he told me to inspan the cart and fetch some salt for his sheep. I told him that he would have to drive the cart himself because it could not be used by a "kaffir". He [de landheer] kept quiet and shook his head. Then he asked me whether I was still on about the same old thing. I refused to do the job and told him to give my trekpas; I told him to sign me off because I was not willing to be treated that way. ${ }^{223}$

Maine vertrok en maakte daarmee een relatief laat en vreedzaam einde aan de betrekkingen. In veel andere gevallen waren de verhoudingen al veel eerder verstoord. Veel boeren die in staat waren geweest te moderniseren kregen te maken met onrust, protesten en "deserterend" werkvolk. Pachters die weigerden zich aan te passen werden op straat gezet of met geweld en intimidatie gedwongen mee te werken. Ook al was een zekere mate van "corrigerend" geweld normaal in de vroegere paternalistische verhoudingen, bij rijke, "progressieve" (=gemechaniseerde) boeren werd geweld in veel gevallen onderdeel van de routine, en werden de arbeidsomstandig-

\footnotetext{
${ }^{220}$ Murray 1989, 107

${ }^{221}$ As white landlords in the 'wet' east slowly accumulated capital and put on the economic muscle that enabled them to mechanise production and expand the areas under cultivation, so black tenants were pressured into wage-labour; when they refused they were evicted, and in a renewed search for land-rich but labour-poor white landlords, they were driven farther north and west into drier areas where grain farming was less dependable. ( Van Onselen 1997, 6/7)

${ }^{222}$ zie ook Giliomee 2003b, 475/6

${ }^{223}$ Van Onselen $1997 \mathrm{~b}$
} 
heden gekenmerkt door wreedheid, mishandeling en zelfs gewelddadige sterfgevallen ${ }^{224}$. Vooral in tijden van verandering kwamen de verhoudingen op scherp te staan. $\mathrm{Na} 1900$ deden zich verschillende periodes van onrust voor, met name voor en na invoering van nieuwe land- en arbeidswetten ${ }^{225}$. In al deze periodes kwamen pachters in meer of mindere mate in opstand tegen het verlies van hun economische onafhankelijkheid, en werden ze door excessief geweld in het (nieuwe) gareel gebracht.

De periode na de Boerenoorlog was zo'n periode. Het uiteenvallen van de sociale en economische orde in de boerenrepublieken leidde tot belangrijke verschuivingen in de relaties tussen Afrikaners en Afrikanen. Veel Afrikanen hadden het Britse leger op allerlei manieren ondersteund. Sommigen hadden tijdens de oorlog land dat hen nog niet zo lang geleden was ontnomen weer in bezit genomen. Ze werden door de Britten ontwapend, maar veel Boeren voelden zich in de rug aangevallen. Dat werd erger toen zwarte boeren bij hun terugkeer na de oorlog dankzij hun nu schaarse trekossen, uitstekende pachtvoorwaarden konden eisen en soms kans zagen blanke boerderijen op te kopen. De slechte concurrentiepositie van blanke bywoners en kleine boeren vormde een goede voedingsbodem voor toenemende, racistisch geladen afgunst, die door de regering onderbouwd werd. Zowel president Botha als later Hertzog organiseerden informatiebijeenkomsten voor blanke boeren waar ze in de woorden van een zwarte Vrijstaatse pachter: "influenced [white farmers] by saying that if they kept on allowing us to plough and practise pastoral farming on our own, it would not be long before we took those farms away from them." ${ }^{226}$

De Native Land Act van 1913 maakte het voor zwarte Zuid-Afrikanen onmogelijk blank land aan te kopen. Ook sharecropping was nu verboden, en daarmee was de wettelijke gelijkwaardigheid tussen blank en zwart verdwenen: landarbeiders en werkpachters vielen in tegenstelling tot sharecroppers onder de Master en Servantwetgeving ${ }^{227}$. Het in werking stellen van de landwet en enkele andere wetten ${ }^{228}$ ging niet zonder slag of stoot. "Between 1908 and 1916 dipping tanks were destroyed, fees withheld, telegraphlines cut and trading stores (..) burnt down"229. In 1916 werden in Oranje Vrijstaat drie Afrikanen neergeschoten die van hun boerderij waren "weggelopen" en zich op een andere boerderij hadden gevestigd. Dit was het begin van een "reign of terror": een reeks intimiderende moorden zorgde, samen met de (geruchten over) opstanden en de lakse houding van de autoriteiten, voor een "exaggerated climate of fear and hysteria" ${ }^{230}$. De

\footnotetext{
${ }^{224}$ Murray 1997, 75

${ }^{225}$ De landwetten van 1913 en 1936, arbeidswetten van 1924, 1925, 1926, en 1932,

${ }^{222}$ Keegan 1988, 21

${ }^{227}$ Bernstein 1996, 3

${ }^{228}$ Bijvoorbeeld de uitbreiding van de Glen Grey Act

${ }^{229}$ Worden 1994, 54

${ }^{230}$ Murray 1989, 117
} 
nieuwe, afgedwongen arbeidsrelaties creëerden een wederzijdse angst: voor ongelimiteerd, willekeurig geweld van blanke bazen én voor een plotselinge uitbarsting van zwarte volkswoede.

white vigilantes formed a kind of paramilitary wing of the white farming class. While the state authorities never officially sanctioned vigilantism, those white farmers who used violence to intimidate their African labourers had little to fear with respect to prosecution, let alone conviction. Yet despite all their efforts to break the will of rural Africans, white farmers lived in continued fear of 'native risings. ${ }^{231}$

In de tweede helft van de jaren twintig brak er na invoering van nog een aantal discriminerende arbeidswetten $(1924,1925,1926)$ een golf van verzet uit onder de zwarte landarbeiders, die begon met sabotage (vergiftigen van vee, verbranden van de oogst, boycotten van winkels) en uiteindelijk uitmondde in landelijk georganiseerd verzet, ondermeer tegen uitzettingen van pachters. Dit gebeurde onder de vlag van de Industrial and Commercial Workers Union of Africa (ICU) die met name in Natal, Oranje Vrijstaat en Transvaal grote groepen landarbeiders en pachters wist te mobiliseren $^{232}$. In de onderliggende ideologie werd teruggegrepen op oude helden als Shaka, Moshoeshoe en Hintsa "and it was generally believed that the ICU was struggling to regain the lands of the ancestors, who would give strength to the movement" ${ }^{233}$. Deze aanval op bestaande verhoudingen, gekoppeld aan een drain van arbeidskrachten, wekte grote woede bij de blanke boeren, ook omdat het werd gezien als een vorm van verraad ${ }^{234}$ :

With the established racial order in the countryside being challenged by smart talking city folk from the outside, and time-honoured social practices on the farm being questioned by previously loyal quasi-kin from the inside, white anger was fuelled almost as much by a sense of treachery and betrayal as it was by feelings of insecurity and vulnerability. ${ }^{235}$

ICU-leden werden door vigilantes van boeren en politie bedreigd, gemolesteerd en soms zelfs (werd er gefluisterd) vermoord ${ }^{236}$. Nadat de opstand was doodgebloed en de beweging door interne verdeeldheid ter ziele was, werd in 1932 de Native Service Contract Bill opgesteld, een arbeidswet die

\footnotetext{
${ }^{231}$ Murray 1989, 123

${ }^{232} \mathrm{http} / / /$ www.country-studies.com/south-africa/conflict-in-the-1920s.html 7-03-2005

${ }^{233}$ Ross 1999, 92

${ }^{234}$ Zie Van Onselen 1997b, Murray 1989, en Schirmer 1997

${ }^{235}$ Van Onselen 1997b, 207

${ }^{236}$ Van Onselen 1997b, 207
} 
de macht van blanke boeren over hun zwarte knechten vergrootte, en zelfs geseling weer geoorloofd maakte.

\subsection{PATERNALISME IN PLAASROMANS}

In de plaasromans die de bovenstaande periode beschrijven, is van deze conflicten nauwelijks iets terug te vinden. De ontwikkelingen van de eerste decennia van de twintigste eeuw roepen in de teksten vooral persoonlijke dilemma's op. Veranderingen dwongen tot het maken van keuzes. Na twee en een halve eeuw expansie waren de grenzen nu gesloten, er viel geen nieuw land meer te ontginnen. Volgens de traditie werd het land onder de nakomelingen verdeeld, zodat steeds minder levensvatbare boerderijen overbleven; armoede en verlies lagen overal op de loer. Maar kapitalisering en schaalvergroting leidden ook tot nieuwe mogelijkheden en dus tot conflicterende loyaliteiten. Wie moest je trouw zijn in het nieuwe ZuidAfrika: je ras, je volk, je land, je boerderij, je vrouw, jezelf? Waar hield vooruitgang op en begon verraad? Welke waarden wegen het zwaarst? Wat, met andere woorden, was identiteitsbepalend? In de plaasromans bewandelden protagonisten de dunne lijn tussen gebrek aan loyaliteit en egoïstisch winstbejag aan de ene kant en "achteruitboeren" aan de andere kant, of tussen eigenzinnig gelijk en sociaal compromis. Conflicten voltrokken zich vooral tussen blanken: tussen vader en zoon, man en vrouw, of tussen broers of buren.

Dat het hier soms ook om een politieke boodschap ging, blijkt duidelijk uit Bart Nel (1936) van Johannes van Melle. Bart Nel had ooit een huis en een stuk land op Kafferkraal, een vruchtbare plaas in het Pretoriadistrict. Kafferkraal is aan de Zuid-, West- en Noordkant ingesloten door bergruggen, maar wekt naar het oosten herinneringen aan een onbegrensd, nomadisch verleden: "na sonop se kant is die uitsig onbelemmer en sien jy tot aan die ver einders die laë, breë bulte agter mekaar wegraak soos die ruë van 'n trop beeste"(3). Op Kafferkraal wonen allemaal telgen uit de families Vermaak en Leroux. Maar Bart Nel hoort daar niet bij en dat hij zijn grond weer zal moeten verkopen is voor hem wel pijnlijk, maar niet onoverkomelijk. Hij is een man van de toekomst; hij denkt groter dan lineages. Als hij tenslotte als eenzame bywoner elders weer een bestaan probeert op te bouwen, is er iets anders dat hem met de wereld verbindt: "Hy gaan in die deur staan en kyk oor die veld wat hom reeds onder die skemer gaan verskuil, na die goud-wit einder van die westerhemel, en hy sien in verbeelding homself daar loop oor die donker veld, swaar en swart, vermoeid, alleen in die wye eensaamheid, maar algaande na die ver ruim lig; en sy siel in hom" ${ }^{237}$.

${ }^{237}$ Van Melle 1949 (1938), 200 
In dit boek staat het conflict centraal tussen Bart en zijn vrouw tegen de achtergrond van de rebellie van 1914, die met een sisser afliep, maar een voorbode was van de groei van Hertzogs Nasionale Party. Nel en zijn vrouw zijn het politiek oneens, en als hij de boerderij verlaat om te gaan vechten, voelt ze zich verraden en gaan ze zwijgend uiteen. Het komt niet meer goed. Van Melle lijkt vooral de tragiek te willen beschrijven van de onderlinge verdeeldheid van de Afrikaners en van een man wiens eigenzinnigheid en politieke vechtlust hem alles ontneemt behalve zijn trots. Dat Bart Nel na terugkeer uit de gevangenis zijn land en zijn vrouw kwijt is aan een "handelaar" (ipv een boer), verwijst niet alleen naar de persoonlijke drama's die zich in deze periode afspeelden, maar ook naar de "uitverkoop" na de Boerenoorlog, toen de Afrikaners hun zelfstandige republieken moesten prijsgeven aan een Afrikaans/Engels bewind, dat meer op buitenlandse (handels)contacten gericht was dan sommige Afrikaners lief was. Net als de rebel Hertzog zal Bart Nel ongetwijfeld ooit weer "zijn eigen land" hebben. Maar is de prijs die hij betaald heeft voor zijn eigenzinnige en vruchteloze heetgebakerdheid niet te hoog geweest? Ondanks dat de geschiedenis Nels "gelijk" bewijst - Hertzog, in 1914 in de oppositie, heeft in 1924 met zijn Nationalistische Partij de verkiezingen gewonnen en er vervolgens alles aan gedaan om de achterstelling van de Afrikaners teniet te doen - lijkt Van Melle niet ondubbelzinnig stelling te nemen.

In de romans van Van den Heever is het dilemma veelal gelegen in loyaal zijn aan de gemeenschap of aan de traditie (voorouders). Zijn hoofdpersonen moeten kiezen tussen solidariteit en vooruitboeren (Laat vrugte), of tussen solidariteit en overleven als boer (Somer). Hebzucht is de valkuil van Oom Sybrand in Laat vrugte. Bij het vooruitboeren stuit hij steeds op dezelfde weerstand: de koppigheid van zijn buurman en zijn moeder die hun land maar niet aan hem willen afstaan. Hij vervreemdt zijn zuster en dochter van zich door hen hulp te weigeren; zijn zoon verlaat de boerderij omdat hij de laatdunkende en gewelddadige heerschappij van zijn vader niet langer accepteert, en zijn vrouw sterft aan emotionele verwaarlozing. Als zij begint te spoken, start er bij Oom Sybrand een langzaam proces van bewustwording (waarover later meer). Waar eenzaamheid bij Bart Nel nog iets heroïsch had, is dat voor Oom Sybrand, meer nog dan de dood, uiteindelijk de grootste straf.

Het belangrijkste verschil tussen de fictieve en de historische plaas is de prominente rol die zwarte boeren speelden in de geschiedenis en hun prominente afwezigheid in de literatuur - en dus in de formatie van een Afrikaner identiteit. Voor zover aanwezig worden de interraciale werkverhoudingen afgeschilderd als statisch en paternalistisch: een meester heerst en waakt als een pater familias over zijn onderdanige, kinderlijke, trouwe knechten. Paternalisme is een heel bruikbaar kader om de verhoudingen te 
beschrijven, juist omdat het zo meerduidig is; zo verhullend en tegenstrijdig. Het is tegelijkertijd discours en praktische organisatie; het heeft een schijn van tijdloosheid, maar past zich uiteindelijk voortdurend aan aan de omstandigheden en de heersende ideologie; het heeft een gezicht naar binnen en naar buiten. Een van de belangrijkste metaforen die het vormgeven, is die van de "familie". Familie was de metafoor die persoonlijke en interraciale relaties, maar ook erfrecht, bezit en nationalisme, kortom de "natuurlijke orde" der dingen, vorm gaf en legitimeerde. Metaforen bestaan bij de gratie van cultureel bepaalde connotaties. Om te begrijpen hoe dit precies werkt "it requires," volgens Turner, "that we understand both the idealized cognitive models of kinship roles in [a] culture and the metaphores that interact with them to yield metaphoric inferences" ${ }^{238}$. In deze situatie zijn er meerdere "idealized cognitive models of kinship roles", die elkaar beconcurreren en tegenspreken. Al die cognitieve modellen genereren verschillende betekenissen bij gebruik van de term (of de praktijk) paternalisme. In elk geval is er een centrum (Wij) en periferie (Onze Anderen) binnen een besloten ruimte met daarbuiten een Vijandige Ander (natuur, barbaren, kapitalisten, (inter)nationale overheden en instanties), die de orde bedreigt.

Paternalisme is in de literatuur in veel gevallen een "natuurlijke orde" die niet bevraagtekend hoeft te (maar wel kan) worden, die de onzichtbare, conflictloze aanwezigheid van zwarte boeren verklaart en de superioriteit (of zelfverlakkerij) van de protagonist illustreert, terwijl de aandacht is gericht op de innerlijke conflicten van het centrum en externe conflicten met de vijandige Ander. In de politiek was het een beeld dat kapitalisme aan nationalisme en apartheid wist te verbinden, dat Afrikaners met elkaar en "hun" feodale verleden verbond, de blanke beschaving veilig stelde, en de macht die boeren en industriëlen over hun arbeiders meenden te moeten hebben, legitimeerde en verhulde. Onderlinge solidariteit, Afrikaner baasskap economisch vooruitboeren en (vader)landsliefde werden opgevoerd als oude boerenwaarden die in de nationalistische politiek overeind werden gehouden: de ziel van Bart Nel bevond zich in Pretoria. De Afrikaner bleef een boer, maar dan in overdrachtelijke zin $^{239}$.

Maar in het boerenbedrijf kon paternalisme weer iets heel anders betekenen. In het ene uiterste geval was het een ingewikkelde, wankele kluwen aan ongeschreven wetten en tegenstrijdige verwachtingen, een in wisselwerking met Afrikaanse pachters gecreëerde extended family, leunend enerzijds op oude Kaaps-Hollandse of Engelse feodale idealen, en ander-

\footnotetext{
${ }^{238}$ Turner, 8

${ }^{239}$ Toen in 1938 door de FAK een grootschalig herdenkingsfeest ter ere van 100 jaar Grote Trek werd georganiseerd, hield Van Wyk Louw er een lezing. In plaats van een ode aan eigenzinnigheid en vrijheidsstrijd, werd dit een ode aan visionair leiderschap en volgzaamheid, een combinatie die Afrikaners uit heel Zuid-Afrika naar een hoger ideaal zou moeten voeren. "Die Ewige Trek" (gepubliceerd in Louw 1939). Zie ook Postel 2003, 321/2
} 
zijds op de Afrikaanse familie waar Afrikaanse pachters zo duidelijk hun stabiliteit en hun welstand aan ontleenden. In het andere uiterste geval was het, met name in een kapitalistische context, een van bovenaf opgelegde arbeidsorganisatie die een zo groot mogelijke controle over de arbeiders garandeerde en een conflictueuze situatie maskeerde.

In zo'n semantische chaos is er altijd ruimte voor (potentiële) verandering en (verborgen) tegendiscoursen. De plaas is zowel symbolisch (literair) als historisch de besloten ruimte geweest waarbinnen Wij en Onze Anderen zich bewogen, en de summier weergegeven, of zelfs alleen veronderstelde "paternalistische" verhoudingen tussen blanke en zwarte boeren bergen in principe alle bovenstaande varianten in zich.

In Bart Nel, bijvoorbeeld, zijn zwarte boeren gemarginaliseerd, zowel in plaats als tijd, tot spoken uit het verleden in verlaten ruïnes in de bergen die Kafferskraal omringen, of tot ingehuurde, luie (als de baas van huis is) voëljaërs. Oom Daan in "Oom Daan en die dood" (1938) van Van Melle ziet zijn zwarte knechten duidelijk als een (zij het marginaal) verlengstukje van de familie. Het zoontje van de boer heeft last van helderziendheid: als iemand uit zijn naaste omgeving gaat sterven, ziet hij diens geest. Als het kind weer spoken ziet, vraagt de boer zich ongerust af wie het dit keer kan zijn, zijn vader, zijn vrouw, hijzelf? Of misschien zelfs de zwarte knecht die zo ziek is? 'Dis een van my eie kaffers; dis moontlik, 'n mens kan nie weet nie." ${ }^{240}$ Zijn relatie tot hen is er een van mededogen die voortkomt uit een gevoel van superioriteit: tegenover blanken is hij egoïstisch, maar "vir sy diere en sy kaffers is hy goed. (..) 'Witmense kan vir hulle self sorg,' dink hy. 'Hulle is slim genoeg daarvoor. Maar die swartgoed is te onnosel. Die Here het hulle so min verstand gegee dat 'n mens hulle gerus kan jammerkry." (91) Van Melle lijkt hier niet zozeer of niet alleen Daans verknochtheid aan "sy eie kaffers" te bespotten en af te keuren, maar ook het misbruik van bepaalde clichés: paternalistische smoezen in een kapitalistische context ${ }^{241}$. De "onnozelheid" van de zwarte bevolking is een paternalistisch cliché, dat vooral ten aanzien van bestuurders controle en geweld legitimeerde ${ }^{242}$. Veel Afrikaner boeren wisten wel beter, maar toen tijdens de "reign of terror" rond 1920 in Oranje Vrijstaat boeren steeds meer gebruik maakten van "frontier justice" (wat wil zeggen dat ze het recht namen ook buiten hun eigen territorium gewelddadig tegen zwarten op te treden), zonder dat hen iets in de weg werd gelegd, "the offcial response to these reports that circulated with increasing regularity in the

\footnotetext{
${ }^{240}$ Van Melle 1949 (1938), 94

${ }^{241}$ Van Melle 1949 (1938), 89-98

${ }^{242}$ Interessant is in dit licht Ross' argumentatie dat paternalisme in de vroeg negentiende eeuwse Kaap wellicht meer tot een Brits-koloniaal discours dan tot een boeren (Afrikaner) werkelijkheid hoorde. Het was namelijk vooral de Britse regering die pleitte voor paternalistische werkverhoudingen, en het zijn de verslagen van rechtzittingen, podia waar zowel meesters als slaven zich voor een Engelse rechter van hun beste kant lieten zien, die voor veel historici de bewijzen leveren voor het bestaan van paternalistische verhoudingen. (Ross 1995, 36/7) Zie voor Engels paternalisme ook hoofdstuk 2.
} 
formal correspondance of state bureaucrats dovetailed neatly their clichéd images of rural Africans as lazy, 'uncivilized', child-like unfortunates who required constant supervision." "243 "Voogdij", een mengsel van Kaaps paternalisme en Brits indirect rule ${ }^{244}$ was ook het begrip waarmee Malan in de jaren veertig de apartheidsplannen een menselijk tintje gaf. Oom Daan lijkt deze supersmoes door overstrekking zijn betekenis te ontnemen, als hij hem gebruikt om zijn buren niet te hoeven helpen. Ook in het verhaal "Die Pad van Afrika" ${ }^{245}$ laat Van Melle zowel het Afrikaner nationalisme, als het paternalisme als het Engelse imperialisme tongue in cheek uit zijn krachten groeien. Tegen de achtergrond van het eeufees ${ }^{246}$ vermengt hij hier het beeld van de Afrikaner als eeuwige trekker en strijder met de Britse Cape-toCairoretoriek en de bekeringsdrang van de missie. Dominee Vermeulen zoekt naar nieuwe idealen om het volk te verenigen, en vindt die in het streven om heel Afrika te kerstenen.

Ons is die aangewese voogde, maar van voogde het ons oorheersers geword en ons voogdyskap is tydelik van ons weggeneem. (..) Nou moet ons ons goeie wil wys en en waarlik voogde wees en die swartes ophef tot " $n$ christelike en beskaafde lewe. Dan sal ons waardig wees om die pad deur te trek tot in Midde-Afrika, tot aan die kuste van die Middellandse See; dan sal ons heers van die Kaap tot in Kaïro en ons sal al die nasies verdryf wat alleen kom om die swart nasies uit te buit (133).

Dat Van Melle voorstander was van stemrecht voor zwarten, nog een serieuze optie tijdens de vorming van de Unie van Zuid-Afrika in $1910^{24}$, zal ik niet willen beweren ${ }^{248}$, maar zijn spot ten aanzien van Malans retoriek is onmiskenbaar. Henriette Roos schreef over hem: "In sy romans word een paradoxale christelike anargisme openbaar, 'n perspektief waardeur op stilistiese en tematiese vlak die konvensionele politieke, klasse-, ras- en geslagsverhoudings versteur word. In sy boeiendste verhale opponeer die komplekse karakters juis die nasionale strewe" ${ }^{249}$.

\footnotetext{
${ }^{243}$ Murray 1989; 110

${ }^{244}$ Zie Giliomee 2003b, 476

${ }^{245}$ Van Melle 1949, 129-133

${ }^{246}$ In 1938 wist de Nasionale party grote aantallen kiezers te trekken door samen met Broederbond en kuluutverenigingen een grootschalige herdenking van de Grote Trek te organiseren. Schrijvers en politici sloegen de handen ineen om de Afrikaners met behulp van geschiedkundge symbolen tot een groot, eendrachtig volk te verheffen (Postel 2003, 308).

${ }^{247}$ Giliomee 2003b, 304

${ }^{248}$ Hertzog zei 1922: "No one will stop the native from eventually otaining the franchise," maar hij achte het dealsniettemin zijn morele plicht dat moment zo lang mogelijk uit te stellen. (giliomee 2003, 302) Al in de loop van de negentiende eeuw was de Afrikaner elite bekeerd tot een niet-raciaal, christelijk liberalisme, terwijl ze tegelijkertijd gelykstelling bleven afwijzen (Giliomee 2003, 128)

${ }^{249}$ Roos 1998, 40
} 
Net zo min als Van Melle heeft Van den Heever een duidelijk antwoord op de verwording van interraciale paternalistische relaties in een kapitalistische context. Worden in de plaasromans de traumatische ervaringen van de plattelandscrisis vooral verbeeld in conflicten tussen vader en zoon of sappelende boeren en stadse, kapitalistische schuldeisers, de wetenschap dat de "familie" die in zijn boeken zo belangrijk was als bindmiddel met de aarde, in de boerenwerkelijkheid voor een deel uit Afrikanen heeft bestaan die de blanke boerderijen levensvatbaar maakten, maakt dat die conflicten net zo goed het uit elkaar groeien verbeelden van de patriarch en zijn extended zwarte familie.

Als Van den Heever hiervoor een oplossing lijkt aan te bieden, dan is dat segregatie. De veronderstelde "eigen Ander" is uiteindelijk een vreemdeling geworden. Dat deze ontwikkeling, hoe onvermijdelijk misschien ook, een heel pijnlijke geweest is, laat Van den Heever in Laat vrugte zien door Jannewarie (meer natuur dan cultuur: "sy verrimpelde gesig en vaal-swart kleur maak hom deel van die taai bossies en skurwe wêreld wat hom omring," observeert Oom Sybrand ${ }^{250}$ ), of in elk geval diens vertrek, in het verlengde te plaatsen van (het vertrek van) zijn zoon. Oom Sybrand wil zelf, karaktergetrouw, zijn eigen rol daarin nog niet zien. Zijn beschrijving van het conflict met Henning doet sterk denken aan de onverhoedse rebellie van een pachterszoon, een veelvoorkomende oorzaak voor conflicten tussen pachters en bazen. Vaak betaalden pachters voor hun grond met de arbeid van een van hun zonen. Als die laatste volwassen werd, kwam er een moment waarop hij rebelleerde tegen zijn baas, waarop de baas geweld gebruikte om de jongeman weer in het gareel te krijgen. Als de zoon dan steun zocht bij zijn vader, kwamen de verschillende opvattingen over de onderlinge verhoudingen aan het licht en was een conflict tussen beide familiehoofden bijna onvermijdelijk. Een dergelijk conflict liep meestal uit op het vertrek van de pachterfamilie ${ }^{251}$.

De ruzie tussen Sybrand en Henning heeft een vergelijkbaar verloop. Als Henning de klappen en intimidatie van zijn pa niet meer accepteert, stuurt Sybrand hem in machteloze woede weg. Sybrand begrijpt er niets van.

Wat hom totaal verbyster, is die onverwagte brutaalheid wat die klein japsnoet teen sy eie vader kon openbaar. Waar kom hy so skielik daaraan? Hy het daë aanmekaar hier by die werk rondgeslenter sonder dat hy boe of ba kan sê, en onverwags, of die duiwel in hom gevaar het, neem hy so 'n houding aan dat dit nie veel gekos het nie of hy het sy eie vader te lyf gegaan! ${ }^{252}$

\footnotetext{
${ }^{250}$ Laat vrugte, 6

${ }^{251}$ Van Onselen 1997b, maar ook Murray (1989) maakt melding van dergelike gevallen.

${ }^{252}$ Laat Vrugte, 130
} 
In dezelfde periode vertrekt ook Jannewarie.

En dat hy ou Jannewarie nou bo-op alles moet verloor! Dit is die beste skaapwagter wat hy ooit gehad het, en al moes hy hom nou en dan bydam, al het hy hom al baie harde klappe gegee, die ou het maar steeds gebly, omdat hy hom regverdig maar streng behandel het, hy het hom gegee wat hom toekom, selfs die slaë as hy verbrou het. Hy het Jannewarie byna gesmeek om te bly, maar dit het geen uitwerking gehad nie. ${ }^{253}$

Sybrand gelooft dat Jannewarie ervandoor is gegaan omdat het gerucht gaat dat het spookt in zijn huis. Tegelijk kan hij nergens nieuwe hulp krijgen, omdat er (volgens hemzelf) rondverteld wordt ${ }^{254}$ dat "hy 'n mens laat werk tot jou oë wit omkeer soos 'n os s'n, tot jy naar die towerdokter moet gaan om "meestergoed" vir jou senings te kry" ${ }^{255}$. Door het paternalisme hier niet alleen te gebruiken om de relatie tussen baas en knecht te definiëren, maar ook om zoon en knecht op een lijn te zetten, lijkt Van den Heever te willen aangeven dat "familiebanden" evenzeer als familiebanden gebaseerd zijn op wederzijds respect en dat ook de bazen debet zijn aan de huidige staat van vervreemding tussen blank en zwart. Daarmee laat hij ruimte voor de interpretatie dat het vertrek van Jannewarie - dat wil zeggen de vertrouwensbreuk tussen blank en zwart- een veel grotere rol in dit drama speelt dan door Sybrand en veel van zijn lezers werd erkend. Een tragische rol bovendien: waar er voor zonen een weg terug is, lijkt die er voor "zonen" niet te zijn. De definitieve vervreemding krijgt vorm in de levenloze blik van een voorbijganger (een vluchteling voor de nieuwe orde), in Sybrands machteloze woede, en in de moeizame communicatie:

In die pad gaan trekvolk verby. [Sybrand] (..) stap dadelik daarheen. Die Basoeto loop slenter-slenter agter sy paar skape aan en op 'n verwaarloosde bultmaagmerrie, met inmekaargekoekte maanhare, ry 'n ou vrou met swart sierstrepe oor die slapende gesig. Op haar rug abba sy twee hoenders in 'n vuil doek. Die ou man, potswart in sy rooi kombers, wys weinig tekens van belangstelling. Dit lyk of daar amper geen lewe in sy oë is nie - net 'n vleugje wil in die lusteloos bewegende liggaam.

Nee hy wil nie bly nie, hy trek Basoetoland toe.

"Loop na jou verstand!" skreeu oom Sybrand toe hy genoeg gesukkel het om hom verstaanbaar te maak en om te begryp wat die ou trae

\footnotetext{
${ }^{253}$ Laat Vrugte 145

${ }^{254}$ Als arbeidsverhoudingen uit de hand liepen, kon er onder pachters en werknemers in een bepaald gebied een "zwarte lijst" gaan circuleren, waardoor de betreffende boeren geen arbeiders meer konden krijgen. Zie bijvoorbeeld Murray 1989, 110

${ }^{255}$ Laat Vrugte 145/6
} 
skepsel trapsuutjiesagtig wil beduie. ${ }^{256}$

\subsection{CONCLUSIE}

Het ontstaan van een Afrikaner identiteit is dus te danken geweest aan maatschappelijke ontwikkelingen die de in de plaasroman bezongen waarden aantastten en veranderden - of het nu de strijdlust van Van Melles individualistische trekboeren was, of de kleinschalige geworteldheid van Van den Heevers patriarchen. Het ontstaan van een Afrikaner arbeidersklasse, de massale trek naar de steden, de mogelijkheid tot organisatie hebben aan de wieg gestaan van het Afrikaner nationalisme. Zonder onteigening, depressie en droogte zou de Afrikaner nooit hebben bestaan. De afgezonderde boerderij is niet de plek waar nationalistische gevoelens ontspruiten, of, zoals Ampie Coetzee opmerkt:

Mens [sou] ook kon aflei dat die plaas, die plek van eensaamheid Eindvlei, Uitdraai, Perdepoort, Basterfontein, Toorberg, Wildeperdehoek - die ruimte van die patriarg was, maar waarskynlik nie die soort terrein vir die skep van die magshegemonie van die Afrikaner nie. Ook omdat hierdie afsondering plekke van stilte was; 'n stilte waarin karakters verdwyn het, en waarin geen identiteit met 'n ander sou kon ontstaan nie. ${ }^{257}$

Een identiteit als Afrikaner had hier misschien niet kunnen ontstaan hoewel Van Onselen in de neiging van Afrikaners om iedereen Oom en Tannie te noemen, een poging ziet om de onderlinge banden en de paternalistische ideologie te versterken "in a society where whites were sometimes a little thin on the ground". ${ }^{258}$ Maar een Afrikaanse (in de breedste zin van het woord) identiteit, hoe wankel en tijdelijk ook, heeft hier juist wel kunnen ontstaan.

Voor het nationalistische discours kwam het goed uit dat Van den Heever zijn lineage-ideeën uitwerkte in een tijd dat de zwarte boeren hun "voorouderlijke" grond definitief elders toegewezen hadden gekregen, zodat er van hen geen ideologische concurrentie meer te duchten viel. Voordien konden ze immers, met dezelfde argumenten, evenveel aanspraak maken op het land. Maar tegelijkertijd heeft segregatie juist ook bijgedragen aan het verlies van identiteit waar Ampie Coetzee over sprak: niet alleen "die onteiening van die plaas" en het uiteenvallen van de sociale (familie)structuur binnen de Afrikaner gemeenschap, maar ook segregatie was

\footnotetext{
${ }^{256}$ Laat Vrugte 146

${ }^{257}$ A. Coetzee 2000, 123

${ }^{258}$ Van Onselen 1997b, 203
} 
debet aan de ontwrichting van de sociale orde. "Grond is gelyk aan identiteit, identiteit gelyk aan betekenis," schreef Coetzee ${ }^{259}$, maar het verlies van landbezit, of contact met het land, was ook het verlies van een (vermeende) sociale identiteit bínnen, of in contact met de Afrikaanse gemeenschap. In de prekapitalistische setting was de blanke boer inderdaad hij-die-het-landbezit, niet in kapitalistische zin, niet in de zin van de apartheidswetten, maar in de betekenis van hij-die-iets-te-bieden-heeft-aan-hem-die-het-zaaden-de-ossen-bezit. In deze betekenis was land voor een boer niet alleen zijn enige garantie op voortbestaan, het was -volgens goed Afrikaans gebruikhet middel om zich een plaats te verwerven binnen een (interraciale) samenleving. Valt deze structuur weg, dan komen (potentiële) conflicten bloot te liggen, wordt Onze Ander een Vijandige Ander, en is men genoodzaakt om óf de grenzen van de besloten Wij-ruimte te verleggen, óf de Ander naar buiten te verplaatsen. Dat laatste gebeurde. In theorie tenminste. In praktijk verdween de vijand nooit helemaal uit het eigen domein en werd hij een verzwegen, unheimliche ${ }^{260}$ aanwezigheid.

$\mathrm{Nu}$ nog even terug naar het begin, en naar wat J.M. Coetzee "the problem of te meaning of the farm" noemde: het probleem van ontglippende betekenis. Uit het voorafgaande is gebleken dat het vormgeven van geschiedenis en landschap in plaasromans een manier is geweest om het land te benoemen, te begrenzen en toe te eigenen, zodanig dat, zoals Gunner ook zei ten aanzien van Zulu en Sotho praise poetry, "the social and historical self is perceived through the land." ${ }^{.61}$ Dit laatste was dusdanig belangrijk dat men, zelfs nadat de mogelijkheid om het land in economische zin vast te houden voor de meesten grotendeels was verdwenen, liever een innerlijke discrepantie accepteerde binnen die identiteit, dan het land, de boerderij, als identiteitgenererende symbolische ruimte los te laten.

De Afrikaners stonden hier niet alleen in. De identiteitgenererende betekenis die in de plaasromans van vooral Van den Heever aan het land wordt gegeven ${ }^{262}$, vertoont opvallend veel overeenkomsten met de betekenis die Afrikanen er volgens John Mbiti aan hechten: "for African peoples the ground has a religious charge, mystically uniting past and present generations", maar ook "time and space" ${ }^{263}$. Dit komt ook terug in de in (latere) zwarte Afrikaanse literatuur tentoongespreide gehechtheid aan de aarde, zoals die door Sam A. Adewoya beschreven wordt in The concept of land in the African novel (1989). In zijn voorwoord omschrijft Adewoya het belang van zijn boek als volgt:

This study focuses on African novelists reflection of phenomena

\footnotetext{
${ }^{259}$ A. Coetzee 2000, 16

${ }^{260}$ Zie ook hoofdstuk 3

${ }^{261}$ Gunner 1996, 120

${ }^{262}$ Zie ook Hoofdstuk 3.6

${ }^{263}$ Mbiti 1969, 160
} 
which touch the lives of everybody in any African community. The African psyche, cosmos, and world-view are inextricably tied to earth - the concept of the inseparability of man from the land. Humanity, to the African, is a factor of triple dimensions:

1 That man is linked to his ancestors through the belief in the concept of continuity, the living, the dead and the unborn.

2 Connected to the above metaphysical concept is the concreteness of land. It is the physical representation of the circle of continuity. It has the custody of man's umbilical cord with which separation is inconceivable. Man therefore seeks replenishment from Mother Earth for regeneration and sustenance.

3 There is also the socio-economic reality of the land: that man feeds on the earth. Man cannot sever his relationship with the land if he is to survive socio-economically.

Given the foregoing assumptions and values, the African writer, in his sensitivity and awareness, creates art that is directly inspired by the existence of the land. ${ }^{264}$

Bij het lezen hiervan vallen al onmiddellijk de overeenkomsten op met het lineage-denken van Van den Heever. Deze indruk wordt bij verder lezen nog versterkt. In Adewoya's analyses van Achebe en Ngugi treft men het "vooruitboeren" als plicht aan de voorvaders:

Achebe and Ngugi both agree that man regards the land as a natural gift of God; they both show the living and the dead interacting visibly on the land; they both hold that the land must be made productive to link one generation to the other (126).

Dichter bij huis; in dezelfde periode dat de plaasroman haar piektijd beleefde, de jaren dertig en veertig van de vorige eeuw, schreven twee Zulu dichters, H.I.E. Dhlomo en B.W. Vilakazi, poëzie "concerned with loss -of land, nation, history- and (..) intent on a process of reclamation through culture" 265 . "Mapping through poetry" stond centraal in het creëren van een thuis: "the renamed land becomes once more something to which an outcast can return and belong." In zijn gedicht The valley of a thousand hills (1941) houdt Dhlomo zich bezig met "the remapping of the present, the conceptual reclaiming of the land" door naamgeving van mensen en plaatsen. Hij noemt zichzelf "an outcast in my own land" en is dit nog eens extra omdat hij door zijn Engels taalgebruik en het gekozen medium afgesneden was van zijn publiek. Vilakazi, die in Zulu schreef, had dat probleem minder. Toch was ook hij, in zijn ijver het verleden te herscheppen, een balling van

\footnotetext{
${ }^{264}$ Adewoya 1989, xiii

${ }^{265}$ Alle citaten uit deze alinea komen uit Gunner 1996, 121-123
} 
het heden. Waar dus in de plaasroman de geschiedenis verdrongen werd door de ruimtelijke inrichting van het heden, overschrijft Vilakazi het hem omringende heden met de herinnering waardoor "the bleakness of the present is only hinted at, as a kind of absent presence." Kortom: in dit literaire landschap zijn het de blanke boeren die zijn teruggebracht tot een unheimliche aanwezigheid.

Volgens Gunner zijn deze teksten geïnspireerd op een sterke, nog steeds levende orale traditie (praise poetry), waarin een verband wordt gelegd tussen het land en de identiteit van het individu. De invloed van dergelijke orale teksten op geschreven literatuur is vaak groter dan veel lezers zich bewust zijn.

Far from existing fenced off and out of time (..) [oral genres] impinge, often awkwardly, on written genres and the discourses constructed from them. Sometimes they seem so awkward that their powerfull, difficult presence is largely ignored or at best underrated. (...) What they have to say needs to be read in consonance with contemporary writing about land and identity. Certainly in South Africa, such oral textuality has had a strong influence on some written traditions" (..) [T] he complicated voice of the so-called colonized subject can be heard constructing a discourse in relation to the land. ${ }^{266}$

Zoals geldt voor veel Afrikaanse constructies in de Zuid-Afrikaanse context: dat het bestaan van dergelijke constructies onderbelicht is gebeleven, wil niet zeggen dat ze niet bestonden of weinig invloed hadden. Receptie van deze teksten is vooral problematisch omdat ze voor een niet ingewijde lezer een nieuwe manier van lezen, zelfs van denken vragen, met name wat betreft de constructie van een thuis.

There are ways of regarding (..) the land, ways of belonging, which are difficult to ascertain without the crossing and recrossing of cognitive boundaries, a revision of what constitutes 'text' and 'post-colonial text' and a search for a new aesthetic. ${ }^{267}$

Voor blanke Zuid-Afrikanen was de Afrikaanse relatie tussen individu en land zowel zeer herkenbaar als onkenbaar, een combinatie die, zoals ook verderop zal blijken, onderdeel uitmaakt van het unheimliche karakter van de relatie tussen beiden.

Wat betreft de overeenkomsten wil ik hier niet ingaan op kip-en-ei-vragen. Achebe en Ngugi e.a. zijn in hun verbeelding van Moeder Aarde vermoedelijk niet alleen beïnvloed door Afrikaanse tradities, maar ook door

\footnotetext{
${ }^{266}$ Gunner 1996, 115-118

${ }^{267}$ Gunner 1996, 118
} 
koloniale metaforen. ${ }^{268}$ Vilakazi en Dhlomo waren natuurlijk eveneens onderdeel van een intercultureel discursief strijdperk. Maar dat waren de plaasromanauteurs ook. Allen verwoordden een band tussen mens en grond die identiteitsbepalend is, en die door zwarten en blanken evenzeer werd (en wordt) verdedigd, maar ook wederzijds werd aangevochten en doelbewust verstoord ${ }^{269}$ Afrikanen en Afrikaners waren concurrenten, niet alleen in hun economische afhankelijkheid van land, maar ook in hun landgebonden identiteit. Die concurrentie werd alleen maar scherper en onwenselijker met het aanscherpen van de segregatiepolitiek. Wellicht heeft niet alleen de aanwezigheid, arbeid en sociale organisatie van Afrikaanse boeren een veel grotere stempel gedrukt op het plaasdiscours en de plaasroman dan men lange tijd heeft willen weten, maar ook hun "ways of regarding the land". En de problematische receptie van (de invloed van) dergelijke concurrerende of gedeelde "ways of regarding the land" kan hebben bijgedragen aan het feit dat de betekenis van de boerderij maar steeds bleef -en blijft- ontglippen.

In latere romans zal de unheimlichheid van ontglippende betekenis zich steeds duidelijker manifesteren, evenals vervreemding en dreigend conflict. Maar daarover later meer. In het volgende hoofdstuk zal ik me eerst richten op wat het pastorale, en met name boederijdicours in de Engelse literatuur behelsde. Dan zal blijken dat ook daar "familie" als metafoor een belangrijke structurerende en betekenis genererende functie vervult, evenals de dood, een van de metaforen die voortdurend met de familiemetafoor in wisselwerking is. In verband met dat laatste zal ik aan het eind van het volgende hoofdstuk nog kort op de plaasromans terugkomen.

\footnotetext{
${ }^{268}$ Stratton 1994, 40

${ }^{269}$ Zie ook hoofdstuk 4
} 
On visiting a missionary settlement By Heaven directed, by the world reviled, Amidst the wilderness they sought a home, (...) Till in the satyr's haunt and dragon's den A garden bloom'd, and savage hordes grew mild. Thomas Pringle, 1834

The serf

I see in the slow progress of his strides Over the toppled clods and falling flowers, The timeless, surly patience of the serf That moves the nearest to the naked earth And ploughs down palaces, and thrones, and towers. Roy Campbell, 1930

\section{"Old frontier fears" Een falende idylle tussen slavernij en barbarij}

\subsection{INLEIDING}

Armoede, paternalisme, geweld en opstanden zijn niet exclusief voorbehouden geweest aan het Afrikaner platteland. Maar Engelse boeren speelden over het algemeen een net iets andere rol in Zuid-Afrika, zowel symbolisch als economisch. Ze schreven geen geschiedenis als rebellen, maar maakten onderdeel uit van Britse rijk, het koloniale discours en de bijbehorende economische infrastructuur. Toch herbergde ook de Engelse boerderij, zowel in literair als in sociaal opzicht, een besloten wereld. Het was de plek waar de woestijn ging bloeien, de heiden ging lezen en mannen heren werden. Maar niet voor lang. De witte plekken van Afrika, haar "inexplicable majestic silence, lying just over the border of memory, or of thought" ${ }^{270}$ -of van omheind land?- bleef oprukken en veranderde de moeizaam gecreëerde idylle uiteindelijk in horror.

Volgens Stephen Gray (1979) had dit wat de literatuur betreft te maken met de onverenigbaarheid van (Europese) ideologie en (Afrikaanse) werkelijkheid. Niet alleen de identiteit van de Afrikaner boer is gebaseerd op een paradox. Gray ziet een discrepantie tussen het zelfbeeld van de Engelstalige blanke Zuid-Afrikaanse schrijver enerzijds en de werkelijkheid die zich aan hem opdringt en die hij -in navolging van het engelse liberale realisme- in zijn boeken wil vangen anderzijds. De ondermijnende onderstroom die steeds weer opduikt is er volgens Gray echter niet alleen één van "doubts

${ }^{270}$ Doris Lessing "Preface" African Stories, 1981, 6 
about the pastoral enterprise" ${ }^{271}$ maar van existentieel verlangen en gebrek aan identiteit, die te maken heeft met het ideologische falen van de Engelse liberale traditie in Afrika ${ }^{272}$. In de eerste helft van de twintigste eeuw kwamen dan ook niet alleen in de Afrikaanstalige boerderijroman dilemma's aan de orde die te maken hadden met kwesties rond culturele identiteit. Michael Chapman schildert de Zuid-Afrikaanse literaire context (en die is in zijn ogen met name Engelstalig) van pakweg 1910 tot 1970 als volgt:

What we find among serious white writers are struggles, hesitations, and retreats involving questions of belonging to Africa or Europe. (...) The large issues are the relationship between the social and the literary practices of the old and the new world, and between the imported language and the South African environment. ${ }^{273}$

Ik zal vrij uitgebreid stilstaan bij de historische confrontaties die zich hebben afgespeeld op het platteland van de Oost-Kaap en Natal, voordat ik probeer de literaire verbeeldingen van het landschap en de confrontaties te interpreteren. Hieruit zal blijken dat de Engelstalige gebieden in feite dezelfde ontwikkeling hebben doorgemaakt als de Afrikaanstalige, alleen in een ander tempo, en met andere machtsmiddelen. Voldoende arbeidskrachten "vrijmaken" was ook hier steeds een belangijke politieke drijfveer, en ook hier was het verzet van zwarte boeren tegen proletarisering groot. Ondanks de verregaande macht en invloed van kerk, leger en koloniaal en later nationaal bestuur, bleven er meer of minder onderhuidse tekens opduiken die verwezen naar veerkrachtige tegendisoursen.

\subsection{FROM CAPE TO CAIRO EN ANDERE MISSIES}

In 1795 vielen de Britten de Kaapkolonie binnen, uit angst dat hun grote rivaal Frankrijk via Nederland de controle over dit strategische punt zou krijgen. Ze handhaafden het pre-revolutionaire Nederlands-Romeins recht dat in de Kaap nog gold en de politieke allianties met de belangrijkste groot-grondbezitters. Wel werd een wat liberaler bewind gevoerd, zowel wat economie als rassenrelaties betreft.

Steeds meer Engelsen vestigden zich in de Oost-Kaap en langs de Oostkust in het huidige Natal. Engeland stimuleerde emigratie van armen naar ZuidAfrika en de kolonie wilde ze graag hebben om gebieden te stabiliseren. In 1820 kwamen 5000 Britse kolonisten aan in de Oost-Kaap, niet wetend dat ze vooral dienden als buffer tussen ruziënde Afrikaners en Xhosa. Ze

\footnotetext{
${ }^{271}$ Coetzee 1988, 11

${ }^{272}$ Gray 1979,133 e.v.

${ }^{273}$ Chapman 1996, 173
} 
hadden het niet gemakkelijk. De grond was hard, het weer onbetrouwbaar, de vrede broos en tijdelijk, en tot 1828 mocht er met de naburige Xhosa ook niet worden gehandeld, omdat men bang was dat dat de positie van de Xhosa alleen maar zou versterken ${ }^{274}$. Bovendien was er een gebrek aan arbeidskrachten. Tussen nieuwe en oude kolonisten ontstond een flink verschil van mening over de rol die slavenarbeid moest spelen in de economische opbouw van het land. Behalve uit "verlichte" ideeën kwam de beslissing tot afschaffing van de slavernij voort uit het besef dat een moderne economie beter zou draaien op goedkope, vrije arbeidskrachten dan op slaven, en dat een dergelijk systeem de macht van de feodale Nederlandse olichargie in de West-Kaap en van de trekboeren in de Oost-Kaap zou breken ${ }^{275}$. Ook de meeste missionarissen gingen er vanuit dat de gekerstende zwarte boeren op hun grondgebied als betrouwbare arbeiders in de kolonie hun diensten zouden aanbieden zodra de gelegenheid zich voordeed. Waar niemand rekening mee leek te houden was de mogelijkheid dat Afrikanen liever hun eigen agrarische surplus zouden generen dan in loondienst te treden bij de blanken. Toch was dit vrijwel overal het geval. Er was steeds grote druk voor nodig om de Afrikanen hun onafhankelijk bestaan te doen opgeven.

De Britse koloniale macht was gebaseerd op een aantal peilers: militaire overmacht, bestuurlijke bureaucratie, en de missie. Aanvankelijk was vooral het koloniale leger in staat van boeren arbeiders te maken. De eerste 35.000 arbeidskrachten die de Kaapkolonie binnenkwamen, waren vluchtelingen voor de difaqana. Latere arbeidskrachten waren gevlucht voor de Britten zelf. In 1846/7 en 1850/3 werden grote stukken Xhosaland door de Kaapkolonie geconfisceerd. De Kaapse autoriteiten streefden naar volledige integratie. '[Gouvernor Grey] could even reach the startling conclusion' stelt J. Rutherford, 'that "throughout British Kaffraria the native has no recognized right in the soil" ${ }^{276}$. Voor de derde golf "arbeidskrachten" die in 1857 de Kaap binnenkwam, hoefde het leger niet eens te worden ingezet. Nadat er een onbekende ziekte post had gevat onder het vee, kreeg Nongqawuse in een visioen te horen dat de Xhosa al hun vee moesten doden en hun graan vernietigen om de wereld te zuiveren. De voorouders zouden hen dan vette kalveren teruggeven, de graanputten vullen en de blanken de zee indrijven. De wanhoop onder de in het nauw gedreven Xhosa was zo groot dat men in groten getale gehoor gaf aan de oproep van het meisje. Maar niet iedereen deed mee, en dat was volgens Nongqawuse's

\footnotetext{
${ }^{274}$ Bunn 1994, 163

275 "The commission of Eastern Enquiry (..) vigourously condemned all forced labour practices," in de overtuiging dat "these rendered the Afrikaner masters indolent and unenterprising," en dat de ex-slaven zich als vrije arbeidskrachten bij de Engelse boeren zouden melden. (J.B. Peires, "Matiwane's road to Mbjolompho: A reprieve for the Mfecane?" Conference paper, University of the Witwatrsrand (1991); 27-28)

${ }^{276}$ J. Rutherford, Sir George Grey, London, 1961: 328-9
} 
volgelingen de reden dat de voorspelling niet uitkwam. Tienduizenden stierven de hongersdood, en nog meer vluchtten de Kaap in op zoek naar voedsel en werk. Velen van hen werden onmiddellijk opgepakt, veroordeeld voor landloperij en naar Kaapstad verscheept, waar ze te werk werden gesteld. Anderen kwamen in loondienst op blanke boerderijen in de grensstreek, of zochten hun heil bij de missieposten. Gouverneur Grey, die volgens sommigen verdacht veel voordeel bij de catastrofe had ${ }^{277}$, liet de chiefs op Robbeneiland vastzetten omdat zij de destructie op touw zouden hebben gezet en liet het ontvolkte land innemen door Britse boeren.

Inmiddels hadden in meer westelijke streken Mfengu en Sotho zich deels gevestigd als zelfstandige boeren met eigen grond. Anderen huurden weidegrond bij blanke boeren in ruil voor geld of arbeid, waarbij de eerste mogelijkheid onveranderlijk positiever voor hen uitviel. In de volgende decennia werden in een reeks wetten delen van de Kaap tot reservaat bestempeld, met ondermeer het doel om het aantal "idle squatters" (i.e. pachters die hun arbeid niet verkochten) op blanke boerderijen te verminderen $^{278}$. Net als in de Boerenrepublieken hadden dergelijke wetten aanvankelijk weinig effect, omdat pachters noch boeren er baat bij hadden. Maar toen de Kaap eindelijk in zijn geheel onder Brits bestuur viel, concentreerden de autoriteiten zich op wetgeving die de zwarte bevolking onder zo gunstig mogelijke voorwaarden zou laten invoegen in de koloniale structuur, niet alleen uit economische overwegingen, maar ook "to destroy all posibility that they might again pose a military threat" ${ }^{279}$. Toen in $1913 \mathrm{de}$ Native Land Act voor geheel Zuid-Afrika werd ingesteld, was in de Kaapprovincie de belangrijkste doelstelling van de landwetten -segregatie die leidde tot een politiek veilige vorm van proletarisatie- al grotendeels gerealiseerd. De minstens 40.000 huurpachters en sharecroppers waren in twintig jaar tijd teruggebracht tot 7.000 .

Evenals de voormalige boerenrepublieken was de Oost-Kaap in de jaren twintig het toneel van geweld, onrust en opstanden. In de Engelssprekende, regenrijke landbouwgebieden van Natal en de Oost-Kaap had de commercialisering van de landbouw zich eerder voltrokken dan in Transvaal en Oranje Vrijstaat. Eind negentiende eeuw kochten in Natal commerciële Engelse boeren op grote schaal land op van absent landlords toen voedselproductie financieel aantrekkelijk werd: de hoeveelheid land die door blanke boeren werd beheerd, groeide tussen 1891 en 1909 van 34.000 naar 216.000 ha. ${ }^{280}$ De Oost-Kaap was inmiddels het domein van Engelse wolboeren, die al rond 1880 (decennia eerder dan de boeren in Transvaal en Oranje Vrijstaat) voor de (inter)nationale markt produceerden en volop

\footnotetext{
${ }^{277}$ Saunders and Southey 2001, 39

${ }^{278}$ Location Acts no 2 (1869); 6(1876); en 37(1884)

${ }^{279}$ Bouch 1993; 8

${ }^{280}$ Bundy 1979
} 
gebruik maakten van zwarte seizoensarbeid ${ }^{281}$. Ook hier leidden raciaal getint verzet en geruchten over opstanden tot extreme gewelddadigheid ${ }^{282}$. Maar hoewel er in dit gebied veel landarbeiders waren die door de nieuwe arbeidswetten hard werden getroffen, vond het massale verzet met name plaats in de steden en de reservaten ${ }^{283}$. Terwijl in de Noordelijke provincies het beleid van onteigening en proletarisatie onder blanke boeren angst voor opstand had veroorzaakt, werd hier, waar de stratificatie al een feit was, continuering van dit beleid gezien als middel om verzet geen kans te geven. Maar de zekerheid was dun. Toen in 1936 het Kaapse kiesrecht bij wet werd afgeschaft in ruil voor land, wilde de regering in de buurt van Cathcart een blanke boerderij aankopen voor zwarte boeren. $\mathrm{Nu}$ sloeg onder de naburige schapenboeren de paniek toe. In een regio waar "settler dominance", ondanks -of dankzij- het zeer gewelddadige verleden van negen oorlogen tussen Engelsen en Xhosa "never became absolute", deed de nabijheid van onafhankelijke zwarte boeren "old frontier fears" herleven. Men wist een zo sterke lobby te mobiliseren dat de aankoop niet doorging. ${ }^{284}$

\subsubsection{Het gekerstende platteland als all purpose metaphor}

Militaire en bestuurlijke macht zouden niet zo succesvol geweest zijn zonder de missie. In de negentiende eeuw moesten met name missionarissen, dankzij een dicht netwerk van missieposten dat heel wat landloze boeren en ex-slaven landbouwgrond verschafte, de culturele omslag bewerkstelligen die van heidense, rebellerende zwarten beschaafde, nuttige en vreedzame mensen maakte. Ze waren bovendien degenen die, omdat ze zeker in het begin veelal langs en buiten de grenzen van de kolonie opereerden, als eerste en als geen ander kennis vergaarden van de vreemde cultuur, en daar -schriftelijk- over berichtten aan het thuisfront. Hun christelijk gekleurde verslagen en beschrijvingen hebben voor een groot deel de (Britse) beeldvorming van zwart Zuid-Afrika bepaald. Afrika was in de ogen van de meeste missionarissen een ongecultiveerde barbarij, een heidense leegte, een "metaphorical mix of virgin bush to be inseminated and fallen Eden to be regenerated." ${ }^{285}$ Hodgson schrijft op 3 augustus 1823 in zijn dagboek:

Oh Africa, long and much neglected Africa, to what state of misery

\footnotetext{
${ }^{281}$ Bouch 1997

${ }^{282}$ Crais 2002, 117. e.v. Zie ook verderop in dit hoofdstuk

${ }^{283}$ De ICU was vooral actief in Port Eizabeth en East-London, In Herschel werd grootschalig geprotesteerd tegen de invoering van de Native Administration Act (1927) (Crais 2002, 142)

${ }_{284}$ Bouch 1997 105-107

${ }^{285}$ Comaroff \&Comaroff 1997, 126
} 
art thou sunk, and who will afford the means of delivering thee from such wretchedness, surely England will yet do things for thee??28

De missionarissen voorzagen het thuisfront van gedetailleerde beschrijvingen van heidense praktijken en gewoonten, "taking pains to underscore how much had either to be erased or remade." ${ }^{\prime 287}$ Toch is het met name de ongecultiveerde, onbegrensde leegte van het Zuid-Afrikaanse landschap geweest, de "iconography of emptiness", die mythe is geworden, zowel in bestuurlijke en kerkelijke als literaire geschriften. Ondanks vele aanwijzingen voor het tegendeel werden ook de Afrikanen zelf in zekere zin gezien als een onbeschreven blad. Omdat prediken op zich niet het gewenste effect sorteerde, raakten de missionarissen ervan overtuigd dat ze het christelijke leven vooral in de dagelijkse praktijk moesten vóórleven. "[W]hile they lacked reflective minds, the Africans would be unable to resist the temporal benefits of civilization. And being childlike and impressionable, they would learn readily by imitation" ${ }^{\prime 288}$. Hen leren ploegen was heel effectief, al was het alleen al omdat het de sociale structuur beïnvloedde: voorheen bewerkten de vrouwen (met een hak) het land en de mannen beheerden het vee, maar ploegen was een mannentaak omdat er ossen aan te pas kwamen. Tegelijkertijd was de ploegende boer een beeld dat zowel gerelateerd was aan de pastorale romantiek van het Engelse feodalisme, als een bijbelse icoon gekoppeld aan verlossing. Paternalisme, kerstening, evolutionisme, imperialisme, landbouw en een liberale economie raakten hierdoor zo onlosmakelijk met elkaar verbonden, dat "rural myth turned all-purpose metaphor"289.

Ook in de praktijk was de opvoedkundige taak van de missie nauw verbonden met koloniale belangen. Dat dit niet altijd tegen de individuele belangen van zwarte boeren inging was ondermeer een verdienste van John Philip, dertig jaar missionaris in Zuid-Afrika, hoofd van de London Missionary Society en verguisd door Boeren en settlers omdat hij pleitte voor landbezit voor christelijke Afrikanen en Khoisan en het voor elkaar kreeg dat "free coloureds (..) enjoy[ed] equal status with whites" ${ }^{290}$. In 1828 publiceerde hij in Londen Researches in Africa, in de hoop politici te kunnen beïnvloeden. Afrikanen met bezit waren goed voor de vrede en de economie, aldus Philip:

[b]y locating them on a particular place, getting them to build houses, enclose gardens, cultivate corn lands, accumulate property, and by increasing their artificial wants, you increase their dependancy on

\footnotetext{
${ }^{286} 1977 ; 185$

${ }^{287}$ Comaroff \& Comaroff 1997, 126

${ }^{288}$ Comaroff \& Comaroff 1997, 120

${ }^{289}$ Comaroff \& Comaroff 1997, 121

${ }^{290}$ Saunders et al. 2001, 133
} 
the colony and multiply the bonds of union and the number of securities for the preservation of peace. ${ }^{291}$

Die gedachte vond weerklank. En dus leerde men de nieuwe christenen voor de markt produceren en vierkante huizen bouwen, omdat daar tenminste tafels in pasten. Onder invloed van de razendsnelle industriële revolutie en de groeiende vraag naar landbouwprodukten wisten sommigen vervolgens goed garen te spinnen van hun economische vrijheid.

Van imitatie was geen sprake, noch van de landbouwmethoden ("[Africans] adapted rather than adopted them"292), noch van de christelijke discoursen die ermee in verband werden gebracht. Maar de economische ontwikkelingen hadden wel gevolgen voor de sociale organisatie. Het verschil tussen arm en rijk werd groter. Vrouwen verloren hun machstbasis ${ }^{293}$. Slechts een enkeling had toegang tot (voldoende) landbouwgrond en velen raakten afhankelijk van fortuinlijker familieleden danwel dorpsgenoten of moesten elders (seizoens)werk zoeken. Vooral degenen die in de marges van de nieuwe economie belandden, gaven een heel eigen betekenis aan het christendom. Onder de Setswana zien Comaroff et al. een groot verschil ontstaan tussen een kleine elite rijke peasants met land, landarbeiders en westerse en (al dan niet oprecht) christelijke idealen - een groep die het ideaalbeeld van de missie het meest benaderde - en een grote groep arme boeren die wel de nadelen maar niet de voordelen van de invloed van de missie ondervonden ${ }^{294}$. Zij beschuldigden de eerste groep veelal van hekserij, sloten zich na 1900 aan bij onafhankelijke kerken en vooral bij "small charismatic congregations, which stressed pragmatic ritual, paid a great deal of attention to healing and material well-being and formed close-knit social communities" ${ }^{295}$.

Ook in de Oost-Kaap ontstonden dergelijke verschillen. Armoede en ontwrichting deden de kerken goed. De massale toestroom naar de missiekerken had plaatsgevonden na de cattle-killing van Nongqawuse wat wil zeggen: na een "considerable weakening, if not in many areas an actual collapse, of local society" ${ }^{296}$. Toen slechts enkele decennia later de Afrikaanse kerken zich van de missiekerken begonnen af te scheiden, groeide hun ledenaantal alleen maar. In het begin van de twintigste eeuw vertrokken er maandelijks tienduizenden straatarme en ondervoede arbeiders vanuit de Oost-Kaap per trein naar de mijnen in Transvaal of de suikerrietplantages in Natal; evenveel mensen waren lid van de seperatistische

\footnotetext{
${ }^{291}$ J. Philip, Researches in South Africa. Illustrating the civil, moral, and religious conditions of the tribes. Vol. II. London, 1828: 72/3

${ }^{292}$ Comaroff \& Comaroff 1997, 153

${ }^{293}$ Comaroff \& Comaroff 1997

${ }^{294}$ Comaroff \& Comaroff 1997, 152-159

${ }^{295}$ Comaroff \& Comaroff 1997, 157

${ }^{296}$ Crais 2002, 132
} 
kerken ${ }^{297}$. Hun houding ten opzichte van de kolonie werd steeds kritischer ${ }^{298}$. De allerarmsten sloten zich aan bij Zionistische genootschappen, die geloofden dat alleen een volledige transformatie, namelijk destructie van het door de machthebbers veroorzaakte dagelijkse, allesoverheersende kwaad, gevolgd door een nieuw, Afrikaans begin, de wereld kon redden ${ }^{299}$. Een klein deel van de christelijke Afrikaanse gemeenschap was echter in staat gebleken een welvarend bestaan op te bouwen en zocht naar minder rigoureuze middelen. Ze had goed onderwijs genoten aan missiescholen of een beurs ontvangen voor een studie in London en vormde een invloedrijke elite van welgestelde, Engelsgezinde Afrikaanse christenen. Uit deze kringen kwamen de verontruste juristen die in 1912 het ANC oprichtten.

Ondanks deze verschillen hadden bijna alle Afrikaanse christenen één ding gemeen: ze waren geen willoze objecten, overgeleverd aan de macht van kerk en missionaris, geen marginalen in een Europees-christelijk discours. De kerk was daarentegen al snel een enclave: "churches comprised a priviledged space within which the colonized imagined itself, narrated its experiences, assembled supra-local identities, and thus brought new identities into being" ${ }^{\prime 300}$.

De "rurale mythe" ${ }^{301}$ bleef echter zonder noemenswaardige aanpassingen voortbestaan. Zij had in de tussentijd tot legitimatie gediend van het Britse imperialisme. Een van de manieren waarop Afrikanen en Afrikaners tot oorlogszuchtige primitievelingen konden worden bestempeld die deugdelijke leiding (en redding) nodig hadden, was te benadrukken dat beide bevolkingsgroepen leefden als rondtrekkende veehouders. Al in 1595 waarschuwde Spencer dat "all who live by [the] kepinge of cattel (...) are both very barbarous and uncivill, and greatly given to warr". ${ }^{302}$ In ZuidAfrika werden Boeren en zwarten in dit (en sommige andere) opzicht(en) over één kam gescheerd, een kwalificatie waaruit hun wetteloosheid werd verklaard. ${ }^{303}$ Dit was het excuus voor bemoeienis met of annexatie van Boeren"territoria" in de Oost-Kaap (1819), Natal (1842) en de rest van de door de Voortrekkers ingenomen gebieden (1848-1902) en annexatie van het grondgebied van de Xhosa (1847-1879), Griqua (1866) Bapedi (1876) en Zulu (1879). Bescherming van economische belangen speelde hierbij geen geringe rol. De vondst van goud en diamanten in Transvaal had in razend tempo een bloeiende, verstedelijkte economie in gang gezet, waar Britten van het begin af aan een belangrijke rol in gespeeld hadden. In het tweede

\footnotetext{
${ }^{297}$ Crais 2002, 119

${ }^{298}$ Crais 2002, 132

${ }^{299}$ Crais 2002, 133

${ }^{300}$ Crais 2002, 133

${ }^{301}$ Comaroff \& Comaroff 1997, 121 (zie noot 298)

${ }^{302}$ (1882-84,9:235) Geciteerd in Comaroff \& Comaroff 1997, 124

${ }^{303}$ Comaroff \& Comaroff 1997, 124
} 
jaar van de Boerenoorlog, waarin een gigantisch Brits leger eindelijk een einde moest maken aan het zelfbestuur van Transvaal en Oranje Vrijstaat, schreef The Times:

That the Transvaal should now be conducting - with a stubbornness and bravery that we all admire - a practically hopeless struggle in arms against the greater power roused at last, is but a supreme expression of the militant spirit by which the Boers of the Transvaal have always endeavoured to dominate the surrounding peoples. Domination, not independence has been their aim. (..)

The predominance in South Africa of a power based on military aggression, would be a source of constant danger to territorial neighbours on every side. Peace, good order and equality of industrial opportunity represent practically the demands of the civilized world in South Africa. The republic beyond the Vaal has signalised its short existence by a blank refusal to satisfy these demands in the territory which lies under its rule. The extension of Dutch influence would necessarily mean a corresponding restriction of the resources of the country. Great Britain, on the other hand, has been the guardian of these general interests since she first established herself at Cape Town. ${ }^{304}$

In het kielzog en onder bescherming van deze retorische en militaire overmacht, vestigden steeds nieuwe Britse settlers zich in de veroverde gebieden, waar ze een verschuiving in de sociale relaties veroorzaakten. De Engelse boeren waren in veel gevallen kapitaalkrachtiger dan hun Afrikaner voorgangers of buren en zakelijker in hun aanpak, wat hen niet altijd in dank werd afgenomen. Een pachter vertelt wat er veranderde toen Engelse boeren failliete Afrikaner boeren in Transvaal uitkochten na de Boerenoorlog:

Under Afrikaner landlords we used to be given sour milk, fresh milk and good food, but the English stopped it. Instead they gave us a few cups of milk per day. They counted how many cups they gave you. If you worked on a [English] farm, your ration consisted of three cups of sour milk per day. Fresh milk was not given to us, we were supposed to buy it. Afrikaners did not sell things. ${ }^{305}$

Anderzijds heeft Robert Morrell laten zien dat vroege Engelse kolonisten, zoals in The Midlands in Natal, lange tijd gebruik bleven maken van mondelinge overeenkomsten met pachters en van paternalistische arbeids-

\footnotetext{
304 "Great Britain and the Dutch Republics", Times 5 Feb. 1900, speciale uitgave

${ }^{305}$ Van Onselen 1997b, 204
} 
verhoudingen. In Natal bestond een klasse rijke, "progressieve" (i.e. gemechaniseerde) boeren die zichzelf "gentlemen" noemden, en evenveel belang hechtten aan het in stand houden van hun eigen lineage en extended family (tot in Engeland toe) als aan hun paternalistische verantwoordelijkheden.

Their self-identity incorporated the notion of a family-line: the inheretance of land obliged the inheretor to hand the farm on a succeding generation. This obligation meant that, in addition to obvious economic imperatives, (to ensure the farm was viable) there were domestic impulses that put their imprint on, -among other things- labor relations" ${ }^{306}$.

Orde en stabiliteit waren een groot goed, en dus waren tevreden pachters even belangrijk als hardwerkende pachters. Dergelijke boeren zetten niet zelden het werk van de missionarissen voort op grond van de "rurale mythe": "improving' the African (or (..) ridding him or her of "old barbarous habits') was a necessary part of the agricultural project." ${ }^{\prime 307}$ Het gevolg was dat er in hun ogen meestal twee soorten Afrikanen bestonden: de bekende en de onbekende. Wie zich buiten de boerderij bevond, hoorde tot de "barbaarse" vijand: onbekende, anonieme, wetteloze of verraderlijke Afrikanen (veedieven, opstandelingen, tresspassers, belastingontduikers) die wreed mochten worden behandeld en zelfs afgeslacht. ${ }^{308}$ De relatie met de eigen pachters kon tegelijkertijd heel vriendschappelijk zijn.

[The ] relationship between tenant and farmer [was] quite distinct from the relationship between white farmers and the African population in general, or between white farmers and neighbouring Africans who were effectively anonymous, not enjoying the special bond that tied tenant to farmer ${ }^{309}$.

In de loop der jaren ontstond binnen de grenzen van de boerderij een heel eigen werkelijkheid, die niet alleen een voortvloeisel was van politieke of paternalistische ideeën.

When a white man could deal directly with a black man of authority, the basis was laid for an agreement. The agreement depended on mutual respect and honour. The term "our natives" may frequently have been used paternalistically, but in another sense it spoke of a team, of a belonging, of mutual trust. ${ }^{310}$ 
Net als op de Afrikaner boerderijen ${ }^{311}$ en de missieposten ${ }^{312}$ vormden dit soort boerderijen een besloten ruimte waarbinnen pachters en landheren zich aan elkaar conformeerden, afspraken maakten en compromissen sloten, in weerwil van de officiële segregatiepolitiek. De boerderij was een enclave binnen de rest van Zuid-Afrika, een veilige, afgeschermde wereld met "eigen" Afrikanen die onderdeel waren van de boerderij en niet van de buitenwereld. Zo lang deze verhouding belangrijker werd geacht dan accumulatie van bezit, konden Afrikanen rekenen op een behandeling en beloning die fair was volgens de gentlemen code. Een zekere mate van geweld was hierbij geaccepteerd, maar binnen bepaalde grenzen.

Net als voor Afrikaner boeren in Transvaal en Oranje Vrijstaat was ook voor deze Engelse boeren de verhouding met zijn pachter dus onderdeel van zijn "Afrikaanse" identiteit. Dergelijke verhoudingen bestonden vooral in gebieden waar blanke boeren zich al vroeg gevestigd hadden en waar samenwerking had kunnen groeien. Maar net als in Transvaal hielden paternalistische idealen steeds moeilijker stand in de jaren dat arbeid een kapitalistische betekenis kreeg en segregatiepolitiek de interraciale verhoudingen deed verslechteren. Het gros van de nieuw gevestigde en/of commercialiserende (Engelstalige) boeren ging geen langdurige pachtrelatie meer aan. Ze maakten gebruik van overheid en wetgeving om hun gezag te vestigen, en waren daardoor eerder geneigd tot geweld en machtsmisbruik, methoden die nog steeds werden gerechtvaardigd "in terms of the civilizing burden of the white man. ${ }^{\prime \prime 13}$ Hun seizoens- of migratiearbeiders hoorden tot de anonieme, onbekende Afrikaanse bevolking, met alle gevolgen van dien. Ook industrialisatie droeg bij aan de anonimisering van het personeel, en dus aan het geweld. "Violence tends to be a feature of control where new groups of workers or youths -who have yet to internalize the harsh discipline of industrial time and labor- are employed in large numbers," stelt Beinart $^{314}$. Dit was bijvoorbeeld het geval op de (Engelse) suikerrietplantages in Natal in de eerste helft van de twintigste eeuw. De suikerindustrie maakte in die periode een enorme groei door. De lonen waren laag en geseling, kinderarbeid, ziekte en zelfs sterfgevallen waren aan de orde van de dag. Ondanks officiële protesten konden plantagehouders vrij ongelimiteerd hun gang gaan, omdat ze met hun belangrijke exportproduct politiek een flinke vinger in de pap hadden. ${ }^{315}$ Frappant is dat enkele van de modernste plantagehouders, die hun imago wilden verbeteren zonder de productie te verlagen, de "brutal indentured labour systeem" vervingen door "a less obvious form of exploitation". Ze maakten van hun plantage een sugar village: gecentraliseerde, gekapitaliseerde, technisch geavanceerde planta-

\footnotetext{
${ }^{311}$ Zie hoofdstuk 1

${ }^{312}$ Zie hoofdstuk 4

${ }^{313}$ Morrell, 191

${ }^{314}$ Beinart 1997, 158

${ }^{315}$ Beinart 1997, 160 e.v.
} 
ges in de vorm van een Zuid-Afrikaanse boerderij, gekenmerkt door een "ostentious display of landowning benevolence" en zo ingericht dat iedere klasse zijn eigen symbolische territorium had. "Landed paternalism" was de vermomming, absolute controle over de arbeiders het doel ${ }^{316}$. Cruciaal was daarbij "the inventing of the labourers family as a supervised unit within the space of the estate". ${ }^{317}$ Waar dus op andere plekken paternalistische verhoudingen aan betekenis inboetten door de opkomst van het kapitalisme, werden hier een koloniaal decor en de ruimtelijke principes van het paternalisme in ere hersteld om de vervreemdende en weinig flatterende effecten van het kapitalisme aan het zicht te onttrekken.

\subsection{Het Platteland van Thomas Pringle: "A Liminal ZONE BETWEEN THE SELF AND SAVAGERY”.}

Deze geschiedenis laat zien dat de idealen van het Europese liberalisme en christendom in de Afrikaanse contekst ofwel verwerden tot koloniale of neokoloniale uitwassen, of door de ander werden aangepast en toegeëigend en dan vaak onherkenbaar en/of vijandig terugkaatsten. Beide metamorfoses hebben bijgedragen aan de diepgewortelde onzekerheid die veel van de Engelstalige Zuid-Afrikaanse literatuur kenmerkt.

De basis voor deze literatuur is ondermeer gelegd door Thomas Pringle. Pringle trok in 1820 met een groep Schotse emigranten naar de Oost-Kaap. Hij leefde twee jaar in de boerengemeenschap van Albany en trok toen naar Kaapstad om zijn beroep als journalist uit te oefenen. Maar zijn uitgaven werden verboden en zes jaar na aankomst ging hij -berooid- terug naar Engeland. In die paar jaar heeft hij blijvende indruk gemaakt. Als bestrijder van de slavernij, hervormer, uitgever en dichter wordt hij algemeen beschouwd als de "key figure in the establishment of liberalism in South Africa and in the advance of English as an instrument of linguistic colonisation." ${ }_{318}$ Bunn schuift hem zelfs de belangrijkste Britse kronkel in de schoenen: "Pringle is the narrative beginning both for the myth of origins that enables liberal ideology to dissociate its own history from that of the monster Apartheid and for the patriarchal and racist version of South African literary history that often portrays him as 'the father of South African poetry" ${ }^{319}$. In onderstaand gedicht is inderdaad de verlichte Engelse koloniaal te herkennen die zwarte en witte barbaren over een kam scheert en zich boven de wederzijdse pesterijen en gevechten tussen Xhosa en Boeren in het Zuurveld plaatst.

\footnotetext{
${ }^{316}$ Bunn 1996, 40-42

${ }^{317}$ Bunn 1996, 40-42

${ }^{318}$ Bunn 1994, 136

${ }^{319}$ Bunn 1994, 136
} 


\section{The Caffer}

Lo! where he crouches by the kloof's dark side,

Eyeing the farmer's lowing herds afar;

Impatient watching till the evening star

Leads forth the twilight dim, that he may glide

Like panther to the prey. With freeborn pride

He scorns the herdsman, nor regards the scar

Of recent wound, but burnishes for war

His assegai and targe of buffalo hide.

$\mathrm{He}$ is a robber? True; it is a strife

Between the black-skinned bandit and the white.

A savage? Yes; though loth to aim at life,

Evil for evil fierce he doth requite.

A heathen? Teach him, then, thy better creed,

Christian! if thou deserv'st that name indeed. ${ }^{320}$

De "strife between the black-skinned bandit and the white" was de beeldvorming die tot in de twintigste eeuw Britse interventie, annexatie en segregatie zou legitimeren. Toen in 1910 de Unie van Zuid-Afrika werd opgericht, een federatie die onderdeel uitmaakte van het Britse Imperium en waarbinnen de vier koloniën een gelijke graad van zelfbestuur genoten, konden veel Afrikaners hun wrok en bitterheid niet zomaar van zich afzetten. Aan de andere kant voelden Afrikanen zich verraden door de concessies die de Kaapkolonie deed op het gebied van rassenwetgeving om de Afrikaners gunstig te stemmen. Afrikanen en Afrikaners begonnen zich bijna tegelijkertijd in de oppositie te organiseren in respectievelijk het African National Congres en de Nasionale Party. Bemiddeling tussen de beide nationalistische bewegingen leek onmogelijk en dus boog de Unieregering voortdurend voor Hertzogs groeiende Nasionale Party of voor de mijnmagnaten, commerciële boeren en suikerrietplanters die riepen om arbeiders. Segregatie kon beide groepen tevreden stellen. Het "zwarte probleem" wuifde Smuts weg door te stellen dat "it was useless, to try to govern blacks and whites in the same way" ${ }^{\prime 22}$. De landwet van 1913, die de basis vormt voor de apartheid van 1948, was hiervan het gevolg. Sol Plaatje reisde met een ANC-delegatie af naar London om zijn beklag te doen over deze in zijn ogen zo on-Engelse, want mensonterende wet, maar kwam gedesillusioneerd terug. De graan producerende, ploegende peasants van de missieposten; de in Shakespeare, Engels recht en Christelijke broederschap opgevoede schrijvers, vakbondsleiders en juristen van de Oost-Kaap; de

\footnotetext{
${ }^{320}$ Thomas Pringle, African Sketches, 1834

${ }^{321}$ Troup, 55
} 
rijke pachters en schoolmeesters uit Transvaal; en "our natives" van The Midlands, ze zouden uiteindelijk allemaal arbeiders en vreemdelingen worden $^{322}$.

Ook al had Pringle, in het begin van de $19^{\mathrm{e}}$ eeuw, kritiek op bepaalde onderdelen van het beleid, hij vond in grote lijnen de Britse aanwezigheid hoopgevend. In werkelijkheid waren de weinige settlers die zich niet uit het veld lieten slaan, net als de Boeren afhankelijk van de lokale Afrikaanse economie en pasten ze zich al gauw sterk aan hun omgeving aan. Ook waren er regelmatig gewelddadige aanvaringen met Xhosa en Khoisan. Pringle zelf heeft tijdens zijn korte bestaan als frontier kolonist KhoiSan squatters van zijn land laten schieten ${ }^{323}$. Maar Pringles poëtische beschrijvingen van Albany weerspiegelen eerder het streven van de Britse kolonisatie om vertroebeling van de (cultuur)grenzen tegen te gaan, dan die inter(of intra-)culturele werkelijkheid. "Without their knowledge, the settlers were to be placed in Albany to act as a sort of cordon sanitaire against displaced Xhosa communities." ${ }^{324}$ De Engelse cottage of cot was in Pringle's ogen dan ook een romantisch toevluchtsoord in Engelse traditie, een symbool van class mobility en burgerlijke waarden, en het bij uitstek vrouwelijke domein $^{325}$. Zijn landschapsbeschrijvingen zijn, net als landschapsschilderijen uit die tijd, en net als de voorbeeldige tuinen van de missionarissen, een herschepping van Afrika ${ }^{326}$, een "liminal zone between the self and savagery (..) emptied of rival human presences." ${ }^{327}$ En zoals we zagen is het beeld van de plaas of farm als harmonische enclave in een vijandige wereld, als haast surrealistisch niemandsland tussen beschaving en barbarij tot in de 20ste eeuw blijven voortbestaan.

In "Evening rambles" een (vanzelfsprekend mannelijk - vrouwen hoorden binnenshuis) ik-figuur door een gedomesticeerd landschap, waar de "Bushman" niet meer is dan

\footnotetext{
${ }^{322}$ Comaroff en Comaroff (1997) vatten het proces treffend samen: "Thanks to recent revisionist histories - and earlier writings by blacks presently being recuperated - the story is now familiar: how colonial capitalists, settlers, statesmen [and evangelists], despite differences among themselves, found common cause in coercing large numbers of Africans into wage employment; how tax Britannica, the seizure of property, the manipulation of agricultural prices and conditions, and other blunt fiscal instruments conduced to make them reliant on supplementary cash incomes, how all but the wealthy had to subsist on an uneasy mix of female peasant production and the income of low-paid male jobs, (..) how a carefully regulated labour force was reproduced by women "at home", the countryside being made to bear the cost of nurturing and sustaining a rising proletariat. "(148) Zie ook Keegan (1988) voor sprekende, individuele gevallen van desillusie en verpaupering.

${ }^{323}$ Bunn 1994, 157; Van Vuuren 2003, 39

${ }^{324}$ Bunn 1994, 154

${ }^{325}$ Bunn 1994, 150 e.v.

${ }^{326}$ Comaroff 1997, 133

${ }^{327}$ Bunn 1994, 128-132

${ }^{328}$ African Poems of Thomas Pringle, ed. Ernest Pereira and Michael Chapman. Durban: University of Natal Press, 1989: 16-20
} 
een "felt presence" in een lege grot, een "ghost of a past epoch" lege landschap komt de wandelaar geknechte en ontheemde veehoeders tegen. De eerste is een Khoi-slaaf: een "brown herder with his flock (..)./ No flute has he, nor merry song/ nor book, nor tale, nor rustic lay/ to cheer him through his listless day./ His look is dull, his soul is dark;/ he feels no hope's electric spark;/ but born the white man's servile thrall,/ knows that he cannot lower fall". Pringles doel is de slavernij aanklagen, maar het effect is tevens "to drain him of life and remove him as a compatitive presence from the phenomenological field" ${ }^{{ }_{330}}$. Dit doet hij niet alleen door hem zijn middelen tot (culturele) representatie te ontnemen ${ }^{331}$, maar ook door gebruik te maken van het etnische onderscheid tussen Khoikhoi (Hottentotten) en San (Bosjesmannen), hoewel dat zeker in die tijd niet meer te handhaven was. Het verschil tussen beide groepen bestond vanaf de tweede helft van de $18^{\mathrm{e}}$ eeuw uit de manier van leven en de mate van vijandigheid ten aanzien van de kolonisten. "Hottentots" waren de (geknechte) herders; "Bushmen" de ontembare danwel uitgeroeide jagers. Maar de grenzen tussen deze groepen waren diffuus: "Khoi-speaking herders who lost their livestock could easily become Bushmen, and vice versa. This is precisely what happened in colonial times. ${ }^{{ }^{3} 32}$ In later tijden konden, zoals al eerder gezegd, Khoisan landarbeiders zich weer gemakkelijk bij groepen vrij rondzwervende Khoisan voegen. Dit betekent dat Pringle in dit gedicht tegelijkertijd de zelfstandige Khoisan doodverklaart en de Khoisanslaven beweent. Om de liberale rurale idylle te kunnen verbeelden had Pringle een vrijwillige arbeider nodig, iemand die een geweldloze, dwangloze, Britse voogdij kon illustreren. Xhosa kwamen hier (nog) niet voor in aanmerking ${ }^{333}$. Dus is de tweede veehoeder die de wandelaar tegenkomt een Tswana, gevlucht voor de Zulu, maar opgevangen door de Engelse kolonie. Hij fluit een vrolijk deuntje. "From the destroying foeman fled, he serves the colonist for bread:/ yet this poor heathen Bechuan/ bears on his brow the port of man;/ A naked, homeless exile, he -/ but not debased by slavery."

Als dit Pringles liberalisme is, dan heeft het, in strikte zin, niet gefaald: Zuid-Afrika is een land geworden vol "homeless exiles". Ze hadden alleen niet de opgewekte tred van Pringles Bechuan. Het falen bestond eruit dat kerstening, segregatie en het bevorderen van economische afhankelijkheid meer een verhulde voortzetting van de grensoorlogen bleek te zijn dan een liberaal gemotiveerde succesformule voor vrijwillige, vreedzame integratie. Soms gebeurde er iets waardoor een onderhuidse, weinig harmonische werkelijkheid zichtbaar werd, die oude frontier fears deed herleven. Zo'n

\footnotetext{
${ }^{329}$ Bunn 1994, 157

${ }^{330}$ Bunn 1994, 159

${ }^{331}$ Bunn 1994, 159

${ }^{332}$ Barnard 1992, 159

${ }^{333}$ Zie ook Bunn 1994, 163/4
} 
honderd jaar na Pringles observaties en het optimisme van de missionarissen, toen de beoogde "integratie" (i.e. proletarisatie) grotendeels een feit was, leden de zwarte inwoners van de Oost-Kaap onder droogte, kou, epidemiëen, honger, uitputting en slechte arbeidsomstandigheden. In die tijd vestigde een profeet zich met zijn volgelingen in de Ntabelanga location van Queenstown. ${ }^{34}$ Queenstown lag in een regio waar missie en koloniaal bestuur meer dan waar ook haar stempel gedrukt hadden. Het was een uitvalsbasis voor arbeiders die per trein naar het Noorden reisden, maar ook een cultureel en politiek trefpunt van de Afrikaanse christelijke elite. Intellectueel protest vond echter geen weerklank in Ntabelanga, waar zo'n duizend mensen een bestaan bij elkaar probeerden te schrapen. Hun christelijk geloof had zich in een heel andere richting ontwikkeld, buiten het bereik van en gekeerd tegen de koloniale macht. Ze noemden zich Israëlieten, verkondigden het einde der tijden en geloofden dat alleen zijzelf van de ondergang gered zouden worden. Hun aantal groeide. Maar niemand wist hoe snel: regeringsbeambten werd niet toegelaten. Omwonenden beschuldigden hen van veediefstal en verklaarden hen voor gek: "[v]isions and pronouncements of the Israelites were those of mad, detribalised people people who had lost their mooring" ${ }^{335}$. Uiteindelijk bestempelde de regering de gemeenschap tot "squatters", illegalen dus, maar voor ze tot ontruiming kon overgaan had een Israëlitisch "leger" zich in de heuvels teruggetrokken en de kolonie de oorlog verklaard. In 1921 viel ze in Bullhoek met zelfgemaakte speren het leger aan, in de overtuiging dat hun geloof kogels in water zou doen veranderen. Ze werden en masse doodgeschoten. Een week later werd Ntabelanga met bulldozers weggevaagd.

Dergelijke confrontaties zijn, zo blijkt uit recente publicaties, slechts het topje van de ijsberg geweest. Onzichtbaar voor het oog van de koloniale volksteller en landmeter ${ }^{36}$ leefde een groot deel van de Afrikaanse bevolking in een duistere wereld. Die duisternis werd in haar ogen echter niet veroorzaakt door "heidense praktijken", maar door de destructieve krachten van oncontroleerbare anonieme machten: de kolonie, de staat, de poll-tax, de landwetten, de kapitalisten. Hun verzet tegen dit kwaad was voor die anonieme machten al even ongrijpbaar en bedreigend: rituele verbrandingen, heksenjachten, nabootsing van machtstructuren en symbolische opstanden verwezen allemaal naar een machtsbasis, een territorium dat niet door de kolonie of de staat kon worden gecontroleerd. ${ }^{337}$ De strijd die in Pringles dagen nog met het geweer werd uitgevochten, wordt een eeuw later gevoerd met heel wat unheimlicher machtsmiddelen, en des te meer

\footnotetext{
${ }^{334}$ Crais 2002, 117 e.v.

${ }^{335}$ Crais 2002, 120

${ }^{336}$ Twee belangrijke instrumenten van koloniale macht (zie ook hoofdstuk 4)

${ }^{337}$ Zie ook hoofdstuk 4
} 
verzwegen. Maar het effect blijft hetzelfde: niemand is zeker van de houdbaarheid van haar discours, en van de grenzen tussen "self and savagery" 338 .

\subsection{ADAMASTOR EN DE GENADELOZE KAROO}

Is Pringle de vader van de Zuid-Afrikaanse poëzie, dan is Olive Schreiner de moeder van de Zuid-Afrikaanse (pastorale) roman In haar non-conventionaliteit en veelvormigheid legt Schreiner de basis voor een literatuur die weliswaar nog koloniaal is in haar manier van zien, maar desalniettemin naar de wereld kijkt vanuit Afrika, en niet vanuit Europa. Wat Schreiner en haar opvolgers zien of laten zien, is voor een belangrijk deel landschap. Een desolaat, onherbergzaam landschap dat "dries the vital juices out of its inhabitants, stunts them and - worst of all - disallows them from achieving man's most sacred desire, the desire to take root and belong" ${ }_{339}$.

Voor een deel is scholing debet aan de onmogelijkheid om een thuis te vinden; Doris Lessing ziet een gebrek aan boeken die de omringende wereld beschrijven als een van de belangrijkste oorzaken voor dit gevoel van vervreemding.

A white child (..) could not see a msasa tree, or the thorn, for what they were. Her books held tales of alien fairies, her rivers ran slow and peaceful, and she knew the shape of the leaves of an ash or an oak, the names of the little creatures that lived in English streams, when the words 'the veld' meant strangeness, though she could remember nothing else. ${ }^{340}$

Het gevolg was dat Zuid-Afrika "[was] exclusively characterised by the 'empty' and stony barrenness of the Karoo landscape (...) Schreiner, Smith and Millin offer us landscape as a metaphor of alienation, exile and isolation." ${ }^{341}$ J.M. Coetzee (1988) ziet in Schreiners boerderijroman een problematische relatie tussen mens en natuur geportretteerd. De boerderij bestaat voor een groot deel uit een ongastvrije, eindeloze vlakte onder een eindeloze hemel in een eindeloze tijdspanne, waarin met name een persoonlijke God schittert van afwezigheid. Tegenover die natuur staat the farm (een dorp in het klein) dat niet samenleeft met de omringende natuur, maar ermee in oorlog is; en evenmin het land bewerkt, want de zichtbare personages werken niet, maar plukken slechts de vruchten. Ook de oorspronke-

\footnotetext{
${ }^{338}$ Bunn 1994, 128 (zie noot 336)

${ }^{339}$ Gray 1979, 150

${ }^{340}$ Doris Lessing "The old chief Mhlanga.” In: African Stories, 1981: 47-58

${ }^{341}$ Wagner, 168
} 
lijke bewoners ontsnappen volgens Coetzee niet aan de dichotomie cultuur - natuur; Schreiner schaart de (uitgeroeide) San aan de natuurkant en de (geknechte) Khoi en Bantu aan de kant van de domme en harteloze boerderijcultuur. Dit negatieve beeld van een door een kinderloze vrouw gerunde, onproductieve, wederzijds vijandige plek, staat recht tegenover het Europese beeld van de patriarchale boer die met zijn familie in harmonie en wederkerigheid leeft met de natuur - een beeld dat ook tot uiting komt in de plaasroman. In deze mythe

[The farmer] must husband [the land], giving it a devoted attention that will bring it to bear manifold, yet keep it fertile for succeeding generations. In the logic of the myth, the sons who inherit the farm husband the same land: or, to put it in an other way, the generations of husband-farmers are the same (mythic) man. ${ }^{342}$

Op Olive Schreiners boerderij komt een relatie die continuïteit moet waarborgen niet tot stand. "[She] is anti-colonial both in her assertion of the alienness of European culture in Africa and in her attribution of unnaturalness to the life of the farm. To accept the farm as home is to accept a living death," stelt Coetzee. ${ }^{343}$

"Paradoxically of course," voegt Chapman daar aan toe, "the uncertainty of belonging is in itself a persistent colonial trait" ${ }^{344}$. Stephen Clingman gaat nog een stap verder door The story of an African farm het prototype van een Zuid-Afrikaanse koloniale roman te noemen met de subjectivering van het landschap als toppunt van arrogantie: "It is not," schrijft hij, "as if Schreiner's work treats the question of land appropriation as a theme; far from it, it takes it entirely for granted. ${ }^{{ }^{345}}$ In plaats daarvan wordt het Afrikaanse land volgens Clingman gebruikt als een leegte waarop de roerselen van de menselijke ziel worden geprojecteerd: "And this is then the novel's colonial arogance: Africa becomes (in more senses than one) subject, a mirror to the settler condition." ${ }^{346}$ Wagner vat bovenstaande samen door te stellen dat in de Engelse koloniale literatuur het landschap enerzijds is geconstrueerd door de door immigranten als ongastvrij ervaren ontvangst, en anderzijds door hun eigen pogingen het vreemde landschap waar te nemen en te plaatsen. De ongastvrijheid symboliseerde individuele gevoelens van vervreemding en mislukking, maar verbeeldde - en camoufleerde - ook de hardheid van een racistische samenleving. Kortom: "The felt personal and ideologically determined need to develop metaphors of exile, alienation, oppression, endurance and survival may be seen to have

\footnotetext{
${ }^{342}$ J.M. Coetzee 1988, 66

${ }^{343}$ J.M. Coetzee 1988, 66

${ }^{344}$ Chapman 1996, 365

${ }^{345}$ Clingman, 135

${ }^{346}$ Clingman, 135
} 
characteristically shaped the representation of landscape in English language South African fiction." In dit landschap zit een impliciete tegenstelling vervat tussen wij en zij, ondermeer in de terugkerende figuur van Adamastor ${ }^{347}$.

Adamastor is in deze interpretaties een opmerkelijke en interessante uitzondering. De rol van Afrika en de Afrikanen blijft in alle bovenstaande uitspraken over literaire verwerking van de koloniale situatie opvallend passief. In koloniale teksten lijkt Afrika altijd "Afrika" te blijven, zich nooit te kunnen onttrekken aan de blik van de kolonist. Ook Adamastor is op het eerste gezicht een puur Europese projectie. Maar uiteindelijk verwijst hij ook naar de onvolledige controle van die blik; naar het feit dat niet alleen de statische tegenstelling tussen $\mathrm{Wij}$ en $\mathrm{Zij}$, maar ook de verzwegen confrontatie tussen Wij en $\mathrm{Zij}$, dat wil zeggen de onafhankelijke, grensoverschrijdende aanwezigheid van de Ander, het landschap heeft gekleurd. Om te kunnen zien of die beweeglijke Ander ook in Schreiners landschap aanwezig is, zal ik eerst aandacht moeten besteden aan Adamastor.

\subsubsection{De razernij van Adamastor}

Als personage in het epische gedicht Os Lusiadas (1572), is Adamastor ontsproten aan het brein van Luís Vaz de Camões, een Portugese dichter die de reizen van Vasco da Gama vastlegde in Homerische stijl. Hij mengde Griekse mythologie met christelijke symboliek en een Middeleeuws wereldbeeld: Adamastor bewaakte de grens tussen het kwade, Islamitische westen van Afrika en het utopische, paradijselijke, "christelijke" oosten. De Camões maakte van Da Gama's ronden van de kaap "a great rite de passage from west to east, from hardship to riches, from damnation to salvation, and from one kind of Africa to the other" ${ }^{348}$. De Kaap was berucht vanwege haar stormen, Afrika was een onbekend continent en de eerste ontmoeting met haar bewoners was niet al te aangenaam geweest. Maar belangrijker dan de realiteit was de allogorische betekenis van Afrika en in het bijzonder de Kaap als een "white man's paradise" ${ }^{449}$, weggestopt achter een vijandige kust of in een desolaat landschap dat getekend was door "hatred, cruel wars, (..) and death" ${ }^{350}$. Stephen Gray (1979) heeft aannemelijk gemaakt dat Adamastor zodanig tot de verbeelding heeft gesproken van Europese schrijvers die na De Camões in Afrika zaten, dat hij een onuitwisbaar onderdeel was van hun perceptie en dus uitbeelding van Afrika. Van Wyk Smith (1988) laat bovendien zien dat Adamastor in die vele teksten voortdurend van aanzien en betekenis is veranderd, zelfs in

\footnotetext{
${ }^{347}$ Wagner, 168-170

${ }^{348}$ Wyk Smith 1988, 3

${ }^{349}$ Wyk Smith 1988, 5-9

${ }^{350}$ Wyk Smith 1988, 19
} 
de opeenvolgende (Engelse) vertalingen van het Portugese gedicht. In het volgende fragment uit een vertaling van 1973 verschijnt de geest van Adamastor aan Vasco da Gama, verteller in Os Lusiadas, die tijdens een gruwelijke storm een poging doet de Kaap te ronden:

I had hardly spoken when a muscular and powerful figure materialized in the cloud itself. It was gigantic in stature, disfigured, with a huge, sunken face and a squalid beard and sunken eyes. His expression was evil and menacing; it had a clayey pallor. His hair was matted with mud. His black mouth was filled with yellow teeth. (..) In a deep and horrifying voice, he spoke as if from the depths of underwater. ${ }^{351}$

Veertien jaar later, in een vertaling uit 1987, is de reus in plaats van "disfigured" en "evil" vooral groot, sterk en kwaad, zodat hij van object in een voorspelbare (en dus beheersbare) symbolische orde, verandert in een onvoorspelbaar subject: "A figure, huge and strong, with heavy jowl/ And unkempt beard, whose sullen eyes, ablaze/ From caves beneath the beetling forehead, scowl/ with hate enough to frighten and amaze." ${ }^{\text {,352 }}$

Adamastor, geboren uit Lucht en Aarde, vertelt zijn verhaal aan Da Gama. Als een der laatste oude helden probeerde hij de nieuwe Griekse goden van hun troon te stoten maar werd verraden en verbannen door de vrouw die hij liefhad: Thetis, de godin van de zee. Hij viel; zuidwaarts van Europa af, zijn gezicht in de modder, terwijl zijn enorme, hoekige voorhoofd erbovenuit bleef steken: Tafelberg. Zijn vlees veranderde in aarde, zijn beenderen werden rotsen, en zo ontstond Afrika, een continent vol onontgonnen goudvelden en anderssoortige achterlijkheid. Thetis steekt haar minachting niet onder stoelen of banken:

Here is Africa, still grasping after the things of this world, uncivilised, full of savagery, with its southernmost Cape, that has always been denied to you [=Da Gama, de Europeaan] until now. Look out over the whole vast continent and see how everywhere it is the home of legions of infidels. ${ }^{353}$

Adamastor ligt, aldus Gray, ten grondslag aan alle beelden die door kolonisten gecreëerd zijn om de Afrikaanse ervaring betekenis te geven. Hij is het achterhaalde, kinderlijke, primitieve monster/continent, behept met oeroude krachten waar desalniettemin terdege rekening mee gehouden dient te worden, want hij heeft een vloek uitgesproken over de Portugezen

\footnotetext{
${ }^{351}$ Uit de vertaling van Alexandre Quintanilha in Stephen Gray (ed.) Writers territory (1973), geciteerd in Stephen Gray 1979, 24.

${ }^{352}$ Wyk Smith 1988, 51 Hij citeert uit de vertaling van Guy Butler, 1987

${ }^{353}$ Idem, pag. 25.
} 
die in de loop der eeuwen niet aan betekenis lijkt te hebben ingeboet. Waar Da Gama (in India) het paradijs weet te bereiken nadat hij de rite de passage heeft doorstaan door Adamastors razernij naast zich neer te leggen en te vragen wij hij nu eigenlijk is, blijven latere "reizigers" toch weer, en steeds vaker, steken in de "blazing and pitiless bush" ${ }_{354}$. Het beloofde paradijs werd in Zuid-Afrika niet gevonden, in plaats daarvan werd overleven op zich een bewijs van superioriteit. Dat de paradijselijke belofte niet werd ingelost komt wellicht omdat van het begin af aan de "tendency to alienate the natural inhabitants of the Cape from their environment or to sanitize the landscape at the expense of the people" zo wijdverbreid is geweest ${ }^{355}$. Adamastor en kolonisten houden elkaar in de tang: zolang de laatsten Afrika in hun grootheidswaan blijven ontheiligen, zal de vloek blijven gelden. In de vertaling van Butler (1987) klinkt Adamastors verwijt als volgt: ${ }^{356}$

\section{(..)}

Since you have come to search and desecrate the mysteries of nature and the main, Avid to master what no being yet, Mere human or immortal could attain,Now here me tell what vengeance future Fate Holds for your conquests and your glories vain:

Wether on waters vast or on the land

Which you by sword or fire will command-

En andersom: het beeld van Adamastors pesterij vanuit het "graf" maakt voor de kolonisten het lijden onontkoombaar, maar bepaalt tevens het machteloze lot van Afrika zelf.

Tot nu toe heeft de discussie zich vooral op de Europese invloeden op de ontwikkeling van Adamastor toegespitst. Dat komt ook omdat de stilte rond zijn Afrikaanse wortels nog nauwelijks is doorbroken. Wat De Camões tijdens zijn reizen heeft opgepikt is nooit meer te achterhalen, maar een feit is dat veel van Adamastors (latere) kenmerken in Afrikaanse mythen en verhalen zijn terug te vinden. De verbeelding van het land als vergeldende macht is een algemeen Afrikaans gegeven ${ }^{357}$ en zal dus op zijn minst de kracht van de mythe hebben vergroot voor wie zich in Afrika bevond. De Afrikaanse voorspelling dat de doden zullen herrijzen om de blanken de zee in te drijven, heeft in de twintigste eeuw voortdurend geloof gevonden en zodoende bijgedragen aan de dreiging van een herrijzende Adamastor.

\footnotetext{
${ }^{354}$ Gray 1979, 27

${ }^{355}$ Wyk Smith 1988, 21

${ }^{356}$ Wyk Smith 1988, 52

${ }^{357}$ Adewoye 1989, 127
} 
Transformaties, met name tijdelijke transformaties om een -fysiek sterkeretegenstander te slim af te zijn, zijn typische wapens van /Kaggen en Haiseb, goden c.q. schelmen uit de Khoisanmythologie. In Schmidts verzamelde Khoisanvertellingen wemelt het so wie so van de transformaties: man wordt steen, ouders worden storm en onweer, doden worden in tientallen verhalen weer levend ${ }^{358}$. Vooral Haiseb (Heitsi-Eibib) is er een meester in om vriend en vijand voor de gek te houden door zich te transformeren of zich dood te houden ${ }^{359}$. Bovendien is Haiseb ook de meester van de reuzenslang $^{360}$ die schepen laat vergaan ${ }^{361}$ en soldaten met geweer en al opslokt ${ }^{362}$. Deze verhalen zijn wellicht niet van invloed geweest op het ontstaan van Os Lusiadas, maar wel een intertekstuele impuls geweest voor het voortbestaan en de invloed van Adamastor. In vele gedaantes weliswaar, want net als de vertaling is ook de receptie van Adamastor in de loop der tijd veranderd door invloeden van buitenaf.

\subsubsection{Adamastor in Schreiners African farm}

Terug naar de pastorale roman: in het Afrikaanse landschap, dat wil zeggen in haar hoedanigheid van "mirror of the settler condition", maar ook als Afrikaans landschap sec, duikt -als gezien vanuit een ooghoek- steeds weer Adamastor op. Al op de eerste pagina van The story of an African farm geeft Schreiner een beschrijving van het landschap die Adamastor Afrikaanser maakt dan hij tot dusver was. De volle maan beschijnt een eentonige vlakte, omringd door heuvels als een afgezwakte of ironische versie van het in Afrika geprojecteerde paradijs, dat op Middeleeuwse kaarten van (Zuid-)Afrika veelal werd afgebeeld als "mountain-top, or moutainringed kingdom (..), a cricular mountain-walled paradise" ${ }^{{ }_{363}}$. Het is een gepersonifieerd landschap: de planten die er groeien hebben "finger-like" of "fleshy" bladeren, of "thorny arms", en de vlakte is net zo eenzaam als het kopje in het midden:

In one spot only was the solemn monotony of the plain broken. Near the centre a small kopje rose. Alone it lay there, a heap of round ironstones piled one upon the other, as over some giant's grave. ${ }^{364}$

Schreiner moet zich ervan bewust geweest zijn dat overal in de Kaap stapels stenen lagen die de vele (tijdelijke) graven van Haiseb verbeeldden.

\footnotetext{
${ }^{358}$ Schmidt 1989 (1), no 1500 en 919; pag. 171/2

${ }^{359}$ Schmidt 1989 (2), zie bijvoorbeeld no 129,133 en 322A

${ }^{360}$ Idem, no $1731 \mathrm{~A} 4$

${ }^{361}$ Idem, no 1705

${ }^{362}$ Idem, no 873

${ }^{363}$ Wyk Smith 1988,5

${ }^{364}$ Schreiner 1989, 29.
} 
Het is dan ook niet verwonderlijk dat op dit reuzengraf rotstekeningen te vinden zijn, die eveneens naar de "verdwenen" Khoisancultuur verwijzen. Maar opvallend is wel dat Schreiner hier de verbinding legt tussen Haiseb en Adamastor, en daarmee zowel de onsterfelijkheid van de Khoisanrepresentatie benadrukt als Adamastor zijn opgelegde machteloosheid ontneemt. In zijn bekende voorwoord bij The story of an African Farm maakt Dan Jacobson duidelijk dat vervreemding te maken heeft met een gebrekkig collectief geheugen. "A colonial culture is one which has no memory", schrijft hij,

The discontinuities of colonial experience make it almost inevitable that this should be so. A political entity which has been brought into existence by the actions of an external power; a population consisting of the descendants of conquerors, of slaves and indentured labourers, and of dispossessed aboriginals; a language in the courts and schools which has been imported like an item of heavy machinery; a prolonged economic and psychological subservience to a metropolitan centre a great distance away... One hardly needs to labour the point that such conditions make it extremely difficult for any section of the population to develop a vital, effective belief in the past as a present concern, and in the present as a consequence of the past's concerns. 365

In reactie hierop stellen Ruth First en Ann Scott in hun biografie van Olive Schreiner dat de Karoo het motief is "by which Schreiner asserted the necessity of memory in her attempts to give the substance of reality to her own impressions and experiences." ${ }^{366}$ Schreiner verklaart het heersende discours ontoereikend om de eigen ervaringen werkelijkheidswaarde te verlenen, en probeert eraan te ontsnappen door in het landschap, met daarin Adamastors graf, te zoeken naar herinneringen die in het sociale en politieke leven geen plaats meer hebben.

Dat helemaal ontsnappen onmogelijk is, blijkt wel uit het feit dat ze zich schuldig maakt aan het idee dat alleen die Afrikanen die zich niet aan het kolonialisme hebben geconformeerd, die onveranderd zijn gebleven, echt zijn, waarmee ze de latere apartheidsdenkers in de kaart speelt, en, net als Thomas Pringle, een interculturele werkelijkheid ontkent. Met haar onderscheid tussen gecorrumpeerde, aanwezige Hottentotten en pure, afwezige Bosjesmannen, maakt Schreiner gebruik van de bekende "rural myth", maar dan vanuit een andere waardering voor het boerderijdiscours. De Ander is of dood (of ten dode opgeschreven) en anders, of levend en onderdeel van "de boerderij". Dat Schreiner de natuur/cultuur dichotomie

\footnotetext{
${ }^{365}$ Jacobson 1976, 7

${ }^{366}$ Chapman 1996, 134
} 
in het voordeel van de natuur laat uitvallen, maakt voor het discours niet zo heel veel uit.

Adamastor wordt in The Story of an African farm vooral opgevoerd als onderdeel van de natuur. Waldo vergelijkt het voorbije bestaan van de Khoisan met hun eigen tijdelijke bestaan op deze zelfde plek (opnieuw door hem aangeduid als het graf van een "great giant" ${ }^{1367}$ ), en plaatst dat tegenover de eeuwigheid van de stenen, een eeuwigheid die elk denken, elke "constructie" relativeert, waardoor zowel Waldo als Khoisan onderdeel worden van het discours van de natuur in plaats van andersom, ook al blijft hij, bijna tegen beter weten in, vasthouden aan wat hij "weet":

"But we will be gone soon, and only the stones will lie on here, looking at everything like they do now. I know it is I who am thinking," the fellow added slowly, "but it seems as though it were they who were talking. Has it never seemed so to you Lyndall?"

"No it never seems so to me," she answered. ${ }^{368}$

Maar ook al is de Ander onschadelijk of onzichtbaar gemaakt door hem onderdeel te maken van de alomvattende cyclus der natuur (in slapende staat is Adamastor Afrika) hij heeft, ook in Waldo's bespiegelingen, iets ambivalents; Afrika/Adamastor heeft vingers, armen, ogen en woorden; hij is zowel verteller als focalisator, al wordt hij door de personages niet als zodanig erkend. Die ambivalentie komt voort uit het feit dat Adamastor niet alleen berg en steen is, maar ook een gevangen, gefrustreerde held. In die hoedanigheid is hij het herkenbare in de Ander $^{369}$. Schreiners gevangen, gefrustreerde heldin Lyndall is zonder moeite te zien als equivalent van Adamastor. Zij is de Zuid-Afrikaanse vrouw die sinds Pringle levend op de Zuid-Afrikaanse boerderij begraven was, gedoemd tot een leven van isolement, onmondigheid en gekmakende verveling ${ }^{370}$. Coetzee's observatie dat "to accept the farm as home is to accept a living death," ${ }^{371}$ geldt vooral voor de vrouwen. Lyndalls uiteindelijke, uit het heden bevrijdende dood krijgt dan ook het aanzien van een rite de passage met een onbekende bestemming: "Had she ceased from being? Who shall tell us? There is a veil of terrible mist over the face of the Hereafter." ${ }^{372}$ Haar dood is een transformatie, niet in steen en modder, maar eruit, en Schreiners boek, als vrouwenstem, is wellicht het bewijs dat ook de reus weer kan gaan leven ${ }^{373}$. In de jaren twintig en dertig van de twintigste eeuw zou, dankzij de maat-

\footnotetext{
${ }^{367}$ Schreiner 1989,42

${ }^{368}$ Schreiner 1989, 43

${ }^{369}$ Crewe 1999, 81. Zie ook hoofdstuk 3.5

${ }^{370}$ Zie Bunn 1994, 150 e.v. De uiterste, tot idee ingeklonken versie van deze vrouw is Martha, uit J.M. Coetzee's In the heart of the country

${ }^{371}$ J.M. Coetzee 1988, 66

${ }^{372}$ Schreiner 1989, 265

${ }^{373}$ Zie ook hst. 3.6
} 
schappelijke ontwikkelingen, de identificatie met Adamastors lot als beklemmend worden ervaren ${ }^{374}$, maar hier wordt die nog gepresenteerd als in potentie bevrijdend: Adamastor is niet de concrete Ander die zich in het eigen territorium bevindt, en niet de concrete barbaar van de andere kant van de grens (die in de Karoo niet meer bestond), maar een abstracte, onderdrukte of miskende kracht, wiens bevrijding of erkenning niet anders dan heilzaam kan zijn, omdat het een mede-Ander is, een spiegel van het Ik.

\subsection{NA 1910: "DOUBLY DISPLACED, DOUBLY INVOLVED, DOUBLY DETACHED"}

\subsubsection{Campbell, Plomer, Van der Post, Bosman}

Een aantal decennia later was het bijna onmogelijk om de concrete Ander over het hoofd te zien. In de eerste decennia van de twintigste eeuw reageerde de Engelstalige literatuur evenzeer op de politieke en sociale ontwikkelingen als de Afrikaanstalige. Ook hier werd een zekere nostalgie of verlangen aan de dag gelegd ten aanzien van een onbedorven samenleven met de natuur. Twee gebeurtenissen met name hadden het optimisme en de zelfverzekerdheid van voorheen getemperd. De Boerenoorlog had gevoelens van schuld en verantwoordelijkheid bij de Engelse overwinnaars achtergelaten, en de vorming in 1910 van een onafhankelijke Unie van Zuid-Afrika had van kolonisten inwoners gemaakt die zich thuis moesten gaan voelen op het vreemde continent. Hun rol als "bevrijders" was niet langer houdbaar en het verzet van de zwarte bevolking tegen de gevolgen van het Brits "liberalisme" groeide. Roy Campbell, Laurens van der Post en William Plomer zochten naar de grens of de overlapping tussen kunst en sociale verantwoordelijkheid ${ }^{375}$. Ze vonden het moeilijk hun positie te bepalen. Het hiervolgende gedicht van Campbell is een beroemde poëtische weergave van de patstelling die de heren ervoeren.

\section{Rounding the Cape $^{376}$}

The low sun whitens on the flying squalls,

Against the cliffs the long grey surge is rolled

Where Adamastor from his marble halls

Threatens the sons of Lusus as of old.

\footnotetext{
${ }^{374}$ Zie 3.5

${ }^{375}$ Chapman 1996, 179

${ }^{376}$ Campbell 1930, 38
} 
Faint on the glare uptowers the dauntless form,

Into whose shade abysmal as we draw,

Down on the decks, from far above the storm,

Grin the stark ridges of his broken jaw.

Across his back, unheeded we have broken,

Whole forests: heedless of the blood we've spilled,

In thunder still his prophesies are spoken,

In silence, by the centuries, fulfilled.

Farewell, terrific shade! Though I go free

Still of the powers of darkness art thou Lord:

I watch the phantom sinking in the sea

Of all that I have hated or adored.

The prow glides smoothly on through seas quiescent:

But where the last point sinks into the deep,

The land lies dark beneath the rising crescent,

And Night, the Negro, murmers in his sleep.

Volgens Jonathan Crewe staat Adamastor ("Night, the Negro") in dit gedicht enerzijds voor de Ander, in een steeds scherpere raciale dichotomie, terwijl anderzijds "increasingly 'African' self-consciousness on the part of the whites settled in southern Africa resulted in identification with the trapped, culturally displaced, and humiliated figure of Adamastor." ${ }^{377}$ In Rounding the Cape wordt een poging te vluchten voor zowel Adamastors vloek als de eigen geschiedenis verijdeld door de laatste strofe. "Negro blackness is essentialized and superinduced on Night the antipodal, the dark unconscious, and so forth" ${ }^{378}$, zodat tegelijkertijd een "tautological European whiteness" wordt geproduceerd die ontsnappen onmogelijk maakt. "The imaginary white man", zegt Crewe, "remains bound to the blackness of his own construction." ${ }^{379}$

Hieraan ten grondslag ligt natuurlijk het proces van proletarisering dat zich in de eerste decennia van de twintigste eeuw had voltrokken, en dat de "eigen" zwarte bevolking in toenemende mate had verpauperd en geanonimiseerd en (opnieuw) tot vijand gemaakt. Voor deze interne dreiging werd een voor velen bijna even angstaanjagende uitweg gevonden door in Adamastor de kiem van nieuw, niet-blank leven te benadrukken: "the clayey features and the hair matted with mud are not only descriptive of how the old rebel is in abeyance - this is the kind of clay and mud out of

\footnotetext{
${ }^{377}$ Crewe 1999, 81

${ }^{378}$ Crewe 1999, 84. Zie ook Hoofdstuk 4.

${ }^{379}$ idem
} 
which the new Adam will one day be born. ${ }^{9380}$ Het succes van de liberale integratiepolitiek wordt hiermee met terugwerkende kracht in twijfel getrokken; Onze Ander wordt weer een Vijandige Ander, zodat de duisternis die de eigen identiteit is binnengeslopen weer het gezicht kan krijgen van die Ander. Campbell doet dit in zijn poëziebundel Adamastor (1930) bijvoorbeeld door de Afrikaanse apocalyptische voorspellingen die in de jaren twintig rondzongen te verbeelden als de verrijzenis van de reus. Ondanks het Bullhoek-debâcle, sarcastisch weergegeven in "Holism" ("The love of Nature burning in his heart,/ our new Saint Francis offers us his book -/ the saint who fed the birds at Bondleswaart/ and fattened up the vultures at Bull hoek" ${ }^{\prime 381}$ ), ziet Campbell in zijn bundel een heroïsche rol weggelegd voor Adamastor: "(..) Short is the peace, though hushed and breathless,/ in which we feel the victor's will/ and its intrinsic hydra, deathless, reviving at the self-same rill" ${ }^{382}$, en plaatst hij "the indigenous people in the landscape with a visionary power that gains succour from the past as it sweeps forward in apocalyptical liberation" ${ }^{383}$. Maar hij durft de consequenties van deze gedachtengang uiteindelijk toch niet onder ogen te zien. Later noemt hij apartheid de enige remedie tegen de ondergang van het Westerse erfgoed en ontstaat in zijn poëzie het bekende beeld van de "noble peasant" als "symbol of the agrarian continuity" ${ }_{384}$. Plomer onderzoekt mogelijkheden om tot een nationale literatuur te komen die een mix zou moeten zijn van de "drie culturen": Engels, Afrikaner en Afrikaans. Ook hij krijgt een en ander echter niet rondgedacht. Net als in de plaasromans blijkt er iets onverzoenbaars te bestaan tussen fictie (of abstractie) en werkelijkheid: "[T]he crux (...)" meent Chapman, "is that in his early African poems the unifying vision of the romantic-symbolist explodes under the pressures of the raw experience. (...) What are challenged are the poets own colonial hankerings after landscapes empty of the indigenous people, his own colonial fears about Africa as savage and atavistic." ${ }^{385}$. Noch Plomer, die zichzelf op een schrijversconferentie in 1956 typeert als "doubly displaced (...), doubly involved, doubly detached""386, noch Campbell, noch Van der Post zullen zich uiteindelijk thuis voelen in "het nieuwe Zuid-Afrika". Ze vertrekken alledrie in de loop van de roerige twintiger jaren naar Groot-Brittanië.

In reactie op het intellectualisme van bovengenoemde dichters maken schrijvers als Stephen Black zich sterk om de gewone (blanke) man pretentieloze kleinschalige literatuur te verschaffen. Populaire literatuur bestaat

\footnotetext{
${ }^{380}$ Gray 1979,26

${ }^{381}$ Campbell 1930, 103

${ }^{382}$ Campbell 1930, 79 Uit: "Resurrection"

${ }^{383}$ Chapman, 1996, 181

${ }^{384}$ Chapman 1996, 181

${ }^{385}$ Chapman 1996, 183

${ }^{386}$ geciteerd in Chapman 1996, 182
} 
overigens al langer: in het begin van de twintigste eeuw zijn er twee soorten avonturenromans te ontdekken. De ene vertelt het verhaal van de koloniaal die in Afrika een exotisch alternatief zoekt voor een onbevredigend bestaan in de grote stad. De ander, een Engelstalige tegenhanger van de Afrikaanse plaassstories, vertelt in overeenstemmming met de rurale mythe "the tale of the settler on the farm in which the ordering eye, hand and gun impose authority on the savage land." ${ }^{387}$ De kring rond Black neemt daarentegen geen duidelijke politieke of ideologische positie in, maar beschrijft de wederwaardigheden op plaatselijk niveau met milde (zelf)spot. In de jaren dertig en veertig hanteert ook Herman Charles Bosman (1905-1951) een afstandelijk, vaak ironisch perspectief als hij zijn ervaringen als onderwijzer op het platteland van de jaren twintig in proza omzet. Maar bij hem verhullen distantie en lichtvoetigheid gefundeeerde kritiek op de staat en een besef van tragiek en gevangenschap in de aloude Adamastor-klem ${ }^{388}$. Zoals in onderstaand gedicht.

\section{Seed}

The farmer ploughs into the ground

More than the wheat-seed strewn on the ground

The farmer ploughs into the ground

The plough and the oxen and his body

He ploughs into the ground the farmstead and the cattle

And the pigs and the poultry and the kitchen utensils

And the afternoon sunlight shining into the window panes of the voorhuis

And the light entangled in the eyes of the children

He ploughs into the ground his wife's brown body

And the windmill above the borehole

And the borehole and the wind driving the windmill

The farmer ploughs the blue clouds into the ground;

And as a tribute to the holocaust of the ploughshare -

To the sowing that was the parting of the Juggernaut -

The earth renders the farmer in due season

Corn $^{389}$

\subsubsection{Pauline Smith en de kroon van Ludovitje}

Een belangrijke exponent van de Engelstalige pastorale literatuur in de bloeitijd van de Afrikaner plaasroman was Pauline Smith (1882 - 1959). Ze

\footnotetext{
${ }^{387}$ Chapman, 1996, 129

${ }^{388}$ Zie ook Hoofdstuk 4.1

${ }^{389}$ Uit: Herman Charles Bosman, Wild seed, Human \& Rousseau, 2004
} 
bracht als dochter van een Engelse dokter haar jeugd in het binnenland van de Kaap door en deed daar stof op voor een heel oeuvre, evenzeer gefascineerd door de Afrikaner boeren als later Bosman. Bij haar is de toon echter niet die van lichte spot, maar van een soort fatalistische bewondering voor wie in staat is dit zware, maar pure leven aan te gaan. Conform de Engelsliberale traditie trekt Smith een vergelijking tussen witte en zwarte "autochtonen", waarbij een zeker schuldgevoel niet afwezig is ${ }^{300}$. Smith zag de Afrikaner boeren net zozeer als slachtoffer van de Engelsen, als de zwarten van de Boeren: "The Dutchman felt himself to be, in the sight of the Lord, the rightful owner of a country which he, and not the Englishman had taken from the heathen" ${ }^{391}$. Deze underdogpositie had een positieve keezrzijde, want: de "Dutchman [lived] almost as close to nature as the Native itself." ${ }^{392}$ Het idyllische verleden dat, net als in de plaasroman, in haar proza doorklinkt is in haar geval geografisch begrensd: de Klein Karoo is een paradijsje afgezet tegen de desolate wereld van de Groot Karoo. In de Klein Karoo "[t]he mythic values that accumulate around the valley are those of the womb: closure and fruitfulness" ${ }^{\prime 393}$. Daar "life played out elemental, almost fatalistic passions to the rhythms of the plough, the church service, and the moods of the season. ${ }^{{ }^{3} 34}$ Smith is, zegt Coetzee

concerned to assert certain myths about the Afrikaner, or rather, to back existing myths with what will look like evidence, namely, the trace of a characteristic Afrikaner consciousness inscribed in his language (...). In particular, Smith's practise of transfer [haar gebruik van Afrikaans en/of oud-testamentisch aandoend Engels in het geval van Afrikaanse focalisatie. GP] is meant to validate the homegrown Calvinist myth in which the Afrikaner has his type in the Israelite, tender of flocks, seeker after a promised national homeland, member of an elect race (volk) set apart from the tribes of the idolatrous, living by simple and not-to-be-questioned commandments, afflicted by an instructable Godhead with trials whose purpose is to test his faith and his fitness for election. ${ }^{395}$

Ondanks deze idyllische setting is kwaad of schuld nooit ver weg. Smith is geroemd om haar beschrijvingen van de kleine onderdrukking (van bywoners en arbeiders, maar vooral ook van de vrouw) binnen het Afrikaner Calvinisme ${ }^{396}$. Zwarte actanten zijn er bij Pauline Smith nauwelijks, maar

\footnotetext{
${ }^{390}$ Driver 1989

${ }^{391}$ Smith 1989, 26

${ }^{392}$ Driver 1989,80

${ }^{393}$ J.M. Coetzee 1988, 67

${ }^{394}$ Chapman 1996, 188

${ }^{395}$ J.M. Coetzee 1988, 118

${ }^{396}$ zie ook Clayton 1989
} 
Dorothy Driver merkt op dat Smith gebruik maakt van analogieën om de lezer ervan te doordringen dat "the chain of oppression binds the hearts, minds and bodies of all." ${ }^{397}$

Een vreemde eend in Smiths oeuvre is het verhaal "Ludovitje" uit The little Karoo (1925). Het verhaal voldoet aan Coetzee's typering ware het niet dat er bij wijze van uitzondering een zwart personage in voorkomt met een opmerkelijke rol. In de loop der tijd is het verhaal niet al te goed gevallen bij de critici. De één deed het verhaal af als "'least succesful", bij een ander "'[it] leaves a nasty aftertaste", weer een ander meende dat "the 'insubstantial' narrative framing device 'does not give enough of a foothold for the external viewer" "'398. Driver is minder negatief en leest in het verhaal de uit tactische overwegingen wat verwrongen weergegeven boodschap dat "Zulu have as much right to the Israëlite myth as have Afrikaners" ${ }^{399}$. Bij nadere bestudering van het gebruik van de ruimte in dit verhaal, valt zelfs op te maken dat de uitverkorenheid van de Afrikaner afhankelijk is van zijn acceptatie door de Afrikaan. Maqwasi's bekering moet de uitverkorenheid van Ludovitje bevestigen, maar zijn morele, geestelijke en fysieke overwicht doet, bedoeld of onbedoeld, eigenlijk het tegenovergestelde.

In Ludovitje vertelt Alida het verhaal over haar zoon. Ze leidt het zelf in: Ludovitje is dood en was altijd al een ziekelijk kind. Maar als de mensen in het dorp suggereerden dat hij ook wel een beetje ziek zou zijn in zijn hoofd, zei zij altijd dat hij het beste boek las dat er is: de bijbel. Er was niemand, aldus moeder, die zo dicht bij God stond. Ludovitje was niet gek, wil ze maar zeggen, maar vroom.

Dan volgt het eigenlijke verhaal: Vader Piet liet een dam bouwen in het Credogebergte, om vandaaruit zijn velden te kunnen bevloeien. Hij had daartoe "kaffers" uit het verre binnenland gehaald: grote sterke mannen zoals je die in de Kaapkolonie niet tegenkwam, en die nog niet in God geloofden. Zo vaak hij kon, ging Ludovitje mee naar boven naar de dam in aanbouw. Hij zong dan altijd psalm 114 en de zwarte mannen zongen al gauw mee. Maqwasi, de leider van de zwarte mannen, wilde meer weten over "Jacob's king" en "the springing well" en Ludovitje vertelde. "Of the wanderings of the Children of Israel he would tell him, and of God's guidance in the Wilderness. Of God's goodness and mercy to those that love Him he would tell him and of the pure River of Water of Life that He has given us." ${ }^{400}$

Toen Ludovitje op een dag te ziek was om te komen, vroeg Maqwasi toestemming om naar het kind te gaan. Hij ging en bleef, en vanaf het

\footnotetext{
${ }^{397}$ Driver 1989, 82

${ }^{398}$ Geciteerd in Driver 1989, 82, noot 19

${ }^{399}$ Driver 1989, 82

${ }^{400}$ Smith 1990, 81
} 
moment dat hij de ziekenkamer betrad, was Maqwasi een gelovig mens. Toen de jongen stierf hakte hij een graf uit in een kopje dat uitkeek op de bergen. Vader Piet vroeg Maqwasi of hij niet wilde blijven, maar Maqwasi wilde terug om zijn volk te kunnen vertellen van de rivier van het levenswater die langs de troon van God en het Lam stroomde. Toen had Piet nog éen laatste verzoek: of Maqwasi graven voor hen wilde uithakken naast dat van zijn zoon "For it may be that when we came to die there will be no man on all the farm that can dig through the claystone like Maqwasi the kaffir, and where than shall we lie?" ${ }^{401}$ En zo geschiedde.

De buurvrouwen hebben niet helemaal ongelijk, want een beetje typisch is Ludovitje wel. Hij leeft in een bijbelwereld en hij geeft zichzelf daarin een opmerkelijke plaats. Het bouwen van de dam in het Credo(=ik geloof)gebergte is voor hem de verwezenlijking van psalm $114^{402}$. Ludovitje hoort tot de Afrikaner stam die het "volk van vreemde taal" (de Engelsen) ontvluchtte, en de droge wildernis introk. Hij hobbelt op een wagen door de heidense Karoo en ziet de bergen voor zijn ogen dansen, "bevend voor het aangezicht des Heeren". Hij ziet hoe "de rots veranderde in een waterplas" en uit steen een waterbron gemaakt wordt. Ludovitje gelooft niet alleen heilig in God en het beloofde land, maar ook in zijn eigen uitverkorenheid. Dit wordt bevestigd door zijn terugkerende uitspraak dat Maqwasi "the pearl in my crown" is. "To wear the crown" betekent zowel "heersen als vorst" als "martelaar zijn“"403. Kijken we naar de Oud-testamentische betekenis, wat toch het belangrijkste referentiekader van Ludovitje lijkt uit te maken, dan is de kroon met name een teken van uitverkorenheid, niet alleen van de mens ten opzichte van ander aards leven, maar ook van bijvoorbeeld koningen ten opzichte van hun onderdanen. Die uitverkorenheid behelst zowel God's welgezindheid, maar ook wereldlijke macht, voorspoed en superioriteit. ${ }^{404}$ In het nieuwe testament is de kroon met name een teken van onbegrip, martelaarschap en vergeestelijkte superioriteit (de doornenkroon). Maar "the pearl in the crown" is natuurlijk ook de bijnaam voor India binnen het Britse imperium.

De kroon die Ludovitje zichzelf opzet lijkt zowel de imperialistische als de oud- en nieuwtestamentische te zijn. Het is een kroon van uitverkorenheid omdat hij deel is van een uitverkoren volk; het is een kroon van superioriteit ten opzichte van de rest van de blanke gemeenschap; en het is een kroon van martelaarschap: hij is het zwakke, onschuldige, onbegrepen kind

\footnotetext{
${ }^{401}$ Idem, 84

${ }^{402}$ Toen Israel uit Egypte toog, Jakobs huis uit een volk van vreemde taal, werd Juda tot zijn heiligdom, Israel zijn rijksgebied. De zee zag het en vluchtte,de Jordaan wendde zich achterwaarts; de bergen sprongen als rammen, de heuvelen als lammeren.Wat was er o zee, dat gij vluchttet? gij Jordaan dat gij $\mathrm{u}$ achterwaarts wenddet?gij bergen dat gij als rammen opsprongt,gij heuvelen als lammeren? Gij aarde, beef voor het aangezicht des Heren, Voor het aangezicht van den God Jakobs, Die de rots veranderde in een waterplas, den keisteen in een waterbron.

${ }^{403}$ Van Dale's Groot Woordenboek der Engelse Taal

${ }^{404}$ Psalmen 8:4; 89:40; 132:18; Klaagliederen 5:16.
} 
dat moest sterven om "gezien" te worden. Dat Maqwasi de parel in zijn kroon zou blijken te zijn (i.e. hem tot eer zou strekken) had Ludovitje wel goed ingeschat; dat een kind sterft om een kaffer te bekeren, sprak opeens zo tot de verbeelding van de buurtbewoners, "[a]11 that day the people came from the farms around us to see the child, for all through the valley it was now known already that Ludovitje had saved Maqwasi the Kaffir and that he now lay dying." ${ }^{\circ 05}$

Bij dit alles moet niet worden vergeten dat het verhaal verteld wordt door Ludovitjes moeder, dat de focalisatie uitsluitend bij haar ligt en dat het verhaal een duidelijk doel heeft: de naam van haar kind te zuiveren. Het is dus mogelijk dat niet Ludovitje zichzelf een kroon opzet, maar dat zijn moeder dat doet. Maar Alida doet ook nog iets anders: ze brengt (onwillekeurig?) een tegenstelling aan het licht tussen de dorpsgemeenschap in het dal en de wildernis daarbuiten, één die in het voordeel van de wildernis uitvalt. Ludovitjes geloof is niet het geloof van de gemeenschap, maar een individueel beleden geloof dat meer verbonden is met de ormingende natuur dan met de kerk. Een ruimtelijke analyse geeft meer inzicht in deze tegenstelling. Het dal wordt verdeeld in een negatief deel: Platkopsdorp, en een positief deel: de boerderij. Platkopsdorp wordt gepresenteerd als een plek van ongeloof, onwetendheid en onbegrip. De vrouwen op de markt geloven niet in Ludovitje, de dokter ziet niet dat Ludovitje stervende is, de kerk is slechts van nut omdat psalm 114 Alida herinnert aan Ludovitje's religieuze ervaringen in de bergen. Daartegenover staat de boerderij: een warm, vrouwelijk, besloten thuis; inderdaad, zoals Coetzee Aangenaam Valley in The Beadle typeerde ${ }^{406}$, een baarmoeder: vol vruchtbaarheid, warme familiebanden, moederliefde, verzoening, leven en dood. Het is een thuis voor meerdere generaties, een plek van inzicht, de plek waar het water naartoe stroomt. Tegenover het dal wordt het (Credo)gebergte geplaatst. Hier bevindt zich het mannelijke en spirituele. Het is een wildernis van barre rots en water, van heidense oerkracht en de kracht van God. Maar ook, tegenover de bekrompenheid van het dorp en de geslotenheid van de boerderij, van openheid en communicatie. En van uitverkorenheid.

Maqwasi speelt een doorslaggevende rol in dit verhaal, terwijl zijn motieven verborgen blijven. Voor de moeder van Ludovitje spitst die rol zich toe op de verhouding met de buren: Als Maqwasi niet bekeerd was, had Ludovitje als een halve gare het leven verlaten; Maqwasi heeft aan de buren haar gelijk bewezen. In werkelijkheid is Maqwasi's rol nog veel groter. Voor Ludovitje's moeder mag het een uitgemaakte zaak zijn dat zijn bekering voortkomt uit Ludovitjes uitverkorenheid, maar in feite is het Maqwasi die alle tekenen van die uitverkorenheid verschaft. Dankzij hun fysieke kracht kunnen Maqwasi c.s. het pad naar boven aanleggen, waardoor Ludovitje en

\footnotetext{
${ }^{405}$ Smith 1990,82

${ }^{406}$ Coetzee 1988, 67
} 
zijn vader uberhaupt de berg op konden komen en waardoor de bergen voor zijn "uitverkoren" ogen konden "opspringen als rammen" 407 ; zij bouwen de dam waardoor "de rots veranderde in een waterplas" en "den keisteen in een waterbron"; zij zorgen ervoor dat het water uit de dam door geulen geleid wordt naar de boerderij van zijn vader, ofte wel: dat de "river of water of life [runs] close to the throne of God and of the Lamb". Bovendien is hij narratologisch gezien eerder subject dan object. Maqwasi redt de naam van de jongen door zich tot Christen te laten bekeren; Maqwasi hakt naar eigen inzicht en eigenhandig -met dezelfde kracht die nodig was om de dam te maken- een graf uit voor Ludovitje, hoog op een kopje, en verschaft ook diens ouders deze eer. De weg van de boerderij naar de berg, tussen vrouwelijke aarde en mannelijk water, tussen zachtheid en kracht, mens en God, beschaving en wildernis, en dus uiteindelijk Europa en Afrika is door Ludovitje en zijn vader slechts met veel moeite én met behulp van heidense vreemdelingen af te leggen. Maar Maqwasi kwijt zich moeiteloos van zijn taak. Hij legt een verbinding van beneden naar boven (de weg, maar ook het graf in de heuvel tussen boerderij en bergen) en van boven naar beneden: hij laat het water stromen ${ }^{408}$ en kent zelf ook weinig fysieke beperkingen; hij "put down his tools and ran from the mountains down the ravine to our farm in the valley. All the way from the mountains he ran". ${ }^{409}$

Het is niet Ludovitje die Maqwasi redt, en hem een plek geeft in het onderen bovenmaanse, maar andersom. Alleen Maqwasi is in staat Platkopsdorp, de boerderij en God in het Afrikaanse landschap, dat wat Doris Lessing "Africa's inexplicable majestic silence" ${ }^{410}$ noemde, met elkaar te verzoenen. Alleen hij kan door de harde, ongastvrije korst van de Afrikaanse aarde heenbreken en er de blanke bewoners een thuis te verschaffen na de doodeen graf dat lijk op een kamertje of, wederom, een baarmoeder ${ }^{411}$, maar dat ook erg doet denken aan de "Bushman's Cave" in Pringles Evening rambles: "(his fortress once, and now his grave)"

Het meest raadselachtige echter is de bekering van Maqwasi, een raadsel dat in stand blijft door zijn ontbrekende focalisatie. Plomer zegt dat Ludo-

\footnotetext{
${ }^{407}$ Smith 1990, 80: "There was no road for [Ludovitje and his father] to go [up] but a track only that the kaffirs had made (..) so rough (..) that (..) the little kopjes would dance before their eyes.".

${ }^{408}$ Idem, 80: "Far up in the mountains [the kaffirs] built [the dam], leading the water from there in furrows to our lands in the valley."

${ }^{409}$ Idem, $81 / 2$

${ }^{410}$ Doris Lessing "Preface" African Stories, 1981: 6

${ }^{411}$ Smith 1990, 83: [Maqwasi said]: Master! Let me now dug a grave for the child on the kopje that lies behind the house and looks towards the mountains. Surely it is towards the mountains that the child would lie.' Piet said to him: 'The kopje is clay-stone, and who now can dig a grave through clay-stone?' Maqwasi answered: 'Have I not dug for master a dam in the mountains, and can I not now, with my tools, dig a grave for the child in the clay-stone?' So he dug the grave. Like a little room in the claystone he dug it.

${ }_{412}$ African Poems of Thomas Pringle, ed. Ernest Pereira and Michael Chapman. Durban: University of Natal Press, 1989: 16-20 Zie ook Hoofdstuk 3.3
} 
vitje en Maqwasi "are brought into communion and rapt away into the supra-mundane sphere for which their innocence and the reasonless fervour kindled by a few bizarre old phrases have fitted them"413. Dat zou kloppen als Maqwasi werd geportretteerd als een kinderlijke, onnozele, "blanco" heiden. Maar waarom zou een man-die-alles-kan zich laten imponeren door een fantast als Ludovitje? Geloof je nog steeds niet?, vraagt Ludovitje hem als hij de ziekenkamer binnenkomt. "Master!" zegt Maqwasi "Now I believe." Maar wát gelooft-ie dan? En waarom op dat moment?

Een antwoord op deze vraag is misschien te vinden in het feit dat de bekering van Afrikanen tot het christendom door de missionarissen vaak anders werd bedoeld en beleefd dan door de Afrikanen zelf. Dat Maqwasi graag met Ludovitje psalmen zong, levert bijvoorbeeld geen bewijs voor een kinderlijk soort idolatie. In "Orality and Literacy on a Berlin Mission Station in the Transvaal" schetst Isabel Hofmeyr hoe missionarissen de interesse van hun toehoorders vaak verkeerd interpreteerden. In de ogen van de missionarissen was lezen, schrijven, bijbelkennis en belijdenis één ondeelbaar geheel. "The idea of disciplined communion with the sacred (and printed) word was, after all, essential to nineteenth century Protestantism in which texts became the kernel of a relgious identity." niet voor de Afrikanen die de missieposten bezochten. Ze kwamen omdat ze iets wilden leren, maar dat wil niet zeggen dat ze allemaal wilden leren lezen en schrijven, laat staan dat ze allemaal bekeerd wilden worden. Lezen was voor velen aantrekkelijker dan schrijven. Sommigen wilden zelfs alleen maar hun eigen literaire repertoire uitbreiden en leerden de "new oral forms of hymns and prayers," of zelfs hele bijbelteksten uit hun hoofd ${ }^{415}$. Als kleine zendeling kan Ludovitje Maqwasi's enthousiasme voor zijn psalmen dus gemakkelijk in een verkeerd kader geplaatst hebben, net zoals de missionarissen "often misread any interest in literacy as a sign of religious feeling and a commitment to the values of the mission world." ${ }^{116}$ Het geeft een doorkijkje naar een wereld waar Ludovitje geen weet van, geen grip op, en geen interesse voor heeft, en versterkt de positie van Maqwasi die wél zijn kennis wil vergroten - als gids in de fysieke en spirituele wereld van Afrika.

Zelfs zijn bekering is misschien niet meer dan een intercultureel misverstand. Het verhaal dat Alida vertelt, is een variatie op een bekend genre dat vaak verteld werd door diezelfde missionarissen, een genre met een onverwachte dubbele bodem die Maqwasi (onwillekeurig) tevens tot morele held verheft. Om de afstand tot hun Afrikaanse (African) publiek te verkleinen pasten predikanten hun presentatie steeds meer aan. Ze legden nadruk op

\footnotetext{
${ }^{413}$ Driver 1989,82 , noot 19

${ }^{414}$ Hofmeyr 1991, 640/1

${ }^{415}$ Hofmeyr 1991, 640/1

${ }^{416}$ Idem
} 
"orality, performance, festival, spectacle and image" ${ }^{417}$. Ze vertelden verhalen waar een (zwart) Afrikaanse moraal of legende in verwerkt zat. Een van de populairste in zijn soort was de death-bed conversion. "Such stories (..) invariably tell of last-minutes conversions and injunctions to descendants to heed the word of God. Ironically," vervolgt Hofmeyr, "such stories return to the original oral [African] meaning of the word 'will', which signified a final and spoken wish. Such oral wills are still highly respected today." "418 Dat het sterven van Ludovitje voor Maqwasi een doorslaggevend argument is om Gods woord te verspreiden, betekent dus dat het verhaal niet alleen in een Christelijke martelaarstraditie past, maar ook in het interculturele discours van de missie, en in een (zwart) Afrikaans normenen waardenstelsel.

Voor de terugkerende verwijzingen naar de "River of Water of Life" geldt hetzelfde. Zoals gezegd legden de missionarissen in hun tijd de nadruk op vóórleven in plaats van prediken, omdat het laatste weinig effect had. Irrirgatie was een van de speerpunten van de door de missie geïntroduceerde landbouwmethodes, die door Afrikanen veelal werden overgenomen. Ludovitje voegt zich helemaal in die traditie. Terwijl Maqwasi innovatieve technische vaardigheden opdoet of perfectioneert, wijst Ludovitje hem op de macht die dit mogelijk maakt. Maqwasi, gezien zijn positie als migrantenarbeider waarschijnlijk afkomstig uit een veranderende, zo niet ontwrichte samenleving, ziet hier nieuwe mogelijkheden. Maar dat wil bepaald niet zeggen dat hij zich daarmee onderwerpt aan de christelijke dogma's of de koloniale macht. Overname van bepaalde landbouwmethoden leidde lang niet altijd tot de culturele, politieke en economische integratie die de missionarissen voor ogen hadden gehad. Traditioneel was macht over water een belangrijk onderdeel van de macht van de chiefs. Dat Maqwasi zijn eigen mensen zal gaan vertellen over de heer van "the River of the Water of Life", krijgt een bepaalde lading door de wetenschap dat in de tijd dat Smiths boek gepubliceerd werd, die macht door veel Afrikanen inderdaad niet meer aan de chiefs werd toegeschreven, maar evenmin aan een bijbelse, blanke God. De onafhankelijke, Afrikaanse Zionistische kerken kwamen tegemoet aan de behoefte om vorm te geven aan Afrikaanse spirituele krachten binnen het Christendom: christelijke beelden werden gekoppeld aan Afrikaanse rituelen, dominees namen de taken van sjamanen over, voor de oogst werden zowel voorouders.als God gedankt. De "securing of agricultural fertility had generally drifted (..) towards the Zionist churches. (..) [God's] 'river of the water of life' brought forth fruit and crops 'and the leaves of the trees [that] are for the healing of the nations"” ${ }^{419}$.

\footnotetext{
${ }^{417}$ Hofmeyr 1991, 642

${ }^{418}$ Hofmeyr 1991, 641

${ }^{419}$ Crais 2002, 134 (hij citeert uit Openbaringen 21:22-22:5)
} 
Maqwasi leek als zwijgend, raadselachtig object, als parel in Ludovitjes kroon, gevangen te zitten in de verstarde Platkopsdorpse focalisatie van Ludovitje's moeder en/of de grootheidswaan van Ludovitje zelf. Maar door het interpretatieve kader te vergroten kan Maqwasi zich ontpoppen tot een gewetensvol subject met een eigen agenda: een sterk, leergierig, grensverleggend middelpunt in een grote, bewegende Afrikaanse wereld. Ook Ludovitje verandert wanneer hij in een groter kader geplaatst wordt. Zijn paternalistische bekeringsdrang, zijn herhaalde verwijzing naar de pearl in the Crown past eerder in de traditie van Brits-christelijk kolonialisme, dan van $19^{\mathrm{e}}$ eeuwse Afrikaner boeren ${ }^{420}$. Net als Plomer heeft Smith misschien geprobeerd de drie culturen met elkaar te laten versmelten. De Ludovitje/Maqwasi-eenheid weerspiegelt niet de verhouding Afrikaan-Afrikaner, maar een idealistische driehoeksrelatie tussen Afrikaan, Afrikaner en Brit, die het tegen een werkelijkheid van Platkopse ongelovigheid en kortzichtigheid moet opnemen. Net als bij Pringle kan de idylle slechts vorm krijgen door de gekleurde werknemers die ongetwijfeld op de boerderij aanwezig waren, voor deze rol te diskwalificeren en te vervangen door immigranten die in de verte verwijzen naar een Brits-koloniaal kader. Maar iedere lezer weet inmiddels, en kon ook in 1925 weten, dat het slecht afliep met de meeste Maqwasi's in de Britse kolonie. Tegen die tijd was de Israëlitische mythe inderdaad niet alleen door Afrikaners geclaimd, maar, zoals eerder in dit hoofdstuk beschreven, ook door een groot aantal door armoede geteisterde Afrikanen die zich "Israëlieten" noemden en hun Zionistisch geloof koppelden aan een politieke boodschap die even weinig interraciale "communion" inhield als de (latere!) Afrikaner versie ${ }^{421}$. De "few bizarre old phrases" wereldorde, verwijzen dus naar een toekomst van oncontroleerbare economische, culturele en politieke verandering - of misschien zelfs wel naar de destructieve invloed die het Engels kolonialisme uiteindelijk gehad heeft op de in potentie aanwezige Europees-Afrikaanse idylle. Smiths poging (?) een utopie te schetsen mondt, bedoeld of onbedoeld, uit in een waarheidsgetrouwe weergave van haar tijd: ideologische chaos tegen een verzwegen achtergrond van ontwrichting, geweld en armoede.

\footnotetext{
${ }^{420}$ Afrikaner boeren waren er helemaal niet zo op gebrand om de zwarte bevolking te bekeren. Giliomee

${ }^{421}$ Pas in de jaren veertig werd de tot dan toe a-politieke predestinatieleer gekoppeld aan het Afrikaner nationlisme. De eerste Calvinistische opleving in de Kaapkolonie halverwege de negentiende eeuw was niet politiek getint, hoogstens lichtelijk gekant tegen de Grote Trek. De Voortrekkers zelf waren zelfs tamelijk onorthodox in hun Calvinisme. In ieder geval, "there was no sense, even among the most fervent Calvinists, that theirs was an exclusive, national religion.” (Ross 1993, 191)

${ }^{422}$ Zie noot 148
} 


\section{6 “DIE VERSKRIKLIKE EENHEID”: NATUUR, FAMILIE EN DOOD}

Interessant in zowel "Ludovitje", als The Story of an African Farm, als in een verhaal van Herman Charles Bosman dat later uitgebreid aan de orde zal komen ${ }^{423}$, zijn de positie van het graf en het effect van het sterven van de hoofdpersoon. Ludovitjes hooggelegen graf sluit de cirkel tussen het neerstromende levengevende water en de opwaarts gerichte dood, terwijl het bovendien in het (prekoloniale) Afrikaanse landschap is opgenomen met name dat laatste is wat zijn "fitness for election" bewijst ${ }^{424}$. Tegelijkertijd is in deze cirkel tussen God en Afrika een paradijsje geschapen dat wederom buiten de sociale werkelijkheid staat.

Zoals gezegd was niet alleen de identiteit van de Afrikaner boer gebaseerd op een paradox. Engelstalige Zuid-Afrikaanse schrijvers leden onder het feit dat de werkelijkheid die ze volgens hun literaire traditie meenden te moeten verbeelden, niet te vangen was in liberaal-realistische termen. "[T]he great liberal tradition, once it was applied to an African colonial situation, had to battle against extraordinary tensions in order to survive at all." ${ }^{225}$ Het zoeken naar een Engels-Afrikaanse identiteit wordt volgens Gray weergegeven als doodsverlangen. De prominente aanwezigheid van het lijk in The Conservationist (1974) van Nadine Gordimer past dan in een trend in de Engelse Zuid-Afrikaanse literatuur die bij Schreiner is begonnen, namelijk

a brooding kind of desire to die in the rich, red earth. (...) What we are being shown [in The story of an African farm] is the first appearance of a struggling but implacable fatalism which has taken its place in the fore of South African English mentality, an uneasy lack of identity which, in the last resort, can only die on the land to prove that it has lived above it. Mulch, Schreiner implies, is the lowest, and first, form of belonging. ${ }^{426}$

In het volgend hoofdstuk zal blijken dat identiteit en dood bijna intrinsiek met elkaar verbonden zijn, en dat het gebruik van die metafoor op zich dus geen bewijs is van fatalisme. Wel is het significant hoe de metafoor gebruikt wordt. Zo wordt composteren in The story of an African farm nu juist zorgvuldig vermeden. Inderdaad vinden Lyndall en Waldo elk op hun eigen manier een oplossing in het sterven; Lyndall als overgang naar een onbekende andere wereld, Waldo als eenwording met de natuur, waarbij

\footnotetext{
${ }^{423}$ Zie hoofdstuk 4.1

${ }^{424} \mathrm{Zie}$ noot 130

${ }^{425}$ Gray 1979, 155

${ }^{426}$ Gray 1979,154
} 
niet de dood zelf die eenwording veroorzaakt, maar het afleggen van elk verlangen. "When the very thirst for knowledge (...) has grown dull; when in the present there is no craving and in the future no hope, then, oh, with a beneficient tenderness, Nature enfolds you. (...) Well to die then." ${ }^{227}$ Als Waldo inderdaad op zo'n moment van verlangenloosheid sterft, vereeuwigt hij het moment, en voegt daarmee wellicht zijn geest bij de "strange little brother spirits" die zich bij leven "so real" door het landschap bewogen ${ }^{428}$. Wat hem in het leven van zijn "broeders" gescheiden houdt, verdwijnt, zo hoopt hij, in de dood.

Hier maakt Schreiner gebruik van wat Mark Turner een "kinship metaphor" noemt. "Moeder Natuur" bevat de basismetaforen "an abstract property is the parent of something having that property" en "the whole is the mother of the parts" ${ }^{\prime 29}$. Dat Waldo wordt voorgesteld als het kind van de Natuur impliceert dat hij haar eigenschappen $\operatorname{erft}^{430}$ en dat hij onbevraagtekend onderdeel is van de plek waar hij is ${ }^{431}$. Bovendien impliceert het "broederschap": gelijkheid en contact met haar andere kinderen, zoals honden, stenen, kuikens, vrouwen, Khoisan en Duitsers ${ }^{432}$. Door zich in de familie van Moeder Natuur te laten opnemen, ontsnapt Waldo aan zijn eigen "familie" en sociale erfenis: zijn door Adamastor vervloekte superioriteit en zijn ontheiligende, eenzame zoektocht naar de waarheid. Sterven is dus vooral ontsnappen; een reis zonder aankomst. Het verhaal stopt voordat Emmy doorkrijgt dat Waldo niet slaapt; dood-zijn (i.e. lijk zijn) zou slechts een andere plek opleveren in dezelfde mensenorde. Het verhaal stopt ook voordat er sprake is van een graf of een begrafenis; composteren zou het doel van broederschap voorbijschieten omdat het ik verdwijnt, en dat is blijkbaar- niet de bedoeling.

Ook Ludovitje en zijn ouders hebben zich door de plaats van hun graf gedistantieerd van hun voorouders op de familiebegraafplaats - en dus van het (bezoedelde?) verleden. Familie en dood grijpen ook hier in elkaar als metaforen voor orde c.q. doorbreking van die orde, terwijl het graf de nieuwe, onschuldige, "prekoloniale" orde bevestigt. De idylle, de uitverkorenheid van deze Afrikaner familie bestaat bij de gratie van haar isolement. Om aan de verwarrende wereld van conflictuerende discoursen en werkelijkheden te ontkomen, koppelt Smith, net als Schreiner, identiteit aan het directe contact tussen mens en Afrika: één waarin Afrika de mens als een moeder omhult en een thuis biedt, alsof het nieuw leven is in plaats van de dood. Van zoiets aards als "compost" is ook hier geen sprake. Een ongebruikelijk, splinternieuw graf in harde rots moet voorkomen dat Ludovitje

\footnotetext{
${ }^{427}$ Schreiner 1989, 279

${ }^{428}$ Idem, 280

${ }^{429}$ Turner 1987, 23

${ }^{430}$ Turner 1987, 27

431 Turner 1987, 28

${ }^{432}$ Turner 1987, 28
} 
opgenomen wordt in een dodenrijk waar voorouders strijden om de oudste rechten en waar de schuld en vervreemding van het leven worden weerspiegeld: doodgaan is een individuele ontsnapping, maar de dode zou, bij de normale gang van zaken, zo weer opgenomen worden in de platvloerse werkelijkheid $^{433}$. Maar de paradox hier is dat onbegraven doden uiteindelijk geen rust is gegund ${ }^{434}$. De poging te ontsnappen aan een door menselijke orde verooraakte vervreemding door de dood te passeren en op te gaan in het eeuwige leven van God of natuur, werkt uiteindelijk averechts; het bevestigt slechts een identiteit als vreemdeling.

$\mathrm{Nu}$ keer ik even terug naar de plaasroman. Belangstelling voor de dood, en voor de verbinding tussen dood en aarde, is ook daar terug te vinden. Grond was, zoals we zagen, de belangrijkste peiler van de plaasroman uit de eerste helft van de twintigste eeuw. In ruimtelijke zin omdat het land van een boer een afgebakend territorium is, en als zodanig het territorium van de culturele identiteit kan verbeelden. Daarnaast heeft de grond een historische betekenis; het biedt houvast in een overigens onbegrensde tijd-ruimte, omdat in die grond de voorouders liggen begraven. Het lineage-denken in ondermeer Van den Heevers romans geeft hier duidelijk blijk van. Dit bewustzijn van de driehoek tussen mens, voorouders en natuur zit veel dichter bij Grays "mulch" als "first form of belonging" ${ }^{435}$. De familiestructuur wordt hier door het sterven (en composteren) niet ontvlucht, maar uitgebreid.

In the myth of natural right elaborated by Van den Heever, the founding fathers pay for the farm in blood sweat and tears, not in money: they hack it out of primeval bush, they defend it against Barbarians, they leave their bones behind in its soil. Inheritance therefore becomes a sacred trust: to alienate the farm means to forsake the bones of the ancestors. ${ }^{436}$

De boer heeft een betekenisvolle opdracht, namelijk de verbinding tot stand brengen tussen individu, natuur en geslacht (lineage). De natuur is in dit geval geen koesterende moeder, maar degene die haar cyclische aard aan haar nakomelingen doorgeeft. Tegelijkertijd is de nakomeling ook Vader van die kringloop, in de zin van Turners "causation as progeneration", afgeleid van de basismetafoor "conditions are parents and results are off-

\footnotetext{
${ }^{433}$ Een dergelijke functie heeft bijvoorbeeld ook de grot in Life \& Times of Michael K. van J.M. Coetzee, waarin Michael K. zich, in een poging aan door anderen opgelegde identiteiten te ontkomen, terugtrekt. Coetzee voert het beeld hier consequent door, door K. tijdens zijn verblijf in de grot in een staat van niet-zijn te brengen: hij is dood, noch levend. Zie ook Hoofdstuk 7.

434 Zie hoofdstuk 4

${ }^{435}$ Gray 1979,154

${ }^{436}$ J.M. Coetzee 1988, 85
} 
spring" ${ }^{373}$. De aarde, Moeder Aarde, zou niet zo vruchtbaar zijn zonder het zwoegen van de mens: zaaien en ploegen resulteert in oogsten, en dat garandeert weer de continuiteit van het leven.

Deur [die] liggame [van die boere], hul siele werk die natuur, werk dit in jaargetye (..) en in hul oë dra hulle die weemoed van lewe wat kom en sterf, want hulle weet dat dit ook met hulle so gaan en dat ook hulle net nou na die donker aarde toe sal buig, en hul kinders weer sal saai en oes.(...) [I]n hul harte huis die donker wete van die lewe wat deur hulle werk, die wete van die krag van die jaargetye wat gaan met onafwendbare sekerheid tot aan die einde van alle skeppingsdade. ${ }^{438}$

In dit "donker wete" spreken de voorvaderen. Eerst als een soort voorouderbewustzijn van de levende protagonisten, in latere romans van Van den Heever als echte geesten die het leven niet kunnen loslaten en willen dat de levenden bereiken wat ze zelf niet konden bereiken. Zo nu en dan staan ze op uit hun graf om de levenden te herinneren aan de plicht die ze hebben om de familie en familietradities in ere te houden (Somer) of zelfs om ze te straffen als ze dit niet doen. De doden hebben een zekere kwaliteit die de levenden missen; Betta, die in Laat Vrugte van Van den Heever in levende lijve welhaast onzichtbaar was voor haar man Sybrand, wordt in haar dode gedaante een factor van betekenis, in staat om de verstarde wereld van haar verbitterde weduwnaar aan het wankelen te brengen.

Maar echt tot inkeer komt Sybrand pas als hij zelf door een beroerte is getroffen. Zijn halfdode staat van zijn (hij is totaal verlamd) gaat gepaard met (bewustwording van) chaos, een chaos die wordt gekoppeld aan het lijk van zijn vrouw Betta. In zijn fantasie ziet hij Betta's gezicht met daarop

'n lag wat verre, vergane dae se liefdesvreugde bind in die smartlike ervaring van die dood. Dit is alles so deureengeweef dat dit vir hom voel of hy binne enkele oomblikke totaal kranksinnig sal word. (..) wat altyd so ver van mekaar gelê het en rustig deur sy verstand geskei is, verskyn hier so dig by mekaar dat die hele lewe, die duister beweging wat veroorsaak word deur die ontmoeting van ruimte en tyd, hom heeltemaal oorweldig. (..) Hy sak almeer af in die afgrond onder waar die lewe onverdeeld lê, 'n groot, verskriklike eenheid; maar die geheim daarvan kan hy aan geen mens sê nie, want hy is nou stom; die geheim is nou veilig. ${ }^{439}$

\footnotetext{
437 Turner 1987,28

${ }^{438}$ Van den Heever 1986, 80

${ }^{439}$ Laat Vrugte 212
} 
Dat deze crisis plaatsvindt terwijl hij zelf tussen dood en leven inzweeft, is veelzeggend. Het geeft hem een verruimd bewustzijn van waaruit hij de zaken anders gaat bekijken: door andermans ogen krijgt hij inzicht in zijn eigen disfunctioneren. Een van zijn ervaringen van "verskriklike eenheid" is dat hij merkt hoe het is om afhankelijk te zijn van zijn nieuwe vrouw, een berekenende geldwolf die nog erger is dan hij vroeger zelf was. Hij ervaart dus hoe het is om zijn eigen slachtoffer te zijn, en voelt zich als: "'n slaaf, 'n bywoner, 'n beledigde op sy eie plaas, (..) 'n gevangene, (..) 'n magtelose kind." ${ }^{40}$ Een volledige transformatie zal dit (nu) niet opleveren; uiteindelijk wordt de chaos bezworen door aan een paternalistisch ideaal vast te houden: de verantwoordelijkheid voor het waarborgen van continuiteit ${ }^{441}$. Baasskap, beseft hij, is niet vanzelfsprekend als hij zijn verantwoordelijkheden als pater familias niet neemt. Vanuit die wetenschap wacht hij met smart op de terugkomst van zijn zoon, zoals hij vroeger "gewag het op die koms van die lente, wanneer hy die grond kon bewerk en die saad aan die aarde kon toevertrou." "442 Hennings uiteindelijke komst bevestigt de driehoek tussen mens en land en lineage; pas als hij in zijn zoon de kracht herkent die hij vroeger zelf ook had, kan hij met een gerust hart sterven. Mannelijke kracht en vrouwelijke vruchtbaarheid moeten de altijd dreigende chaos bezweren. Identiteit is niet gestoeld op bezit an sich, maar op innerlijke waarden en een morele en sociale orde, waarin niet persoonlijk gewin, maar verantwoordelijkheid en verbondenheid een belangrijke rol spelen. Maar zoals eerder bleek, vertoont die Afrikaner orde belangrijke overlappingen met die van de Afrikanen die in Laat vrugte zo zorgvuldig tot vreemdeling worden bestempeld. Zouden "in die afgrond onder waar die lewe onverdeeld lê," in de chaos van "'n groot, verskriklike eenheid" die Oom-Sybrand vanuit zijn halfdode staat van zijn waarneemt, dan niet toch alle voorouders samenkomen? We zullen het niet weten, want "die geheim is nou veilig." ${ }^{\prime 43}$

Ook in Engelsetalige literatuur keren protagonisten, om zichzelf een plek toe te eigenen in Afrika, om orde te scheppen, zich uiteindelijk ook tot de dood, in dit geval een te hoog gegrepen dood met een averechts effect: een eenwording met "Africa's majestic silence", met de eindeloze vlakte onder een eindeloze hemel in een eindeloze tijdspanne van Schreiner, de onverwoestbare claystone van Smith, de eeuwige kringloop van Gordimers vlei (waarover later meer). Deze vebeeldingen van de dood overschreeuwen niet alleen de Zuid-Afrikaanse werkelijkheid, maar ook de Afrikaanse voorouders en een daaraan gekoppeld oncontroleerbaar discours - Van den Heever doet dat door ze met eigen lineages te overschrijven, Smith en Schreiner door hun territorium, het territorium van de dood, te vermijden.

\footnotetext{
${ }^{440}$ Laat Vrugte 214

${ }^{441}$ Zie ook hoofdstuk 2.

${ }^{442}$ Laat Vrugte 218

${ }^{443}$ Laat Vrugte 212
} 
De koppeling van dood aan identiteit is uiteindelijk de achillespees van de blanke identiteit in Zuid-Afrika. Wie zijn, kun je je afvragen, "the walking dead that stalk the pages of [white South African] fiction?" ${ }^{44}$. Wie bevindt zich in Van den Heevers geheimzinnige "verskriklike eenheid"? De veelgebruikte metafoor van de dood maakt deze teksten ambivalent, geeft vrij baan aan allerlei interpretaties, allerlei ruimtelijke en kosmologische kaders. En dat is, zoals in hoofdstuk 4 zal blijken, niet toevallig.

${ }^{444}$ Gray 1979,154 


\author{
Ontkenning 1 \\ (..) \\ Die dood is in elk geval nie \\ die dood nie \\ dis net ' $n$ ontkenning van \\ die lewe wat dit nie is nie (..)
}

Fransi Philips

\title{
4
}

\section{De dood als pluriforme metafoor: orde, chaos, das unheimliche}

\subsection{DOOD EN RUIMTE IN "UNTO DUST"}

Een schoolvoorbeeld van hoe dood als middel gebruikt kan worden om identiteit tegelijkertijd te begrenzen en te ondergraven, is te vinden in het verhaal "Unto Dust" van Herman Charles Bosman. Bosman vestigde zich in de jaren twintig als onderwijzer op het platteland van Noordwest-Transvaal. Geïnspireerd door zijn omgeving schreef hij korte, humoristische verhalen en publiceerde die in de jaren dertig en veertig in kranten en tijdschriften. Zijn verhalen werden graag gelezen, maar door critici werd hij lange tijd niet serieus genomen. Pas in 1947 werd zijn eerste verhalenbundel, Mafeking road, gepubliceerd; het meeste van zijn werk verscheen pas na zijn dood in 1951. Lionel Abrahams stelde in 1963 de bundel Unto dust samen. De meeste verhalen hieruit waren al in de jaren veertig in diverse tijdschriften gepubliceerd, het titelverhaal als een van de laatste.

Volgens Chapman valt uit Bosmans werk af te lezen dat hij in de harten van blanke Zuid-Afrikanen angst voor wonen in Afrika ziet; "supremacy needs to be enforced, therefore, by laws that make a mockery of human nature" ${ }^{44}$. "Unto dust" bevestigt dit beeld. In dit verhaal spot Bosman met de mythische betekenis die aan de voorouders gegeven wordt en met de segregatiepolitiek van de jaren veertig. Maar het gaat dieper dan dat: het spot ook met de angst voor het onbekende en het onwillekeurige ontzag voor de omringende Afrikaanse werkelijkheid.

"Unto Dust" begint met filosofische uitlatingen over de dood: als jonge mensen doodgaan heeft dat altijd iets romantisch, vindt verteller Oom Schalk Lourens ${ }^{446}$, maar voor oude mensen die sterven is het heel belang-

\footnotetext{
${ }^{445}$ Chapman 1996, 192

${ }^{446}$ De externe verteller wordt in het verhaal niet bij name genoemd, maar is volgens critici een late versie van Oom Schalk Lourens. (Gray 1989, Plomer 1963)
} 
rijk hoe ze op hun leven terugkijken. Mensen die bang zijn voor de dood, voelen zich schuldig over hun leven. Zelf zweefde hij ooit in een aanval van malaria op de grens van leven en dood. In zijn koortsdromen

it seemed to me (..) that the whole world was a burial ground. I thought it was the earth itself that was a graveyard, and not just those little fenced-in bits of land dotted with tombstones, in the shade of a western-province oaktree or by the side of a Transvaal koppie. This was a nightmare that worried me a great deal, and so I was very glad, when I recovered from the fever, to think that we Boers had properly marked out places on our farm for white people to be laid to rest in, in a civilised Christian way, instead of having to be buried just anyhow, along with a dead wild cat, maybe, or a Bushman with a claypot, and things.

Als Oom Schalk later deze overpeinzingen deelt met Stoffel Oosthuizen, is die het met hem eens dat sommige zaken strikt gescheiden moeten blijven en dat het onzin is dat "everyone is made kin by death". Ter illustratie vertelt Stoffel zijn eigen verhaal:

Tijdens een "bygone Transvaal Kafir war" loopt een Afrikaner commando in een hinderlaag. Stoffel en zijn vrienden zien hoe Hans Welman wordt doodgestoken door een zwarte man met een hond. Als de man ook nog Hans' kleren begint uit te trekken wordt Stoffel zo boos dat hij hem met gevaar voor eigen leven doodschiet. De Boeren moeten vluchten en zien pas enkele maanden later kans om de beenderen van Hans op te halen. Tot hun verbazing is de hond nog steeds ter plaatse, trouw aan zijn baas.

Het scheiden van de stoffelijke resten van de zwarte en de blanke man blijkt een hele klus, want de beenderen zijn allemaal even wit en al het vlees is even zwart geblakerd in de zon. "“Afterwards" vertelt Stoffel,

'several other men who were there that day told me that they had the same feelings of suppressed anger that I did. They wanted somebody - just once - to make a remark such as 'in death they were not divided'. Then you would have seen an outburst all right.'

Uiteindelijk wordt "Welman" keurig in een christelijk graf begraven. Tot drie maal toe wordt er in dit verhaal een bewust, gewenst, gecreëerd beeld van de werkelijkheid doorkruist door een ander, onbewust, ongecontroleerd beeld. Ten eerste: Oom Schalks idee van een veilige dood op een beschut kerkhof wordt doorbroken als de koorts zijn ratio uitschakelt waardoor zijn (ongecontroleerde) angst om begraven te worden tussen bosjesmannen en wilde katten de ruimte krijgt. Ten tweede: Stoffel wil een verhaal vertellen dat moet illustreren dat zwart en blank fundamenteel 
verschillen. Zijn verhaal had echter "features as strange," zoals Oom Schalk tot twee keer toe zegt, "as the African veld" en bewijst onwillekeurig het tegendeel. Ten derde: de vrienden van Hans Welman proberen zo goed en kwaad als dat gaat de werkelijkheid naar hun hand te zetten en geven een hoopje beenderen een keurige Boerenbegrafenis. Maar Stoffel vertelt en passant dat hij ooit bij het graf van Hans Welman de "yellow kafir dog" weer tegen het lijf is gelopen.

Ruimtelijke analyses van droom versus werkelijkheid van Oom Schalk en van het verhaal van Stoffel Oosthuizen geven een vergelijkbaar beeld. Er is maar één goede plek, is Oom Schalks conclusie, om begraven te worden: de begraafplaats op een boerderij. Deze krijgt de woorden little, fenced-in, tombstones, civilized, white, en Christian mee, en de beschutting (schaduw) van een boom of een kopje. Wie daarbuiten wordt begraven, ligt in een onbegrensde ruimte, samen met alles wat niet-blank, onbeschaafd, nietchristelijk en zelfs niet menselijk is.

In het verhaal van Stoffel Oosthuizen komen dezelfde elementen terug. De dood van Hans Welman en zijn tegenstander is niet alleen een weerspiegeling van Oom Schalks nachtmerrie, maar laat ook zien waarom het zo angstaanjagend is: buiten de beschutting van het eigen territorium boet Welmans blanke huid, zijn geloof, en zijn cultuur in aan superioriteit en betekenis. Immers: zwart heerst er over blank, 'onbeschaafd' heerst er over 'beschaafd' en natuur heerst er over cultuur. Geen wonder dat Welmans weduwe de resten van haar man weer binnenboord wil halen, waar ze een naam krijgen en een plek van betekenis in een culturele orde.

Voor Welmans weduwe, en voor ieder ander die niet beter wist, was de hele kwestie nu opgelost. Maar voor de mensen die erbij waren, was er een groter probleem dan het verloren gaan van Welmans stoffelijke resten in het veld, namelijk het begraven van de verkeerde beenderen op de verkeerde plek: de strikte scheiding tussen een zwart en een wit territorium blijkt (na de dood) niet te handhaven. En dus bracht het verhaal Oom Schalk "no peace in my broodings after that attack of malaria". Zijn angst dat er geen afgegrensde, blanke, christelijke, geciviliseerde plek voor hem was om begraven te worden, was erdoor bevestigd; de grenzen bleken een idee-fixe. In dit hoofdstuk zal blijken waarom dat zo'n existentiële angst oproept, en hoe Bosman die angst koppelt aan de segregatiepolitiek van de jaren veertig.

\subsection{DE CONSOLIDERENDE DOOD}

De dood wordt in het verhaal van Bosman gebruikt als ambigu en meervoudig metafoor: als gelijkmaker, als grensoverschrijder én als bewaker van de orde. In een notendop geeft dit weer wat in dit hoofdstuk verder zal 
worden uitgewerkt: namelijk dat de dood een brandpunt is waar de ZuidAfrikaanse geschiedenis, haar geografische werkelijkheid, en de literaire verbeelding van die werkelijkheid bij elkaar komen. De dood speelt een rol bij de constructie van een collectief verleden en bij de constructie, of deconstructie, van het heden, maar ook kan de dood -of liever, de overgang tussen dood en leven- de (literaire) representatie zijn van het overschrijden van een existentiële of epistemologische grens - met name de grens tussen Wij en Zij, of Ik en Ander.

Welke betekenis de dood heeft binnen een religieuze traditie, zegt iets over haar symbolische of metaforische lading - en van die lading wordt in de literatuur gebruik gemaakt. Als metafoor verwijst de dood voortdurend naar andere metaforen, en dat geheel aan relaties bepaalt haar betekenis ${ }^{447}$. Dergelijke betekenissen zijn overigens geenszins statisch. Een zekere continuiteit met het verleden zal er natuurlijk wel zijn, maar iedere religieuze traditie, inclusief de metaforen die daarin gebruikt worden, past zich aan de veranderende historische omstandigheden aan. ${ }^{448}$ Toch bestaan dergelijke tradities bij de gratie van hun imago van onvergankelijkheid en absolute betekenis. Dit kan, aldus Jennifer Hockey in Experiences of death (1990), doordat er in rituelen een verbinding gemaakt wordt met de dagelijkse, materiële werkelijkheid. "[T]hrough the appropriation of the material of every day life (...) a society's fluid and possibly inconsistent metaphoric system [can] come to be experienced as an unquestionable representation of wholeness and order." ${ }^{449}$ Werkelijkheid en de representatie van die werkelijkheid beïnvloeden elkaar voortdurend.

\subsubsection{Continuïteit als bezwering van de chaos}

In verschillende antropologische studies blijkt de dood een weerspiegeling te zijn van het leven. Of zoals Hockey het formuleert:

The issues of life can be seen metaphorically to give form to death, whilst the event of death is similarly elaborated in such a way as to affirm the validity and permanence of the issues of life ${ }^{450}$.

Net als geschiedenis is de dood bij uitstek manipuleerbaar. Eenmaal dood is iemand niet meer, of minder nog dan levend, van zichzelf. Hij is onderdeel van een symbolisch systeem. Enerzijds is de gestorven mens tijdloos en daarmee een bevestiging voor het tijdloze van dat systeem, anderzijds is er een vergankelijk object, een lijk, dat verwijst naar de tijdelijkheid van het

\footnotetext{
${ }^{447}$ Bultinck 1998, 12

${ }^{448}$ Chidester 1992, 1

${ }^{449}$ Hockey 1990, 85

${ }^{450}$ Hockey $1990,81 / 2$
} 
leven en naar het lot van de overlevenden. Dat lijk vraagt om veel handelingen in korte tijd: er moet een graf worden gegraven, op een bepaalde plek, met een bepaalde markering; familie en vrienden moeten afscheid nemen. De rituelen die dit soort handelingen begeleiden geven betekenis aan de dood - en spiegelen wat belangrijk is in het leven, zowel in concrete als abstracte zin.

It is bodily or in-the-world experience which can be seen as the basis of metaphors through which death is encountered - for example the flowing quality of blood, the body's visible and invisible surfaces; and the historical and geographical circumstances of a community. Ritual can be seen as a literal presentation of the set of metaphors through which death is encountered in a particular society. Within the framing of ritual time and space, everyday objects and familiar spatial and temporal arrangements are re-ordered, thereby evoking participants' most fundamental physical and emotional experience and bringing it to line with the most abstract cosmological theorising. 451

Tijdens onderzoek in Oeganda ontdekte John Middleton dat de morele orde die geldt voor de levenden (binnen $=$ geordend $=$ goed; buiten $=$ chaotisch $=$ niet goed), terug te vinden is in de opvattingen over een "goede" en een "slechte" dood. De beste dood is een aangekondigde dood waarbij de stervende in bed ligt, met een heldere geest, omringd door geliefden die luisteren naar zijn of haar laatste woorden en begeleid door een strak geordend geheel van ceremoniën. De slechtste dood is een plotselinge dood ver van huis, waar de juiste rituelen niet worden uitgevoerd, het lijk niet op de juiste plek wordt begraven, en de geest de weg niet kan vinden naar zijn eigen stek in het dodenrijk. ${ }^{452}$

De plek waar de dode wordt begraven is daarbij een belangrijke, tastbare link tussen historische, geografische, economische en rituele tijd en ruimte. In bovenstaand geval werden de doden begraven in braakliggend land tussen graasland en bebouwde velden; een niemandsland tussen binnen en buiten. Na de begrafenis werd het graf even gemarkeerd, maar zodra het land voor landbouw in gebruik genomen werd, werd het omgeploegd en vergeten. Zodra de dode in de orde van het hiernamaals was opgenomen, was hij/zij niet meer van belang voor de levenden. Alleen als hij een belangrijke figuur in het dorp (elder) was, werd er een boom op het graf geplant. De elder was, als middelpunt van een patriarchaal netwerk dat zich in beide rijken uitstrekte, degene die de band tussen levenden en doden

\footnotetext{
${ }^{451}$ Hockey 1990, 89

${ }^{452}$ Middleton 1969
} 
smeedt. Zou hij na zijn dood verdwijnen, dan zou er een ordebedreigend gat ontstaan in de sociale structuur. ${ }^{453}$

Ook in Europa was (en is) de begraafplaats veelzeggend, en de veranderingen die zich hier in de loop der tijd hebben voorgedaan weerspiegelen de veranderende machtstructuren ${ }^{454}$. Zowel Germanen als Romeinen zagen de doden vooral als bedreigend, en hun dodencultus was erop gericht hen te beletten terug te keren naar het land der levenden. Begraafplaatsen bevonden zich dan ook op respectabele afstand van dorp of stad. In de vroege middeleeuwen werd dit in heel Europa radicaal anders. In een samenleving waar de kerk als toegangspoort naar de hemel de dienst uitmaakte, werd de heilige grond van de kerk het centrum van zowel doden als levenden: kerkhof en handelscentrum. Het individuele lot van de doden was onbelangrijk; de begraafplaatsen waren overvol en de lijken werden vaak al weer opgegraven voor ze helemaal vergaan waren. De omwonende elite die zich om het handelscentrum had verzameld, stelde hier ten slotte paal en perk aan en luidde daarmee een nieuwe periode in waarin individueel, overerfbaar eigendom centraal zou staan: doden gingen respect verdienen en kregen een graf met een naam, want zij waren de garantie op grondrechten en bezit. Ook nu nog zijn individuele graven slechts van belang als individueel grondbezit de belangrijkste verdeelsleutel van een samenleving is. Op het Portugese platteland is alleen het symbolische familiegraf in de kerk belangrijk, dat onder de verantwoordelijkheid valt van de erfgenamen van de boerenfamilie. De rituelen rond deze graven maken duidelijk wie wel en niet aanspraak kan maken op collectieve rechten. "Masses said for the collective dead are devoted to all former owners or none, but excluding those who have moved out. In this way the sepulchre represents the uninterrupted integrity of the basic unit of rural society and economy." "455 Ook in Bolivia en Madagascar staan graftomben symbool voor "the continuity of the property-holding kinship group". ${ }^{456}$

Hoewel de representatie van de dood en de plek die de dode krijgt onder de levenden dus een bevestiging is van het sociale systeem en het dominante wereldbeeld, is er ook vaak sprake van inconsistenties in opvattingen over de dood. Regisseurs zijn nooit almachtig, het systeem is nooit waterdicht. ${ }^{457}$ Sterker nog: dubbelzinnigheid, inconsistentie en ongrijpbaarheid blijken bij nadere beschouwing tot de belangrijkste kenmerken van de dood te horen. De dood is een belangrijk ijkpunt van de geordende werkelijkheid, juist omdát het de structuur van het hier en nu aan het wankelen brengt. Het is een moment van potentiële chaos. Dit speelt op verschillende niveaus. Heel praktisch: een bovengronds lijk is een gevaar voor de gezondheid en het gat

\footnotetext{
${ }^{453}$ Middleton 1982, 137 e.v.

${ }^{454}$ De komende twee alinea's zijn gebaseerd op Ariès 1975, 25 e.v. en Barley 1996, 139 e.v.

${ }^{455}$ Bloch \& Parry 1982, 34

${ }^{456}$ Bloch \& Parry 1982, 34

${ }^{457}$ Bloch \& Parry 1982, 15
} 
dat in de sociale structuur ontstaat doordat iemand wegvalt, kan grote veranderingen tot gevolg hebben. In de rituelen die de dood begeleiden wordt alles gedaan om de (hygiënische) orde te handhaven en zonodig te herstellen. Alle emoties en verschuivende machtsverhoudingen die het gevolg zijn van het wegvallen van het individu moeten in goede banen worden geleid. Maar op een symbolisch niveau is de betekenis van het lijk en dus van het ritueel is nog veel groter: met name in de periode tussen sterven en begraven in, maar soms ook langer, is de gestorvene een bedreiging van de symbolische orde. Zo wordt de dood een kruispunt van verandering en chaos aan de ene kant en tijdloosheid en onveranderlijkheid aan de andere, en raakt daarmee aan een heel scala van betekenissen:

In ritual processes associated with death, at a time of potential chaos and incompleteness, the symbolic manipulation of objects, space and indeed the corpse itself, can serve to transform the present experience of confusion and loss by placing it within the context of a set of meanings which resonate throughout the entire cultural system ${ }^{458}$.

\subsubsection{Ordening door ruimtelijke metaforen}

Het bovenstaande verklaart al voor een deel waarom dood en ruimte als koppel zo belangrijk zijn bij de verbeelding van een culturele of sociale identiteit. De dood weerspiegelt de sociale orde en wordt door rituelen voortdurend in verband gebracht met de concrete, dus ook ruimtelijke werkelijkheid. Maar er is meer. De beelden die gebruikt worden om dood en sterven begrijpelijk te maken, zijn vaak ook heel ruimtelijk. Over het algemeen wordt sterven beschouwd als het overschrijden van een grens, als een beweging van de ene ruimte naar de andere. Arnold Van Gennep, in zijn beroemde boek Les rites de passage (1909) trok al de vergelijking tussen transformaties als geboorte en sterven en het overschrijden van geografische grenzen. Voor Van Gennep zijn deze grensoverschrijdingen in wezen hetzelfde omdat ze beide magisch van aard zijn ${ }^{45}$. Van oudsher gaan grensoverschrijdingen gepaard met ceremoniële handelingen (offers) en voorwerpen (amuletten in deuropeningen, kapelletjes bij bergpassen), die Van Gennep allemaal rekent tot de rites de passage. In feite, concludeert hij, is het hele leven een aaneenschakeling van rites de passage tussen verschillende levensfasen: "Pour les groupes, comme pour les individus, vivre c'est sans cesse se désagréger et se reconstituer, changer d'état et de

\footnotetext{
${ }^{458}$ Hockey 1990, 89

${ }^{459}$ Hij stelt dat in de oude Chinese, Griekse en Romeinse rijken "each plot of ground was sacred for its inhabitants and owners (...) [T] he prohibition against entering a given territory is therefore intrinsically magico-religious". (1960, 16).
} 
forme, mourir et renaître. C'est agir et plus s'arrêter, s'attendre et se seposer, pour recommencer ensuite à agir, mais autrement" ${ }^{\prime 460}$.

Het meest invloedrijk is zijn theorie echter geweest bij de bestudering van sociale en fysieke grensoverschrijdingen: geboorte, volwassen worden, huwelijk, dood. Doel van een rite de passage is "to effect the transition from one state to another," waarbij het individu beschermd wordt tegen de gevaren die samenhangen met de "sacredness" van het geheel ${ }^{461}$. Van Gennep deelde de riten op in drie fasen: een fase van separatie, waarin het individu afgescheiden wordt van zijn vorige staat van zijn; een liminale of marginale fase, gekarakteriseerd door ambiguïteit en gevaar, waarin het individu zich in een niemandsland bevindt tussen de ene en de andere staat; en een integratiefase, waarbij het individu wordt binnengeleid in zijn of haar nieuwe bestaan. Deze vorm is universeel: "ethnographic evidence has demonstrated over and over again in different parts of the world that this tripartide structure was to be found in all rituals of transition." ${ }^{462}$ Niet alleen de structuur, maar ook de symbolen die gebruikt worden bij deze rituelen zijn opvallend vaak inwisselbaar, zowel intercultureel als tussen de verschillende levensfasen ${ }^{463}$. Zo kan zowel het hoofd van een pasgeboren baby als van een pasgestorven vrouw kan worden kaalgeschoren, en is wassen, besnijdenis, het oversteken van een rivier en kaalscheren van het hoofd bijna overal onderdeel van separatie, terwijl balsemen, eten en aankleden universeel tot de integratiefase hoort. ${ }^{464}$

Maar een rite de passage is niet alleen een ritueel, het is ook een verhaal. De drievormigheid "dramatizes the transition by creating a margin, a boundary between the two states concerned, and transferring the individual across from one to another" ${ }^{\prime 465}$. Deze reis van leven naar dood bergt zowel op concreet als symbolisch niveau risico's in zich voor zowel stervende als achterblijvers, en dient dus zorgvuldig voorbereid en geregisseerd te worden. Een Zulu sjamaan legt uit:

'Doing the things that pertain to a funeral is like accompanying a man on the way. If you go with the man, especially if he is going through an unknown land, then you are helping him to find the way. So this is done so that the man may find his way, being on the journey to that place. ${ }^{466}$

\footnotetext{
${ }^{460}$ Van Gennep 1909, 272

${ }^{461}$ La Fontaine 1986, 27

${ }^{462}$ idem

${ }^{463}$ Van Gennep 1909, 272 e.v.; La Fontaine 1986, 25

${ }^{464}$ La Fontaine 1986, 25

${ }^{465}$ La Fontaine 1986, 25

${ }^{466}$ Berglund 1976, 379
} 
Dit regisseren van een fictieve, of in elk geval voor derden niet-waarneembare reis is een vorm van "vertellen". Er bestaat volgens Langdon Elsbree een homologische relatie tussen ritueel en verhaal, omdat beide geworteld zijn in dezelfde "primary activities of the brain. (....) [They are] among the primary means we employ to structure ourselves and our societies and to generate the semantic systems which go beyond both self and society" ${ }^{\prime 467}$. Ook Clifford Geertz zag het ritueel als een expressie van culturele motieven in de vorm van een tekst ${ }^{468}$. Dit betekent dat rituelen in een intertekstuele relatie kunnen staan tot andere teksten. In latere hoofdstukken zal blijken dat rites de passage inderdaad als intertekst fungeren in romans van ondermeer Nadine Gordimer en Anna Louw.

Maar er is nog een andere relatie tussen ritueel en literatuur. De hierboven genoemde vaste vorm en elementen van de rite de passage geeft het de structurerende kracht van een metafoor. De essentie van een metafoor is volgens Lakoff \& Johnson "understanding and experiencing one kind of thing in terms of another" ${ }^{\prime 469}$. Dat metaforen volgens de auteurs zo invloedrijk zijn in het dagelijks leven, komt omdat ze niet onafhankelijk functioneren, maar bijna altijd naar andere metaforen verwijzen. Dood, geboorte en huwelijk, voorgesteld als passage, grensoverschrijding, horen tot de "orientational metaphors", metaforen die op grond van ruimtelijke structuren "[organize] a whole system of concepts with respect to another" Vooral de dood, in haar hoedanigheid van ultieme grens(overschrijding), verwijst naar alle andere grens(overschrijdingen) ${ }^{471}$, maar met name naar die grenzen die bepalend zijn voor de ervaring en vormgeving van het hier en nu. De grens an sich is een van de belangrijkste "cultural universals" van het mens-zijn, "separating the living from the dead, settled peoples from nomadic ones, the town from the plains; it may be a state frontier, or a social, national, confessional, or any other kind of frontier"472. Aan die ruimtelijke tweedeling (binnen en buiten) worden in elk sociaal-politiekreligieus discours reeksen tegenstellingen gekoppeld; die gedeeltelijk universeel zijn. Binnen is bijna altijd "eigen", "goed", "veilig", "geordend" en "onveranderlijk"; buiten is bijna altijd "vreemd", "kwaad", "gevaarlijk", "chaotisch" en "veranderlijk" Mar7. Mar iedere verdere aanvulling van deze reeksen is afhankelijk van plaats en tijd.

Dat de dood ambivalenties in deze reeksen kan aanwijzen, blijkt bijvoorbeeld uit onderzoek naar Karanga vooroudergeesten. Zij zijn verdeeld in goede en kwade geesten. De laatsten, shaves genoemd, "like outcasts roam

\footnotetext{
${ }^{467}$ Elsbree 1991, 1

${ }^{468}$ Clifford Geertz, The interpretation of cultures. New York, Basic Books, 1973

${ }^{469}$ Lakoff \& Johnson 1980, 5

${ }^{470}$ Bultinck 1998, 12

${ }^{471}$ Okely 1983, 230

${ }^{472}$ Yuri Lotman, Universe of the mind. A semiotic theorie of culture,1990:131

${ }^{473}$ Idem
} 
about the land without water." ${ }^{474}$. Deze shaves zijn de geesten van mensen die niet zijn "thuisgebracht" door de kugadzira-ceremonie, en symboliseren de vreemdeling. Het bijzondere van deze shaves is dat ze weliswaar worden beschouwd als negatief, maar desalniettemin in ceremonies positieve invloed blijken uit te oefenen op allerlei belangrijke aspecten van de Karanga-cultuur zoals dans, jacht, muziek en healing. Dit komt voort uit een besef dat men de Ander nodig heeft om de eigen cultuur vorm te geven. "The alien -symbolised in the shave- is a compelling necessity for the preservation of the incestuous 'weltbild'. Of this the Karanga are conscious" ${ }^{475}$. Daarmee lijkt de keten vreemd-slecht-verandering te worden doorbroken. Toch is dat niet helemaal waar. In feite functioneren de shaves hier op een reflectief meta-niveau: de grens tussen leven en dood verwijst naar de grens tussen Ik en Ander, tussen eigen en vreemd. Tegelijkertijd probeert men ook hier het onbekende onder controle te houden, alleen nu niet door het buiten de deur te houden, maar door het te verwelkomen als functioneel en het een plek te geven binnen de eigen cultuur - waarmee het vreemde eigenlijk al weer "eigen" is geworden. Een dergelijke ambiguïteit is ook terug te vinden in mythen en verhalen van Zuid-Afrikaanse Khoisan, waarover meer in een later hoofdstuk.

\subsection{DE REIS DOOR HET DUISTER}

Ondanks alle diversiteit geldt dat de dood bijna overal -zij het niet uitsluitend- gebruikt wordt als "orientational metaphor", die zowel verwijst naar een in principe statische ruimteordening, als naar een reis, dat wil zeggen, een verandering van ruimte. In de romans die ik zal bespreken zal blijken dat van deze dubbelzinnigheid gebruik wordt gemaakt om de tegenstrijdige krachten waar Zuid-Afrika in de jaren zeventig in verstrikt raakte, te verbeelden. Maar eerst wil ik aan de hand van twee van de belangrijkste thema's in de Zuid-Afrikaanse geschiedenis: landrechten en migratie, laten zien hoe de dood onderdeel wordt van een "set of meanings which resonate throughout the entire cultural system" ${ }^{476}$. En hoe in tijden van crisis en verandering die "set of meanings" meer de destabiliserende dan de stabilerende kanten van de dood benadrukt.

\subsubsection{Kolonisatie als rite de passage}

In het Zuid-Afrikaanse verleden is op verschillende manieren grond toegeeigend, en grondgebruik of grondbezit gelegitimeerd. Een van die manieren

\footnotetext{
${ }^{474}$ Aschwanden 1987, 30

${ }^{475}$ Aschwanden 1987, 157/8

${ }^{476}$ Hockey 1990, 89
} 
is het schrijven of doorvertellen van een "collective memory" of geschiedenis. Voor de constructie van een sociaal en/of cultureel geheugen zijn, zoals gezegd, onveranderlijke elementen nodig (huizen, steden, landschappen), plus een waarneming van die geografische werkelijkheid die gestuurd wordt door verhalen, genealogieën en monumenten. Met deze hulpmiddelen kan het collectieve geheugen dienen ter bescherming van de sociale orde of culturele, politieke en geografische eenheid, maar ook als legitimatie voor de uitbreiding van een territorium. Zo beschrijft Gerdien Jonker in Topografie van de herinnering (1993) hoe in het oude Mesopotamië de wereld verdeeld werd in hier en daar, met daaraan gekoppeld de begrippen "eigen" en "vreemd". Dit wereldbeeld leverde landkaarten op waarop alles wat vreemd was buiten de randen van de geordende wereld werd geplaatst en daar in lege plekken verdween, zelfs als er in werkelijkheid allang kennis vergaard was over die gebieden. Volgens Jonker had dit te maken met gebiedsuitbreiding en de dreiging die uitging van deze op handen zijnde veranderingen: "De wereld buiten de grenzen was in beweging en deed Mesopotamië een vesting worden. Het wapen om anderen buiten de deur te houden was de herinnering (...) Wat in de herinnering geen plaats had gekregen, bestond niet." ${ }^{\prime 477}$ Ook in verhalen en legendes komen die blinde vlekken terug. Zo wordt de reis van Sargon, de koning onder wie het oude Mesopotamië zich aanzienlijk uitbreidde,

voorgesteld als een 'reis door het duister', gevaarlijk en vol angsten, ja, maar ook een terrein waar de reiziger, door louter 'duisternis' gehinderd, geen details meer waarneemt. De ongetwijfeld aanwezige praktische kennis over die landen (...) wordt in al deze teksten nauwelijks tot uitdrukking gebracht. Wat ze wel tot uitdrukking brengen, is [dat] (...) de historische Sargon de legitimatie [vormde] voor de enig mogelijke omgangsvorm die nieuw-assyrische vorsten voor hun buurlanden in petto hadden: die van aanval, verovering en deportaties. De herinnering bood de coulissen waartegen iedere nieuwe hoofdrolspeler (..) zichzelf in scène zette. In feite maakte men in gedachten steeds opnieuw de mythische reis door 'het vijandige duistere land' ongehinderd door aan de ervaring ontsprongen details die een gedifferentieerde omgang zouden kunnen afdwingen. ${ }^{478}$

Bij culturen die aan verandering onderhevig zijn, aan wiens grenzen wordt getornd of die strijden voor hun onafhankelijkheid, neemt op allerlei vlakken de fascinatie voor het eigen verleden toe ${ }^{479}$. Er vindt een dialectisch proces plaats tussen uitbreiding en terugtrekking, nieuwsgierigheid en

\footnotetext{
${ }^{477}$ Jonker 1993, 64

${ }^{478}$ Jonker 1993, 68

${ }^{479}$ Basnett 1993, 14
} 
afscherming, innovatie en conservatisme. Dit was ook het geval in Europa in de $18^{\mathrm{e}}$ en $19^{\mathrm{e}}$ eeuw, een tijd waarin de wereld dankzij de grote zeereizen en het kolonialisme radicaal groter werd, en overal in Europa het nationalisme de kop op stak. Net als Sargon, reisden Europese handelaren en kolonisten door "duister gebied" dat hen -en het thuisfront- fascineerde en afkeer inboezemde tegelijkertijd ${ }^{480}$. De mythische duisternis uit de tijd van Sargon doet sterk denken aan het beeld van Afrika dat in Europa lange tijd dominant geweest is. Het boek dat "has become the chief (..) meeting ground for opposing schools of thought among literary critics, cultural anthropologists, and historians dealing with the difficult and often tragic relations between Europeans and Africans at (and even since) the beginning of the twentieth century", is Heart of Darkness van Joseph Conrad ${ }^{481}$. Hierin lonken de lege (witte) plekken op de kaart van Afrika als verrukkelijke geheimen tot een eerste kennismaking ze heeft veranderd in een "oord van duisternis" $"$ "82.

Ontsluiering van het onbekende leidt lang niet altijd tot kennis, maar wel tot ordening - in dit geval in licht en donker: weten en onwetendheid zijn beide licht, maar het onbekende, dat wil zeggen het vermoeden van iets anders, verdwijnt in een angstaanjagende duisternis ${ }^{483}$. Een meer gedetailleerde ordening moest de duisternis vervolgens hanteerbaar maken. Zoals ontdekkingsreizigers in de zeventiende eeuw onbekende dieren, planten en mensen in rassen en families sorteerden, zo werd door koloniaal bestuur de sociale en politieke werkelijkheid zo snel mogelijk in bekende categorieën ondergebracht. Crais betoogt dat de nauwkeurigheid waarmee in de $19^{\mathrm{e}}$ en begin $20^{\text {ste }}$ eeuw Transkei door het koloniaal bestuur in kaart werd gebracht, eerst door het tekenen van kaarten en het trekken van grenzen, en later door het laten uitvoeren van tellingen, niet zozeer bedoeld was om de werkelijkheid te leren kennen alswel om de chaos te bezweren. "To count was to know. (..) As with mapping, statistics were a colonial operation of the margin, an exercise most pronounced where colonial control was weakest." "484 Het uiteindelijke doel was controle te verkrijgen door de bestaande machtstructuren te ondermijnen: "[The] data did not so much reflect social reality as provide the basis for social transformation" ${ }^{\prime 485}$.

Desalniettemin vormde het contact met vreemde culturen een intellectuele uitdaging die mede oorzaak geweest is van de Verlichting, een cognitieve

\footnotetext{
${ }^{480}$ Hier komen een metonymische betekenis van duisternis als het kwade (gebaseerd op "convential cultural associations"), en de metaforische betekenis van duisternis als dat wat we niet kunnen zien, ofte wel: waar we niets van weten, gebaseerd op de basismetafoor: "begrijpen is zien", samen: "frequently, both senses are used to reinforce each other, since the unknown is often feared and seen as evil. (Turner 1987: 17,21)

${ }^{481}$ Firchow 2000, 3

${ }^{482}$ Conrad 1985, 13. Zie ook Vivan 2000, 51/2

${ }^{483}$ Zie ook Itala Vivan 2000

${ }^{484}$ Crais $2002,79,80$

${ }^{485}$ Crais 2002,81
} 
gebiedsuitbreiding die, zo stelt ook Vidler, het effect had dat men bang werd voor het donkere, onzichtbare, onbegrijpbare. De angst werd fascinatie en fascinatie bracht een "spatial phenomenology of darkness" tot stand: een ruimtelijk ervaren duisternis die meer was dan de afwezigheid van licht ${ }^{486}$. Het is een "living entity", diep, grenzeloos en mysterieus, en, in tegenstelling tot de lichte ruimte, "it touches the individual directly, envelops him, penetrates him, and even passes through him." ${ }^{\text {487 }}$ In de loop van de negentiende eeuw "'light space' is invaded by the figure of 'dark space' on the level of the body as in the form of epidemic and uncontrollable disease, and on the level of the city in the person of the homeless." ${ }^{\prime 48}$ Op het niveau van de westerse beschaving, kan daar aan worden toegevoegd, wordt deze rol vervuld door primitieve irrationaliteit in het algemeen en Afrika in het bijzonder. Heart of Darkness, schreef Chinua Achebe in zijn beroemde kritiek, "projects the image of Africa as 'the other world,' the antithesis of Europe and therefore of civilization, a place where man's vaunted intelligence and refinement are finally mocked by triumphant bestiality." ${ }^{899}$ Achebes ideologische kritiek is op zijn beurt weer fel bekritiseerd en het boek wordt nu vooral gezien als ironisch, ambigu en vol onopgeloste contradicties ${ }^{490}$. Maar dat de duisternis zich er vooral in het hart van een koloniale ambtenaar bevindt, zodat Heart of darkness meer een beeld geeft van het koloniale denken dan van Afrika, doet aan de ruimtelijke verbeelding van de phenomenology of darkness in Conrads klassieker niets af.

Zowel de ontdekking van het Afrikaanse continent als de kolonisatie ervan, als de cognitieve gebiedsuitbreiding werden weergegeven als een rite de passage: een reis van geordend naar geordend via chaos, waarbij de middelste fase wordt geassocieerd met duisternis, ziekte, nomadisme, irrationaliteit, gevaar, barbarisme en zwart Afrika. Dit is bijvoorbeeld terug te zien in het eerder besproken Os Lusiadas (1572) van Luís Vaz de Camões ${ }^{491}$, waarin de reis van Vasco da Gama te lezen is als een rite de pas$\operatorname{sag} e^{492}$.

\footnotetext{
${ }^{486}$ Vidler 1992, 168/9

${ }^{487}$ Caillois "Mimicry and legendary Psychastenia," A. Michelson et al (eds) October: The first decade 1976-1986, Cambridge, 1987: 70

${ }^{488}$ Vidler 1992, 169

${ }^{489}$ Achebe, Chinua. "An Image of Africa: Racism in Conrad's 'Heart of Darkness'" Massachusetts Review. 18. 1977. Rpt. in Heart of Darkness, An Authoritative Text, background and Sources Criticism. 1961. 3rd ed. Ed. Robert Kimbrough, London: W. W Norton and Co., 1988, pp.251-261, p252

${ }^{490}$ Zie Firchow 2000

${ }^{491}$ Zie 3.4 .1

${ }^{492}$ Wyk Smith 1988, 30 In 1966 pikt Clouts Da Gama's rite de passage op als thema in The Navigator, verbeeld als een "at once terrifying and exhilarating venture deep into the unknown, where the 'raw images of darkness (..) that can torment the sturdy mind' are transfomed into 'night's huge and driving breath [which] ordains the heart of knowledge'." (idem 30/1))
} 


\subsubsection{Doden als voertuig van de herinnering}

Het veroveringsbeleid dat de Mesopotamiërs aan deze verbeelding van de werkelijkheid koppelden vertoont eveneens opvallende overeenkomsten met dat van het Zuid-Afrikaanse koloniale regime. Om nieuwe gebieden aan het Mesopotamische rijk toe te kunnen voegen of om conflicten "op te lossen", werden de te overwinnen of te overtuigen bewoners de voertuigen van hun herinnering ontnomen. Grote groepen mensen werden gedeporteerd, huizen en landerijen vernietigd, de vruchtbare bovenlaag van hun landbouwgrond afgeschraapt en naar het centrum van het rijk vervoerd, en doden uit hun graven gehaald. Ook in Zuid-Afrika probeerden machthebbers de controle over hun nieuwe onderdanen te versterken door hun relatie met het land te verstoren, een methode die op niet aflatende weerstand is gestuit en dan ook met steeds nieuwe middelen moest worden toegepast. Tegen het eind van de $20^{\text {ste }}$ eeuw was het doel bijna bereikt ${ }^{493}$.

Er zijn in de eerdere hoofdstukken talloze voorbeelden gegeven van deze strategie. Onderdeel van de segregatiepolitiek was van allochtonen autochtonen maken en andersom: in $1913 \mathrm{kreeg}$ een minderheid aan immigranten exclusief recht op 67\% van het landoppervlak, en tussen 1950 en 1980 werden zelfs bulldozers en vrachtwagens ingezet om mensen van hun "voertuigen van de herinnering" te scheiden: 3,5 miljoen zwarte ZuidAfrikanen werden naar zwarte "lokaties" en "thuislanden" gedeporteerd, gebieden die in 1981 7,5 miljoen mensen huisvestten, dat wil zeggen drie keer zoveel als er volgens het Tomlinson rapport van 1955 konden leven ${ }^{44}$. Grote aantallen zwarte boeren keerden dus weer als "gastarbeiders" of zelfs "illegale immigranten" naar hun land terug.

Deze ontheemde zwarte Zuid-Afrikanen hebben, net als de schrijvers uit het vorige hoofdstuk, gebruik gemaakt van de metaforische kracht van de dood om een eigen plek in tijd en ruimte te creëren. In een ruimte die volledig door de Ander gedefinieerd leek te zijn, creëerden ze onbezoedelde, rituele ruimtes waar een collectieve identiteit kon ontstaan. Crais schrijft ten aanzien van de Oost-Kaap:

From the end of the nineteenth century, space became increasingly racialized (..). The shift towards indirect rule, and, in the 1950s the beginnings of apartheid, made the colonial organization of space an

\footnotetext{
${ }^{493}$ Tegen de tijd dat er sprake kon zijn van landhervorming (1994), waren er in de 'blanke' gebieden nauwelijks tot geen zelfstandige zwarte boeren meer te vinden, alleen landarbeiders. In de droge jaren tachtig werd het aantal zwarte plattelanders in 'blank' Zuid-Afrika gehalveerd. Rond 1990 woonden ca. zeven miljoen mensen in grootsteedse krottenwijken. (Pickles \& Weiner, Rural and regional restructuring of Apartheid,: ideology, development Policy and the competition for space. in: Antipode, vol. 23, no 1 (special issue on SA) p. 18; Ross 1999, 154; White paper on South African Land Policy, Dept. of Land Affairs, April 1997)

${ }^{494}$ Saunders \& Southey Dictionary of South African history, Cape Town/ Johannesburg, David Philip, 2001: 20
} 
essential feature of state formation and policy. The state's expanding regulation of labor made control of space an absolute necessity. Commonages, however, were relatively free from the more detailed mapping of the state. As early as the late 1890 s, in the context both of new state intervention and spiraling poverty and landlessness, they had become sites of a new politics and religious sensibility. To the state squatting was of course a metonym for illegibility. But for those who lived on them commonages offered the possibility of addressing a world that had gone astray ${ }^{495}$.

In Zuid-Afrika had apartheid onwillekeurig ruimtes gecreëerd waarin onzichtbaarheid gewaarborgd kon worden. Voor zwart Zuid-Afrika vormde dit een (machts)basis voor een eigen, onbezoedelde identiteit en voor blank Zuid-Afrika was het een unheimliche, onaanwijsbare dreiging. Door de Ander buiten de eigen ruimte te plaatsen en aan het zicht te onttrekken (wat in de ruimtelijke ordening van apartheid heel letterlijk gebeurde), werden de voorwaarden gecreëerd voor het voortbestaan en floreren van een oncontroleerbaar, alternatief discours ${ }^{496}$.

In dergelijke alternatieve ruimtes vormden voorouders de peilers die tijd en ruimte aan elkaar verbonden. Het vooroudergeloof bood een referentiekader dat volgens Chidester "could discount the white colonial presence in South Africa. (...) Identified with the homestead, the land, and a specific locality, the ancestors might have become even more crucial as a spiritual anchor that tied people to places that were being threatened and destabilized by European colonial encroachment." ${ }^{497}$ De conservatieve Amaqaba of Red People in Transkei en Ciskei bijvoorbeeld "strove for human dignity by maintaining their identity in the ways laid down by the ancestors (iminyanya)" ${ }^{\prime 498}$. Ze vormden meer en meer een minderheid in een gebied waar het kolonialisme zijn diepste sporen had achtergelaten en de invloed van blanke steden en boerderijen al vier of vijf generaties merkbaar was. Net als de missionarissen een eeuw eerder, gebruikten ze hun religie om een alternatieve ruimte te creëren in een vijandige omgeving, ofte wel:

as a way of carving out an independent enclave in a larger economic, social and political world. Therefore, the ancestors not only represented an ancient world but also a more recent way of life, that was being undermined. Within that context, adherence to ancestor religion was a particular strategy of resistance to displacement and domination in South Africa. ${ }^{499}$

\footnotetext{
${ }^{495}$ Crais 2002, 136

${ }^{496}$ Zie ook Hst. 4.4.4

${ }^{497}$ Chidester 1992, 13

${ }^{498}$ Mayer 1980, 3-4

${ }^{499}$ Chidester 1992, 13
} 
Ook op blanke boerderijen werden dergelijke ruimtes gecreëerd. Ondanks alle anti-pachtwetgeving kwam zelfs in 1992 werkpacht in blank ZuidAfrika nog regelmatig voor. Werkpachters hadden naast hun loon toegang tot een stuk land waarover ze op geen enkele manier rechten konden doen gelden, maar dat desondanks meer economische zekerheid bood dan de arbeidsrelatie. Bovendien kreeg dit land, juist omdat het onzichtbaar was voor de wet, een speciale waarde. "Dit is mijn land, want hier liggen mijn voorouders begraven," was een veel gehoorde uitspraak van Zuid-Afrikaanse landarbeiders als hen in de jaren negentig van de $20^{\text {ste }}$ eeuw door rechters, activisten en onderzoekers naar hun mening wordt gevraagd $\mathrm{d}^{500}$. Graven van voorouders hadden hier de functie gekregen van wat Elizabeth Colson land shrines noemt; eenvoudig vormgegeven monumenten die in heel Zuidelijk Afrika voorkwamen, en een concreet alternatief boden voor de officiële geschiedenis en landverdeling van Zuid-Afrika. Middels de land shrines werden de stamvaders vereerd die de plek waar men woonde, hadden ontgonnen of veroverd. Ze vertegenwoordigden "the continuity of human life forces" in de vorm van een specifieke relatie tussen mens, tijd en ruimte en boden, net als in vroeger dagen, ook aan de vele migranten die het platteland bevolkten een thuis en voorouders:

Local shrines may be built at grave sites or the site of the reputed first settlement. The placement, therefore, is seen as an artifact of local history. In either case the shrine evokes the idea of continuity over several generations. Shrines also remind supplicants that they belong to discrete communities occupying space. Appeal is made to the shrines and spirits of dead pertaining to the community of residence, not to shrines and spirits of the neighboring communities. Immigrants associate themselves with the shrines of their new community. The local shrines (...) supply named landmarks and (...) define the terrain associated with the community and emphasize its distinctiveness ${ }^{501}$.

Europese immigranten in Zuid-Afrika, met name die immigranten die in direct contact stonden met de grenzen van de Europese orde (burghers, trekboeren, settlers, koloniaal bestuurders), deden dus hun best de relatie tussen Afrikanen en hun land te verstoren en hen in hun eigen symbolische orde te plaatsen, een orde die door de dood werd geschraagd. Maar in diezelfde tijd en ruimte creëerden zwarte Zuid-Afrikanen, toen zij van autochtonen (im)migranten waren geworden, met behulp van de dood nieuwe (symbolische) territoria als basis voor een nieuwe of hernieuwde

\footnotetext{
${ }^{500}$ Zie bijvoorbeeld Dithlake 1997, 222 en Levin, Solomon \& Weiner 1997, 110

${ }^{501}$ Colson 1997, 53
} 
eigen identiteit. In zijn meest rudimentaire vorm lijkt niet land, maar dood de basis van het bestaan te zijn: ruimte is een discours dat rond de dood vorm krijgt. Het is dan ook niet verwonderlijk dat in een tijd waarin de vraag opnieuw gesteld werd wie de immigrant was en wie niet, boerderijromans prominent bevolkt werden met (levende) doden. Maar wiens verleden, wiens heden gaven ze vorm?

\subsection{DE VERSCHIJNING VAN MORBIDE SYMPTOMEN: DAS UNHEIMLICHE}

"Crisis," schreef Antonio Gramsci in een veel aangehaalde passage, "consists precisely in the fact that the old is dying and the new cannot be born: in this interregnum a great variety of morbid symptoms appear." ${ }^{502}$ Deze morbide symptomen kunnen zich in allerlei culturele representaties manifesteren, maar hebben allemaal te maken met chaotische, onbeteugelde kant van de dood: de dood in haar liminale staat. De negentiende-eeuwse Engelse literatuur werd bevolkt door vampieren, monsters, spoken; ZuidAfrikaanse literatuur in de jaren zeventig en tachtig van de twintigste eeuw zuchtte onder on- of slecht begraven lijken, en het laat twintigste-eeuwse postkoloniale Afrika wordt in toenemende mate bevolkt door heksen en zombies $^{503}$. In Europa noemde men eind negentiende eeuw de kluwen aan associaties en betekenissen waar literaire morbiditeiten onderdeel van uitmaakten Das Unheimliche. Het begrip werd met name onder invloed van Sigmund Freud gebruikt om zowel psychische als maatschappelijke verschijnselen te interpreteren. Net als in het voorafgaande wordt de dood in dit verband gekoppeld aan het overschrijden van een grens, aan het contrast tussen "eigen" en "vreemd", aan onzekerheid en het onkenbare.

\subsubsection{Freud: herrijzenis van oude angsten}

Edgar Allan Poe en E.T.A. Hoffmann waren de eerste Europese schrijvers die, onder invloed van allerlei maatschappelijke ontwikkelingen, een bepaalde collectieve ervaring verbeeldden die later als unheimlich werd geïnterpreteerd. Het contrast tussen een vreemde indringer en (in) een veilig "thuis" was een van hun favoriete onderwerpen. Op het psychologische vlak werd er gespeeld met de dubbelganger, waarbij er onduidelijkheid bestond over de grens tussen Ik en Ander. Anthony Vidler plaatst in

\footnotetext{
${ }^{502}$ Gramsci, Antonio. Selections from the Prison Notebooks. Ed. \& trans. Quintin Hoare and Geoffrey Nowell Smith. New York: International Publishers, 1971: 276.

${ }^{503}$ Comaroff \& Comaroff 1999, 21 In de jaren negentig werden Zuid-Afrikaanse zombies, hoewel enerzijds "harsh realities", ook onderdeel van een cultureel spektakel dat onder invloed van allerlei media tot stand kwam. Als zodanig verschilden ze niet wezenlijk van de eerder genoemde literaire personages.
} 
The architectural uncanny (1992) deze thematiek in het kader van de opkomende burgerklasse: "At the heart of the anxiety, provoked by such alien presences, was a fundamental insecurity: that of a newly established class, not quite at home in its own home." ${ }^{504}$ Karl Marx zag een dergelijke angst als symptoom van de vervreemding van de arbeidersklasse. De arbeider was immers de eerste die geen thuis meer had: "instead he finds himself in someone else's house, in the house of a stranger who always watches him and throws him out if he doesn't pay the rent." ${ }^{\prime 505}$. In latere cultuurkritische teksten was het vooral de stedeling die zich unheimlich voelde, omdat hij vervreemd was van zijn natuurlijke omgeving als gevolg van een discrepantie tussen het moderne ideaal van beheersbaarheid en de onbeheersbaarheid van de natuur. Vanaf 1870 is het unheimliche niet meer klassegebonden, zegt Vidler, maar werd het steeds meer geïdentificeerd met wat hij noemt "metropolitan illness":

The Uncanny emerged in the late nineteenth century as a special case of the modern diseases, from phobia's to neuroses, variously described by psychoanalysts, psychologists and philosophers as a distancing from reality forced by reality. Its space was still the interior, but now the interior of the mind (..) the symptoms included spatial fear, leading to paralyses of movement, and temporal fear, leading to historical amnesia. In each case, the Uncanny arose, as Freud demonstrated, from the transformation of something that once seemed homely into something decidedly not so. From the heimlich, that is, to the unheimlich. ${ }^{506}$

Maar het unheimliche verlegde zijn grenzen steeds, afhankelijk van wat dankzij de aard van aantasting of bedreiging als "thuis" werd beleefd. Tijdens de eerste wereldoorlog schreef Sigmund Freud een essay over Das Unheimliche, waarbij hij een van Hoffmans verhalen gebruikte als case om de psychologische aspecten van het verschijnsel te analyseren. Deze oorlog met al zijn trauma's maakte opnieuw een heim unheimlich.

Themes of anxiety and dread, provoked by a real or imagined sense of unhomeliness seemed particular appropriate to a moment when, as Freud noted in $1915^{507}$, the entire 'homeland' of Europe, craddle and apparently secure house of western civilisation, was in the process of barbaric regression, when the territorial security that had fostered the notion of a unified culture was broken, bringing a powerful disil-

\footnotetext{
${ }^{504}$ Vidler 1992, 4

${ }^{505}$ Carl Marx "Economic and Philosophic manuscripts of 1844" C. Marx \& F. Engels Collected Works Vol. III: Marx and Engels 1843-1844 New York, 1975: 314

${ }^{506}$ Vidler 1992, 6

${ }^{507}$ Onder meer in: Thoughts for the Times on War and Death
} 
lusionment with the universal 'museum' of the European 'fatherland'. The site of the Uncanny was no longer confined to the house or the city, but more properly extended to no-man's land between trenches or the fields of ruins left after bombardment. ${ }^{508}$

"Das Unheimliche," zegt Freud, "is that class of frightening that leads back to what is known of old and long familiar" ${ }^{509}$. Volgens hem wordt bij ervaring van het unheimliche geappelleerd aan onderdrukte gevoelens uit de kindertijd (gekenmerkt door het ontbreken van grenzen tussen Ik en buitenwereld) dan wel aan onderdrukte discoursen uit een pré-modern, préempirisch verleden (gekarakteriseerd door geloof in geesten en (eigen) magische krachten). "It seems as if each one of us has been through a phase of individual development corresponding to this animistic stage in primitive men (..) and that everything which now strikes us as uncanny fulfils the condition of touching those residues of animistic mental activity within us and bringing them to expression." ${ }^{10}$ Aangezien Freud uit zijn psychoanalytische bevindingen geleerd had dat alles wat onderdrukt wordt, tot angst leidt, of het nu oorspronkelijk angstaanjagend was of niet, was het unheimliche logischerwijs ook angstaanjagend. In de literatuur onderscheidt hij meerdere thema's en stijlvormen die een unheimlich effect hebben. Hieronder valt intellectuele onzekerheid, alles wat verwijst naar de grens tussen dood en leven (sterfscènes, (levende) lijken, spoken en geesten, maar ook dubbelgangers), intellectuele onzekerheid en wat hij noemt "omnipotence of thoughts"

Dat laatste zou in Afrika hekserij (witchcraft) worden genoemd, en hiermee is de eerste van vele linken tussen beide continenten gelegd. Unheimliche manifestaties en de veranderende opvattingen over de dood in de negentiende eeuw in Europa waren niet alleen het gevolg van industrialisatie en verstedelijking, maar ook van het overschrijden van de eigen territoriale grenzen: de koloniale "reizen door de duisternis". Freud zelf maakt in "Das Unheimliche" gebruik van evolutietheorieën die opnieuw orde probeerden te scheppen in de verwarrende hoeveelheid informatie die het contact met verre landen en volken had opgeleverd. De rechtlijnige logica van het evolutiemodel gaf een begrijpelijke en geruststellende plaats aan overeenkomsten en verschillen tussen de "beschaafde" en "primitieve" mens. Desondanks bleven morbide symptomen niet uit: "[t]he horror of it!" vat Kurtz zijn avontuur in Afrika samen in Conrad's Heart of Darkness ${ }^{512}$. De

\footnotetext{
${ }^{508}$ Vidler 1992, 7

${ }^{509}$ Freud 1976, 620

${ }^{510}$ Freud 1976, 631-634

${ }^{511}$ Freud 1976, 633

${ }^{512}$ Achebe zegt hierop dat niet vreemdheid ten grondslag ligt aan zijn afschuw, maar "the lurking hint of kinship, of common ancestry" (Achebe 1988, 252) Als Freud gelijk heeft zou het besef van die verwantschap vooral tot angst en horror leiden, omdat het onderdrukt wordt.
} 
kennismaking met de Afrikaanse Ander leidde in elk geval, in meer of mindere mate, tot een gevoel van existentiële onzekerheid bij Europeanen.

\subsubsection{Shipoko, het spook van Witwatersrand}

Ook in Afrika bracht het contact met de Europese kolonisten nieuwe geestverschijningen met zich mee. Niet alleen de westerse "territorial security" werd ondermijnd door oorlog en industrialisatie. De kolonisatie van Afrika had een vergelijkbaar effect. Slavenhandel, landonteigening, commercialisering van de landbouw en arbeidsmigratie leidde hier tot een "problematic relation of work to the production of social being secured in time and place," ${ }^{13}$ en dit leidde op verschillende momenten en locaties tot een grootschalige angst om als zombies tewerkgesteld te worden in de mijnen of op onzichtbare plantages. Een zombie is "a person who is believed to have died, but because of the power of a witch, he is resurrected.. [and] works for the person who has turned him into a zombie." ${ }_{514}$ Zombies bestonden al voor de komst van de kolonisten, maar op een andere, kleinschaliger manier. Hekserij is altijd sterk verbonden geweest met verwantschap. "Witchcraft," stelt Geschiere,

is (..) the dark side of kinship in several senses. It expresses the frightening realization that aggression threatens from within the family - that is, from the very space where complete solidarity and trust should reign without fail. But this discourse also expresses the effort to maintain relations despite this terrible threat - after all, (..) 'one must learn to live with one's sorcerer', [as the Duala say.] (..) The continuing force of this discourse is that it expresses the permanent struggle of living with this dark threat from the inside ${ }^{515}$.

Geschiere had met deze woorden ook kunnen doelen op de angst van ZuidAfrikaanse landheren voor de transformatie van de eigen Ander in een vijandige Ander, een transformatie die het paternalistische "familiegevoel" van binnenuit aantast. Het beschrijft ook precies de ambiguiteit van het begrip Unheimlich: het thuis dat geen absolute veiligheid biedt. In de woorden van Kristeva:

Freud wanted to demonstrate (..) that a negative meaning close to that of the antonym [unheimlich] is already tied to the positive term heimlich, 'friendlily' (sic), 'comfortable', which would also signify

\footnotetext{
${ }^{513}$ Comaroff et al. 1999, 23-24 cursivering is van mij.

${ }^{514}$ Ralushai N.V., M.G. Masingi, D.M.M. Madiba e.a. Report of the Commission of Inquiry into Witchcraft Violence and Ritual Murders, 1996; 5

${ }^{515}$ Geschiere 1995, 212
} 
'concealed' , 'kept from sight', 'deceitful and malicious', 'behind somebody's back'. Thus in the very word heimlich, the familiar and intimate are reversed into their opposites, brought together with the contrary meaning of 'uncanny strangeness' harbored in unheimlich. ${ }^{516}$

Hoewel de manifestaties van het unheimliche in een Afrikaanse context wel te maken hebben met geesten, gaat het hier bepaald niet om een "onderdrukt geloof" in die geesten ${ }^{517}$, maar wel om een anomalie, een geheimzinnige, grensoverschrijdende kracht die een bedreiging vormt voor het dominante discours en dus in goede banen dient te worden geleid. Hekserij is - net als de dood - een in principe ordeverstorende macht die echter, mits goed gecontroleerd, in staat is interne contradicties te reguleren. Het is gekoppeld aan

a deep suspicion of power, viewed as 'a kind of original sin' but it was also recognized as indispensable to the organization of society. Moreover, the [witchcraft] discourse itself indicated how to contain these occult forces and the dangerous ambitions they inspired. ${ }^{518}$

Met het veranderen van de machtsverhoudingen, veranderden ook de heksen en waartoe zij in staat waren. In de loop van de twintigste eeuw werd hekserij steeds meer geassocieerd met bureaucratie, kapitaal en grootgrondbezit, zowel van blank als zwart. Zwarte Zuid-Afrikanen hebben de verstoorde relatie tussen mens en land, de verdroging en uitputting van de landbouwgrond, de verspreiding van ziektes, armoede en eenzaamheid geweten aan kwade machten die de wereld in chaos hadden gedompeld. Het land was dood ${ }^{519}$, de inwoners half-dood ${ }^{520}$. Wellicht omdat heksen in staat waren de doden hun plek in het dodenrijk te ontzeggen zoals apartheid en kapitalisme in staat waren mensen hun plek in het rijk der levenden te ontnemen, werden apartheid en kapitalisme, maar ook collaboratie met het apartheidssysteem, geassocieerd met hekserij ${ }^{521}$. In de jaren twintig in de Zuid-Afrikaanse Oost-Kaap, "Africans saw the bureaucratic state as a ritual operating on the basis of magic; indeed, very often on the basis of witchcraft (..). Witchcraft constituted African representation of otherness, a simulacrum of evil." De staat werd ook wel "satan" genoemd, of "blood sucker", een begrip dat over de hele wereld in anti-kapitalistische bewegingen werd gebruikt $t^{52}$. In de rechtszaal werden de bankjes behandeld met

\footnotetext{
${ }^{516}$ Julia Kristeva Strangers to ourselves New York, Columbia University Press, 1991: 182

${ }^{517}$ Een van de door Freud genoemde oorzaken va $n$ het intstaan van het Unheimliche.

${ }^{518}$ Geschiere citeert Philippe Laburthe-Tolra Minlaaba, histoire et societé traditionelle chez les Beti du sud Cameroun. Paris, Champion 1977: 1080

${ }^{519}$ Crais 2002, 118

${ }^{520}$ Comaroff \& Comaroff 1999

${ }^{521}$ Crais 2002, 116

${ }^{522}$ Crais 2002,138
} 
"'herb water' to protect people from the colonial state's powerfull magic" ${ }^{\prime 523}$. Ook elders werd hekserij of verspreiding van het kwaad bestreden met rituele zuiveringen, soms in de vorm van symbolische verbrandingen; niet zelden ook in de vorm van moord of verkapte zelfmoord ${ }^{524}$. Arbeidsmigranten werden in toenemende mate geassocieerd met zombies. In 1910 observeerde Junod in het zuiden van Mozambique moderne heksen die jonge mannen ertoe brachten af te reizen naar de mijnen van Witwatersrand, waarna ze voorgoed verdwenen ${ }^{525}$. In Kameroen troffen zowel Ardener als Geschiere onder de Bakweri een geïntensifeerd geloof in zombies aan nadat Duitse kolonisten land in beslag genomen hadden en de bewoners gedeporteerd $^{526}$. De heksen veranderden hun verwanten, zelfs kinderen, in zombies die op afgelegen plantages te werk werden gesteld. ${ }^{527}$ Zowel Berglund als Chidester observeren hetzelfde verschijnsel in Zuid-Afrika tijdens de apartheid. Waar migranten in de oude sociale structuren zonder veel moeite werden opgenomen, waren ze nu zodanig ontworteld en losgeslagen dat hun lot en destabliserende kracht gelijkgesteld werd met dat van mensen die in het chaotische en dus kwade niemandsland tussen dood en leven waren blijven hangen ${ }^{528}$. Hoewel unheimliche representaties als hekserij en levende doden in sommige gevallen een regulerende en zelfs consoliderende functie kunnen vervullen ${ }^{529}$, lijken collectieve zombieobsessies, zoals alle unheimliche excessen, te ontstaan uit een ontregelende interactie tussen verschillende werelden en onstuimige veranderingen in "control over the essential means of producing value, means like land and labour, space and time." ${ }^{930}$

Het doorbreken van de eigen grenzen en het contact met immigranten of inheemse volkeren hebben dus de culturele identiteit van alle partijen zowel ondergraven als versterkt. Grenzen tussen Wij en Zij vervagen, en worden, in reactie daarop, heel sterk getrokken ${ }^{531}$. Maar de onderhuidse vermenging gaat door, misschien juist ook wel daar waar men dit mechanisme bij elkaar

\footnotetext{
${ }^{523}$ Crais 2002, 137-138

${ }^{524}$ Crais 2002, 133 citeert uit een preek in The Church of the Prophetes Nonthetha, 1992

${ }^{525}$ Henry A. Junod, Life of a South African tribe, London, MacMillan, 1927 In 1899 waren er bij de goudmijnen zo'n 11.000 Europeanen en 17.000 Afrikanen in dienst, in 1909 waren dit er respectievelijk 23.000 en 200.000. Omdat zwarte boeren uit de omgeving goed wisten te profiteren van deze groeiende afzetmarkt en er dus niet over piekerden hun boerenbestaan op te geven, kwam een groot deel van de arbeiders uit landen als Mozambique, Botswana en Namibië.

${ }^{526}$ Edwin Ardener, "Witchcraft, Economics and the Continuity of belief" Witchcraft confessions and accusations, M. Douglas (ed.), London, Tavistock, 1970; Geschiere 1995

${ }^{527}$ Comaroff \& Comaroff 1999, 24

${ }^{528}$ Zie ook Comaroff et al. 1999 en Geschiere 1995.

${ }^{529}$ Zie bijvoorbeeld Patrick Harries, Work, culture and identity, migrant labourers in Mozambique and South Africa, 1860-1910, Portsmouth, Heineman 1991 en Isak Niehaus "witches of the Transvaal Lowveld and their Familiars. Conceptions of duality, power and desire." Cahier d'Etudes Africaines XXXV (2) :138-139, (3):513-510

${ }^{530}$ Comraoff et al. 1999, 24

${ }^{531}$ Gelder \& Jacobs 1998, 26
} 
herkent. Saillant detail: de Mozambikaanse zombies van 1910 werden Shipoko genoemd, een woord dat, evenals het in de jaren negentig gebruikte Tswana woord Diphoko, afstamt van het Nederlandse en Afrikaanse woord spook. Deze overeenkomst "points to the existence here of a cultural interplay across lines of race and language, of ideas of haunting and enchantment" ${ }_{332}$. Het wijst er ook op dat de interactie bij alle partijen unheimliche verbeeldingen tot stand heeft gebracht. Of zoals Comaroff \& Comaroff het elders stellen:

Between conscious and unconscious lies the most critical domain of all historical anthropology and especially for the analyses of colonialism and resistance. It is (..) the realm of partial recognition, of inchoate awareness, of ambiguous perception, (..) [where] individuals and groups know that something is happening to them but find it difficult to put their fingers on quite what it is. ${ }^{533}$

\subsection{3 "A secret geography of the unspoken"}

Cognitieve onzekerheid is een essentieel aspect van het unheimliche. Freud gaat hier niet zo diep op in, maar zijn navolgers des te meer. Hélène Cixous is een van de eersten die de ongrijpbare, talige kanten van het begrip unheimlich benadrukt. Het unheimliche, zegt zij, heeft altijd te maken met het ontbreken van iets, met een onopgelost raadsel, een onvolledige tegenstelling. In een kritische analyse van Freuds "Das Unheimliche" wijst ze op het feit dat ook zíjn tekst unheimlich is, vooral omdat het ene gat met het andere gedicht wordt; de ene angst wordt verklaard vanuit de andere angst. "It is this dodging from fear to fear, the unthinkable secret since it does not open on any other meaning (..) the effect of uncanninnes reverberates (rather than emerges) for the word is a relational signifier. Unheimliche is in fact a composite that infiltrates the interstices of the narrative and points to gaps we need to explain." ${ }^{334}$ Wat Cixous lijkt te willen zeggen, is dat Freud, in zijn viri-centrische obsessie voor castratieangst en alle sublimaties daarvan die verwijzen naar een niet (langer) bestaande werkelijkheid, volkomen voorbijgaat aan een wel degelijk bestaande /betekenisdragende bedreiging (?) voor de man: de vrouw ${ }^{53}$.

Cixous wijst verder op een cirkelredenering in Freuds verklaring voor het unheimliche karakter van de dood: de dood is eng omdat hij verwijst naar

\footnotetext{
${ }^{532}$ Comaroff \& Comaroff 1999, noot 16 en 36

${ }^{533}$ Jean \& John Comaroff (1991) Of revelation and revolution, vol. 1: Christianity, Colonialism and Consciousness in South Africa: 29

${ }^{534}$ Cixous 1976, 536

${ }^{535}$ Cixous gaat niet verder dan het aanstippen van deze vorm van onderdrukking. Allan Lloyd-Smith (1989) werkt dit idee wel uit. Ook de zombiehetze in Zuidelijk Afrika is wel getypeerd als een politieke afleidingsmanoeuvre van een onderhuids klassenconflict. (Comaroff \& Comaroff 1999, 25)
} 
doodsangst. Volgens haar is die angst niet te verklaren omdat de dood niet bestaat: "As an impossible representation, death is that which mimes, by its very impossibility, the reality of death" ${ }^{336}$. Angst voor dood en geesten verklaart ze dan ook uit het feit dat de dood grensoverschrijdend is en als zodanig de categorieën die de waarneming en kennis van de werkelijkheid structureren op de helling zet:

[F]or what renders [the Ghost] intolerable is not so much that it is an announcement of death nor even the proof that death exists, since this Ghost proves and announces nothing more than its return. What is intolerable is that the Ghost erases the limit which exists between two states, neither alive nor dead; passing through, the dead man returns in the manner of the Repressed. (...) In the end, death is never anything more than the disturbance of the limits. (...) [T] he relationship of presence to absence is in itself an immense system of "death", a fabric riddled by the real and a phantomization of the present. ${ }^{537}$

Artikelen van Cixous en Derrida ${ }^{538}$ leidden tot een diepgravende discussie over de esthetische en taalkundige kant van het unheimliche onder poststructuralistische denkers ${ }^{539}$. Het voert te ver deze discussie uitvoerig te behandelen, maar een aspect ervan is wel degelijk van belang voor deze studie, namelijk de opvatting dat de kern van het unheimliche het overschrijden van de grens van het bekende is, en dat dat leidt tot een angstaanjagende onzekerheid. Ook zij concluderen dat de dood verwijst naar iedere andere grensoverschrijding - met gepaard gaand controleverlies - én andersom. Een belangrijk veld van onzekerheden (en betekenis) ligt voor de poststructuralisten in de relatie tussen taal en werkelijkheid. Literatuur is een bron van dubbelzinnigheden; de kern is dat wat er niet is. Betekenis is dus, net als de dood, zeker in de liminale fase, een "absent quality", en net als sterven is "betekenen" een transformatie die op twee niveaus onzekerheid brengt:

$[\mathrm{T}]$ he activity of writer and reader is shared, a joint enterprise not subject to ordinary laws of existence but obeying other rules and inhibitions: some cultural and formalised, some apparently personal and idiosyncratic. Neither writer nor reader are fully in control (...) Revelation may not be made, even ultimately, and neither the reader nor the writer may be sure exactly what is sought. At its crudest this absent quality might be explanation (..), or more subtly it might be

\footnotetext{
${ }^{536}$ Cixous 1976,543

${ }^{537}$ Cixous 1976,543

538 "La double séance" in: La Dissemination (Parijs, 1972)

${ }^{539}$ Sarah Kofman, P. Lacoue-Labarthe, Neil Hertz, Samual Weber, Friedrich Kittler, Françoise Meltzer
} 
moral illumination (..), or it might simply hover perpetually just out of sight. (..)

The situational context of the literary speech is not given but constructed: 'the iconic signs of literature (..) designate instructions for the production of the signified.' The transformation required by this production brings about not one but two 'ranges of indeterminacy': one between the text and the reader and one between the text and reality. ${ }^{540}$

Wat aanwezig is, verwijst naar wat afwezig is, en in zijn geheel kan de tekst zelf dan weer een verwijzing zijn naar allerlei andere vormen van aanwezige afwezigheid: "the signifier implies the absence of the signified and the co-ordinates of discourse plot a secret geography of the unspoken. ${ }^{\prime 41}$ Het is slechts gedeeltelijk mogelijk om wat niet gezegd wordt bloot te leggen. Metaforen in de tekst kunnen nog enigszins houvast bieden: "metaphor is always a bridge opening on to the unknown because of the vacancy at its centre, between the two elements it juxtaposes" ${ }^{542}$. De dood, als metafoor, en bovendien als metafoor voor aanwezige afwezigheid, is dus bij uitstek geschikt om dat wat verzwegen wordt te verbeelden.

Laurence Lerner stelt in The frontiers of literature dat men er niet naar zou moeten streven om dat wat niet gezegd wordt te definiëren, omdat het de afwezigheid zelf is die betekenis genereert: "[ $t]$ hat which is not said in a book is not (...) a lack we can supply, an inadequacy which it might be our task to see to: it has a necessary status in the work" ${ }^{\prime 43}$. Hij gebruikt als voorbeeld het ontbrekende perspectief van de zwarte bediende in Doris Lessings The Grass is Singing: "we can feel the presence of the unsaid as a way of representing a cleavage in society" ${ }^{44}$. Ook in romans als The conservationist en Kroniek van Perdepoort zijn dergelijke ontbrekende perspectieven prominent aanwezig. Het ongezegde is hier niet alleen een gemarginaliseerde stilte, maar ook een bewaarde stilte, een geheim, en als zodanig neemt het een grote ruimte in. Deze stilte wordt vertegenwoordigt door onbegraven doden: doden die zich, net als de zombie uit de vorige paragraaf, in de liminale fase bevinden van hun transformatie. Ook zombies zijn per definitie stil:

[t]o make it impossible for him to communicate with other people, the front part of his tongue is cut off so that he cannot speak. It is believed that he works at night only.. [and] that he can leave his rural

\footnotetext{
${ }^{540}$ Lloyd-Smith (1989 11-12) citeert Iser, "The reality of fiction”. In: Literary History, 1975, 7.Zie ook Roland Barthes S/Z London Cape, 1975: 121

${ }^{541}$ Lloyd-Smith 1989, 12

${ }^{542}$ Lloyd-Smith 1989,14

${ }^{543}$ Lerner 1988, 169

${ }^{544}$ Lerner 1988, 169
} 
area and work in an urban area, often far from his home. Whenever he meets people he knows, he vanishes. ${ }^{545}$

Deze liminale doden zijn sprakeloos, onzichtbaar en onkenbaar; het prototype van de monddood gemaakte, machteloze Ander. Maar er gaat ook een bepaalde macht van hen uit. Net zoals "the state's fantasy of discrete tribes occupying equally discrete spaces," onwillekeurig had geleid tot de creatie van ruimtes die "sacred" en daarom machtig waren "in part precisely because [they were] free from the state's field of vision", ${ }^{546}$ heeft de stilte, het geheimzinnige een heel eigen kracht. Net als duisternis is stilte een "living entity", met een effect dat groter is dan dat van de woorden die zijn weggevallen ${ }^{54}$. Over "the aboriginal sacred" schreven Gelder en Jacobs dat "the withdrawal [from modernity], this silence, carries with it losses, as well as gains. (...) [T] his often secret thing is, in fact, talked about incessantly, with the boundaries between secret and the public constantly negotiated. (..) [F]ar from being mute, far from having nothing to say to modernity, [it] becomes activated and dialogic" ${ }^{448}$. Gemarginaliseerd als ze mogen zijn in de moderne open wereld van taal, kennis en rationaliteit, hebben de stilte, het geheim, het heilige, het spook - juist in hun hoedanigheid als anomalie - een onbegrensde potentie, een potentie "to shake the whole, to make something tremble in it's entirety" ${ }^{{ }_{449}}$.

\subsubsection{Ruimte voor pluraliteit: het unheimliche als cultuurkritiek}

In psychologische zin verwijst het unheimliche naar het onwillekeurig bovenkomen van innerlijke tegenstrijdigheden die het "eigene" iets angstaanjagends geven. Dan is er een taalkundig aspect, waarin het unheimliche verwijst naar grensoverschrijding van het kenbare, en naar een latente, ambivalente of onduidelijke betekenis van een tekst die, dankzij haar verborgenheid, des te meer gewicht krijgt. Deze tekstuele unheimlichheid is niet alleen een verwijzing naar de ingewikkelde verhouding tussen tekst en lezer, of tekst en werkelijkheid, zoals de poststructuralisten benadrukken, maar kan ook een icoon zijn van verborgen betekenissen bínnen die werke-

\footnotetext{
${ }^{545}$ Ralushai N.V., M.G. Masingi, D.M.M. Madiba e.a. Report of the Commission of Inquiry into Witchcraft Violence and Ritual Murders, 1996; 5

${ }^{546}$ Crais 2002, 136

${ }^{547}$ Caillois "Mimicry and legendary Psychastenia," A. Michelson et al (eds) October: The first decade 1976-1986, Cambridge, 1987: 70. Zie noot 493

${ }^{548}$ Gelder \& Jacobs 1998, 19-22. In hun onderzoek naar het unheimliche karakter van postkoloniaal Australië zien Gelder \& Jacobs "secrecy" als een de gunstige peilers van wat zij noemen "a productively unstable dynamics"; een (on)balans tussen "sacredness" en "modernity" en tussen eenheid en gespletenheid. (24 e.v.). Zie voor een gunstig effect van secrecy in Afrika ook Birgit Meyer,

Translaslating the devil. An African Appropriation Pietist Protestantism: The case of Peki Ewe in South-Eastern Ghana, 1847-1992. PhD diss. University of Amsterdam, 1995

${ }_{549}$ Jacques Derrida, "Différance” Margins of Philosophy. Harvester Wheatsheaf, Hertfordshire, 1982, noot 16
} 
lijkheid - zoals Freuds tekst verwees naar de onzichtbaarheid van vrouwen uit zijn tijd. Hoewel al deze aspecten van het unheimliche een rol spelen, zal in de hiervolgende hoofdstukken met name de koppeling gemaakt worden tussen de dood als sociaal-cultureel fenomeen, en de dood als symbool voor dit soort verborgen betekenis. Uitgangspunt daarbij is dat er niet alleen sprake is van een eindeloze reeks van verwijzingen van afwezigheid naar afwezigheid, maar dat er wel degelijk een stoffelijke aanwezigheid aan alle verwijzingen ten grondslag ligt - zoals de vrouw in de tekst van Freud.

In recente benaderingen van het begrip "unheimlich" is ook een dergelijk uitgangspunt terug te vinden. In de jaren negentig "it has become possible to extract the unheimlich out of its purely psychological and aesthetic context and make it into a category with larger social and cultural implications, indeed one with a certain critical charge," aldus Martin Jay ${ }^{550}$. De onbestemdheid van het unheimliche wordt nu niet gezien als verstorend of beangstigend, maar, zoals ook in het geval van de Aboriginal sacred, vooral ruimte-scheppend. Opvallend is dat heim hierbij een concrete invulling krijgt; vaak wordt het begrip gebruikt bij de analyse van een bepaalde ruimte of territorium: sociale ruimte, woonruimte, (nationaal) grondgebied. Een voorbeeld hiervan is de analyse van Gelder \& Jacobs van de Mabo-zaak ${ }^{51}$ in Australië, die de onbegrensde potentie van het onzichtbare maar al te duidelijk maakte. In deze beroemde rechtzaak werd voor het eerst besloten dat sacred landclaims van Aboriginals geldigheid hadden, zelfs als ze geheim werden gehouden. Het gevolg was dat hoewel "at an earlier point in Australia's modern history Aborginal people were imagined as owning nothing (..) now (..) Aboriginal ownership has the potential to reach right across Australia: all over the place." ${ }^{552}$ Iets dergelijks zou voor Zuid-Afrika ook denkbaar zijn. In de Zuid-Afrikaanse boerderijromans die uitkwamen in de jaren voorafgaand aan de eerste vrije verkiezingen, was dit een van de dingen die de stilte van de Ander, of diens onzichtbare territorium, zo unheimlich maakte.

Deze hernieuwde, deconstructionistische waardering van het begrip unheimlich $^{553}$ was een reactie op de opleving van het nationalisme na de val van het communisme; opnieuw een uiteenvallen van een oude orde, waarbij interne contradicties bloot kwamen te liggen. Derrida betoogt in Spectres de Marx (1993) dat deze nieuwe tijd zorgde voor een wederopstanding van Marx' geesten.

\footnotetext{
${ }^{550}$ Jay 1989,159

${ }^{551}$ Hieruit volgde de Native Title Act (1993), de eerste wet die landrechten voor Aboriginals vastlegde.

${ }^{552}$ Gelder \& Jacobs 1998, 16

${ }^{553}$ Veelal geinspireerd op Walter Benjamin, die ooit schreef over archaïsche residuen in steden die zuiver gericht leken te zijn op toekomst en verandering.
} 
Au moment où une nouveau désordre mondial tente d'installer son néo-captalisme et son néo-liberalisme, aucune dénégation me parvient à se débarrasser de tous les fantômes de Marx. L'hégémonie organise toujours la répression et donc la confirmation d'une hantise appartient à la structure de toute hégémonie ${ }^{554}$.

In de woorden van Jay is Derrida's "structure of uncanny haunting"

exemplified by the ghost's return - or, more precisely, the waiting for that return. Protesting against the rhetoric of one-directional temporality (...) Derrida defends a repetitive time that is perpetually 'out of joint'. Noting that the seemingly positive category of the 'heimlich', which implies a safe haven to be restored, is itself deeply fraught into Freud's discussion of its implications, Derrida adds that Heidegger's description of Dasein's relation to the world expresses the same structure of unfulfilled longing that for an eerily familiar home that, however, was never really inhabited and therefore can never be regained. No interior can be made safe from the incursion of the alien other. Ultimately, then, the alternative between the uncanny and the canny is, for Derrida, undecidable ${ }^{555}$.

Derrida plaatst hauntology tegenover ontology; hij stelt dat haunting geïntroduceerd dient te worden in de constructie van elk concept, te beginnen met zijn en tijd. Door het unheimliche te zien als onvervreemdbaar element in een samenleving dat in bepaalde omstandigheden tijdelijk kan worden bezworen, kan het begrip een cultuurkritische functie vervullen en de mensheid behoeden voor een al te star wereldbeeld. Op deze manier is het unheimliche niet (alleen) een bron van angst en ongemak, maar "a bulwark against the dangerous temptations of conjuring away plural specters in the name of a redeemed whole, a realization of narcistic fantasies, a restauration of a true heimat." ${ }^{556}$

Ook Homi Bhabha wil in Nation and narration (1990) aan de hand van het unheimliche ruimte creëren voor een ander discours dan het dominante. Hij gebruikt het begrip om "the cultural representations of the ambivalence of modern society" te duiden ${ }^{557}$. Interessant voor mijn onderzoek is dat volgens

\footnotetext{
${ }^{554}$ Derrida 1993, 69

555 Jay 1998,160

${ }^{556}$ Jay 1998,161

${ }^{557}$ Bhabha verwijst naar Michael Oakeshotts visie op de moderne Europese staat: "The national space is, in his view, constituted from competing dispositions of human association as societas (the acknowledgement of moral rules and conventions) and universitas (the acknowledgement of common purpose and substantive end). In the absense of their merging into a new identity they have survived as competing dogma's - societas cum universitate - 'imposing a particular ambivalence upon all the institutions of a modern state and a specific ambiguïty upon its vocabulary of discourse"”. (Bhabha 1990, 2)
} 
hem het unheimliche in feite de aanwezigheid van de Ander is in onszelf. Het gevolg is dat grenzen en afscheidingen veranderen in "in-between spaces through which the meanings of cultural and political authority are negotiated. (...) The other is never outside or beyond us; it emerges forcefully, within cultural discourse, when we think we speak most intimately and indigenously 'between ourselves'. ${ }^{\prime 58}$ Dus de natie bevat, bijna noodzakelijkerwijs, een interne "cultural liminality", die ruimte biedt aan afwijkende visies. Zodra die visie zich binnen de grenzen bevindt, gaat het niet meer om de mening van de Ander, maar om "a question of otherness of the people-as-one",559.

De metaforen die zowel in de literatuur als daarbuiten ontstaan rond de overgang tussen dood en leven, hebben dus allemaal te maken met een voortdurend verschuivende balans en een interactie tussen continuïteit en verandering, eenheid en gespletenheid, bekendheid en vreemdheid. De vreemdeling is er altijd, maar in hoeverre die gezien wordt als bedreiging hangt zowel af van externe factoren, als van, in Kristeva's woorden, "how familiar we are with our own ghosts" ${ }^{\text {"560 }}$. De romananalyses in de volgende twee hoofdstukken zullen gericht zijn op de vraag hoe de dood in zijn relatie met andere metaforen, en in relatie tot de narratologische ruimte, gestalte krijgt binnen twee boerderijromans uit de jaren zeventig. De bezwering van de bestaande situatie (Derrida's ontology) dreigde in die tijd om te slaan in een alles omvattende verandering en leidde tot een "structure of uncanny haunting". ${ }^{561}$ Verwijzen de metaforen in deze structuur naar de irrationaliteit van duister Afrika, of naar onderdrukte irrationele angst voor dat duister? Spreek de dode, zwijgende Ander over genegeerde, geheime grondrechten, of verwijst de verschijning alleen naar een eindeloze reeks stiltes? In hoeverre heeft er een "verduistering" van het onbekende plaatsgevonden in Zuid-Afrika die een gedifferentieerde omgang tussen zwart en wit in de weg heeft gestaan? En in hoeverre is de orde van het hiernamaals congruent met die van de levenden? Wat betekent dat? En misschien wel de belangrijkste vraag: is de unheimlichheid die in deze teksten verbeeld wordt alleen een bron van vrees en onbehagen, of spreekt er ook de Derridaanse hoop uit dat er ontsnapping mogelijk is uit de constructies waarin men zichzelf gevangen heeft gezet?

\subsection{BOSMANS EIGEN GEESTEN}

\footnotetext{
${ }^{558}$ Bhabha 1990, 4

${ }^{559}$ Bhabha 1990, 301

${ }^{560}$ Julia , Jkristeva , Strangers to ourselves, New York: Columbia University Press, 1991:191

561 Jay 1998,160
} 
Aan de hand van bovenstaande informatie kan de interpretatie van "Unto Dust" nader worden uitgewerkt. Verteller Oom Schalk Lourens is een oudere boer die in de jaren twintig met zijn "old Boer War comrades" in het afgelegen Marico district woont in het westen van het toenmalige Transvaal, vlakbij de grens met Botswana ${ }^{562}$. Daar woonden in Bosmans eigen woorden "real Boers", mensen, aldus William Plomer in het voorwoord van de uitgave in 1963, met een negentiende-eeuwse geest, die nog niet in contact waren geweest met de industriële revolutie noch met de eerste tekenen van zwart verzet. Ze waren vanuit de Kaap of uit andere delen van Transvaal het verlaten gebied binnengetrokken en hadden grote stukken land in bezit genomen. Ze stamden af, nog steeds volgens Plomer, van "men who had advanced heroically into the interior" en hadden zelf in het verleden moeten vechten met zowel "kaffirs" als Britten. ${ }^{563}$

Het hier geschetste isolement is om twee redenen maar schijn. Het Maricodistrict is nooit volledig geïsoleerd of verlaten geweest, al hebben blanke kolonisten pas vrij laat belangstelling getoond voor het gebied. Onder invloed van de goud- en diamantkoorts en bijkomende verstedelijking raakte dit gebied steeds meer bevolkt, waarbij het merendeel van de door blanken in bezit genomen "great tracts of land" onderverhuurd werd aan zwarte pachters. Juist in de jaren twintig, toen Bosman hier woonde, was er als gevolg van de veranderende economie en wetgeving sprake van onrust en opstanden, die met geweld werden onderdrukt ${ }^{564}$. Het is dus onwaarschijnlijk dat de blanke boeren waar Plomer over spreekt geen effect hadden ondervonden van de industriële revolutie of geen weet hadden van zwart verzet, al is het heel goed mogelijk dat wel die schijn werd opgehouden. De gevoelens van onzekerheid, angst en ongetwijfeld ook schuld, die uit deze situatie voorvloeiden, worden weerspiegeld in Bosmans verhaal.

Bovendien staat het gebied model voor Zuid-Afrika. Weliswaar is Oom Schalk onderdeel van een plattelandsgemeenschap en geeft hij als zodanig een kijkje in de keuken van wat Stephen Gray een "unenlightened and even embarassingly anti-progressive milieu" noemt, en een "bigoted, class-riden, sexist and racially divided locus of violence, ignorance and squalor". Maar, zegt Gray, de grap is natuurlijk dat Bosman in deze verhalen niet het Maricodistrict op de hak neemt, maar dat "his Marico District stands in a viciously comic allegorical relation to the South Africa of his own time as a whole. ${ }^{565}$ Bosmans boerengemeenschap staat niet buiten de geschiedenis, maar reageert juist op allerlei actuele ontwikkelingen. Hoezeer het Maricodistrict ten prooi is aan verandering blijkt ondubbelzinnig uit de zogenaamde Voorkamerstories, die Bosman in de laatste jaren van zijn leven schreef. Deze verhalen spelen zich een generatie na Oom Schalk af, in een

\footnotetext{
${ }^{562}$ MacKenzie 2000, 85

${ }^{563}$ William Plomer 'Forword' in H.C. Bosman, Unto Dust (1963)

${ }^{564}$ Zie hoofdstuk 2

${ }^{565}$ Gray 1989,4
} 
tijd waarin de "unbounded liberties of frontier life" hebben plaatsgemaakt voor overheidsbemoeienis, droogte, schulden en de trek naar de stad. ${ }^{566} \mathrm{Ze}$ portretteren de boeren als ontworteld en vervreemd: "imprisoned, impotently, (..) cut off from the veld outside." ${ }^{667}$

"Unto Dust" is een van de laatste Oom Schalk verhalen, en was als zodanig een voorbode van een veranderende focus in het werk van Bosman, maar ook in de Zuid-Afrikaanse literatuur. $\mathrm{Na}$ de tweede wereldoorlog was er weinig aandacht meer voor het platteland. Het werd een armoedig, vergeten en verlaten oord; de snelgroeiende steden met hun heel eigen verlokkingen en problemen trok de jeugd naar zich toe en eiste de aandacht op van een nieuwe generatie schrijvers ${ }^{568}$. In de Voorkamerstories "impoverished and abandoned, but obstinately resisting the inevitable, these farmers gather to pit their homely wisdom against all innovations. ${ }^{~}{ }_{69}$ Oom Schalks angst voor de naderende dood is ook de angst voor het eind van een tijdperk.

Het unheimliche speelt een belangrijke rol in dit verhaal. Om te beginnen wordt een unheimlich effect bewerkstelligd doordat in een ingebedde fabula een vijandige zwarte Ander opgevoerd wordt die in de kadervertelling ontbreekt - hoewel dat ingebedde verhaal juist bedoeld was om de verhoudingen tussen blank en zwart in het vertelde heden te verklaren. In die kadervertelling is die Ander dus een stemloze, onzichtbare Ander geworden. Deze doodgezwegen Ander gaat "spoken" in andere -niet menselijke- gedaantes die door de vermenging angstaanjagende, grensoverschrijdende, magische krachten lijken te krijgen: "the strange African veld", het vreemde verhaal, en Ooms Schalks nachtmerrie.

Het effect van de homologie wordt nog eens versterkt doordat het in het verleden gesitueerde heden van Oom Schalk een commentaar vormt op het heden van de lezer: de jaren veertig. In die jaren werd de wetgeving die in de jaren twintig tot zulke grootschalige onrust had geleid, verder aangescherpt. Op het platteland was de situatie slechter en het verzet onzichtbaarder dan ooit. Gebrek aan landbouwgrond, overbevolking en bodemerosie zorgde voor "desert conditions" en "the spectre of mass starvation" ${ }^{570}$ in de reservaten. Mijnmagnaten en blanke boeren ronselden hier hun tijdelijke arbeiders en stuurden ze vervolgens weer naar "huis", waar de opbrengst uit hun boerenbestaan een aanvulling moest vormen op hun uitzonderlijk lage lonen ${ }^{571}$. De Chamber of Mines schilderde in 1940 de situatie als volgt: "[their] independant position as peasant farmer and stock holder" verzekerde de mijnwerkers van een "prolongued holiday at home(...) [Was there]

\footnotetext{
${ }^{566}$ MacKenzie 2000, 85

${ }^{567}$ Gray 1977, 86

${ }^{568}$ MacKenzie 2000, 83

${ }^{569}$ MacKenzie 2000, 86

${ }^{570}$ Bernstein 1996, 7. Zie ook Bundy 1979: 226

${ }^{571}$ Bernstein 1996, 4
} 
any other body of workers in the world so fortunately placed?" ${ }^{572}$ Het gevolg van deze fortuinlijke situatie was dat ondanks allerlei regels die de toevloed van Afrikanen naar de steden moest beperken, tussen 1936 en 1951 de permanente zwarte stedelijke bevolking verdubbelde en binnen de zwarte beroepsbevolking het percentage zwarte peasants daalde van 51 naar acht procent ${ }^{573}$. Blanke boerenbedrijven kampten daardoor nog steeds, of weer, met een tekort aan arbeidskrachten.

In de verkiezingsstrijd die aan de overwinning van de Nasionale Party (1948) vooraf ging, gebruikte Malan het al decennia lang gevoerde beleid van rassenscheiding in verscherpte vorm en onder de naam Apartheid als hoofditem in zijn campagne. Om zijn ideeën meer diepte te geven gebruikte hij in navolging van na-Boerenoorlogse theologen de predestinatieleer van het calvinisme om de Afrikaners uit te roepen tot Gods uitverkoren volk. Mythologisering en idealisering van het voortrekkersverleden deden de rest. Mede dankzij de arbeidscrisis op het platteland, wist hij tenslotte de meerderheid van de kiezers voor zich te winnen. Alle 15 rurale kiesdistricten in Transvaal schaarden zich achter de NP, in de hoop dat Malans Apartheid de aanvoer van arbeidskrachten zou regelen.

Apartheid moest in twee fasen van de grond komen. In de eerste fase mochten zwarte werknemers voorlopig blijven als tijdelijke immigranten. In blanke landbouwgebieden werden arbeidsbureaus ingesteld, aangescherpte paswetten reguleerden de instroom van zwarten in de steden, en op de boerderijen werden op grote schaal zwarte gevangenen - vaak veroordeeld onder de paswetten - te werk gesteld. ${ }^{574}$ Ter voorbereiding van de tweede fase, waarin de zwarte uit de blanke samenleving gebannen zou worden, werden alvast de Bevolkingsregistratiewet en de Groepsgebiedenwet in werking gesteld. De eerste zorgde ervoor dat ieder mens werd geregistreerd als behorende bij een bepaalde etnische groep en de tweede stelde de regering in staat voor elk van die groepen woon- en werkgebieden aan te wijzen waar de betreffende mensen zonodig onder dwang geplaatst konden worden.

"Unto dust" bespot deze ruimtelijke segregatie en de gedachte die erachter ligt. Het ingebedde verhaal, verteld door de wat dommige Stoffel, bevat een Malanachtige boodschap die gebaseerd is op een cirkelredenering, namelijk: "Dat de dood ons allemaal gelijk zou maken is een onzinnige gedachte, want dan zou je ook zwarten stemrecht kunnen geven en dat is nu juist de

\footnotetext{
572 Geciteerd in Bundy 1979, 225

${ }^{573}$ Bernstein 1996, 8 .

${ }^{574}$ Een zwarte boer uit Cork herinert zich: At the end of 1945, the soldiers returned from World War II. The Boers were given huge farms and we were given bicycles. The Boers' farms were too big for them to farm profitably. Black people therefore had towork for them without pay to subsidize their farms' profitability. When farm workers and tenants complained, they were chased of the farms. When we wanted to try to get a better job on the mines, then the pass laws were used to control our movements. Also we needed the farmers' permission to leave. Without his permission, we would have to serve a 14 days's prison sentence. (Levin, Solomon \& Weiner 1997, 109)
} 
reden dat we zijn vertrokken uit de Kaap." Net als Malan gebruikt Stoffel de geschiedenis om zijn stelling te onderbouwen, terwijl die daar eigenlijk niet zo geschikt voor is. Stoffels confrontatie met de zichtbare werkelijkheid van Welmans beenderen - alle mensen zijn na de dood gelijk - laten hem des te meer beseffen dat hij moet blijven vasthouden aan de overtuiging dat er fundamentele verschillen zijn tussen zwart en blank, zowel voor als na de dood, wil de bodem niet onder zijn bestaan wegzakken. En dus doet hij dat. Uiteindelijk gaat het erom dat er een grafsteen van Hans Welman staat waar die hoort te staan. De representatie van de dood is zoals hij moet zijn, dus de orde is hersteld.

Maar Oom Schalk bekommert zich niet zo om sociale representatie van de dood of de sociale of politieke orde. Zijn nachtmerrie confronteert hem met de beperktheid, de relativiteit van de sociale en religieuze orde van de Boeren. Hij is een oude man; voor hem heeft de dood haar sociale functie verloren en is onversneden werkelijkheid geworden. Waar zal hij terecht komen? Hij weet opeens niet meer zeker wie er heerst over de dood - en dus over het leven. De vraag is niet eens hemel of hel; de vraag is of een christelijke God überhaupt nog bestaat als hij eenmaal die magische grens heeft overschreden. Hij is bang buiten het bereik van zijn eigen God te belanden want God, zo leert de Apartheid hem, heerst alleen maar op dat keurige Boerenkerkhof. Daarbuiten heerst chaos. De grenzen tussen mijn en dijn, blank en zwart, christelijk en niet-christelijk, natuur en cultuur vervagen er. De angstaanjagende dood die hij voor ogen heeft is een onvoltooide rite de passage: een reis die eindigt in liminale chaos, verbeeld door een alomvattend Afrika. Bosmans verhaal is in feite een verbeelding van de eerder aangehaalde stelling van Bhabha dat "the other is never outside or beyond us; it emerges forcefully, within cultural discourse, when we think we speak most intimately and indigenously 'between ourselves'." ${ }^{775}$ Door die Ander desondanks uit het eigen cultuurdomein te verstoten, zegt Bosman, halen we uiteindelijk de grond onder onze eigen voeten vandaan; er is, per definitie, geen "eigen" stof om naar terug te keren.

${ }^{575}$ Bhabha 1990, 4 


\section{Intermezzo}

In de drie decennia die de eerste publicatie van "Unto dust" van Herman Bosman scheiden van het verschijnen van The conservationist van Nadine Gordimer, gebeurde er, zoals gezegd, niet zoveel met de pastorale literatuur. Jonge schrijvers richtten hun aandacht vooral op de stedelijke problematiek, en in de Afrikaanstalige literatuur werd tot de jaren zestig of zelfs zeventig, geen behoefte meer gevoeld de rassenrelaties vorm te geven, zoals bij uitstek in de plaasromans gebeurde ${ }^{576}$. Met zwarte boeren gebeurde er ondertussen des te meer; ontwikkelingen die van belang zijn voor de interpretatie van de latere (anti-)pastorale literatuur.

Vanaf het moment dat Verwoerd in 1950 als minister van Native Affairs werd aangesteld was Zuid-Afrika grotendeels officieel blank. Elke zwarte man of vrouw die zonder baan in blank gebied verbleef was illegaal, wie wel werkte verbleef in een eigen "locatie", vaak ver van zijn/haar werk. Op de blanke boerderijen werden bijna alle pachters in de loop der tijd officieel landarbeiders. Veel van hen waren, net als huishoudelijk personeel, "inwonend", en verbleven dus in feite illegaal op blank gebied.

Terwijl in de jaren vijftig en zestig in heel Afrika de koloniale regimes aan het wankelen werden gebracht, namen ook hier de protestacties hand over hand toe. Het van het ANC afgescheiden PAC draaide in 1959 het Apartheidsstandpunt om en beschouwde de blanken als ongewenste vreemdelingen. Ook uit het buitenland klonken protesten, met name na het beruchte bloedbad van Sharpeville in 1960. Speerpunt van Verwoerds beleid was inmiddels het "behoud van de bedreigde blanke minderheid" geworden, ondanks dat er onder de blanke bevolking stemmen opgingen om tegemoet te komen aan de eisen van de zwarte bevolking. Minister van justitie en Verwoerds opvolger B.J.Vorster breidde de periode waarin hij mensen zonder vorm van proces kon laten opsluiten uit van twaalf dagen (1963) tot "onbepaalde tijd, zonder toestemming van de rechter" (1976). De grotere vrijheden van politie en justitie zorgden voor stabilisering en opbloei van de economie, en dus voor regeringssteun van met name Engelssprekende industriëlen.

Mehring, hoofdpersoon in The conservationist, hoort tot die groep. Hij weet dat voor stabiliteit een prijs wordt betaald, maar hij gelooft in de heilzame krachten van een goed functionerende economie. Overigens zal hij niet van alle activiteiten van leger en politie op de hoogte zijn geweest; veel zaken zijn pas tijdens de hoorzittingen van de Commissie van Waarheid en Verzoening in de openbaarheid getreden: systematische en grootschalige martelingen en moordaanslagen door speciale afdelingen van de geheime

${ }^{576}$ Gerwel 16 en $75 / 6$ 
politie, verminking en verduistering van lichamen, manipulaties door "de derde macht" die de zwart-zwart tegenstellingen vergrootten en het "etnisch geweld" deden oplaaien. Maar hij is, net als de meeste van zijn landgenoten, niet onwetend van de buitenlandse boycots, van de toenemende armoede onder de zwarte bevolking, van verbannen schrijvers en politieke gevangen die stierven in politiecellen.

Toch is het niet zo verwonderlijk dat noch Mehring, noch de personages in Kroniek van Perdepoort hun boerderij in een politiek kader plaatsen. Vrijwel alle aandacht, zowel van buiten- als binnenland, van regeringszijde als van de verzetsorganisaties, was gericht op de steden en de townships, met als gevolg dat " $[\mathrm{t}]$ he negotiated settlement at the World Trade Centre in Kempton Park which brought about democracy in 1994, was inspired far more by urban mass struggles (...) than by rural interests." ${ }^{\prime 77}$ In dezelfde periode dat het bedrijfsleven in de steden concessies deed aan de vakbonden, verhardden veel blanke boeren zich in hun standpunten. Ze sloten zich aan bij de Conservatieve Partij, die zich van de NP afsplitste. Hun politieke invloed was zo groot dat zowel landarbeiders als huishoudelijk personeel op geen enkele manier meeprofiteerden van de rechten die industrie-arbeiders gaandeweg veroverden. Het recht om zelf vorm te geven aan de arbeidsrelaties baseerden de boeren nog immer op de "paternalistische" arbeidsverhoudingen die van oudsher op boerderijen en in huishoudens zouden hebben bestaan ${ }^{578}$. Het gebrek aan aandacht voor (en literatuur over) land- en plattelandsstrijd in de nationale politiek, zorgde voor een wazig beeld van het zwarte platteland ${ }^{579}$. Voor zover er een beeld was, werd dit gekenmerkt door een zichzelf versterkend imago van onveranderlijkheid, zowel in positieve (nostalgische) als negatieve zin (achterlijk, passief, contra-revolutionair) ${ }^{580}$. De boerderij was nog steeds, zoals Coetzee het formuleerde, "a territory 'outside' history"

Veel historici hebben zich afgevraagd waarom het platteland zo achterbleef op de road to freedom. Gebrek aan voedingsbodem voor verzet was er op het platteland niet bepaald, ook geen gebrek aan verzet. De landwetten van 1913 waren van grote betekenis bij de oprichting van het ANC; in de jaren veertig en vijftig maakte het ANC gebruik van plattelandsopstanden om een brede, nationale basis te kweken; in de jaren zestig en zeventig bleven plattelandsbewoners zich openlijk en heimelijk verzetten tegen het Apartheidsregime. Desalniettemin wist de landelijke politiek er niet op te reage-

\footnotetext{
${ }^{577}$ Levin \& Weiner 1996, 97

${ }^{578}$ Zie hoofdstuk 2

${ }^{579}$ Levin \& Weiner 1996; 98

${ }^{580}$ Mulqueeny betoogt bijvoorbeeld dat het beeld van de Bantustans als onderontwikkelde, conservatieve bolwerken die slechts dienden tot reproductie van arbeidskrachten voor blank ZuidAfrika, in feite een verhulling was van (vaak vrouwelijk) verzet tegen machtsstructuren en van onafhankelijke agrarische productie (Mulqueeny, 1996)

${ }^{581}$ J.M. Coetzee 1988, 11 Zie ook hoofdstuk 2
} 
ren $^{582}$, deels omdat een aantal eigenschappen van het platteland en haar bevolking weinig bevorderlijk waren voor een grootschalige organisatiegraad. De infrastructuur was minimaal. Daarnaast speelden persoonlijke achtergronden en geschiedenis altijd een belangrijke rol $^{183}$, waardoor de veel voorkomende sociale fragmentatie op grond van etnische, klasse-, sekse- en genderverschillen, generatiekloven en tegenstellingen tussen lineages de kans op massale actie aanzienlijk verkleinden ${ }^{584}$. Verzet had op het platteland een ander gezicht. Men vocht voor toegang tot een rivier of waterput; het gebruik van weidegrond; het recht om te jagen in natuurreservaten ${ }^{585}$; of het recht ergens te wonen ${ }^{586}$. Men vocht, kortom, voor behoud van controle over de eigen arbeid en de daarmee samenhangende culturele identiteit, "that is, the struggle to control the reshaping of the symbols and institutions associated with subsistence farming." 587 Dit uitte zich in kleinschalige acties, van het onthouden van arbeid tot bedekte vergeldingsacties, die in de jaren negentig steeds minder bedekt werden. In tijden van droogte liepen de spanningen geregeld uit op gewelddadige conflicten. ${ }^{588}$

$\mathrm{Nu}$ Zuid-Afrika volledig postkoloniaal geworden is, kunnen eindelijk de "problems of transmuting time into space, with the present struggling out of the past" ${ }^{\prime 89}$ worden aangepakt. De frustrerende nadruk op deconstructie van de Zuid-Afrikaanse (tekstuele) realiteit was deels noodzakelijk omdat alternatieve informatie domweg ontbrak. Andere opvattingen en betekenissen die door recent onderzoek naar boven zijn gekomen, vragen om nieuwe interpretaties van historische en literaire ontmoetingen. Nieuw is bijvoorbeeld de wetenschap dat op de blanke boerderijen zelf verzet tegen de bestaande verhoudingen veel aanweziger, maar ook onzichtbaarder, of ondefinieerbaarder was dan men tot dusver dacht. De concrete ruimte waar men voor streed, bleek gekoppeld te zijn aan een symbolische of rituele ruimte, die met heel eigen, "unheimliche" middelen werd bevochten ${ }^{50}$. Meer dan iets anders is de blanke boerderij in de twintigste eeuw een "contact zone" gebleven "between African and western conceptions, perceptions and practices of power and authority," het toneel van crossculturele "communication and (..) misunderstanding"

\footnotetext{
${ }^{582}$ Colin Bundy. Land and liberation: the South African national liberation movements and the agrarian question 1920-1960. In Review of African political economy 29(1984) 14-29: 28; Mulqueeny, 1996; 91

${ }_{583}$ Aninka Claessens "Contemporary Land Struggles in Rural Transvaal," Antipode 23.1(1991): 144

${ }^{584}$ Bernstein 1996, 39

585 "Competition for power and space around issues of land and water have been a continuous struggle for Africans in rural South Africa in a context of limited resources for, and severe repression of, rural political organisation.' (Levin \& Weiner 1996; 98)

586 "This Umlungu (white man) has evicted me six times and I kept on coming back. (..) There is no reason why I should leave. I will die here. I will not leave even if they shoot me with a gun. This is my father's place and as an elder son I have inherited it." Geciteerd in Dithlake 1997, 222

${ }^{587}$ Mulqueeny 1996, 92

${ }^{588}$ Cousins 1996; 191

${ }^{589}$ Ashcroft et al. 1989, 36

${ }^{590}$ Zie ook hst. 4

${ }^{591}$ Crais 2002, 6
} 
openbare discours van onaantastbaar, gelegitimeerd blank landbezit waarin zwarte boeren geen rol van betekenis speelden, werd op de boerderijen voortdurend ondergraven door de dagelijkse praktijk van zowel samenwerking als tegenwerking. Er onstond een onderhuidse, niet publiekelijk erkende werkelijkheid, die, als Freuds onderdrukte bewustzijn, zich een weg naar buiten zocht in morbide fantasieën. Net als in de weergave van het "ongastvrije" Zuid-Afrikaanse landschap waren zowel schuldgevoel als de praktijk van onderdrukking hier debet $a{ }^{592}$, maar tegelijk vonden de geestverschijningen die het gevolg waren van die fantasieën weerklank in de Afrikaanse werkelijkheid. Tekens van de aanwezigheid van de Ander wáren in niet-Afrikaanse ogen zo niet morbide dan toch unheimlich want ongrijpbaar: graven; heiligdommen; vooroudergeesten; magische krachten; onaanwijsbaar, maar wel voelbaar protest.

In 1962 verscheen weer een belangrijke en invloedrijke plaasroman: Sewe dae by die Silversteins van Etienne Leroux, "een van die duidelikste manifestasies van die vernuwing van Sestig" ${ }^{993}$ genoemd. Het boek riep vele, tegenstrijdige reacties op in de Afrikaner gemeenschap ${ }^{54}$. Het won een belangrijke literaire prijs, maar werd door andere critici als immoreel en "duister" beoordeeld, het eerste omdat er niet duidelijk stelling genomen werd voor goed of kwaad, het laatste vanwege de talrijke onoplosbare verwijzingen ${ }^{595}$. Het sjabloon is dat van de traditionele plaasroman, maar in plaats van een kleinschalige bedrijf treffen we hier een grote wijnboerderij hét voorbeeld van commerciële landbouw en dus van verwording van de oude plaasromanwaarden. En in plaats van tegen de elementen, schuldeisers en voorouders, strijden de personages tegen "die bose geeste in die lug" ${ }^{966}$ : chaos en decadentie. Behalve voor geesten blijkt Leroux ook gevoelig voor Adamastors aanwezigheid: in een volgend boek, Een vir Azazel (1964), keert Welgevonden terug, ditmaal als decor voor een detectiveroman. Hierin wordt de detective die een moord op de boerderij moet oplossen misleid door zijn assistent, die hem wijsmaakt dat hij, net als Herakles, tot taak heeft reuzen te vernietigen. De onschuldige, maar reusachtige plaasidioot wordt hiervan het slachtoffer ${ }^{597}$.

In de Engelstalige poëzie heeft Adamastor zich inmiddels ontwikkeld tot een politieke belofte, zij het soms eveneens met meewarige ondertoon: "I will walk again ... when I can get up" "'598. De reus heeft in de meeste teksten nog steeds iets dubbels: als projectie van koloniale gevoelens van onbeha-

\footnotetext{
${ }^{592}$ Wagner 1994, 168

${ }^{593}$ Botha 1998, 587

${ }^{594}$ Leroux was behalve schrijver ook boer op een boerderij die "Ja-Nee" heette en onderdeel was van het groot-grondbezit van zijn familie. In 1990 werd hij daar op het familiekerkhof begraven.

${ }^{595}$ Botha 1998, 587

${ }^{596}$ Leroux 1962

${ }^{597}$ Zie ook Botha 1998, 593

${ }^{598}$ Douglas Livingstone "The sea my winding sheet", Sjambok, and other poems from Africa. London, 1964
} 
gen is hij onderwerp van spot, maar hij heeft ook een andere, nog steeds dreigende kant: een verdrongen of nog onbekende Afrikaanse werkelijkheid die die gevoelens van onbehagen oproept. De onzichtbaarheid van die werkelijkheid leidt in toenemende mate tot een zwijgend Afrika ${ }^{599}$. In de jaren die volgen neemt Adamastor steeds meer ruimte in. Zowel The conservationist (1974) als Kroniek van Perdepoort (1975) luidden het einde in van de boerenmythe en geven daarmee ruimte aan de wederkomst van veel oudere helden. In The conservationist beginnen die helden met behulp van abathakathi (heksenkracht) door de beschermende laag van schuld- en (de)constructiegeesten heen begint te breken, zodat "the giant (..) [becomes] the main character of Gordimer's The conservationist, Adamastor resurrected"

\footnotetext{
${ }^{599}$ Wyk Smith 1988, 35

${ }^{600}$ Gray 1979, 158
} 
That which is beyond all consciousness cannot be thought about or experienced by the mind. But what is it then that has perceived and is aware of something totally different from the projections of the mind? Who is it that experiences it?

P.Jayakar: J.Krishnamurti. A biography.

\section{Eva, amandla en abathakathi Scheppingsmythen en transformatierituelen in The conservationist}

\section{$5.1 \quad$ INLEIDING}

"I believe that the chief gift from Africa to writers, white and black, is the continent itself; its presence which for some people is like an old fever, latent always in their blood; or like an old wound, throbbing in the bones as the air changes. That is not a place to visit unless one chooses to be an exile ever afterwards from an inexplicable majestic silence lying just over the border of memory, or of thought," schreef Doris Lessing in 1981 ${ }^{601}$. De onverklaarbare, majestueuze stilte van Afrika verwijst in dit geval naar de post-exotische representatie van Afrika als symbool voor een diep weggestopte spirituele kracht. Een dergelijke, voor sommigen nauwelijks waarneembare kracht projecteert ook Nadine Gordimer in het landschap als ze in 1990 spreekt over The conservationist:

There's always something mysterious and wonderful about walking anywhere in the country and finding some humble and persistent element of life, like bird's eggs: so fragile, but just there. And then (..) that farmer, Mehring, chases the black children who are playing with the eggs, because they are going to destroy them. (..) But there's a feeling that comes from the black part of his brain, that he does not know what he is seeing. Just as when he sees those eggs at the beginning - the "pale freckled eggs" - he sees different things from what the kids see. ${ }^{602}$

\footnotetext{
${ }^{601}$ Doris Lessing "Preface" African Stories.1981 6

${ }^{602}$ Dorsman \& Postel 1993: 49-50
} 
Over The conservationist is al veel geschreven. In de dertig jaar nadat Gordimer het boek schreef is het elke paar jaar wel een keer grondig herlezen en opnieuw geïnterpreteerd. Van een pessimistisch boek waarin de kloof tussen blank en zwart onoverbrugbaar wed neergezet en het lot van de blanke Zuid-Afrikaan gedoemd leek, is het in de ogen van critici veranderd in een roman die zowel op verschillen als overeenkomsten wijst. De onmiskenbaar unheimliche kenmerken van dit boek dragen bij aan die veranderlijke interpretatie. De aanwezigheid van de dood in het domein van de levenden, van illegale autochtonen en gelegaliseerde vreemdelingen in een met talloze grenzen doorsneden land, van stemloze personages, onderdrukte oorsprongsmythen en halfvergeten rituelen, maar vooral ook van wat Gordimer hierboven noemde "the feeling that comes from the black part of [Mehring's] brain that he does not know what he is seeing", leiden tot een dubbelzinnigheid die er uiteindelijk voor zorgt dat "de" betekenis van het boek blijft ontglippen en veranderen. Zoals Lars Engle opmerkte:

Good novels have in them the uncanny materials that let them continue to mean in different ways under new conditions of reception. (...) [T] he Conservationist speaks to [political/economical] transformation even as it spoke to the apparent historical impasse which preceded it, and (..) it does so not by simply authenticating black claims and denying white ones, but by mapping subtle and largely unseen axes of similarity which coexist with the imposed differences of Apartheid." ${ }^{003}$

Gordimer doet inderdaad twee dingen tegelijk, en die dubbelzinnigheid heeft te maken met de ambivalentie die inherent is aan de dood. Ze laat zien hoe een onvermijdelijke mythische intertekstualiteit - waarin de dood een centrale metaforische positie inneemt - ten grondslag ligt aan de patstelling van de jaren zeventig en dat ook zij daaraan niet ontkomt. Tegelijkertijd suggereert ze echter een uitweg, niet door een politieke revolutie te voorspellen of een nieuw sociaal systeem te presenteren, maar door de individuele lezer een methode aan te reiken, in de vorm van een ritueel, waarmee hij /zij zich uit de sociale en politieke realiteit (als tekst) kan bevrijden.

Het feit dat in The conservationist van begin tot eind een zwarte man oppervlakkig begraven ligt op Mehrings land, is cruciaal voor deze interpretatie. Als zijn lijk wordt gevonden aan de oever van de rivier, waarschuwt Mehring de politie, maar in plaats van hem op te halen, dekken de agenten hem toe met wat aarde. Mehring weet dit, en het verandert hem. Hij komt steeds vaker naar de boerderij. Zijn drukke maar oppervlakkige stadse leven begint hem tegen te staan en als het even kan, wijkt hij uit naar de stilte van het platteland en met name van de rivieroever. Daar is hij zich

${ }^{603}$ Engle 1993, 106 
altijd vaag bewust van de aanwezigheid van het lijk; soms vriend, soms vijand, maar altijd fascinerend. Totdat het lijk na een overstroming boven is komen drijven. Mehring vlucht in doodsangst terug naar de stad. Het lijk wordt, ten slotte, keurig begraven.

Ruimte en intertekstuele verbanden zijn in dit verhaal belangrijke generatoren van betekenis. Handelingen lijken bijna geen rol te spelen; Mehring, protagonist en belangrijkste focalisator, handelt vreemd genoeg nauwelijks. Ook is hij vrijwel nooit object van handeling. Zijn tekst bestaat voor het overgrote deel uit herinneringen, observaties, gedachten en verplaatsingen, vooral heen en terug tussen stad en boerderij en tussen huis en vlei ${ }^{604}$. Met name die laatste repeterende verplaatsing roept vragen op. Wat zoekt hij, en waarom daar?

Van de handelingen die wel plaatsvinden, hebben de belangrijkste bovendien geen aanwijsbaar subject. Een man is vermoord; het lichaam wordt verstopt, wordt weer gevonden en begraven, maar moordenaar, noch slachtoffer worden geïdentificeerd. De relatie tot de hoofdpersoon is onduidelijk. Voor zover we weten veroorzaakte Mehring deze gebeurtenissen niet en evenmin brachten de gebeurtenissen wezenlijk verandering in Mehrings situatie. Desalniettemin is de rationele, beheerste, wat cynische man uit het begin van het boek aan het eind behoorlijk de weg kwijt. Wat is er gebeurd?

Dat de The conservationist zo onheilspellend is, komt vooral doordat betekenis niet zozeer wordt gegenereerd door wat er gebeurt, maar door wat er zou kunnen gebeuren ${ }^{605}$. Potentiële scenario's worden voor een groot deel opgeroepen door de ruimte die Mehring -als belangrijkste focalisatorwaarneemt. Bij nadere beschouwing blijkt dat de beelden en metaforen met behulp waarvan hij zijn omgeving, met name de vlei, waarneemt en dus ordent, terug te voeren zijn op betekenisvolle ruimtes in koloniale en religieuze mythen. Die intertekstueel geladen ruimtes (bijvoorbeeld de vlei als paradijs) worden in het hoofd van de lezer gekoppeld aan verhalen, waardoor Mehrings observaties een voorspellende waarde krijgen (Adam zal worden verbannen). Tegelijkertijd wordt de onontkoombaarheid van Mehrings lot doorkruist door de aanwezigheid van andere, soms minder in het oog springende intertekstuele verbanden. De vlei blijkt een brandpunt te zijn van ondermeer Europese en Afrikaanse scheppingsverhalen, koloniale mythen en Zulu rituelen. Het is vooral deze ambivalentie die Mehring in verwarring brengt. In welk verhaal bevindt hij zich? Hij staat voor de schijnbaar tegenstrijdige opgave om voor zichzelf een "noodlot" te kiezen.

\footnotetext{
${ }^{604}$ (Moerasachtige) laagte, plek waar water zich verzamelt in regentijd.

${ }^{605}$ Zie ook Clingman, 167
} 


\subsection{GORDIMERS HOOGVELD}

Gordimer heeft in haar oeuvre aan de twee door Coetzee gedefinieerde ideaalbeelden van het Zuid-Afrikaanse landschap ${ }^{606}$ - het lege, onbezoedelde landschap en het bewoonde, ingerichte landschap - haar eigen draai gegeven. Kathrin Wagner toont aan dat ze in haar werk bijna altijd gebruik maakt van de tegenstelling tussen een onaangenaam kaal en droog landschap enerzijds en een aangenaam groen en vruchtbaar landschap anderzijds. Aanvankelijk speelden hierin vooral gevoelsmatige motieven een rol: had Gordimer niets met het droge, kale landschap van Witwatersrand, waar ze woonde. Het bevatte geen schoonheid, want schoonheid, zo leerde ze in de boeken die ze als kind tot haar beschikking had, was gekoppeld aan een idyllische Europees landschap of een exotisch Afrika. "We children simply took it for granted," schrijft Gordimer zelf, "that beauty - hills, trees, buildings of elegance - was not a thing to be expected from ordinary life." ${ }^{607}$ Het landschap fungeerde voor haar slechts als leeg, betekenisloos decor voor de respectloze en inhalige bedrijvigheid van haar volk. "All around us the shafts went down, and the gold came up; our horizon was an Egyptian looking frieze of man-made hills of cyanide sand, called 'dumps', because that is what they are (...). It is characteristic of the Witwatersrand that any feature of the landscape that strikes the eye, does so because it is a reminder of something else; considered on its own merits, the landscape is utterly without interest - flat, dry and barren." ${ }^{608}$

En dus, ondanks het feit dat Gordimer zich bewust was van de vervreemding die de stereotiepe beelden van Afrika voor haar zelf tot gevolg hadden gehad, haakten diezelfde beelden zich onwillekeurig vast in haar denken. Zowel de Engelse opvatting van landschappelijk schoon als de koloniale constructies van Afrika als exotisch enerzijds en vijandig en ontoegankelijk anderzijds ${ }^{609}$, verwerkte ze tot een symbolische tegenstelling. Groen landschap (in Natal, de Kaap, of Europa) verwijst naar leven, hoop en sensualiteit, terwijl "most of what is repudiated or found lacking in the novels is contextualised within metaphors of drought, bleakness, barrenness, colourlessness and ugliness" ${ }^{10}$, stelt Wagner, en daarmee "the basic elements of Schreiner's archetypically alienated Karoo are reinscribed in the arid landscapes of the Transvaal Highveld" ${ }^{\prime 11}$.

\footnotetext{
${ }^{606}$ Zie inleiding

${ }^{607}$ N. Gordimer "A South African childhood: Allusions in a landscape." The New Yorker 30 (1954): 112

${ }^{608}$ Gordimer "A South African childhood: Allusions in a landscape“. The New Yorker 30 (1954): 111-

112

${ }^{609}$ Zie ook hst 3

${ }^{610}$ Wagner 1994, 183

${ }^{611}$ Wagner 1994, 215
} 
In de periode dat ze The conservationist schreef, bevond Gordimer zich op een kruispunt in haar denken. In de loop der jaren heeft ze een ontwikkeling doorgemaakt die door critici vaak gezien is als de uitbreiding van een persoonlijk naar een breder sociaal-politiek kader, of als deconstructieproces van Zuid-Afrikaanse koloniale mythen. Stephen Clingman beschouwt in zijn invloedrijke studie The novels of Nadine Gordimer. History from the inside (1986) Gordimer als typerend voor haar plaats en tijd en wijdt haar groeiend bewustzijn aan interactie met haar omgeving. Het verbannen en gevangen zetten van zwarte politici en schrijvers in de jaren zestig en zeventig, de opkomst van de Black Consciousnes Movement die samenwerking met blanken radicaal van de hand wees en het daaruit voortvloeiende isolement van blanke symphatisanten, maakten Gordimer bewust van de beperkingen van haar blikveld en haar mogelijkheden. Toch was ze niet alléén een produkt van haar tijd, want hoewel ze erop hamerde dat blanke Zuid-Afrikaanse schrijvers zich vooral dienden bezig te houden met de deconstructie van hun eigen denken, kon ze het toch niet laten de grenzen van de haar opgelegde beperking op zijn minst te tarten, en dát was in haar oeuvre niets nieuws. David Ward (1989) bijvoorbeeld ziet in deze jaren vooral een continuering van haar persoonlijke thematiek, zij het in een wat ander jasje; thema's als de Ander, de dood, de eigen integriteit, de marginaliteit van het menselijk bestaan. Wat ook altijd terugkeert is de wens om te ontsnappen aan alles wat begrenst, zelfs aan de grenzen van haar fictie. Ze wil, als het ware, over de horizon schilderen: "[t]here is a sense in which the whole fiction is designed to point out of itself, out of the whole protocol of European fiction, to a historical reality which finally engulfs it" ${ }^{\prime 12}$.

Wagner bestrijdt dat Gordimer heeft kunnen losbreken van haar achtergrond. Het verlangen naar ontsnapping dat personages in oudere teksten tentoonspreiden, is volgens Ward gekoppeld aan een doodswens, maar in Wagners ogen aan een verlangen om op te gaan in de natuur. Wat Ward omschrijft als destructie, interpreteert Wagner als regeneratie: Gordimer, zegt ze, zag de oplossing in transformatie: jezelf verliezen om opnieuw geboren te kunnen worden. Maar met het groeien van haar bewustzijn, werd niet alleen de ontmoeting met de ander steeds problematischer, maar kreeg ook het ter zuivering terugtrekken in de natuur (als voorwaarde voor transformatie) iets ongepasts. Vanaf dat moment verliest haar landschap zijn romantische betekenis en wordt het alleen nog gebruikt als onderdeel van ideologische tegenstellingen. Het Hoogveld wordt symbool voor de troosteloze realiteit van apartheid, kapitalisme, vervreemding, isolement en ballingschap, dat de blanke Zuid-Afrikaan onder ogen zal moeten zien. Het groene landschap krijgt daarentegen een utopische lading; het is het verlangde paradijs dat (nog) niet bereikbaar is voor de blanke Zuid-Afrikaan.

${ }^{612}$ Ward 1989, 130/1 
Gordimer noemt zichzelf "a romantic struggling with reality" ${ }^{13}$; ondanks haar eigen romantische inslag worden pastorale en romantische impulsen van haar personages vanaf nu geïroniseerd. Het zoeken van verlossing of vergetelheid in Europa of in eenheid met de natuur voordat de politieke issues zijn opgelost, beschouwt ze als een vlucht uit de realiteit - en als zodanig moreel verwerpelijk. Het werkelijke leven speelt zich af op de dorre vlakte van het Hoogveld, hoe troosteloos ook ${ }^{614}$.

Toch lijkt in The conservationist Gordimers romantische bloed, haar geloof in helende en transformerende krachten, te kruipen waar het niet gaan kan. Het is een van de weinige romans die zich bijna volledig op het Hoogveld afspeelt, terwijl de bekende tegenstelling zich hier volgens Wagner openbaart in een "ironic, anti-pastoral contrast" 15 tussen stad en platteland. De titel heeft een dubbele, inderdaad ironische betekenis: Mehring ziet zich als natuurbeschermer, maar is in feite vooral cultuurbeschermer; zijn "natuur" bevindt zich binnen de cultuurgrenzen. De twee in de vorige paragraaf geformuleerde literaire doelstellingen, namelijk bescherming van de culturele orde in een vijandige natuur of (re)creatie van een culturele orde in een paradijselijke natuur, vallen hier met enige spot samen. Maar anti-pastoraal is de roman vooral vanuit Mehrings perceptie, in zijn ogen kan de natuur uiteindelijk "no longer be constructed as 'a land of dreams', but is in fact the a bleak battle for survival without divine pupose" ${ }_{116}$. Tegelijkertijd probeert Gordimer daadwerkelijk transformatie als serieuze oplossing aan te bieden én de beperkingen of onmogelijkheden ervan te laten zien in een wereld en een tijd als die van Mehring - en van haarzelf. Een analyse van de onderliggende structuur kan Gordimers gebruik van ruimte in The conservationist inzichtelijk maken en laten zien hoe alternatieve percepties, ondanks de blinde vlekken van focalisator en schrijver, ruimte krijgen in een tekst.

\subsection{MEHRINGS RUIMTE}

De primaire locatie van The conservationist is een deel van een ZuidAfrikaanse hoogvlakte met een rivier en meerdere gebouwen. Iedere minder summiere omschrijving zou al niet meer door alle personages worden onderschreven en dus tot space, ruimte horen. Een tweede locatie is Johannesburg, met Mehrings flat, zijn kantoor, een café, en de woningen

\footnotetext{
${ }^{613}$ Nadine Gordimer, A Writer in South Africa, 1965: 28

${ }^{614}$ Wager 1994, 215. Wagner concludeert hieruit dat "[Gordimer's] work is firmly linked to both metropolitan and colonial iconologies which she modifies and varies rather than abandons entirely," (215) Dat Gordimer vooral buiten Europa bejubeld wordt, is volgens Wagner niet voor niets. Een tekst die voor een Zuid-Afrikaan vol staat met koloniale cliche's en daarom weinig vernieuwend of verlossend is, bevat voor een Europeaan net voldoende houvast om de vreemde wereld te begrijpen. ${ }^{615}$ Wagner 1994, 192

${ }^{616}$ Gifford, 120
} 
van vrienden. De autoweg langs de minedumps en het zwarte arbeidersghetto, vormt de verbinding tussen de eerste en de tweede locatie. Deze locaties krijgen in eerste instantie betekenis door hun relatie tot elkaar en tot andere elementen uit de fabula, bijvoorbeeld confrontaties tussen actoren. ${ }^{617}$ In The conservationist blijken locatie en confrontatie vaak aan elkaar gekoppeld te zijn $^{618}$, vooral in de vlei, waar het landschap zelf gepersonifieerd wordt. Dit blijkt uit de manier waarop Mehring (op verhaalniveau) de vlei waarneemt, maar ook uit het feit dat hij een relatie opbouwt met de vlei zoals hij dat doet met andere personages, volgens een terugkerend, vast stramien.

De belangrijkste (levende) tegenspelers van Mehring zijn Terry, Antonia en Jacobus. Mehring maakt met Terry ongeveer hetzelfde mee als met Antonia: zijn uitnodiging wordt afgeslagen, de ander vraagt om hulp, hij biedt hulp, de geliefde vertrekt. Bij andere personages herhaalt deze sequens zich min of meer, maar altijd vanuit Mehrings focalisatie; het lijkt een manier te zijn waarop hij zichzelf een hem vertrouwd lot toeschrijft. Onveranderlijk staat in deze reeks gebeurtenissen een open ruimte tegenover een besloten ruimte, een door Mehring ingekleurd "buiten" tegenover "binnen", terwijl er een halfslachtige poging wordt gedaan een ander van buiten naar binnen te lokken. De ontmoeting is onderwerp van verlangen, maar ook van angst: het uitblijven van de ontmoeting wordt achteraf door Mehring vaak getypeerd als een narrow escape $e^{619}$ - waarbij hij zijn angst onveranderlijk projecteert op de Ander.

Als Mehring bijvoorbeeld op oudjaarsavond aankomt op de boerderij, staat Jacobus hem, enigszins dronken, op te wachten: "Baas, I'm going to wake you up, twelve o'clock. Knock on the door" (203). In eerste instantie interpreteert Mehring Jacobus' woorden als een uiting van vriendschap en hij nodigt hem uit om whiskey te komen drinken. Jacobus begint te lachen. Mehring, die de hele avond vergeefs op hem zit te wachten, valt ten slotte buiten in slaap, terwijl de geluiden van het oudjaarsfeest in de compound half tot hem doordringen. De volgende ochtend heeft hij het vage gevoel aan iets vreselijks ontsnapt te zijn.

Mogelijk is zijn angst gewekt door de herinnering aan een historische knock on the door. In 1835 brak een slavenopstand uit toen bleek dat, ondanks geruchten die daarop wezen, de slavernij na nieuwjaar nog niet was afgeschaft, een gebeurtenis die destijds "continued to haunt the [slave]

\footnotetext{
${ }^{617}$ De vele verwijzingen naar The conservationist worden in dit hoofdstuk slechts weergegeven door een paginanummer tussen haakjes.

${ }^{618} \mathrm{Op}$ de boerderij vinden de confrontaties plaats met Jacobus (in en rond het farmhouse) en het lijk (in de vlei). In de stad ontmoet Mehring zijn collega's en vrienden en hun kinderen. Een liftster ontmoet Mehring tweemaal langs de autoweg. Zijn zoon Terry is de enige in het primaire verhaal die behalve in de stad ook eenmaal op de boerderij aanwezig is. Ten slotte zijn er nog een paar prominente nietconfrontaties: die tussen Mehring en zijn ex-vrouw, zijn ex-minnares en zijn ouders of verzorgers. Zij wonen allemaal buiten Zuid-Afrika.

${ }^{619}$ Zie appendix
} 
owners" ${ }^{20}$. In 1920 bijvoorbeeld, "numerous rumours were flying about amongst (..) farmers that a native rising had been planned for christmas or New Year's Day" ${ }^{21}$. Maar Mehrings "bewustwording" van dit historisch conflict - en van zijn eigen "historische" angst - is eigenlijk niet meer dan een dekmantel voor wat hem werkelijk angst aanjaagt: de herinnering aan wat hij die nacht heeft ervaren - waarover later meer.

In elk geval verraden de zich herhalende fabula's, en tegen dat licht ook Mehrings herhaalde bezoekjes aan de vlei, zijn heimelijk en ambigu verlangen naar en angst voor intimiteit en een gedeelde identiteit: samen met iemand binnen zijn. Buiten is in alle gevallen open, eerzaam en eenzaam, vol mensen die van elkaar gescheiden zijn door de realiteit, dwz: opvattingen, leeftijd, ras, afstand, tijd, wettelijke beperkingen en sociale mores; binnen is afzondering, beschutting, schemering; een fantasiewereld waarin een intimiteit kan bestaan die de grenzen van het realisme of het toelaatbare overschrijdt. Ook de verplaatsingen tussen vlei en farmhouse, boerderij en stad zijn verplaatsingen tussen binnen en buiten. Sterker nog: in het primaire verhaal is er uiteindelijk maar één met wie Mehring herhaaldelijk een intiem samenzijn heeft in een binnenruimte, en dat is met (de dode man in) de vlei ${ }^{622}$.

\subsubsection{Stad \& land; erf \& vlei}

Eerder bleek een handelend subject te ontbreken bij de belangrijkste gebeurtenissen van The conservationist. Maar zelfs bij de handelingen die hij verricht, namelijk zijn verplaatsingen, is Mehring eerder object dan subject. In zijn eigen beleving beweegt hij zich zelden doelbewust naar de vlei; hij Loopt "like an old horse" (75), onwillekeurig altijd dezelfde route ${ }^{623}$. Andersom vlucht hij er regelmatig weg. Wat hem daar heen lokt en vandaan drijft, blijkt pas als van de locatie een waargenomen ruimte wordt gemaakt.

In Mehrings ogen is er aanvankelijk geen duidelijke scheidslijn tussen stad en land; de overgang is net zo geleidelijk en schimmig als die tussen Mehring als ondernemer en Mehring als boer (23). Onderweg van zijn flat naar de boerderij moet Mehring eerst een gebied doorkruisen dat gekenmerkt wordt door lelijkheid, nut en afval: buitenwijken, industriegebied, "factories with landscaped gardens", supermarkten, snackbars en de oude minedumps die Gordimer al kende in haar jeugd - het afval van Mehrings

\footnotetext{
${ }^{620}$ Giliomee 2003b, 111 André Brink schreef over deze opstand de roman Houd-den-Bek (1982)

${ }^{621}$ Murray 1989, 119

${ }^{622}$ Zodra de man "begraven" is, laat Mehring hem ahw verdwijnen in of samenvallen met de ruimte (vlei); hij duidt hem alleen nog aan met de plaatsaanduiding "down there" (Gordimer 21).

623 "Everything has its range. (..) A closed system. No farther. Wherever he sets out from, or however without direction he seems to roam, on his farm, it's always here that he ends up. Down over the third pasture at the reeds. Peacefull of course." (75).
} 
rijkdom. Dan volgt een vuilnisbelt en een "endless" omheinde locatie met 150.000 zwarte arbeidskrachten. Op het eind van de locatie slaat Mehring links af, een zandweg op - links nog steeds geflankeerd door de omheining van de locatie en rechts door de oude, armoedige troep van zijn buren.

Dan wordt het beter. Na een bocht in de weg kan hij zijn boerderij zien liggen en in een poging ernaar te kijken vanuit de ogen van vroegere gasten, schetst hij een beeld dat niet past in de tegenstelling die Wagner uiteenzette:

From that point on you could see the farm, the mile of willows (people remarked that it would have been worth buying for the willows alone) in the declivity of two gently rising stretches of land, see the Katbosrand in the distance, see the house nobody lived in. No one would believe (they also said) the city was only twenty-five miles away, and that vast location was just behind you. Peace. The upland serenity of high altitude, the openness of grassland without indigenous bush or trees; the greening, yellowing or silverbrowning that prevailed, according to season. A landscape without theatricals except when it became an arena for summer storms, a landscape without any post-card features (..) - a typical Transvaal landscape that you either find dull and low keyed or preferred to all others (they said). (24).

Dit Transvaal is niet het lelijke, dorre Transvaal uit de tegenstelling van Wagner; Schreiners "land of rock and sun" ${ }^{224}$. het bevat evenmin de vervuilde kenmerken die een herinnering zijn aan menselijke hebzucht. Wat overblijft is ruimte en rust; een leeg en onbewoond landschap, een onbeschreven blad, op de Europese wilgen na. De verbeelding van het ZuidAfrikaanse landschap als leeg, is onderdeel geweest van een mythe die lange tijd gebruikt is om de koloniale geschiedenis te rechtvaardigen. "Traders operating from the European settlement Post Natal had an interest in reporting that the region had recently been cleared of its African population by the tyrant Shaka because they were trying to establish claims to large tracts of land at a time when the Cape government was attempting to prevent further acquisition of territory. Along with their financiers in Cape Town, they promoted the British annexation of Natal by depicting Shaka as a dangerous monster."' 225

Voor zover het land inderdaad onbewoond was, was dit een gevolg van het feit dat de bevolking op de vlucht was geslagen voor oorlog en politieke instabiliteit - een situatie waar ook Europese kolonisten en handelaren aan hadden bijgedragen. Sterker nog, de mythe zelf bevatte een akelige tegen-

\footnotetext{
${ }^{624}$ J.M. Coetzee 1988,7

${ }^{625}$ Chidester 1996, 119
} 
strijdigheid. Ten eerste moest het gebied verlost worden van Shaka en zijn Zulu's, want Shaka was zo'n monster dat iedereen op de vlucht was geslagen. Ten tweede woonde er niemand, dus het land lag klaar voor Europees gebruik. Dit was het beeld waarmee het Noordelijk deel van Zuid-Afrika op de kaart werd gezet: "[t]hese two themes - the vacant, depopulated land and the dominance of the Zulu nation under the tyrant Shaka - whether exaggerated or fabricated, persisted in the earliest European reports from Natal." ${ }_{626}$ Ofte wel: hoe leger het land, des te wreder en aanweziger de Zulu's. Een land vol onzichtbare Zulu's. De kiem voor een leeg landschap vol dreiging, een, zoals Itala Vivan het formuleerde, "paranoia generating emptiness" ${ }^{27}$, is mede hier gelegd.

Coetzee (1988) liet zien dat het lege landschap in de (anti-)pastorale letteren uitgroeide tot een van de twee ideale landschappen, die beide de dreiging van onderhuids gevaar met zich mee bleven dragen. Zoals zal blijken is Mehrings waarneming van het landschap onomkeerbaar beïnvloed door dergelijke teksten, zelfs wanneer hij zich terdege van die beïnvloeding bewust is. In bovenstaande passage is zijn beschrijving enigszins ironisch. Hij distantieert zich ervan door zijn uitspraken anderen in de mond te leggen. Hij weet dat de leegte schijn is. Hij weet ook dat het onbewoonde huis erop wijst dat hij zélf de onzichtbare aanwezige is. En toch heeft hij niet echt een antwoord op dit beeld - hij zit er als het ware in gevangen. Dat laatste komt ook tot uiting in de ruimtelijke structuur: het door Mehring waargenomen lege, serene, open landschap dat van oorsprong diende om de grootsheid van de Afrikaanse natuur en de nietigheid van de mens te illustreren, behelst hier zijn eigen territoriumpje dat als een enclave ligt ingeklemd tussen uitgestrekte gebieden vol mensen, rommel en stedelijk afval. Het is dan ook een van de weinige keren dat Mehring zijn hele terrein in ogenschouw neemt. Over het algemeen houdt hij zijn blikveld zo klein mogelijk, kijkend naar de grond onder zijn voeten, gefocust op details, of liggend in het lange gras. Want hij hoeft zijn ogen maar op te slaan of hij ziet - ja, wat? Wellicht toch die ene component van Wagners tegenstelling - de realiteit van apartheid, kapitalisme, vervreemding, isolement en ballingschap, die de blanke Zuid-Afrikaan onder ogen zal moeten zien en die Gordimer situeert in het Transvaalse landschap? Ook. Maar hij ziet vooral Zulu's.

Dus werpt Mehring zich op als de beschermheer van het laatste stukje koloniaal oer-Afrika. Hij is zich in toenemende mate bewust van de grenzen van zijn territorium, van de veiligheid en rust die hij daarbinnen hoopt te vinden en de bedreigingen van buitenaf. Mehring lijkt de enige te zijn die zich van zijn grenzen iets aantrekt. Zowel Afrikaanse als Afrikaner buren gebruiken zijn land als een "short cut" $(56,140)$ : Pringles wetteloze "black

\footnotetext{
${ }^{626}$ Chidester 1996, 119

${ }^{627}$ Vivan 2000, 55
} 
and white bandits". En uiteindelijk zal het uitdijend leger van zwarte arbeidskrachten hem overspoelen: er zijn plannen om de locatie naar het noorden toe uit te breiden. Ook het gebied rond het huis, de compound en de vlei zijn allemaal scherp omlijnde binnenruimtes in Mehrings beleving. Hekken, greppels, brandgangen en muren dienen om de illusie van beheersbaarheid en onveranderlijkheid in stand te houden. Maar ook deze grenzen zijn niet waterdicht

\subsubsection{Hof van Eden \& Land van God}

Aan de hand van een aantal passages kan Mehrings ruimte nader worden ingevuld. De openingsscène laat Mehring zien die, lopend over zijn land, verwikkeld is in een strijd om de controle die hij, zonder het te willen beseffen, steeds verliest. Bij aankomst op zijn landgoed ziet Mehring tot zijn ergernis de kinderen in het derde weiland spelen met de eieren van het door hem beschermde parelhoen. Saillant detail in dit verband is dat de parelhoen in het Afrikaans tarentaal heet, een naam die is afgeleid van Terra Natal, de eerste Europese naam voor wat nu Kwazulu-Natal heet. Terra natal is Portugees voor "geboortegrond". Hiermee wordt meteen al een van de belangrijkste thema's van het boek angestipt: oorsprong, in historische, biologische en mythologische of spirituele $\operatorname{zin}^{628}$. Lang stilstaan bij de historische betekenis is voor Mehring niet opportuun: dit is de geboortegrond van de kinderen, en misschien van hun ouders en hún ouders, maar zeker niet van hemzelf; Mehring stamt van Duitse (voor)ouders af en is opgegroeid in Namibië. Zijn vreemdheid in deze omgeving wordt meteen duidelijk als hij de kinderen niet op hun gedrag kan aanspreken omdat hij hun taal niet spreekt, zodat hij het veld oversteekt naar de compound, op zoek naar Jacobus.

Tijdens die wandeling vervangt Mehring de historische betekenis van terra natal door de mythische. Hij loopt, met zijn blik naar de grond gericht, voortdurend zijn omgeving te benoemen. Hij determineert planten en dieren, een talige manier van toeëigenen, zoals dat ook in verschillende oorsprongsmythen gebeurt, waaronder de joods-christelijke. We zijn in het mythische land van oorsprong beland, ofte wel: het paradijs met Mehring als de nog eenzame ${ }^{629}$ Adam, die weliswaar dieren en gewassen tot zijn beschikking had gekregen, maar nog steeds iets miste ${ }^{630}$, ook al weet hij nog niet wat. Voor Adam maakte God ten slotte een vrouw.

\footnotetext{
${ }^{628}$ In de Indische spirituele traditie staat het ei bovendien symbool voor de oorsprong van de wereld, maar ook voor wedergeboorte. (Zie ook noot 64)

${ }^{629}$ Het besef van zijn eenzaamheid toont zich in de wat pruilerige bijzin: “.. past the paddock where the cows about to calve stand hugely in company, and the tiny paddock where the old bull, used less and less now, with the convenience of artificial insemination available, is always alone..." (19)

630 "En de Here God zeide: Het is niet goed dat de mens alleen zij. Ik zal hem een hulp maken die bij hem past. En de Here God formeerde uit den aardbodem al het gedierte des velds en al het gevogelte des
} 
Prompt treft Mehring een vrouw in de overigens verlaten compound, maar zij is, als "onzichtbaar" onderdeel van zijn lege landschap, duidelijk niet Eva. De compound bevindt zich op het hoogste en vruchtbaarste gedeelte van de boerderij: onbereikbaar voor de vorst (51) en voor het water in geval van overstromingen (237): eigenlijk de beste plek om te wonen. Voor Mehring is het een ontoegankelijk en in toenemende mate storend oord, omdat het letterlijk tussen het huis en de vlei en figuurlijk tussen hem en zijn eenwording met de natuur in staat. De compound verstoort zijn lege landschapmythe, zijn Adamsgevoel. Met zijn ogen kan hij zich voor de aanwezigheid ervan afsluiten, maar geuren en geluiden dringen altijd tot hem door. ${ }^{631}$ Hoe vaker hij op de boerderij verblijft, des te meer hij zich bewust wordt van de kracht en de samenhang van een gemeenschap waar hij van is uitgesloten. Sinds hij op een mysterieuze avond het hart van de boerderij heeft horen kloppen toen in de compound de drums werden bespeeld (157-160), groeit zijn onuitgesproken vermoeden dat niet het huis maar de compound het centrum is dat de boerderij in leven houdt (202), en daarmee ook zijn jaloezie en wantrouwen.

Mehring (alias Adam) is intussen nog steeds op zoek. De gemaaide klaver ruikt als de "breath from the mouth of a cow, or the mouth of a sleepy woman turned to in the morning"(10) een ervaring die hem onmiddellijk zijn hoofd doet heffen en naar de vlei kijken: "As the air plunges in him, his gaze widens and sweeps: down along the river the willows have gone blond."(11) Dáár is Eva. Blonde Eva. Verleidster, maar ook (oer)moeder, de derde, biologische betekenis van terra natal.

Dat de vlei narratologisch de functie van een personage kan vervullen komt inderdaad ondermeer doordat de boerderij, in Mehrings ogen, de vorm heeft van een vrouwenlichaam. De compound is het hart; het huis (het centrum van communicatie, bestuur en zakelijke overwegingen) is het hoofd; het in onbruik geraakte buitenhuisje met de geknotte moerbeiboom midden in het land waar de mest, als vetreserves, ligt opgeslagen, is de navel; en de vlei is de schede/baarmoeder. Maar afhankelijk van de tegenstelling waar de vlei in geplaatst wordt, kan ze behalve de vrouwelijke organen ook ofwel de vrouw in haar geheel zijn, die hij moet beschermen en begrenzen, ofwel de ruimte waarin zij verblijft: een besloten ruimte waarin Mehring zich afzondert van de realiteit, en waarin hij rust, contemplatie en intimiteit zoekt.

hemels. Ook bracht hij het tot den mens, om te zien hoe deze het noemen zou; en zoals de mens elk levend wezen noemen zou, zo zou het heten. En de mens gaf namen aan al het vee, aan het gevogelte des hemels en aan al het gedierte des velds, maar voor zichzelf vond hij geen hulp die bij hem paste." Genesis 2; 18-20

631 "He has the farm to himself. They ignore him. Over at the compound, a kind of swarming in the air, a thickening of sound and activity. Every now and then a reek of burning meat (..). Drumming has been going on quite a while; it started so vaguely and sporadically he's not sure when it really began." $(155 / 6)$ 
In koloniale literatuur is Afrika veelal gemythologiseerd als "the Other, as female, as treacherous and seductive" ${ }^{632}$. Deze chaos bevorderende Evaachtige Afrikavrouw, heeft als positieve tegenhanger "moeder Aarde" of "moeder Natuur" Heever, Smith en Schreiner. Moeder Aarde is daarbij vergelijkbaar met het tweede landschap van Coetzee: natuur in een relatie van reciprociteit met de mens (voedend en beschermend: een thuis biedend); terwijl Moeder Natuur de oncontroleerbare oerwildernis is die de mens heeft voortgebracht, van wie hij of zij zijn of haar genen heeft gekregen en die hem of haar dus ook onderdeel maakt van een familie met wie h/zij die oorsprong gemeen heeft. In Mehrings ogen is de vlei alles tegelijk: moeder Aarde, moeder Natuur en Eva. Ze is het grensgebied tussen onbeheersbaar water (natuur) en gecultiveerde aarde (cultuur). De post-paradijselijke, in cultuur gebrachte, voedende moeder Aarde die de basis vormde van Van den Heevers antwoord op de Afrikaanse wildernis, en de paradijselijke wildernis (moeder Natuur) van Schreiner die zich aan de menselijke wetten onttrekt en al haar kinderen even lief heeft, komen hier bij elkaar en spreken elkaar tegen. De vlei is de (baar)moeder die een oorsprong, een thuis en een tegenstrijdige identiteit verschaft. In haar tijdloosheid, met zwangerschapsstriemen "made over millenia in rock" (14) is deze moeder ook oermoeder: wederom Eva, die een eind maakte aan het paradijs en tegelijk met (de regeneratie van) het leven de dood introduceerde.

De verraderlijkheid van deze Eva-Afrika lijkt een voortzetting van de koloniale literaire traditie. Maar Mehrings andere erotische escapades werpen een ander ligt op haar. Als de zoveelste vrouw in zijn leven met wie hij een intiem en afgezonderd samenzijn zoekt, dient zij meer ter karakterisering van Mehring dan van iets anders ${ }^{634}$. Hij stelt zich tegenover haar net zo egocentrisch en opportunistisch op als tegenover andere vrouwen. In tegenstelling tot die andere vrouwen lijkt Eva-Afrika zich echter aan Mehrings objectiveringen te onttrekken. Ze laat hem aan zichzelf twijfelen. Zoals Gordimer zelf zei: "there's a feeling (..) that he does not know what he is seeing." ${ }^{{ }^{35} 5}$ Even lijkt hij in staat te zijn zijn blik te verruimen en haar wezenlijk als anti-subject te zien, maar uiteindelijk projecteert hij ook haar in het verhaal dat hij zo goed kent: verleiding, toenadering, verraad.

Als dit alles was zou er een sluitend verhaal liggen: Mehring geportretteerd als driedubbele exploitant, van Afrika, arbeiders en vrouwen, die uiteindelijk in zijn eigen valkuil valt. De vergelijking tussen de positie van vrouwen en van gekoloniseerden is vooral in feministische kringen vaak getrokken, waarbij de eigen, dikwijls contradictoire identiteit van beide groeperingen

\footnotetext{
${ }^{632}$ McLuskie, Kathleen and Lyn Innes 'Women and African literature' in: Wasafiri 8(1988):4. Zie ook Stratton 1994

${ }^{633}$ Voor een specificatie van de gebruikte moeder-metaforen zie Turner 1987, 28; 139 e.v.

${ }^{634}$ Zie Bal 1997, 125

${ }^{635}$ Dorsman \& Postel 1993: 49-50
} 
uit het zicht raakte ${ }^{636}$. In deze roman legt Gordimer echter niet zozeer de link tussen vrouwen en gekoloniseerden, alswel tussen Mehring als man, als kapitalist en als koloniaal, en de spanningen die het samenkomen van die rollen in hem oproept. De castratie-angst die Freud als bepalend zag voor de mannelijke psyche, en die volgens Cixous is terug te voeren op angst voor de macht van vrouwen ${ }^{637}$, raakt vermengd met de angst voor wraak en revolutie die de koloniaal en de kapitalist in het bloed zitten. Deze cocktail zou al voldoende zijn om Mehring van zijn boerderij te doen vluchten.

Maar er gebeurt meer. Er ligt een lijk in de vlei en de vermenging van aarde, vrouw en dood maakt deze ruimte tot een brandpunt van betekenissen en mythes die de grenzen van Mehrings perspectief als man/ kapitalist/ koloniaal lijken te overschrijden. De vlei wordt van ultieme binnenruimte, opeens ultieme buitenruimte. Ze wordt als het ware een poort naar een andere werkelijkheid, een veld van betekenissen die tornen aan Mehrings perceptie van de ruimte en zodoende aan zijn identiteit en geestelijke gezondheid. Want behalve dat er sociale, religieuze of economische redenen zijn om een ruimte te benoemen en in te richten en aldus toe te eigenen, is er ook een psychische noodzaak:

Zonder deze vorm van inrichting is er ruimtelijke desoriëntatie, die kan leiden tot psychose. Het belangrijkste aspect van onbekend land is dan ook niet dat de leegte door de verbeelding wordt gevuld, maar dat die leegte wordt afgesloten en de mensen ervoor worden behoed. Men kan niet ongestraft een grens passeren. ${ }^{638}$

Dat het passeren van een grens angstaanjagend is, bleek al eerder. Het unheimliche is de overschrijding van de grens van het bekende, en kan leiden tot angstaanjagende onzekerheid. De dood, zo bleek ook, is het ultieme symbool voor die grensoverschrijding, en verwijst als zodanig ook naar latente, ambivalente of onduidelijke betekenissen die, dankzij hun verborgenheid, des te meer gewicht krijgen.

Zoals hieronder zal blijken wordt de vlei in The conservationist meer en meer een topos van grensoverschrijding. Hier komen ondermeer Europese en Afrikaanse scheppingsverhalen ${ }^{639}$ (Kaïn en Abel, Adam en Eva, Unkulunkulu) en koloniale mythen (representaties van Afrika als leeg landschap, Adamastor en Moeder Aarde) samen. Het is de overgang tussen cultuur en

\footnotetext{
${ }^{636}$ Zie bijv. Laura E. Donaldson 1996, pag. 5 e.v.

${ }^{637}$ Zie Cixous 1976

${ }^{638}$ Kommers 1994, 61-63

${ }^{639} \mathrm{Er}$ zijn ook meerdere verwijzingen naar Indische mythen en symbolen. Omdat ik me in het kader van dit boek geconcentreerd heb op de relatie tussen Mehring, zijn arbeiders en zijn boerderij, heb ik me daar niet verregaand in verdiept. Maar voor zover ik heb kunnen nagaan, ondersteunen de verwijzingen mijn interpretatie van de vlei als grensoverschrijdend brandpunt van mythen en betekenissen en topos van transformatie.
} 
natuur, tussen chaos en orde, dood en leven, de versmelting van mannelijk en vrouwelijk en van verleden, heden en toekomst. Het is deze ambivalente en alleen al daarom voor Mehring fundamenteel andere werkelijkheid die zich, als via een achterdeur, aan Mehring opdringt terwijl hij zich openstelt voor de natuur. Want hoewel hij in iedere confrontatie met een ander zijn discours hermetisch afsluit voor invloeden van buitenaf, zit dáár zijn achilleshiel: voordat hij Eva-Aarde uiteindelijk ontvlucht, dringt ze verder in hem door dan welke andere vrouw ook.

Ondertussen is Mehring nog steeds op weg naar Jacobus. Jacobus woont niet in de compound maar hij en Alina en hun beider families wonen op het stuk grond rond het huis. Dit erf, het hoofd van Mehrings Afrika-vrouw, is de plek waar Mehring zijn werknemers ontmoet. Hier parkeert hij zijn auto en staat Jacobus hem op te wachten. Het is het zakelijke centrum van zijn bedrijf ("All serious discussion of farm business is held here in he kitchen, standing up") en aanvankelijk heeft Mehring nog wel het gevoel dat hij van hieruit controle uitoefent ${ }^{640}$. Ook in noodgevallen, vooral na een akelige ervaring in de vlei, trekt hij zich hier, het bolwerk van de ratio, terug.

Maar de veiligheid is schijn. Het huis zelf is ongezellig en onpersoonlijk en Mehring voelt zich er een vreemdeling, ook al zijn de dingen die erin staan van hemzelf (107). Er zijn altijd sporen (geuren) van andermans aanwezigheid. In feite is Mehring hier de afwezige huiseigenaar die volgens Marx maakte dat de arbeider woonde in "the house of a stranger" en zo das Unheimliche introduceerde ${ }^{641}$. Hoe vaker hij op de boerderij verblijft, hoe meer hij erachter komt dat de "farm business" zich buiten hem om voltrekt $(10,143,208)$. Het terrein rond het huis wordt regelmatig in beslag genomen door groepjes onbekende bezoekers en seizoensarbeiders die door Jacobus worden ingehuurd, $(143,182)$. Mehrings positie blijkt slechts een afgeleide positie te zijn: hij dankt zijn macht op de boerderij aan zijn geld, dat wil zeggen aan de economische positie die hij inneemt in de stad, niet hier. Zag hij Jacobus aanvankelijk als medestander $(26,145)$, naarmate zijn zelfredzaamheid zich verder openbaart, wordt hij in Mehrings ogen steeds meer "one of them": sluw en onpeilbaar (203).

Al op deze najaarsochtend, als Mehring, op zoek naar Jacobus, alles nog onder controle denkt te hebben, is de ambiguïteit van hun relatie voelbaar. Zodra hij aan Jacobus denkt, stapt hij over op een ander discours door

\footnotetext{
640 "He had made it his business to pick up a working knowledge of husbandry, animal and crop, so that he couldn't easily be hoodwinked by his people there and could plan farming operations with some authority."(23) Zo nodig legt hij z'n oor te luisteren bij de Afrikaner buren: "I'll (..) sit on the stoep and pick their boer brains if I need to" (23).

641 "instead he finds himself in someone else's house, in the house of a stranger who always watches him and throws him out if he doesn't pay the rent." Marx - Economic and Philosophic manuscripts of 1844 (zie ook jì 3.3.1).
} 
zichzelf the farmer te noemen en Jacobus zijn herdsman. Om de relatie tussen hen als landbezittende blanke en landloze zwarte te definiëren en te legitimeren maakt hij in de eerste plaats gebruik van de rurale mythe uit het Brits koloniaal discours ${ }^{642}$ - waarin gevestigde landbouw en landbezit wordt geassocieerd met blanke christelijke beschaving en nomadische veehoederij met barbaarse (zwarte) wetteloosheid ${ }^{643}$. Het plaatst Jacobus in een positie waarin hij -als "nomadische" veehoeder- historisch gezien geen "eigen" territorium kan claimen, zodat de huidige stand van zaken niet meer lijkt te zijn dan het logische gevolg van de evolutie, een realiteit waarmee een ieder heeft te leven.

Maar in een intertekstuele relatie met Genesis, worden farmer en herdsman Kaïn en Abel in een post-paradijselijke ruimte: het Land van God. In dit kader is de boerenidentiteit die Mehring zichzelf aanmeet niet meer zo geruststellend. De landbouwer Kaïn doodde zijn geitenhoedende broer Abel uit jaloezie om diens goede relatie met God. Hij werd door God verbannen en vervloekt: de landbouw zou hem niets meer opbrengen en hij zou "een zwerver en een vluchteling (..) op aarde zijn". Om hem in de buitenwereld te laten overleven maakte God hem echter wel onoverwinnelijk. Vanuit de rurale mythe is Mehring-de-boer tegenover Jacobus-deherder landbezittend en gezegend, vanuit het bijbels discours is Jacobus (binnenkort) dood, en hij ontheemd en vervloekt. ${ }^{64}$ De aanwezigheid van Jacobus, en de noodzaak voor Mehring om hem "onschadelijk" te maken, berooft hem tegelijkertijd van de mogelijkheid in het paradijs te geloven en dus thuis te zijn. Mehring is dus of Adam en onschuldig, maar eenzaam en kwetsbaar voor concurrentie, of hij is Kaïn en onderdeel van een familie, maar tegelijk schuldig en/of verbannen.

Deze paradox is typisch voor de afstammelingen van kolonisten in een postkoloniale "settler nation". Ze zijn onschuldig in de zin dat ze niet daadwerkelijk hebben meegewerkt aan het proces van kolonisatie, maar schuldig in de zin van een historische schuld. Paradoxaal genoeg maakt de onschuld de kolonistennazaat tot buitenstaander, want niet betrokken bij de geschiedenis, terwijl de schuld hem tot erfgenaam maakt van het (koloniaal) verleden en dus tot insider ${ }^{645}$. Ook Gordimer past in haar oeuvre een symbolische verdeling toe tussen binnen en buiten. Er is geen overgangsgebied; tussen beide werelden lopen scherpe grenzen die niet zonder meer overschreden kunnen worden. Binnen is aanvankelijk de dagelijkse, schuldbeladen realiteit van de Rand, waarin het personage zich gevangen

\footnotetext{
${ }^{642}$ Zie hoofdstuk 3

${ }^{643}$ Comaroff et al. 1997,124

${ }^{644}$ Kaïn stichtte een stad ten oosten van Eden. Zijn nakomelingen werden "[zij] die in tenten en bij de kudde wonen, (..) allen die citer en fluit bespelen. En (..) allen die koper en ijzer bewerken”. Ook

Mehrings is een stedeling en handelaar in ruw ijzer en reist, net als zijn zoon, de hele wereld over. Zijn boerderij is, conform de vloek, niet winstgevend.

${ }^{645}$ Gelder \& Jacobs gebruiken Australië als voorbeeld $(1998,26)$
} 
voelt, terwijl buiten de fel-begeerde zuivering is. In later werk ${ }^{646}$ bevindt het personage zich door een gebrek aan ervaring of bewustzijn buiten, namelijk buiten het werkelijke Zuid-Afrikaanse leven, waar zij als blanke geen

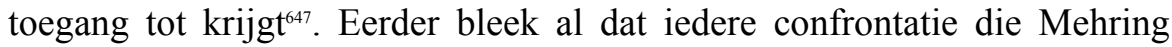
doorloopt aan een binnen-buiten tegenstelling gekoppeld kan worden: het subject wil herhaaldelijk een object naar (een met schuld beladen) binnen lokken, maar het object ontsnapt naar buiten. Maar mede onder invloed van de paradox van de kolonisten-nazaat wisselen buiten- en binnendomeinen en object en subject voortdurend van rol.

Terwijl Merhing nog op zoek is naar Jacobus ziet hij tot zijn verbazing Jacobus om hém afkomen: er ligt een lijk in de vlei. Even is hij de controle kwijt, Jacobus neemt de leiding en "there is nothing for the farmer to do but follow" (13). Vanaf dit moment zal er meer en meer aan zijn grenzen worden getornd. Ze naderen nu de vlei, het terrein dat Mehring waardeert als tegenhanger voor de stadse drukte; als waterbron die een zegen is voor zijn boerderij in deze jaren van droogte; en als broedplaats voor de cyclus van de natuur (97). Maar terwijl hij er heen en doorheen loopt, zijn blik naar beneden gericht, verraden zijn associaties dat hij er meer in ziet dan alleen deze drieledige functionaliteit. De wetten van ruimte en tijd lijken hier niet te gelden ${ }^{648}$. De plek is alomtegenwoordig, oeroud en vrouwelijk ${ }^{649}$, het is een hinderlaag, waar Mehring naar toegezogen wordt door geheimzinnige, onweerstaanbare krachten ${ }^{650}$. De rietkragen doemen voor hem op als een palissade (stockade (14)), een verwijzing naar bescherming en gevangenschap ${ }^{651}$. Achter, of in die palissade: het lijk.

\footnotetext{
${ }^{646}$ Burger's Daughter 1979; July's people 1981; A sport of Nature 1987

${ }^{647}$ Wagner 1994, 191

${ }^{648}$ Ruimte: Met zijn ondergrondse, onzichtbare bron en zijn principiële waarde ontworstelt het zich aan menselijke grenzen: "Soon there will be nothing left (aan parelhoendereieren, geraapt door de kinderen van de compound in het derde weiland), in the country, the continent, the oceans, the sky. (9)" Tijd:

"The road has ruts and incised patterns from the rains of seasons long past, petrified, more like striations made over millenia in rock than marks of wheels, boots and hooves in live earth" (14).

${ }^{649}$ Onder de 'half naked willows' (14) ziet Mehring het aardoppervlak als een huid, met striae (zwangerschapsstriemen) en onderhuidse vruchtbare vochtigheid. Hij beziet de rivier 'in the declivity of two gently rising stretches of land' (24) met de 'stretch of reeds, broken, criss-crossed, tangled' (14) ertussen. Ook later blijven associaties met een vrouwenlichaam terugkomen: "The hump of the bank here where, when it is higher, the river flows out of the reeds, has emerged from its plump rump of summer green, the bony hip of an Amazon torso.."(76)

${ }^{650}$ Naarmate Mehring en Jacobus de rivier naderen wordt de helling stijler en gaan ze harder lopen, gedwongen door de zwaartekracht: “(...) as the slope quickens his pace through momentum." (14). Hij voelt in zijn gezicht iets dat lijkt op spinnewebben. Veel later in het verhaal, als Mehring steeds meer in de ban is geraakt van deze plek, ziet hij een kever verstiukt in spinnewebben: "sometimes it will be there for days untill the spider drags it down into the hole - everything takes its own time out here, whatever you do. (..) This place is a quiet sleeper." (180)

${ }^{651}$ A stockade is bijvoorbeeld de eerste ommuring van het Kaapse fort of de omheining van een ouderwetse Zulu-nederzetting, maar het woord wordt ook gebruikt voor een gevangenis voor dwangarbeiders.
} 


\subsubsection{De broedermoord}

De verhouding tussen Mehring en de dode man is cruciaal voor het boek, en is dan ook al onderwerp geweest van veel discussie. De meeste critici benadrukken zijn symbolische betekenis. Volgens Stephen Clingman is hij de verpersoonlijking van Mehrings onderdrukte (politieke) bewustzijn: "thereby avoiding any sense of his own complicity in the system that has caused such an horrendous violation." ${ }^{652}$ Voor Judie Newman (1981/1988) staat hij voor verandering en voor wederopstanding van de onderdrukte Zulu-cultuur, terwijl David Ward (1989) als enige de aantrekkingskracht van het lijk op Mehring in zijn analyse verwerkt en laat zien waarom die aantrekkingskracht uiteindelijk in conflict komt met de werkelijkheid: "the magical properties with which Mehring endowes the corpse in his land (...) are given it by a European mind - by his fictive imagination". ${ }^{653}$

Maar het is ook mogelijk de dode man niet als symbool te zien, maar als personage. Als Mehring door de palissade van rietstengels heenbreekt, blijft hij -bijna bezwerend- doorgaan met determineren: de dode man is gezichtsloos, maar duidelijk "one of them", afkomstig uit de locatie. Ver van zijn bed. Maar Mehrings kaderscheppende achtergrondverhalen vertellen hem iets anders: als "een van hen" is deze man een soort Jacobus, maar dan dood: een dode Abel in het veld ${ }^{654}$; hij is, met zijn gezicht in de modder ${ }^{655}$, de slapende reus Adamastor; afkomstig uit de locatie is hij onderdeel van het leger aan arbeidskrachten waar Mehring zijn rijkdom aan dankt; als "city slicker" met kleren die ooit door een blanke zakenman (merkt Mehring op) moeten zijn gedragen, is hij zelfs zijn andere ik. Het lijk krijgt, binnen Mehrings eigen interpretatie, een onafhankelijke beweging die naar hem terugwijst. De grens tussen Wij en Zij vervaagt. Voor Julia Kristeva ${ }^{656}$ is dit precies wat de omgang met vreemdelingen in een land problematisch maakt. Het vervagen van die grenzen tussen $\mathrm{Wij}$ en $\mathrm{Zij}$ leidt tot een zekere angst, gebaseerd op het feit dat het dan nog moeilijk uit te maken is wat "thuis" is en wat niet, wat vreemd is en wat eigen ${ }^{657}$.

Mehring schudt deze ervaring zo snel mogelijk van zich af. Hij zal de man nooit meer zien of hardop benoemen. Als om hem nog verder van zichzelf te verwijderen, laat Mehring hem in het vervolg samenvallen met de plek waar hij ligt: "You'd better take something, to put over, down there," zegt hij tegen Jacobus. (21) Maar omdat hij de man reduceert tot de plek, zal de plek in het vervolg ook samenvallen met het lijk, en is hij nooit meer alleen

\footnotetext{
${ }^{652}$ Clingman 1986, 163

${ }^{653}$ Ward 1989, 124

${ }^{654}$ Genesis $4 ; 8$

655 "The face is in the tacky mud" (14)

${ }^{656}$ Julia Kristeva (1991) Strangers to ourselves, 171-3

${ }^{657}$ Gelder \& Jacobs 1998, 26
} 
in de vlei. De vlei krijgt de kenmerken van een hotelkamer waarin een geheim rendez-vous plaatsvindt: een gedeelde afzondering, een heimelijke, verboden intimiteit. De vlei is de veilige, besloten ruimte waarin hij samen kan zijn met zijn "geliefde" (197-200).

Het thuis dat hij in de vlei zoekt is dus niet alleen gestoeld op een band met Moeder Aarde of Moeder Natuur, maar, daaruit voortvloeiend, ook met de veronderstelde andere kinderen, die dan logischerwijs broers en zusters zijn ("Members of a natural group are siblings" ${ }^{\text {(6688 }}$ ). Volgens de niet-menselijke wetten van Moeder Natuur zijn Mehring en de zwarte (dode) man familie van elkaar, een gedachte die even geruststellend als verontrustend is. Net als in zijn andere relaties, is er ook hier dus sprake van een besloten (binnen)ruimte (de vlei) tegenover een open (buiten)ruimte (de rest van de boerderij). Ook hier is buiten realistisch en eenzaam, en terwijl binnen wordt geassocieerd met een ambivalente, heimelijke intimiteit.

Die ambivalenties in Mehrings eigen perceptie komen naar voren als er een veldbrand op zijn land heeft gewoed. Mehring reageert ongewoon heftig als hij de zwartgeblakerde vlei ontdekt. Wat eerst blank, vrouwelijk en vol leven was, wordt nu in zijn ogen beheerst door dood en zwarte, mannelijke krachten (95). Hij blijft er rondlopen, als een vogel rond een verwoest nest, als "a lone piece of vermin through that convict's head of stubble manged with ash." (97) De brand heeft hem zijn idylle ontnomen; hij is zijn schuilplaats kwijt: zijn kleine stukje Europese paradijs is veranderd in een voor hem onleefbare woestenij. Maar er is meer dan dat: hij wordt ergens door achtervolgd: "he is closing the window against the dust that is blowing up this afternoon (the burnt vegetation makes it worse. (...)The wind (..) makes a loose hinged window screech so that someone seems to be shaking at the house for entry" (106-107).

Volgens Clingman is historische schuld de voornaamste reden van Mehrings vermijdingsgedrag en de bewustwording daarvan de oorzaak van zijn uiteindelijke crisis ${ }^{659}$. In dat geval staat de dode man symbool voor zijn verdrongen herinnering. Herinnering is een speciale vorm van focalisatie, "a narrative act of vision of the past, situated in the present" "660, en als zodanig afhankelijk van het personage dat herinnert. De herinnerde dode is dus uiterst manipuleerbaar en zal in de meeste gevallen consoliderend zijn. Maar door hem niet als symbool te bestempelen, maar als personage, kan hij zich onttrekken aan Mehrings controle, uit zijn rol en zijn territorium stappen, en voor een confrontatie met de levenden zorgen.

Als personage is de dode man onderdeel van een fabula waarin op het eerste gezicht, de volgende actoren een rol spelen: Jacobus (J), Solomon $($ So), politieagenten $(\mathrm{P})$, een anonieme moordenaar $(\mathrm{M})$ en een anoniem

\footnotetext{
${ }^{658}$ Turner 1987,27

${ }^{659}$ Clingman 1986, 164

${ }^{660}$ Bal 1997, 147
} 
slachtoffer (S) ${ }^{661}$. M vermoord S; M? verstopt S, So vindt S; P verstopt S; J vindt $S$; iedereen begraaft $S$. Mehring lijkt niet of nauwelijks een rol te spelen in dit verhaal. Als íemand hier actief een doel nastreeft, dan is dat de moordenaar die een lijk wil verstoppen: wellicht is $M$ dezelfde als P. Niet voor niets denkt Mehring: "better go to police headquarters at John Vorster Square and see someone responsible" (cursivering van mij). In 1971 brak er een internationale rel uit rond dit bureau omdat Ahmed Timol van de tiende verdieping zou zijn gesprongen tijdens zijn verhoor. In Zuid-Afrika zelf was het bureau bovendien berucht om de verdwijningen van zijn arrestanten. Maar als de politie verantwoordelijk is voor de dood van deze man, dan is Mehring hoofdschuldige, want de politie handelt in feite in opdracht van degenen die baat hebben bij de politiestaat, mensen als Mehring.

Maar dergelijke abstracties zouden Mehring niet uit zijn evenwicht brengen. Het pijnlijke en angstaanjagende is dat het lijk niet meer een anoniem lijk is, gedropt door een anonieme moordenaar. Het heeft, in alle geheime ontmoetingen die tussen hen hebben plaatsgevonden, een relatie met hem gekregen. Hij is zijn broer die hem een thuis en identiteit biedt, maar als zodanig ook het bewijs is van zijn persoonlijke schuld. Mehring is de broedermoordenaar die keer op keer terugkeert naar de scene of the crime. Hij is Kaïn, en zijn schuld zal hem verbannen. Het is zijn lijk. Als moordenaar wordt Mehring de rest van het boek achtervolgd door zijn slachtoffer: een waar spookverhaal.

\subsubsection{Conclusie: de vlei als paradox}

Aan de hand van de voorgaande scènes kan een tamelijk compleet beeld geschetst worden van Mehrings "ruimte". De door Mehring geïnterneerde mythes en metaforen verdelen de ruimte in bepaalde territoria met de bijbehorende rolverdeling en verhalen. Hoewel de bijbelse, koloniale en patriarchale mythes elkaar eerder aanvullen en overlappen dan tegenspreken, doen er binnen iedere groep meerdere verhalen de ronde die bepaalde ruimtes tegenstrijdige betekenissen meegeven. Huis en boerderij kunnen bovendien, binnen dezelfde mythe, zowel tot de ene als de andere pool van de tegenstelling gerekend worden, afhankelijk van Mehrings perspectief van dat moment.

Samenvattend zijn er de volgende ruimtelijke tegenstellingen te destilleren:

1. Vanuit een bijbels kader:

a) het paradijs. Een plek van onschuld, oorsprong, eenzaamheid, (seksueel) verlangen. Hier is Mehring, als Adam, thuis (binnen), maar uitzetting dreigt.

${ }^{661}$ Zie appendix ?1. 
b) het land van God t.o. de stad van Kaïns nakomelingen. Een plek van broederschap, dood, schuld en ballingschap. Adam is verbannen; Kaïn wordt verbannen (buiten).

2. Vanuit een koloniaal kader:

a) De lege, onbereikbare wildernis van Afrika (oorsprong/familie, natuur, buiten (vlei; boerderij)) t.o. de Europese enclave (eenzaamheid/ vervreemding, cultuur, binnen (huis; stad)); Mehring is binnen, maar wil naar buiten (binnen $\rightarrow$ buiten).

b) Afrika als bewoonde, barbaarse vijandige natuur, oftewel de modder waar Adamastor met zijn gezicht in ligt te slapen, omringt enclaves van Europese cultuur. Mehring is binnen, maar voelt dreiging van buiten (buiten $\rightarrow$ binnen).

3. Vanuit een patriarchaal kader:

a) (baar)moeder (met name de vlei): intimiteit, onschuld en oorsprong. Mehring is (als ongeboren kind) thuis en binnen, maar uitzetting dreigt.

b) vrouw: intimiteit, schuld, dreiging en toekomst. Mehring is (als man) buiten, maar wil naar binnen, of is verstrikt in het web en wil naar buiten.

In alle drie discoursen is er sprake van enerzijds (a)) een tijdelijke staat van onbedorvenheid, en anderzijds (b)) een situatie in het heden waarin het subject zowel schuld draagt als slachtoffer is of dreigt te worden. Het paradijs en de baarmoeder zijn natuurlijk per definitie eindig gebleken, maar ook de lege wildernis is verdwenen zodra de toeschouwer zijn/haar intrede doet. De b)-situatie is steeds het gevolg van een confrontatie - met de Ander, leven \& dood, de geschiedenis, de werkelijkheid. De paradox die Jacobs en van Gelder beschreven voor postkoloniaal Australië, namelijk dat onschuld geen (blijvend) thuis kan bieden, is dus ook hier terug te vinden. Maar ook schuld lijkt tot verbanning, of in elk geval tot een zeer onaangename confrontatie te leiden.

Deze confrontatie wordt verbeeld door de vondst van de dode man in de vlei. De confrontatie met zijn aanwezigheid verandert de vlei van een a)ruimte in een b)-ruimte. De typering van de vlei als onschuldig, paradijselijk en leeg is dan niet langer houdbaar. Iedere hernieuwde confrontatie met de aanwezigheid van de dode man verandert het paradijs of het Land van God in het slagveld van de broedermoord, verandert het lege landschap in een veld met slapende doden, en verandert de passieve, ontvangende, reproducerende vrouw in een vrouw die weigert, ontrouw is, aborteert en daarmee de toekomst afsnijdt.

\subsection{CALLAWAY'S RUIMTE}


Een andere, nadrukkelijk aanwezige intertekstuele bron is The Religious System of the Amazulu (1885) van de missionaris en etnograaf Henry Callaway. Als een soort motto's plaatste Gordimer tussen hoofdstukken in citaten $^{62}$ uit Callaway's boek, waarin hij uitgebreid verslag deed van gesprekken met Zulu-informanten, en een poging deed hun oorsprongsmythen, hun relatie met de voorouders, en de rol van regenmakers en sjamanen weer te geven. Ook de tekst van The conservationist zelf bevat allerlei verwijzingen naar Callaway's tekst, en The religious system... informatie die Gordimers tekst verduidelijken en verdiepen. De vlei krijgt in het kader van deze verhalen heel nieuwe betekenissen. Het "bed of reeds" is de plek waar Unkulunkulu, de eerste mens, "broke off from Uthlanga", de oerwereld. Zulu scheppingsmythen blijken minstens even invloedrijk te zijn voor de vormgeving van de vlei als de bijbelse, waardoor de dode man niet alleen overeenkomsten vertoont met Abel, maar ook met Unkulunkulu. Ook biedt The religious system aanvullingen voor sommige zeer summier uitgewerkte verhaallijnen.

Deze elementen zijn onderdeel van wat Newman de "Zulu-subtext" noemde, een tekst die door Gordimers verwerking van die elementen in toenemende mate zichtbaar wordt en uiteindelijk, zegt Newman, Mehrings werkelijkheid overschrijft: "The text, burried like the black man, rises to the surface of the novel and repossesses it, obliterating the paper possession of Mehring and his story." "663 Newmans boodschap is dat Gordimer hiermee een opening biedt voor culturele en politieke dekolonisatie. Ze gaat er daarbij van uit dat er op het niveau van de tekst sprake is van meerdere discoursen die elkaar bestrijden, zoals groepen mensen dat doen: "the separate existence of different codes and circumscribed worlds which communicate only crudely, underhandedly, violently." ${ }^{664}$ Dit uitgangspunt is een erfenis van Bakhtin. Een bevrijdend uitgangspunt, aldus Bal: "The very notion that language is not unified provides access to bits and pieces of culturally different environments within a single text. It makes readers aware of (..) the impossibility of completely repressing ideological and social others." ${ }_{665}$ In Newmans visie is revolutie de onvermijdelijke consequentie van onderdrukking.

Maar hoe verschillende discoursen zich tot elkaar verhouden is uiteindelijk ook afhankelijk van narratologische kwesties: wie spreekt en wie kijkt?

\footnotetext{
${ }^{662}$ De citaten in The conservationist verwijzen a) naar dankrituelen waarbij de voorouders verzocht wordt om veel mais zodat er veel gasten kunnen komen en om veel kinderen zodat je naam blijft voortbestaan; b) naar de dromen van een sjamaan in wording c) naar een annotatie van Callaway waarin hij suggereert dat een oud geloof in Hades verloren zou zijn gegaan; d) naar de fricties tussen het geloof in de Amatongo en in God; e) naar een oorsprongsmythe die het verschil in rijkdom tussen zwart en blank verklaart; en f) naar het verhaal van de moord op regenmaker Umkqaekana en de overstroming die daar op volgde.

${ }_{663}$ Newman 1981, 40

${ }^{664}$ Newman 1981; 38

${ }^{665} \mathrm{Bal} 1997,66$
} 
Wie introduceert de Zulu-subtekst? Is Callaway's tekst in dit boek eigenlijk niet vooral onderdeel van Mehrings cultureel erfgoed, en dus van zijn bewustzijn? Het is Mehring die ziet dat het lijk als een ei of een pasgeboren Unkulunkulu ligt "on a nest of reeds" (15). En het is in Mehrings ogen dat de vlei in haar geheimzinnige man/vrouw/natuur gedaante niet alleen kleur en kenmerken van Eva of de "smooth-olive coloured" Antonia, maar ook van Inkosazana, die op dezelfde dag als de eerste mens uit de aarde kwam. Soms ontmoet ze een man en deelt hem bevelen uit, maar zonder zich te laten zien. Inkosazana is net als de vlei zwart-wit gestreept (133) en "on one side grows a bed of reeds, a forest and grass, the other side is that of a man" 666 .

Hetzelfde geldt voor Callaway's boek: wie schrijft, wie spreekt en wie kijkt? Wie was, om te beginnen, Henry Callaway? Newman beschouwde Gordimers verwijzingen naar Callaway als een metafysische ondersteuning voor de "black claims to authenticity on the land, to genuine conservation, which contrasts to Mehring's superficial or spurious conservation". ${ }^{667}$ Lars Engle (1989) interpreteert de citaten als een verwijzing naar een interculturele ontmoeting en stelt dat

The critical or theoretical issue to be raised here (..) is whether Gordimer in a contrast between black and white is contrasting inauthentic modes of being or occupation with authentic ones (...) or whether her novel instead elaborates a contrast between less and more successful or authentic modes of occupation, so that the distinction becomes one of degree, and the novel charts areas or axes of similarity at the same time that it points to difference. (93)

De parallellen die hij aantreft suggereren volgens hem dat het niet zozeer gaat om de vraag van wie het land is, maar "that African culture may have a diagnosis of what troubles Mehring" ${ }_{668}$. Maar waar ook hij aan voorbij lijkt te gaan is het feit dat The religious system.. geen neutrale weergave is geweest van de ontmoeting tussen een blank en zwart wereldbeeld. John Comaroff liet zien dat de gemiddelde missionaris zijn eigen rol zag als die van "conscience of the colonizer" 69 , en Callaway was daarin geen uitzondering. Om aan te kunnen tonen dat The religious system Mehrings wereldbeeld eerder versterkt dan ondergraaft, dat in feite zowel Gordimer als Mehring Callaways blikveld hebben georven, is het nodig stil te staan bij Henry Callaway en de tijd waarin hij leefde.

\footnotetext{
${ }^{666}$ Callaway 1970, 253

${ }^{667}$ Newman 1988, 41

${ }^{668}$ Engle 1989, 99

${ }^{669}$ Comaroff 1989, 674
} 


\subsubsection{Religieuze domeinen in de tijd van Callaway}

Callaway heerste over zijn missiepost zoals Mehring over zijn boerderij; hij was, net als Mehring, een product van de tegenstellingen en de machtstrijd van zijn tijd. Wat er gebeurde toen christendom en Zulu-religie met elkaar in contact kwamen, laat zich raden. Negentiende-eeuwse missionarissen en Zulu koningen en sjamanen vochten min of meer openlijk de strijd namens hun goden uit. Omdat de missionarissen het schrift in handen hadden, geven veel geschreven bronnen uit die tijd, waaronder die van Callaway, de indruk dat de missionarissen controle over de situatie hadden. De werkelijkheid was veel genuanceerder.

Buiten de missieposten bestond er aanvankelijk nauwelijks belangstelling voor het christendom. Aangezien de Afrikaanse religie, zeker op het niveau van het chiefdom, duidelijke politieke implicaties had ${ }^{670}$, voelden de Afrikaanse machthebbers zich bedreigd door de nieuwe religieuze orde die door de missionarissen werd gepresenteerd. ${ }^{671}$ De vijandigheid was het grootst in gebieden waar de komst van kolonisten tot gewelddadige conflicten en wederzijdse veeroof had geleid. Vaak werden zendelingen op Afrikaans grondgebied slechts geduld voor zover ze van nut konden zijn als technische innovatoren of bemiddelaars in hun relatie met de koloniale bewindhebbers. ${ }^{672}$ Voor de missionarissen gold evenzeer dat het sociaal-politieke systeem en de religie met elkaar verweven waren. Trouw aan de geldende scheiding tussen staat en kerk beloofden ze zich niet met de plaatselijke politiek te bemoeien, maar in hun ijver bijgeloof te bestrijden, maakten ze onderscheid tussen de "wereldse" en "rituele" taken van de chiefs, wat tot vele openlijke conflicten leidde. ${ }^{673}$ Uiteindelijk bleek hun overtuigingskracht onvoldoende; bijna alle missionarissen riepen tenslotte de hulp van het Britse leger in om de boodschap over te brengen.

In het begin was de missiepost dus een christelijke enclave in een Afrikaanse wereld, een afgeschermde ruimte waarbinnen men het eigen systeem intact probeerde te houden: "the mission station itself became a ritual space for a particular kind of European, Christian worldview in Africa. European clothing, square houses, irrigation, fenced gardens, hammers, saws, and ploughs all became ritual artefacts of that Christian worldview." ${ }^{674}$ De ambities reikten echter heel wat verder. Doel van de missie was cultivering van de Afrikaanse woestijn en haar bewoners door een totale reconstructie van de Afrikaanse cultuur. Dit lukte maar heel gedeel-

\footnotetext{
${ }^{670}$ Chidester 1992, 5

${ }^{671}$ Chidester 1992, 37

${ }^{672}$ Hofmeyr 1991, 636

${ }^{673}$ Comaroff 1989,674

${ }^{674}$ Comaroff 1989. Zie ook Comaroff, Jean and J.L. Comaroff "The colonisation of consciousness in South Africa." In: Economy and society 18 (1989)
} 
telijk. Ten eerste werden de missionarissen zelf ook door de koloniale situatie beïnvloed. Het begon er al mee dat hoewel de kolonisten aanvankelijk geen enkele religiositeit bij de Afrikanen meenden te kunnen ontdekken, de missionarissen zoveel weerstand ondervonden bij hun pogingen tot bekeren, dat ze niet anders konden dan erkennen dat er toch zoiets als een Afrikaanse religie, of in de woorden van de negentiende-eeuwse ambtenaar J.C. Warner: "a regular system of superstition" ${ }^{6675}$ moest bestaan. Er ontspon zich een theologisch debat tussen de missionarissen en hun doelgroep. Volgens de verslagen die de missionarissen van deze ontmoetingen naar huis zonden, veegde het Europese absolutisme en exclusivisme het meer plurale, pragmatische Afrikaanse wereldbeeld van tafel. "On the purely theological level," vertelt Chidester, "Africans were willing to select and adapt elements of the Christian message, even viewing the missionaries themselves as sacred specialists with knowledge and power that might be useful. Intolerant of such African adaptations, however, missionaries insisted on an exclusive, total domination of the religious field." Daarvan geeft hij het volgende voorbeeld:

Robert Moffat recorded an argument between himself and a Tswana sacred specialist in rainmaking. Impatient with Moffat's arrogant claims, the rainmaker offered a theological compromise. 'He said that my God dwelt in the South,' recalled Moffat, 'and that their God dwelt in the North.' Closing the debate, Moffat rejected this negotiated compromise by insisting on the universal scope of his religion. In Moffat's account, the rainmaker 'looked rather stupid when I informed him that my God ruled over all the earth' ${ }^{676}$

Maar of Moffat in de praktijk net zo vasthoudend, principieel en arrogant was als in zijn verslagen, is maar zeer de vraag. Het debat bleef niet lang puur theologisch. Aan beide zijden werd het een strijd om de macht. In een poging de autoriteit van sjamanen, chiefs en elders te ondermijnen, keerden de zendelingen zich bijvoorbeeld heel fel tegen heksenjachten, voorouderrituelen, initiatieriten, polygamie, en bruidschatten. Aan de andere kant pasten ze zich in het vuur van de strijd onwillekeurig ook aan aan het Afrikaanse wereldbeeld. In zijn mildste vorm gebeurde dit doordat het christendom steeds vaker gedefinieerd werd in termen van Afrikaanse praktijken die verboden waren. Maar soms werden rituelen, zoals het maken van regen, ook gewoon overgenomen. In Afrikaanse ogen waren de chiefs degenen die, al dan niet via (externe) regenmakers, macht over regen hadden, of zouden moeten hebben ${ }^{67}$. Als tijdens perioden van droogte de

\footnotetext{
${ }^{675}$ Chidester 1992, 38

${ }^{676}$ Chidester 1992, 38

${ }^{677}$ Chidester 1992, 25
} 
eigen regenmakers en zelfs de Khoi of Mfengu specialisten ${ }^{678}$ gefaald hadden, wilden Xhosa chiefs nog wel eens bij een missionaris aankloppen met het verzoek om regen. Het verhaal gaat dat een zendeling antwoordde dat mensen geen regen konden maken, dat die taak was voorbehouden aan God, maar dat hij wel wilde bidden om regen. Toen die inderdaad kwam, bracht de chief hem een koe als dank voor de bewezen diensten. In andere gevallen trok de zendeling het initiatief naar zich toe door na het falen van de Afrikaanse regenmakers een gebedsdienst te organiseren waarin om regen werd gebeden. Dergelijke voorvallen deden zich in heel zuidelijk Afrika voor. "[The] Christian mission inserted itself into the local religious arena as an alternative 'environmental religion', making contested claims on the rain as a symbol of religious truth, meaning and power." ${ }^{\prime 79}$. Maar dat is natuurlijk niet de interpretatie die in de geschreven bronnen uit die tijd naar voren komt. De zendeling die de koe had gekregen, bijvoorbeeld, geeft in zijn verslag een Bijbelse betekenis aan het hemelwater. Na zeven dagen onafgebroken regen, zo vertelt hij, kwam de chief bij hem terug om de regen te laten ophouden. Zijn homestead was door de zondvloed weggespoeld.

Ook binnen de grenzen van de missieposten, in het "eigen" territorium, was de invloed van de missionarissen minder groot dan zij de buitenwereld, en misschien ook zichzelf, voorspiegelden. In plaats van uit passieve volgelingen, bestonden de bewoners van de missieposten uit Afrikanen die om uiteenlopende redenen ervoor gekozen hadden zich daar te vestigen. Voor zover er sprake was van "bekering" bestond die slechts uit een zeer beperkte overname van het christelijke gedachtengoed. Veelal moesten missionarissen, om enig succes te boeken, zelf hun waarden laten varen en raakten ze meer en meer betrokken in de denkwereld van het hen omringende "heidendom".

De Afrikanen die zich vanuit de Afrikaanse vorstendommen bij de missieposten aansloten, waren vaak mensen die gebaat waren bij een andere politieke, economische of religieuze orde: (alleenstaande) vrouwen, politieke dissidenten of etnische minderheden. Een andere bron vormden de reeds tot het christendom bekeerde migranten die uit de koloniale centra terugkeerden en vervreemd waren van de oude orde of zich wilden onttrekken aan de forse belastingen die hen bij thuiskomst werden opgelegd. Bij de missie werden ze als trofeeën binnengehaald ${ }^{600}$. Pas toen de politieke en economische onafhankelijkheid van de Afrikaanse volken grotendeels was verdwenen, ontstond er een grotere toestroom naar de missieposten. Naarmate de ordening van de wereld in homesteads minder vanzelfsprekend

\footnotetext{
${ }^{678}$ Zie ook Crais 2002, 47

${ }^{679}$ Chidester 1992, 40

${ }^{680}$ Hofmeyr 1991, 637
} 
werd, nam onder Afrikanen de belangstelling voor een "hogere" of abstractere godheid toe, uit behoefte aan een macht die verder reikte dan die van de plaatsgebonden voorouders. Maar ook toen was er, zoals eerder gezegd, van een totale reconstructie van de Afrikaanse cultuur geen sprake. Voorouders bleven een belangrijke rol spelen. En behalve de christelijke god groeiden ook goden als Unkulunkulu, Uhlanga of de Lord of the Sky in populariteit ${ }^{681}$.

\subsubsection{De derde scheppingsmythe}

Voor negentiende eeuwse Europese antropologen en theologen was de Engelse missionaris Henry Callaway dé autoriteit op het gebied van Zulu religie $^{682}$. Maar de informatie die hij verzamelde, was grotendeels afkomstig van Afrikanen die zich op missieposten langs de koloniale grenzen hadden gevestigd, veelal vluchtelingen en outcasts die afhankelijk waren van de kolonie, en dus onmogelijk representatief kunnen zijn voor de negentiendeeeuwse Zulucultuur. Bovendien was ook hijzelf onontkoombaar onderdeel van bovenstaande machtstrijd. Zijn onderzoek stond in het kader van zijn missie. In zijn boek geeft hij veelvuldig het woord aan een informant die de traditionele religie als achterhaald en onwetend bestempelt. Deze Umpengula Mbanda, door Callaway getypeerd als "an educated, intelligent, Christian native" ${ }^{683}$ heeft meer dan wie ook een stempel gedrukt op Callaways beroemde boek, zozeer zelfs, dat "[t]he majority of the text appeared in the words of Mbanda, reflecting [..] his own ambiguous position on the colonial frontier as a recent Christian convert, [w]ith one foot on either side of the frontier battle line that divided the colonial mission from African society." ${ }^{684}$

In de afgeschermde wereld van de missiepost, waar macht officieel gekoppeld was aan een Europees, christelijk systeem, maar waar in feite blank en zwart elkaar beïnvloedden, trok Callaway een vrij willekeurige grens, en verklaarde het gebied aan de overkant van die grens als het opzichstaande, inferieure systeem van de Ander: het wereldbeeld van de Ander. Dit werkte natuurlijk zeer vertekenend. Voor zover de uit verschillende regio's afkomstige informanten al verwezen naar eenzelfde religieuze systeem, had dat in hun ogen zijn samenhang en macht verloren. De bewoners van de missiepost maakten geen onderdeel uit van "the religious system of the Amazulu", maar van het interculturele religieuze systeem van de grensmissiepost. Volgens Chidester suggereert Mbanda dat "the Christian mission had

\footnotetext{
${ }^{681}$ Chidester 1992, 8. Zie ook Berglund 1976, 32 e.v.

${ }^{682}$ Chidester 1996, 152

${ }^{683}$ Callaway 1970, voetnoot op pag. 31

${ }^{684}$ Chidester 1996, 153
} 
learnt de Zulu the genuine meaning about their own religion," ${ }^{985}$ en was hijzelf "able to exercise new sacred power not only as a priest, but also in his sustained critique of the old Zulu religion that he conducted in collaboration with Henry Callaway." ${ }_{686}$ Door hem desalniettemin te laten optreden als woordvoerder van de Ander, isoleert Callaway hem van iedere machtsstructuur en suggereert hij dat zowel de bekeerde als de onbekeerde Zulu volledig onschadelijk zijn gemaakt. In zijn boek verdoezelt Callaway zowel de wederzijdse culturele beïnvloeding binnen de missiepost, als het feit dat zowel daarbuiten als daarbinnen een Zulu-cultuur bestaat waarin mogelijk vele elementen die zijn informanten zijn "vergeten", wellicht omdat ze aan economische en politieke macht (en dus grondrechten!) gekoppeld zijn, een veel grotere rol spelen dan Callaway wilde weten.

Het komt in koloniale situaties regelmatig voor dat zich in orale oorsprongsmythen een tegenstelling ontwikkelt die aan andere tegenstellingen wordt gekoppeld, "used to impose on the basis of the manichean allegory of colonizer versus colonized." ${ }_{687}$ Die tegenstellingen kunnen echter verschillend worden ingevuld. Zo werd in 1850 verteld hoe Unkulunkulu niet alleen man en vrouw, maar ook zwarte en witte mensen schiep, en aan ieder een eigen territorium toebedeelde.

According to this myth Unkulunkulu said: 'The white men may live in the midst of water, in the sea. He gave them clothing'; but 'the black people shall live within this land.' (...) Certain oppositions in that world - white/black, sea/land, guns/spears - were clarified, but they were also transcended by placing all those oppositions under the supreme authority of Unkulunkulu. In this creation story, therefore, myth (...) not only explained the conflicts of the present world, but also validated black entitlement to the land in terms of the ultimate authority of a high god. ${ }^{68}$

Deze mythe is niet door Callaway opgetekend. Een andere versie van dezelfde mythe wel, en een fragment daarvan als Callaway-citaat in The conservationist is opgenomen. In deze versie wordt de dominantie van de blanke man verklaard en gelegitimeerd en blijft er voor de zwarte mens niets anders over dan onderwerping en bijleren wat de blanke al weet. ${ }^{699}$ Of Unkulunkulu behalve stamvader of ook God (schepper) was, was in Callaways tijd ook een belangrijk punt van discussie. Callaway vond de gedachte dat Unkulunkulu een God zou zijn "inappropriate for a frontier

\footnotetext{
${ }^{685}$ Chidester 1996, 166

${ }^{686}$ Chidester 1996, 160

${ }^{687}$ Schipper 2000, 146

${ }^{688}$ Chidester 1992, 7-8

${ }^{689}$ Chidester 1992, 8
} 
mission that had to distinguish itself from a surrouding heathendom" ${ }^{\prime 690}$. Het is niet verbazingwekkend dat Callaway's informanten die visie weerspiegelen ${ }^{691}$ :

The old men say: 'The bed of reeds still exists'. But where is that bed of reeds? They do not say that Unkulunkulu, who sprang from the bed of reeds, still exists. They say that Unkulunkulu, who sprang from the bed of reeds, is dead. They say: "we do not know where he is.' (32)

We do not understand what the black men say. We say. 'they are mistaken. Why do they tell us about Unkulunkulu?' We hear them say that he created all the black nations; but we do not hear of the place where he created them. (...) But since the white men came and the missionaries we have heard it said that there is God. (136)

We say this matter about Unkulunkulu is a vain thing. They wandered with folly as a companion. (..) There is no truth in it; for there are none who say, they know the place where Unkulunkulu broke off the people. (137)

Kortom, de missiepost was, net als Mehrings vlei en de boerderij in het Afrikaner nationalistische discours, een symbolische, identiteit genererende of bewakende binnenruimte waarin vreemde elementen ideologisch werden ingekapseld, maar waar die laatsten zich desalniettemin ontpopten tot onafhankelijke discoursen, die in praktijk die binnenwereld infiltreerden en veranderden. Callaway's boek weerspiegelt de ideologie, meer dan de werkelijkheid.

Wat Callaway niet kon weten, maar Mehring en Gordimer wel, was dat die "ingekapselde" discoursen in toenemende mate vijandigheid en omgekeerde marginalisering zouden gaan uitstralen, waardoor de infiltratie met terugwerkende kracht nog unheimlicher zou worden. In de twintigste eeuw zal de voornamelijk door blanken uitgedragen eensgezindheid tussen blank en zwart meer en meer tegenstellingen maskeren, ook binnen de christelijke

\footnotetext{
${ }^{690}$ Chidester 1996, 153

${ }^{691}$ Een van de informanten lijkt middels een parabel een doorkijkje te geven in zijn eigen beleefdheid of op zijn minst zijn twijfel. Jullie blanken hebben gelijk, zegt hij, er is een God en hij is in de hemel, en al die andere verhalen zijn allemaal onzin. Ondanks dat verhaal van de kameleon, waaruit blijkt dat wie al iets gelooft, niet meer iets anders kan geloven. Unkulunkulu stuurde een kameleon en een hagedis naar de mensen, de eerste met de boodschap: de mens zal niet sterven en de tweede met de boodschap: de mens zal sterven. Maar de kameleon treuzelde en de hagedis was er eerst. "And when the chameleon made his proclamation, men refused to listen and said '(..) What you now say is in vain; the word we have received is that of the lizard, which came and said: "Unkulunkulu says, Man must die". That is the word we have accepted. We do not understand the matter, Chameleon, of which you speak.' We thus say, teacher, that these are false accounts; the tale is not real. Men were made by the Lord. We ask how could Unkulunkulu send animals which creep on their bellies, to take a message to man? We say they are deceived."
} 
gemeenschap. ${ }^{62}$ Was Unkulunkulu in sommige kringen dankzij de koloniale overheersing enigszins op de achtergrond geraakt, in heel Zuid-Afrika werd het geloof in zowel voorouders als hekserij gebruikt om tegenwicht te bieden aan de "patterns of dominance" waar men zich aan probeerde te onttrekken. Eerder dan een pure voortzetting van oude waarden en normen was dit een bewuste reactie op de bestaande situatie. Zelfs voor Afrikaanse christenen die hun waardigheid veelal zochten "in the achievement of civilisation (impucuko)" ${ }^{\prime 693}$, bleven de voorouders een grote rol spelen:

Compromise and syncretism were highly developed: even staunch members of mission churches managed to combine Christian worship with ancestor worship - openly, secretly, or in disguise. (...) The residual or sometimes parallel practice of the ancestor religion had the power to generate a special warmth and intimacy because it was "uncontaminated" by whites. (..) [It] gave meaning, above all, to the relations between the generations, which school attendance tended to undermine and which Christianity could not establish with equal conviction ${ }^{64}$.

De aan de voorouders toegeschreven krachten werden aangepast aan de nieuwe werkelijkheid. De invloed van voorouders was niet langer beperkt tot de grenzen van de homestead, zodat de mensen die ver van huis aan het werk waren toch door hen beschermd konden worden. Weggaan naar de stad en (rijker) terugkeren, werd zelfs een nieuwe rite de passage. ${ }^{695}$

Net als voorouderverering, bood ook hekserij een tegenwicht tegen koloniale machtstructuren, mede omdat het zich aan de waarneming en de controle van de machthebbers onttrok. Zelfs op het Afrikaans christelijke wereldbeeld is de invloed ervan altijd behoorlijk groot geweest. Hoewel missionarissen zich beijverd hadden om zowel hekserij als de bestrijding ervan als duivelse praktijken uit te roeien, was de versmelting van christelijke en Afrikaanse waarden een eigen leven gaan leiden. De oncontroleerbare macht van de staat was in de ogen van veel Zuid-Afrikanen synoniem geworden met duivelse hekserij. "Witchcraft", schrijft Crais

became a constant, indeed an indissoluble feature of social life in the twentieth century. While the data are admittedly scarce, it would seem that Christian ideas of good and evil helped create more starkly rendered beliefs about witchcraft, nourishing and sustaining a bleak conception of a world overrun by darkness that could be combated only by exceptional faith and extraordinary action. In short, there

\footnotetext{
${ }^{692}$ Mayer 1980, 3-4

${ }^{693}$ Chidester 1992, 13

${ }^{694}$ Mayer 1980, 32-33

${ }^{695}$ Chidester 1992, 13
} 
arose a subaltern Manicheanism, a social reality of terror and prophesy, perdition and delivery, the abyss that is present and the possibilities of salvation somewhere in the future. ${ }^{696}$

Hoewel het vooroudergeloof in het discours van de missie dus gepresenteerd werd als een gemarginaliseerd, verdwijnend discours, stond het voor "the vast majority" ${ }^{697}$ van zwarte, al dan niet christelijke, Zuid-Afrikanen in toenemende mate voor een besloten wereldbeeld of werkelijkheid waar de blanken geen toegang toe hadden, en die, door verbanden te leggen in tijd en ruimte, een alternatieve "kaart" en een verleden opleverde, die niet door de blanken konden worden gemanipuleerd. Als onderdeel van dit discours was hekserij -in een samenleving waar de zwarte bevolking in toenemende mate machteloos stond tegenover haar eigen lot- een middel om de machteloosheid te benoemen en te bestrijden met middelen waar de machthebbers geen woorden voor en geen antwoord op hadden. Soms ging dit vreedzaam: "people enlisted ritual specialists to reorder symbolic space and thus restore health, order and tranquility". ${ }^{698}$ Maar er vielen ook steeds meer doden, vaak "within the domestic sphere, but it also involved the intricate and competitive politics of power and authority" ${ }^{699}$

Als er een Zulu subtekst is die zich aan het koloniale beeld ontworstelt, dan is dat dus niet de tekst van Callaway. De citaten verwijzen naar de koloniale weergave van een ontmoeting tussen twee culturen, naar verzwegen en vergeten oorsprong en traditie, naar twee religieuze systemen die beide, in toenemende mate, een politiek van uitsluiting zouden gaan hanteren en daarmee naar het begin van de vervreemding tussen beide partijen, die in de jaren zeventig een (voorlopig) hoogtepunt bereikte. Callaways boek is in feite de derde scheppingsmythe waar Zuid-Afrika uit ontstaan is: uit het paradijs kwamen Adam en Eva, uit het bed of reeds kwam Unkulunkulu en uit de frontier-missieposten ontstonden de blanke man en zijn zwarte knecht, die tot elkaar veroordeeld waren in een gezamenlijk territorium, maar tegelijkertijd zoveel mogelijk hun eigen territoria afbakenden, ieder op zijn eigen manier.

The conservationist weerspiegelt deze verhoudingen. De boerderij is, zoals gezegd, bij uitstek de plaats waar de verhoudingen en problematiek van de frontier settlements zijn blijven voortbestaan. De ruimte die er literair verbeeld wordt bevat de tegenstrijdigheden en ambivalenties van een eenzijdig opgelegde "universaliteit", onderdrukte en ondergrondse werkelijkheden en uitvergrote tegenstellingen. Ook in Mehring leeft het bewustzijn voort dat er een alternatief systeem tot zwijgen is gebracht:

\footnotetext{
${ }^{696}$ Crais 2002, 129

${ }^{697}$ Crais 2002, 129

${ }^{698}$ Crais 2002, 129

${ }^{699}$ Crais 2002, 130
} 
Come to think of it: all the earth is a graveyard, you never know when you're walking over heads - particular this continent, cradle of man, prehistoric bones and the bits of shaped stone (sometimes a plough has actually turned one up) that were weapons and utensils. It's all the same. Their ancestors. No one knows who they were, either. No way of making known: their mouth stopped with mud. Doesn't exist unless one happens to know - always knows, down here - that it's there alright. Already the new growth of reeds must be eight inches high (148).

Deze wetenschap van het niet-weten is als het ware een herinnering aan de lege plekken die Philip Marlow zag op de kaart van Afrika in Joseph Conrads Heart of Darkness, lege plekken die het begin zijn van het opdoemen van een alternatieve kaart en die, aldus Itala Vivan, "get wider and wider in order to allow the discourse of the other to emerge, and with it the alterity of a former colonial object who now speaks out for him/herself and weaves his/her own tale. A tale which constructs their own territory and geography." ${ }^{700}$ Maar er is in Mehrings dagen nog geen voormalig koloniaal object die volledig voor zichzelf spreekt en door Mehring gehoord kan worden. De witte plekken zijn vogelvrij: een ieder kan ze naar eigen inzicht invullen, en dus zullen ze naar alle waarschijnlijkheid worden ingevuld aan de hand van mythische tegenstellingen.

\subsection{JACOBUS' RUIMTE}

Een enigszins alternatieve kaart komt van Jacobus, die zowel ruimtelijk als ideologisch met één been in de compound staat en met één been in Mehrings territorium, die zijn belangen afweegt en goed gebruik weet te maken van zijn positie als tussenpersoon. Ook hij is een erfgenaam van de derde scheppingsmythe: hij kan zonder al teveel fantasie gezien worden als een moderne versie van Umpengula Mbanda.

Tegenover de joods-christelijke traditie die sturend is gebleken voor een deel van Mehrings perceptie van de ruimte, staat een Bantu traditie ${ }^{701}$ die minstens even oud is en, mogen we aannemen, minstens even invloedrijk in deze Europees-Afrikaanse setting. Hoewel Jacobus zich (net als Mbanda) van de oude tradities afkeert, is ook hij niet helemaal vrij van deze invloed, net zomin als de niet-gelovige Mehring vrij is van bijbelse invloeden.

\footnotetext{
${ }^{700}$ Vivan 2000, 51/2

${ }^{701}$ Hoewel er natuurlijk culturele en religieuze verschillen waren in tijd en ruimte, blijkt het onderscheid tussen verschillende autochtone bevolkingsgroepen in Zuid-Afrika lang niet zo absoluut als het koloniale regime heeft willen doen geloven en zijn er genoeg constanten in zowel tijd en plaats om algemene uitspraken te kunnen doen. (Chidester 1992, 1-3)
} 
In het dagelijkse (religieuze) leven van prekoloniale zwarte Zuid-Afrikanen stonden twee elementen centraal: de relatie met de voorouders ("levende doden" genoemd) en de rites de passage die gekoppeld waren aan geboorte, volwassen worden, huwelijk en dood. Deze elementen waren samen te brengen in een mentale kaart die de mens relateert aan een territorium door een ordening aan te brengen tussen goed en binnen enerzijds en kwaad en buiten anderzijds.

For example, Cape Nguni religion orchestrated its various elements in terms of a symbolic, cognitive, or mental map that opposed the domestic space of the homestead with the wild and uncontrollable, and potentially dangerous region of the natural world beyond. Within the centered space of the homestead, the ancestors and ancestor spirits maintained order, bestowed blessings and protected the family from evil. Beyond the boundaries of that centered world, however, the wild forest region held spirits, demons and familiars that threatened to unsettle the domestic order anchored in the homestead..$^{702}$

"The homestead," verduidelijkt Chidester verder,

was a symbol of the world, a central arena in which the symbolic relations of persons and place were negotiated. The home was the nexus of symbolic and social relations among the living and between the living and deceased relatives of the household who continued to live as ancestors or ancestor spirits. It was a place for being human. ${ }^{703}$

Tot zover zijn er opvallende overeenkomsten tussen dit Afrikaanse wereldbeeld en dat wat Coetzee schaarde onder Engels kolonialisme of Comaroff $^{704}$ onder het "civilising colonialism" van de missionarissen. In alle gevallen is er een in cultuur gebracht, menselijk centrum, dat omringd en bedreigd wordt door ongeciviliseerde en dus kwalijke invloeden van buitenaf.

Behalve van deze symbolische grenzen is Jacobus zich ook, in tegenstelling tot wat Mehring denkt, wel degelijk bewust van de grenzen van Mehrings boerderij. Het zijn die grenzen waarbinnen hij zijn macht uitoefent. Volgens Newman is dit een kwestie van nabootsing: "Each closed culture mimics the one above it, absorbing and passing on the agression." " daad zijn er veel overeenkomsten, al is de schaal van Jacobus' wereld wat kleiner: wat voor Mehring de boerderij is, is voor Jacobus de compound. Nabootsing hoeft overigens lang niet altijd te betekenen dat de nabootsende

\footnotetext{
${ }^{702}$ Chidester 1992, 4

${ }^{703}$ Chidester 1992, 5

${ }^{704}$ Comaroff 1989, 673

${ }^{705}$ Newman 1981; 38
} 
cultuur in het verlengde ligt van de dominante cultuur. Soms is het juist een middel tot verzet, een poging "to penetrate the hidden abode of colonial power and to create a space within which to critique the authoritarian colonial state." ${ }^{066}$ Maar Jacobus zal niet snel tegen Mehring in opstand komen; net als die van Mehring is ook Jacobus' machtspositie een afgeleide. Hij dankt zijn macht in de compound aan het (economisch) belang dat hij heeft voor Mehring, zoals Mehring zijn macht op de boerderij dankt aan zijn economische positie in de stad. Hij ontkent het belang van alternatieve sociale en religieuze structuren zoals Mehring de compoundbewoners negeert. Tegelijkertijd is hij zich, net als Mehring, bewust dat zijn aanwezigheid in de compound bijna een negatieve aanwezigheid is $(172)^{707}$. Jacobus moet, net als Mehring, een deel van de werkelijkheid ontkennen om zijn positie te handhaven. In zijn geval is dat dat de reikwijdte van zijn macht beperkt wordt door de aanwezigheid van twee autoriteiten die zeggenschap over de compound claimen, ook al wenst hij niet in hun macht te geloven ${ }^{708}$. Jacobus' herhaalde opmerking over de dode man: "Nobody can know this man. Nothing for this man," is een echo van Mbanda's verloochening van Unkulunkulu. De opmerking heeft een sociale betekenis: de dode man heeft geen familie die zich om hem bekommert, en dus wordt er niets voor hem wordt geregeld. Maar het feit dát hij geen familie(naam) heeft, is ook een verwijzing naar Unkulunkulu "[who] had no longer a son who could worship him; there was no going back to the beginning, for people increased, and were scattered abroad, and each house had its own connections." "'o9 (Of, zoals in het fragment dat ook door Gordimer werd geciteerd: "'Where is he now?' 'O, he is no longer, he died."') en naar de koloniale theorie van Callaway (waar Gordimer eveneens een fragment uit citeert) dat Unkulunkulu geen God was, maar slechts een machteloze voorouder ${ }^{710}$.

De vlei is voor Jacobus, meer nog dan voor zijn absent landlord, onmisbaar als bron van leven voor de boerderij, en grensgebied van zijn territorium. De dode man beschouwt hij als een indringer vanuit het vijandige buitengebied, waar men niet in staat is om de twee kwaden - criminaliteit en politie - buiten de deur te houden. Tegenover Mehring ontkent Jacobus dan ook iedere betrokkenheid ten aanzien van de moord en plaatst hij de oorzaak van het voorval in de location (16). Maar in eigen gelederen legt hij de connectie met de shebeen in de shanty-town achter de boerderij van De Beer (67). Shebeens (illegale kroegen) zijn niet alleen een doorn in Jacobus' oog vanwege de alcohol die er geschonken wordt en de criminaliteit en prostitutie die dat aantrekt, maar ook omdat ze illegaal zijn en dus een

\footnotetext{
${ }^{706}$ Crais 2002, 136-137

${ }^{707}$ Vergelijk Mehring op pag. 156

${ }^{708}$ Op 172 bant hij Mehring uit zijn gedachten zoals Mehring hem.

${ }^{709}$ Callaway 1970, 18

${ }^{710}$ Callaway 1970,8
} 
risico vormen voor mensen die, zoals Jacobus, hun positie verwerven door tweezijdige loyaliteit. Bovendien was voor vrouwen, die onder invloed van de kolonisatie aan vrijheid, status en macht hadden ingeboet ${ }^{711}$, het runnen van een shebeen een van de weinige manieren om zich aan de beperkingen van de steeds meer door mannen gedomineerde maatschappij te onttrekken en een onafhankelijk bestaan op te bouwen ${ }^{712}$. In die zin lijken shebeeneigenaressen op moderne diviners, want sjamanisme was, zoals Newman ook constateerde, "for pagan Zulu women the only socially recognized way of escape from an impossible situation in family life," en een beproefd middel om een zeker prestige te verkrijgen. ${ }^{713}$ Geen wonder dus dat de vrouw van Phineas, die een sjamaan wil worden, haar contacten heeft in de shebeen en dat Jacobus de shebeen, het lijk en het geambieerde divinerschap van de vrouw van Phineas evenzeer wantrouwt.

Als erfgenaam van Mbanda schuift Jacobus "that crazy woman", haar volgelingen, de shebeen, het geloof in de Amatongo, de dode man alias Unkulunkulu en de vlei op een hoop als ongewenst en iets van buiten. Mbanda zegt: "I say then that there is not one amongst us who can say that he knows all about Unkulunkulu, for we say, 'Truly we know nothing but his name; but we no longer see his path which he made for us to walk in. We now worship him by drunkenness and a greedy pursuit of those things which we do by our own wickedness." "14 Jacobus geeft een ruimtelijke invulling aan die afwijzing: in feite wordt het hele gebied rond de vlei en richting de shanty-town (dat wil zeggen: precies het stuk land dat later door de brand verwoest wordt) tot gevaarlijk terrein verklaard.

Zowel Mehring als Jacobus lijken dus gebruik te maken van manicheïstische modellen om de wereld te ordenen, die dankzij het feit dat beiden gevormd zijn door de frontiertraditie, in elkaar overvloeien. Tegelijkertijd, en dat is typisch voor de (post-)koloniale situatie, is het voor allebei niet meer vanzelfsprekend wat "home" is, oftewel: waar de grens tussen binnen en buiten loopt. Als Mehring er niet is, is "binnen" voor Jacobus de boerderij met soms het erf van de Indiërs, die zich in eenzelfde dubbele positie bevinden als hijzelf en door Jacobus tot Ons worden gerekend. Maar hoort de compound daarbij of niet? Helemaal thuis is hij niet in de compound, ook al duikt hij er soms onder. En wat is zijn domein als Mehring er wel is? Voor de vrouw van Phineas, die niets met het boerenhuis en de schuren of de Indiërs van doen heeft, of voor Solomon, die familie heeft wonen aan de andere kant van de rivier, of de man van Dorcas die in de stad werkt, liggen de grenzen weer heel anders. De compoundbewoners vertonen overeen-

\footnotetext{
${ }^{711}$ Zie bijvoorbeeld Stratton 1994, 8

${ }^{712}$ Bier brouwen was van oudsher vrouwenwerk.

${ }^{713}$ S.G Lee, "Spirit possession among the Zulu" in: John Beattie and John Middleton (eds) 1969 - Spirit mediumship and society in Africa, pp 128-158. Zie ook Newman 1981, 42

${ }^{714}$ Callaway $1970,23-25$
} 
komsten met het allegaartje van de grensmissiepost, terwijl de wereld die door hen bewoond wordt, even veranderlijk en diffuus is als de "symbolische topografie" die Auslander waarnam bij de Ngoni in Zambia. Er is zoveel beweging in wat Auslander noemt de "migratory, political economy of Southern Africa" dat er geen duidelijk binnen en buiten, of goed en kwaad meer is. Zowel vrouwelijke onafhankelijkheid als mannelijke thuisloosheid kan door de wederpartij worden aangemerkt als grensoverschrijdend en dus ordebedreigend. In de jaren tachtig, stelt Auslander,

[rural Ngoni communities] had developed complex inchoate maps, 'moral geographies', of recruitment networks, informal migration routes, and shifting patterns of urban-rural employment (..). Yet in comparison to printed two-dimensional cartographic texts (..) the symbolic topographies are highly fluid and contestable, suffused with apprehended dangerous flows of persons and substances (..) Senior men claimed that economically independent market women were bringing AIDS into the village, from "roads" originating in South African gold mines and rural slums. Women, in turn - in ritual song and oratory- decried men who traveled aimlessly on the region's highways ${ }^{715}$.

Voor zowel Mehring als Callaway als Jacobus als Mbanda is het dichtgooien van de grenzen tegen oprukkende chaos dus tegelijkertijd een ontkenning van de eigen innerlijke ambivalentie en thuisloosheid.

Waar Mehring Auslanders "mannelijke thuisloosheid" vertegenwoordigt, vertegenwoordigt de vrouw van Phineas "vrouwelijke onafhankelijkheid", maar ook de witte plekken van The religious system...; dat wat niet gezegd wordt. De vrouw van Phineas (voortaan X genoemd) is anoniem en haar verhaal openbaart zich slechts indirect en onvolledig, ze focaliseert en vertelt niets. Haar fabula beslaat slechts de volgende gebeurtenissen z: X droomt veel; $X$ voert verschillende rituele handelingen uit; $X$ heeft rust ${ }^{716}$. Ondanks deze minimale informatie beschouwt Newman (1981) X terecht als Mehrings belangrijkste anti-subject. Volgens Newman staat de dode man voor verandering en is $\mathrm{X}$ dankzij haar initiatie in staat om zijn geest in goede banen te leiden en de crisis die het land teistert (geweld, droogte, onderdrukking) op te lossen ${ }^{717}$. In bredere zin: de Zulu-cultuur bevat voldoende flexibiliteit en duurzaamheid om grote sociale veranderingen het hoofd te bieden, en het zijn de vrouwen die dat op waarde weten te schat-

\footnotetext{
${ }^{715}$ Auslander 1993, 169/170

${ }^{716}$ Het slachtfeest is ambivalent; zijn de geit en de diviners er ter ere van de initiatie van X (zoals Jacobus tegen Mehring vertelt (maar niet denkt (170)) en Judie Newman veronderstelt $(1981,32)$ of, zoals vanuit Solomons focalisatie wordt beschreven, ter ere van Solomons herstel?

${ }^{717}$ Newman 1981; 35
} 
ten. Het is volgens Newman een antwoord op de exploitatie van zowel land als vrouwen, waar Mehring zich schuldig aan maakt. De storm die vanuit zee over het land raast is in haar ogen een vorm van vrouwelijke wraak. $\mathrm{X}$ is tegengesteld aan Mehring, ze bevindt zich aan de andere kant van een wipwap die uiteindelijk doorslaat: zijn perspectief is dominant in het boek, het hare is verborgen; maar zijn onderbewuste blijft onderdrukt, terwijl haar onderbewuste "shapes her society" sciousness - rising from its buried position to the surface of he text." 719

$\mathrm{X}$ krijgt dus noch tekst, noch focalisatie toegewezen, net zoals er in Callaway's boek bepaalde perspectieven ontbreken. Wordt er over X gesproken, dan gebeurt dat voortdurend vanuit een vertroebelend kader. Een van haar danssessies wordt bijvoorbeeld beschreven vanuit het perspectief van Solomon, die wel wat milder in zijn oordeel is dan Jacobus, maar zich toch (met name tegenover Jacobus) van haar distantieert (165) en praat over "those dreams of her", hoewel het dankzij haar is dat hij weet wat hij met zijn eigen dromen aan moet. De verteller legt haar, terwijl Solomon toekijkt hoe ze staat te dansen, woorden in de mond die letterlijk zijn overgenomen uit The religious system ${ }^{720}$. De bewuste passage gesproken door James, in een verhaal dat wordt verteld door Mbanda, en ingeleid door Callaway. "The subject of the following narrative," schrijft de laatste,

was a convert of some eleven or twelve years standing. He has always manifested great uncertainty of character and a very impressible nervous system, and for many years has had from time to time subjective apparitions, and been in the habit of dreaming strange, life-like dreams. One day he suddenly left the mission station. The following account was obtained from a native who was sent to inquire of him at the village where he was living. I have had an opportunity of seeing him since the underneath was given me. He has many symptoms of hysteria, appears fully to believe in his feelings; and yet at the same time to be practising deceit on others, and probably on himself too ${ }^{721}$.

Het beeld dat Callaway hier geeft van James is het stereotiepe beeld van een vrouw: labiel, hysterisch, irrationeel en onbetrouwbaar: een, zoals Jacobus X typeert, "crazy woman." Mbanda is vervolgens wat milder, maar spreekt wel over "James' illness", terwijl zijn ziekte in feite dezelfde "ziekte" is die Freud in zijn tijd aan "hysterische" vrouwen toeschreef:

\footnotetext{
${ }^{718}$ Newman 1981; 43

${ }^{719}$ Newman 1981; 44

${ }^{720}$ Gordimer pag. 166: ... describing (..) how in her sleep there were also elephants and hyenas and lions and full rivers, all coming near to kill her, how they followed her, how ther was not a single place in the whole country that she did not know because she went over it all (..) in her sleep...

${ }^{721}$ Callaway 1970,185
} 
onderdrukking van identiteit en talenten. De ziekte is een "desease which predicts the power to divine" 22 . Dit ervaren van de roeping tot sjamaan wordt "brooding" genoemd: een geest zit als het ware op de man of (wat vaker voorkomt) een vrouw als een kip op haar ei, in de hoop een sjamaan uit te broeden ${ }^{723}$. Het broeden geeft onrust (veel dromen!), maar met de juiste rituelen en hulpmiddelen is het mogelijk het broeden in de hand te houden en tijdelijk te stoppen. Gevaarlijk wordt het vooral als het te lang duurt, bijvoorbeeld als iemand zich tegen de roeping verzet ${ }^{724}$, zoals James doet. Waanzin is dan het gevolg. Callaway en Mbanda laten echter doorschemeren dat toegeven aan de heidense roeping een karakterzwakte of een diplomatieke misstap is, en dat vooral dáár het gevaar schuilt. Dat blijkt bijvoorbeeld ook uit het verhaal van Umkquaekana ${ }^{725}$, waar Gordimer ook fragmenten uit citeert. Umkquaekana vertoont als de vreemdeling met de ongewenste talenten overeenkomsten met $\mathrm{X}$, en als toegedekt lijk met de dode man in Mehrings vlei.

Tot zover lijkt iedereen gevangen te zitten in zich herhalende mythen. Mehring erft van Kaïn het verlangen om met God (de natuur) te communiceren, maar ook zijn fatale jaloezie en zijn ballingschap, en van Callaway de neiging om de grenzen van de eigen identiteit te onderzoeken zonder er ooit echt overheen te durven gaan. Jacobus stapt in de voetsporen van Mbanda, en de getalenteerden, zij die in staat zijn om met de andere wereld te communiceren, zijn kanslozer, stemlozer en onzichtbaarder dan ooit.

\subsection{RITUELE TERRITORIA}

En toch is het waar wat Newman beweerde, namelijk dat er een andere boodschap boven komt drijven. Wat Gordimer doet is, behalve Mehrings beperkingen blootleggen en deconstrueren, via de vlei als topos van cyclische tijd, ambivalentie en transformatie, ruimte scheppen voor een andere interpretatie, voor herschepping, een ruimte die alleen door de lezer kan worden opgevuld. Voor een deel gebeurt dit, zoals bij X, door het ontbreken van een (eenduidige) fabula. X valt buiten Mehrings, Callaway's en in zekere zin zelfs Gordimers invloedssfeer, juist omdat ze tekst- en stemloos is, en dat vacuüm, zoals we zullen zien, slechts gedeeltelijk door intertekstuele parallellen met Callaway's boek kan worden aangevuld. Door dat laatste wordt de lezer zich bewust van een lege ruimte. "The reality of the out-group cannot be experienced internally," stelt Mineke Schipper, want het denken over het bestaan van deze groepen, veroorzaakt slechts, in de

\footnotetext{
${ }^{722}$ Callaway 1970, 195

${ }^{723}$ Berglund 1976, 127

${ }^{724}$ Berglund 1976, 128

${ }^{725}$ Callaway 1970; 389-393
} 
woorden van Zavalloni, "an emptiness, a blank feeling". ${ }^{726}$ Maar de grenzen tussen in-group en out-group zijn veranderlijke constructies. Als ze beginnen te vervagen, als binnen en buiten overlappingen gaan vertonen, dan is die leegte het begin van een bewustzijnsverandering en/of (daardoor) een verandering van identiteit.

Vanuit een maatschappelijk kader worden de meeste transformaties of identiteitsveranderingen begeleid door overgangsrituelen om het destabiliserende effect van de verandering teniet te doen ${ }^{727}$. Het ritueel is uiteindelijk, net als de mythe, een "authorative mode of symbolic discourse and a powerful instrument for the evocation of those sentiments (affinity and estrangement) out of which society is constructed." ${ }^{228}$ In veel gevallen zal dit een bevestigende rol vervullen, maar het kan, in tijden van conflict of verandering, ook betekenen dat de samenleving "[is] disarticulated and rearticulated, literally, taken apart and put back together". ${ }^{229}$ Dat is wat er in The conservationist op kleine schaal gebeurt. Door het gebruik van rituele "personages" (vuur, lijk, sjamaan), ruimtes (vlei, rivier) en fabula (zowel Mehring, als X, als het lijk doorlopen de drie fasen van een rite de passage: separatie, liminaliteit, integratie), krijgt de tekst van The conservationist zelf de functie en misschien zelfs de kracht krijgt van een ritueel.

\subsubsection{Vuur en vlei: zuivering en transformatie}

Het is mogelijk Mehrings staat van zijn, zoals zijn onrust na het aanschouwen van de verbrande vlei, geheel vanuit zijn bewustzijn, zijn "gesloten circuit" van mythen te verklaren. Maar net als Adamastor niet alleen een symbool is voor koloniale vervreemding, maar ook een verwijzing naar een concrete Afrikaanse werkelijkheid, is het vuur meer dan een spookbeeld in Mehrings hoofd. Terwijl Mehring zijn eigen onrust "minitieus onderzoekt", negeert hij de concrete tegenspeler van de confrontatie die dat gevoel oproept: het vuur. Waarom is juist dit gebied, het natste gebied van de boerderij, in vlammen opgegaan? Wie heeft het vuur aangestoken, en waarom daar?

Als Mehring voor de tweede keer het verbrande terrein betreedt, wordt duidelijk dat zijn beeld van zichzelf en van wat hij zoekt allerminst eenduidig is. Met het bravoure van een rücksichtlose zakenman probeert hij zijn twijfel te overschreeuwen. Hij neemt met grote passen de verbrande aarde opnieuw in bezit, als een settler die de grenzen van zijn nieuwe land afmeet (110), maar zijn gedachten laten zich niet tot de orde roepen. Het ambiva-

\footnotetext{
${ }^{726}$ Schipper 1993, 43 citeert Marisa Zavalloni: Eco-Ecology: The study iof interaction between social and personal identities. In: Anita Jacobson-Widding Identity: personal and socio-cultural, A symposium. Stockholm, Almqvist and Wiksell, 1983, 208

${ }_{727}$ Zie ook Hst 4

${ }^{728}$ Lincoln 1989, 53

${ }^{729}$ Lincoln 1989, 73
} 
lente gebruik van persoonlijke voornaamwoorden (wie is "you"? wie is "he"? wie is "they"?) en de dubbele associatie bij het woord "possessions" (bezittingen en bezetenheden), verraden verwarring en gebrek aan controle. Zijn stappen zijn stappen in het grote onbekende.

What is it that he has? It is something they would never believe. It's not convenient for any to believe, it's contrary to all ideology; stop your ears, cover your eyes, then, if you don't like it. (..) My - possessions - are - enough - for - me.

Who dares say that? He has not spoken. There's no one to speak to, on the farm. He's aware that he's accountable to no one. There's no answer. You are not here, nor he. You are not here, nor she. A dead man, but he doesn't speak the same language. (..) Even in this wind, the burnt reeds are silent, all strings broken (110).

De verbrande vlei, de verwoesting van zijn idylle, legt iets van onbenoembaarheid bloot; stilte, de onmogelijkheid van communicatie, het besef misschien zelfs, van zijn eigen afwezigheid, en de aanwezigheid van iets anders. Mehring kijkt naar de verbrande vlei alsof een indringer van buiten het gebied heeft geannexeerd ("the fire's territory (...) Taken overnight." (94)), maar doet geen moeite de oorzaak van de brand te achterhalen. Judie Newman doet dat wel. Zij oppert dat het vuur is ontstaan als onderdeel van een Zulu-ritueel: sjamanen stoken vuur rond hun huizen om de god van de hemel duidelijk te maken dat er behoefte is aan regen. ${ }^{70}$

Traditioneel rekenen Zulu's het maken van regen tot de rituele functies van de koning. De droogte die Zuid-Afrika teisterde in de zeventiger jaren, werd wel geweten aan het feit dat de koningen hun oude taken niet meer serieus namen, een effect van de kolonisatie. "The trouble is that our kings do nothing today. They simply sit in an office, dressed nicely and writing letters," zegt één van de informanten van Berglund. ${ }^{731}$ Als de koning faalde, werden er regenmakers aangetrokken van elders, en een van hun methoden is inderdaad het afbranden van het gras rond de hut. Maar ze doen dit nooit in de winter, omdat iedereen weet dat er dan geen regen valt. ${ }^{732}$ Ten tijde van de veldbrand is het hartje winter.

Er zijn allerlei andere redenen te bedenken waarom dat vuur aangestoken zou kunnen zijn. Vuur is bijvoorbeeld een middel om abathakathi (heksen of hekserij) te bestrijden. Zoals gezegd "[f]ire has continued to be a basic way of dealing with witchcraft, a strategy of doing away with evil." ${ }^{\prime 33}$ Zoals hekserij gekoppeld wordt aan oncontroleerbare, kwade macht, wordt vuur gerelateerd aan een positieve kracht of macht, in het bijzonder aan de term

\footnotetext{
${ }^{730}$ Newman, 1981

${ }^{731}$ Berglund 1976, 53

${ }^{732}$ Berglund 1976, 56

${ }^{733}$ Crais 2002, 130; zie ook Berglund 1976
} 
amandla: "the power of fertility in a clan and lineage is often referred to as heat (ukushisa), work, or desire. All are enveloped in the general term amandla. ${ }^{\prime 334}$ Kruiden worden verbrand om mensen, dieren, huizen, stallen of velden te zuiveren van boze krachten. ${ }^{735}$ Huizen van vermeende heksen worden 's nachts in brand gestoken. In later tijden werd de locatie van het kwaad meer en meer in het menselijk lichaam gezocht en werd het verbranden van het lichaam een manier om de ziel te vernietigen en "thus to prevent it from returning to haunt the living" ${ }^{\prime 36}$. Wellicht is het vuur dus aangestoken om de kwade geest uit de vlei (en de shantytown) of zelfs uit het dode lichaam in de vlei te verdrijven, zo vlak nadat Solomon daar aangevallen is. En in de manicheïstische wereld die aan (ondermeer) de missie was ontsproten, heeft vuur zelfs een specifiek anti-blanke betekenis. Vuur werd niet alleen als abstracte, politieke kracht tegen de macht van de blanken ingezet (de strijdkreet van het ANC was Amandla) maar ook als concreet wapen. Het koloniale regime en de blanke machthebbers, die armoede, droogte ${ }^{737}$ en ziekte hadden gebracht, werden beschuldigd van hekserij en "magic became an instrument to probe modern power, to understand the evil of whites who were seen as the "descendants of Cain, accursed by God". ${ }^{738}$ Dit wereldbeeld werd gekoppeld aan een profetische zuivering, waarbij de blanken de zee in zouden worden gedreven, maar kon ook uitmonden in opstanden of andere, meer of minder grijpbare vormen van verzet. Sinds de jaren twintig "rumors about colonial uprisings invariably included references to the use of fire to destroy houses of Europeans (...) When Africans 'were going to make an attempt to get rid of white people (..) houses were to be burnt and the children killed"". ${ }^{739}$ Mogelijk ervaart Mehring, die de vlei als zijn belangrijkste thuis ervaart, deze brand dus niet alleen als een symbolische verbanning, maar ook als een politieke, of zelfs persoonlijke bedreiging.

Mehrings bijbels gemotiveerde beeld van zichzelf als zondaar (Kain) valt hier bijna samen met het Afrikaanse beeld van de blanke als bron van het kwaad. Al heel vroeg zijn Afrikaanse en Europese beelden van het kwaad in Zuid-Afrika vermengd geraakt. Zonde, schreef een missionaris in 1827, "was the greatest sorcery, having bewitched all mankind, and would destroy all who continued under its dominion." " ${ }^{40}$ Andersom heeft het christendom het beeld van de twintigste-eeuwse heks mede bepaald:

\footnotetext{
${ }^{734}$ Berglund 1976, 253

${ }^{735}$ Berglund 1976, 310

${ }^{736}$ Crais 2002, 130 De halsbandmoorden van de jaren tachtig en negentig van de 20ste eeuw, waarbij collaborateurs met het apartheidsbewind met een autoband om de nek in brand werden gestoken, kunnen ook in dit licht worden gezien.

${ }^{737}$ In de prekoloniale samenleving was het bij uitstek de taak van de chiefs om regen te genereren.

${ }^{738}$ Crais 2002, 139

${ }^{739}$ Crais $(2002,137 / 8)$ citeert een getuigenverklaring uit 1921 uit het archief van het ministerie van justitie.

${ }^{740}$ Crais $(2002,125)$ citeert dominee Brownlee, 1827
} 
Witchcraft beliefs were, and are, wonderfully malleable, if frighteningly and very often tragically so. They have, for example, fused with Christian ideas of sin and evil and purity and goodness, creating visions of terrible malevolence and nourishing dreams of an apocalyps that would set the world aright and return the downtrodden to a land of harmony and plenty. Believe in occult forces have at times shaped people's perceptions of whites and the state. ${ }^{741}$

Het is dus heel goed mogelijk dat Mehring zichzelf ziet als de zondaar/ heks die wordt verdreven door de vlammen van Gods zwaard danwel van woedende Afrikanen.

Maar vuur is in de Afrikaanse traditie meer dan een middel om blanken te verdrijven. Het wordt gezien als een bijzonder positieve kracht. Het is een middel voor communicatie ${ }^{742}$ en transformatie. Het transformeert van kwaad naar goed en is een "temporal marker separating past and present" Sjamanen maken gebruik van vuur om in contact te treden met de shades (vooroudergeesten), want hitte, of dit nu de hitte tussen mannen en vrouwen is die kinderen veroorzaakt, of de hitte tussen twee stokjes die vuur veroorzaakt, is "the gift of the shades to men"

Is vuur het aangewezen middel voor transformatie en communicatie, dan is de vlei er de plek voor. Tussen de veilige homestead enerzijds en het wilde buitengebied anderzijds, bevond zich in het bantu-discours een ambivalent niemandsland dat werd geassocieerd met de rivier; het territorium van ambiguë riviergeesten. ${ }^{75}$ De vlei is onmiskenbaar een prototype van dit ambivalente niemandsland. De rivier, net als vuur een symbool van vruchtbaarheid, is bij uitstek het domein van de sjamanen. Sjamanen hadden tot taak grenzen te doorbreken en te communiceren met de Andere wereld. Het was op de rivieroever dat ze contact legden met voorouders. Bovendien is het de plek waar sjamanen worden "geboren". In de rivier woont de python. Zijn macht is zo groot dat degene die te vaak dicht bij hem in de buurt komt, gek wordt: "he brings this thing of fearfulness on men" "746. Maar omdat hier de geboorte van de mens heeft plaatsgevonden"' 74 , zal een sjamaan in wording symbolisch moeten afdalen in de rivier, zodat de mens kan sterven om de sjamaan geboren te laten worden ${ }^{748}$.

\footnotetext{
${ }^{741}$ Crais 2002, 4

${ }^{742}$ Berglund 1976, 197

${ }^{743}$ Crais, 2002, 130

${ }^{744}$ Berglund 1976, 232

${ }^{745}$ Chidester 1992, 4

${ }^{746}$ Berglund 1976, 142

${ }^{747}$ Het riet heeft de aarde gepenetreerd en bevrucht met water, "causing conception of mankind Berglund 1976, 144

${ }^{748}$ Berglund 1976 140-145
} 
De verbrande vlei is zo bezien dus geen breuk of interne tegenstelling, maar juist een teken van de band tussen dood en leven, verleden en heden, mens en natuur. En misschien zelfs een verbinding naar "de reality of the outgroup". ${ }^{79}$ Als hij het vuur in al deze hoedanigheden zou kunnen herkennen, kan er iets veranderen ${ }^{750}$. Een aanzet is er wel: het aanschouwen van de veldbrand brengt bij Mehring zo'n schok te weeg dat hij zich onbewust bewust wordt van de kracht van de python: "[It] roused an anguished revulsion, an actual physical reaction, as if the python of guts (..) uncoiled against some inner wall of his body" (94). ${ }^{71}$

\subsubsection{De liminale dode}

Zo is het ook mogelijk dat de dode man geen onderdeel is van Mehrings verhaal van schuld en boete, maar dat Mehring onderdeel is van een heel ander verhaal, waarin de dode man een hoofdrol vervult. Behalve na de brand zijn er nog een paar momenten beschreven waarop Mehring zich in de vlei bedreigd voelde; waarin heimlich voor hem unheimlich werd. Terwijl hij naar het lijk staat te kijken, gebeurt er bijvoorbeeld iets griezeligs: terwijl Mehring al enige tijd vergeefs het gekriebel op zijn gezicht dat hij aan herfstdraden wijdt, probeert weg te vegen, ontdekt hij een vlieg bij het hoofd van de dode man (16). Hiermee worden twee uitingsvormen van Freuds "Unheimliche" geïntroduceerd: de dubbelganger en de levende dode. De relatie tussen een personage en zijn dubbelganger, stelt Freud, "is accentuated by mental processes leaping from one of these characters to another (..) so that the one possesses knowledge, feelings and experience in common with the other. Or" en dat is een aspect dat, zoals al door verscheidene critici is opgemerkt, in The conservationist heel duidelijk vorm krijgt: "it is marked by the fact that the subject identifies himself with someone else, so that he is in doubt as to which his self is, or substitutes the

\footnotetext{
${ }^{749}$ Schipper 1993, 43

${ }^{750}$ Hetzelfde geldt voor het water in de laatste scenes van het boek. De overstroming kan worden geassocieerd met de straf van God, de wraak van de natuur, of, zoals Newman (1981) deed, de wraak van de vrouw. Maar ook hier is een andere interpretatie mogelijk. In Zulu-rituelen wordt water niet gebruikt om te straffen, maar om te zuiveren. In geval van ziekte wordt het lichaam aangespoord het gif uit te drijven, bijvoorbeeld door grote hoeveelheden water te drinken zodat men gaat braken (ukuhlanza). Ook een abortus wordt beschouwd als een zuivering (Berglund 1976, 331). Zionistische secteleden, die een groot deel van de armste 20ste eeuwse Zuid-Afrikanen uitmaakten, geloofden dat de wereld alleen gered kon worden door volledige transformatie. Veel van hun rituelen waren gericht op heling. Voor hen "water symbolically restored health, made that which was barren fertile again (..) transformed person, reawakened 'the mysterious sense of human connection between things', relocated the faithfull within a fabric of history ultimately rooted in the very birth of humanity - a time we should note, that people associated with proper morality. Baptism created a new subject." Het is een zionistische secte die uiteindelijk de begrafenis van het lijk met de nodige rituelen omgeeft.

${ }^{751}$ De slang is ook in andere spirituele tradities een symbool voor transformatie-energie. Yoga kent kundalini: een slang die bij ieder mens in het bekkengebied ligt te slapen. Diens ontwaken symboliseert het activeren van een transformerende kracht, die ook hier niet ongevaarlijk is.
} 
extraneus self for his own (..." "752 Maar wat gebeurt hier nu eigenlijk? Kruipt Mehring onwillekeurig in de huid van de dode man, of maakt de dode Mehring deelgenoot van zijn ervaringen? De relatie tussen Mehring en zijn dubbelganger krijgt een tweede unheimlich aspect doordat de dubbelganger dood is: als Mehring kan voelen wat de dode man voelt, is hij dan wel dood? $?^{753}$.

Later valt Mehring in de vlei in "slaap":

Perhaps he has dozed; he suddenly - out of blackness, blankness - is aware of breathing intimately into the earth. (..) For a moment he does not know where he is, or rather who he is. But this situation in which he finds himself, staring into the eye of the earth with earth in his mouth is strongly familiar to him. It seems to be something already inhabited in imagination.

At this point his whole body gives one of those violent jerks (..) one of those leaps of terror that land the poor bundle of body, safe, in harmless wakefulness. The abyss is no deeper than a doorstep; the landing, home. (41)

"Home", of "heimlich" was de wakende wereld die hij beschreef voor hij in slaap viel: wat verre, Afrikaanse geluiden, een horizon die hij naar believen kon laten inkrimpen door in de vlei in het gras te gaan liggen en naar zichzelf te kijken als naar een personage in een pastorale roman: "I have my bit of veld and my cows..." (41) Unheimlich is Mehrings besef dat er niet alleen een persoonsverwisseling lijkt plaats te vinden, maar dat daarmee ook, op deze plek, een andere, onbekende ruimte wordt betreden: een afgrond ("blackness, blankness"); "the wrong place" (50) die desalniettemin vertrouwd aanvoelt en "leaves space in his mind" (42). Het is de ruimte van de Ander, maar ook van de dood: "It is fatal to fall asleep in the afternoon" (46).

Het gevoel dat er een confrontatie met deze Ander nadert wordt steeds sterker. Als Mehring zich maanden later na overvloedige regenval in het gebied waagt, hoort hij zijn eigen voetstappen "as if he were coming towards himself (...) He is almost tempted to speak, the sense is strong; you're there. It seems to you that it is to you that observations are being addressed." (227) Even verderop zakt hij met een been in een gat,

[the mud] holds him in a cold thick hand round the ankle. A soft cold black hand. (..) He pulls and pulls; down there he's pulled and pulled. It's absurd. (..) And then, he's been let go. (..) something lets go. (..)

\footnotetext{
${ }^{752}$ Freud 1976, 629

${ }^{753}$ Twijfels over het al dan niet bezield zijn van mensen en dingen horen tot de belangrijkste oorzaken van het unheimliche, volgens Freud vooral omdat de moderne mens niet meer in geesten meent te geloven. (Freud, 1976)
} 
He has to stump up to the house with an elephantiasis of mud on one foot. It feels as if part of him is still buried." (228).

In deze passage is Freuds Unheimliche in vele gedaantes aanwezig. De dode is niet alleen vijand van de levende ${ }^{754}$, maar ook dubbelganger, volgens Freud (en velen met hem ${ }^{755}$ ) een vorm van zelf-verdubbeling: de ziel was ooit bedoeld als een bezwering van de dood, maar wordt in een volgende fase "the uncanny harbinger of death":

the quality of uncanniness can only come from the fact of the 'double' being a creation dating back to a very early mental stage, long since surmounted - a stage, incidentally, at which it wore a more friendly aspect. The 'double' has become a thing of terror, just as, after the collapse of their religion, the gods turned into demons. ${ }^{756}$

Volgens Alan Gardner Lloyd-Smith zijn er echter ook veel voorbeelden te vinden van dubbelgangers die een verdubbeling zijn van de Ander, met name de vrouwelijke Ander. Dat Freud hieraan voorbij gaat heeft veel te maken met de onzichtbaarheid van vrouwen in zijn tijd, hun onderdrukking en hun dubbele imago; brenger van zowel leven als dood. ${ }^{757}$ Voor de neiging van zowel Mehring als van sommige critici om in de dode alleen zijn (Mehrings) eigen spiegelbeeld te zien in plaats van de Ander, geldt precies hetzelfde.

Het vermengen van dood en Ander is in Gordimers oeuvre een terugkerend gegeven. David Ward ziet in Chronicles of Darkness (1989) met name in haar verhalen een verwrongen ontmoeting met de ander terugkomen in combinatie met de dood of een doodswens. De dood is een begeerlijke staat van onthechting; opgenomen worden door de dood is deel worden van de oneindigheid die het marginale menselijke bestaan omringt. Tegelijkertijd is de dode nog steeds levend: de dode die gezien wordt, gaat zien, object verandert in subject en vice versa ${ }^{758}$. Dood en Ander vallen dus samen als dat wat buiten de grenzen van het ik bestaat.

Er is in Mehrings bewustzijn voortdurend een wisselwerking te bespeuren tussen zijn vormgeving van de werkelijkheid en een andere werkelijkheid die zich opdringt, even teruggedreven wordt en dan weer verder oprukt. Sommige critici zien dit als het stapsgewijs naar boven komen van een onderdrukt bewustzijn ${ }^{759}$. Een andere mogelijkheid is echter dat er daadwerkelijk iets of iemand anders zijn hoofd binnendringt - niet in de vorm van

\footnotetext{
${ }^{754}$ Freud 1976, 635

${ }^{755}$ Zie bijvoorbeeld Lloyd-Smith 1989, 8

${ }^{756}$ Freud 1976, 631

${ }^{757}$ Lloyd-Smith 1989, 5

${ }^{758}$ Ward 1989, 109-111

${ }^{759}$ Ward 1989, 123; Clingman 1986, 165
} 
revolutie of replacement, maar van een ontmoeting - elk onverwacht bezoek een stukje verder. De ruimte die in Mehrings hoofd achterbleef nadat hij in slaap gevallen was in de vlei en het gevoel van vertrouwdheid was verdwenen is dan natuurlijk de leegte die het vertrek van "de geliefde" of in elk geval de Ander achterlaat - in dit geval de dode man. Naderhand doet hij zijn best om de grenzen tussen zijn wereld en de andere te sluiten, maar echt kwijt raakt hij het gevoel pas als hij in het huis een douche genomen heeft (49), voor Zulu-sjamanen een geijkte methode om weer in het hier en nu te komen ${ }^{760}$.

Net als het vuur, wordt de dode in de vlei door Mehring als ordeverstorend en bedreigend gezien omdat de vlei blank, vrouwelijk en eeuwig levend zou moeten zijn. Maar ook voor de bewoners van de compound is de dode man in Mehrings vlei een anomalie. In de Zulu-traditie is de dood van oudsher gekoppeld aan bepaalde territoria. Bij het normaal doorlopen van de stadia van het leven en de rituelen die de rites de passage begeleiden, valt de dood binnen de grenzen en regels van de homestead, daar waar de elders en de vooroudergeesten de orde bewaren. Het lijk onttrekt zich om meerdere redenen aan die ordening.

Wie sterft, bevindt zich niet meteen als shade in de homestead. Met behulp van rituelen de dode worden begeleid naar het volgende leven. Tot de tijd dat de dode "thuiskomt", meestal pas een jaar na de sterfdatum, is hij marginaal en dus een potentieel gevaar voor zowel zichzelf als de omge$v$ ing $^{761}$. Al die tijd moet er iemand op hem passen. Een extra probleem ontstaat bij een ontijdige dood. Sterven mensen onverwacht en te jong, dan is dat het werk van heksen en valt de dode binnen hun invloedsfeer. "It is a fearful thing, in truth. (..) It is an evil. It must not be talked about as if you wish that it came over you. (..) When a man dies young, there is one who is the cause of the death. The aim of the killer is to kill utterly (..) he must die without children." ${ }^{762}$ Omdat heksen het wilde buitengebied als territorium hebben, bevinden de jong gestorvenen zich in symbolisch opzicht ook daar. Hun graf moet vooral 's nachts goed in de gaten worden gehouden "because we know the work of abathakathi (the people of death). They come at night and dig up the grave." ${ }^{963}$ Als ze de kans krijgen doden ze de geest voor hij shade heeft kunnen worden en maken hem tot zombie-slaaf, het ergste wat een mens kan overkomen ${ }^{764}$. Pas als de shade zich openbaart, bijvoorbeeld door te verschijnen in een droom, is de dode veilig.

Zoals eerder gezegd is angst voor zombies groter geweest in perioden van "social disruption, periods characterized by sharp shifts in control over the

\footnotetext{
${ }^{760}$ Berglund 1976, 129

${ }^{761}$ Berglund 1976, 379. Zie ook Hst 4.

${ }^{762}$ Berglund 1976, 80

${ }^{763}$ Berglund 1976, 81

${ }^{764}$ Berglund 1976, 81
} 
fabrication and circulation of value" ${ }^{965}$. Vooral de toestroom van migrantenarbeiders als gevolg van Apartheid en/of kapitalisme ${ }^{766}$ deed het aantal zombies toenemen. Ontworteling en migratie ontwrichtten de vertrouwde structuren, en "[t]he living dead comment on the disruption of an (..) order through which the present was kept in place. And the future was secured." ${ }^{\prime 67}$ Ook in het Zuid-Afrika van de jaren zeventig gold dat potentieel gevaarlijke hekserij niet meer door sociale structuren in goede banen werd geleid. Met name in verstedelijkte gebieden werden rituelen niet meer (strikt) nageleefd. ${ }^{768}$ Een informant van Berglund weet de rampzalige gebeurtenissen van die tijd, waaronder droogte en toename van geweld, aan het feit dat "'today there are not many shades but a large majority of abathakathi. They are increasing in numbers because there is no watching [of the grave] any more. .. Nothing there is done. Nothing. So the shades are dying. .. So what can we expect these days except bad things." "' 769 Deze "bad things" zijn dezelfde bad things die de boerderij aanvankelijk ontregelen in The conservationist: droogte en geweld.

Dit geeft een extra dimensie aan Jacobus' handelwijze. De dode man is een ondubbelzinnige verwijzing naar chaos, naar het van buiten naar binnen oprukken van de verwaarlozing van een sociale orde. Jacobus' reactie is even kortzichtig als Mehrings reactie op de dood van zijn collega: hij wil er niets mee te maken hebben. In Jacobus' ogen zijn bedreigingen van de huiselijke vrede vooral afkomstig uit de stad - van de ontwortelden uit de shantytown en de locatie - en hij zoekt zijn oplossingen dan ook in het sluiten van de grenzen en het uitbannen van het niemandsland, inclusief de stadse dode die zich daar bevindt.

Maar vanuit het perspectief van een pasgestorvene, of een sjamaan, is dit dichtgooien van de grenzen nu juist wat de ellende veroorzaakt. Wil de dode niet in handen vallen van de heksen, met alle gevolgen van dien, dan zal er iemand over hem moeten waken in zijn kwetsbare staat. Maar wie? Zijn familie weet niet waar hij is en de hem omringende mensen weten niet wíe hij is, en voelen zich niet verantwoordelijk. Om een onbekende dode aan de gemeenschap van de shades toe te voegen, is er een sjamaan nodig. Maar er is geen sjamaan, en dus moet de dode man er een "roepen", of uitbroeden.

\footnotetext{
${ }^{765}$ Comaroff et al. 1999,18

${ }^{766}$ Comaroff et al. 1999, 21-24 Meerdere bronnen wijzen erop dat zombies in de moderne tijd niet meer worden opgegeten, maar geëxploiteerd. (Geschiere 2000, Chidester 1992, 15, 17)

${ }^{767}$ Comaroff et al. 1999, 24

${ }^{768}$ Berglund 1976, 81; Chidester 1992, 15, 17 Dat Comaroff et al. tijdens hun onderzoek in Bophutatswana in de jaren zestig en zeventig geen preoccupatie met zombies hebben aangetroffen, kan te verklaren zijn uit het door henzelf genoemde feit dat migratie-arbeid in die tijd een inmiddels vertrouwd fenomeneen geworden was dat in de sociale structuur was geïntegreerd door de functie van een rite de passage te vervullen (Comaroff e.a. 1999, 23-25)

${ }^{769}$ Berglund 1976, 82
} 
Narratologisch gezien heeft de dode niet alleen een sjamaan nodig, maar de sjamaan ook een dode. Om sjamaan te worden moet hij of zij de geest kunnen identificeren die verantwoordelijk is voor het broeden; door te dansen wordt met die geest contact gezocht. Voor een sjamaan is de dode man in de vlei geen anomalie. De ambivalente, maar vitale betekenis van de vlei wordt er alleen maar door wordt versterkt. Elementen die voor anderen bedreigend zijn (ambivalentie, dood, chaos, zijn voor hem of haar geen vijanden, maar medestanders. Symbolisch gezien is de dode man in de vlei behalve een exponent van chaos ook alter-ego van de sjamaan: de mens die in de rivier is gestorven om de sjamaan geboren te laten worden, de sjamaan die zich in de liminale fase bevindt van zijn/haar rite de passage de persoon die tussen twee identiteiten (levend en dood, mens en sjamaan) in zweeft.

Vanuit deze wetenschap is het mogelijk te ontsnappen aan het doemscenario dat de hierboven beschreven mythen de personages oplegden. Hoewel ze tekst- en stemloos zijn, kunnen sjamaan en dode man samen de geschiedenis herschrijven. De geest van de dode man roept, en de sjamaan herkent zijn/haar "roeping" en geeft de dode man zijn plaats in het dodenrijk. Daarmee wordt de ban van Callaway doorbroken: van "hogerhand" wordt het toedekken van het lichaam en de talenten van Umkquaekana ongedaan gemaakt, zodat op grond van een nieuw verleden een nieuwe toekomst open ligt. Maar dit alles wordt nergens verteld. Net als in The religious system ontbreekt in The conservationist het perspectief van deze Ander. De verteller van dit verhaal is de lezer. Het is de lezer die de subtekst, of liever: déze subtekst, naar boven brengt.

De verbrande vlei, met daarin de dode man, is al met al dus een zwaarbeladen verwijzing naar een wereldbeeld dat ambivalentie toelaat en vandaaruit communicatie en verandering kan bewerkstelligen. Clingman heeft gelijk als hij stelt dat Mehring heen en weer geslingerd wordt tussen ontkenning en acceptatie, maar het gaat hier niet om de acceptatie van een onontkoombaar $\operatorname{lot}^{77}$. De waarheid die hij onder ogen zou kunnen zien, is dat zijn lot (en dat van de lezer) bezegeld is, zolang hij zich niet buiten de hen conditionerende mythen begeeft. Mehrings ontwikkeling is geen gesloten circuit. Tegelijk met het bovenkomen van zijn eigen onderdrukt bewustzijn, dringt zich ook het bewustzijn van een alternatieve werkelijkheid op. Van iets wat hij nauwelijks kan benoemen omdat het niet tot zijn discours behoort, maar waarvan hij het bestaan op zijn minst aanvoelt.

${ }^{770}$ Clingman 1986, 154-164 


\subsubsection{Mehrings ziekte}

Het ligt voor de hand in dit verhaal X de rol van sjamaan toe te dichten. Mehrings rol is moeilijker te duiden, enerzijds omdat hij er zelf geen woorden voor heeft, en anderzijds omdat hij erg passief is. Hij blijft heen en weer geslingerd worden tussen tegengestelde polen: binnen en buiten; dader en slachtoffer; wij en zij. Alle rollen die hij daarbinnen kan aannemen zijn weinig verheffend. Hij is de heks en kapitalist die de dode man in zijn liminale staat gevangen houdt, om hem te kunnen toevoegen aan het leger zombies dat hij inzet voor eigen gewin. Hij is moordenaar, bijbelse of postkoloniale balling, of onvruchtbare zombie-immigrant. Maar ergens voelt hij wel dat er een andere mogelijkheid is: als hij uit die tegenstelling zou durven stappen kan hij zijn krachten ten goede aanwenden en geen witch zijn, maar witch-doctor; geen tegenpool van $\mathrm{X}$ maar een collega.

Lars Engle wees op overeenkomsten tussen Mehring en X: ze zijn beiden "possessed by the ancestors". Hij wordt, zegt Engle, geplaagd door stemmen van "departed ones" "7?1: Terry, Antonia, zijn ex-vrouw. Inderdaad vertoont hij, voor zover na te gaan, zelfs meer dan $X$ gelijkenissen met James uit The reiligious system. James vertelde Mbanda hoe hij zich voelde tijdens het broeden van de shades:

'I am now dead altogether. (..) Attend for I am a man who loves my children dearly. But now I do not care whether they are alive or not. The great thing is this disease alone. (..) And now I begin to go out by night, having an internal intimation about medicine; it is said, "The medicine is in such place; go and dig it up" I go out and reach the place, but do not find the medicine. (..) I am harassed by the dogs (..) I am greatly afraid of the noise (..) And now I no longer love any-one. My heart no longer loves men. It is as though I could stay where it is perfectly still - where there is not the least sound. (..)'.772

Zodra Mehring zich in de vlei bevindt, identificeert hij zich met de dode man, verliest hij zijn belangstelling voor zijn medemens, bekijkt hij alle planten, stoort hij zich aan honden en geluid. Hij krijgt een voorliefde voor de nacht (het tijdstip waarop de shades actief zijn), zijn voeten brengen hem waar zijn hoofd niet heen wil, hij zoekt iets wat hij niet kan vinden. Maar er zijn verschillen: Mehring herschrijft, net als X, gedeeltelijk James' geschiedenis. In tegenstelling tot James, lijkt $\mathrm{X}$ niet echt te lijden onder

\footnotetext{
${ }^{771}$ Engle 1989, 100

${ }^{772}$ Callaway 1970,189 e.v.
} 
haar "ziekte" "773. Ook Mehring voelt zich radeloos noch ziek. De separatie kost hem weinig moeite en in zijn liminale staat voelt hij zich broederlijk verbonden met de dode, maar onbegraven man.

Engle suggereert dat de Zulu-cultuur een geneesmiddel heeft voor de ziekte van Mehring: het identificeren en tot rust brengen van de geest die hem plaagt. ${ }^{774}$ Maar door Mehrings staat te interpreteren als ziekte neemt hij ongewild de interpretatie van Callaway's Mbanda over. Het gaat er niet zozeer om dat de Zulu-cultuur rituelen kent die geesten kunnen uitdrijven, al is dat wel een gevolg. Basaal is dat er door sjamanen een categorie onderkent wordt die zich onttrekt aan de zo menselijke neiging om te denken in absolute tegenstellingen en dus aan de wetten en de beperkingen van het alledaagse leven. Mehrings "ziekte" zou niet zo negatief zou worden geïnterpreteerd als de symptomen erkend werden als aankondiging van een gave. Zijn isolement is een barrière voor wie veel kinderen wil en veel graan om zijn gasten voor te zetten. Maar voor wie de ambitie heeft om de grenzen van het beperkende hier en nu te doorbreken, is het noodzakelijk om zich los te maken van alles wat hem aan het hier en nu bindt. En misschien is dat in crisistijd belangrijker dan kinderen krijgen en graan oogsten - wat zo veel wil zeggen als continuïteit waarborgen. "Spirits are brooding in times of crisis," zegt Berglund, en Beattie en Middleton stellen dat "mediumship plays an important role in situations of radical and disturbing social change"

Mehring gedraagt zich, zonder het te kunnen benoemen, steeds meer als sjamaan. Hij maakt zich los van zijn omgeving $(154,156)$,maakt contact met het hiernamaals en gebruikt, als een sjamaan, water om weer "terug" te komen. Hij verwaarloost de rites de passage die de continuïteit van een gemeenschap waarborgen. Hij overschrijdt grenzen van tijd en ruimte, sluit vriendschap met een dode, en onttrekt zich aan de plichten van zijn samenleving. Zijn schrik op nieuwjaarsochtend (zie ) gold in wezen niet de mogelijkheid van een revolutie, maar het feit dat hij die nacht de chaos heeft ervaren, de grensoverschrijding die normaal door rituelen rond de jaarswisseling beteugeld wordt. En terwijl hij zich daarvoor openstelde, kwam de Ander steeds dichterbij (205-210).

$\mathrm{X}$ en Mehring horen beiden tot een categorie die ordeverstorend is (zij als vrouw die haar eigen weg gaat en hij als man die voortdurend onderweg is $\left.{ }^{77}\right)$, maar daarom ook de potentie hebben om te helen. Het enige aanwijsbare verschil tussen hen is dat zij bij de begrafenis aanwezig is, en hij niet.

\footnotetext{
${ }^{773}$ Niet zij, maar Phineas "was plagued by dreams - those of his wife" (164). Na de danssessie ziet Solomon haar haar handen wassen "like a woman who had just finished plucking a fowl or some other ordinary work.."(166)

${ }^{774}$ Engle 1989, 100

${ }^{775}$ John Beattie and John Middleton (eds) Spirit mediumship and society in Africa, 1969, p. XXVIII

${ }^{776}$ zie Auslanders observatie in Hst 4.3.3
} 
Ze creëert haar eigen mogelijkheden ${ }^{777}$ en, in tegenstelling tot de "begiftigden" uit The religious system wordt ze uiteindelijk weer beter (267). Dit laatste verwijst naar integratie (de derde fase van de initiatierite) en dus naar een nieuwe of hernieuwde sociale structuur waarin zij als sjamaan een plaats heeft. Voor zover we weten blijft Mehring een man die altijd onderweg is. Maar dat is niet het gevolg van het oordeel van de compound, of van het lijk, of zelfs van Gordimer, maar van hemzelf. De beweging die Mehring steeds herhaalt ten opzichte van tegenspelers: toenaderen, terugtrekken, verder toenaderen en dan ternauwernood ontsnappen, is uiteindelijk ook de overkoepelende beweging in The conservationist. De laatst beschreven narrow escape is zijn vlucht van de boerderij en vlei.

Als Jacobus uiteindelijk na de overstroming "Come and look!" roept, staat hij voor een keuze. Als hij zou kijken, als hij zijn angst zou overwinnen, dan was de vlei geen paradijs dat door moord, erfzonde, verleiding, verbanning en het verstrijken van de tijd onbereikbaar is geworden, maar in een meer cyclisch tijdsbeeld een plek van transformatie. Vanuit dat perspectief hoeft de dode man geen bewijs van zijn schuldig verleden of voorbode van zijn eigen anonieme dood te zijn, maar kan het een verwijzing zijn naar zijn mogelijkheden voor persoonlijke groei. Maar hij durft niet te kijken, en daarom bespringen al zijn oude fantasieën hem. Hij raakt in paniek en vlucht. Als Mehring faalt is dat omdat hij, als kind van zijn tijd en zijn achtergrond (nog) niet buiten zijn mythen heeft kunnen treden. Maar hij zal ook nooit meer dezelfde zijn.

\subsection{CONCLUSIE}

Later, terugkijkend vanuit het bijna post-apartheid perspectief van 1990, zei Gordimer naar aanleiding van The conservationist: "It seems so easy to say: 'I love the land, I love South Africa, it's so beautiful'. For years now one thought this was a denial of the reality, the real other entity, the people whose land it is... or was. But those of us who have been born here, we do love it, and I think we can stop being ashamed of the fact that we love the veld and the physical things about it". ${ }^{778}$ The conservationist is (na twintig jaar strijd) veel meer geworden dan wat Wagner noemde een "ironische anti-pastorale" "79. De vlei is niet alleen een lachwekkend residu, een laatste klein stukje groene weelderigheid, paradijselijke hoop in een landschap van troosteloos isolement; het is ook seminaal, in die zin dat het de symbolische tegenstelling kan doorbreken. Gordimers opvattingen over transformatie en

\footnotetext{
777 "That crazy woman seemed to have asked some people of her own; they behaved almost as if it were her goat that was going to be killed (170)," denkt Jacobus.

${ }^{778}$ Dorsman \& Postel 1993, 49

${ }^{779}$ Wagner 1994, 192
} 
de heilzame werking van de natuur als gemeenschappelijke bron hebben nieuwe betekenis gekregen. De hoop is gestorven om opnieuw geboren te kunnen worden.

Maar transformatie kan in elk geval geen geïsoleerd proces zijn. Voor mens noch maatschappij is het mogelijk om gedeeltelijk te transformeren; heling vraagt een bereidheid tot algehele openheid. De opmerking van Lars Engle dat het niet gaat om het recht op het land, maar om het feit dat "African culture may have a diagnosis of what troubles Mehring" dan ook een tegenstelling die niet bestaat: landrechten hebben te maken met de ervaring van ruimte en van de Ander binnen die ruimte, en Mehrings onvermogen om met de pluriforme realiteit daarvan om te gaan, ís "what troubles Mehring". De voortdurende herhaling van Mehrings handelingen, die aangeeft hoezeer hij gevangen zit in zijn discours, geeft door kleine verschuivingen tegelijkertijd aan dat verandering onontkoombaar is. Ambivalentie kan nooit eeuwig onderdrukt blijven. The conservationist is wel degelijk, of zelfs bij uitstek een boek over transformatie, over de beperkingen ervan, maar ook de onontkoombaarheid. Zuid-Afrika was in de jaren zeventig op weg naar haar dieptepunt, en daarmee in feite al bijna halverwege haar herstel.

Maar wie is nu de dode man? Judie Newman heeft gelijk als ze zegt dat in The conservationist de divination cult wordt gepresenteerd als een manier om veranderingen het hoofd te bieden en dat "the murdered black (..) represents change and is therefore spiritualized" "781. Dit moet echter niet gezien worden als een pleidooi voor herwaardering van de oude Zulucultuur, maar voor herwaardering van talenten en categorieën die mensen kunnen helpen om de aanstaande veranderingen het hoofd te kunnen bieden. Want wat is "de Zulu-cultuur"? Wie is de Ander? Wie glipt steeds Mehrings bewustzijn binnen? Mehring creëert zijn eigen Ander, zijn horror, vanuit zijn eigen discours, maar ondertussen is er een andere Ander die daarom heen beweegt, als de voetstappen om het buitenhuisje na oudjaarsnacht. Hij ziet hem niet, kán hem niet zien, maar is zich toch vagelijk van hem bewust. Dat is wat Gelder en Jacobs uncanny noemen: "meaning withdrawn from knowledge, obscure and inaccesible" "782.

De Ander is een veranderlijke, pluriforme Ander. Erfgenamen van een Afrikaanse orde, maar ook van degenen die zo pragmatisch waren zich te voegen in een Europese orde omdat de Afrikaanse onvoldoende zekerheid bood. De Ander is dus ook, zoals Homi Bhabha al liet zien, onderdeel van onszelf. ${ }^{783}$ Dit overvloeien van Ik in Ander komt terug in de symbolische kenmerken van de dode man. Hij staat niet alleen voor toekomst en verandering, maar ook voor verleden en voor de fictieve continuering van orde

\footnotetext{
${ }^{780}$ Engle 1989, 99

${ }^{781}$ Newman 1981, 35

${ }^{782}$ Gelder \& Jacobs 1998, 26

${ }^{783}$ Bhabha 1990, 4
} 
en identiteit. Grenzen en structuur zijn immers niet absoluut. Stammen en volkeren worden niet gevormd door bloedlijnen, maar door samenleving. Ook de compound op Mehrings boerderij is geen door bloedbanden begrensde eenheid; het verandert voortdurend in samenstelling.

The conservationist suggereert dat daarom de apartheidspolitiek, die eropuit is geweest om mensen van hun geschiedenis en hun mythologie en daarmee hun identiteit te vervreemden -en zo hun eenheid te breken- niet hoeft te werken. Volgens Callaway wordt het begrip Unkulunkulu op twee manieren gebruikt. Hij is de eerste mens en als zodanig (zegt Callaway) niet plaatsgebonden, maar hij kan ook de stamvader zijn van een volk: een ieder die een eigen stam sticht, zal uiteindelijk Unkulunkulu zijn. In die betekenis is Unkulunkulu meer verbonden aan een plaats, dan aan tijd: hij is de oudste op die plek. ${ }^{74}$ Pogingen van Callaway en zijn nakomelingen om de Zulu-religie af te bakenen en los te koppelen van landrechten, krijgen in The conservationist uiteindelijk een omgekeerd effect. Was de vlei aanvankelijk het grensgebied van Mehrings territorium, een gemarginaliseerd gebied, uiteindelijk wordt het, als decor van het ontstaan van Unkulunkulu, maar ook als de ruimte waarin het handelend subject zich bevindt, het centrum van waaruit "binnen" en "buiten" worden bepaald. Zoals Gelder $\&$ Jacobs schreven over de heilige plaatsen van de Australische Aboriginals: "even at the very moment of its restraint, Aboriginal sacredness is capable of generating effects far beyond the boundaries ascribed to it." ${ }^{785}$ Zowel degenen die het belang ervan marginaliseren als degenen die het belang ervan vergroten, "are both drawn to the sacred (willingly or unwillingly, wittingly or unwittingly) and are thus compelled to represent it not as residual or marginal, but as something of profound significance, something whose significance extends well beyond its actual locality which may itself be 'insignificant' ${ }^{786}$."

Dit wil echter niet zeggen dat in The conservationist, zoals Stephen Clingman schreef, het realistisch kader omvergeworpen wordt door een symbolisch kader, die staat voor een "unspecified, but nonetheless distinctively alternative, reality" die zich in de toekomst zal voltrekken ${ }^{787}$. Die alternatieve werkelijk is hier en nu. Beide betekenissen van Unkulunkulu, als eerste mens en als stamvader, in elkaar overvloeien, zodat de mythische waarheid een fundament kan vormen voor de waarheid van alledag. Chidester zei immers: "Although the precise location of the ancestors might not have been clearly specified, perhaps living under de earth, in the sky, or beyond the horizon, their presence in and around the homestead was

\footnotetext{
${ }^{784}$ Callaway 1970, 51 Er bestonden ook oorsprongsmythen, waarin Unkulunkulu als god optrad, bijvoorbeeld door een territorium toe te wijzen aan blank (water) en aan zwart (land). Alleen werden die verhalen niet door Callaways informanten verteld, of door Callaway genoteerd.

${ }^{785}$ Gelder \& Jacobs 1998, 2

${ }^{786}$ Gelder \& Jacobs 1998,3

${ }^{787}$ Clingman 1986, 167
} 
activated through ritual attention". ${ }^{788}$ "We weten niet waar Unkulunkulu is," zei Mbanda. "Hier!" zegt Gordimer, en ze schetst Unkulunkulu's rieten wieg midden in de realiteit van Witwatersrand, waar hij door (onwillekeurige) rituelen weer tot leven wordt gewekt. Unkulunkulu is de onzichtbare Ander die om Mehring heendraait als hij zich in zijn paradijs bevindt, en die hem angst aanjaagt als onzichtbare Zulu. Maar Unkulunkulu is ook zijn stamvader: hij was man en vrouw, zwart en wit.

De werkelijkheid die hieruit voortvloeit is symbolisch noch onspecifiek, revolutionair noch toekomstig. Hij is net zo pluriform en alledaags als hij altijd al was. Er is ook bijna niets gebeurd. De niet met name genoemde landeigenaar (maar waarom zou dat niet Mehring zijn?) is weer op reis, $\mathrm{X}$ heeft haar rust weer gevonden, de boerderij draait gewoon door. Er heeft alleen even een wisseling van perspectief plaatsgehad. Met de komst van de dode man c.q. Unkulunkulu zijn verstarde verhoudingen tussen binnen en buiten gaan schuiven. Vrouwen klommen uit hun verdomhoekje ${ }^{789}$; voorouders uit hun vergeethoekje. Ook de bewoners van de shanty-town en de location bleken nodig om de noodzakelijke rituelen te voltrekken omtrent het dankfeest voor Solomon. En uiteindelijk komen er overal vandaan mensen en spullen om het opgedoken lijk te begraven, ook geld van de landeigenaar. De dode man is een voorvader geworden van een gemeenschap die alle "realistische" grenzen negeert en tegelijkertijd realistischer en alledaagser is dan de alledaagse realiteit, omdat het een gemeenschap is van de mensen die er zijn. Mehrings tegenstelling tussen binnen (grensoverschrijdend) en buiten (publiekelijk) is op dit moment geen tegenstelling meer.

Tenslotte bleek uit deze analyse ook dat ruimte een subjectief gegeven is; het wordt gevormd door kennis en intertekstualiteit. Mythen, rituelen, en opvattingen over dood en leven leveren de grondstoffen voor een ruimtelijk kader. Vervolgens is het het ruimtelijk kader dat bepaalt wie zich binnen of buiten bevindt, wie vijand en wie vriend is, wie de Ander is en dus wie het Ik. Mehrings denken in elkaar uitsluitende tegenstellingen, zijn lineair tijdsbesef en zijn positivistische opvattingen over realiteit, sluiten bepaalde ruimtes uit en maken daarmee de Ander -en zichzelf- tot vijand. Alleen door het radicaal frustreren van verwachtingspatronen kan deze vicieuze cirkel worden doorbroken en kan er een alternatieve werkelijkheid opdoemen. In The conservationist gebeurt dit door verschillende subteksten ruimtelijk te laten samenvallen, zodat tegenstellingen ontkracht worden en beelden hun eenduidigheid verliezen. Dit gebeurt in de vlei: de plek van gemeenschappelijkheid: de oorsprong van mens, mythen, en vervreemding. En het gebeurt in het bijzijn van de dood als bron van ambivalentie, grens-

\footnotetext{
${ }^{788}$ Chidester 1992, 11

${ }^{789}$ Zie Newman 1988
} 
overschrijding, transformatie en veranderlijkheid. Het is zelfs de dode zelf die de verandering in gang zet door zijn sjamaan uit te broeden, waardoor verandering even onontkoombaar wordt als de dood.

Wat onderdrukt wordt en naar boven komt, is dus niet alleen de Ander, maar ook de Ander in onszelf. Niet het discours van een ander, maar een discours dat op dat van een ander lijkt. Niet de ander als onkenbaar, maar als kenbaar, als vreemd, en toch vertrouwd. Hier komt de analyse van Lars Engle over culturele parallellen samen met Newmans opvattingen over een onderdrukt en begraven subtekst. Wat onderdrukt wordt, is ambivalentie. "Thus," stelt Kristeva, "in the very word heimlich, the familiar and intimate are reversed into their opposites, brought together with the contrary meaning of uncanny strangeness harbored in unheimlich. "' ${ }^{90}$ In de beschreven tijdspanne (tien maanden, net iets langer dan de officieel veertig weken durende zwangerschap van een vrouw) is er aan de oppervlakte weinig veranderd. Maar de lezer is veranderd, en zal blijven veranderen. Hij of zij heeft, net als Mehring, en als een sjamaan die geboren wordt, vertoefd in de vlei en is er anders uitgekomen. Doordat bepaalde verhaallijnen en perspectieven onverteld zijn gebleven, dankzij de openingen die door de lezer, met zijn/haar veranderende discours, steeds anders kunnen worden ingevuld, krijgt de roman de mogelijkheid om aan de perspectieven van Callaway en Mehring, en aan de beperkingen van Gordimers tijd, te ontsnappen.

${ }^{790}$ Kristeva 1991, 173 
Daar is al in die verlede sulke "reinigingsoefeninge" gedoen. In 1999 is die migrasieroetes van die eerste inwoners van Suid-Afrika, die San Boesmans, gevolg om in gebed en bekering die verbonde ongedaan te maak wat hulle met die geesteswereld gesluit het. Hierdeur het hulle ' $n$ vesting van afgodediens geskep waardeur al die opkomende geslagte gebind is. In die plek hiervan moet nou ' $n$ nuwe grondslag vir gebed en diens aan die ware God gevestig word.

(...) Sodoende moet ' $n$ land wat deur sy eerste inwoners aan vreemde geeste verbind is, bevry en gesond gemaak word. Onder die leiding van die Heilige Gees moet die duistere magte wat deur die San ingenooi is, verwyder en met eer aan die Here vervang word. So ook moet die Here gevra word om die bande van voorvaderaanbidding en toorkuns in Afrika se swart kulture te verbreek, sodat al die mense die lig kan sien.

J. Malan en L. Coetzee, $2003^{791}$

6

\section{"Satang dwaal vennag" \\ Ambiguïteit en liminaliteit in Kroniek van Perdepoort}

\subsection{INLEIDING}

Hoe alternatieve ruimte zich binnen een traditioneel kader kan manifesteren laat W.J.T. Mitchell goed zien in Imperial landscapes (1994). Landschappen, als genre in de Europese schilderkunst, zijn uitermate ideologisch geladen. Ze vormen een dubbelzinnig communicatiemiddel tussen mensen en tussen mens en natuur dankzij een gelijktijdige "articulation and disarticulation of the difference between nature and convention" "792. De groei van het genre gaat in Europa bovendien gelijk op met de groei van de koloniale machten, en dat is niet voor niets, aldus Mitchell.

These semiotic features of landscape, and the historical narratives they generate, are tailor-made for the discourse of imperialism, which conceives itself precisely (and simultaneously) as an expansion of landscape understood as an inevitable progressive development in history, an expansion of 'culture' and 'civilisation' into a

\footnotetext{
${ }^{791}$ Verdere Transformations misleiding... Geraadpleegd op 03-06-2003 op $\mathrm{http}: / / \mathrm{www}$. bibleguide.com/old/articles/afrikaans/transformasie/valseherlewing2.htm ${ }^{792}$ Mitchell 1994, 17
} 
'natural' space in a process that is in itself narrated as 'natural'. (..) And this movement is (..) typically accompanied by a renewed interest in the representation of the home-landscape, the 'nature' of the empirical center. ${ }^{793}$

De confrontatie met het onbekende roept dus de behoefte op om het bekende vast te leggen: het landschap met zijn nostalgische lading is zoiets als de plaasroman van de schilderkunst. Het bekende wordt, net als bij de plaasroman, nog vertrouwder door het in genreregels te vangen: "pittoresk" bijvoorbeeld is een landschap dat bekeken wordt als door de ogen van een roofdier dat het landschap scant als een strategisch veld ${ }^{794}$ : op de voorgrond aan weerszijden bomen of bosjes die beschutting bieden aan de kijker en in het midden een vergezicht of doorkijkje "to provide deep access" $"$ "9s. Het kader op de voorgrond verwijst dan weer naar het kader van het schilderij zelf, zodat een veilige afstand wordt geschapen. Ook vreemde landschappen werden volgens deze regels geschilderd, waardoor het bekende het vreemde absorbeert. Door "inboorlingen" en hun gebruiken in het open vergezicht te plaatsen, weerspiegelt zo'n schilderij bij uitstek de machtsrelatie tussen de koloniaal als strategisch roofdier en de gekoloniseerde als zijn weerloze prooi.

Dat een subtiele verdraaiing van de genreregels een heel ander beeld kan opleveren, bewijst vervolgens Mitchells lezing van een schilderij van Augustus Earle: Distant view of the bay of Islands, New Zealand (ca. 1827). Hier staat op de voorgrond van een boomloos landschap een Europese ontdekkingsreiziger met de rug naar de kijker in de verte te staren. Rechts naast hem, op enige afstand, staat in plaats van de obligate boom een houten beeld "that stares back into the space of the beholder." Dit beeld, zegt Mitchell, "may stand 'in the place of' the repoussoir, but it does so only to show that convention is displaced by something else."”96

Waardoor de conventie wordt vervangen blijkt pas na toevoeging van externe kennis. De wetenschap dat dit beeld in Maori-cultuur gebruikt wordt om over verboden gebied (tabooed territory) te waken, verplaatst op unheimliche wijze de kern van het schilderij buiten het schilderij, en maakt een andere, onzichtbare ruimte "zichtbaar". In plaats van naar het blikveld van de ontdekkingsreiziger wordt de aandacht getrokken naar dat wat niet verbeeld wordt - niet verbeeld kan worden - door de schilder, namelijk de "visual field of the Maori, that is beyond the frame, out here in the dark with us" "797. In plaats van de almacht van schilder en kijker worden beider beperkingen benadrukt, en representeert dat wat wel verbeeld wordt die

\footnotetext{
${ }^{793}$ Mitchell 1994, 17

${ }^{794}$ Jay Appleton (1975) The experience of landscape. London

${ }^{795}$ Mitchell 1994, 16

${ }^{796}$ Mitchell 1994, 25

${ }^{797}$ Mitchell 1994, 26
} 
typische vermenging van eigen en vreemd die Bhabha tot het Unheimliche rekende: "The other is never outside or beyond us; it emerges forcefully (..) when we think we speak most intimately and indigenously 'between ourselves'." ${ }^{\prime} 98$

Wat het schilderij als het ware doet, is "terugkijken", zoals de moderne plaasroman als anti-pastoraal in de termen van Ashcroft, Griffiths \& Tiffin (1989) "terugschrijft". In 1975 schreef Anna Louw Kroniek van Perdepoort. De Nasionale Party regeerde al zevenentwintig jaar en had nog bijna twintig jaar te gaan. Een jaar eerder was The conservationist verschenen. Beide romans zijn postkoloniaal in die zin dat ze de machtsbasis van de blanke patriarch bekritiseren, ondermijnen en zelfs ridiculiseren, hoewel een concreet alternatief nog niet wordt geboden. Kroniek en The conservationist vertonen opmerkelijke overeenkomsten. In beide romans is de plaats van handeling bijna uitsluitend het territorium van een blanke grondbezitter. In beide gevallen kan de boerderij worden gezien als een (post-)paradijselijke plek, met een dode niet-blanke man die begraven moet worden, maar waarvoor een kist en de nodige rituelen ontbreken. De blanke bewoners, in het geval van Kroniek inclusief de vader van de dode, negeren hun verantwoordelijkheden. De zwarte arbeiders wonen op een hoger gelegen en meer zichtbare plek dan de huidige eigenaar zou willen. Er is in beide boeken sprake van een zwervende zoon die nooit erfgenaam kan zijn, van een eigenaar die zich op eigen terrein beweegt alsof hij op verboden gebied is, van een onbetrouwbare verleidster en van een graf aan de oever van de rivier. En misschien het belangrijkste: tijdens de periode dat de lijken wachten op hun begrafenis gebeuren er vreemde dingen. Mensen worden geplaagd door onwelkome herinneringen, unheimliche ervaringen, hallucinaties en onbekende angsten.

Ondanks al deze overeenkomsten kent Kroniek een ambivalentie die bij The conservationist ontbreekt. Deels komt dat verschil voort uit een verschil in literaire traditie of persoonlijke achtergrond, maar ook speelt het verschil in setting een rol: het Hoogveld versus de Kaapprovincie. De (etnische) tegenstellingen die Gordimer in haar roman opvoert zijn veel absoluter dan die van Louw. Ondanks de gedeelde discoursen is het contrast tussen Mehring en zijn plaasbewoners groot. In Louws boek zijn de verschillen veel kleiner. Weliswaar zijn er duidelijk twee afzonderlijke leefgemeenschappen op Perdepoort, geïllustreerd door de twee begrafenissen met elk hun eigen publiek: een kleurlinggemeenschap ${ }^{799}$ en een blanke

\footnotetext{
${ }^{798}$ Bhabha 1990, 4

799 "In ander lande word "Coloured" gebruik om mense aan te dui wat deels swart, deels wit is, maar in Suid-Afrika dui dit op 'n gemeenskap, of groepering gemeenskappe, wat hoofsaaklik van bruin- of geelvellige herkoms is, alhoewel die meeste Kleurlinge 'n mate van blanke afkoms het en baie is deels swart. Die term is in die statistiek van die Kaapkolonie gebruik om almal aan te dui wat óf Engels óf Afrikaans gepraat het, maar nie deel was van die "Europeaanse" groep nie. Die gebruik het sy oorsprong in 'n klassifikasie van die VOC waaronder sulke mense geklassifiseer is as "vrij zwarten". Dit sluit mense in van Asiatiese herkoms, veral dié van Maleise herkoms (Indonesiese of Skiereilandse
} 
gemeenschap, maar tussen landeigenaren en plaaswerkers is op het eerste gezicht eerder sprake van een klasseverschil dan van een cultuurverschil. In The conservationist zijn de etnische tegenstellingen ook veel explicieter tot thema verkozen. Waar Gordimer onomwonden naar Zulu-mythen en rituelen verwijst, is het in Kroniek veel lastiger om een alternatief discours te traceren. Daarentegen is de christelijke achtergrond in Louws boek veel explicieter dan in dat van Gordimer. Tot nu toe is Kroniek dan ook vooral beschouwd als een boek dat vanuit een christelijke optiek handelt over filosofische en psychologische aspecten van goed en vooral kwaad ${ }^{800}$, over de zes hoofdzonden die voortkomen uit de zevende. Aanvankelijk zag men hierin een voortborduren op de traditionele plaasroman ${ }^{801}$ en een bevestiging van de christelijke leer en het is dan ook vooral in die termen dat tegenstellingen gedefinieerd worden. Minnaar schrijft:

Dit is te verwagte dat die religieuse motief skering en inslag sal wees in 'n verhaal oor die sonde. Dié motief impliseer die bedrywigheid van die Bose in sy verskeie gedaantes; bygeloof, ongeloof en sinisme; Boedhistiese leringe, nihilisme; ook verskillende verduisteringe van die Christelike religie. ${ }^{802}$

Over de interpretatie van goed en kwaad is hiermee nog niet het laatste woord gezegd, maar onmiskenbaar aanwezig zijn inderdaad de zeven doodzonden, die in de vorm van een kinship metaphor de basisstructuur vormen voor het boek. Koos Lotriet, alias Koos Nek, vertegenwoordigt als stamvader de hoogmoed. Zijn zondige nakomelingen zijn Jan (afgunst), Attie (vrekkigheid), Kobus (gulzigheid/vraatzucht), Klaas (traagheid/ledigheid) en Chris (lust), die op hun beurt een generatie hebben voortgebracht van (mannelijke) woede: Jaco - maar ook de andere, gemarginaliseerde, kleinzoons: Fielies en Kolie. ${ }^{803}$

In de loop der jaren hebben critici steeds vaker de nadruk gelegd op waar Kroniek van de traditie en stereotiepen in de plaasromans afwijk ${ }^{804}$ of die zelfs ondermijnt ${ }^{805}$. En inderdaad is bijvoorbeeld de kinship metaphor zoals die door Van den Heever is gebruikt (een vruchtbare moeder Aarde en

\footnotetext{
Maleiers), maar ook dié van Khoikhoi- en Boesman-herkoms. In die Kaapse metropool toon die Kleurlingbevolking kenmerke van beide Oosterse herkoms (veral in buurte wat moskees het) en Khoisan-herkoms, en onder hulle is heelwat Engelssprekendes, maar in die plattelandse dele val die meeste Kleurling-inwoners in hierdie laaste kategorie (Khoikhoi of Boesman) en is Afrikaanssprekend." Bron: http://uk.geocities.com/landswapen/9prov/WKaap.html geraadpleegd op 26-01-2004.

${ }^{800}$ Minnaar 1977, 112-130; Cloete (ed.) 1980, 344-345; Steenberg \& Minnaar 1985179,14

${ }^{801}$ Kannemeyer 1983, 313

${ }^{802}$ Minnaar 1977, 123

${ }^{803}$ De kinship metaphor "Hoogmoed is de vader aller zonden" valt onder het door Turner onderscheiden type "causation as progeneration", dat weer is afgeleid van "Conditions are parents and results are offspring”. (Turner 1987, 28; 139 e.v.)

${ }^{804}$ Kannemeyer 1983, 114; André Brink in: Lindenbergh 1987, 147-148

${ }^{805}$ Van der Merwe 1994, 110; A. Coetzee 2000, 14/15
} 
hardwerkende vader Boer brengen samen kinderen/vruchten voort die de eeuwige kringloop van het leven garanderen) in Kroniek op zijn minst nogal versleten geraakt. De mannen werken niet, het land verdroogt, en in plaats van voor leven, kracht, saamhorigheid en maatschappelijke orde, is de familie een metafoor geworden voor onontkoombare degeneratie, verdeeldheid en dood. Waar ze er voorheen voor zorgde dat de boerderij een besloten, veilige binnenruimte was die het kwaad en de chaos buitenhield, is die familie nu bron van het kwaad, zodat de binnenruimte niet meer goed en veilig is, maar slecht en onveilig; niet meer heimlich, kortom, maar unheimlich.

Er is een politieke kant aan deze omkering. Volgens Van der Merwe suggereert Kroniek dat Hoogmoed en haar zes dochterzondes het Afrikaner bolwerk van binnenuit aantasten. ${ }^{806}$ Kroniek kan gezien worden als een allegorie waarin in het bereiken van het Afrikaner ideaal tegelijkertijd het verval besloten zit. Dit is een boodschap die sterke gelijkenis vertoont met die van het $17^{\mathrm{e}}$-eeuwse Lucifer van Joost van den Vondel. Vondel ergerde zich aan het feit dat "politieke rampen in het leven der volkeren gewoonlijk uit dezelfde kiem, een persoonlijke zonde van hovaardij te verklaren vielen." ${ }^{807}$ Hoogmoed is bij Vondel vooral "staatszucht": "een bijzondere vorm van hoogmoed die erin bestaat dat de mens een hogere status nastreeft dan God voor hem bedoeld heeft." ${ }^{808}$ In Lucifer is het de duivel die met zijn hoogmoed zichzelf de das om doet; in Kroniek is het de mens zelf die ten val komt, terwijl de duivel in talloze gedaantes rondwaart.

Maar evenmin als Vondels Lucifer is Kroniek slechts een politieke allegorie. Op een persoonlijk plan is het een boek over streven naar perfectie en omgaan met beperkingen; over dogma's en onmacht. Koos Nek, die vanuit de Kaap naar de binnenlanden trok om zijn eigen paradijsje en dynastie te stichten, moest uiteindelijk toch toegeven dat de wereld zich niet liet voegen in zijn plan. Levend bewijs zijn zijn zoons, die allemaal op hun eigen manier een uitvlucht zoeken uit het leven dat hen (door hun vader) gegeven is, en daarbij vastlopen in onverenigbare tegenstellingen. Zelfs hun opstand tegen het vaderlijk gezag is, in vergelijking met die van Vondels "zoon" Lucifer, halfslachtig en mislukt - ze hebben zich, ook na zijn dood, nooit geheel uit zijn greep kunnen losmaken en zijn blijven steken in puberaal verzet. De ultieme anti-climax van Koos' leven wordt in de drie dagen die dit boek beslaan beschreven: Koos en zijn vrouw worden opgegraven uit hun praalgraf midden in het land en verplaatst naar een kleine grot in een rotswand aan de rand van de boerderij. Tijdens de verplaatsing laten de dragers ook nog de kist vallen zodat hij van de berg aftuimelt en uit elkaar valt.

\footnotetext{
${ }^{806}$ Van der Merwe 1998, 606 e.v.

${ }^{807} \mathrm{http}: / / \mathrm{cf} . h u m . u v a . n l / d s p / l j c / v o n d e l / l u c i f e r /$ inleidin.html. geraadpleegd op 14-3-2005

${ }^{808}$ Rens 1979,12
} 
Tenslotte is Kroniek ook een boek met raadselachtige elementen ${ }^{809}$ en een zoektocht naar verborgen en vooral verloochende relaties en gebeurtenissen. Zowel de a-chronologie van de roman als de titels van de drie delen (Sondag 9 maart-Die lykskouing; Saterdag 8 maart- Die begrafnis; en Vrydag 7 maart - Die getuies) suggereren dat de roman "die aard het van geregtelike ondersoek, 'n speurtog na die waarheid." $" 10$ De voordehandliggende verborgen waarheden die de lezer in dit boek gaat zoeken is die omtrent de in verschillende stadia van ontbinding verkerende Koos, Kobus en Fielies en de relatie tussen die drie. Een geheel bevredigend antwoord krijgt de lezer niet. Als er al een waarheid boven tafel komt is dat een postmoderne: namelijk dat er geen zekerheid te geven is omtrent een objectieve waarheid. Dankzij de wisselende perspectieven blijft de spanning tussen verschillende waarheden bestaan, en blijft dus ook de mogelijkheid open dat er nog meer, niet gefocaliseerde waarheden zijn.

Als Kroniek een herinneringsroman is, zoals Afrikaner critici de (traditionele) plaasromans typeren ${ }^{81}$, dan van een heel wrange soort. De herinnering, het verleden, dat in eerdere plaasromans de binnenruimte en diens waarden schraagde, is in Kroniek een mijnenveld geworden. Koos, de vroegere Koos, was de laatste die met zijn praalgraf de herinnering levend probeerde te houden - en zijn graf is geruimd. De latere, verlichte danwel kindse Koos heeft alles losgelaten. Zijn zoons worden, gedurende deze drie dagen, geplaagd door herinneringen die ze al lang achter zich hadden willen laten. De herbegrafenis is behalve de feitelijke begrafenis van lichamen, ook een (her)begrafenis van de herinnering ${ }^{812}$. Toch is het m.i. niet Kobus' "vervloekte geheuë" dat hem tot zelfmoord drijft ${ }^{813}$; Kobus wordt al twee dagen geplaagd door zijn geheugen. Ook is het niet Koos' symbolische val. Significant is vooral dat de kist openbarst en leeg blijkt te zijn, maar alleen de externe verteller maakt daar een paar droge woorden aan vuil:

Toe blyk dat niemand beseer is, kon daar ondersoek word wat daar te ondersoek mog wees. (..) Die kis het op die sy gelê en half uitmekaar, dit was te verstane. 'n Kolonie glasige insekte met lang bleek pote wat in die hoek krioel, kon, ten dele, verantwoordelik gewees het. Van die oorspronkelike inhoud van die kis is daar geen teken nie. Behalwe 'n paar hande vol growwe grond. Of beenmeel? (68)

\footnotetext{
${ }^{809}$ Minnaar 1977, 114; Van der Merwe 1998

${ }^{810}$ Van der Merwe 1998, 608. Zie ook Minnaar 1977

${ }^{811}$ Steenberg 2000, 92; Kannemeyer 1983, 17, 22, 25, 41 en 302; Ampie Coetzee 2000, 14

${ }^{812}$ Minnaar 1977, 114

${ }^{813}$ Minnaar 1977, 114

${ }^{814}$ Naar de vele aangehaalde passages uit Kroniek van Perdepoort zal in dit hoofdstuk met slechts een paginanummer worden verwezen.
} 
$\mathrm{Na}$ lezing van deel drie zal de lezer terugkeren naar dit begin en dan, als een rechercheur in een detectiveroman, tot de conclusie komen dat hij of zij op het verkeerde been is gezet. De herinneringen aan Koos Nek, en daarmee ook de macht van het verleden is een luchtbel. "Dit is 'n herbesoek aan die verleden wat nóg herinnering, nóg nostalgie is." zegt ook Ampie Coetzee, ${ }^{815}$ maar het is zelfs geen herbezoek aan het verleden, maar een herbezoek aan het heden. Het unheimliche gevoel bekruipt de lezer dat er, tijdens het lezen, net als bij het schilderij van Earle, parallel een ander verhaal heeft meegelopen, net buiten beeld. Het gaat niet om Koos Nek. Koos Nek is al lang dood. (Of kijkt hij stiekem mee? ("Outa sit agter die bos" (36))) En is het niet juist dát besef dat Kobus naar zijn geweer heeft doen grijpen? Wat zag hij, toen hij Koos Nek niet meer zag?

Dat wat net buiten focus lag, kan nu in beeld komen: en dat doet het ook, zoals de steeds wijzigende receptie van dit boek aantoont. Ik zal op zoek gaan naar die onderbelichte verhalen; het verhaal van het verval van Perdepoort, ooit een toppunt was van de overwinning van cultuur op natuur, maar nu langzaam terugkerend in zijn originele staat; het volgens Kannemeyer $^{816}$ al te zeer gemarginaliseerde parallelverhaal van Ertmanstasie; het verhaal van Fielies' dood. Grotendeels onzichtbare tegendiscoursen kunnen zichtbaar gemaakt worden door te laten zien waar ze aan de randen van het blikveld van de focalisatoren opdoemen. Op die manier kan dat wat Minnaar afdeed als duivels "bygeloof", namelijk Oompie Dansters "geskoffel" uitgroeien tot, zoals André Brink terecht opmerkte, de spil van de roman ${ }^{817}$.

\subsection{PERDEPOORT: GESCHONDEN PARADIJS}

De boerderij, dat wil zeggen het land dat Koos Nek ooit heeft aangekocht en waar nu de vier broers boeren, ligt tussen twee noordelijke uitlopers van een hoge bergpiek: Duiwelsdans. Het heeft er in Koos' tijd paradijselijk uitgezien; met haar bergwanden en grotten, dalen vol vruchtbomen, bloemen en grazende kudden, met de verschillende, samenkomende rivierlopen met watervallen en vruchtbare oevers (21) leek het op de invloedrijke beschrijvingen van het paradijs die John Milton gaf in Paradise lost of Vondel in Lucifer. ${ }^{818}$ In het vertelde heden overheerst het beeld van verwaarlozing en langzame verdroging. Het grondgebied bestaat uit een hoog en een laag gedeelte, die met elkaar verbonden zijn door een nu en dan stijl oplopend wagenpad. Boven is het verwilderde grondgebied van Kobus: Land van Onskuld. Lager in de vallei ligt de vruchtbare landbouwgrond

\footnotetext{
${ }^{815}$ A. Coetzee 2000, 14-15

${ }^{816}$ Kannemeyer 1983; 314

${ }^{817}$ Brink 1976, 159

${ }^{818}$ Milton 1976 boek IV vers 205-287; Vondel 1979, 63 (I; 53-70)
} 
langs beide oevers van de rivier. Atties erf rond het oude huis, "'n uitstekende voorbeeld van Nieu-Kaaps-Hollands" (27), ligt aan de voet van een van de westelijke koppen voor in de Poort. Ook hier zijn overal tekens van verwaarlozing. De brug over de rivier is kapot, het huis moet geschilderd worden, de bloemperken, vogels en beeldjes van vroeger ontbreken. Miemie is ziek, en Attie zelf heeft geen aandacht voor dingen die niet direct geld opleveren. Wat er nog aan schoonheid is, komt van de natuur: bloemen, kikkers en de rivier (27).

Voor (beneden) in de vallei liggen de tuinen en velden van Jan en Attie. Jans huis, Eikenhof, ligt oostelijk van de rivier (het ouhuis als enige westelijk). Op de rivieroever is zijn zoon Jaco, in een poging zijn vaders schulden en mismanagement teniet te doen en de hypotheek die op het huis rust kwijt te raken, een vakantiepark aan het bouwen. Helemaal voor in de Poort wonen Klaas en Annie in het oude bywonershuis (116). Daar schuin boven, tegen de helling van Kasteelkop aangebouwd, heeft Koos Nek Ertmanstasie gebouwd, de huizen voor zijn arbeiders. Voor Attie een doorn in het oog, zo pal vooraan (83); voor de bewoners een uitgeleefde plek (220/1). Behalve het rijtje huizen staan er de twee skerms ${ }^{819}$ van Ta'Johanna en $\mathrm{Ou}$ Vaalwater. In het midden van de boerderij, op de westelijke rivieroever, ligt de begraafplaats. Het -nu lege- praalgraf is met tralies omringd en getooid met een witte, gebarsten, marmeren steen. Koos Nek legde hem aan nog voor zijn dood, het werd een lusthof en bezienswaardigheid en een trendsetter voor mensen uit de omgeving ${ }^{820}$. Nu heeft Attie het graf leeggehaald, struiken gerooid (212) en bomen laten afbranden ${ }^{821}$. Achter het ouhuis, aan de rand van het landgoed, is in een rotswand een kleine grot met uitzicht over de vallei, waarin hij zijn overleden ouders wil bijzetten. Er loopt een oud, slecht onderhouden, doodlopend teepad naartoe.

De drie dagen die beschreven worden horen tot de warme, droge Kaapse nazomer: 7, 8 en 9 maart. De laatste spanspek moet van het land, de zon is heet en de lucht wazig van de hitte - alles is droog en verbleekt en het stroomgebied van de rivier " "n groen oase tusse brandende windverwaaide koppe" (43). Het verhaal wordt dag na dag verteld, maar a-chronologisch. Op zondag treedt de familie buiten de grenzen van Perdepoort en wordt van buitenaf bekeken, gefocaliseerd door een personage van buiten de boerderij. Aan het eind van het hoofdstuk wordt de focalisatie door de bewoners, die terugkeren naar huis, overgenomen. De a-chronologische volgorde maakt de zondag tot introductie voor een flashback: door dorpsbewoners wordt geroddeld en gespeculeerd over de drama's die zich in de loop der tijd hebben afgespeeld op Perdepoort, met als apotheose de kist van Koos

\footnotetext{
${ }^{819}$ Skerm is het woord dat gebruikt werd voor de traditionele, verplaatsbare onderkomens van de San, gemaakt van takken en eventueel graszoden (Krog 2003, 155).

$82012 / 13$

821 "Bome wat Attie Hardehand by die ou begraafplaas al laat afbrand van hier soos verbrande lyke in die tipiese vuisvegtershouding.' (122)
} 
die op raadselachtige wijze zou zijn gevallen en Mietjie die na de dood van haar zoon uit haar huis gezet zou zijn. Bovendien beleven Jaco en Adriana iets wat de slotscène van een liefdesfilm zou kunnen zijn. Een vierde verhaallijn in retrospectief wordt uitgezet als Mietjie bij thuiskomst het lijk van Kobus vindt. Zaterdag, de dag waarop tijdens een "woedende bergwind" (4) twee begrafenissen plaatsvinden (de herbegrafenis van Koos en Dora Lotriet en de begrafenis van Fielies, die donderdag is overleden) speelt zich af op Perdepoort zelf. Het is een van de zeldzame gelegenheden dat mensen van buiten Perdepoort het grondgebied betreden - én dat de familie bij elkaar komt. Bij de beschrijving van deze dag wisselt de focalisatie voortdurend, maar ligt nu vooral bij de bewoners van de boerderij, waardoor de lezer een indruk krijgt van de betrekkingen tussen hen. Tevens wordt duidelijk dat er op vrijdag verschillende dingen zijn gebeurd die ieder voor zich als ballast met zich meedraagt. De vrijdag beslaat ten slotte het grootste deel van het boek. Belevenissen en beleving van de boerderijbewoners, hun gedachten en herinneringen, staan op deze dag centraal. Hoewel sommige personages elkaar af en toe tegenkomen, gaat ieder duidelijk zijn of haar eigen, afzonderlijke gang. De focalisatie ligt in dit deel dan ook altijd - en langere tijd aan een stuk - bij een van hen.

Het effect van deze focalisatiestructuur is bijna visueel. Minnaar omschrijft het verhaal bijvoorbeeld als een soort draaikolk die uitkomt bij de kern:

Die drie dele van die verhaal gee 'n progressiewe onthulling van die verlede, al dieper die verlede in en al dieper in die sondigheid van die mense - 'n afstroping van laag na laag tot in die kern van die mens se aard. Die perspektiefaanwending - die oorkoepelende alwetende sowel as die beperkte perspektief van die verskillende karakters kan voorgestel word deur drie konsentriese sirkels met as gesamentlike middelpunt die Lotrietfamilie ${ }^{822}$.

Vanuit een dergelijk beeld kan Minnaar niet anders dan concluderen dat "by herlees van deel een - Sondag se perspektiewe - nadat die boek met vrijdag se gebeure afgesluit het, kry elke gebeure en gesegde sy plek en betekenis in die geheel." " ${ }^{23}$ Louws hantering van focalisatie heeft echter nog een andere uitwerking. Bijna alle gebeurtenissen worden slechts door één persoon gefocaliseerd. De afzonderlijke scènes sluiten bijna altijd naadloos op elkaar aan, en vrijwel zonder overlappingen. Omdat de personages ook voortdurend, al dan niet in beweging, in de ruimte geplaatst worden, heeft dit een ruimtelijk effect dat Minnaars interpretatie lijkt tegen te spreken: hoewel alle ogen inderdaad op de Lotriets gericht zijn kun je nauwelijks van een geheel spreken waarin alles een plek en betekenis, laat staan een

\footnotetext{
${ }^{822}$ Minnaar 1977, 115

${ }^{823}$ Minnaar 1977, 114
} 
kern heeft. Als er al sprake is van een gezamenlijk middelpunt dan wordt dat volledig geïroniseerd door de lege kist van Koos Nek. Eerder is het alsof alle personages zich in een eigen, begrensd domein bevinden. Zeker op vrijdag beheerst ieder personage als het ware een gedeelte van het verhaal; net zoals de vier broers lijken te heersen over hun afzonderlijke domein binnen Perdepoort - "lijken", want deze heerschappij blijkt uiteindelijk zeer relatief te zijn.

Wat de focalisatie betreft zijn er een aantal uitzonderingen op bovenstaande regel. Soms vindt er dubbele focalisatie plaats - de bijna-verkrachtingsscène van Adriana wordt bijvoorbeeld twee keer beschreven, zowel vanuit Chris als vanuit de bespiedende Jaco. Bovendien vallen er gaten; sommige gebeurtenissen worden juist níet gefocaliseerd, hoewel ze wel (al dan niet met enige moeite) gereconstrueerd kunnen worden ${ }^{824}$. Ook in de herinnerde tijd zijn essentiële gebeurtenissen weggelaten ${ }^{825}$. De grootste gaten worden echter geslagen door de ontbrekende focalisatie (en herinnering) van beide lijken: Koos Nek en Fielies.

Beide procedés (verdubbeling en weglating van de focalisatie) hebben tot gevolg dat verteller en focalisator over het geheel gerelativeerd worden, en dat er extra nadruk komt te liggen op de gebeurtenissen die dubbel en vooral niet gefocaliseerd zijn. Je krijgt, met andere woorden, het gevoel dat de werkelijkheid net buiten beeld ligt - een typisch geval van het unheimliche. Daarnaast zijn er ook andere aanwijzingen dat er zich iets essentieels buiten beeld bevindt. Verschillende personages hebben zelf unheimliche ervaringen (Attie, Jan, Chris, Klaas, Annie, de kinderen van Ertmanstasie). Ook kan uit hun terloopse waarnemingen worden vastgesteld dat bepaalde elementen uit de omringende natuur- water, kikkers, wind, zon en maan wel erg nadrukkelijk aanwezig zijn. Wat is hun betekenis? Ten derde is er de voortdurende herhaling van de woorden duiwel, Satan en Bose in zowel vertellerstekst als gesproken tekst, die als het ware de loper leggen voor de herkenning en interpretatie van Klaas' nachtelijke bezoeker. Maar is er geen andere interpretatie mogelijk?

\subsubsection{Vacuüm}

Ruimtegebruik heeft een sleutelfunctie in deze roman. Zoals gezegd is er het beeld van concentrische cirkels om een lege kern: ruimtelijk verbeeld door het lege praalgraf midden in Perdepoort en symbolisch door de lege kist van de nog zo in ieders gedachten aanwezige Koos Nek. Ook elders bevinden zich lege plekken. Hoewel de blanke mannen het verhaal voor het

\footnotetext{
${ }^{824}$ Dit geldt bijvoorbeeld voor de stenengooierij van Kolie, de trancedans (buiten) van Oompie Vaalwater, het vertrek van Mietjie van Perdepoort, Miemie's besluit om toch te blijven, en de dood van Kobus.

${ }^{825}$ de dood van Fielies, de breuk tussen Kobus en Koos en de verkrachting van Mietjie door Kobus.
} 
overgrote deel focaliseren, en hoewel ze vanuit dat perspectief de macht, het geld en het land in handen hebben, is de ruimte die zij daadwerkelijk innemen zeer beperkt. Ze begeven zich nauwelijks buiten hun huizen. Ze hebben geen contact met hun omgeving. Ze willen uit de wind blijven, uit de zon en uit het zicht. Hun blik - en focalisatie - is of naar binnen gericht, of ver weg in ruimte of tijd.

Attie bijvoorbeeld, houdt zich voortdurend bezig met grenzen $(78,91$, etc.). Aan de ene kant beschermt hij zijn eigen domein tegen invloed van anderen; aan de andere kant is hij gericht op in bezit nemen van andermans domein. Tegelijkertijd neemt hij de ruimte die hem op dit moment toebehoort niet eens in. Hij is de intertekstuele nazaat van Oom Sybrand uit Laat vrugte, met dat verschil dat Sybrand de (onderdanige) aanwezigheid van zijn zoon en arbeiders nodig had voor de bevestiging van zijn op baasskap gebaseerde identiteit, en zijn imperialisme gericht was op status en bezit ${ }^{826}$, terwijl Attie er -in zijn eigen ogen- vooral op gebrand is Perdepoort te zuiveren van kwaad, vuil, wanorde en lelijkheid, wat erop neerkomt dat hij het liefst iedereen met een zondvloed zou wegvagen (83). Onder die goddelijke pretenties verbergt Attie een dieper liggende onzekerheid. Ondanks (of dankzij) zijn formele greep op het geheel, zijn gewettigd bezit en zijn imperialisme, voelt hij zich bijna overal bekeken, bedreigd, geclaimd, uitgelachen en opgejaagd ${ }^{827}$ : hij sluipt rond alsof hij zich op verboden terrein bevindt. Iedere confrontatie met een ander - knecht of broer- lijkt een aanslag te zijn op zijn wereldbeeld. De stereotiepe, in veel vroegere plaasromans gebruikte tegenstelling tussen de wakkere boer en zijn luie knechten $^{828}$ wordt bijvoorbeeld ironisch verdraaid als Attie op vrijdagochtend zelfgenoegzaam zijn huis uitkomt, Hij is ervan overtuigd dat hij als eerste uit de veren is: “Altyd eerste op, wakker as daar net 'n strooi kraak in die nag, saans weer die laaste om te gaan lê - die bruinvolk wonder of die baas óóit slaap," denkt hij tevreden (77). Maar dan ziet hij tot zijn ergernis de melkjongen die, als "vir 'n wonder" buiten al op hem staat te wachten, en hij buigt diens vroege aanwezigheid razendsnel om in luiheid: hij staat daar "of hy die wêreld se tyd het" (78). Atties droom is een Perdepoort zonder broers, zonder werklieden, zonder vrouwen, zonder stadsmensen, maar nog steeds vanuit een paternalistische visie. Attie, die zichzelf zo graag ziet als "Attie die sorgsame" (241) is de ontspoorde versie van Oom Sybrand: de verhouding vader-zoon/arbeiders uit Laat vrugte heeft plaatsgemaakt voor een utopische, maar a-sociale één-op-éénrelatie met de grond

\footnotetext{
${ }^{826}$ Sybrand loopt tot aan de grens van het land van zijn buurman en "daar kom 'n ou begeerte in hom op om díe draad met pale en al af te breek, sodat Langvlei kan aansluit by Boskloof. Voor sy dood wil hy dit nog sien," als hij tachtig is wil hij de man zijn "wat die hele Boskloof en Langvlei besit, die grootboer van die distrik." Van den Heever 1987, 7-8)

${ }_{827}^{78}, 79,90,91,93,99,118,240$.

${ }^{828}$ zie Hoofdstuk 1
} 
in de vorm van bezit en baasskap die Atiie kracht en een thuis moet verlenen:

Sýne, binnekort alles syne alleen; baas oor elke sandkorrel, bossie en struik, elke boom en druppel water. (..) Joue, die stukkie aardbol: geduldig, getrou - jou gedienstige hond! En soos vanoggend voel hy hom sterk, weer volkome tuis in sy vierkantige gesonde lyf. (105)

Binnenshuis voelt hij zich zo mogelijk nog minder op zijn gemak dan buiten. Hij ontloopt zijn huisgenoten en heeft zich afgeschermd voor het roemrijke verleden van Koos en Kobus door alle erfstukken en trofeeën in de mooie kamer op te sluiten. De enige plek waar hij zich veilig voelt is zijn werkkamer, in Atties focalisatie: "'n vertrek met buitedeur op die agterstoep waar hy hom (na het zondagse middagmaal) besig hou met dinkwerk en drukstukke wat ter sake is" (28). Het schrijnende contrast dat de verteller laat ontstaan tussen Atties formele status, zijn zelfbeeld en zijn gedragingen, komt hier heel sterk naar voren: de man die alle formele macht van Perdepoort naar zich toe heeft getrokken, die -in zijn eigen ogen- Perdepoort behoedt voor verval, zit in een achterafkamertje als een ekster in zijn nest de zilveren lepel te poetsen die hij Annie heeft ontfutseld. En te dutten.

De broers Jan, Klaas en Kobus missen weliswaar Atties loze pretenties en gebrek aan zelfkennis, maar het gevolg is dat ze zich in nog kleinere ruimtes hebben teruggetrokken. Ondanks de ruimte en de talenten die ze van huis uit meekregen, verschansen ze zich in een kamer en maken vervolgens gebruik van geestverruimende middelen om uit hun zelfopgelegde gevangenschap te ontsnappen: Klaas heeft zijn boeken, Kobus zijn drank en Jan zijn verrekijker.

Ook de jongste zoon, Chris, koppelt grensoverschrijdend gedrag aan een terugtrekkende beweging. Hij beweegt zich, net als Attie, over het gehele terrein van Perdepoort; niet omdat hij vindt dat het aan hem toebehoort, maar omdat grenzen hem niet zoveel zeggen. Hij wordt in zijn bewegingen gedreven door een dubbele en tegenstrijdige begeerte: de begeerte naar Adriana's lichaam en naar Gods (en Koos') genade. Zijn valkuil is hierbij "die dinkmoeras waar goed en kwaad twee kante van dieselfde munt is" (180). Terwijl het georven domein van zijn broers een ruimtelijke dimensie heeft, woont Chris in het "huis van God". Een gevangenis is het echter evenzeer.

Hy dink aan sy vader wat duiwel en heilige was; sy gedagtes vlie poort op na sy broer Kobus, vlug weer trug. Chris bevind hom in 'n hoek en kan nie bid nie. 
Hij skud homself los: Jy sit in jou Calvinisme vas soos 'n fossiel in die oerklei.

Wie is jy om die Huis van jou vaders af te breek? kom die gestrenge antwoord (219)

Chris zoekt - net als zijn broers uit hun vaders huis - een uitweg door grenzen te overschrijden en, in zijn geval, toe te geven aan zijn amorele seksuele begeerte. Dilemma's rondom "binnen" en "buiten" en Ik en Ander spelen ook hier een rol: tegenover de zo menselijke, innerlijke zeven doodzonden die ieder in zichzelf zou moeten overwinnen staat het beeld van Satan als ondubbelzinnig kwaad en ultieme Ander, waarop tegelijkertijd de eigen zondes zo prachtig geprojecteerd kunnen worden. Als Chris na bepeinzingen vol wroeging over zijn wellustig verleden recht in het "reusagtige geslag" van een van Kolies bokken kijkt, vlamt een onbeheersbare woede in hem op: "'Duiwelskind!' adem Chris. Hy breek 'n lat af en nader die bokram. 'n Hou, dink hy, 'n hou oor die walglike kruis." (142)

Chris heeft geen ruimtelijke basis op Perdepoort; de tijdelijkheid van zijn verblijf wordt nog eens benadrukt doordat hij zijn grondrechten aan Attie verkoopt. Waar Attie de imperialist is die zijn ruimte probeert uit te breiden is Chris de nomade die een ruimte "binnendringt" en vervolgens weer op de vlucht slaat. Dankzij zijn materiële onthechtheid is hij in staat de boerderij niet zozeer als begrensde ruimte en eigendom te zien, maar als onbegrensd onderdeel van Gods schepping. Als hij naar Kobus' Land van Onschuld klimt krijgt hij "die koddige gevoel dat hy die uiteinde van die bekende aarde bereik het. (..) Stil hier, jy voel jy gaan 'n oud verlede binne". Tijdens deze waarneming voelt hij een tijdelijke bevrijding uit zijn dilemma (201202). Maar als hij bij de verloederde Kobus is geweest heeft Land van Onschuld natuurlijk al zijn onschuld verloren, en na de mislukte herbegrafenis vertrekt Chris onmiddellijk en zonder een woord. Wellicht moet Chris gezien worden als degene die het "verloren paradijs" achter zich laat en dus (vanuit de heilsgedachte die bijvoorbeeld ook ten grondslag lag aan Vondels Lucifer $^{829}$ ) de enige is die de weg naar de verlossing kan afleggen. Ik zal daar verder niet op in gaan, omdat mijn aandacht vooral uitgaat naar een alternatieve invulling van dit "verloren" paradijs.

In hun terugtrekkende bewegingen laten de Lotriet-heren als het ware een vacuüm achter. Binnenshuis wordt dit vacuüm gevuld door de vrouwen. Afrikaner vrouwen hebben behoorlijk aan macht en status verloren in de $20^{\text {ste }}$ eeuw. Volgens historicus Hermann Giliomee "Afrikaner women of the eighteenth and nineteenth century enjoyed possibly the strongest position in the family of all white women in the history of colonial expansion. They were people that men could cross or thwart only at great peril. In all the

${ }^{829}$ Rens 1979,10 
crucial political developments they played a decisive role." Maar in de eerste decennia van de $20^{\text {ste }}$ eeuw verdwenen deze vrouwen uit het openbare leven en uit de geschiedenis. ${ }^{830}$ Louw portretteert hen dan ook als formeel machteloos, maar ze schrijft hen informeel veel macht toe, met name door hun gebruik van de ruimte. Mietjie is slechts Kobus' bediende, maar zij is degene die vrij in en uit beweegt, Kobus opdrachten geeft en verscheidene keren $^{831}$ geen sjoege geeft als Kobus haar roept. Voor zover Kobus een privé-ruimte heeft, wordt die voortdurend geschonden door Mietjie, ook doordat zij hem dingen in herinnering roept die hij niet wil weten. Andersom durft hij de keuken nauwelijks in te komen als Mietjie haar zoon en kleinkinderen op bezoek heeft en gaat hij slechts na flinke aarzeling Mietjies kamer binnen als ze te lang wegblijft. Daar staat tegenover dat hij ooit Mietjies grenzen zwaar heeft overschreden door haar overigens buitenshuis- te verkrachten.

In Atties huis is het Adriana die de touwtjes in handen heeft. Ook zij loopt in en uit naar eigen goeddunken. Ook zij betreedt ongestraft Atties privéruimte (de werkkamer) en weet daar de sleutel van de mooie kamer te bemachtigen, of tewel - net als Mietjie bij Kobus- de herinneringen te ontsluiten. Andersom blijft Attie voor de gesloten deur van haar kamer staan (166). Letta, ten slotte, is de baas in Eikenhof en laat Jan geen enkele illusie wat betreft zijn status als boer, als broer, als vader en als echtgenoot. Zelfs de illusie van haar liefde wordt hem niet gegund, wat uitmondt in een zelfmoordpoging en een ruzie met zijn zoon die doet denken aan Oom Sybrands ruzie met Henning in Laat vrugte. Ook Jan stuurt zijn zoon weg, maar in tegenstelling tot Henning neemt Jaco zijn vaders woede geen moment serieus en piekert hij er niet over om op te stappen.

Buitenshuis wordt het vacuüm deels ingenomen door de bewoners van Ertmanstasie en de plaasidioot Kolie. Zoals de vrouwen zich onbegrensd door het huis bewegen, zijn het buiten de arbeiders en hun moeders, vrouwen en kinderen die voortdurend het beeld van een blanke, mannelijke alleenheerschappij verstoren. Attie wordt op zijn rondgang meermalen onaangenaam met hun aanwezigheid geconfronteerd ${ }^{832}$, evenals $\mathrm{Klaas}^{833}$, die overigens iedere aanwezigheid van een ander als een schending van zijn privacy beschouwt. Met name geluiden storen Klaas: huilende kinderen en het getimmer aan Fielies' doodskist. Jaco wordt woest als Kolie met zijn bokken op zijn territorium komt, of als de kinderen van Ertmanstasie fruit en groente stelen uit de moestuin.

\footnotetext{
${ }^{830}$ Giliomee 2003a, 1

${ }^{831} 100,102,166$

$83278,82,83,119$

${ }^{833} 120,124,127$
} 
Op een ander niveau wordt er "illegaal" ruimte ingenomen door het parallelverhaal van Ertmanstasie. Dit parallelverhaal is een van de traditionele elementen uit de roman. Kannemeyer somt op:

Kroniek van Perdepoort sluit aan by die ouer Afrikaanse verhaalkuns deur die gebruik van 'n plaasmilieu as agtergrond, tipiese situasies en figure, soos die tradisonele patronerende landheer, die Joodse winkelier en hoteleienaar (..), bruin karakters wat in parallelle situasies die hoofhandeling begelei (..) en bekende temas (.. $)^{834}$.

De manier waarop bruine personages hun begeleidende rol vervulden in de Afrikaanse literatuur was onveranderlijk een verwijzing naar hun politieke en sociale status. Jakes Gerwel benadrukt dat "gekleurde persone vorm geen heterogene groep nie. Die heterogeniteit (..) is sy uitstaande kenmerk en dit is veral ander groepe, in die besonder die Afrikaners, wat gekleurdes as 'n entiteit beskou en behandel." ${ }^{935}$ Kleurlingen waren vooral literaire uitbeeldingen van de rassenrelaties waar Zuid-Afrikaanse schrijvers zich altijd zo overbewust van zijn geweest.

Stephen Gray (1979) beschrijft de weerslag van de (vroege) koloniale geschiedenis op het beeld van Khoisan personages in uiteenlopende ZuidAfrikaanse teksten. De in de ogen van de kolonisten moeilijk verenigbare tegenstelling tussen de dienstbare of geïntegreerde Hottentot en de vijandige Boesman ${ }^{836}$ werd in die teksten aan mannelijke en vrouwelijke personages gekoppeld. Terwijl mannen ten onder gingen omdat ze vijandig bleven staan ten opzichte van de blanke overheersers en dus niet konden meekomen in de vaart der volkeren, gingen vrouwen ten onder aan hun hebzucht en ambitie - als echte Eva's. Een oplossing was er niet vanuit dit gezichtspunt, hoogstens een treurige en ambivalente patstelling: de enige Khoisan die een plek kreeg in het koloniale Zuid-Afrika was de Hotnot die zijn/haar plaats kende, die streefde naar Westerse verlichting en tegelijkertijd accepteerde dat het onbereikbaar voor hem/haar was; die, met andere woorden, zijn/haar eigen inferioriteit accepteerde..$^{837}$

Inferioriteit is dan ook lange tijd een vaste karaktertrek van het bruine personage. E. Boniface schreef in 1832 het toneelstuk De Temperantisten, met als doel het gebruik van sterke drank aan banden te leggen. Hottentotten en kleurlingen - voor Boniface bestond er geen verschil - zijn sindsdien beschreven als karakterloos, dociel, lui en voorzien van een zwak gestel. ${ }^{838}$ Met hun drankzucht, vechtlust, oppervlakkigheid, gevatheid, luidruchtigheid, morele losbandigheid en domheid vervulden ze een komische rol,

\footnotetext{
${ }^{834}$ Zie ook Kannemeyer 1983, 313

${ }^{835}$ Gerwel 1988, 19

${ }^{836}$ Zie hoofdstuk 2

${ }^{837}$ Gray 1979, 38-71

${ }^{838}$ February 1982, 19
} 
vaak als negatieve spiegel van de blanke protagonisten. ${ }^{839} \mathrm{Ze}$ zijn ongevoelig, hebben geen enkel moreel besef en geen respect voor de wet. En ze zijn bijgelovig: spookverhalen horen tot de vaste attributen. ${ }^{840}$ Volgens Jakes Gerwel wordt van 1875 tot 1925 de "jollie Hotnot" gebruikt als oppositie van de Afrikaner, die in deze periode zijn identiteit vormgaf. ${ }^{841}$ Maar onder invloed van Hertzog, die kleurlingen aan de kant van de blanken wilde scharen, werd de stereotiepe kleurling tussen 1925 en 1935, in met name de plaasromans, een mindere variant van de blanke: hij functioneerde als tekortschietende, leidingbehoevende "randdeelnemers aan die wel en wee van die "witmensverhale" "\$42. In de periode daarna, waarin kleurlingen geen politieke rol van betekenis speelde, kregen ze vervolgens een centralere rol toebedeeld in de verhalen, maar nog steeds vooral als "kinderen" van een welwillende, goedhartige baas ${ }^{843}$.

Verschillende van deze stereotiepe verhaalelementen en karaktertrekken zijn terug te vinden in Kroniek. Inderdaad worden gebeurtenissen en verhoudingen uit het blanke hoofdverhaal gespiegeld in een gekleurd parallelverhaal. Terwijl Koos Nek met veel tamtam naar zijn tweede laatste rustplaats wordt begeleid, staat op Kobus' grond, bij het verse graf van Fielies, een bruin gezelschap te wachten tot Chris zo goed is om voor dominee te spelen. Er zijn duidelijke overeenkomsten tussen beide begrafenissen: in beide gevallen is er een bonte stoet met plaasbewoners en dorpelingen, onderling geruzie en gespannen verhoudingen. Maar waar in de traditionele plaasromans het parallelverhaal de komische of kinderlijke variant zou zijn van het serieuze hoofdverhaal, doet hier de begrafenisstoet van Koos Nek aan komische elementen zeker niet onder voor die van Fielies. Ook andere parallellen - de alcoholverslaving van Kobus en $\mathrm{Ou}$ Vaalwater, het toch niet vertrekken van Miemie en Mietjie, en de woede van Jaco en Fielies zijn niet eenduidig tot de tegenstelling positief - negatief terug te voeren. Stereotiepe karakteriseringen komen voor, maar de bewoners van Ertmanstasie zijn, in tegenstelling tot de blanke bewoners van Perdepoort, niet dociel, ziekelijk of karakterloos, en steken wat hun drankzucht, vechtlust en morele losbandigheid betreft gunstig af bij personages als Kobus, Jaco en Chris. Luidruchtig zijn ze alleen in de oren van Klaas, die het getimmer aan Fielies' doodskist en het huilen van (Fielies?) kinderen niet kan verdragen, lui zijn ze alleen in de ogen van Attie omdat hij vergeten is dat ze Fielies moeten begraven, en ongevoelig is Mietjie alleen in de ogen van Kobus, omdat hij niet herinnerd wil worden aan het feit dat Fielies zijn zoon is. Mietjie speelt bovendien niet de rol van Eva, maar van Maria, rouwend om haar zoon, en is zo eerder de bron van verlos-

\footnotetext{
${ }^{839}$ February 1982, 23-27

${ }^{840}$ February 1982, 29

${ }^{841}$ Gerwel 1988, 20-21.

${ }^{842}$ Gerwel 1988 74-75

${ }^{843}$ Gerwel 1988 134-137
} 
sing dan van het kwaad. Tenslotte wordt de relatie tussen blanke en kleurling niet neergezet als een goede "vader"-“zoon"relatie, maar als een slechte vader-zoonrelatie.

De vraag dringt zich op of het parallelverhaal niet eigenlijk Kannemeyers hoofhandeling is. Alles wijst erop dat de begrafenis van Fielies veel meer tragiek en waardigheid in zich bergt dan die van Koos Nek, en dat de blanke personages gebruik maken van stereotiepen om dat blote feit te kunnen ontkennen. Narratologisch gezien is er natuurlijk wel veel meer ruimte beschikbaar voor het blanke verhaal. Zowel Fielies als Koos Nek vallen op doordat de lezer hun visie op het geheel mist, maar waar Koos Nek nog door iedereen wordt herinnerd, is Fielies het toppunt van afwezigheid en marginalisatie. Tijdens de dubbele begrafenis vindt echter een omkering plaats, die een opening zou kunnen bieden voor een andere interpretatie. Zowel het ritueel als het verhaal van Fielies' begrafenis wordt zorgvuldiger afgerond dan dat van Koos Nek. Chris komt weliswaar niet opdagen, maar Oompie Vaalwater spreekt de nodige woorden bij het graf voordat hij aan Atties oproep om Koos' kist te repareren gehoor geeft. Bij Fielies wordt er gezongen door zijn kinderen en gehuild door zijn moeder, het graf wordt dichtgegooid en er wordt een boom op geplant. Wat er verder met Koos gebeurt, nadat de kist is opengesprongen en de omstanders zich naar alle windrichtingen hebben verspreid, blijft onvermeld.

Ook op metaforisch niveau vindt demarginalisatie plaats. Fielies' graf neemt ruimte in op Kobus' land, terwijl het graf van Koos Nek wordt geruimd en naar de marge van het territorium verplaatst. Ook de boom op Fielies' graf zorgt voor symbolische demarginalisatie. Net als in The conservationist blijkt in Kroniek een op schuld gefocust christelijk discours in de weg te staan van een terugkeer naar (de onschuld van) het paradijs, maar ook van integratie in de cyclus van leven en dood (het mens-zijn) en zo van de verlossing ${ }^{84}$. Aarde en ontbinding worden meer dan eens gekoppeld aan iets niet-blanks of verre gehouden van alles wat blank is. Zo is de doodskist van Koos Nek vervaardigd uit olienhout, een zeer harde inheemse houtsoort die in de vijftien jaar dat de kist begraven is geweest nog lang niet is vergaan en dus ook heeft (of had moeten) voorkomen dat het lichaam een is geworden met de aarde - op een manier die doet denken aan het stenen graf van Ludovitje $e^{845}$. Ook in dit opzicht is Van den Heevers cyclische familie gestagneerd: de boer die zijn bloed, zweet, tranen en vlees gaf aan de aarde is een paardenfokker geworden met een olienhouten kist in een marmeren praalgraf; staatszucht heeft de Afrikaner van zijn toekomst afgesneden. Op het eerste gezicht een vrij traditioneel lesje in nederigheid, ware het niet dat er in Kroniek een nieuw verbond tussen mens, god en

\footnotetext{
${ }^{844}$ De zondeval, en dus de dood, is een voorwaarde voor het verdere verloop van de heilsgeschiedenis: menswording (Christus als zoon van God) en verlossing (Christus' onschuldige dood herstelt de band tussen mens en God). (Rens 1979, 10, 28.)

${ }^{845}$ Zie 3.6
} 
aarde wordt gesloten. De compostering van Fielies is een gegeven: tijdens zijn begrafenis vraagt iemand zich af of Attie wel zal accepteren dat Fielies op Kobus' land begraven ligt.

'Dit kom toetentaal nie opaan nie,' sê Willem. 'Hy stink dan al klaar, daar's niks meer wat met sy lyf aangevang kan word nie. Die ertmanne en die molle sal hom hoeka gou uitskarrel.' (70)

Ofte wel: Fielies zal nooit, zoals Koos Nek, opgegraven kunnen worden; hij zal onderdeel worden van de grond en van de boom die er is geplant: een olienhoutboom, ofte wel een Afrikaanse olijfboom. De duurzaamheid van het hout, dat door de familie Lotriet is gebruikt om de tijd te bevriezen en integratie te voorkomen, staat in het geval van Fielies -die ook nog stierf doordat een boom die hij omhakte op hem viel- juist symbool voor de duurzame cyclus van leven en dood. Olienhoutbomen kunnen erg oud worden, ze zijn bestand tegen vorst, droogte en wind en leveren grondstoffen voor allerlei praktische en medicinale producten ${ }^{846}$. Het is bovendien de Afrikaanse (en oer- ${ }^{847}$ ) variant van de zo bijbelse olijfboom. De olijftak staat voor een nieuw begin; voor vrede, verzoening en christelijke verlossing. ${ }^{848}$ Terwijl de Lotrietfamilie blijft steken in het verleden; met spijt over de zondeval en heimwee naar het paradijs, is Ertmanstasie bezig met heden en toekomst.

Hoewel Kroniek van Perdepoort dus nog verankerd zit in de traditie van de Afrikaanse plaasroman en een stereotiepe manier van kijken, biedt de dood als metafoor een opening naar een ander perspectief. De dood verwijst naar wat afwezig is; zoals Lloyd-Smith zei: "the signifier implies the absence of the signified and the co-ordinates of discourse plot a secret geography of the unspoken." ${ }^{\prime 49}$ Het is slechts gedeeltelijk mogelijk om deze geheime geografie bloot te leggen, maar er zijn mogelijkheden om een begin te maken. Hoe ziet Perdepoort eruit als het niet het verloren paradijs is?

Hoewel ruimte in de literatuur natuurlijk nooit zo concreet is als in de schilderkunst, en hoewel in Kroniek culturele artefacten niet zo rechtstreeks en op de voorgrond de lezer aanstaren als het Maori-beeld uit het begin van dit hoofdstuk, bevat de roman wel degelijk elementen die verwijzen naar een alternatieve perceptie van ruimte. Het ontbreken van een graf voor en

\footnotetext{
${ }^{846} \mathrm{http}: / /$ www.plantzafrica.com/plantnop/oleaeurop.htm 04-03-2004

${ }^{847}$ Armoria academica. Hoërskool P.J. Olivier geraadpleegd (04-03-2004) op http://www.geocities.com/wapenskild/skole/PJOlivier.html

${ }^{848} \mathrm{Na}$ de zondvloed kwam de duif bij Noach terug met een olijftak in zijn snavel: "de olijf staat voor een nieuwe wereld, een nieuw begin met een vernieuwde mens" (04-03-2004)

http://www.plantaardigheden.nl/plant/beschr/wel/olijf.htm In Lucifer van Vondel komt Rafaël met de olijtak om vrede te stichten met Lucifer en zo de zondeval te voorkomen. De olijftak verwijst ook naar het kruis, waaraan Christus stierf om de de gevolgen van de zondeval teniet te doen.(Rens 1997, 10).

${ }^{849}$ Lloyd-Smith 1989,12
} 
het lijk van Koos Nek kan vergeleken worden met het ontbreken van de obligate beschuttende boom op het schilderij. Namelijk: waar in een traditionele plaasroman de graven van de voorouders dienden ter illustratie van de verbondenheid tussen mens en land, en zo ter legitimering van landbezit en fundering van de Afrikaner identiteit, laat nu de potsierlijke herbegrafenis van Koos Nek -die uiteindelijk niet eens voltooid wordt en dus blijft steken in het respectloos ruimen van een graf- van deze centrale waarden niet veel heel. Hieruit blijkt al dat "convention is displaced by something else." ${ }^{\$ 50}$ De stamboom van Van den Heever die aarde en mens aan elkaar verbond, wordt vervangen door de olienhoutboom op Fielies graf die verwijst naar een ruimte (een cyclus van leven en dood, maar ook een alternatieve christelijke ruimte) waar de familie Lotriet en de toeschouwer buiten staat. Hoewel technisch gesproken de focalisatie zich beweegt van buiten naar binnen, verschuift tegelijkertijd het perspectief van de lezer waardoor binnen opeens niet meer binnen is, maar buiten.

Maar wat bepaalt de grens tussen binnen en buiten? In hoeverre bestaan er twee werelden naast elkaar en in hoeverre zijn die cultureel bepaald? Meer in het oog lopend dan het olienhoutboompje zijn enkele natuurlijke ruimteelementen die in de roman zeer nadrukkelijk en voor de meeste personages storend aanwezig zijn: de maan, de wind en de zon. Bij bestudering van deze elementen als onderdeel van een overgeleverd Khoisan discours, namelijk als symbolen en/of personages uit de Khoisan mythologie, blijken ze een grote toegevoegde waarde te hebben voor de betekenis van de roman. Meer in het bijzonder blijken de mythen rond /Kaggen een rol te spelen, een complexe figuur die zowel godheid als schelm was; een intrigerend ambiguë tegenhanger in een boek dat handelt over goed en kwaad. Het duiden van betekenis wordt nog ingewikkelder wanneer men in ogenschouw neemt dat christendom en Khoisan mythologie in de loop der tijd vermengd zijn geraakt, en hoe Satan, naast Koos en Fielies de derde grote afwezige aanwezige in Kroniek, daar een rol in speelde.

\subsection{DE UNHEIMLICHE AMBIGUÏTEIT VAN HET HIER EN NU}

“"Disse nag vir geeste,"” (236) zegt Ou Vaalwater tegen zijn vrouw als ze tijdens de wake voor Fielies even buiten zijn. En ze haasten zich terug naar het huis waar de mensen zich hebben verzameld. De geluiden die ze hoorden blijken door de kinderen te zijn gemaakt, maar de stemming zit er nu in. Oompie Vaalwater begint te vertellen over "die spook" die hem bij klaarlichte dag bevolen had om het biezen huis van zijn overleden vader in brand te steken:

${ }^{850}$ Mitchell 1994, 25 
'Ek kom smerrag van die lanne af toe slaat die doodskis voor my uit die grond op, die lyk het prirrekantsklere aan en hy staat regop in die kis en wys met die vinger: brand af! Ek trek 'n metjie en steek bietjie fyngoed brand, maar trap weer dood. Brand af, seg hy weer. Hy lyk toe so kwaai lat ek nie kô anners nie.' (..) 'Party siet hulle,' verduidelik Oompie Vaalwater, 'party voel hulle net aanie lyf.' (237)

Dan komt Oompie Danster binnen,

Hy kyk na g'niemand nie, maar prakseer al met sy kierie op die vloer tot hy sy staan kry: eers brom hy net: umm-ma-umm...dan, al leunende op die kierie, die ou agterwerk ver uitgestoot, begin skoffel hy op maat.

Ta'Jehanna wijst hem terecht ("'ôs issie heidings tesame nie, dis die dood""), maar hij "voel ondersteuning van die ander lede van die geselskap" en houdt niet op. Hij begint "'n rympie uit die klippe" te prevelen:

'Brand die bossie brand

Satang dwaal vennag.

Oog verloor en ramkattand.

Satang dwaal vennag.'

Kinderen dansen om hem heen, Ouma Oumeid begint in haar handen te klappen en als Ta'Jehanna ontsteld dreigt te vertrekken, voelt Willem Frey zich verplicht om Oompie Danster "te verwilder". Buiten horen ze hem voortdurend "brom en skoffel" (237/8). Als Mietjie laat in de nacht aankomt zijn de anderen al gaan slapen, maar Oompie Danster staat buiten nog te dansen en te zingen.

Onrustig staan Mietjie hom 'n oomblik en aanluister.

'Brand die bossie brand

Weglê nog die voordag

Kry jou koers na sterreland

Satang dwaal vannag.' (250)

“'Oompie Danster"” (..) zegt Mietjie bezorgd: “'Jy moenie sukke goete sing nie. Wil jy sien ek tug jou?"'. En ze duwt hem een huis in waar hij "dadelik omval". Zelf maakt ze haar bed op in een andere hut, gaat liggen en huilt. "Sy voel haar inniglik een met Oompie Danster - in allenigheid, in boosheid, in die donkerte wat sy voel uitsak oor die ganske aarde." (250) 
Opvallend is hier vooral dat niet nader verklaarde reactie op Oompie Dansters "heidens" geskoffel. Zijn zang en dans roept een zekere angst en afkeer op bij de omstanders, maar ook vrolijkheid en herkenning. De gepaste reactie is het "verwilderen" van Oompie Danster. Ondanks dit distantiërende gebaar wordt met Oompie Dansters geskoffel een scheidslijn getrokken tussen de familie Lotriet (en de niet-ingewijde lezer) enerzijds en de (ingewijde) omstanders anderzijds, die meer behelst dan alleen onderscheid in sociale of economische status. De dansende Oompie Danster kijkt als het ware uit over een onzichtbaar "tabooed territory" dat Mitchell omschreef als het "visual field" van de Ander, "that is beyond the frame, out here in the dark with us". ${ }^{852}$ De tekst van het liedje is waarschijnlijk een door Louw zelf opgetekende, mondeling overgeleverde tekst; de typering ervan als "rympie uit die klippe", verwijst vermoedelijk naar de afdeling "Klipwerk" in Nuwe Verse (1956) van Van Wyk Louw ${ }^{853}$. In de jaren vijftig waren Afrikaanstalige dichters "besig skatte op te grawe uit dié laë van hierdie land se beskawing wat as die 'onder-kultuur' bestempel word," en Van Wyk Louws bijdrage daaraan was voor de populariteit van dit soort verzen doorslaggevend. ${ }^{84}$ De verzen grijpen terug op een oude, orale literatuur en bevatten onmiskenbaar elementen uit een kleurling- of Khoisancultuur, zoals "dans en toordery." ${ }_{855}$ Louws verwijzing naar de verzen van Van Wyk Louw kan heel goed bedoeld zijn om te wijzen op intertekstuele relaties tussen orale en geschreven literatuur, meer in het bijzonder: de invloed van Khoisan mythen op Kroniek zelf. Maar paradoxaal genoeg maakt ze tegelijkertijd gebruik van intertekstuele verbanden met een (geschreven) tekst van Van Wyk Louw, met zijn centrale positie in de Afrikaner literaire canon, om het vers een zekere betekenis of status te geven, terwijl ze naar alle waarschijnlijkheid een anonieme bron citeerde, onderdeel van een gemarginaliseerde, orale literatuur. Daarmee bewijst ze (onwillekeurig?), net als Gordimer, dat het referentiekader dat zij tot haar beschikking heeft om de Ander te kunnen kennen of representeren beperkt is, én benadrukt ze de onvermijdelijke vermenging van culturen die heeft plaatsgehad. Deze onontwarbare kluwen van "eigen" en "vreemd" is naar mijn mening een van de belangrijkste thema's uit deze roman.

\subsubsection{Afrikaners, kleurlingen en Khoisan}

Want wat moeten we ons bij dit onzichtbare territorium, het visuele veld van de Ander, voorstellen in de $20^{\text {ste }}$-eeuwse Kaapprovincie? Het is de

\footnotetext{
${ }^{851}$ Zie inleiding van dit hoofdstuk

${ }^{852}$ Mitchell 1994, 26

${ }^{853}$ Wium van Zyl, persoonlijke correspondentie, 2004.

${ }^{854}$ Van Zyl 2003, 56

${ }^{855}$ Van Zyl 2003, 59
} 
vraag of we het kunnen scharen onder een andere cultuur, want die bestond in de Kaapprovincie hooguit een eeuw eerder en in de $20^{\text {ste }}$ eeuw alleen ettelijke honderden kilometers noordwaarts. Sinds het eind van de achttiende eeuw bestond er überhaupt geen onafhankelijke Khoi of $\operatorname{San}^{856}$ samenleving meer in Zuid-Afrika. Hun afstammelingen waren in de $20^{\text {ste }}$ eeuw opgegaan in bevolkingsgroepen die Basters, Kaapse kleurlingen of Griqua werden genoemd en leidden een leven dat in veel gevallen heel vergelijkbaar was met dat van de Afrikaners met wie ze al eeuwen samenleefden. Omgekeerd had een onafhankelijke blanke Afrikaner samenleving natuurlijk nooit bestaan.

De scheidslijn tussen blanke en zwarte Afrikaanssprekenden, of tussen Afrikaners en niet-Afrikaners is in de loop der eeuwen heel vloeiend geweest, en was afhankelijk van de politieke situatie. Aanvankelijk was in de Kaapprovincie onderscheid in klasse, en in mindere mate religie, belangrijker dan ras. ${ }^{857}$ De term Afrikaners werd in de achttiende eeuw gebruikt voor alle bewoners van Zuid-Afrika die daar geboren waren, terwijl de term kleurling oorspronkelijk gebruikt werd voor iedere inwoner die niet van Europese origine was $^{888}$. Naast de gegoede blanke burgerij uit Kaapstand en omstreken, die onderling Nederlands sprak, maar Afrikaans met de knechten, was er een grote groep arme Afrikaanssprekenden: de "bruine Afrikaners", die niet perse bruin hoefden te zijn: "It was control over property rather than ethnic origin which tended to determine who would be deemed 'white Afrikaners' or 'brown Afrikaners'." ${ }^{859}$ Ook de laatsten hadden sinds de aantreding van een parlement in de Kaapprovincie in 1853 stemrecht, maar in de praktijk stelde dat weinig voor. Omdat er eisen gesteld werden wat betreft opleidingsniveau en vermogen (land!), kon aan het begin van de $20^{\text {ste }}$ eeuw slechts $3,7 \%$ van de bruine Afrikaners daadwerkelijk stemmen. Onder de oppervlakte van gelijkheid ging een sterk bewustzijn van de aanwezigheid van de Ander schuil, zoals William Porter, destijds pleitbezorger voor het algemene stemrecht, bewijst met de uitspraak: "I would rather meet a Hottentot at the hustings voting for his representative than meet the Hottentot in the wilds with his gun upon his shoulder". ${ }^{860}$ Bruine Afrikaners zijn sindsdien steeds inzet geweest van een verdeel-en-heerspolitiek door hen meer rechten te geven dan de zwarte bevolking, maar minder dan de blanke. In 1904 werd voor het eerst de Zuid-Afrikaanse

\footnotetext{
${ }^{856}$ Het woord San is in gebruik geraakt omdat Boesman of Bosjesman een negatieve bijklank had. Dat heeft echter het woord San ook, wat in KhoiKhoi betekent: 'bijna-dieren'. In 1995 is op een conferentie van San/Boesman-groepen in Namibie overeen gekomen dat de term Boesman gebruikt zou worden. Ik gebruik toch het woord San omdat ik regelmatig Khoikhoi en San of Boesman onder een noemer zal vangen, nl Khoisan.

${ }^{857}$ Goldin 1987, 158

${ }^{858}$ Marks \& Trapido 1987, 27

${ }^{859}$ Marks \& Trapido 1987, 27

${ }^{860}$ Stanley Trapido (1964) 'The origins of the Cape Franchise qualifications of 1853'In: Journal of African History V, 1 p. 51
} 
bevolking onderverdeeld in "three clearly defined race groups (..) white, Bantu and Coloured", waarbij tot de laatste groep behalve de afstammelingen van Khoisan ook "all intermediate shades between the first two" behoorden. ${ }^{801}$

Twee kenmerken van de Afrikaner cultuur droegen specifiek bij aan de ambiguë relatie tussen bruin en wit: de taal en de godsdienst. Afrikaans was een mengeling van verschillende Nederlandse dialecten, Khoisan talen en de oorspronkelijke talen van geïmporteerde slaven. Deze taal, ook wel Hotnotstaal genoemd, "reflected the inextricalble connections between Dutch/Afrikaner settlers and those they called 'Kleurling', throughout the expansion of European settlement." ${ }^{\prime 62}$ Toen in de jaren twintig Afrikaanssprekenden zichzelf begonnen te organiseren en emanciperen tegenover de veel machtigere en rijkere Britten, legde de taalbeweging, die nationalistische tendensen uitdroeg op grond van een gemeenschappelijke taal, opnieuw nadruk op de gemeenschappelijke wortels van zwarte en blanke Afrikaanssprekenden. "In view of especially the rural "coloureds" involvement with Afrikaansdom, if not Afrikanerdom, there developed between the Afrikaner and a large section of the coloureds a relationship of ambiguity and a feeling of almost near-kinship." ${ }^{663}$ Bijna-verwantschap, want de grenzen van die sociale familie (Afrikaners spreken mensen uit hun omgeving aan met tannie, oupa, of seun) werden ook door middel van die taal bewaakt: een seun is altijd blank. "Putatively, [the family] could include any white, but no blacks. (..) In this respect at least, the language of Afrikaans betrays its origins in the system of domination of the rural Cape." ${ }^{864}$

Die tweeslachtigheid zou de gehele twintigste eeuw terug te vinden zijn in discussies rond de Afrikaner identiteit en het Afrikaans ${ }^{865}$. Hertzog zei in een speech in 1925 dat de kleurling hoorde tot

a section of the community closely allied to the white population (..) fundamentally different from the natives. He owes his origin to us and knows no other civilisation than that of the European (..) even speaks the language of the European as his mother-tongue. (..) CapeColoured people must be treated on an equality with Europeans economically, industrially and politically. ${ }^{866}$

Malan volgde hem hier aanvankelijk in; hij pleitte voor afschaffing van de kleurgrens voor Maleisiërs en kleurlingen. Maar tegen de tijd dat de poli-

\footnotetext{
${ }^{861}$ Census of the Cape of Good Hope, 1904, G19-1905, 10.4, para. 102

${ }^{862}$ Shula Marks and Stanley Trapido 1987, 12

${ }^{863}$ February 1982, 2

${ }^{864}$ Ross 1995,43

${ }^{865}$ Giliomee 2003b, 389

${ }^{866}$ L. Thompson The Cape Coloured franchise. Johannesburg, Institute of race relations., 1949, 21
} 
tieke overwinning voor Afrikaners binnen handbereik kwam en de BoerBrit tegenstelling langzaam veranderde in zwart-wit, was zijn mening 180 graden gedraaid. In 1938 pleitte hij voor een politiek van algehele segregatie tussen Europeanen en niet-Europeanen ${ }^{867}$. Afrikaners waren vanaf dat moment blank en de verhoudingen tussen de voorheen bruine en witte Afrikaners verslechterden: "racial discrimination and exclusion flourished once the victimized group had been shut out." ${ }^{\text {868 }}$ Ook Verwoerd stelde in 1962, een jaar na het ontstaan van de republiek, opnieuw dat kleurlingen weliswaar Zuid-Afrikaanse burgers waren, maar daarmee nog geen onderdeel van "this homogeneous entity that can be described as 'the nation'." 869 In 1976 trok het Erika Theron-rapport echter weer enkele opvallende conclusies: ten eerste was de kleurlingbevolking verpauperd $(20 \%$ was werkloos of werkte in deeltijd, $75 \%$ van de gekleurde landarbeiders leefde onder het bestaansminimum) en ten tweede bestond er geen aparte kleurlingcultuur. De commissie sprak uit dat "a large percentage of the coloureds do indeed form an integral part of the Afrikaans- or English-speaking communities through language, religion and general orientation." ${ }^{870}$ Daarom, zo pleitten de commissieleden, zou er geen onderscheid meer moeten worden gemaakt tussen blank en kleurling, zouden kleurlingen moeten kunnen meebeslissen, land kopen en met blanken trouwen. Aan de conclusies van het rapport werd nooit gevolg gegeven. Door afschaffing van raciale wetgeving vreesden Afrikaner machthebbers afstand te doen van de politieke macht. ${ }^{871}$

Ook het geloof was een bindende factor die tijdens de opkomst van het Afrikaner nationalisme sterk werd benadrukt $t^{872}$. Voor zover het stereotiepe beeld van de boer met bijbel en geweer al juist was ${ }^{873}$, ging het hier niet om een rechtsreeks uit Europa overgeleverd christendom, maar om een geloof dat zich gevormd had in wisselwerking met de Afrikaanse werkelijkheid: "Far from being an attribute of the earliest Dutch settlers, "primitive Calvinism' was (..) a mythical construct brought into being in the specific conditions of late-nineteenth-century Cape parochial politics. ${ }^{\$ 74}$ Kolonisten gerbuikten hun christelijke identiteit als een politieke identiteit die hen onderscheidde van en superieur maakte aan anderen. Christenen waren burghers: vrije, beschaafde (soms ook "niet-Engelse") inwoners van de kolonie ${ }^{875}$. Over het algemeen waren ze blank, maar ook het verschil tussen

\footnotetext{
${ }^{867}$ February 1982, 8

${ }^{868}$ Giliomee 2003b, 393

${ }^{869}$ M. Horrell Action, reaction and counter-action. Johannesburg, Institute of race relations, 1971, 125

${ }^{870}$ E. Theron Verslag van de kommissie van ondersoek na aangeleenthede rakende die

Kleurlingbevolkingsgroep. Pretoria, Staatsdrukkery. 1976, 525

${ }^{871}$ February 1982, 10

${ }^{872}$ Zie voor voorbeelden Du Pisanie 1999, 95

${ }^{873}$ Zie Du Pisani 1999

${ }^{874}$ Marks en Trapido 1987, 14

${ }^{875}$ Giliomee 2003b, 41
} 
heidense en gekerstende (en/of vrije) "kaffirs" was in de ogen van de kolonisten cruciaal ${ }^{876}$. Dat was een van de redenen dat eigenaren hun slaven aanvankelijk maar zeer beperkt tot het christendom lieten bekeren ${ }^{87}$.

Van een actieve, centrale rol van de kerk of de bijbel was in de eerste eeuwen van de kolonisatie weinig sprake ${ }^{878}$. Pas in de negentiende eeuw, vooral na afschaffing van de slavernij in 1838, ontstond er een groeiende belangstelling voor een stroming binnen het calvinisme waar de predestinatieleer een centrale plaats innam. Geboorte, niet bekering, bepaalde wie de echte christenen waren; zij die direct voortkwamen uit de joden die een verbond met God gesloten hadden ${ }^{879}$. De kerk was grotendeels blank, in elk geval Nederlandssprekend, en functioneerde als zodanig als een versterking van de burgher gemeenschap. Maar in de jaren 60 van de $19^{\mathrm{e}}$ eeuw ontbrandde ook buiten de kerken om, in informele, emotioneel geladen gebedsbijeenkomsten,

a major outbreak of religious enthusiasm, a revival, and also in a series of bitter theological and ecclesiastical debates - which not infrequently ended up in the state courts. ${ }^{880}$

In deze bijeenkomsten "the ministers lost control over their flocks" ${ }^{81}$. Dat was het werk van de Heilige Geest, werd er gezegd. De gebedsrage verspreidde zich razendsnel door de Karoo en Oranje Vrijstaat, tot in de verste uithoeken, en doorkruiste alle sociale en dus ook raciale grenzen. "Gekleurde" en Afrikaanse bedienden die tot dan toe hadden geloofd dat God een blanke god was, bekeerden zich nu tot het christendom.

As soon as the awakening impulse of God's spirit was felt, old and young, parents and children, whites and blacks, at almost every farm were desirous to join in social prayer and immediately prayer meetings were multiplied. ${ }^{882}$

Ondanks dit verbroederende effect lag ook hier, net als bij het Kaapse stemrecht, juist de angst voor de vreemdeling ten grondslag aan het egaliserende systeem. De populariteit van de emotionelere predestinatie-religie is namelijk te verklaren uit een behoefte de sociale stratificatie te reorganiseren nadat de slavernij was afgeschaft en voormalige vijanden als nieuwe (overwonnen) burgers toetraden tot de maatschappij. Bovendien was er de

\footnotetext{
${ }^{876}$ Goldin 1987, 158; Gilimee 2003b, 39

${ }^{877}$ Giliomee 2003b, 43

${ }^{878}$ Giliomee 2003b, 41

${ }^{879}$ Giliomee 2003b, 42

${ }^{880}$ Ross 1993,186

${ }^{881}$ Ross 1993, 186

${ }^{882}$ N.J. Hofmeyr $A$ brief account of the present revival of religion in some parts of the colony. Cape Town, Robertson \& Marais, 1860: 5-6
} 
onzekerheid van een snel commercialiserende samenleving. ${ }^{883}$ Deze dubbele sociale onzekerheid vertaalde zich in een wereldbeeld waarin het Kwaad was verinnerlijkt; een zeer unheimlich wereldbeeld. Een neefje van een van de dominees vertelt:

'The sermon ended with terrible threats of hell and damnation, the sufferings of the damned and the various chambers of hell were described in the fullest detail. I often felt sick with terror. Nor were these endless agonies to be the portion only of naked and godless sinners; even the best were in imminent peril for they might not belong to he elect and only the elect could escape the clutches of the devil. ${ }^{\text {} 884}$

Het christendom werd dus inzet van nieuwe, rivaliserende begrenzingen van identiteit. Een select gezelschap van uitverkorenen werd onderscheiden van het grote kwaad daarbuiten, maar "there was no sense, even among the most fervent Calvinists, that theirs was an exclusive, national religion" ${ }^{885}$. Pas veel later kreeg de religieuze elite een politieke en puur blanke invulling: in de jaren dertig van de $20^{\text {ste }}$ eeuw werd de tot dan toe apolitieke predestinatieleer gekoppeld aan het Afrikaner nationalisme, terwijl tegelijkertijd de "Afrikaner" blank werd. Toen in 1948 de Nasionale Party aan de macht kwam werd er middels een reeks apartheidswetten een rigide definitie van alle etniciteiten opgesteld. Ieder individu werd geregistreerd als behorende tot een ras, en "gekleurd" was daar een van. Seksueel verkeer tussen rassen werd verboden. Deze nieuwe identiteit werd bovendien, bij gebrek aan een thuisland en als doekje voor het bloeden na de afschaffing van het kiesrecht voor kleurlingen, gekoppeld aan een territorium door de Coloured preference policy. Dit kwam erop neer dat binnen een groot deel van de Kaapprovincie (waar het overgrote deel van de kleurlingen woonde) banen niet aan zwarten mochten worden toegewezen zolang er kleurlingen voor in aanmerking kwamen. Op grond van deze wetgeving ontstond er een groep die "Kaapse kleurlingen" werd genoemd.

Kortom: de relatie tussen kleurlingen en Afrikaners was in de jaren zeventig van de twintigste eeuw voornamelijk politiek bepaald. In de loop der eeuwen hadden Fransen, Nederlanders, Duitsers, Khoisan en her en der geïmporteerde slaven en werklieden zich vermengd tot een gedifferentieerde bevolkingsgroep die op politieke gronden grofweg was ingedeeld in kleurlingen en Afrikaners, waarbij kleurlingen uiteindelijk die Afrikaanssprekenden waren die geen politieke zeggenschap hadden, geen land

\footnotetext{
${ }^{883}$ Ross 1993, 188

${ }^{884}$ D.P. Fauree (1907) My life en times. Cape Town, Van de Sandt de Villiers. Pp. 22

${ }^{885}$ Ross 1993, 191
} 
mochten kopen en geen seks mochten hebben met een man of vrouw die beide voornoemde voorrechten wel had. Voorzover er sprake was van een "etnische identiteit" van de kleurlingen, ontwikkelde die zich als antwoord op de politieke identiteit ${ }^{886}$, en pas in een laat stadium ${ }^{887}$. Bovendien bestonden er grote verschillen binnen de verschillende bevolkingsgroepen, ondermeer tussen stad en platteland. In 1905 bestond maakten kleurlingen in Kaapstad bijvoorbeeld gebruik van Maleisische en Afrikaner tradities "combined with petty-bourgeois and artisan identifications". ${ }^{88}$ Barnard observeert daarentegen overal, maar vooral op het platteland, ook Khoisan elementen:

Although [Cape coloureds, Griqua and Basters] are in many ways different from the Khoekhoe proper, they nevertheless have some clearly identifiable Khoekhoe customs. This is particular true of those of certain rural areas where stock rearing forms a major part of the economic sphere of activity. ${ }^{889}$

Lange tijd lieten afstammelingen van de Khoisan zich niet op hun afkomst voorstaan, omdat die beschouwd werd als primitief of onbeschaafd. ${ }^{890}$ De benaming "Boesman" of "Hotnot" werd door Afrikaners nog veelvuldig gebruikt, maar had een zeer negatieve bijklank. Pas in de jaren tachtig en negentig van de 20ste eeuw herleefde onder afstammelingen van Khoisan de interesse voor dat deel van hun geschiedenis toen de bevolking van Namaqualand een rechtzaak won die voorkwam dat gemeenschappelijk land opgedeeld zou worden. "This new-found power and identity resulted in "Nama" (both language and culture) having a cachet that was previously downplayed." ${ }^{891}$ Van alle lijnen waarlangs kleurlingen zich konden identificeren, was de Khoisanlijn dus lange tijd de meest verguisde.

Dit alles in aanmerking genomen, is het onmogelijk om de bewoners van Ertmanstasie een Khoisan-identiteit toe te schrijven met een bijbehorende perceptie van ruimte, ook al wordt Mietjie door personages in Kroniek getypeerd wordt als "Hotnot" (196) of "ou Boesman" (42) en doet ze dit zelf ook (249). Wel denk ik aannemelijk te kunnen maken dat Ertmanstasie een fictieve verbeelding is van de Ander, waarbij die Ander in zeer sterke mate kenmerken vertoont van wat Bhabha noemde "de Ander in onszelf". Elementen uit een vervlogen Khoisandiscours worden gebruikt om zowel die Ander te definiëren, als om die definiëring te ondermijnen. Dit discours

\footnotetext{
${ }^{886}$ Marks and Trapido 1987, 1

${ }^{887}$ Zie Goldin 1987

${ }^{888}$ Goldin 1987, 163.

${ }^{889}$ Barnard 1992, 193

${ }^{890}$ Andrew B. Smith, 2002

${ }^{891}$ Andrew B. Smith, 2002. Deze zaak werd aangespannen in 1998, en zal op z'n vroegst in april 2006 worden beslist.[http://www.lrc.org.za/Articles/Articles_Detail.asp?art_ID=117]
} 
kan slechts in beperkte mate en grofweg gereconstrueerd worden op grond van beperkte en indirecte bronnen - bronnen die Anna Louw ongetwijfeld zelf ook gekend heeft.

Sinds het begin van de twintigste eeuw zijn de Khoisan, inclusief hun orale literatuur, als zodanig verdwenen uit Zuid-Afrika. Maar een deel van hun verhalen bleef bewaard: missionarissen en etnologen schreven ze op en verspreidden ze over de hele wereld, waar ze werden opgenomen in de westerse, schriftelijke canon - zeker in Zuid-Afrika. De beroemdste hiervan zijn de /Xam mythen en verhalen die door William Bleek en Lucy Lloyd zijn opgetekend aan het eind van de negentiende eeuw. Dit materiaal wordt nog steeds van grote waarde geacht. Bleek wordt gezien als een man die zijn tijd ver vooruit was, en de San en hun verhalen in hun waarde kon laten ${ }^{892}$. Andrew Bank toont echter aan de hand van andere geschriften aan dat Bleek ook een overtuigd evolutionist was, met sterke raciale opvattingen $^{893}$. Wat het effect van zijn theoretische uitgangspunten was op zijn, ook volgens Bank "remarkable", onderzoek naar San talen en mythen, zal nog onderzocht moeten worden ${ }^{894}$. Dit oude materiaal kan worden aangevuld met meer recent materiaal dat op grond van diverse bronnen is samengesteld en waaruit gemeenschappelijke elementen gedestilleerd konden worden, vooral in het literaire en religieuze discours. ${ }^{895}$ Want hoewel er veel verschillende groepen Khoi en San in Zuidelijk Afrika leven en leefden, zijn er in de diverse mythische en religieuze systemen zulke duidelijke overeenkomsten, dat er toch van een eenheid kan worden gesproken. ${ }^{896}$

\subsection{2 //Gãuwa: schelm, god en duivel.}

Wat vertelt nu de dans van Oompie Danster? Waarom danst hij? Waarom zingt hij over Satan? Heeft zijn dans te maken met de wake die gehouden wordt voor Fielies? Van dansen als specifiek Khoisan begrafenisritueel wordt in de mij bekende literatuur nergens melding gemaakt. Van oudsher waren er niet veel rituelen verbonden aan de dood. Mensen werden begraven, hun hut eventueel verbrand of verlaten en het graf gemeden, omdat het werd geassocieerd met geesten ${ }^{897}$ - het spookverhaal van Oompie Vaalwater was dus een verwijzing naar een oud begrafenisritueel. Deze geesten maken niet zoals Zulu vooroudergeesten onderdeel uit van de sociale structuur,

\footnotetext{
${ }^{892}$ Deacon, J. \& Dowson, T.A. (eds.). Voices from the past: /Xam Bushmen and the Bleek and Lloyd collection. Johannesburg. Witwatersrand University Press, 1996; Lewis-Williams, J.D. Believing and Seeing: Symbolic Meanings in Southern San Rock Paintings. London: Academic Press, 1981. J.D. Lewis-Williams, Discovering Southern African Rock Art. Cape Town: David Philip, 1996

${ }^{893}$ Bank 2000, 163/4

${ }^{894}$ Bank 2000, 177

${ }^{895}$ Guenter $1989,17-20$

${ }^{896}$ Guenter $1989,17-20$ en $30-36$

${ }^{897}$ Guenter 1986, 282; Barnard 1992, 87
} 
maar ze kunnen volgens Biesele die sociale structuur wel bedreigen. Dansen is een middel om hun kwade invloed te bestrijden. Dit is de taak van de sjamanen. "[!Kung Shamans] go into trance at dances and do battle in that context with the spirits of the dead who are sent by God to bring misfortune and sickness (..) [They] attempt to drive away bad luck by reviling the spirits of the dead and their captain //Gãuwa, the lesser God." ${ }^{998}$ Guenter ziet in de trancedans eerder een directe communicatie met de goden. Hij observeerde $20^{\text {ste }}$ eeuwse Nahro die, dansend rond een groot vuur, in trance raakten om //Gãuwa of N!eri te bewegen de ziektes die door hen veroorzaakt waren weer te verdrijven ${ }^{899}$. Volgens Guenter

[t]he role of //Gãuwa in the trance healing dance is that of custodian of the medicins and healing arrows. (..) If the trance-dancer's pleas or threats towards //Gãuwa, on behalf of the sick person who he is treating, fall on deaf ears, then death will strike. ${ }^{900}$.

Ondanks kleine variaties in karakter en verschillende benamingen is //Gãuwa (//Gaua) een godheid die bij alle Khoisangroepen terug te vinden is ${ }^{901}$. Bij de /Xam heette hij /Kaggen ${ }^{902}$. Tegenover //Gãuwa staat altijd een tweede godheid: !Khwa of N!eri. //Gãuwa wordt verbonden met spirituele aspecten uit het dagelijks leven van de Khoisan, zaken rond leven en dood: met name de jacht, healing en rites de passage. Zowel tijdens healingsessies als tijdens de inmiddels in onbruik geraakte initiatieriten voor jongens, wordt de trance dans gebruikt als middel om met hem te communiceren. Volgens Guenter is //Gãuwa geen boze god, maar even schelmachtig als zijn mythische tegenhanger ${ }^{903}$. Hij is lastig en soms gevaarlijk, maar niet kwaadaardig en uiteindelijk ook van levensbelang. Hij is "unpredictable, quixotic, morally and sexually ambiguous; he may be feared and revered, taunted and cursed; he may bring game and health, death and disease; he may be evil and good." ${ }^{904}$ Die ambiguïteit wordt ook door Barnard onderkend $^{005}$. //Gãuwa is volgens hem een veel gebruikte term in verscheidene Khoisan talen, en kan zowel "God", "duivel" als "geesten der doden" betekenen ${ }^{906}$.

\footnotetext{
${ }^{898}$ Biesele 1975, 173.

${ }^{899}$ Guenter 1986, 253 e.v.

${ }^{900}$ Guenter 1989, 116

${ }^{901}$ Guenter 1989, 34

${ }^{902}$ Guenter 1989, 32

${ }^{903} \mathrm{Bij}$ de /Xam is /Kaggen zowel personage als godheid, maar bij andere Khoisan is //Gãuwa de religieuze, maar even contradictoire tegenhanger van de schelm /Kaggen. "That the Nahro clearly and readily identify //Gãuwa with the narrative trickster figure is evident from the fact that the name they loosely apply to most of the various veld tricksters is //Gãuwa." (Guenter 1989, 117)

904 Guenter 1989, 117

905 Barnard 1992, 256

${ }^{906}$ Barnard 1992, 56
} 
//Gãuwa's ambiguiteit is door etnologen in de loop der tijd niet altijd als zodanig geinterpreteerd. Hij is vaak gepresenteerd als een kwade geest of godheid en een collectieve representatie van de geesten der doden. ${ }^{907}$ Guenter vermoedt dat dit komt omdat//Gãuwa verward is met de veel bekendere Khoi-godheid //Gaunab, ook wel omschreven als "the great evildoer" ${ }^{908}$. Ik neem aan dat dit dezelfde is als die Barnard //Gâuab noemt: een term die gebruikt wordt voor "the evil God, the evil aspect of the good god, the evil spirits, or the spirits of the dead." "Soms vallen de laatste twee categorieën samen. //Gâuab is ook de naam die christelijke Nama gebruiken voor satan, en hij lijkt inderdaad beter in een christelijke goed-kwaad dichotomie te passen dan de ambiguë //Gãuwa ${ }^{910}$.

Toen de vloeibare en inconsistente opvattingen in het geloofssysteem van de Khoisan ("consistency is (..) an epistomological quality conspiciously absent from Nahro belief"'11) in contact kwamen met de christelijke leer, traden er vrij gemakkelijk versmeltingen op. De aardse of mythische tegenhanger van Tsûi-//goab, Haitsi-Eibib, was een gemeenschappelijke voorouder die steeds opnieuw stierf en opnieuw geboren werd. Her en der in de Kaapprovincie markeerden stapels stenen zijn graven. Vroege Europese kolonisten dachten dat de graven monumenten waren die de kinderen van Israël hadden achtergelaten tijdens hun reis naar Canaän ${ }^{912}$; de Khoi werden gezien als de "lost tribes" en er zijn veel parallellen getrokken tussen Khoi-religie en het oude (en soms ook nieuwe) testament. Ook door Khoisan zelf. ${ }^{913}$ Barnard vertelt dat met name San een zodanige flexibiliteit hanteerden in hun geloof dat

ideas and stories are easily assimilated without threat to the belief system as a whole. (..) Religious notions have a fluid character which has led historically to cross-cultural uniformity and at the same time to intra-cultural diversity. In the case of Khoekhoe and Damara, the greater rigidity of form has given rise to a greater tendency towards structural transformation, rather than fluidity of discourse, although both elements are present in these religions too ${ }^{914}$.

\footnotetext{
${ }^{907}$ Zie bijvoorbeeld de invloedrijkie studie van Isaac Schapera The Khoisan Peoples of South-Africa: Bushmen and Hottentots. London, Routledge 1930. pp. 186-195

${ }^{908}$ Guenter 1989, 35

${ }^{909}$ Barnard 1992, 259

${ }^{910}$ Barnard 1992, 257/259

${ }^{911}$ Guenter 1986, 246

912 Theophilus Hahn (1881) Tsuni-//goam: the supreme being of the Khoi-Khoi. London, Trübner and Co. p. 47

${ }^{913}$ Barnard 1992, 263

${ }^{914}$ Barnard 1992, 261 Ironically, the greater structural consistency of Khoekhoe and Damara relgions seems to have made the peoples more, rather than less, receptive to Christian conversion (Barnard 1992 p. 264)
} 
De ambiguïteit en vloeibaarheid heeft van begin af aan etnografen tot spoorzoeken aangezet, vooral om beide discoursen weer van elkaar te kunnen scheiden. Toen bijvoorbeeld een informant William Bleek liet weten dat /Kaggen hem in verleiding bracht om schapen en koeien te stelen, dacht Bleek "that this belief might have been influenced by the associations of /Kaggen with the Devil, caused by contacts with European farmers. ${ }^{915}$ Maar ook voor Khoisan zelf waren de christelijke en traditionele noties niet altijd te rijmen. Waar in de oude setting de ambiguïteit van /Kaggen en //Gãuwa probleemloos was geaccepteerd, ondermijnde de associatie van //Gãuwa met de ondubbelzinnige slechtheid van Satan het in de koloniale situatie toch al wankele zelfbeeld. Gaishe, een van Guenters informanten, was lid van de missiekerk en volgens zijn werkgevers een ideale landarbeider. Maar hij liet zich voortdurend negatief uit over zijn eigen cultuur. "The negative outlook Gaishe extended towards his culture's beliefs and values can be seen as a fairly classic personality trait of the 'marginal man' ${ }^{916}$ (...) The Ganzi Nahro refer to themselves as "kam ka kwe': the mouthless people. (...) The inferiority of the Bushman people is a theme that runs through a number of myths and stories." Gaishes lidmaatschap van de kerk

had heightened his sense that the old beliefs were false and tainted (..) with evil and sin. The presence of sin with mankind, from birth to death, was something of an obsession of the Calvinist evangelist (..). Gaishe also reached the unsettling conclusion that the Bushman trickster divinity //Gãuwa and Satan were one and the same ${ }^{917}$.

Ook een andere informant geeft er blijk van beïnvloed te zijn door christelijke opvattingen omtrent Satan. Tijdens de uitvoering van een rituele dans slaat hij het trance-onderdeel over, deels omdat hij zich "uneasy" voelt "about this phase of the ritual since it is informed with //Gãuwa whom he has come vaguely and disconcertingly to identify with satan." ${ }^{918}$

Hoewel het dus de vraag is of er door Khoisan ooit gedanst is als onderdeel van een begrafenisritueel, is het wel aannemelijk dat in dit geval Oompie Dansters dans iets met Fielies' dood te maken heeft. Met Satang zou hij gezien het bovenstaande heel goed //Gãuwa kunnen bedoelen, en //Gãuwa wordt op uiteenlopende manieren in verband gebracht met de dood en de geesten der doden. In de tekst van het lied zijn verwijzingen naar Khoisan opvattingen en rituelen rond de dood, zoals het snel begraven ("weglê nog

\footnotetext{
915 Hewitt 1986, 130

${ }^{916}$ Guenter 1989, 23 Een "marginal man" is in zijn ogen iemand die twee culturen tegelijkertijd afwijst en door beide wordt afgewezen

${ }^{917}$ Guenter 1989, 23

${ }^{918}$ Guenter 1986, 265
} 
die voordag") ${ }^{919}$, het afbranden van de hut, en het geloof dat de geesten der doden opstijgen naar de sterrenhemel. ${ }^{920}$ De "dodendans" is dus een mengelmoes van culturele artefacten en geeft in een notendop weer wat er van het oude wereldbeeld van de Khoisan geworden is. Oompie Danster danst waarschijnlijk om in contact te treden met //Gãuwa en zo het ongeluk af te wenden dat Ertmanstasie heeft getroffen. Ooit stond deze handeling te boek als een niet alleen nuttige, maar ook moedige daad, want "it requires strength and courage to seek out //Gãuwa, who is believed to lurk somewhere not far beyond the dark perimeter that surrounds the nocturnal, firelit dance circle". ${ }^{921}$ Maar nu leidt zijn dans slechts tot negatieve reacties. Ook al is Satang in Oompie Dansters ogen waarschijnlijk niet dezelfde als de Satan die Klaas diezelfde nacht op bezoek krijgt, de vrome Ta'Johanna wil noch met Satan noch met het heidendom dat aan //Gãuwa kleeft, geassocieerd worden. En dus wordt Oompie Danster "verwilder", wat zoveel betekent als "weggejaagd", maar natuurlijk ook: buiten de sociale context, de beschaving, de collectieve herinnering geplaatst - waar hij alleen in de nacht zijn handelingen voortzet.

Het is dit miskend, verloochend en verbannen worden, de miskenning van welwillendheid, de verloochening van geschiedenis en identiteit, wat Mietjie in Oompie Danster herkent. Ze delen - zij als moeder van haar onwettige en verloochende dode kind, hij als vertegenwoordiger van een verboden wereldbeeld - een wereld die zich, hoezeer ook behorend tot de dagelijkse werkelijkheid ${ }^{22}$, buiten het formele gezichtsveld, in de duisternis bevindt: "die donkerte wat sy voel uitsak oor die ganske aarde," het "tabooed territory" buiten het kader van het schilderij van Earle.

Louw brengt deze miskende, verloochende ruimte weer enigszins in zicht. Net als Gordimer maakt ze gebruik van intertekstuele relaties met zowel westerse als Afrikaanse teksten om Perdepoort in beeld te brengen. Niet alleen de dans van Oompie Danster, maar ook narratieve en ruimtelijke elementen en structuren in de tekst verwijzen naar (oude) Khoisanmythen en -verhalen. Deze verwijzingen worden nog pregnanter in de wetenschap dat tijd, net zoals veel andere zaken, iets heel betrekkelijks was in het Khoisandiscours. Net zo min als er een duidelijke scheidslijn bestond tussen goden en mensen of tussen goed en kwaad, bestond die tussen de mythische oertijd waarin alle dieren nog mensen waren, en de moderne tijd. ${ }^{923}$ Zeker in verhalen hebben vroeger en nu geen eigen afgescheiden tijd

\footnotetext{
${ }^{919}$ Guenter 1986, 283/4

${ }^{920}$ Guenter 1986, 247

${ }^{921}$ Guenter 1989, 116

${ }^{922}$ In 1976 concludeerde Erika E. Theron in Verslag van die kommissie van ondersoek na aangeleenthede rakende die Kleurlingbevolkingsgroep, dat 43\% van de kinderen van gekleurde vrouwen "onwettig" waren. (Pretoria, Staatsdrukkery, 1976)

${ }^{923}$ Barnard 1992, 83
} 
en ook geen eigen afgescheiden ruimte. Genres zijn nauwelijks te onderscheiden:

Therianthropic humans, whose place should be in primal time, crop up on frontier farms and have their dealings with Boer baases. (..) Tricksters are found in all of the narrative types, crossing back and forth between the different mythological scenario's. ${ }^{924}$

Verleden en heden, en dus ook verschillende ruimtes, lopen in elkaar over; het mythische verleden is "a time that spills over in the present" "25. Khoisprekende Nahro in de Kalahariwoestijn vertelden in 1985 "humorous stories about a fox (or jackal) trickster who works as a gardener for a foolish, brutal, white farmer and whose efforts are largely aimed at outwitting his employer." ${ }^{26}$ Eenzelfde wereldbeeld (de voortzetting van de oerwereld tot in het heden) wordt weerspiegeld in een Khoisan hervertelling van Genesis. In deze versie worden Adam en Eva niet uit het paradijs verbannen, zoals in de joods-christelijke versie, maar leidt het ontstaan van dood en seks slechts noodzakelijkerwijs tot hard werken en pijnlijk bevallen. ${ }^{927}$ Deze "zondeval" is dus alleen maar een verandering in omstandigheden, geen breuk met het verleden, noch een definitief verlies van een heimat. Beelden uit dit fluïde discours, die als signifiants van een ander wereldbeeld door de tekst zijn gestrooid, ondermijnen de pijlers waarop de macht, maar ook de ondergang van de Lotriets is gebouwd: namelijk de begrenzing en beheersing van ruimte en tijd. De Lotrietzonen zien een verloederde, verdrogende plaas, doorkruist met grenzen en grensschermutselingen en gefixeerd op een lege kern; een ruimte waarin hun afgesneden verleden, de gedoemde toekomst en het onvervulde, verbannen, impotente heden geworteld zitten. Daaroverheen worden, meestal door focalisatie van de Lotriets zelf, elementen van een alternatieve kaart geprojecteerd. Wie wil, kan aan de hand daarvan een ruimte creëren waarin God en //Gauwa tegelijk bestaan; waar meerdere oorsprongen, een variabele toekomst en een pluriform heden een plaats krijgen en in elkaar overlopen.

\subsubsection{De maan: vruchtbaarheid, geweld en wedergeboorte}

/Kaggen maakte de maan, en gaf hem iets schelmachtigs mee. De maan gaf licht, wat gunstig was voor de jacht, maar kon het wild ook helpen ontsnappen; hij was gewelddadig, maar ook alwetend. Diä!kwain, een van de

\footnotetext{
924 Guenter 1989, 37

925 Guenter 1989, 115

${ }^{926}$ Hewitt, R.L. (1985) The oral literature of the San and Related People. In B.W. Andrezejewski et. al. (eds.) Literatures in African Languages. Warschau/Cambridge, 30

${ }^{927}$ Guenter 1989, 43 t/m 50
} 
informanten van Bleek en Lloyd, omschreef de maan als: "a thing which knows things; for it sees things which will come to pass. It is the one who knows them, things we do not know." 228 Net als //Gãuwa wordt de maan geassocieerd met de dood, maar ook met initiatieriten, vruchtbaarheid en wedergeboorte ${ }^{229}$. Zuidelijke Khoisan geloofden dat de zielen van de overledenen naar de maan gaan, daar weer tot leven komen, en als de maan vol is weer op aarde worden afgezet voor een nieuw leven ${ }^{930}$. Maan is volgens de mythologie betrokken bij het ontstaan van de dood. Een bekende versie gaat als volgt: de moeder van Haas ligt te slapen, maar Haas denkt dat ze dood is. Maan verzekert haar dat ze straks weer wakker zal worden, maar Haas gelooft Maan niet. Dan wordt Maan zo boos dat hij Haas een hazenlip slaat. ${ }^{931}$ Als Haas (die voor de mensheid staat) Maan had geloofd, had de mensheid het eeuwige leven van de maan georven. ${ }^{932}$

Tijdens de zo prominente vrijdagnacht op Perdepoort, de nacht waarin Fielies' wake gehouden wordt, waarin Klaas "de duivel" ontmoet, Mietjie Kobus' stookketel aan diggelen slaat, Jan een UFO spot en Chris Adriana aanrandt, is het volle maan. Bijna iedereen is zich ervan bewust en heeft er een associatie of gedachte bij. Attie verlustigt zich aan het zilver, "koel soos maanlig" (167); Adriana houdt van "volmaanaande en van haar spel met seuns" (28); Jan is de maan liever kwijt dan rijk, want het moet donker zijn om vliegende schotels te kunnen zien (29); en Chris vindt haar aanwezigheid hinderlijk omdat hij zelf niet gezien wil worden (229). De maan krijgt menselijke eigenschappen toegedicht die haar iets bovennatuurlijks geven en de nacht iets unheimlichs. Mietjie, bijvoorbeeld, voelt zich door het maanlicht verwarmd, nadat ze besloten heeft Kobus te verlaten. Ze klimt tegen de berghelling op en kijkt naar beneden. "In die maanlig sien jy helder 'n stuk van die werf onder en die huis. Bo haar kop het die maan gestaan en sy lig ondertoe gegiet, haar vir die oomblik uitgelig uit haar smart en vernedering. Sy het haar kieste ingesuig om speeksel bij mekaar te kry en gespuug, twee keer ondertoe gespuug, lighoofdig van die regverdige oordeel" (249/50). Als ze daarentegen de volgende nacht toch terugkomt, Kobus dood aantreft en naar beneden holt, struikelt ze over de stenen en oordeelt: "Die maanlig is ook so vals" (31). Ook Klaas staat ambigu tegenover de maan. Aanvankelijk noemt hij zichzelf net zo onverschillig als de maan, maar even later, terwijl hij langs de oude begraafplaats loopt, "verbeel [hy] hom hy voel die maanlig warm op sy nek (..) Een keer is dit vir Klaas of hy die grond onder sy voete voel opbult en hij bly staan vraend, staar vraend na die maanverligte kamme van die koppe. 'n Onnatuurlike

\footnotetext{
${ }^{928}$ J.D. Lewis Williams, ed. Stories that float from afar.: ancestar folklore of the San of Southern Africa. Cape Town, David Philip 2000: 249-250

${ }_{929}$ Barnard 1992, 87

${ }^{930}$ Hewitt 1986, 42

${ }^{931}$ Bleek \& Lloyd 1911, 57-63

${ }^{932}$ Barnard 1992, 83
} 
nag!" (242). Hoewel meer factoren die nacht zijn unheimlichkeit geven ook Attie heeft vrijdagavond bijvoorbeeld het gevoel alsof hij "op onvaste grond wieg, op 'n voorgevoel van toekomstige gruwels" (238) - speelt de maan wel een opvallende rol.

Wat haar betekenis is in dit boek, begint vooral te dagen tijdens het samenzijn van Chris en Adriana. Terwijl Chris naar de rivier sluipt, en de kikkers hoort "die mekaar tot paring onder die lig van die volmaan (..) roep" bezweert hij de maan: "Nie nou al opkom nie; die lig sal teveel lig maak." (229). Later, als hij naast Adriana zit en haar over haar haar strijkt, duikt ze weg:

“O, kijk", adem sy. "Die maan!"

Hy word teen sy wil gedwing om ook te kyk.

"Soos silwer bubblegum," sê sy (die Engelse woord hinder hom).

Maar iewers agter die heuwels is 'n kind dit met die mond aan die blaas, jy sien dit dobber. Dan kom dit los uit die kind se mond en begin dryf selfstandig op.

"Los nou die maan," sê hy knorrig. (..)

"Wat is verkeerd met die maan?" vra sy afgetrokke. (230)

Om vervolgens te vragen: "Was jy al ooit verlief?". Adriana is vijftien. Haar "spel met seuns", en met Chris, is onderdeel van een proces van volwassenwording. Dat vooral dit aspect van haar identiteit van belang is voor het verhaal, wordt gesuggereerd door de belangstelling van Chris, van wie de lezer weet dat hij geobsedeerd is door meisjes die zowel vrouw als kind zijn. Maar er zijn ook intertekstuele verbanden die haar halfwassenheid benadrukken. Bovenstaande maanscène vertoont bijvoorbeeld gelijkenis met een gedicht van Elizabeth Eybers waarin een kind pijnlijk de grens ervaart tussen haar magische wereld en de volwassen werkelijkheid achter haar waar ze al half deel van uitmaakt. Vanuit een ruimte "vol lig en mensestemme en gelag" kijkt ze door een raam naar buiten en ziet de opkomende maan als een zeepbel "uitswel bo die silwer vlei". Ze voelt "angs en weekheid sonder naam/ terwyl ek op die maan se loskom wag." Nog pregnanter is de gelijkenis met een andere tekst, waarin eveneens een onvrijwillige overgang van meisje naar vrouw centraal staat. Aan het romantisch en onschuldig samenzijn van Chris en Adriana komt abrupt een eind als zij hem onverwachts begint te zoenen. Bij Chris gaan nu alle remmen los. Hij zet zijn bril af, werpt zich op haar en zou haar verkracht hebben als niet het vervormde gezicht van de maan en de geur van rotting hem hadden gehinderd.

${ }^{933}$ Elisabeth Eybers “Herinnering'. Uit: Die vrouw en ander verse Pretoria/ Johannesburg 1945 
As die maan net nie so hinderlik was nie, want wanneer jy op jou rug is, lyk die maan gekneus en vormloos en kyk verskrik saam met jou na die donker vierbeen-gestoei. Maar wanneer jy op jou maag draai, ruik jy vrot biesies en grond en die oerstof van paring. Terwyl niks jou nog kan wegrky van die driedubbele oortreding nie..

Sy slagoffer is aan die worstel om weg te kom. (..) sy's veel sterker as hy kon raai. 'Jou klein..' hy wurg die vieslike woord en sou sy tong kon afgebyt het, as hy nie die dodedans solo op de kweek aan die uitvoer was nie. Dan lê hy stil: uitgeput, of dood. En God ook. Sy hel is ysig koud en verlate. (231)

Het hier door Chris gelegde verband tussen seks en dood, komt natuurlijk ook al voor in het verhaal over de verbanning van Adam en Eva uit het paradijs. Maar door seks voor te stellen als een strijd tussen de seksen, met het geschonden aangezicht van de maan als stille getuige, wordt een link gelegd met een derde versie van de Maan-en-Haasmythe ${ }^{934}$. In deze versie verkracht Maan de maagd Haas en geeft haar vervolgens de boodschap mee dat de mens-dieren zullen herleven. Uit woede geeft Haas echter de verkeerde boodschap door ("you must all die because the pus of a person smells disgustingly" ${ }^{935}$ ), waarop Maan, als hij dat hoort, Haas' lip splijt en Haas op haar beurt Maans gezicht verbrandt met haar boven het vuur verhitte kleren. De sporen daarvan draagt Maan nog steeds op z'n (volgens Chris "gekneusde") gezicht. ${ }^{936}$ Een andere mythe verklaart waarom Chris in het eerste citaat niet naar de maan wilde kijken en waarom Adriana, nadat hij toch gekeken heeft, weet weg te komen: /Xam jagers vermeden het om naar de maan te kijken als ze wild hadden aangeschoten, want dan zou de maan de prooi alsnog helpen ontsnappen. ${ }^{937}$ Eenmaal opgenomen in dit Khoisan discours lijkt Chris na zijn "dood" ook het Khoisan landschap van de dood te betreden: zowel God als het hellevuur van de duivel zijn verdwenen, in plaats daarvan is "sy hel (..) ysig koud en verlate" - als een maanlandschap.

Zo wordt stukje bij beetje een Khoisan perceptie van ruimte geïntroduceerd, die de waarnemingen van personages een onwillekeurige betekenis meegeeft. Klaas' observatie bijvoorbeeld dat "[die maan] vanaand nie helderder kon geskyn het nie, byna driedimensioneel, die melkweg lê soos 'n uitgebrande tak oor die hemel" (242) krijgt een heel andere lading wanneer we weten hoe in een van de oorsprongsmythen van de /Xam het ontstaan van de Melkweg (!ko) wordt verklaard. Een meisje van "the Early Race" gooide "wood ashes" in de lucht zodat haar mensen wat licht hadden

\footnotetext{
934 Guenter 1989, 51 e.v

${ }^{935}$ Guenter 1989, 54

${ }^{936}$ Guenter maakt aannemelijk dat deze verkrachting een belangrijk onderdeel was van de mythe, die echter in latere versies is weggevallen.

${ }^{937}$ Bleek \& Lloyd 1911, 66-69
} 
op weg naar huis. ${ }^{938}$ De sterren "offered [the /Xam] a kind of cosmological completeness and, more immediately, a path to safety and food"; ze waren hun belangrijkste "markers of place" "onnatuurlike nag" nog wel in hun "eigen" universum?

\subsubsection{Adriana: meisje, vrouw en kikker}

De maan werpt haar unheimliche licht over Perdepoort; plaatst alles in een ander perspectief, ondermijnt zekerheden en benadrukt de onsterfelijkheid en aanwezigheid van een Khoisan discours. Kijken we in dit licht naar de rivier, waar ondermeer de twee belangrijke ontmoetingen tussen Chris en Adriana plaatsvinden, dan zal blijken dat ook die Adriana's puberteit uitvergroot. Die rivier is niet alleen het domein van Adriana en Kolie, maar door intertekstuele verbanden ook van!Khwa en /Kaggen c.q. //Gãuwa. Op deze manier duidt Adriana's verbondenheid met de rivier zowel op haar eigen proces van volwassenwording als op het gevaar dat ze als puber vormt voor de haar omringende culturele orde.

In tegenstelling tot in veel andere samenlevingen was de initiatierite van meisjes voor de San heel belangrijk. Het sloot naadloos aan bij Van Genneps model van separation, liminality, incorporation. ${ }^{940}$ Een meisje dat voor het eerst ongesteld werd, moest zich enige tijd afzonderen in een hut. Alleen strikte rituelen konden ervoor zorgen dat ze daarna volledig terugkeerde in het cultuur-domein. "If she fails in this she is bound to move in the other direction and become absorbed into pure nature." ${ }^{941}$ Haar falen zou niet alleen over haarzelf onheil afroepen, maar ook over haar naasten: verschillende verhalen vertellen over !Khwa, de personificatie van alle soorten water, maar vooral van (mannelijk) regenwater, die ongehoorzame meisjes en haar familie veranderde in kikkers en hun spullen in de grondstoffen waaruit ze waren vervaardigd ${ }^{942}$.

Behalve over (sociale) transformatie van kind in volwassene ${ }^{943}$ gaan deze verhalen ook over fundamentele tegenstellingen tussen goed/ kwaad; binnen/ buiten; cultuur/ natuur. Volgens Lewis-Williams was water in het wereldbeeld van de /Xam de ontmoetingsplek tussen het bekende en het onbekende. Hij stelt: "Xam cosmos comprised (A) the realm of material, daily life and (B) an 'adjacent', immanent, spiritual realm that included a region below the earth and another situated in the sky." "944 Het spirituele

\footnotetext{
${ }^{938}$ Bleek \& Lloyd 1911, 73

${ }^{939}$ Green Musselman 2003, 69

${ }_{940}$ Elsbree, 26

${ }^{941}$ Hewitt, 1986, 79

${ }^{942}$ Hewitt 1986, 77; L. Lloyd, A short account of further Bushmen material collected. London, David Nut, $1889 ; 21$

${ }_{943}$ Hewit 1986, 207

${ }^{944}$ Lewis-Williams 1997, 199
} 
domein (B) is het domein van de sjamanen "immanent rather than seperated spatially from the natural world" ${ }^{45}$. Het domein van het dagelijks leven (A) werd onderverdeeld in 1. het kamp, gekenmerkt door sociale activiteit, orde, samenwerking, en healing dance; 2. de jachtgronden: gekenmerkt door (wilde) dieren (vooral de leeuw), onbekende mensen, gevaar en onvoorspelbaarheid; en 3. water, of de waterbron, waar de bewoners van 1 . en 2. elkaar al dan niet toevallig ontmoetten. Die ontmoetingen konden zowel gunstig als gevaarlijk zijn. Ook A. en B. worden door water met elkaar verbonden. Water heeft regeneratieve en transfomerende krachten, die door sjamanen kunnen worden toegepast.

De rivier is een plek van transformatie en hoort als zodanig tot het niemandsland dat het domein is van ambiguë wezens, die zowel heilzaam als gevaarlijk kunnen zijn. Gevaar bestond voor de /Xam vooral uit transformatie van orde (cultuur) naar chaos (natuur).

[The] concept of potential transformation from the social, ordered world of humans to the purely natural world was one of the most common features of /Xam magico-religious thought. The more social life was threatened, the more the natural world tended to be seen as beyond the powers of men to control. (...) [B]etween order and disorder there existed a borderland inhabited, in the imagination of the /Xam, by various ambiguous creatures and powers which symbolised all kinds of natural danger. ${ }^{946}$

Tot deze ambiguë wezens hoorden ondermeer!Khwa, /Kaggen, //Gãuwa, roofdieren, kikkers, naderende vreemdelingen, sjamanen en menstruerende meisjes. ${ }^{947} \mathrm{Bij}$ de vrouwelijke initiatierite is //Gãuwa bovendien personage in de rituele tekst:

[//Gãuwa] hovers about the menstrual hut as a male, making sure the proper rules are observed (a role assumed among the /Xam by !Khwa (..)). One rule in particular he enforces: to keep away men, especially young men, whom he deems his rivals, having taken a proprietorial as well as wooing attitude to the secluded young woman. ${ }^{948}$

Twee sterk op elkaar lijkende /Kaggen-verhalen verwijzen beide naar deze vrouwelijke initiatie. /Kaggen gooit een stukje van zijn door leeuwen/ bavianen gedode zus (zoon) in het water van de rivier en geeft het de tijd om te groeien. Hij gaat een paar keer kijken en probeert dat ongezien te

\footnotetext{
${ }^{945}$ Idem

${ }^{946}$ Hewitt 1986, 134

${ }^{947}$ Hewitt 1986, 133

${ }^{948}$ Guenter 1989, 117. Zie ook Guenter "The Nahro Bushmen of Botswana. Tradition and change." in: Quellen zur Khoisanforschung vol. 3 Hamburg, 1986. Hoofdstuk 7 en 8.
} 
doen; want zodra het kind hem ziet, vlucht het het water in. Uiteindelijk, als hij denkt dat de tijd rijp is ("she seemed to be a young woman"), keert hij terug met een schort en een karos of /koroko, sluipt ongezien nader en grijpt zus (zoon) voor zij (hij) kan vluchten. Niet bang zijn, zegt hij, ik ben je broer (vader). En hij "made her smell his scent". Dan geeft hij de kleren en neemt de herborene mee terug naar huis ${ }^{49}$. De rol van /Kaggen in deze verhalen is die van de beschermer van het leven en de maatschappelijke orde: hij doet de dood, veroorzaakt door de wilde dieren, teniet; hij laat het kind haar periode van afzondering doorlopen waardoor ze veilig volwassen wordt; met zijn zweet zorgt hij ervoor dat ze weer een van hen wordt ${ }^{950}$; en door haar te kleden zorgt hij ervoor dat ze terugkeert in het cultuur-domein.

Op vrijdagochtend is Chris Adriana gevolgd als ze het pad afloopt. Hij vindt haar bikini op de oever. Adriana ziet hem en vraagt hem haar de bikini toe te gooien. Hij weigert en daagt haar uit en uiteindelijk komt ze naakt het water uit. Chris schrikt, eerst van de tekens van volwassenheid op haar lichaam en vervolgens van de situatie, gooit snel een handdoek over haar schouders en wendt zich af, boos "omdat sy die bekoorlike ban verbreek het" (136). In dit fragment verenigt Chris in zich zowel het wilde roofdier ("net 'n oomblik het Chris se oë vraatsugtige wolve geword" (136) als het familielid (geen broer, geen vader, maar wel de broer van haar vader) die haar eraan herinnert dat zij bij hem hoort ("Vir wat is jy skaam? Jy 't dan vir my grootgeword" (136)) en probeert haar aan de heersende zeden te laten conformeren ("Hemelse vader, skrik hy egter, die kind moet aantrek voor daar iemand kom!" (136)).

Chris is dus enerzijds /Kaggen die een karos om haar heen slaat, en anderzijds!Khwa die een behouden thuiskomst probeert te verhinderen. Hij bergt de tegenstrijdigheden van //Gãuwa of een van de schelmen in zich: enerzijds wellustig en onbeschaamd ${ }^{951}$, anderzijds beschermend. Chris' rivaal Jaco, die zich die avond zal staan te verbijten tussen de bosjes, wordt inderdaad door Chris" "wooing attitude" op afstand gehouden. ${ }^{952}$

/Kaggen en !Khwa, soms verenigd in //Gãuwa, staan voor een evenwicht tussen stabilisatie en transformatie. /Kaggen morrelt aan de grenzen van de menselijke orde, maar beschermt het leven. !Khwa versterkt de menselijke orde door het leven te bedreigen ${ }^{953}$. Zowel Chris als Adriana horen tot de categorie van wezens die balanceren op de grens tussen verschillende werelden, en hebben daarmee invloed op dit evenwicht. Chris is met zijn

\footnotetext{
${ }^{949}$ Hewitt 205 en 206

${ }^{950}$ The /Xam practised anointing with perspiration in contexts where one person wished to transfer certain of his own attributes to another. (Hewitt in een noot op p. 211)

${ }^{951}$ Zie ook: Matthias Guenter "The Nahro Bushmen of Botswana, Tradition and change." in: Quellen zur Khoisanforschung vol. 3 Hamburg, 1986.

${ }_{952}$ Guenter 1989, 117. Zie noot 183

953 "The social aspect of order was, to some extent, shaped by its own dangerous elements: de margins" Hewitt 1986, 135. Zie ook Guenter 1989, 117
} 
ambiguïteit en zijn spirituele gaven ("die snaakse gevoel” (141) waarin "straatoppervlak en bome en ander siele (..) met hom (..) kommunikeer, terwyl die tyd in 'n ewigheid vervloei" (140)) als een sjamaan, of als /Kaggen, die toegang heeft tot een immateriële wereld en een belangrijke rol vervult bij rites de passage. Adriana is het vrouwwordende meisje dat zich niet stoort aan de mores en verwachtingen van haar ouders ("Jy kan jou ou erfgoed in jou agterend steek" (166)) en al kikkertrekken begint te vertonen ("sy swom paddastyl nader" (135)). Ze is het "half-kind, half heks, half vrouw-dier" (142) dat thuis gebracht moet worden, en zo onschadelijk gemaakt. Maar Adriana's initiatie staat niet op zich. "Like all rituals", zegt de antropoloog Jean la Fontaine,

these rituals display symbols whose multiple meanings draw on many different layers of social life, from assumptions about the nature of the world and of human beings, to abstract ideas, often vague and ill defined, which must be deduced from the context, not merely of one ritual but of others performed in the same society, and from secular life. (..) Initiation is a patterned performance whose purpose is action to achieve transformed individuals but whose effect is to demonstrate the power of traditional knowledge and legitimize a continuing social order. ${ }^{954}$

Tegelijk geeft elke transformatie, en dus ook deze, niet alleen de mogelijkheid tot bestendiging, maar ook tot verandering. Zal Adriana zich laten thuisbrengen? Door wie laat ze zich thuisbrengen? Zal ze de gedoemde traditie van de Lotrietfamilie voortzetten, of zal ze een nieuw thuis kiezen? De toekomst van Perdepoort hangt voor een groot deel van haar af.

\subsection{5 /Kaggen: ordeverstorend en levengevend}

Hoezeer /Kaggen verweven zit in Kroniek, blijkt na een nadere bestudering van het personage. De schelm (trickster) is, in verschillende gedaantes, de centrale figuur in Khoisan mythologie ${ }^{955}$. De /Xam noemden hem /Kaggen. De Nahro kennen een menselijke variant die het in het veld opneemt tegen de mens-dieren uit de mythische tijd, toen er nog geen onderscheid was tussen mens en dier; en Jakhals, die niet op het veld woont, maar op een frontier farm. Jakhals is de mythische equivalent van de landarbeider. ${ }^{956}$ Zowel voor Nahro als /Xam "the settlers are an integral component of their existence and their oral traditions respond to and reflect this reality." ${ }^{957}$

\footnotetext{
${ }^{954}$ La Fontaine 1986, 178/9

${ }_{955}$ Guenter 1989

${ }^{956}$ Guenter 1989, 22

${ }^{957}$ Guenter 1989, 19
} 
Bevindt de schelm zich op de boerderij, dan is zijn tegenspeler een blanke boer, in het veld is dat de leeuw. Leeuw en Boer lijken veel op elkaar. ${ }^{958}$ /Kaggen betekent "bindsprinkhaan" (in Afrikaans: hotnotsgod) en was lang geleden mens, net als alle andere dieren. Uiteindelijk, zo gaat het verhaal, werden alle inwoners van de aarde veranderd in dieren, behalve de San. /Kaggen leefde in die tweede fase voort als een bovennatuurlijk wezen. ${ }^{959}$ Hewitt noemt hem een "Transformer", dat wil zeggen: "an establisher of the present order of things, utterly non-ethical, only incidentally and inconsistently beneficent". ${ }^{60}$ /Kaggen alias Jakhals onderwerpt zijn omgeving aan practical jokes die over het algemeen weinig schade berokkenen. Vaak ook wordt hij zelf de dupe van zijn eigen plannen. Zoals bij schelmen overal ter wereld is ambiguiteit zijn belangrijkste eigenschap. ${ }^{961} \mathrm{Hij}$ is

at one time human or animal, at another animal or tree or plant; he is both vindictive and destructive and beneficent and creative; he is weak and cowardly and powerful and courageous; foolish and clever; cunning and readily duped ${ }^{962}$.

Hewitt analyseerde een groot aantal verhalen over /Kaggen en ontdekte hierin vaste ruimtelijke structuren en terugkerende confrontaties en handelingen ${ }^{963}$, die een opvallende en interessante gelijkenis vertonen met bepaalde verhaallijnen en structuren in Kroniek.

/Kaggen kan soms zeer hulpvaardig zijn in het bemiddelen bij onenigheid tussen anderen, maar vaker is hij ruziezoekerig, hebberig en asociaal. /Kaggen is half man en half vrouw; tegelijk kind en grootvader, zodat hij kan ontsnappen aan alle sociale rollen. Hij is impulsief en lijkt niet gestoord te worden door kennis van zeden en gewoontes, noch van enig praktisch inzicht. Hoewel hij altijd ruzie uitlokt, is hij in een directe confrontatie kansloos. Zijn belangrijkste karaktertrek in een confrontatie met de buitenwereld is hebzucht. De regel die hij doorgaans overtreedt is diefstal en tresspassing: het ongeoorloofd betreden van het domein van een vreemdeling. ${ }^{964}$

Maar er is ook een positieve kant aan deze kinderlijke normloosheid. Zijn magische en creatieve krachten zijn er voor een deel op gestoeld. Juist "in his very freedom from the practical, mundane world of adults (..) he finds a realm of possibility for re-arranging the order of things through spontaneity unrestrained by social and economic obligations, or rational and realistic

\footnotetext{
${ }^{958}$ Guenter 1989, 35

${ }^{959}$ Hewitt 1986,124

${ }^{960}$ Hewitt 1986, 131

${ }^{961} \mathrm{Zie}$ ook Hewitt 1986,145

${ }^{962}$ Guenter 1989, 115

${ }^{963}$ Hewitt 1986

${ }^{964}$ Hewitt 1989, 147-163
} 
thought." ${ }^{965}$ Hij is in staat de magische krachten van bepaalde elementen uit de natuur, zoals honing, water of zweet, aan te wenden voor transformaties van negatief (dood, conflict) naar positief (leven, vrede). ${ }^{966}$

$\mathrm{Er}$ is dus een verschil tussen de ordeverstoring van /Kaggen en die van levensbedreigende, uitsluitend destructieve buitenstaanders ${ }^{967}$. /Kaggen is marginaal, maar geen buitenstaander. In zijn ambiguïteit kan hij bemiddelen tussen de bedreigden en de dreiging, en zo functioneert hij in de verhalen "almost as an operational principle rather than as an actor" verhalen eindigen met een terugkeer naar het normale en een bevestiging van de sociale cohesie door een huwelijk ${ }^{969}$.

In de verhalen hebben goed en kwaad, gevaar en veiligheid net als in de eerder beschreven kosmologie, een duidelijk ruimtelijke component. $\mathrm{Na}$ zijn avonturen keert/Kaggen terug naar zijn familie voor orde, veiligheid en rust. Ook hier is /Kaggen een wat asociaal buitenbeentje, maar chaos en verwarring zaait hij alleen buiten dit eigen domein. ${ }^{970}$ Als hij terugkeert passeert hij altijd de rivier en wordt daar weer "zichzelf"; hij wast zich, verzorgt zijn wonden, legt zijn magische veren af en verkwikt zich voor hij naar huis gaat.

De verhaalstructuur die in veel van deze/Kaggenverhalen terugkeert, is de volgende:

/Kaggen

1. gaat weg van huis;

2. wekt vijandigheid op bij wie hij tegenkomt en/of belandt in (levensbedreigend) fysiek conflict;

3. overwint zijn tegenstander en/of weet op magische wijze te ontvluchten;

4. transformeert of wast zich in de rivier;

5. keert terug naar huis;

6. wordt vermanend toegesproken door zijn familie.

Kijken we nu weer naar de tekst van Kroniek, dan blijkt niet alleen Chris gelijkenissen met /Kaggen te vertonen. Attie ziet weliswaar overal Jakhalzen om hem heen die hem bedreigen en bedriegen ${ }^{971}$, wat hem de domme, blanke boer maakt uit de Nahro-mythen, maar hij is zelf ook niet vrij van /Kaggen- alias Jakhalstrekjes. Atties uitstapjes naar zijn broers op vrijdag blijken bijvoorbeeld bijna volledig volgens bovenstaand stramien te verlo-

\footnotetext{
${ }^{965}$ Hewitt 1986, 153/4

${ }^{966}$ Hewitt 1986, 178

${ }^{967}$ Hewitt 1986, 168

${ }^{968}$ idem

${ }^{969}$ idem

${ }^{970}$ Hewitt 1986, 175/6

${ }^{971}$ De dreiging van buiten wordt gepersonifieerd door de 'stedelike jakkals' (85) en 'stadskelms' die liegen en bedriegen en vervuilen (84) en hij ziet Chris als "die paar skelm oë wat die deur die bril loer soos 'n jakkals uit sy gat" als hij op het punt staat Chris landloos te maken (163).
} 
pen. Ook hier verdeelt de rivier het thuisdomein van de buitenwereld, al is het opvallend en betekenisvol dat Atties buitenwereld ook zijn broers omvat. Het ouhuis staat aan de ene kant van de rivier, alle andere huizen aan de andere kant. Net als die van /Kaggen zijn Atties uitstapjes allemaal uit hebzucht ingegeven. Als hij de domeinen van zijn broers betreedt, krijgt hij ruzie met Kobus omdat hij zijn grond wil inpikken; met Klaas omdat hij een zilveren lepel inpikt; en wekt hij vijandigheid bij Jaco, Jan en zijn arbeiders. Zijn vertrek is steeds in zekere zin een vlucht. Bij thuiskomst treft Attie eerst Miemie die hem als harlekijn ziet (152), "Gaan kak!" zegt (151), en de rest van haar commentaar binnenhoudt (150). Vervolgens treft hij Oompie Vaalwater bij de achterdeur, die hem wijst op zijn verantwoordelijkheden jegens zijn dode neef (161).

In zijn hebzucht en ruziezoekerij lijkt Attie op /Kaggen, maar er is een verschil. Attie legt niet, zoals /Kaggen, zijn hebzucht af zodra hij thuis is. Het moment van oversteken van de rivier wordt bij Attie niet beschreven; zijn transformatie vindt dus nooit plaats. Hij klampt zich vast aan zijn spullen ("hij had gehoopt nu eindelijk met die lepel.." (163)) en als Chris komt aanlopen, nodigt Attie hem mee zijn werkkamer in om hem over te halen zijn recht op de grond aan hem over te dragen (165).

Toch is er wel een aanzet tot transformatie, veroorzaakt door Adriana, het kikkermeisje. Als Adriana Attie wijst op zijn verantwoordelijkheden jegens zijn familie en haarzelf lijkt er iets met hem te gebeuren. Hij geeft haar de sleutels tot de mooie kamer die hij haar aanvankelijk weigerde en "terug in sy kantoor is dit asof iets aan sy voorkoms moet verander het" (166). In een zakspiegeltje kijkt hij naar zichzelf: "Nooit daaraan gedink nie - dat die kind so vas aan hom is nie. Soort nuwe verantwoordelikheid; byna beter dat niemand vir jou omgee nie - jy voel vryer" (166/7). In zijn verzet tegen deze betrokkenheid zoekt hij weer waar hij mee bezig was: de lepel, die nu, niet toevallig, met de maan geassocieerd wordt.

Die silver skemer deur ooral - koel soos maanlig. Terselfdertyd proe Attie steeds aan die metamorfose wat hom wil inneem. (..) sy sleep jou onwillekeurig saam met die krag van iets in haar wat - hy besef nou- sy van kleins af gehad het. So of sy meer lewe gekry het as ander mense, sodat sy nie anders kán nie as om haar sin te kry. (167)

De transformatie zet niet door; hij verwerpt opnieuw de verantwoordelijkheid (167). Attie is /Kaggen zonder thuisbasis: als hij zich ooit verbonden had gevoeld met de mensen om hem heen, had zijn hebzucht zich nooit zo ongebreideld kunnen ontwikkelen. Dat als gevolg van die hebzucht de brug over de rivier langzaam uit elkaar valt omdat Attie hem niet onderhoudt, zal hem uiteindelijk volledig isoleren van de buitenwereld - of thuisloos maken. 


\subsubsection{Rite de passage: separatie, liminaliteit, ... ?}

"From the story tellers point of view," stelt Elsbree, “(..) liminality is the phase during which values are tested, issues are clarified, choices begin to have consequences. (...) [L]iminality is the medium of change. In the homology between ritual and narrative, the liminal is the threshold between past and future. It is the present tense of destinies in the making." ${ }^{972}$ Adriana vertegenwoordigt in Kroniek de liminaliteit; zij kan verandering teweegbrengen. In Khoisanverhalen kunnen vrouw-meisjes destructief zijn, maar ook scheppen: het meisje dat de sterren en de Melkweg maakte om de weg naar huis te belichten, deed dat bijvoorbeeld terwijl ze in de isolatiehut vertoefde ${ }^{973}$. Maar wat doet Adriana? Hoewel Chris wordt verscheurd door zijn eigen ambiguïteit, lijkt het erop dat hij met zijn asociale gedrag onwillekeurig de verstoring van de sociale orde afwendt: hij brengt Adriana "thuis" en versterkt daarmee (wenselijk of niet) de sociale samenhang van de Lotriets. Na haar stoeipartij met Chris lijkt Adriana immers haar vrijheidsdrang ${ }^{974}$ te vergeten. Ze laat zich verleiden door Jaco, die in een toekomstvisioen zichzelf met Adriana naast zich op de trekker ziet zitten terwijl hij iedereen van zijn terrein jaagt (227/8) Hier wordt een toekomstbeeld geschapen waarin de huidige cultuur van geslotenheid, tegenstellingen en geweld wordt voortgezet - een cultuur van Boeren en Jakhalzen. Een andere interpretatie, die de eerste overigens niet tegenspreekt, is ook mogelijk: Chris heeft gefaald: hij heeft haar niet beschermd: noch tegen zichzelf, noch tegen zijn rivaal Jaco. Perdepoort zal daarom verder verloederen en uiteindelijk terugkeren tot haar natuurlijke staat. Dat deze transformatie al enige tijd geleden in gang gezet was, blijkt wel uit de ontbrekende bloemperken, de verwilderde paarden, het verveloze huis en de grote aantallen kikkers.

$\mathrm{Nu}$ blijkt dat de verwikkelingen tussen Chris en zijn nichtje als een onwillekeurige initiatierite kunnen worden beschouwd, is het de vraag of de meest raadselachtige episode uit dit boek, namelijk Koos' nachtelijke bezoek aan Kobus, niet onder dezelfde noemer geschaard zou kunnen worden. Koos' grootste verdriet immers was dat zelfs zijn meest getalenteerde zoon Kobus maar niet wilde deugen. Uiteindelijk neemt hij maatregelen om aan die situatie een eind te maken. Op een nacht, vertelt Kobus aan Chris, kwam Koos Nek onder Kobus' raam staan met een geweer in zijn hand "om af te rekenen". De maan scheen. "'Kom!' Het hy gesê, 'als jy nog "n greintjie trots in jou het." Kobus liep mee in de veronderstelling dat Koos hem als een mismaakt paard zou gaan afschieten. Onderweg

\footnotetext{
972 Elsbree 1991, 22

${ }^{973}$ Bleek \& lloyd 1911, 72-78

${ }^{974}$ Zie pagina 28.
} 
raakte hij zichzelf kwijt: "In die ontbinding van flou maanlig, paddastemme en grint onder die voete kon Kobus geen aanduiding vind dat hy hý was nie" (210). "Gee my vanaand iets waaroor ik jou weer kan respekteer," zei Koos. Kobus nam zich voor zich niet te verzetten, maar vluchtte toch hals over kop weg, waarbij "dit was of dierelewe ooral uitborrel, of kranse opwaarts spring in die flou maanlig" (210).

Wat was Koos van plan? Wilde hij Kobus doodschieten? Of wilde hij dat Kobus de stookketel bij dwarsrivier zou vernielen, zoals Mietjie vele jaren later deed? Of was het allemaal maar een droom, waarin Kobus "dood" stond voor de dood die een jongen sterft voordat hij man wordt en Koos met zijn geweer voor de jager die in de oude initiatieriten voor Sanjongens het ritueel begeleidde? ${ }^{975}$. Kobus' gevoel van desintegratie in de aanwezigheid van maan, kikkers, water en ongecontroleerde natuur wijst in een dergelijke richting ${ }^{976}$. Evenals zijn terugkerende gevoel, naderhand, dat hij een kans gemist heeft: "Hy dink, nie vir die eerste keer nie: ek moes gaan staan het, daardie nag". Kobus heeft, net als Attie, de transformerende initiatierite nooit doorlopen; hij is nooit volwassen geworden. Voor Chris, die zowel bij zichzelf als bij zijn vrouwelijke lustobjecten "die stigmata van volwassenheid" afstotelijk vindt (135), geldt hetzelfde, voor Jan ${ }^{977}$ en Klaas al helemaal.

Oompie Dansters trancedans is uiteindelijk een verwijzing naar een rode draad in de roman, namelijk de rol van //Gãuwa of /Kaggen ten tijde van rites de passage. Het unheimliche van de beschreven dagen op Perdepoort, te danken aan de liminale staat waarin meerdere lijken (die van Koos en Dora Lotriet, van Fielies en van Kobus) zich bevinden en de prominente aanwezigheid van signifiants uit het Khoisan discours, bestaat eruit dat bestaande grenzen tijdelijk vervagen en zekerheden worden opgeschort ${ }^{978}$. Juist datgene wat de broers houvast verleent, komt op losse schroeven te staan. Attie, die zijn leven verankerd heeft in grond en bezit, ervaart dat hij stroomopwaarts beweegt, tot boven in de bergen, in plaats van de rivier stroomafwaarts (213) en een andere keer dat hij "op onvaste grond wieg" (238) of dat zijn huis wegdrijft (104). En als hij in de mooie kamer zit, is het of het vertrek "asof hy nie die eienaar is nie, maar geëien word" (240). Terwijl Attie vooral worstelt met verlies van houvast in de ruimte, dreigt Kobus, die zich vasthoudt aan het verleden, los te raken uit de tijd: "'n draai van die verkyker se skroef bring die ouhuis verbluffend nader, bring

\footnotetext{
${ }^{975}$ In feite bestond die 'initiatierite' uit een jachtritueel dat al dan niet tot een veranderde soiale status leidde. Guenter 2000, 192/3

${ }^{976}$ Deze riten dienden niet alleen om de jongens gehoorzaamheid en moraal bij te brengen, maar ook om hen te wijzen op de aanwezigheid en het belang van //Gãuwa. (Guenter 1986, 277/8)

977 Jaco tegen Jan: ‘Kyk hierso pa, kyk hierso - kan jy jou nie soos 'n groot mens gedra nie?” (218)

978 "Through the ambiguity acknowledged and celebrated during the liminal phase of the transition rites, which reverberates through all of Bushman religion, belief, and society, polarities are suspended, between men and women, old and young, human and animal."
} 
die onaardse gevoel wanneer 'n bekende ding jou skielik 'n vreemde aangesig bied. En die vrees wat hy soveel jare uitgestel het dat daar geen levenslyn meer is tussen verleden en toekoms nie, neem Kobus vlietend in besit" (43). Klaas, de koele rationalist, de ongelovige, is vooral bang de greep op zichzelf te verliezen. Nadat hij bezoek heeft gekregen van "de duivel" consumeert hij voor het eerst zijn huwelijk en valt de volgende dag ten prooi aan knagende onzekerheid (55).

De ervaren onzekerheid en twijfel worden door de verscheidene personages geprojecteerd op omstanders en omgeving en vervolgens onveranderlijk aan de duivel gekoppeld, met als hoogtepunt Klaas' nachtelijke bezoeker. Het woord duivel komt bijzonder vaak voor in de tekst. Annies dominee vereenzelvigt de duivel met Klaas (149); Chris met Adriana, Klaas en zijn eigen lusten (142); Jan met Letta, als ze ruzie hebben (107). Kobus noemt zichzelf een duiwelskind (195) en Attie "vrees (..) die bokpoot van 'n stedelike ontwikkelingsgroep" (84). Maar het woord wordt ook opvallend veel gebruikt in combinatie met natuurlijke elementen, met name de wind. In de loop van vrijdagnacht steekt er een wind op die Miemie bang maakt (241), Annie laat schrikken "of die duiwel haar gedagtes lees" (145), Attie "laat steier" (241; 103), Klaas laat huiveren $(60,122)$, Chris "afsydig in die gesig [slaan]" (199) en Kobus "met deurmekaar woorde op de lippe" wakkermaakt (195). Tijdens de herbegrafenis van Koos is het de wind die het geheel tot een lachwekkende vertoning maakt: "Buite sou daar stemmigheid geheers het as die wind dit toegelaat het. So 'n geruk aan hoede, baadjiepante en rokke. Wolke blare word opgeraap en in die gesigte gesmyt. Daar 's diegene wat nie kon help om te giggel nie toe 'n minirok opgeskep en omgedop word soos 'n sambreel", ziet Kobus (60). "[D]ie wind word ondraaglik," ziet de dominee. "Dit veroorsaak 'n voortdurende geflap-flap van rokke, baadjiespante en broekspype, dit smyt al wat das is, minagtend oor die skouer. (..) Klaas Kamer is doodsbleek gewaai, of nog bleker." Het is of de wind maskers wegblaast; de schertsvertoning blootlegt (64-66). Uiteindelijk drijft de wind mensen voortijdig terug naar hun auto's (67). Maar als de kist valt, gaat hij liggen.

De wind wordt voorgesteld als iets met een eigen wil, een duivelse plaaggeest die mensen angst aanjaagt en Koos Neks herbegrafenis verstoort. Maar de wereld gaat er heel anders uitzien als die wind niet aan de duivel toebehoort, maar aan Fielies, en niet negatief is maar positief. Hewitt vertelt dat bij de Khoisan

each male person had a wind associated with him, cold and harsh, or warm and pleasant (..). When a person died his wind blew, removing the footprints from the ground. There is no textual evidence that the San regarded this force as supernatural or magical. Indeed it appears 
to have been thought of more as a physical attribute than a spiritual one. ${ }^{979}$

Deze persoonsgebonden wind heet N!ow, en hoort tot de positieve krachten van de natuur ${ }^{98}$. Bij de begrafenis van Fielies, die natuurlijk onder dezelfde winderige omstandigheden plaats vindt, lijken mensen zich dan ook nauwelijks aan de storm te storen: slechts een enkele keer wordt melding gemaakt van een "onstuimige" wind (70), een kwalificatie die ook voor Fielies had kunnen gelden. Hoewel het "duivelse" voorkomen van deze wind dus voor een groot deel afhankelijk is van beleving, is het niet onaannemelijk dat hij Fielies' woede weerspiegelt: tenslotte is hij het die postuum- Kolie ertoe aanzet een steen naar Jaco te gooien, waardoor de kist valt. Fielies is dood en wordt doodgezwegen, maar zijn energie is nog zeer aanwezig.

Overigens hebben de duivel, zeker in de vorm van Vondels Lucifer, en Fielies meer overeenkomsten dan op het eerste gezicht lijkt. Vondel en Louw hadden gemeen dat ze leefden in een tijd die enerzijds bepaald werd door een op Gods genade steunende, absolutistische macht, terwijl ze anderzijds "krioel[de] van allerlei soorten aanslagen tegen het gezag." Vondel dankte hieraan zijn levenslange fascinatie voor de opstand, die in zijn ogen zowel gerechtvaardigd als ongerechtvaardigd kon zijn. In ongerechtvaardigde vorm is de opstand ingegeven door de eerder genoemde staatszucht, een vorm van hoogmoed waarin men meer wil zijn dan God toestaat. Staatszucht staat bij Vondel "vaak in nauw verband met het probleem van het eerstgeboorterecht waaraan door ouderlijke, in laatste instantie goddelijke wil afbreuk wordt gedaan"982. Lucifer kwam ertegen in opstand dat God de mens boven hem wilde stellen. Maar ook Kroniek gaat over schending van het eerstgeboorterecht. Koos passeerde Jan en wekte daarmee de woede van diens hele gezin; Atties verwerping van Kolie roept verzet op bij zowel Kolie als Adriana; en Kobus verloochent Fielies, die zijn bij leven machteloze woede richt tegen de vader die hem niet erkent, maar in de dood het land, het thuis opeist dat hem toekwam.

Net als Koos Nek is Fielies zowel duivel als verlosser; of zijn "opstand" gerechtvaardigd is, hangt af van wat we zien als de door God gegeven orde. Louw lijkt daarover geen uitspraken te doen. De oude orde voldoet niet meer, zoveel is duidelijk, maar een nieuwe orde kan nog niet echt vorm krijgen, omdat er iets ontbreekt. Kroniek is te lezen als een roman die gaat over de onvoltooide rite de passage van een cultuur. Ook Koos Nek is in bepaalde opzichten /Kaggen: een "establisher of the present order of

\footnotetext{
${ }^{979}$ Hewitt $1986,41 / 2$

${ }^{980}$ Hewitt 1986, 138

${ }^{981}$ Rens 1979,13

${ }^{982}$ Rens 1979,13
} 
things" ${ }^{983}$, een man die mythische proporties heeft aangenomen: hij is net als /Kaggen hoogmoedig, marginaal en ambigu; hij is duivels en heilig, "God se nar" (165) en een "kinds-ou-man"(7). De Lotriets, zoals ze nu samenleven op Perdepoort, lijken bovendien qua samenstelling op een typische San-samenleving: broers en zussen en hun kinderen. Maar ook Koos Nek heeft gefaald in zijn begeleiding van de rites de passage, met name die van het huwelijk: terwijl een van /Kaggens rollen het sluiten van huwelijken was, keurt Koos elk huwelijk van zijn zoons af. Al zijn zonen (dat wil zeggen: een hele generatie) zijn blijven steken in de liminale fase: in het isolement dat aan de wedergeboorte voorafgaat; in zondige verbanning zonder verlossing; in dood zonder begrafenis. "In those occasional cases where incorporation is absent, (..) this omission gaines significance, because (as with so many modern narratives) it implies that there is no stable social order to return to, or that the interests of the self and society are antagonistic" stelt Elsbree. ${ }^{984}$ Onvoltooide rituelen zijn een bedreiging voor de orde, maar wijzen andersom ook op een gebrek aan vertrouwen in die orde. Net als in The conservationist ontbreekt het de blanke boerderijbewoners aan een thuisbasis die zichzelf serieus neemt, en dus aan rituelen om de patstelling te doorbreken.

Anderzijds is dit het moment waarop er verandering kan optreden. In de liminale fase tussen leven en dood, tussen de ene levensfase en de andere kan immers een nieuwe identiteit worden gecreërd. Ook in die zin is Oompie Danster richtinggevend: de trancedanser wordt ook wel beschouwd als een "agent of social change". ${ }^{885}$ Satang is, in al z'n verschijningsvormen, vooral het bewustzijn van de Ander in onszelf en Oompie Danster is wellicht de enige die in hem Derrida's hauntology herkent: het unheimliche dat fungeert als "a bulwark against the dangerous temptations of conjuring away plural spectres in the name of a redeemed whole, a realization of narcistic fantasies, a restauration of a true heimat". ${ }^{986} \mathrm{Om}$ recht te doen aan deze "plural spectres" en zo een nieuwe, labiele orde te kunnen scheppen in ruimte en tijd, zijn niet alleen alle kinderen van belang, maar ook alle (voor)ouders en tradities. Op Perdepoort valt een aantal van deze laatste evenzeer ten prooi aan verloochening als sommige van de kinderen. Dora Lotriet lijkt in de ogen van haar kinderen nauwelijks te bestaan, Jaco

\footnotetext{
${ }_{983}$ Hewitt 1986, 131

${ }^{984}$ Elsbree 1991, 25

${ }^{985}$ Guenter 1975, 165 Naar aanleiding van onderzoek onder farm Bushmen in het Ghanzi-district, concludeerde Guenter in 1975 dat de trancedans een krachtig en "rallying" symbool was in een tijd dat acculturatieprocessen allerlei economische, politieke en sociale veranderingen tot gevolg hadden. Een groeiend politiek bewustzijn leidde hier bijvoorbeeld tot het verlangen naar een eigen stuk grond. Daarbij hoorde ook een veranderend zelfbeeld: "the identification of the trance-dancer with 'Bushmannes' has the effect of revitalising the self-image held by the farm-Bushmen. It becomes possitive and assertive, offsetting the worthless and inferior self-image hitherto held by the majority of the farm Bushmen."

${ }^{986}$ Jay 1998, 161 Zie ook 4.4.4.
} 
minacht zijn ouders, Fielies haatte zijn vader en zijn eigen blanke bloed, Oompie Danster wordt "verwilderd". Het toelaten van de ambiguë krachten van //Gãuwa, maar ook het onder ogen zien van de ambiguïteit van de eigen identiteit, kan verandering in goede banen leiden en een nieuwe orde vormgeven. Zoals Mietjie probeert haar kleinkinderen ervan te doordringen dat hun blanke bloed onlosmakelijk deel van henzelf is en dat ze er goed voor moeten zorgen, wijst Louw erop dat de (Zuid-)Afrikaanse literatuur en cultuur zowel schatplichtig zijn aan Lucifer en Jezus als aan /Kaggen, in een orde en een landschap die even Goddelijk als //Gãuwaans zijn. De werkelijkheid daarvan aanvaarden kan nieuwe inzichten en wellicht sociale en politieke verandering opleveren. Maar de Lotrietzonen lijken - net als Mehring in The conservationist - vooralsnog te vluchten. 


\section{7}

\section{Conclusie}

In Zuid-Afrikaanse pastorale literatuur en andere "pastorale" teksten als land- en arbeidswetten, politieke mythen en geschiedschrijving, wordt een relatie tussen mens en ruimte weergegeven die in feite een andere relatie definieert: die tussen Ik en Ander. In de loop der tijd is die relatie tussen land en bewoner voortdurend aangepast en herbevestigd. Vanuit het perspectief van eerst de koloniale en later de republikeinse machthebbers was er steeds een onvoorzien element dat de aangebrachte orde verstoorde. Guerillastrijd van Khoisan; langdurige oorlogen in de Oost-Kaap; bezetting van verlaten boerderijen tijdens de Boerenoorlog; economische welstand van zwarte pachters; opstanden in de jaren twintig; rituele ruimtes die ondanks alles onaantastbaar bleken; openlijk en ondergronds verzet; de Soweto -opstand die door kinderen werd geïnitieerd; en uiteindelijk, toen de vervreemding van zwarte boeren van hun land zijn hoogtepunt bereikte burgeroorlog en politieke omwenteling. Op iedere aantasting van het beeld hoe mens en ruimte zich tot elkaar verhielden, werd met een combinatie van middelen gereageerd. Met geweld, wetgeving en mythevorming probeerde men de werkelijkheid te re-creëren. Maar daar waar de confrontatie plaats vond (aan de grenzen van de kolonie; in de missieposten; op het land van blanke boeren) vond uit lijfsbehoud altijd een zekere aanpassing en vermenging plaats, zowel van ruimte, als van wereldbeeld. Die aanpassingen werden vervolgens geïnterneerd danwel geannexeerd en door een politieke elite die zijn macht op tegenstellingen baseerde, opnieuw gepolariseerd - uiteindelijk vooral in een wit/zwart- en alles/niets-oppositie.

De literatuur verbeeldt deze verschuivende werkelijkheden. Teksten die zich op het platteland afspelen, behandelen eigenlijk onveranderlijk de zoektocht naar of definiëring van identiteit. En omdat die identiteit gekoppeld wordt aan een machtspositie, wordt zij vooral vormgegeven in de relatie tussen de mens en zijn natuurlijke omgeving. Het was immers dankzij macht dat "land rights can be conceived by landowners as merely 
as 'a relation between people and things' rather than a 'relation between people" ${ }^{987}$.

De harmonie tussen mens en natuur wordt benadrukt in de plaasromans, waarin een Afrikaner identiteit gestalte kreeg als bewaker van de natuurlijke orde binnen een grote, getransformeerde familie. Ook in Engelstalige literatuur wordt in diezelfde periode het landschap gebruikt om de eigen koloniale identiteit te weerspiegelen ${ }^{988}$. Een zekere vervreemding van de Engelssprekende Zuid-Afrikaan ten opzichte van de sociaal-politiek-materiële werkelijkheid (dat wat het landschap verbeeld) was hierbij niet alleen onvermijdelijk maar ook gewenst; het was onderdeel van een ideologische distantie die te maken had met de koloniale tegenstelling tussen beschaving en barbarij, maar ook met "the myth of origins that enables liberal ideology to dissociate its own history from that of the monster Apartheid" ${ }^{89}$. Het literaire landschap is bijgevolg ofwel een onbereikbaar object voor een romantisch verlangen, ontdaan van of in harmonie met zijn Afrikaanse (of Afrikaner) bewoners, ofwel een weerbarstige, onbewoonde, vijandige realiteit. Maar uiteindelijk geldt die tweeslachtigheid ook voor Afrikaanstalige literatuur. Openlijk thuisloos waren in de eerste decennia van de $20^{\text {ste }}$ eeuw de vele Afrikaners die weggetrokken waren naar de "Engelse" steden $^{990}$. En in het thuis dat ze hadden moeten achterlaten, de pastorale idylle, bleef altijd iets dubbelzinnigs behouden. De Boer die een continuering met het heden had moeten vormen dankte zijn geworteldheid en positie aan peilers die in datzelfde heden niet konden worden genoemd: geweld en interculturaliteit terwijl de peilers die wel werden opgevoerd (trekboeren, pioniers, eenzame strijders tegen barbarij), zijn identiteit als migrant alleen maar versterkten.

In een rurale orde grijpen familie, land en dood doorgaans in elkaar tot een eeuwigdurende cyclus. Familie biedt dankzij overerving van rechten of kennis garantie op een zeker territorium in de ruimte, maar ook in de tijd. Beide territoria (in ruimte en tijd) komen tot stand door de dood. Met name voor migranten biedt de dood, en de rituelen die de dood omgeven, een belangrijk houvast991. De dood bepaalt wie "familie" is en wie niet, wie "binnen" is en wie "buiten", aan wie het verleden en de toekomst toebehoort. Deze orde was en is in Zuid-Afrika op sommige plekken, zeker binnen de grenzen van de boerderij, in zekere zin intercultureel. Een belangrijk, maar impliciet Wij was en is de Wij als bewoners van de boer-

\footnotetext{
${ }^{987}$ Wenzel $(2000,96)$ citeert Tony Buckle, "Land relations and social dynamics: reflections on contemporary land issues in South Africa, with partical reference to the Eastern Cape". Anthony Lemon (ed) The geography of change in South Africa. Chichester, Wiley, 1995: 80

${ }_{988}$ Wagner 1994, 174

${ }^{989}$ Bunn 1994, 136

990 "In 1936 skryf Die Vaderland: 'Johannesburg is die Sodom en Gomorra, waar die Boer sy tradisies op die altaar van die heidendom gelê het; waar hy na siel en liggaam vermink word en waar 'n Afrikaanse Abraham tevergeefs na tien van sy soort sal soek. "” Van Jaarsveld, 1979, 33

${ }^{991}$ Jonker 1993:187/8
} 
derij, een samenleving waarbinnen de (territoriale) rechten en bestaansgrond van blanke boeren vermengd waren met die van de zwarte boeren. Tegelijkertijd was en is er altijd een Wij en $\mathrm{Zij}$ gebaseerd op ras, waardoor zowel "familie" als "dood" (geschiedenis) een difference within herbergen. Daarom werden Afrikanen opgedeeld in twee groepen: een vijandige Ander buiten het eigen territorium, en een Ander binnen het eigen territorium die in de marge van de (blanke) boerenfamilie was opgenomen. Conflicten waren zo een beheersbaar en logisch en bevestigend onderdeel van ofwel de paternalistische verhoudingen binnen het eigen domein, ofwel de oorlogssituatie die verondersteld werd buiten het eigen domein te heersen. Maar toen in de jaren twintig en dertig iets fundamenteel in de verhoudingen ging schuiven, toen pachtafspraken moesten worden omgezet in (tijdelijke) arbeidscontracten en vreemden het land kwamen bewerken, toen landbezit geen garanties meer gaf maar vooral een zware hypotheeklast, toen het verzet grootschaliger, effectiever, bedekter of (on)persoonlijker werd, waardoor "rebelse zonen" "vijanden" werden, toen, kortom, de boerderij zijn betekenis van veilige enclave in een vijandige wereld dreigde kwijt te raken, werd heimlich unheimlich en schemerde via de dood de aanwezigheid van de ander door in het hart van de blanke boerengemeenschap.

In een nieuw, grootschaliger discours werd deze onzekerheid opnieuw gekanaliseerd. In combinatie met een strengere segregatiepolitiek werd ondermeer in boerderijromans een (nieuw) Wij gecreëerd dat niet alleen door individueel bezit of gebruik gebonden was aan het land, maar ook symbolisch, moreel en collectief. Boeren waren daarin niet zozeer onderdeel van een lokale orde, maar hun band met het land werd vooral bepaald door hun wijze van leven en sterven; i.e. leven en sterven als de oudste stamvader, de eerste boer en balling (=immigrant) Adam: tot wie God immers gezegd had nadat hij hem de toegang tot het paradijs had ontzegd: "al zwoegende zult gy [van de aardbodem] eten (..) totdat gij tot den aardbodem wederkeert, omdat gy daaruit genomen zyt" ${ }^{\prime \prime 92}$. Deze symbolische orde was ook toegankelijk voor symbolische boeren: voor de ballingen in de stad. De band met de aarde stond nu voor een onbemiddelde relatie met God, het was een herinnering aan het paradijs én aan het verlies daarvan. Thuiskomen kon alleen door te sterven op eigen grond (of "eigen bodem"); door opgenomen te worden door de door eigen arbeid "bewerkte" aarde. Niet (land)bezit maar arbeid, spiritualiteit en solidariteit creëerden een thuis; een christelijke en/of nationale identiteit. De boer is niet alleen kind van zijn directe voorouders en bewoner van zijn boerderij, maar ook afstammeling van Adam en Eva en inwoner van het Land van God, rechtmatig bewoner van het beloofde land, deel van de christelijke samenleving. Burger, kortom, in het "nieuwe Zuid-Afrika" van de twintigste eeuw. Net

${ }^{992}$ Genesis 3: 17-19 
als landrechten gaven boerderijromans zo vorm aan basale kwesties als bestaansrecht en identiteit.

Dit discours is niet alleen door Afrikaner plaasromanauteurs gebruikt (of gecreëerd) en niet alle Afrikaner plaasromanauteurs geven dezelfde boodschap. Maar in een groot deel van de boerderijromans van voor de Tweede Wereldoorlog is er iets van terug te vinden. Van Melle geeft een nieuw, groter doel aan de rebelse strijdlust van Bart Nel; Van den Heever legt de nadruk op het belang van bloedbanden en (blanke) solidariteit in een kapitalistische samenleving. Maar ook Pauline Smith maakt in "Ludovitje" onderscheid tussen een lokale en nationale, religieuze of koloniale orde, al is haar grote "familie" niet op bloedbanden gebaseerd, maar op economische en religieuze gelijkgestemdheid. Herman Bosman toont later in "Unto Dust" de achillespees van dit discours door het symbolisch kader te negeren en de boodschap toe te passen op basale en banale kwesties als doodgaan en begraven worden in een uithoek van Zuid-Afrika. En dan blijkt maar al te goed dat de politiek geïnspireerde thuisconstructie slecht gefundeerd en unheimlich is. Als men op het uitgestrekte platteland, waar de blanken altijd een in wezen kwetsbare minderheid geweest zijn, daadwerkelijk tot stof wederkeert, daadwerkelijk de cyclus van leven en dood en het begrafenisritueel dat die cyclus vorm moet geven ${ }^{993}$ voltooit, betekent dat één worden met Afrika, niet terugkeren naar de fictieve oerklei van "ons eigen" paradijs - alle segregatie en beschaving en kerstening ten spijt. Hoewel thuiskomen (in Afrika) eigenlijk het doel zou moeten zijn van het discours, roept de voltooiing van de cyclus in wezen angst op, omdat het stof waarnaar men zou moeten "terugkeren" uiteindelijk vooral het stof is van miljoenen Afrikaanse doden, doden die, zo leert hetzelfde discours, niet horen tot het beoogde Wij. Of men er nu deels uit voortkomt of niet: dit stof is, dankzij de maatschappelijke ontwikkelingen, in toenemende mate níet het stof waarnaar men terug wil keren.

In een discours verwant aan het bovenstaande, ondermeer gehanteerd door missionarissen en "moderne" boeren, was landbezit niet zozeer gekoppeld aan voorouders, maar aan fysieke overmacht, vooruitgang en godsvrucht: aan een allesbepalende, absolute, militaire, economische en religieuze macht en orde. Unheimlich waren in dit discours vooral de tekens van ontbrekende controle, tekens die voor de Europese machthebber soms moeilijk te duiden waren en dan de vorm aannamen van een herrijzende Adamastor, verhuld schuldgevoel of openlijke vervreemding. Dat er steeds opnieuw geweld gebruikt moest worden om terugkerende tegenstand te breken, was een bron van zorg en existentiële twijfel. De effecten zijn te zien bij Schreiner, Smith, en diverse dichters. Zij hadden gemeen dat ze

\footnotetext{
${ }^{993}$ Een ritueel was, immers, "a coherent set of symbolic actions that has a real, transformative effect on individuals and social groups."Llincoln, Bruce, Emerging from the Chrysalis: studies in the Rituals of Women's initiation. Cambridge: Harvard UP 1981 (2-3)
} 
zowel Afrika (met haar voorgeschiedenis) als de eigen aanwezigheid in Afrika ervoeren als problematisch voor het bereiken van een ideale samenleving. Het absolutisme van het vooruitgangsideaal problematiseerde Afrika's weerspannigheid, maar die weerspannigheid ondergroef ook de absolute waarheid van de eigen visie. Terugkeren naar het eigen, Europese stof was geen optie, maar een nieuw Afrikaans Wij was ook niet zomaar geschapen. Onthechting werd onderdeel van de koloniale identiteit; weggaan of doodgaan was een bevrijding uit een vervreemdende, onoplosbare werkelijkheid. In de dood werd bovendien een antwoord gezocht op existentiële vragen: als onderdeel van de natuur kon men het beperkende, verdeelde mens-zijn - het menselijk tekort - ontstijgen. Ook deze dood had een kern van vervreemding: het was wederom een niet-dood, een in rituele zin onvoltooide dood omdat er geen reïntegratie plaatsvond in een maatschappelijke structuur.

In deze discoursen wordt gebruik gemaakt van het vermogen van de doden om te ontsnappen aan de wetten van tijd en plaats en zodoende een nieuwe identiteit te creëren. In de dood zit immers een (tijdelijke) vrijheid besloten die geen enkele levende is gegeven: de liminale fase van de rite de passage, een periode van potentiële verandering en chaos. Pas met het voltooien van het ritueel krijgt de dood zijn consoliderende werking - en niet altijd wordt het ritueel voltooid. Bijna alle culturen kennen zwervende geesten die op de een of andere manier niet op hun plaats van bestemming zijn aangekomen. Zij zijn blijven steken in de liminaliteit, en zijn als zodanig dé personificatie van het unheimliche. Ze zijn veranderlijk en hybride: object en subject, verleden en toekomst, binnen en buiten, aanwezig en afwezig, Wij en $\mathrm{Zij}$. Dit unheimliche kan in een literaire tekst worden opgeroepen door een onvoltooid ritueel (een niet correct uitgevoerde begrafenis, een sterfgeval ver van huis, een vermissing, een anoniem lijk), maar ook door beide ordes van elkaar te laten verschillen. Dit laatste is een situatie die verandering impliceert: de wens tot verandering, een verandering van bewustzijn en, in wisselwerking daarmee, misschien een maatschappelijke verandering. Of andersom. Schreiners gedroomde dodenorde is vooral een geforceerde ontkenning van bestaande tegenstellingen die geen weerklank vindt in leven of dood. Smith doet in feite hetzelfde; ze reageert op maatschappelijke veranderingen, maar wil de tegenstellingen die daarin bestaan of dreigen te ontstaan, ontstijgen door de dood buiten (boven) de mensen te plaatsen. Beide schrijfsters blijven daardoor in feite steken in de separatiefase van de rite de passage: hun personages sterven wel, maar keren niet terug tot stof; ze scheiden zich slechts af van het leven.

Van den Heever heeft in Laat Vrugte minder moeite de dood aan het leven te verbinden. Zijn boek is dan ook van later datum, en stamt uit de tijd dat verandering bijna overal was ingezet. Zijn doel lijkt niet het doorbreken van categorische grenzen, maar een mentale en morele aanpassing aan de 
gegeven situatie: veranderde arbeids- en bezitsverhoudingen. Hij rondt in Laat Vrugte de drie fasen van het ritueel ogenschijnlijk mooi af; na een periode van verwarring en chaos bij een half-dode Sybrand, weerspiegelt zijn dodenorde keurig de heerschappij van de Afrikaners en de segregatiepolitiek die het land moet behoeden voor "die groot, verskriklike eenheid" waar Smith en Schreiner nog mee lonkten. Daarmee levert hij een bijdrage aan de nieuwe, politiek gedekte identiteit die een hele tijd stand zal houden. Oom Schalk in "Unto Dust" is, zoals gezegd, de eerste die vervolgens een vinger op de zere plek legt. Aan zijn bijna-doodervaring heeft hij een dubbel bewustzijn overgehouden: de wetenschap dat de dood die hij gezien heeft een andere werkelijkheid spiegelt, belet hem terug te keren naar de valse vanzelfsprekendheden van het leven. Maar zijn geworteldheid in die vanzelfsprekendheden belet hem zich neer te leggen bij de orde van de dood. Ook hij bevindt zich in feite tussen leven en dood; zijn geest zal nog decennia lang blijven spoken.

In de loop van de eerste helft van de twintigste eeuw werden Wij en $\mathrm{Zij}$ in Zuid-Afrika steeds absoluter gedefinieerd in raciale en daaraan gekoppelde culturele termen. Toch is "ras" niet meer dan een discours - en een schoolvoorbeeld van wat discours vermag. ${ }^{994}$ Eenmaal getrokken grenzen tussen Ik en Ander worden zelden vrijwillig losgelaten of bijgesteld, uit angst voor het uiteenvallen van het bekende interpretatiekader. ${ }^{995}$ Nielsen spreekt ten aanzien van een Amerikaans blank literair discours bijvoorbeeld over de "signifying blindness" ervan en "its redoubled efforts not to read the Africanity of its own texts, not to hear the blackness of its own tongue." ${ }^{996}$ Maar omdat een intertext geen gesloten en onveranderlijk geheel is, omdat gemarginaliseerde personages raadsels en witte plekken achterlaten in een verhaalstructuur, omdat confrontaties leiden tot een "'in-between' reality" ${ }^{997}$, doemt het onbenoemde graf van Tsui-goab alias Heitsi-eibib, de Khoisan held die steeds opnieuw geboren wordt, op in het midden van een desolate vlakte op de eerste bladzijde van The story of an African farm, en laten veeboeren bij wie "amper geen lewe in [hul] oë is nie" boerderij links liggen op weg naar Lesotho in Laat vrugte.

Zoals eerder bleek kunnen de ruimtelijke grensoverschrijdingen die onderdeel zijn van een (post)koloniale geschiedenis in verband worden gebracht met grensoverschrijdingen in tijd. De dood maakt die grensoverschrijdingen zichtbaar en ontneemt ze hun interne logica. Als onderdeel van het landschapdiscours, het boerderijdiscours, is de dood een geïntegreerde anomalie. Binnen de verstarde, tijdloze ruimte van de begrensde boerderij,

\footnotetext{
${ }^{994}$ Nielsen 1994, 3

${ }^{995}$ Nielsen 1994, 23

${ }^{996}$ Zie: Julia Kristeva, Revolution in poetic language. New York, Columbia UP, 1984: 59

${ }^{997}$ Bhabha 1994, 13

${ }^{998}$ Van den Heever 1987, 147
} 
van de minitieus in kaart gebrachte kolonie, van de geografisch vastgelegde etniciteiten van de Apartheid, verwijst de dood naar een proces, naar de (rituele) handeling van het in kaart brengen en begrenzen, en dus naar het overschrijden van grenzen en de mogelijkheid van een herhaling, maar dan in omgekeerde of andere richting. Deze potentiële destabilisatie, het wankelen van de structuur, is het gevolg van een verloochende of dreigende ontmoeting met dat wat aan de andere kant van de grens ligt en leidt tot unheimlichheid: het binnendringen van ambivalentie, ongrijpbaarheid, van het Vreemde in het Eigene. Dit is niet uniek voor Zuid-Afrika. In Australische en Amerikaanse literatuur is een vergelijkbaar unheimlich landschap terug te vinden; mogelijk zijn zelfs alle postkoloniale landschappen "haunted". ${ }^{999}$ In de grenzeloze enclave van de in-between reality tussen leven en dood, een ruimte die in haar ondefinieerbare aanwezigheid alom aanwezig is, bevindt zich de Ander. En als in de jaren zeventig Zuid-Afrikaanse schrijvers zich beginnen los te weken van het establishment en gaan zoeken naar een uitweg uit de escalerende polarisatie, zoeken ze daar.

In Zuid-Afrika werden pogingen om de door de Ander gedefinieerde ontologische realiteit te ontsluieren na de rellen uit de jaren zestig en de toename van ondergronds verzet in steeds mindere mate een vrijwillige optie. Het is daarom de "signifying blindness" zelf die in Zuid-Afrikaanse boerderijromans uit de jaren zeventig tot onderwerp wordt gekozen. De wetenschap dat de hegemonie van de dominante discoursen stoelde op een met geweld afgedwongen macht van een groep mensen die door demografische ontwikkelingen in toenemende mate een numerieke minderheid vormde, en dat alleen al daarom "shattering" van die discoursen niet kon uitblijven, leek schrijvende lezers te dwingen naar de Ander en de Ander in zichzelf te kijken. Een griezelige ervaring, want men zag zo weinig. Naarmate de Ander meer in het eigen systeem "verdween", werd hij of zij een unheimliche aanwezigheid: tegelijkertijd zichtbaar en onzichtbaar, bekend en onbekend, angstaanjagend en vertrouwd. Zoals Martha zegt in Coetzee's In the heart of the country (1977): "[T]he pitiful warrior in the hills was never as formidable as the enemy who walked in our shadow and said Yes Baas. To the slave who would only say Yes my father could only say No, and I after him and that was the start of all my woe. (..) Some things are not visible from the skies." 1000

Dit onzichtbare, alternatieve wereldbeeld is een belangrijke voedingsbodem geweest voor het unheimliche in de Zuid-Afrikaanse literatuur. Personages in de besproken romans uit de jaren zeventig zijn noodzakelijkerwijs behept met de blindheid van hun auteurs, een blindheid die bij de eersten

\footnotetext{
${ }^{999}$ J.M. Coetzee, persoonlijke corr. Zie bijvoorbeeld D.H. Lawrence, Studies in Classic American Literature (1923)

1000 J.M. Coetzee 1999, 140
} 
leidt tot angst en depressie, doemscenario's en fatalisme. Waar pastorale romans uit de jaren twintig en dertig reageren op ontwikkelingen die al in gang zijn gezet, reageren de boerderijromans uit de zeventiger jaren op een dreigende apocalyps. De verschillende "Afrikaner" en "Britse" discoursen zijn elkaar heel dicht genaderd. In The conservationist is Mehring een cosmopolitische liberaal die in de grond van zijn hart niets liever wil dan wortelen in Afrikaanse aarde. Koos Nek is in Kroniek van Perdepoort een Afrikaner status-boer die niets liever wil dan zich verheffen boven het aardse geploeter. Hun beider streven is tot mislukken gedoemd. Maar die mislukking is dubbelzinnig; zowel fatalistisch als hoopvol, doordat in de ogenschijnlijk potdichte discoursen van beide heren "the echoes of palimpsestic black texts" ${ }^{1001}$ te traceren zijn, vermomd, wellicht, als gekoloniseerde mastertext, of als stopwol voor de zwarte gaten in de collectieve herinnering, maar desondanks aanwezig als onderdeel van Kristeva's proces van transpositionerende tekensytemen. ${ }^{1002}$

Dood voldoet in deze context niet meer als bestendiging van een (nieuwe) maatschappelijke orde, of als ontkenning van de oude. Daarentegen is ze betekenisvol geworden als metafoor voor transformatie naar het onbekende, als de liminale fase in een rite de passage. Omdat ook de Ander rituelen rond de dood gebruikt om een samenleving vorm te geven, biedt de rite de passage bovendien een doorkijkje naar een ander wereldbeeld. Louw en Gordimer lijken beiden de culturele verdubbeling en verstrengeling die in de representaties van de dood hebben plaatsgevonden te erkennen en gebruik te maken van de liminaliteit van de dood om die verdubbeling zichtbaar te maken ${ }^{1003}$. In hun universele staat van ontheemdheid zijn liminale doden zeer herkenbaar. Levenden en doden bevinden zich altijd in sociaal en cultureel begrensde en gedefinieerde ruimtes, maar wie zich in het daartussengelegen niemandsland bevindt, is voor iedereen even onbestemd en onbepaald en dus even toegankelijk. De dood is gemeenschappelijk terrein, niet alleen tussen tekst en werkelijkheid, maar ook tussen verschillende werkelijkheden. Het betreden van dit terrein, het schrijven en lezen over de dood, wordt zodoende een rituele handeling waarin niet alleen de familiegrenzen een beetje worden uitgerekt of verschoven, maar waarin het vertrouwde interpretatiekader, en dus de controle, in zekere zin wordt losgelaten.

In hun samenhang creëren familie, dood en land/natuur (de belangrijkste metaforenuit de boerderijromans) identiteit. Als onderdeel van bepaalde mythen benadrukken ze hun syntagmatische, schijnbaar onveranderlijke en

\footnotetext{
${ }^{1001}$ Nielsen 1994, 24

1002 Julia Kristeva (1984). Revolution in poetic language. New York, Columbia University Press. 59

${ }^{1003}$ De "double vision" van schrijvers die in twee culturen zijn opgegroeid "stems in part at least from the conflicting or differing ritualized ways of experiencing and understanding these intersections." Elsbree 1992, 4
} 
gesloten samenhang binnen een bepaald discours. Maar er zijn ook paradigmatische relaties. De genoemde metaforen hebben Afrikaanse tegenhangers die alleen al dankzij de werking van het metafoor (een metafoor is een metafoor dankzij andere metaforen) altijd aanwezig zijn. Het benadrukken of aanstippen of openlaten van interculturele intertekstuele verbanden kan die paradigmatische relaties blootleggen. In zijn meest concrete, literaire vorm gebeurt dit door overeenkomsten te suggereren tussen (mythische) personages (Hans Welman en de Kaffir; Adam en Unkulunkulu; /Kaggen, Koos Nek, Fielies en de duivel) of fabula's (oorsprongsmythen, overgangsrituelen, schelmverhalen). Abstracter en veelomvattender zijn de parallellen tussen culturele of mythische ruimtes (de boerderij, het paradijs en het bed of reeds) of ruimtelijke structuren (binnen/buiten; beschaving/wildernis; begrensd/onbegrensd; veilig/vijandig). Op deze manier zijn alternatieve, tegengestelde visies, of ze nu verwoord werden door Vilakazi in de jaren dertig ${ }^{1004}$ of door landarbeiders in een landclaims court in de jaren negentig, in alle boerderijteksten aanwezig. Maar in de romans van Gordimer en Louw krijgen ze opeens, voor wie het wil zien, veel meer narratologische ruimte.

Dat bij bestudering van de boerderijromans in een pre-postkoloniale periode ruimte zo belangrijk blijkt te zijn voor het aangeven van intertekstuele verbanden, is niet verwonderlijk. Postkolonialisme heeft alles te maken heeft met het opnieuw innemen en inrichten van ruimte. Maar ook intertekstualiteit heeft iets ruimtelijks. Aldon Nielsen spreekt in zijn boek over interraciale intertekstualiteit voortdurend in ruimtelijke metaforen. Hij schrijft over "reterritorializ[ed] (..) identity"; "nomadic affair"; "aesthetic space"; en "recolonisation of imaginitive space"; over ruimten die gescheiden zijn door "the walls racism has erected in language" en door "white textual veils". ${ }^{1005}$ Ook anderen gebruiken dergelijke termen in combinatie met intertekstualiteit. Lisa Lowe heeft het over "writing positions"; Allan over "divided space of discursive formations"; Bhabha over "an "in-between' reality". ${ }^{1006} \mathrm{Al}$ deze metaforen betreffen het optrekken, verschuiven en slechten van culturele en identiteitsgrenzen. En dit proces kan nergens zo mooi verbeeld worden als in de Zuid-Afrikaanse boerderijroman, waar de grensdraden van de boerderij als afbakening van grondbezit en identiteit in het politieke discours gelijk staan met de "walls racism has erected" 1007 ,

\footnotetext{
${ }^{1004}$ In de jaren dertig werd zowel in boerderijromans als in Zulu-poëzie gebruik gemaakt van de ruimtelijke tegenstelling tussen begrensd en onbegrensd landschap. Maar waar de bergensde ruimte in boerderijromans stond voor veiligheid en beschaving, stond die in de poëzie van Vilakazi voor gekooide krachten uit het verleden: "the present is constricted and confined, the past wide, inhabited with the free movement of figures as the Zulu king Shaka". In zijn poëzie "the map of the past presses heavily on a different present." (Gunner 1996, 122)

1005 Nielsen, 3, 11, 8, 21, 22-23, en 11

${ }^{1006}$ Lowe 1990, 142/3; Allan 2000, 165; Bhabha 1994, 13

${ }^{1007}$ Nielsen 1994 22-23
} 
maar die binnen die grensdraden tegelijkertijd "a difference 'within"”,1008, een interculturele samenleving, herbergt.

Vervolgens kon de narratologische, en wederom ruimtelijke structuur die inherent is aan de dood, die interne difference blootleggen. Doodgaan is in de tekst veelal (een deel van) een verborgen fabula - een reis - verbeeld door een verschuivend perspectief op de omringende ruimte. Ook daarom is met name de dood, als ultieme metafoor, als metafoor, bovendien, voor grensoverschrijding, ambivalentie, transformatie en non-identiteit; en als de onbekende bestemming van de belangrijkste rite de passage uit een mensenleven, in staat de syntagmatische geslotenheid te doorbreken en een nieuwe identiteit mogelijk te maken. De ruimtelijke structuur van de boerderijromans kan dankzij de echo's van alternatieve percepties van ruimte de "uncanny structure of cultural difference" blootleggen die het voor de lezer mogelijk maakt "to coincide with forms and activity which are both at once ours and other". ${ }^{1009}$ Het lezen van een dergelijke tekst is als het betreden van een liminale fase, het gedeeltelijk ondergaan van een ritueel waardoor een individu een andere identiteit kan krijgen. Maar de uiteindelijke integratie is aan de lezer zelf.

Wat het effect is geweest van de pogingen van Gordimer en Louw om een plurale toekomst voor te spiegelen, blijkt ondermeer uit de boerderijromans die in de jaren erna zijn verschenen. Kroniek verscheen een jaar na The conservationist, weer een jaar later werd binnen- en buitenland opgeschrikt door de Sowetorellen, en het jaar daarna verscheen In the heart of the country (1977) van J.M. Coetzee. Het is verleidelijk in deze tragikomische boerderijroman een ironische (zo niet sarcastische) reactie te zien op de pogingen van Gordimer en Louw om, vlak voordat het vuur geopend werd op stakende schoolkinderen, openingen en gemeenschappelijke grond te vinden. Martha is de tot het bot ontklede erfgename van Schreiners Lyndall, een vrouw die zich uit eenzaamheid en verveling middelpunt maakt van een (fictief?) morbide drama. Haar geforceerde pogingen om zich uit haar wereld te bevrijden door haar vader te vermoorden, het lijk te laten verdwijnen ${ }^{1010}$ en intimiteit met haar bedienden af te dwingen, zijn des te vruchtelozer omdat ze niet in staat is de enige plek die ze kent te verlaten. Haar huis is een fort in een onbegrijpelijke, desolate, eindeloze wereld, waarmee ze op halfslachtige, ontoereikende en absurde wijze contact probeert te maken. Niet de begrenzing van het land bepaalt in deze roman

\footnotetext{
${ }^{1008}$ Bhabha 1994, 13

${ }^{1009}$ Bhabha 1990, 313

${ }^{1010}$ Saillant detail is dat Martha, omdat ze zelf niet in staat is een gat in de harde aarde te graven, haar vaders lijk wegstopt in het verlaten hol van een stekelvarken, dat zich onder de grafsteen van een langvergeten plaasbewoner bevindt. Daarmee geeft ze hem onbedoeld toegang tot een Afrikaans hiernamaals: "There are many stories describing the adventures of people who have accidentally reached this country, usually through following a porcupine, or some other burrowing animal, into its hole." Werner, Chapter 1: Introduction.
} 
het isolement van de hoofdpersoon, maar juist de onbegrensdheid ervan: een onmetelijkheid van tijd ${ }^{1011}$ en ruimte die voor Martha ondoordringbaar is. Pas wanneer aan het slot blijkt dat haar daden vooral aan haar fantasie zijn ontsproten, wordt duidelijk waarom ze niet weg gaat: het is de zorg voor haar zieke vader die haar gevangen houdt. Haar gefrustreerde streven naar contact vertoont subtiele overeenkomsten met de pogingen van Gordimer en Louw om via fictieve ondermijning van het patriarchaat, distantiëring van de geschiedenis, en tekstuele interculturele kruisbestuiving een uitweg te zoeken, terwijl ze hun bastion niet (kunnen) verlaten.

In de jaren tachtig vielen er vervolgens zoveel gewelddadige doden dat men met goed fatsoen nauwelijks meer over een symbolische dood kon schrij$v{ }^{1012}$ laat staan over een individuele transformatie naar een hoopvolle toekomst. De integratiefase van de rite de passage bleef uitgesteld worden. In Life \& Times of Michael K. (1983) rekte Coetzee liminaliteit op tot een voorlopige identiteit, de enige die voor $\mathrm{K}$. acceptabel bleek in een land in oorlog. K. blijft zoeken naar een niemandsland in de hoop te kunnen zijn wie hij is: een "gardener" "013. Vanuit Kaapstad trekt K. de Karoo in om de as van zijn gestorven moeder naar haar geboortegrond te brengen. Hij treft de boerderij waar ze als pachtersdochter woonde verlaten aan en begraaft de as in het midden van wat ooit de akker is geweest; waarmee hij als het ware, meer nog dan met Fielies' begrafenis gebeurde, Koos Neks praalgraf overschrijft. "This was the beginning of his life as a cultivator," schrijft Coetzee $^{1014}$. K. vindt hier kortstondig zijn geluk als een tot de essentie teruggebrachte boer, iemand die in alle eenzaamheid en anonimiteit voor zichzelf pompoenen kweekt. Het uitblijven van enige confrontatie, iets wat voor Martha in In the heart of the country nog een gruwel was, is voor K. een weldaad. Maar zoals alle plattelandsidylles heeft ook deze geen toekomst. De kleinzoon van de eigenaar duikt op, ziet in K. de knecht van zijn grootouders en wil met hem een nieuwe paternalistische enclave oprichten: "There is no war here on the farm. (..) No one will disturb us. (..) But I need your cooperation, Michael. You must help me. Otherwise there is no future for either of us." ${ }^{1015} \mathrm{~K}$. verbreekt met pijn de banden met zijn "thuis". In een grot in de bergen leeft hij een tijd lang een bewegingloos bestaan tussen leven en dood in, tot hij beseft dat hij niet, als Waldo of Ludovitje, zal eindigen in een fictieve, verlossende, thuiskomende niet-dood in de schoot van moeder Natuur -"preserved whole"1016-, maar dat, net als voor de op de waarheid jagende jager uit The story of an African farm "his story might

\footnotetext{
${ }^{1011}$ J.M. Coetzee 1999, 134/5

1012 Hattingh 1995, 144.

${ }^{1013}$ J.M Coetzee 1985, 248

${ }^{1014}$ Idem, 81

${ }^{1015}$ Idem, 88/9

${ }^{1016}$ Idem 93
} 
end with his bones growing white in this far-off place"1017. Hij wil het menszijn niet ontstijgen, kruipt naar beneden en vanaf dat moment is hij voortdurend op de vlucht. "Perhaps the truth is that it is enough to be out of the camps, out of all the camps at the same time," concludeert hij uiteindelijk. "Perhaps that is enough of an achievement, for the time being." 1018

Drie jaar na Coetzee's vergaande deconstructie probeert Van Heerden in Toorberg (1986) voorzichtig vanuit de oude plaasromantraditie een nieuwe identiteit te transformeren. Hij begint waar Louw en Gordimer zijn opgehouden: de dood als potentieel verbroederend element in een verscheurde familie. Hij laat die verbroedering plaatsvinden in een recent verleden, maar daarbij dienen zich meteen nieuwe dilemma's aan: als uiteindelijk de gemeenschappelijkheid erkend wordt; wat dan? Net als Coetzee verschuift ook Van Heerden in Toorberg uiteindelijk de focus van boerderij naar stad, maar niet voordat alle traditionele plaasromanelementen de revue zijn gepasseerd - in een iets andere vorm, waardoor ze uiteindelijk hun coherentie verliezen.

Dood is ook in deze roman gekoppeld aan een grensoverschrijdende ruimte. Intercultureler dan die van Schreiner en Smith, maar minder herleidbaar dan die van Gordimer en Louw. Op het tweedimensionele vlak is de ruimte in Toorberg al op te delen in de gefixeerde, begrensde aarde van de Moolmannen enerzijds en de meer dynamische verbindingslijnen van de stiefMoolmannen anderzijds, maar daar tegenover staat nog een ander soort tijd/ruimte; één die niet in stambomen of kaarten kan worden uitgetekend. Deze ruimte van water, wind en levende doden, van ganzen, Bosjesmannen en andere nomaden is beweeglijk in plaats van star, cyclisch in plaats van lineair, verticaal in plaats van horizontaal. De cyclus van water, die bijna steeds verbonden is met de cyclus van leven en dood $^{1019}$, is er een belangrijk onderdeel van.

Noag, de verloochende kleinzoon van Abel Moolman, is een jaar eerder in een boorgat gevallen en met een geweerschot door Abel uit zijn lijden verlost. Familie en skaamfamilie sluiten rond dit boorgat voor één keer de gelederen en Van der Ligt, die de zaak onderzoekt, loopt dood in een "ontglippende" waarheid omtrent oorsprong en recht. ${ }^{1020}$ Net als Koos Nek

\footnotetext{
${ }^{1017}$ Idem 95

1018 Idem 248/9

${ }^{1019}$ Noag (alias Druppeltjie) werd geboren op de droge rotsen van het Oog, maar na zijn dood bevond hij zich volgens zijn vader in het grondwater: "daardie kind van my is nou hier in Toorberg se watertafels opgelos, Edelbare, hy dryf elke dag onder my voete deur. Edelbare, u sal seker dink ek is verkeerd in my kop, maar ek dink ek dra Noag Moolman hier in dié botteltjies rond" (39 vert: WdP foc. AvdL). Ook Abel zag, zoals vermeld, de gezichten van zijn dode kinderen in het grondwater drijven. Later zien we de geest van Druppeltjie spelen in het Oog, dat in het leven na de dood kennelijk weer vol water staat. Ook de grafsteen van StamAbel is na een stortbui in de diepte verdwenen, volgens

Waterwyser "na daardie plek van die dood waaroor ons maar net kan gril" (TB 35/6). Tijdens diezelfde bui begonnen echter ook alle tot dan toe droge boorgaten water te spuwen (36); opnieuw een beweging naar boven.

${ }^{1020}$ Wiehahn 1995,17
} 
verdwijnen Noag en Abel in een zwart gat: Noag letterlijk, Abel doordat Van der Ligt (bijna) iedereen rond Abel spreekt behalve Abel zelf, net zo lang tot zijn getuigenis in feite niet meer nodig is en hij geruisloos sterft op zolder $^{1021}$. Het raadsel rond Noags en Abels dood is uiteindelijk een postmodern verdwijnen van betekenis, van de familie Moolman, van de kaders die betekenis gaven. Of liever: net als de hekken van Toorberg staan de kaders nog overeind, maar water, vruchtbaarheid en betekenis zijn er door Derridaanse verschuivingen uit verdwenen. ${ }^{1022}$

Net zo min als Gordimer of Louw is Van Heerden dus in staat de confrontatie op de boerderij zelf vorm te geven. Transformatie (reïntegratie) lijkt in deze omgeving geen optie, wellicht uit politieke noodzaak ${ }^{1023}$. Van Heerden laat de plaas met al haar problematiek en (symbolische) doden imploderen of "oplos in (..) geheimsinnigheid en raaiselagtigheid" 1024 en verschuift de frontlinie naar de stad, waar de zoveelste heldere grensoorlog wordt uitgevochten. De dynamische driehoek tussen Halte, Stiefveld en de township van Eerste Stasie is de ruimte van de toekomst, een ruimte waarin niet de onvruchtbaarheid en de graven van de Moolmannen centraal staan, maar het zeskoppig nageslacht van de "skaamfamilie" en de graven.van de achteloos gedode anonieme townshipkinderen. Deze driehoek heeft alle kenmerken van de jaren tachtig in zwart Zuid-Afrika: oorlog, beweging en een bevolkingsexplosie. De zwarte bevolking groeide minstens vijf maal zo snel als de blanke. ${ }^{1025}$ Bovendien werd de trek naar de steden sinds de jaren zeventig minder streng gecontroleerd. De laatste decennia werd de blanke landbouw geteisterd door droogte en inkrimping van subsidies. Voor de zwarte boeren zijn de gevolgen het grootst. Pickles \& Weiner stellen dat "the black population of white farms declined by one million between 1980 and 1985 alone. A total of 1.6 million black left rural white South Africa during this period...the highest rate of black out migration ever recorded." ${ }^{1026 .}$ Al met al was er een vrijer verkeer van arbeidskrachten gaande, wat overigens financieel gezien niet altijd nadelig hoefde uit te pakken voor de zwarte bevolking. Migratiearbeid was in de loop der jaren bovendien

\footnotetext{
${ }^{1021}$ Als Abel, als geest, uiteindelijk toch nog het woord krijgt, lijkt hij zich daarvan bewust. "Vat 'n spoor en los hom nooit nie, het OuAbel hom geleer. Maar wat as die spoor al óm jou loop? (161).

${ }^{1022}$ Toorberg verdroogt langzaam dankzij "verschuivende watertafels".

1023 "Het die dood nog hoegenaamd simboliese verlossende waarde in "n land waarin so veel mense slagoffer van de politiek geword het?" (Hattingh 1995, 144)

${ }^{1024}$ Erasmus 1999, 688

${ }^{1025}$ In 1980 was de zwarte bevolking gegroeid tot 20 miljoen, tegen 3,5 miljoen in 1901 en 8,5 miljoen in 1951, terwijl de blanke bevolkingsgroei nauwelijks de 1\% haalde (Beinart 2001, 202).

1026 "Rural and regional restructuring of Apartheid,: ideology, development Policy and the competition for space" Antipode 23.1: 18 Het percentage van de zwarte bevolking dat op blanke boerderijen woonde was gedaald tot 20,6\%\# maar omdat de bevolking zo explosief groeide was hun absolute aantal in 1980 nog steeds stijgende: 4,2 miljoen zwarte mensen woonden op blank grondgebied.
} 
verheven tot een nieuwe rite de passage $e^{1027}$ en ontheemding werd soms tot basis gemaakt van een positieve identiteit ${ }^{1028}$.

Van Heerden lijkt deze tegenstelling tussen een krimpend, statisch, blank machtscentrum van bezitters en soldaten en een groeiende, bewegelijke, oprukkende groep "marginalen" te gebruiken als basis voor een nieuw perspectief. Als (voorlopige) oplossing voor de gewelddadige etnische patstelling draagt hij een nieuwe, non-raciale tegenstelling aan: blanke (grootgrond)bezitters versus zwarte (land)arbeiders worden getransformeerd tot boer-soldaten versus zwervers. Ontheemdheid - een combinatie van het oude koloniale zelfbeeld en het dagelijks leven van de zwarte ZuidAfrikaan - wordt de nieuwe, collectieve, strijdvaardige identiteit. De (skaam)familie Moolman, gevangen in een aan grond en geschiedenis gebonden identiteit, kan zich een nieuwe identiteit en een nieuwe toekomstgerichte "familie" aanmeten door gemeenschappelijkheid te herkennen in wat Deleuze en Guattari1029 "nomadism" noemen; een vorm van indirecte oppositie

[that] describes both the form of society that preceded feudalism and capitalism as well as a certain strategic manoevering that can be employed in the terrain of the present. As the idea of movement across territories in its name suggests, nomadism involves forms of lateral resistance to any assertion of hegemonic control through strategies of multiplicity, forms of deterritorialization because they frustrate interpretation and recoding. (..) Nomadism involves any activity that transgresses contemporary social codes through dissolution of cultural and territorial boundaries ${ }^{1030}$.

OneDays uithuizigheid, Waterwysers gewichel, Shala's geitenhoederij, Slams toverij, Noags dood, de liefde van Koevert voor Klein-Kittie, maar ook de postmoderne "raaiselagtigheid" van Van Heerden zelf zijn allemaal te zien als "nomadische" activiteiten, gericht tegen de statische wereld van de Zuid-Afrikaanse politiestaat.

In Die Stoetmeester (1993) werkt van Heerden dit concept verder uit. Siener, de dode verteller, is hier de vleesgeworden "dode auteur" 1031 . Marion Hattingh schrijft:

\footnotetext{
${ }^{1027}$ Comaroff 1999, 22

${ }^{1028}$ Een voorbeeld hiervan is difela, Sotho poëzie die de ervaring van de migratiearbeider bezingt, "songs of the dispossessed who travel over the land rather than existing within it,"\# met als doel uit ontheemding en versplintering een positief zelfbeeld te creëren. (David Coplan, "Eloqent Knowledge: Lesotho mirgants' songs and the Antrhoplogy of Experience." American Ethnologist 14 March 1987, 429)

${ }^{1029}$ Gilles Deleuze en Felix Guattari: A thousand plateaus: capitalism en schizophrenia. London, Athlone, 1988

${ }^{1030}$ Young 1994, 24

${ }^{1031}$ Hattingh 1995, 137
} 
die meervoudige vertelaanbod van die roman problematiseer die imperialistiese binêre logika van ' $n$ sentrale self teenoor ' $n$ gemarginaliseerde ander deur aan te toon dat daar ondanks die groot politieke magswanbalans, reeds 'n eie [interkulturele] Suid-Afrikaanse identiteit aan die ontwikkel is. ${ }^{1032}$

Maar ondanks het feit dat de natuur als verzoenende en bruggenbouwende factor een belangrijke rol speelt en Siener (als dode) kan wat Mehring of een van de Lotriets (nog) niet konden, namelijk bewust open staan voor "alternatiewe wyses van waarneming" om "natuurtekens" 1033 te lezen en zo blijk te geven van een "sensitiwiteit vir die ander (in die wydste sin van die woord)" ${ }^{1034}$, is die multiculturele identiteit ook hier vooral een stedelijke identiteit.

Naarmate een herziening van "die groot politieke magswanbalans" ${ }^{1035}$ dichter bij komt, lijkt de boerderij steeds minder de plek te worden waar ontmoeting of communicatie tot stand kan komen. Net als in de jaren twintig en vergrootten maatschappelijke en economische veranderingen in de jaren negentig de tegenstellingen op het platteland uit. Maar waar in de jaren twintig en dertig dat platteland desondanks in de literatuur gebruikt werd als een ruimte vol tijdloze waarden en waarheden, benadrukt Eben Venter in Foxtrot van die Vleiseters (1993) het tijdelijke en onwaarachtige van de idylle. Het boek laat zich lezen als een herschrijving van Van den Heevers Laat vrugte, met dat verschil dat de onzekerheden die worden veroorzaakt door een door verandering aangetaste paternalistische orde in Laat Vrugte slechts bedekt aanwezig waren, terwijl ze hier centraal staan. Boerenzoon Petrus zoekt antwoorden of vergeving bij arbeidersdochter Buziwe, maar ze laat hem voelen dat elke vorm van communicatie een farce is zolang zij hoogstens één sinaasappel per jaar kan eten, en hij soms wel vier op een avond. De echte confrontatie blijft nog steeds uit; Petrus' vader stuurt Buziwe en haar familie na levenslange dienstverlening weg omdat hij ze niet meer vertrouwt. Hun reactie is een unheimlich zwijgen.

In 1997 liet het Department of Land Affairs weten dat "[1]and does not only form the basis of our wealth, but also our security, pride and history (..) Land is an important and sensitive issue to all South Africans. It is a finite resource which binds all together in a common destiny." ${ }^{1036}$ Maar de werkelijkheid was weerbarstig; de hoge verwachtingen die gewekt waren, werden

\footnotetext{
${ }^{1032}$ Hattingh 1995, 141

${ }^{1033}$ Van Heerden 1993; pp. 7, 17-18, 227

${ }^{1034}$ Hatting 1995, 140

${ }^{1035}$ Zie citaat Hattingh hierboven

1036 "White paper of land policy" 1997, 2.1
} 
niet waargemaakt ${ }^{1037}$. Steden waren overvol geworden en migratie verloor iedere positieve bijklank. Wetgeving versoepelde: al gauw maakten werkgevers voor $80 \%$ van steeds goedkopere migratiearbeid gebruik. ${ }^{1038}$ Voor zowel migranten als thuisblijvers was de situatie (opnieuw) een bron van onvrede, ontwrichting en armoede geworden. Vele verhalen over door heksen geëxploiteerde zombies "dramatize the strangeness of what had become real; in this instance, the problematic relation of work to the production of social beings secured in time and place". ${ }^{1039}$

Veel zwarte Zuid-Afrikanen zochten na 1994 opnieuw hun heil in het "land van hun voorouders", ook al was dat vaak nog in blank eigendom. Nu niet alleen blanke boeren een podium krijgen, blijkt iedereen (blank, zwart, landheer, landarbeider) van dezelfde retoriek gebruik te maken: net als in vroegere plaasromans wordt de relatie tot het land verwoord als "love for the land that their families have 'worked' for generations" ${ }^{1040}$. Spanningen tussen witte en zwarte boeren liepen steeds hoger op. Het aantal vaste ("inwonende") arbeidskrachten dat van blanke boerderijen werd weggestuurd nam na 1994 weer toe, uit angst voor het toekennen van landrechten. ${ }^{1041}$

Het indienen van een land claim was slechts een van de manieren om tegen de situatie te protesteren, en een weinig effectieve. Ingediende zaken blijven vaak jarenlang slepen, en geen enkele blanke boer wordt tot nu toe van overheidswege gedwongen zijn land te verkopen. Beproefde, unheimlicher strijdmiddelen als (bestrijding van) hekserij en vormen van "nomadism" (negeren van territoriale grenzen door ongebruikt land te gebruiken als graas- of jaagland; stelen van vee en groente; neerhalen van afrasteringen) worden nu in verhevigde vorm toegepast. Sommige acties zijn bedoeld als persoonlijke wraak of intimidatie, al wordt dit door de blanke gemeenschap vaak met klem ontkend. Een boer in de Midlands van Kwazulu-Natal gaf zijn tenants al dertig jaar stilzwijgend toestemming om hun mielies te malen in zijn maalmachine. Als zijn zoon het bedrijf overneemt en de gewoonte abrupt stopzet, vindt hij enige tijd later vijf van zijn koeien met doorgesneden keel in het veld. De zwarte gemeenschap weet dat dit een wraakactie was. Maar de blanke boeren uit het district, inclusief de landeigenaar, determineren het als een politieke actie. "Maybe [the farmer] doesn't know that he knows," zegt een van de tenants schamper, "but he

\footnotetext{
${ }^{1037}$ De toename, danwel verdeling van welvaart die na de val van apartheid verwacht werd, is uitgebeleven. De Reconstruction and Development Plan, bedoeld om armoede aan te pakken, "has thusfar had minimal impact" De illegale, meest kwetsbare groep migranten (vaak vrouwen en kinderen) belandt vaak in de "highly exploitable reaches of rural agriculture." (Comaroff et. al. 1999, 22).

${ }^{1038}$ Adam, Heribert, Frederik van Zyl Slabbert en Kpgila Moodley Comrades in Business: postliberation politics in South Africa, Cape Town, Tafelberg, 1998

${ }^{1039}$ Comaroff et al 1999, (23-24)

${ }^{1040}$ Wenzel 2000, 101

${ }^{1041}$ Wenzel 2000, 91
} 
knows." ${ }^{1042}$ Hoe vaak zullen dit soort aanwijzingen niet in het politieke, raciale, onpersoonlijke getrokken zijn omdat dat minder bedreigend was? Terwijl onderhuids de wetenschap er altijd was dat er een andere boodschap werd gegeven, die niet alleen de machtsbasis, maar ook de thuisbasis ondergroef? De dode koeien in het veld zijn niet perse occult, maar wel unheimlich, omdat er een vreemde taal wordt gesproken in het eigen territorium, die tegen wil en dank verstaan wordt.

De onderhuidse dreiging uit de romans van de jaren zeventig en tachtig culmineert in de jaren negentig in langverwachte wraakacties: moord op blanke boeren. Tussen de verkiezingen van 1994 en het eind van de $20^{\text {ste }}$ eeuw werden er in Zuid-Afrika 500 blanke boeren vermoord. ${ }^{1043}$ Er werd in brede kringen gespeculeerd dat de moorden politiek gemotiveerd zouden zijn. Afrikaner boeren spraken, conform de paternalistische logica, van een "oorlogssituatie". In reactie op de uitkomst van een onderzoek van de geheime dienst (waarvan de inhoud nooit openbaar is gemaakt) liet Derek Hanekom, destijds minister van landbouw, in 1998 op zijn beurt weten dat "the overwhelming trend is pure criminality". ${ }^{1044}$ Dat de werkelijkheid ingewikkelder is, toont onderzoeksjournalist Jonny Steinberg in zijn inmiddels beroemde boek Midlands (2002). Hij onderzocht rond de laatste eeuwwisseling de moord op een blanke boerenzoon in Kwazulu-Natal. De vermeende moordenaar, een van de tenants die op de boerderij woonde, werd tijdens zijn verhoor door de politie gedood. Steinberg probeerde de zaak zorgvuldig van alle kanten te belichten, maar net als Louw en Gordimer bleek hij een gevangene van zijn afkomst. Voor het vergaren van een groot deel van het materiaal heeft hij gebruik moeten maken van zwarte informanten en het derde deel van zijn boek, waarin de visie van de tenants uiteengezet wordt, is beduidend dunner dan de andere twee delen. "The problem is," schrijft hij, "that nobody who features in this story allowed me to write about them. (...) [P]ivotal characters refused their place in this book." ${ }^{1045}$ Toch heeft hij duidelijk al weer veel meer informatie tot zijn beschikking dan schrijvers hadden in de jaren zeventig en creëert ook hij, door de onvolledigheid en soms onbetrouwbaarheid van zijn eigen informatie te erkennen, ruimte voor een alternatief beeld.

En dan is er de moord zelf. Wat ooit een nachtmerrie was voor iedere blanke boer in Zuid-Afrika werd werkelijkheid: pachter doodt boer, jong doodt baas, "zoon" doodt zoon. Misschien meer nog dan de verkiezingen van 1994 was deze moordzaak een aantasting van de plaatselijke orde. En ook hier grepen boeren terug op de oude, paternalistische retoriek om de dreiging te reduceren: het ANC zat er achter, werd er gezegd. Niks per-

\footnotetext{
1042 Steinberg 2002, 213

${ }^{1043}$ Wenzel 2000, 90

${ }^{1044}$ Idem

${ }^{1045}$ Steinberg 2002, 217/8
} 
soonlijks. Maar dat was het wèl. In een tijdperk waarin de revolutie al voorbij was en weinig verbetering had gebracht, waarin migratiearbeid geen soelaas meer kon bieden en de nieuwe landeigenaar kwam vertellen dat de met moeite behouden of langzaam terugveroverde jaag- en graasrechten alsnog zouden worden ontnomen, voelden de pachters zich als "'a prisoner in the white man's countryside. (..) It's you against him for the rest of time" "1046. "Zoon" doodt zoon: als een van de pachters het inderdaad gedaan heeft, had hij geen beter slachtoffer kunnen kiezen om een gat in de structuur te slaan en zichzelf en daarmee de schaduwstructuur waar hijzelf deel vanuit maakt zichtbaar te maken. De dood van Peter Mitchell is de onweerlegbare manifestatie van de gemarginaliseerde Ander; een grensoverschrijding in alle opzichten.

Aan dit toekomstbeeld heeft bijna geen enkele romanschrijver zich willen wagen. Tot 1994 doen zwarte boeren in anti-pastorale romans nauwelijks meer dan (al dan niet vrijwillig) de blanke boerderijen zwijgend de rug toekeren. Maar tegelijkertijd zit in dat zwijgen dit, of een ander gruwelijk, toekomstbeeld besloten. De zwijgende, terugtrekkende Ander manifesteert zich in de loop der decennia in steeds angstaanjagender alterego's: van schaduwzoon, kaffir dog en een hulpeloze Adamastor tot duivel en levend lijk; mensetende aarde en mensetende Bosjesmannen. ${ }^{1047}$ De dood is niet alleen steeds een symbool voor verlossing en transformatie van het Ik geweest, maar tegelijkertijd, en dat maakte haar zo unheimlich, een manifestatie van de Ander. Levende doden verwezen naar het discours van hekserij en kapitalistische en koloniale vervreemding; onverklaarbare, unheimliche gebeurtenissen verwezen naar onderdrukt bewustzijn van interne conflicten; familiegraven verwezen naar Afrikaanse voorouders en ontkende landrechten; de onbarmhartige aarde verwees naar de ontkende aanwezigheid van een alternatief religieus, maar ook politiek discours ${ }^{1048}$. Dat Van Heerden in Toorberg de symbolische doden en de mensetende aarde tot de lege kern maakt van een imploderende plaas die de nieuwe Zuid-Afrikaan achter zich zal laten, is opnieuw een ontkenning van die Ander. Men ontmoet hem of haar blijkbaar liever elders, op neutraal terrein, ontdaan van iedere unheimlichheid, iedere "dark threat from the inside". Van Heerdens nomadisme is een andere vorm van de eeuwige vlucht van Michael K.: een uitgestelde reïntegratie.

In 1999 laat J.M. Coetzee eindelijk reïntegratie plaatsvinden binnen het territorium van de boerderij. Waar André Brink in Houd-den-Bek (1983) de romantische mogelijkheid van een liefdesbaby openlaat die de kloof tussen slaven en meesters zou moeten dichten (maar dat natuurlijk nooit zal

\footnotetext{
${ }^{1046}$ Steinberg 2002, 246

${ }^{1047}$ Buziwe's wraak is Petrus de ontbrekende informatie van een plaatselijke legende te geven: De benen van Misses Aldrich waren niet opgevreten door jakhalzen of weggekookt in de hete bron, maar opgegeten door uitgehongerde Bosjesmannen. Vednter 1993 (240)

${ }^{1048}$ Wenzel 2000, 95
} 
kunnen), verbeeldt Coetzee in Disgrace de nieuwe Zuid-Afrikaan in de vorm van een uit wraak, geweld en schuld verwekt, maar nog ongeboren boerderijkind, dat in al zijn/haar rauwheid rassen en klassen onwillekeurig verbindt. Niet alleen land is de voedingsbodem voor een gezamenlijke toekomst, maar ook de wrede geschiedenis die daar zo onlosmakelijk mee is verbonden. Geen discours van hoop en pijnloze verandering is tegen de hardnekkige, pijnlijke werkelijkheid opgewassen; alleen het onder ogen zien en leren kennen van die werkelijkheid kan waarschijnlijk de "changes in cultural understandings of land" bewerkstelligen, "that might allow South African farms to resemble the 'places of freedom, of life' (...), rather than war zones or crime scenes." ${ }^{1049}$ In Disgrace kijkt de stadse vader naar zijn verkrachte, zwangere dochter en beseft dat zij na zijn dood zal overleven, en dat "she is becoming a peasant". "Do you love him yet?" vraagt hij haar en schrikt er zelf van. "The child? No. How could I? But I will."”1050

${ }^{1049}$ Wenzel 2000, 92

${ }^{1050}$ J.M. Coetzee 2000, 216/7 


\section{Bibliografie}

-_- "Great Britain and the Dutch Republics” Times (05-02-1900) (speciale uitgave)

Adewoye, Sam A. The concept of land in the African novel. Ibadan, Evans Brothers, 1989

Allen, Graham Intertextuality. London/ New York, Routledge, 2000

Alpers, Paul What is pastoral? Chicago/London, University of Chicago Press, 1996

Anderson, Benedict Imagined communities. London/New York, Verso, 1991

Andrews, William L. "Inter(racial)textuality in nineteenth-century southern narrative." Clayton, Jay \& Eric Rothstein (eds) Influence and intertextuality in literary history. The University of Wiscounsin Press, Madison/London, 1991: 298-317

Ariès, Philippe Essais sur l'histoire de la mort en Occident du moyen age à nos jours. Paris, Seuil, 1975

Arnzen, Michael "Introduction to 'The return of the Uncanny'." Para.doxa 3.3-4 (1997) http://paradoxa.com/excerpts/3-3intro.htm

Aschwanden, Herbert Symbols of death: an analysis of the consciousness of the Karanga. Gweru, Mambo Press, 1987

Ashcroft, Bill, Gareth Griffiths \& Helen Tiffin The empire writes back. Theory and practice in post-colonial literatures. London/New York, Routledge, 1989

Aucamp, Hennie (ed.) Sewe sondes, nee meer: Verhale en essays oor dooden ander sondes. Kaapstad/ Johannesburg/ Pretoria, Human \& Rousseau, 1995

Auslander, Mark “'Open the wombs!': The symbolic politics of Modern Ngoni Witchfinding." Jean Comaroff \& John Comaroff (eds) Modernity and its malcontent: Ritual and power in postcolonial Africa. Chicago/London, University of Chicago Press, 1993

Bal, Mieke Narratology. Introduction to the theory of narrative. Toronto/Buffalo/London. University of Toronto Press, 1997

Bank, Andrew "Evolution and racial theory. The hidden side of Wilhelm Bleek." South African historical journal 43(2000): 163-178

Barley, Nigel Dancing on the grave: Encounters with death, London, John Murray, 1995

Barnard, Alan Hunters and herders of southern Africa: A comparative ethnography of the Khoisan peoples. Cambridge/ NY/Melbourne, Cambridge University Press, 1992

Basnett, Susan Comparative Literature: A critical introduction. Oxford, Blackwell, 1993 
Beinart, William "Transkeian migrant workers and youth labor on the Natal sugar estates, 1918-1948" White farms, black labor. The state and Agrarian change in Southern Africa 1910-1950 Jeeves, Alan H. \& Jonathan Crush (eds) Portsmouth/ Pietermaritzburg/Oxford Heinemann/University of Natal Press/ James Currey 1997: 147-171

- Twentieth-century South Africa, Oxford, Oxford University Press, 2001 Beinart, William \& Colin Bundy Hidden struggles in rural South Africa: Politics and popular movements in the Transkei and Eastern Cape 1890-1930. London/Berkeley/Johannesburg, Currey/UCP/Ravan press, 1987

Bergh, Erik van den "'Oh later land of rising and belief'. On Christian motives in Afrikaans literature." Exchange 25.2(1996): 119-135

Berglund, Axel-Ivar Zulu thought patterns and symbolism. London, C. Hurst \& Co., 1976

Bernstein, Henry "South Africa's agrarian question: extreme and exeptional?" The journal of Peasant Studies. 23.2/3(1996): 1-52

Bhabha, Homi K. Nation and Narration. London/ New York, Routledge, 1990

- The location of culture. London/New York, Routledge, 1994

Biesele, Megan "Song texts by the master of tricks: Kalahari San thump piano music." Botswana notes and records 7(1975): 171-188

Bleek, W.H.I. Reynard the fox in South Africa; or Hottentot fables and tales. London: Trübner and Co, 1864.

Bleek, W.H.I., \& L.C. Lloyd Specimens of Bushman folklore. London, George Allen \& Co. Ltd., 1911

Bloch, Maurice \& Jonathan Parry (eds.) Death and the regeneration of life. Cambridge, Cambridge University Press, 1982

Bosman, Herman Charles Unto Dust (1963). Cape Town, Human \& Rousseau, 1991

Botha, Elize Suid-Afrikaanse skryfsters van die sestiger jare. 'n Reeks radiopraatjies deur dr Elize Botha. Suid-Afrikaanse uitsaaikorporasie, 1965

- "Inleiding" in C.M. van den Heever, Laat vrugte, Pretoria, Van Schaik, 1987

— "Etienne Leroux (1922-1989)" Coller, H. van (ed.) Perspektief en profiel. 'n Afrikaanse literatuurgeskiedenis. Deel 1. Pretoria, J.L. van Schaik, 1998

Bouch, Richard "Eastern Cape Wool farmers: production and control in Cathcart, 1920-1940" Alan H. Jeeves \& Jonathan Crush (eds) White farms, black labor. The state and Agrarian change in Southern Africa 1910-1950 Portsmouth/

Pietermaritzburg/Oxford Heinemann/UNP/ James Currey 1997: 94-113 
Brink, André Voorlopige rapport. Beskouings oor die Afrikaanse literatuur van Sewentig, Kaapstad, Human \& Rousseau, 1976

- Houd-den-Bek. Kaapstad, Human \& Rousseau, 1982

- "Afrikaanse literatuur: tot sover en dan verder." Insig, augustus 1999

Bullock, Alan \& Stephen Trombley (eds) The new Fontana dictionary of modern thought. London, HarperCollins Publishers, 2000

Bultinck, Bert Metaphors we die by:Conceptualizations of death in English and their implications for the theory of metaphor. Universiteit Antwerpen, diss., 1998

Bundy, Colin The rise and fall of the South African peasantry. Londen, Heinemann, 1979

Bunn, David "'Our Wattled Cot': mercantile and domestic space in Thomas Pringle's African landscapes". W.J.T. Mitchell (ed.) Landscape and power. Chicago/London, The university of Chicago press, 1994.

- "Comparative barbarism. Game reserves, sugar plantations, and the modernization of South African landscape." Text, theory, space. Land, literature and history in South Africa and Australia. Kate Darian-Smith, Liz Gunner \& Sarah Nutall (eds.) London/NY, Routledge, 1996: 37-52

Callaway, Henry The religious system of the Amazulu. (1885) C. Struyk (pty.) ltd. Africana specialist and publisher, 1970.

Campbell, Roy Adamastor. Poems. London, Faber \& Faber Ltd. 1930 Chapman, Michael Southern African Literatures in English. Londen, Longman, 1996.

Chidester, David Religions of South Africa. London/NY, Routledge, 1992

- Savage systems. Colonialism and Comparative Religion in Southern Africa. Charlottesville/London, University Press of Virginia, 1996

Cixous, Hélène "Fiction and its phantoms: a reading of Freuds's Das Unheimliche." New Literary History VII.3 (1976): 525-548

Clayton, Cherry (ed.) Women and writing in South Africa. A critical anthology. Marshalltown, Heinemann Southern Africa, 1989

Clayton, Jay \& Eric Rothstein Influence and intertextuality in literary history. The University of Wiscounsin Press, Madison/London, 1991

Clifford, James \& George E. Marcus (eds.) Writing Culture. The poetics and politics of ethnography. University of Califormia Press, Berkeley/ Los Angeles/ Londen, 1986

Clifford, James The predicament of culture: twentieth-century ethnography, literature, and art. Cambridge, Harvard University Press, 1988

Clingman, Stephen R. The novels of Nadine Gordimer. History from the inside. Johannesburg, Ravan Press, 1986

Cloete, T.T. (ed.) Die Afrikaanse literatuur sedert sestig. Goodwood, Nasou beperk, 1980. 
Coetzee, Abel Jacobus Die Afrikaanse volksgeloof. Amsterdam, Swetz \& Zweitlinger, 1938

Coetzee, Ampie Letterkunde \& krisis. 'n Honderd jaar Afrikaanse letterkunde en Afrikaner-nationalisme. Bramley, Taurus, 1990

— "To join instructions with delight. On literary studies and literary history." Harald Hendrix, Joost J. Kloek, Sophie Levie and Willie van Peer (eds), The Search for a New Alphabet. Literary studies in a changing world. Amsterdam/ Philadelphia, John Benjamins, 1996: 57-61

- 'n Hele os vir 'n ou broodmes. Grond en die plaasnarratief sedert 1595.

Van Schaik/ Human \& Rousseau, Pretoria/Kaapstad, 2000

- The genealogy of the South African farm novel. (ongepubliceerd)

Coetzee, John M. Waiting for the barbarians, Harmondsworth, Penguin Books, 1980

— Life \& Times of Michael K. (1983) Harmondsworth, Pinguin Books, 1985

- White Writing. On the culture of letters in South Africa. New

Haven/London, Yale University Press, 1988

- Boyhood. New York, Viking, 1997

- In the heart of the country (1977) London, Vintage, 1999

- Disgrace (1999). London, Vintage, 2000

Colson, Elizabeth "Places of power and shrines of the land." Paideuma. Mitteilungen zur Kulturkunde 43(1997): 47-58

Comaroff, Jean \& John Comaroff "The colonisation of consciousness in South Africa." Economy and society 18(1989): 267-296

- (eds) Modernity and its malcontents. Ritual and power in Postcolonial Africa. Chicago/London. University of Chicago Press, 1993

- Of revelation and revolution vol 2. The dialectics of modernity on a South African frontier Chicago/London. University of Chicago Press, 1997

- "Alien-nation: Zombies, immigrants and millenial capitalism".

Codesria Bulletin 3\&4(1999): 17-28

Comaroff, John "Images of empire, contests of consience: models of colonial domination in South Africa." American ethnologist 16(1989): 661-685

Conrad, Joseph Heart of darkness. London, Penguin, 1985

Cousins, Ben "Livestock production and common property struggles in South Africa's agrarian reform." The journal of Peasant Studies 2.2/3(1996): 166-208

Crais, Clifton The politics of evil: Magic, state power, and the political imagination in South Africa. Cambridge, Cambridge University Press, 2002 
Crewe, Jonathan "Recalling Adamastor: Literature as cultural memory in 'white' South Africa". Mieke Bal, Jonathan Crewe \& Leo Spitzer (eds) Acts of memory. Cultural recall in the present. Hanover/ London, University Press of New England, 1999

Darian-Smith, Kate, Liz Gunner \& Sarah Nutall (eds.) Text, theory, space. Land, literature and history in South Africa and Australia. London/ NY, Routledge, 1996

Davenport, T.R.H. \& Christopher Saunders South Africa: a modern history, Basingstoke, Macmillan, 2000

Dept. of Land Affairs White paper on South African Land Policy, 1997

De Reuck, Jenny "Women on the frontier: self-representation of the conquerer: which frontier? conquerer of what?" Current Writing 7.1(1995): 34-45

Derrida, Jacques Spectres de Marx. L'etat de la dette, le travail du deuil, et la nouvelle internationale. Paris, Galilee, 1993

Ditlhake, Abie "Labor tenancy and the politics of land reform in South Africa". Levin, R \& D. Weiner (eds) (1997) No more tears. Struggles for land in Mpumalanga, South Africa. Trenton, Africa World Press, 1997

Dolny, Helena \& Heinz Klug "Land reform: legal support and economic regulation." South African Review 6(1992): 322-337

Donaldson, Laura E. Decolonising feminisms. Race, gender \& empirebuilding. London, Routledge, 1996

Dorsman, Robert \& Gitte Postel "Interview with Nadine Gordimer, Johannesburg, 10 july, 1990" Between the lines II, Eva Hunter \& Craig MacKenzie (eds.), Grahamstown, NELM, 1993: 37-52.

Driver, Dorothy "God, fathers, and white South Africans: the world of Pauline Smith" Cherry Clayton (ed.) Women and writing in South Africa. A critical anthology. Marshalltown, Heinemann, 1989: 73-97

- "Modern South African literature in English: a reader's guide to some recent critical and bibliographic resources." World literature today 70(1996): 99-106.

— "Nadine Gordimer at 70." Southern African review of books nov/dec 1993. Geraadpleegd op www.uni-ulm.de/ rturrel/antho4html/Driver.html 28-03-2002

Du Pisani, Kobus "'Volkshelde': die boerekrygerbeeld en die konstruksie van Afrikanernasionalisme." Literator 20.3(1999): 87-111

Du Toit, Maryke The general view and beyond: Social documentary and photography, Slum Clearance and State Social Welfare Porgrammes, ca. 1934-1948. Lezing gegeven aan Queens University, september 2003. Geraadpleegd op www.queensu.ca/sarc/Conferences/1940s/Toit.htm (24-02-2004) 
Du Toit, André "No chosen people. The myth of the Calvinist origins of Afrikaner nationalism and racial ideology." The American historical review 88.4(1983): 920-953

Elsbree, Langdon Ritual passages andd narrative structures. New York, Peter Lang Publishing, 1991

Engle, Lars "The political uncanny: the novels of Nadine Gordimer." The Yale journal of criticism 2.2(1989): 101-125

- 'The Conservationist' and the political uncanny. In: Bruce King (ed.) The later fiction of Nadine Gordimer. Basingstoke/London, The Macmillan press, 1993

Erasmus, Mabel "Etienne van Heerden (1954-)" Coller, H.P. van (red.) Perspektief \& profiel. 'n Afrikaanse literatuurgeskiedenis II Pretoria, J.L. van Schaik, 1999

February, Vernon A. Mind your colour. The coloured stereotype in South African Literature. London/Boston, Kegan Paul International Ltd., 1982

- (ed.) Taal en identiteit. Afrikaans en Nederlands. Kaapstad, Tafelberg, 1992

Fentress, James \& Chris J. Wickham Social Memory. Oxford, Blackwell, 1992

Firchow, Peter Edgerly Envisioning Africa : racism and imperialism in Conrad's Heart of darkness Lexington, KY : University Press of Kentucky, 2000

Francken, Eep "De omgekeerde wereld op z'n afrikaans?" Theo d'Haen (red), Weer-werk. Schrijven en terugschrijven in postkoloniale literaturen. Semaian 15(1996): 71-86

- "Literatuur voor het oude en nieuwe Zuid-Afrika? Bart Nel van J. van Melle en de Afrikaner natievorming." TNTL 114(1998): 156-163

Francken, Eep \& Luc Renders Skrywers in die strydperk. Krachtlijnen in de Zuid-Afrikaanse letterkunde. Amsterdam, Uitgeverij Bert Bakker, 2005

Freud, Sigmund “The 'Uncanny'.” New Literary History 7.3(1976): 619645

Galgut, Damon The beautiful screaming of pigs, New York, Scribner, 1991.

Gates, Henri Louis Jr. The signifying monkey. A theory of Afro-American literary criticism. Oxford University Press, New York/ Oxford, 1988

Gelder, Ken \& Jane M. Jacobs Uncanny Australia. Sacredness and identity in a postcolonial nation. Carlton South, Melbourne University Press, 1998

Gennep, Arnold van The rites of passage. Chicago, University of Chicago Press, 1960 
Gerwel, Jakes Literatuur en apartheid. Konsepsies van 'gekleurdes' in die Afrikaanse roman tot 1948. Bellville, Universiteit van WesKaapland, 1988

Geschiere, Peter The modernity of witchcraft. Politics and the occult in postcolonial Africa. Charlottesville/London, University press of Virginia, 1995

Gifford, Terry Pastoral London/New York, Rutledge, 1999

Giliomee, Hermann The rise and fall of Afrikaner women. Talk given at lunch hosted by Cape Times Literary Lunch and by Fine Music radio, 2 augustus 2003(a)

- The Afrikaners. Biography of a people. Kaapstad, Tafelberg, 2003(b)

Goldin, Ian (1987) "The reconstitution of coloured identity in the western Cape.” Marks, Shula \& Stanley Trapido (eds.) The politics of race, class, and nationalism in twentieth-century South Africa. London / New York, Longman, 1987

Gordimer, Nadine The Conservationist (1974) Harmondsworth etc., Penguin Books, 1983

Gray, Stephen "Bosman's Marico Allegory: A study in topicality" English Studies in Africa 20.2 (1977):79-94

- Southern African Literature. An introduction. Cape Town, David Philip, 1979

- "A tale larger than the sum of its parts: Herman Charles Bosman's use of short fictional forms." Matatu. Zeitschrift für Afrikanischer Kultur und Gesellschaft. 3.5(1989): 1-10

Green Musselman, Elizabeth "Worlds Displaced: Projecting the Celestial Environment from the Cape Colony," Kronos: Journal of Cape History 29(2003): 64-85.

Guenter, Matthias G. "The trance dancer as an agent of social change among the farm Bushmen of the Ghanzi District. Botswana notes and records 7(1975): 161-166

- The Nharo Bushmen of Botswana. Tradition and change. Hamburg, Helmut Buske Verlag, 1986.

- Tricksters and trancers. Bushmen religion and society. Bloomington/ Indianapolis, Indiana University Press, 1999.

- Bushman folktales. Oral traditions of the Nahro of Botswana and the /Xam of the Cape. Stuttgart, Franz Steiner Verslag Wiesbaden, 1989. Gúllon, Ricardo "On space in the novel." Critical Inquiry.2 (1975): 11-28 Gunner, Liz "Names and the land. Poetry of belonging and unbelonging, a comparative approach." Text, theory, space. Land, literature and history in South Africa and Australia. Kate Darian-Smith, Liz Gunner \& Sarah Nutall (eds.) London/NY, Routledge, 1996: 115130 
- "Hidden Stories and the light of the new day: A Zulu manuscript and its place in South African writing." Research in African literatures 31.2 (2000): 1-16

Hattingh, Marion "Die stoetmeester van Etienne van Heerden: Gesigte van 'n gestorwe siener." Marion Hattingh \& Hein Willemse (reds) Vernuwing in die Afrikaanse letterkunde, Bellville, Afrikaanse Letterkunde Vereniging, 1995: 133-145

Heerden, Etienne van Toorberg (1986) Kaapstad, Tafelberg, 1997

- Die Stoetmeester. Kaapstad, Tafelberg, 1993

- Kikoejoe, Kaapstad, Tafelberg, 1996

Heever, C.M. van den Somer (1935). Pretoria, J.L. van Schaik, 1986

- Laat vrugte (1939). Pretoria, van Schaik, 1987

Hewitt, Roger L. Structure, meaning and ritual in the narratives of the southern San. Hamburg, Helmut Buske Verlag, 1986.

Hockey, Jennifer Lorna Experiences of death. An anthropological account. Edinburgh, Edinburg University Press, 1990

Hodge, Robert Literature as Discourse. Textual strategies in English and history. Polity Press, Cambridge, 1990

Hofmeyr, Isabel "Building a nation from words: Afrikaans language, literature and ethnic identity, 1902-1924" Shula Marks \& Stanley Trapido (eds.) The politics of race, class, and nationalism in twentieth-century South Africa. London/ New York, Longman, 1987: 95-123

— "Jonah and the swallowing monster: orality and literacy on a Berlin Mission Station in the Transvaal." Journal of Southern African Studies 17.4 (1991): 633-653

Huggan, Graham "Decolonizing the map." Bill Ashcroft, Gareth Griffiths $\&$ Helen Tiffin (eds) The post-colonial studies reader. London, Routledge, 1995

Jaarsveld, F.A. van Die evolusie van apartheid en ander geskiedkundige opstelle. Kaapstad, Tafelberg, 1979

Jacobson, Dan "Introduction". Olive Schreiner. The Story of an African farm. Gloucester, Smith, 1976

Jay, Martin Cultural semantics: keywords of our time. London, The Athlone Press, 1998

Jonker, Gerdientje De topografie van de herinnering: doden, traditie en collectief geheugen in Mesopotamië. Dissertatie. Universiteit Groningen, 1993

Kannemeyer, J.C. Geskiedenis van die Afrikaanse literatuur II. Pretoria/Kaapstad/ Johannesburg, Academica, 1983

- Die Afrikaanse Literatuur 1652-1987 Kaapstad/Pretoria, Human \& Rousseau, 1990 
Keegan, Tim Facing the storm. Portraits of black lives in rural South Africa. London/Athens, Zed books ltd./Ohio Universiy Press, 1988

Keto, C. Tsehloane "The Africans and the Dutch in the seventeenth and eighteenth centuries: the failure of peacefull coexistence." Journal of Southern African Affairs. An interdisciplinary research quarterly 3.2 (1978): 195-210

King, Bruce (ed.) The later fiction of Nadine Gordimer. Basingstoke/London, The Macmillan press, 1993.

Kommers, Jean "Mythische geografie. Landschap en wereldbeeld in nietwesterse culturen." H. Driessen \& H. de Jonge (red.) In de ban van betekenis. Proeven van een symbolische antropologie. Nijmegen, SUN, 1994.

— "Koloniale etnografie en antropologie." Tydskrif vir Nederlands en Afrikaans 2(1996). Digitale versie geraadpleegd op: www.sun.ac.za/afrnd1/tna/962/

Kommers.html (29-08-2002)

Komrij, Gerrit De Afrikaanse poëzie in duizend en enige gedichten, Amsterdam, Meulenhoff, 1999

Korsten, Frans Willem Lessen in literatuur. Vantilt, Nijmegen, 2002 Krog, Antjie Country of my skull. Guilt, sorrow and the limits of forgiveness in the New South Africa. Johannesburg, Random House, 1998

- Liederen van de blauwkraanvogel. Amsterdam/ Den haag, Uitgeverij Podium/Novib, 2003

- A change of tongue, Johannesburg, Random House, 2003

Lakoff, George \& Marc Johnson Metaphors we live by. Chicago, University of Chicago Press, 1980

La Fontaine, J.S. Initiation Manchester, Manchester University Press, 1986 Lerner, Laurence The frontiers of literature. Oxford, Blackwell, 1988

Leroux, Etienne Sewe dae by die Silbersteins. Kaapstad, Human \& Rousseau, 1962

- Magersfontein, O Magersfontein! (1976) Kaapstad/ Pretoria, Human \& Rousseau, 1984

Levin, Richard \& Daniel Weiner "Peasants speak: the land question in Mpumalanga." The journal of Peasant Studies 23.2/3 (1996): 278301

- "The politics of land reform in South Africa after Apartheid: perspectives, problems, prospects." The journal of Peasant Studies 23.2/3 (1996): 93-119

Levin, Richard, Ian Solomon \& Daniel Weiner "Forced removals and land claims." Levin, R \& D. Weiner (eds) No more tears. Struggles for land in Mpumalanga, South Africa. Trenton, Africa World Press, 1997 
Lewis-Williams, David "The mantis, the eland and the meerkats. Conflicts and mediation in a nineteenth-century San myth". African Studies 57.2 (1997): 195-216

Lincoln, Bruce Discourse and the construction of society. Comparative studies of myth, ritual and classification. New York/ Oxford, Oxford University Press, 1989

Lindenbergh, E. (red.) Inleiding tot die Afrikaanse letterkunde. Pretoria, Academica, 1987

Lloyd-Smith, Alan Gardner Uncanny American fiction. Medusa's face, Macmillan, 1989

Lourens, Amanda Afwesig uit die kanon: die prosageskrifte van die Klerewerkers geraadpleegd op http://www.sun.ac.za /afrndl/tna/972/Lourens.html (08-02-2002)

Louw, Anna M. Kroniek van Perdepoort (1975), Kaapstad, Tafelberg, 1992 - Vos Kaapstad/ Pretoria/ Johannesburg, Human \& Rousseau, 1999 Louw, N.P van Wyk Berigte te velde. Opstelle oor die idee van 'n Afrikaanse nasionale letterkunde. Pretoria, J.L. van Schaik, 1939

- Lojale Verset. Kritiese gedagtes oor ons Afrikaanse kultuurstrewe en ons literere beweging. Kaapstad, Nasionale Boekhandel, 1939

- Nuwe verse. Kaapstad, Nasionale boekhandel beperk, 1956

- Versamelde gedigte, Kaapstad, Tafelberg/Human \& Rouseau, 1981

Lowe, Lisa "Rereadings in orientalism." Cultural Critique 15 (1990): 11543

MacKenzie, Craig "Bosmans 'Voorkamer' stories. A reconsideration." Current Writing 12.1 (2000): 75-90

Marks, Shula \& Stanley Trapido (eds.) The politics of race, class, and nationalism in twentieth-century South Africa. London / New York, Longman, 1987

Mayer, Philip "The origin and decline of two rural resistance ideologies." Mayer, Philip (ed.) Black villagers in an industrial society. Anthroplogical perspectives on labour migration in South Africa. Cape Town, Oxford University Press, 1980.

Mbiti, John S.African religions and philosophy. London/Ibadan/ Nairobi, Heinemann, 1969

Merwe, C.N. van der Breaking barriers. Stereotypes and the changing of values in Afrikaans writing 1875-1990. Amsterdam, Rodopi, 1994

— “Anna M. Louw (1914-)" Coller, H.P. van (red.) Perspektief \& profiel. 'n Afrikaanse literatuurgeskiedenis I Pretoria, J.L. van Schaik, 1998

Metcalf, Peter \& Richard Huntington Celebrations of death. The anthropology of mortuary ritual. Cambridge, Cambridge University Press, 1991

Meyer, Maaike In tekst gevat: inleiding tot een kritiek van representatie. Amsterdam University Press, Amsterdam, 1996 
Middleton, John The Lugbara of Uganda. New York, Holt Rinehart \& Winston, 1969

Milton, John Paradise Lost (Books III-IV / ed. by Lois Potter and John Broadbent.) Cambridge, CUP, 1973- 1976)

Minnaar, Lucia C. "Kroniek van Perdepoort van Anna M. Louw." D.H. Steenberg (red.) Rondom Sestig. Perspektiewe op die nuwer Afrikaanse prosa. Kaapstad, Hollandsch Afrikaansche Uitgevers Maatschappij, 1977

Mitchell, W.J.T. "Imperial landscapes." W.J.T. Mitchell (ed.) Landscape and power. Chicago/London, The university of Chicago press, 1994.

Moodie, Donald (ed.) The record or a series of official papers relative to the condition and treatment of the native tribes of south africa. Kaapstad/Amsterdam, Balkema, 1960

Morrel, Robert "Synonymous with gentlemen?" White farmers, schools and labor in Natal, c. 1880-1920 Alan H. Jeeves \& Jonathan Crush (eds) White farms, black labor. The state and agrarian change in Southern Africa 1910-1950 Portsmouth/Pietermaritzburg/Oxford Heinemann/University of Natal Press/ Jammes Currey 1997: 172191

Murray, Colin Black Mountain: land, class and power in the Eastern Orange Free State 1880-1980s, Edinburgh, Edinburgh University Press for the International African Institute, 1992

- "Land Reform in the Eastern Free State: Policy dilemma's and Political Conflict." The journal of Peasant Studies 23.2/3 (1996): 209-244

Murray, Martin J. “"The natives are always stealing': white vigilantes and 'the reign of terror' in the Orange Free State, 1918-24" Journal of African History 30(1989): 107-123

— "Factories in the fields: capitalist farming in the Bethal district, c. 19101950" Alan H. Jeeves \& Jonathan Crush (eds) White farms, black labor. The state and Agrarian change in Southern Africa 1910-1950. Portsmouth/ Pietermaritzburg/ Oxford, Heinemann/ University of Natal Press/ Jammes Currey, 1997: 75-93

- "Moralising the agrarian question: concealed meanings and competing master narratives in the construction of an imagined South African countryside." Journal of Contemporary African Studies 14.1 (1996): $5-28$

Newman, Judie "Gordimer's The Conservationist: 'That book of unknown signs"”. Critique. Studies in modern fiction 12.3 (1981): 31-44

- Nadine Gordimer. London/ NY, Routledge, 1988.

Niekerk, Annemarié van "Liberating her-story from history." Johannes A. Smit, Johan van Wyk \& Jean Philippe Wade (eds.) Rethinking South African Literary History. Durban, Y Press, 1996 
- "Die Afrikaanse vrouwskrywer - ven egotekste tot postmodernisme $\left(18^{\mathrm{e}}\right.$ eeu - 1996)" H.P. van Coller (red.) Perspektief en profiel. 'N Afrikaanse literatuurgeskiedenis. Deel 2. Pretoria, J.L. van Schaik, 1999

Nielsen, Aldon, L. Writing between the lines: race and intertextuality. University of Georgia Press, Athens GA/ London, 1994

Nuttal, Sarah "Flatness and fantasy. Representation of the land in two recent South African novels." Text, theory, space. Land, literature and history in South Africa and Australia. Kate Darian-Smith, Liz Gunner \& Sarah Nutall (eds.) London/NY, Routledge, 1996: 219229

Odendal, F.F. e.a. (reds.) Verklarende Handwoordeboek van die Afrikaanse Taal Johannesburg/ Kaapstad, Perskor uitgeverij, 1988

Okely, Judith The traveller-gypsies. Cambridge, Cambridge University Press, 1983

Onselen, Charles van "Race and class in the South African countryside: cultural osmosis and social relations in the sharecropping economy of the South-Western Transvaal". The American review of history 95.1(1990): 99-123

- The seed is mine. The life of Kas maine. A South African Sharecropper 1894-1985. Oxford, James Currey, 1997(a)

- "Paternalism and violence on the maize farms of the South-Western Transvaal, 1900-1950" Alan H. Jeeves \& Jonathan Crush (eds.), White Farms, black Labor. The state and Agrarian Change in Southern Africa, 1910-1950, Portsmouth/ Pietrmaritzburg/ Oxford, Heinemann/University of Natal Press/ James Currey, 1997(b): 192314

Plaatje, Sol T. Mhudi, Johannesburg, Guagga press, 1975

- Native life in South Africa. Before and since the European war and the Boer rebellion, Johannesburg, Ravan Press, 1982

Plooy, Helna du "C.M. van den Heever (1902-1957)" Coller, H. van (ed.) Perspektief en profiel. 'n Afrikaanse literatuurgeskiedenis. Deel 2.

Pretoria, J.L. van Schaik, 1998: 653-664

Postel, Gitte "Van homes en empires sing hy niet/ maar van sy vanderland" Rapsoden en rebellen. Literatuur en politiek in verschillende culturen. Amsterdam, Rozenberg publishers, 2003: 307-326

Pritchard, Stephen. "Sacred-secrets, justice and reconciliation." International Journal of cultural studies 3.3(2000): 389-406

Rivkin J., \& M. Ryan (eds.) Literary theory: an anthology. Oxford, Blackwell, 1998

Renders, Luc Paradise regained and lost again: South African Literature in the post-apartheid era. Lezing gehouden op ICLA-conferentie, Hong Kong 2004 
Rens, Lieven “Inleiding”. Joost van den Vondel, Lucifer. Treurspel (1654).

Den Haag/ Noorduijn, Martinus Nijhoff/ Tjeenk Willink, 1979

Roos, Henriette "Perspektief op die Afrikaanse prosa van die twintigste eeu." H. van Coller (ed) Perspektief en profiel. 'n Afrikaanse literatuurgeskiedenis. Deel 1. Pretoria, J.L. van Schaik, 1998

Rooyen, Piet van Bemoeienis met die ander. Boerskrijwer en Boesman.

Port Elizabeth, Universiteit van Port Elizabeth, 1999

Ross, Robert Beyond the pale. Essays on the history of colonial South

Africa. Hanover/London, Wesleyan University Press, 1993.

- "Paternalism, patriarchy and Afrikaans" South African Historical Journal 32(1995): 34-47

- A concise history of South Africa, Cambridge, Cambridge University Press, 1999

- Status and respectability in the Cape colony 1750-1870. A tragedy of manners. Cambridge/ NY/ Melbourne, Cambrdige University Press, 1999

Saunders, Christopher \& Nicholas Southey Dictionary of South African History. Cape Town/ Johannesburg, David Philip, 2001

Schipper, Mineke (ed.) Text and context. Methodological explorations in the field of African literature. Leiden, Afrika Studiecentrum, 1977

- "Culture, identity and interdiscursivity." Research in African Literatures 24.4(1993): 39-48

- Afrikaanse Letterkunde. Tradities, genres, auteurs en ontwikkelingen in de literatuur van Afrika ten zuiden van de Sahara. Baarn/'s Gravenhage, Ambo/Novib, 1990

- De Boomstam en de krokodil. Kwesties van ras, cultuur en wetenschap. Amsterdam, Van Gennep, 1995

- "The verbal and the visual in a globalizing context: African and European connections as an ongoing process." Research in African literatures 31.4(2000): 139-154

Schipper, Mineke \& Piet Schrijvers (reds.) Bezweren en betoveren: magie en literatuur wereldwijd. Baarn, Ambo, 1995

Schirmer, Stefan "Land, legislation and Labor Tenants: Resistance in Lydenburg, 1938" White Farms, black Labor. The state and Agrarian Change in Southern Africa, 1910-1950, Alan H. Jeeves \& Jonathan Crush (eds). Portsmouth/ Pietrmaritzburg/Oxford, Heinemann/University of Natal Press/ James Currey, 1997: 46-60

Schmidt, Sigrid "Khoe Khoe Gowab (Nama/Dawara) oral traditons." Fasette/Facets/Facetten 12.1(1993): 1-14

- Katalog der Khoisan-Volkserzählungen des südlichen Afrikas. Catalogue of the Khoisan folktales of Southern Africa 1: Quellen und Register. Sources and indices. Hamburg, Buske, 1989 (1) 
- Katalog der Khoisan-Volkserzählungen des südlichen Afrikas.

Catalogue of the Khoisan folktales of Southern Africa 2: Die

Erzahlungen. The tales. Hamburg, Buske, 1989 (2)

Schreiner, Olive The story of an African farm (1880), Craighall, Ad Donker 1989

Setiloane, G.M (1998) How African (Bantu) mythology has anticipated Darwin and Prof. Philip Tobias. C.W. du Toit (ed) Faith, Science \& African Culture. African Cosmology and Africa's contribution to science, Pretoria, UNISA, 1998

Smit, Johannes A., Johan van Wyk \& Jean Philippe Wade (eds.) Rethinking South African Literary History. Durban, Y Press, 1996.

Smith, Andrew B. Where have all the Hottentots gone? The history and archeology of the Khoenkhoen. geraadpleegd op www.scienceinafrica.co.za/2002/august/khoi (13-09-2002)

Smith, Pauline The Little Karoo (1925). New York, St. Martin's press, 1990

- The Beadle (1926). Claremont, David Philip, 1989

Speerstra, Uldrik Representaties van culturele identiteit in migrantenliteratuur. De Indiase diaspora als case studie. Dissertatie. Universiteit Leiden, 2001.

Steenberg, D.H \& L.C. Minnaar "Die bybelse horison in die Afrikaanse letterkunde." Standpunte 178 (1985): 26-34 en Standpunte 179 (1985): 11-17

Steenberg, D.H. "The rural novel as cultural memory: framing (esp. social) transition in South Africa." Hendrik van Gorp \& Ulla Musarra (eds.) Genres as repositories pf cultural memory. Proceedings of the xvth Congress of the International Comparative Literature Association "Literature as Cultural memory". Amsterdam/ Atlanta, Rodopi, 2000

Steinberg, Jonny Midlands. Johannesburg/Cape Town, Jonathan Ball Publishers, 2002

Stratton, Florence Contemporary African literature and the politics of gender. London/ NY, Routledge, 1994.

Thom, H.B. Die Geskiedenis van die skaapboerdery in Suid-Afrika, Amsterdam [s.n.], 1936

Totius Trekkerswee: verse, Potchefstroom, [s.n.], 1915

Troup, Freda South Africa. An historical Introduction. Harmondsworth, Penguin Books 1975

Turner, Mark Death is the mother of beauty. Mind, metaphor, criticism. Chicago/London, University of Chicago Press, 1987

Venter, Eben Foxtrot van die Vleiseters. Kaapstad, Tafelberg, 1993

Vidler, Anthony The architectural uncanny. Essays in the modern unhomely. Cambridge, MIT, 1992 
Viljoen, Hein "Borders and their transgression in recent South African fiction." Bauer, Roger \& Douwe Fokkema (eds.) Space and boundaries in literature. Proceedings of the XIIth congress of the International Comparative Literature Association, Munich 1988 2, München, Iudicium, 1990: 118-123

Viljoen, Louise 'n Nuwe ruimte vir die Afrikaanse letterkunde. Oratie uitgesproken aan de Universiteit van Stellenbosch (ongepubliceerd).

- "Postkolonialisme en die Afrikaanse letterkunde: 'n verkenning van die rol van enkele gemarginaliseerde diskoerse." Tydskrif vir Nederlands en Afrikaans 3.2(1996): 158- 175

Vivan, Itala "Geography, literature and the African territory: some observations on the western map and representation of territory in the South African imagination." Research in African Literatures 31.2(2000): 49-70

Vondel, Joost van den Lucifer. Treurspel. Ingeleid en van aantekeningen voorzien door Prof. dr. Lieven Rens. Den Haag/ Noorduijn, Martinus Nijhoff/Tjeenk Willink, 1979

Vuuren, Helize van "Thomas Pringle (1798-1834) en Die Boesmans" Tydskrif vir Letterkunde 40(2003) 34-43

Wagner, Kathrin Rereading Nadine Gordimer. Bloomington/ Indianapolis, Indiana University Press, 1994.

Ward, David Chronicles of darkness. Routledge, London/New York, 1989

Wasserman, Herman "Terug na die plaas - postkoloniale herskrywing in

Etienne van Heerden se 'Die Stoetmeester'” Tydskrif vir Nederlands en Afrikaans 7.1(2000) Geraadpleegd op www.sun.ac.za/

afrnedl/tna/00jun/wasser.htm (13-01-2003)

Werner, Alice Myths and legends of the Bantu. London, Frank Cass \& Co. Ltd., 1968. Geraadpleegd www.afrikaworld.net/afrel/mlb03.htm (2405-2005).

Wenzel, Jennifer "The pastoral promise and the political imperative: the plaasroman tradition in an era of land reform". Modern Fiction Studies 46.1(2000): 90-113

White, Landeg \& Tim Couzens Literature and Society in South Africa. Londen, Longman, 1984

Wiehahn, Rialette " "n Herbesoek aan Toorberg." Tydskrif vir letterkunde 33.2(1995): 5-21

Wilmsen, Edwin N. "Horizons of knowledge. Fictive antecedents of the canonic 'Bushmen' Image.” African Studies 57.2(1997): 375-396

Wolf, Eric Europe and the people without history. Berkeley, University of California Press, 1982

Worden, Nigel The making of modern South Africa. Conquest, segregation and Apartheid. Oxford/ Cambridge, Blackwell, 1994 
Wyk Smith, M. van (ed.) Shades of Adamastor. Africa and the Portuguese connection. An anthology of poetry. Grahamstown, NELM, 1988

Young, Davis A. "The Antiquity and the Unity of the Human Race

Revisited". Christian Scholar's Review 24.4(1995), 380-396

Young, Robert "Colonialism and the desiring-machine" Theo D'haen \& Hans Bertens (eds.) Liminal postmodernisms: the postmodern, the (post-)colonial, and the (post-)feminist. Amsterdam, Atlanta, 1994: 11-34

Zyl, Wium van "Boerneef en die volkspoësie". Tydskrif vir letterkunde 40(2003): 54-70 


\section{Index}

\section{A}

Adamastor $80-88 ; 141 ; 280 ; 286$

ANC $69 ; 74 ; 137 ; 138 ; 182 ; 262$ anti-pastorale literatuur Zie pastorale literatuur en (post)kolonialisme

\section{B}

baasskap $52 ; 102 ; 207 ; 208$

Bakhtin, M.M. $14 ; 163$

Barthes, Roland $17 ; 19 ; 30$

Bhabha, Homi $14 ; 15 ; 131 ; 136 ; 193 ; 199 ; 223 ; 254 ; 266$

Bleek, William $13 ; 224 ; 227 ; 230 ; 265 ; 266$

Boerenoorlog $24 ; 27 ; 48 ; 51 ; 70 ; 86 ; 246$ Bosman, Herman Charles .. 25; 89; 90; 98; 104; 106; 133-137; 249; 266; 271; 285; 287

Brink, André $29 ; 203 ; 263$ C

Callaway, Henry $162-179 ; 189-196$ calvinisme $90 ; 91 ; 97 ; 135 ; 209 ; 220-222 ; 227$ Campbell, Roy.... $86 ; 88$ cattle killing..... $64 ; 68$ chaos $53 ; 191 ; 250$ en (post)kolonialisme en dood in literatuur christendom. Afrikaans Coetzee, J.M. Conrad, Joseph. $97 ; 115 ; 116 ; 124 ; 154 ; 177 ; 288$ $101 ; 102 ; 109 ; 110 ; 136 ; 188 ; 251 ; 286$ $201 ; 238$ D

Derrida, Jacques $127 ; 130-132 ; 244$ Dhlomo, H.I.E. $12 ; 23 ; 59 ; 61$ difaqana ..... $36 ; 38 ; 64$

\section{F}

Foucault, Michel 12 Freud, Sigmund. $21 ; 68 ; 73 ; 165-167 ; 182 ; 215 ; 220 ; 221 ; 222$ $95 ; 96$ $.7 ; 13 ; 252 ; 255-257 ; 263$ $115 ; 116 ; 122 ; 268$

$\boldsymbol{G}$

Gordimer, Nadine $7 ; 10 ; 16 ; 17 ; 25 ; 26 ; 98 ; 102 ; 112 ; 137 ; 141-200 ; 217 ; 228 ; 253$ $258 ; 269 ; 273$

Grote Trek $36 ; 52 ; 54 ; 97$ 
$\boldsymbol{H}$

hekserij...... $.68 ; 120-125 ; 170-172 ; 181 ; 187 ; 188 ; 261 ; 263$

I

industrialisatie $1 ; 4 ; 72 ; 122 ; 123$

interculturaliteit $10 ; 84$

en Zuid-Afrikaanse identiteit $260 ; 286$ in literatuur $24 ; 61 ; 164 ; 254 ; 256 ; 287$ in religie. $96 ; 168$ op boerderijen $45 ; 247 ; 255 ; 285 ; 287$ intertekstualiteit .. 12-15;20;24;83;112;144; 157; 162; 179; 207; 217; 228; 231; $233 ; 254$

\section{$\boldsymbol{K}$}

Kristeva, Julia $12-15 ; 123 ; 124 ; 132 ; 159 ; 195 ; 196 ; 253$

$\boldsymbol{L}$

Lévi-Strauss, Claude $17 ; 19$

Louw, Anna $112 ; 197-246 ; 253-257 ; 262 ; 274$

Louw, N.P. van Wyk 217

M

Marx, Karl. $121 ; 131 ; 156$ metafoor (dood) ..............7; 9; 18; 20; 61; 98; 99; 103; 106; 107; 128; 132; 214; 253; 255 (familie) $52 ; 61 ; 99 ; 101 ; 200 ; 201 ; 253$

(Moeder Aarde) $61 ; 101 ; 154 ; 155 ; 160 ; 200$ (Moeder Natuur). $99 ; 147 ; 154 ; 160 ; 256$ en (post)kolonialisme $61 ; 132$ ruimtelijke $161 ; 254$ werking van $112 ; 254$ mfecane Zie difaqana migranten arbeids$96 ; 97 ; 125 ; 135 ; 187 ; 261$ en landrechten $38 ; 117 ; 119$ missie $7 ; 39 ; 54 ; 64-68 ; 77 ; 96 ; 118 ; 165-168 ; 171 ; 182 ; 246$ mythen als culturele artefacten $82 ; 113 ; 200 ; 224$ en (post)kolonialisme .........3-8; 32; 144; 146; 155; 179; 180;189; 192; 220; 224 en intertekstualiteit $16 ; 195 ; 215 ; 217 ; 228 ; 238 ; 253$ oorsprongs$3 ; 143 ; 144 ; 152 ; 155 ; 163 ; 169 ; 172 ; 173 ; 232 ; 254 ; 288$ rural myth..... $67 ; 69 ; 71 ; 89 ; 157$ sociale functie van $19 ; 30$

$N$

Nasionale Party $29 ; 51 ; 74 ; 135 ; 199 ; 222$ nationalisme. $3 ; 10 ; 27-30 ; 52 ; 54 ; 57 ; 74 ; 115 ; 130 ; 170 ; 219 ; 220 ; 222 ; 268$ 
Native Land Act (1913) $11 ; 48 ; 65 ; 74 ; 117 ; 138$

natuur Zie metafoor

- versus cultuur $1 ; 2 ; 79 ; 84 ; 156 ; 203 ; 233 ; 234$ $\boldsymbol{O}$

orale literatuur $11 ; 12 ; 60 ; 169 ; 217 ; 224$

\section{$\boldsymbol{P}$}

pastoraal discours

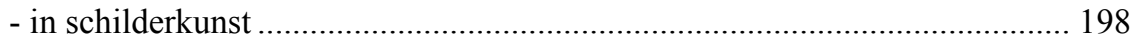

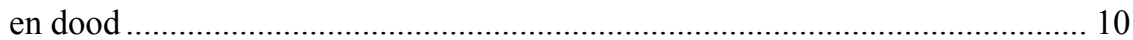

pastorale literatuur

dood in $10 ; 83 ; 98-101 ; 214 ; 215$

en (post)kolonialisme $4-6 ; 10 ; 12 ; 59 ; 61 ; 79 ; 137 ; 147 ; 151 ; 192 ; 199 ; 246 ; 261$ en culturele identiteit $3 ; 6 ; 14 ; 23 ; 24 ; 31 ; 32 ; 41 ; 50 ; 58 ; 63 ; 78 ; 247 ; 249 ; 255$; 257

en de literaire canon $10 ; 29 ; 78 ; 140$ en industrialisatie. $23 ; 24$ en landrechten. $31 ; 58$ en nationalisme $3 ; 30 ; 57$ interculturele relaties in $26 ; 42 ; 45 ; 50 ; 55 ; 137 ; 212$ kenmerken van $1 ; 4 ; 25 ; 42 ; 200 ; 202 ; 207$ ruimtegebruik in $9 ; 254$ paternalisme als ideologie. als sociale structuur in interculturele context in literatuur kenmerken van $46 ; 47 ; 53 ; 54 ; 57 ; 67 ; 71 ; 72 ; 97 ; 262$ $47 ; 70 ; 71 ; 73 ; 123 ; 138 ; 248$ 46 Plaatje, Sol.... $45 ; 52-56 ; 207 ; 256 ; 260$ plattelandscrisis $43 ; 44$ Pringle, Thomas $11 ; 36 ; 74$ $24 ; 40$

\section{$\boldsymbol{R}$}

rites de passage

als sociale structuur

$173 ; 191$

en (post)kolonialisme $116 ; 171 ; 259$

en dood $187 ; 250 ; 255$

en transformatie $5 ; 110 ; 189 ; 233 ; 236 ; 241$ in literatuur $62 ; 73-78 ; 84 ; 85 ; 97 ; 279$ structuur van rituelen

als culturele artefacten $44 ; 96 ; 111 ; 143 ; 144 ; 166 ; 191$ begrafenisfunctie van $5 ; 19 ; 180$

in literatuur $80 ; 82 ; 85 ; 112 ; 136 ; 180 ; 243 ; 244 ; 250 ; 253 ; 256$ $16 ; 195 ; 200 ; 254$ 


\section{$S$}

schelm $83 ; 215 ; 225 ; 235-237$

Schreiner, Olive $13 ; 25 ; 78-84 ; 98-103 ; 145 ; 154 ; 249 ; 251 ; 257 ; 285$ segregatiepolitiek (apartheid). 11; 41; 61; 72; 88; 104; 106; 117; 118; 193; 248; 251 sjamanisme

en (post)kolonialisme $96 ; 165 ; 166 ; 176 ; 178$

en dood $111 ; 188 ; 189$ in literatuur $180-191 ; 196 ; 236$ sociale functie van $163 ; 191 ; 225 ; 234$ slavernij $36 ; 44 ; 62 ; 64 ; 73 ; 76 ; 148 ; 221$

Smith, Pauline $25 ; 90-99 ; 102 ; 154 ; 249-251 ; 257$

Sowetorellen $246 ; 255$

\section{$T$}

thuislanden. $39 ; 40 ; 117 ; 138$

\section{$U$}

Unie van Zuid-Afrika (1910) $26 ; 54 ; 74 ; 86$

\section{V}

Van den Heever, C.M. $29 ; 31 ; 38 ; 57 ; 100 ; 103 ; 154 ; 213 ; 260$ Van Heerden, Etienne $7 ; 257-259 ; 263$

Van Melle, Johannes $29 ; 50-55 ; 249$

Vilakazi, B.W. $12 ; 23 ; 59-61 ; 254$ Vondel, Joost van den $201 ; 203 ; 243$ voorouders $96 ; 163$ als onderdeel van sociale structuur. $101 ; 112 ; 173 ; 183 ; 187 ; 224$ en identiteit $30 ; 51 ; 99-104 ; 112 ; 195 ; 248 ; 263$ en landrechten. $31 ; 119 ; 167 ; 215 ; 249 ; 261$ en postkolonialisme $64 ; 118 ; 140 ; 170 ; 171$

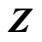

zionisme 69; 96; 97 


\section{Summary}

This book studies the relationship between social and political developments in the countryside of South Africa and the metaphorical use of nature, family and especially death in pastoral and anti-pastoral literature. In pastoral literature, or at least in South African pastoral literature, a relationship between land and people is constructed in order to define the relationship between Self and Other. The same thing happened in the numerous land laws, the told and retold history of the Boers and their Great Trek and the detailed mapping of British colonial rule. Events that undermined this spatial organisation, like Khoisan guerrilla warfare in de eighteenth, economic successes of black farmers in the nineteenth, and the construction of inaccessible black ritual spaces in the twentieth century, were met with more violence, more laws and more mythical constructions. But at places where the dominant perception was actually confronted with alternative perceptions, intercultural spaces and world views arose. This happened for instance at colonial frontiers, mission stations and whiteowned farms. Nevertheless, as political power was based on polarisation, in formal discourse these intercultural adaptations were always reconstructed into oppositions between blacks and whites and have-s and have-nots.

Pastoral literature has followed and anticipated these constant movements. Afrikaans plaasromans foremost emphasised the organic relationship between land and Afrikaner people, thereby marginalising or overlooking black inhabitants. J. van Melle, writing in a time when Afrikaners, however bitterly, had to accept British control after the Boer War, portrays the Afrikaner as a lonely, stubborn fighter, individualistically related to the open, empty and fenceless landscape he moves through. Later-on, when Afrikaner nationalism consolidated, C.M. van den Heever portrays in his farm novels the Afrikaner Boer as the pater familias of a big transformed family, with the reproductive earth as his wife and mother and the African servants as his stepchildren. As was the case on many Afrikaans and English farms, paternalism is used here as a concept to conceal internal conflicts and other tabooed realities.

In English pastoral literature the South African landscape is the idyllic or hostile, but always slightly alien home of romantic or alienated pioneers and their exploited or non-present farm workers in a wider colonial context. Olive Schreiner was the first to display an ambivalent relationship between farmer and farm in The story of an African farm; Pauline Smith and Herman Bosman followed. Featuring as farmers in their novels and stories, however, were mostly Afrikaners, while English characters, when present, were merely passers-by in someone else's history. 
Because of hidden spaces and non-told narratives of violence, dispossession and interculturality, in both Afrikaans and English pastoral literature home has always been interspersed with notions of alienation and hostility, while the identity of both Self and Other has never been regarded free of migratory elements. In some of these texts death has been used to contingent on contemporary political and historical circumstances and discourses- camouflage or display the ambiguities and veil or unveil the hidden discourses. In a stable rural situation, metaphors of land, family and death reinforce each other. Family secures, through death, a territory in time and space. This is why, and for migrants especially, death and the rituals that surround it, are very important. While death is chaos, the rituals that control it define all kinds of spatial, temporal and social boundaries. Therefore death most often reinforces the present order of things. But where control is somehow less effective, death can, being chaos, also bring change.

Moreover, death is a story in itself. In literature as in real life, death is almost exclusively represented as a narrative. Ritually speaking, the narrative consists of three stages (or events) making up a rite of passage: separation, liminality, and (re)integration. When someone dies, he or she will leave the community of the living, pass a dangerous period/territory of chaos, and enter the community of the dead - which usually mirrors the community of the living. Van den Heever, while making use of this stabilising function of death, still recognises the frightening possibility of alternatives, hidden in "die groot, verskriklike eenheid". Elsewhere in South-African (anti-)pastoral literature death rituals more often than not accentuate this frightening face of death. Graves at far-off places, unburied corpses, and the giant Adamastor waiting for its revival, all point to a sense of homelessness and wanted or unwanted instability. The deceased character might (temporarily) get stuck in liminality, or, if he or she does get out, might enter a community that does not mirror the one of the living. This way existing discourses can be criticised or (more or less involuntarily) deconstructed, and thus give way to other discourses.

Of course at the South African countryside there was, from the start, an ambiguity in the relationship between land, family and death. Especially within the boundaries of the white farm, the paternalistically and historically defined We was an intercultural We; while at the same time race had always been and was increasingly an identifying discourse. In times of change even paternalism could not conceal the ambiguity of this identity. When for example in the 1920s and 1930s white farmers either went bankrupt and left for the cities or started to use black seasonal workers in stead of indefinite sharecrop agreements with black farmers, black inhabitants of the white countryside started to rebel against the exploitation, evictions and 
violence that accompanied these changes. At that point, home became unheimlich and death involuntary showed the difference within. For instance, Pauline Smith in "Ludovitje" seems to plead for the creation, through Ludovitje's death, of an interracial, international Christian community as a substitute for the inadequate local rural order. But given the social and political context of this story, the new community Ludovitje enters after he died, is an illusory one. All the story does, in fact, is point to its own ideological fallacy.

Segregation politics were meant to solve the problem of non-secure homes, while pastoral literature sought to create a new social identity. The state took over control. Dissatisfied black farmers were given a new home with their "own" family in their "own" homelands. The rest of South Africa was to be the untroubled territory of a large white family, still paternalistically controlling its servants at their now safely distant homesteads. This system however denied the actual ongoing intercultural conflicts at white farms (and elsewhere), and home was as uncanny as ever. By this time, conflicts were often fought out on a personal or spiritual level, black workers using intangible methods as cutting fences, slow-down actions, or illegal hunting, while shamans and black churches created inaccessible but omnipresent spiritual and moral realms. In "Unto Dust" Herman Bosman uses the ambiguity of death, and this time plainly intentional, to ridicule segregation politics and its attempts to secure a purely white, Christian identity in an African country.

While the National Party is firmly in power for some decades after World War II, pastoral literature lies low. But in the early seventies, when Apartheid's stability begins to crumble and civil war seems to be a real possibility for the near future, two important farm novels appear: Nadine Gordimer's The conservationist, and Anna Louw's Kroniek van Perdepoort. The resemblance between the two novels is striking. They both use the failing control of a white farmer to ridicule the grim, frightened conservatism of white rule. They also both try to create alternative cultural identities and future scenario's through cross-cultural identification. Imbedded in colonial or biblical myth, the metaphors death, family and land seem to be connected as part of a syntagmatic, invariable construction of white identity. But death, family and land are and always have been just as essential for the construction of black identity. When the metaphors are being used in white texts, their black counterparts are always present, if only because as metaphors their meaning is dependent on their connection with other metaphors.

In The conservationist and Kroniek van Perdepoort these paradigmatic aspects of identity are being revealed by cross-cultural intertextuality. The novels point at parallels between (mythical) characters like Mehring, Adam and Unkulunkulu; or /Kaggen, Koos Nek, Fielies and the devil. Likewise, 
the narrative structure of creation myths, transition rituals and trickster stories from different cultural backgrounds look alike. More abstract and more meaningful are similarities or overlaps between cultural or mythical spaces (farm, paradise, the bed of reeds) or spatial structures (in/out; civilisation/ wilderness; safe/ unsafe; order/chaos). Through these intertextualities, alternative pastoral discourses, whether written down by Vilakazi in the 1930s or voiced by farm workers at land claims courts in the 1990s are always present in all pastoral texts.

However, given the historical circumstances, these alternative discourses could not be voiced free of the coloniser's (and writer's) discourse. Therefore something else was needed to give space to them. Both The Conservationist and Kroniek van Perdepoort introduce the rite of passage as a means to establish real change. They do so by describing the period between death and burial of a (semi-)anonymous black man on a whiteowned farm, and the destabilising effects of the presence of these unburied bodies. Here, death is no longer the reinforcement of a (new) social order, or the denial of an old one. It is used as a metaphor of transformation into the unknown (or the unseen, or the unheard). It is made clear that the final stage of change, reintegration, can not take place as long as liminality (i.e. erasing spatial, temporal and social (racial) boundaries) is not acknowledged as the frightening but inescapable and beneficent part of the process. Finally, pastoral novels in the 1980s and 1990s show that in these decades reintegration is still not completed. While in reality conflicts over land use linger or even get worse, in literature both farm and death are foremost being used as a metaphor for deconstruction and non-communication.

In all these texts the unknown is more than what is left out by the writers. Over the past decades anthropologists, historians and experts on oral literature have provided material that throws some light on what was not known in the 1930's or 1970s or even 1990s. And because death is inhabited by the unknown, the meaning of texts that hold death as an important theme, will change. Being nothing but a narrative, a metaphor, and being a metaphor of transition, death is the common territory of otherwise incompatible realms like text and reality or different cultural or temporal realities. Writing and reading about death, is like entering the territory of liminality: a rite of passage in itself. 


\section{Curriculum Vitae}

Christine Geertrui (Gitte) Postel werd geboren in 1963 in Lochem. Vanaf 1982 studeerde zij aan de Katholieke Universiteit van Nijmegen eerst drie jaar antropologie, waarna ze haar propedeuse Nederlands behaalde en afstudeerde op Zuid-Afrikaanse literatuur in de Algemene Literatuurwetenschap. Na haar studie werkte ze jarenlang als freelance (literair) journalist en vertaler; ze publiceerde in diverse dagbladen, (vak)tijdschriften en essaybundels en bracht met regelmaat advies uit aan het Fonds voor de Letteren. Daarnaast werkte zij ondermeer als onderzoeksmedewerker op het gebied van binnenlands integratiebeleid en Zuid-Afrikaanse land- en mensenrechten bij verschillende advies- en informatiebureaus. Ook was ze enige jaren als eindredacteur werkzaam bij een educatieve uitgeverij. De laatste jaren heeft ze als gastmedewerker bij het CNWS aan de Universiteit Leiden dit proefschrift afgerond. Momenteel is ze opnieuw werkzaam als freelance journalist en redacteur. 